\title{
DISSERTATION
}

\section{SYNTHETIC STUDIES ON (-) LEMONOMYCIN: \\ CONSTRUCTION OF THE TETRACYCLIC CORE}

\author{
Submitted by \\ Alberto Jiménez-Somarribas \\ Department of Chemistry
}

\author{
In partial fulfillment of the requirements \\ For the Degree of Doctor of Philosophy \\ Colorado State University \\ Fort Collins, Colorado
}

Fall 2013

Doctoral Committee:

Advisor: Robert M. Williams

John L. Wood

Yian Shi

Branka M. Ladanyi

Dean C. Crick 
Copyright by Alberto Jiménez-Somarribas 2013

All Rights Reserved 


\section{ABSTRACT \\ SYNTHETIC STUDIES ON (-)-LEMONOMYCIN: CONSTRUCTION OF THE TETRACYCLIC CORE}

Documented herein are efforts towards the asymmetric total synthesis of (-)lemonomycin, a member of the tetrahydroisoquinoline antitumor antibiotics family of natural products. We describe a concise route for the assembly of the tetracyclic core of this molecule, which involves a Pictet-Spengler reaction for the construction of the tetrahydroisoquinoline fragment and an azomethine ylide [3+2] dipolar cycloaddition for the construction of the diazabicyclo[3.2.1]octane ring system. The above-described synthetic efforts, while not totally successful, provide the basis for the future completion of the total synthesis of this natural product and other related compounds. 


\section{ACKNOWLEDGEMENTS}

First, I would like to thank Professor Robert M. Williams, my advisor, for providing the dynamic research environment that allowed me to learn and grow as chemist. It has been an honor to work for you and I am very grateful for the valuable advise and support that you provided over the years.

I would also like to thank the Williams group members, both past and present, for their help, friendship and encouragement during my journey. To the members of the THIQ group, thank you for laying the foundations for my work and for your helpful ideas. To Dan Gubler, Timmy McAfoos, Aaron Pearson and Guojun Pan, thank you for the helpful discussions about chemistry. To Sarah Stevens, Michelle Sanchez, Jennifer Finefield, Jennifer Bubb and Tenaya Newkirk, thank you for your friendship and help.

I would like to especially thank my dear friend Ryan Rafferty, for your generous help, your friendship and the encouragement that you provided over the years. Thank you for the lengthy discussions about chemistry and for inspiring me to become a better chemist and a better person.

I would like to extend my gratitude to my family, starting with my mother Lidia Somarribas. Thank you for all of your love and the constant support and encouragement that you provided at every step along the way. I thank my grandmother Lydia Chavarría and my aunt Lilliana Somarribas for your love and support. I thank my brother and sisters Juan, Virginia and Marie Jiménez, and my niece Andrea Castro for your love and support throughout this journey. I also would like to thank my mother-in-law María Josefa Quirós and my sisters-in-law Evelyn and Grettel Chaves for your love and support. 
To my three wonderful sons, Daniel, Gabriel and Sebastián, thanks for filling my days with joy, love and hope.

Finally, I would like to extend my utmost gratitude my beloved wife Yorleny. Thanks for all of your love, dedication and patience, and for the encouragement that you provided over these years. None of this would have been possible without you. Thanks for helping me to become the person I am today and for being an awesome wife and mother. I love you with all of my heart. 


\section{DEDICATION}

To Yorleny, Daniel, Gabriel and Sebastián 


\section{TABLE OF CONTENTS}

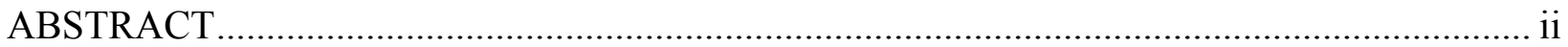

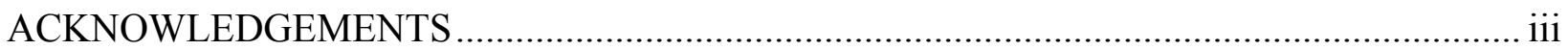

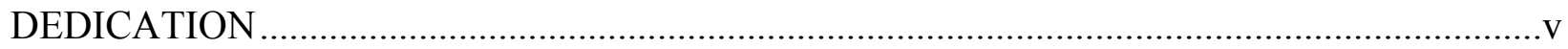

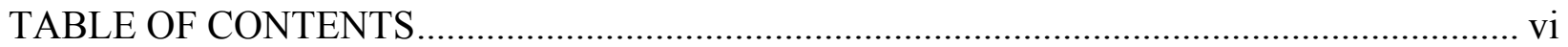

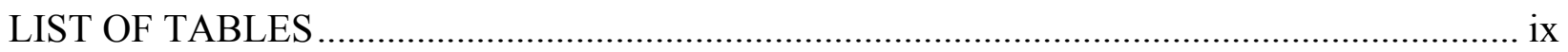

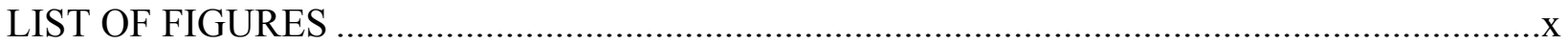

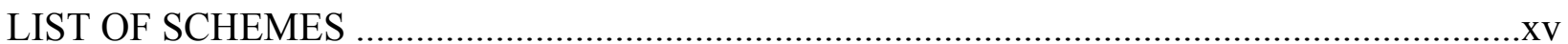

Chapter 1: The tetrahydroisoquinoline family of antitumor antibiotics

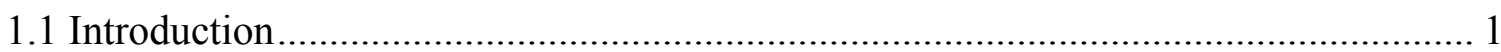

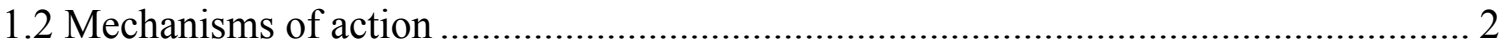

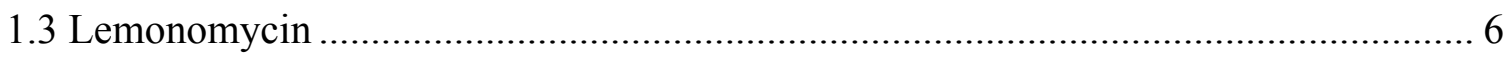

1.4 Proposed biosyntheses for the tetrahydroisoquinoline antitumor antibiotics ............... 8

1.5 Biosynthesis proposal for lemonomycin ........................................................... 15

\section{Chapter 2: Previous synthetic work on lemonomycin}

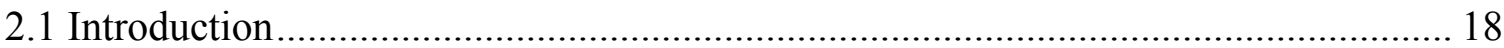

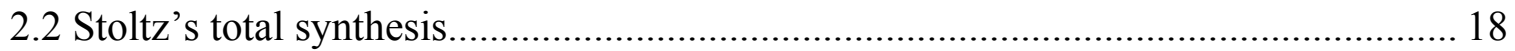

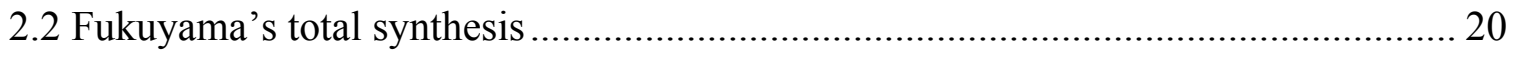

2.3 Magnus's racemic synthesis of lemonomycinone amide............................................ 23

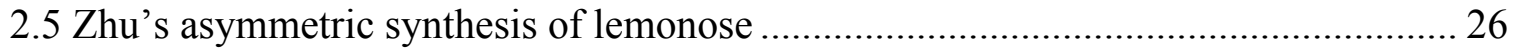


2.6 Mulzer's asymmetric construction of the tetracyclic core

2.7 Fukuyamas's asymmetric construction of the tetracyclic core .................................. 28

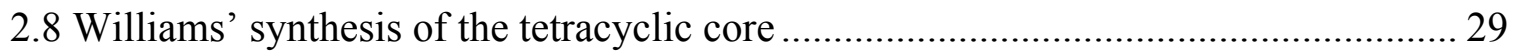

\section{Chapter 3: Studies towards the synthesis of lemonomycin}

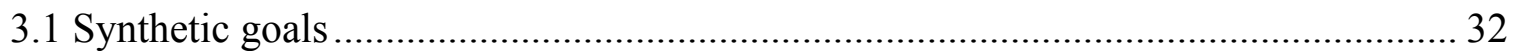

3.2 Dithiane approach

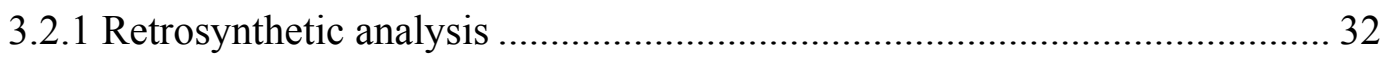

3.2.2 Synthesis of the first Pictet-Spengler substrate........................................... 33

3.2.3 Formation of the tetrahydroisoquinoline system ........................................ 34

3.2.4 Incorporation of the of the glycine fragment ............................................. 35

3.3 Hosomi-Sakurai approach

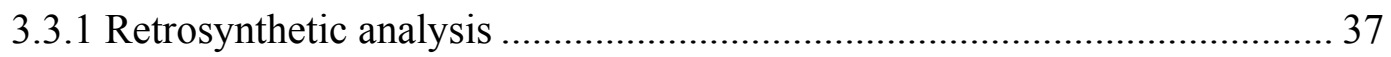

3.3.2 Synthesis of the allyltrimethylsilane glycine derivative ............................. 38

3.3.3 Attempted formation of the cyclization precursor ........................................ 38

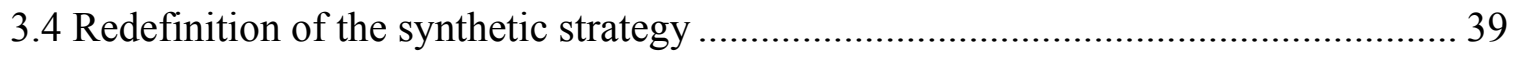

3.5 Attempted formation of alternate cycloaddition precursors

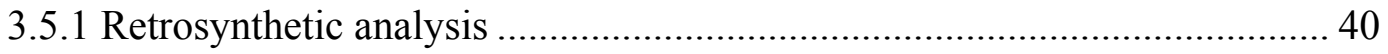

3.5.2 Attempted formation of the tetrahydrosiquinoline system .......................... 41

3.5.3 Attempted formation of a tricyclic hemiaminal.......................................... 42

3.6 Construction of the tetracyclic core

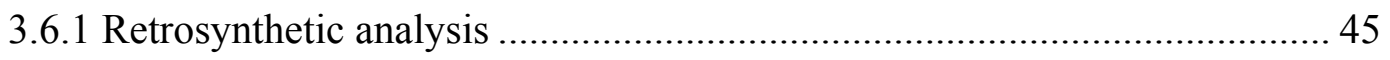

3.6.2 Synthesis of the tetrahydroisoquinoline fragment ..................................... 47 
3.6.3 Formation of the tetracyclic ring system ........................................... 48

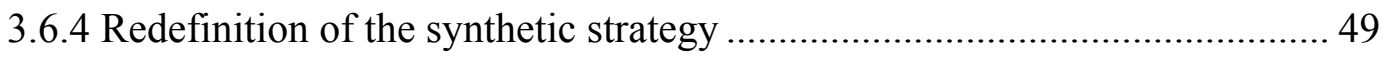

3.6.5 Initial modification of the tetracyclic core.......................................... 51

3.6.6 Epimerization of the southern benzylic stereocenter ............................. 52

3.6.7 Hydrogenation of the enamide double bond ........................................ 54

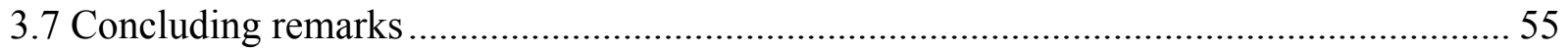

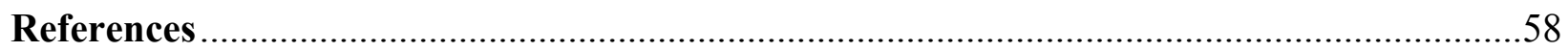

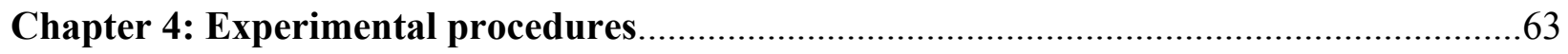

Appendix 1: Substrates and conditions of the enamide hydrogenation attempts listed in

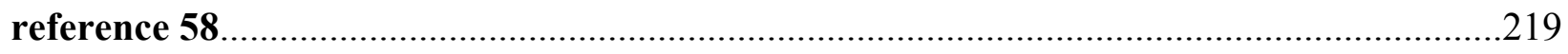

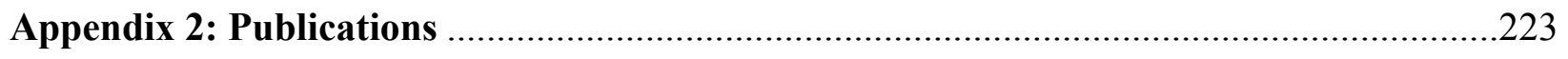

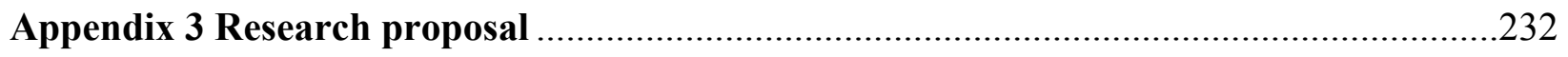

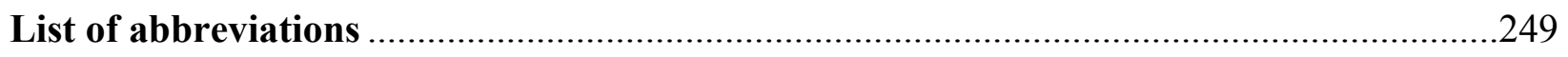




\section{LIST OF TABLES}

\section{Chapter 1}

Table 1.1. In vitro antibacterial activities of lemonomycin ..............................................6

Table 1.2. Comparison of antibacterial activities of lemonomycin (1.20), tetracycline (A),

penicillin $\mathrm{G}(\mathrm{B})$ and erythromycin (C), against various staphylococci and streptococci ................7 


\section{LIST OF FIGURES}

\section{Chapter 1}

Figure 1.1. Representative members of the tetrahydroisoquinoline antitumor antibiotics ............1

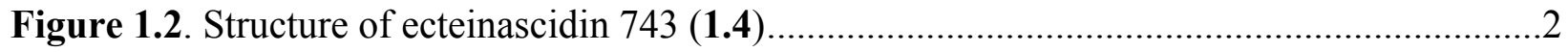

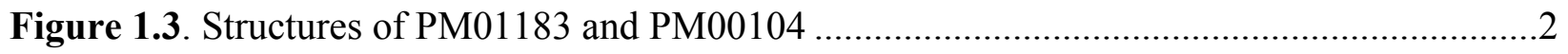

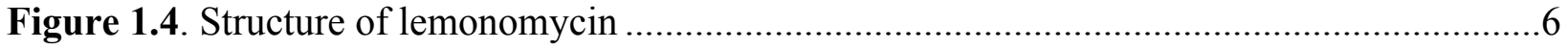

Figure 1.5. Domain organization of NRPSs for tetrahydroisoquinoline antitumor antibiotics

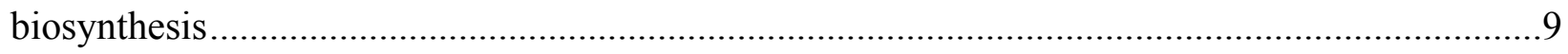

\section{Chapter 3}

Figure 3.1. Representative members of the tetrahydroisoquinoline antitumor antibiotics .50

\section{Chapter 4}

Figure 4.1. ${ }^{1} \mathrm{H}$ NMR spectrum of compound $3.9\left(300 \mathrm{MHz}, \mathrm{CDCl}_{3}\right)$.....................................65

Figure 4.2. ${ }^{1} \mathrm{H}$ NMR spectrum of compound $3.7\left(300 \mathrm{MHz}, \mathrm{CDCl}_{3}\right)$...................................67

Figure 4.3. ${ }^{1} \mathrm{H}$ NMR spectrum of compound $3.10\left(300 \mathrm{MHz}, \mathrm{CD}_{3} \mathrm{OD}\right)$................................69

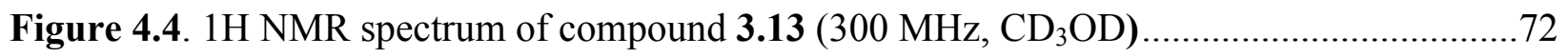

Figure 4.5. ${ }^{1} \mathrm{H}$ NMR spectrum of compound 3.14 (300 MHz, $\left.\mathrm{CD}_{3} \mathrm{OD}\right)$.................................... 74

Figure 4.6. ${ }^{1} \mathrm{H}$ NMR spectrum of compound $3.19\left(300 \mathrm{MHz}, \mathrm{CDCl}_{3}\right)$..................................76

Figure 4.7. ${ }^{1} \mathrm{H}$ NMR spectrum of compound $3.20\left(300 \mathrm{MHz}, \mathrm{CDCl}_{3}\right)$.................................78

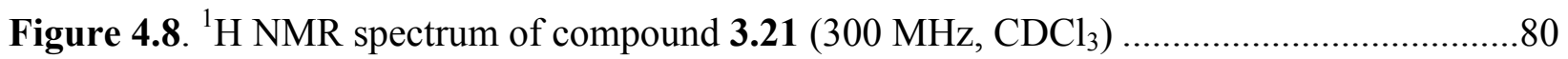


Figure 4.9. ${ }^{1} \mathrm{H}$ NMR spectrum of compound $3.22\left(300 \mathrm{MHz}, \mathrm{CDCl}_{3}\right)$...................................82

Figure 4.10. ${ }^{1} \mathrm{H}$ NMR spectrum of compound $\mathbf{3 . 2 3}\left(300 \mathrm{MHz}, \mathrm{CDCl}_{3}\right)$.................................84

Figure 4.11. ${ }^{1} \mathrm{H}$ NMR spectrum of compound $\mathbf{3 . 2 4}\left(300 \mathrm{MHz}, \mathrm{CDCl}_{3}\right)$.............................86

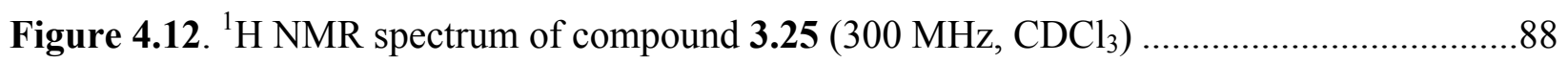

Figure 4.13. ${ }^{1} \mathrm{H}$ NMR spectrum of compound $\mathbf{3 . 2 6}\left(300 \mathrm{MHz}, \mathrm{CDCl}_{3}\right)$................................. 90

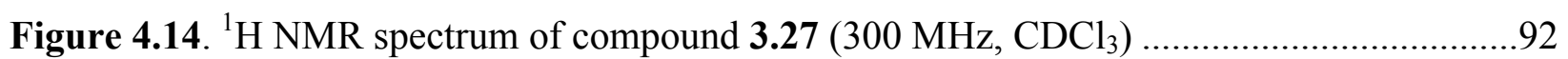

Figure 4.15. ${ }^{1} \mathrm{H}$ NMR spectrum of compound $\mathbf{3 . 2 8}\left(300 \mathrm{MHz}, \mathrm{CDCl}_{3}\right)$................................94

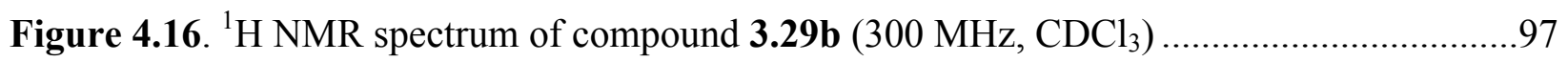

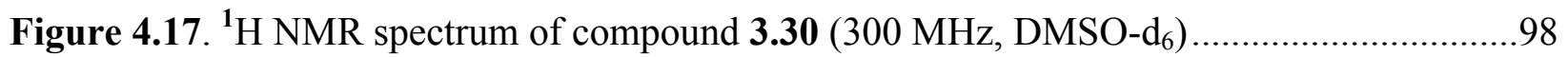

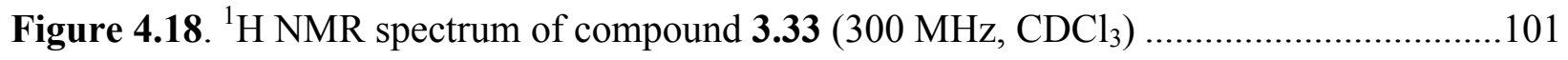

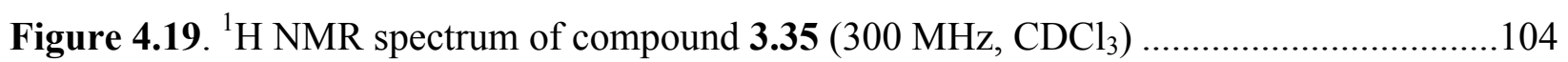

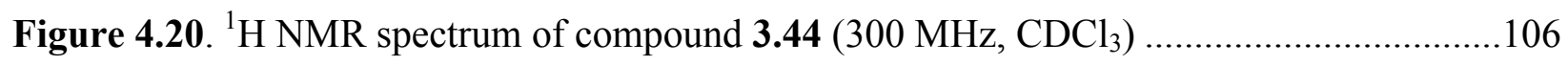

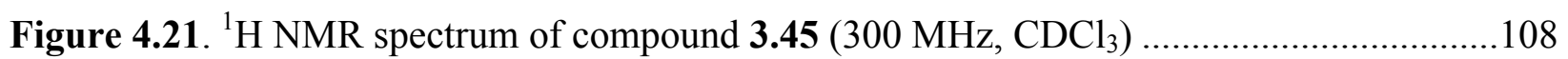

Figure 4.22. ${ }^{1} \mathrm{H}$ NMR spectrum of compound $\mathbf{3 . 4 0}\left(300 \mathrm{MHz}, \mathrm{CDCl}_{3}\right)$..............................110

Figure 4.23. ${ }^{1} \mathrm{H}$ NMR spectrum of compound $3.47\left(300 \mathrm{MHz}, \mathrm{CDCl}_{3}\right)$..............................112

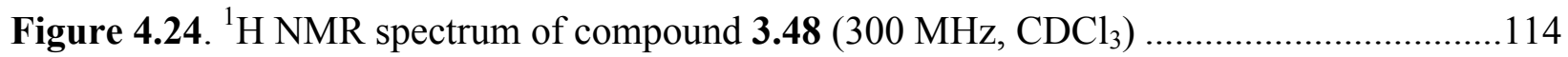

Figure 4.25. ${ }^{1} \mathrm{H}$ NMR spectrum of compound $3.57\left(300 \mathrm{MHz}, \mathrm{CDCl}_{3}\right)$............................116

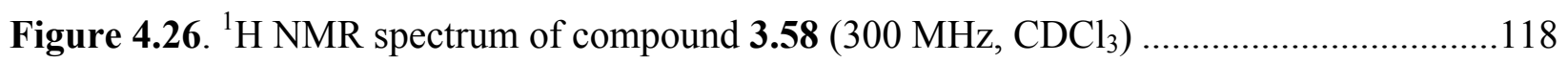

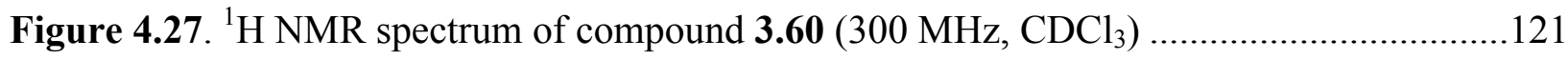

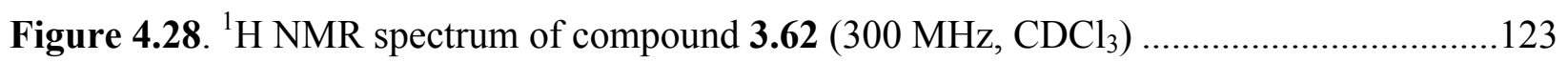

Figure 4.29. ${ }^{1} \mathrm{H}$ NMR spectrum of compound $3.54\left(300 \mathrm{MHz}, \mathrm{CDCl}_{3}\right)$..............................125

Figure 4.30. ${ }^{1} \mathrm{H}$ NMR spectrum of compound $\mathbf{3 . 6 3}\left(300 \mathrm{MHz}, \mathrm{CDCl}_{3}\right)$.............................127

Figure 4.31. ${ }^{1} \mathrm{H}$ NMR spectrum of compound 3.65 (300 $\left.\mathrm{MHz}, \mathrm{CDCl}_{3}\right)$..............................129 
Figure 4.32. ${ }^{1} \mathrm{H}$ NMR spectrum of compound 3.66 $\left(300 \mathrm{MHz}, \mathrm{CDCl}_{3}\right) \ldots \ldots \ldots \ldots \ldots \ldots \ldots \ldots \ldots \ldots \ldots . . . . .131$

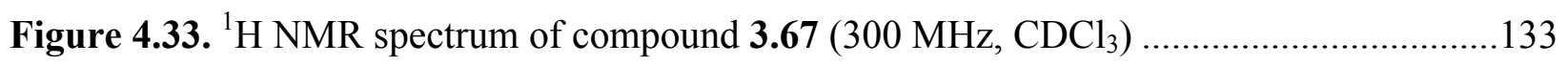

Figure 4.34. ${ }^{1} \mathrm{H}$ NMR spectrum of compound $3.70\left(300 \mathrm{MHz}, \mathrm{CDCl}_{3}\right) \ldots \ldots \ldots \ldots \ldots \ldots \ldots \ldots \ldots \ldots \ldots \ldots . . .135$

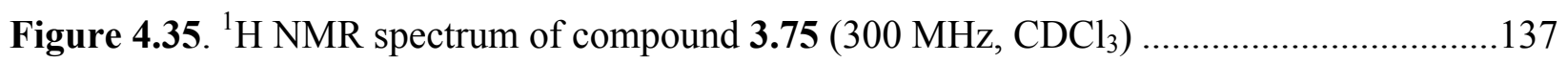

Figure 4.36. ${ }^{1} \mathrm{H}$ NMR spectrum of compound $3.76\left(300 \mathrm{MHz}, \mathrm{CDCl}_{3}\right) \ldots \ldots \ldots \ldots \ldots \ldots \ldots \ldots \ldots \ldots \ldots \ldots . . .139$

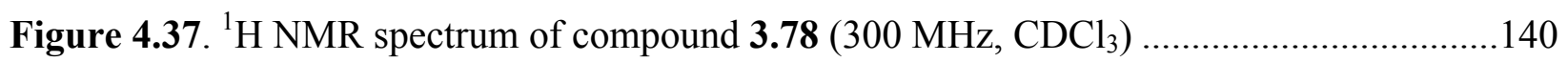

Figure 4.38. ${ }^{1} \mathrm{H}$ NMR spectrum of compound $3.79\left(300 \mathrm{MHz}, \mathrm{CDCl}_{3}\right) \ldots \ldots \ldots \ldots \ldots \ldots \ldots \ldots \ldots \ldots \ldots . . .142$

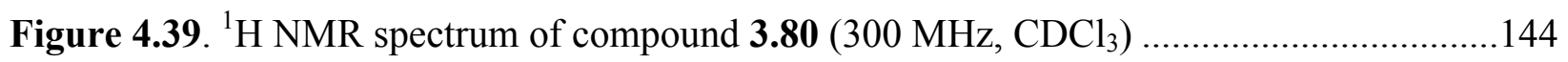

Figure 4.40. ${ }^{1} \mathrm{H}$ NMR spectrum of compound $3.88\left(400 \mathrm{MHz}, \mathrm{CDCl}_{3}\right) \ldots \ldots \ldots \ldots \ldots \ldots \ldots \ldots \ldots \ldots \ldots \ldots . . .146$

Figure 4.41. ${ }^{13} \mathrm{C}$ NMR spectrum of compound $\mathbf{3 . 8 8}\left(101 \mathrm{MHz}, \mathrm{CDCl}_{3}\right) \ldots \ldots \ldots \ldots \ldots \ldots \ldots \ldots \ldots \ldots \ldots . . .147$

Figure 4.42. ${ }^{1} \mathrm{H}$ NMR spectrum of compound $3.89\left(400 \mathrm{MHz}, \mathrm{CDCl}_{3}\right) \ldots \ldots \ldots \ldots \ldots \ldots \ldots \ldots \ldots \ldots \ldots . . . . .149$

Figure 4.43. ${ }^{13} \mathrm{C}$ NMR spectrum of compound $\mathbf{3 . 8 9}\left(101 \mathrm{MHz}, \mathrm{CDCl}_{3}\right) \ldots \ldots \ldots \ldots \ldots \ldots \ldots \ldots \ldots \ldots \ldots . . .150$

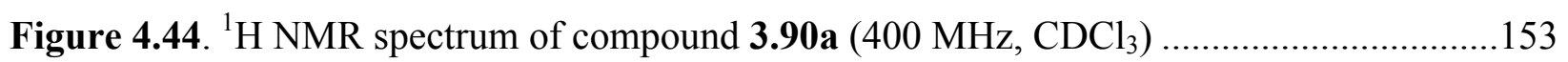

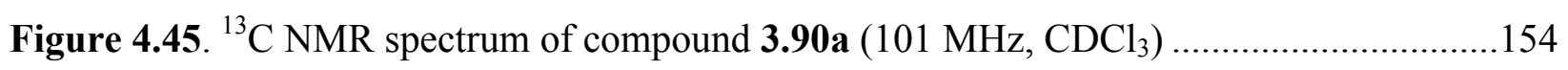

Figure 4.46. ${ }^{1} \mathrm{H}$ NMR spectrum of compound 3.90b $\left(400 \mathrm{MHz}, \mathrm{CDCl}_{3}\right) \ldots \ldots \ldots \ldots \ldots \ldots \ldots \ldots \ldots \ldots \ldots . . .155$

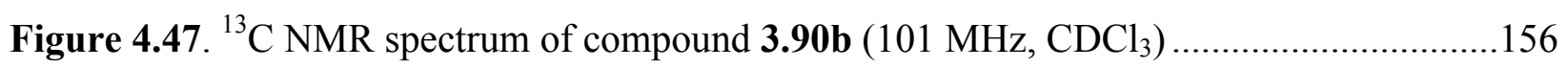

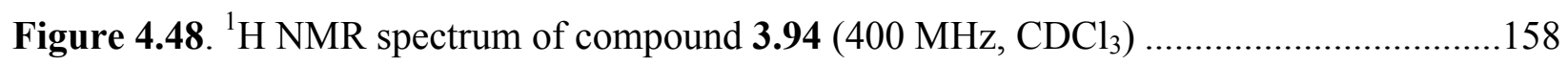

Figure 4.49. ${ }^{13} \mathrm{C}$ NMR spectrum of compound $3.94\left(101 \mathrm{MHz}, \mathrm{CDCl}_{3}\right) \ldots \ldots \ldots \ldots \ldots \ldots \ldots \ldots \ldots \ldots \ldots . . .159$

Figure 4.50. ${ }^{1} \mathrm{H}$ NMR spectrum of compound $3.95\left(400 \mathrm{MHz}, \mathrm{CDCl}_{3}\right)$...................................161

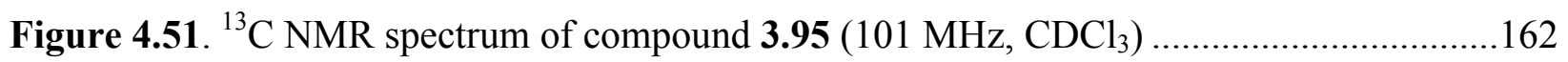

Figure 4.52. ${ }^{1} \mathrm{H}$ NMR spectrum of compound 3.96 (300 MHz, DMSO- $\left.\mathrm{d}_{6}, 393 \mathrm{~K}\right) \ldots \ldots \ldots \ldots \ldots \ldots \ldots . . .165$

Figure 4.53. ${ }^{1} \mathrm{H}-\mathrm{NMR}$ spectra of compound $3.96(300 \mathrm{MHz}$, DMSO-d 6 , 295, 323, 348, 373 and $393 \mathrm{~K})$ 165 


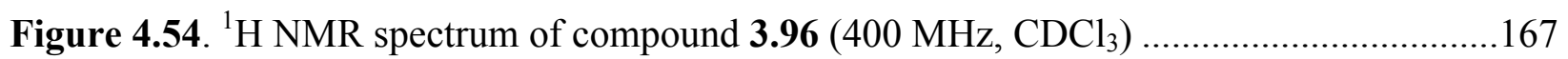

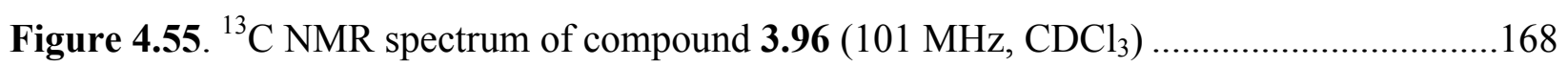

Figure 4.56. ${ }^{1} \mathrm{H}$ NMR spectrum of compound 3.97 (300 MHz, DMSO-d 6 , 393K) ................170

Figure 4.57. ${ }^{1} \mathrm{H}-\mathrm{NMR}$ spectra of compound 3.97 $\left(300 \mathrm{MHz}, \mathrm{DMSO}-\mathrm{d}_{6}, 295,323,348,373\right.$ and $393 K)$ 171

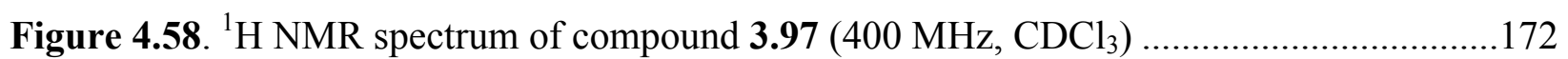

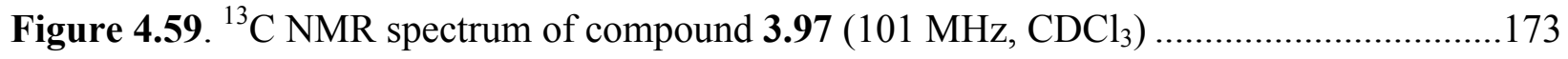

Figure 4.60. ${ }^{1} \mathrm{H}$ NMR spectrum of compound 3.85 (300 MHz, DMSO-d $\left.\mathrm{d}_{6}, 373 \mathrm{~K}\right) \ldots \ldots \ldots \ldots \ldots . . . .176$

Figure 4.61. ${ }^{1} \mathrm{H}-\mathrm{NMR}$ spectra of compound $3.85\left(300 \mathrm{MHz}, \mathrm{DMSO}-\mathrm{d}_{6}, 295,323,348,373\right.$ and 393K)

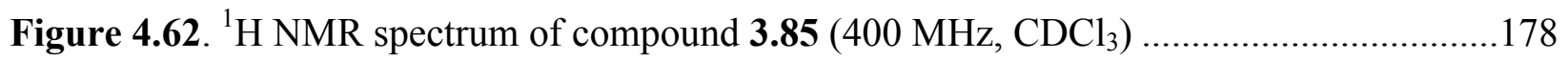

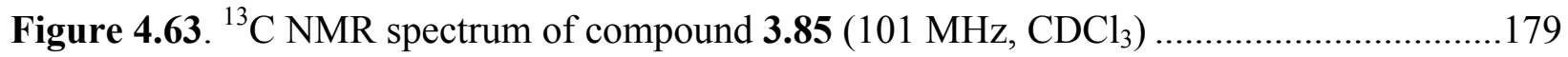

Figure 4.64. ${ }^{1} \mathrm{H}$ NMR spectrum of compounds 3.102a and 3.102b $\left(400 \mathrm{MHz}, \mathrm{CDCl}_{3}\right) \ldots \ldots \ldots \ldots 182$

Figure 4.65. ${ }^{13} \mathrm{C}$ NMR spectrum of compounds 3.102a and 3.102b $\left(101 \mathrm{MHz}, \mathrm{CDCl}_{3}\right) \ldots \ldots \ldots . .183$

Figure 4.66. ${ }^{1} \mathrm{H}$ NMR spectrum of compounds 3.103a and 3.103b $\left(300 \mathrm{MHz}, \mathrm{CDCl}_{3}\right) \ldots \ldots \ldots . .185$

Figure 4.67. ${ }^{1} \mathrm{H}$ NMR spectrum of compounds 3.104a and 3.104b $\left(300 \mathrm{MHz}, \mathrm{CDCl}_{3}\right) \ldots \ldots \ldots . .187$

Figure 4.68. ${ }^{1} \mathrm{H}$ NMR spectrum of compounds 3.105a and 3.105b $\left(300 \mathrm{MHz}, \mathrm{CDCl}_{3}\right) \ldots \ldots \ldots \ldots 189$

Figure 4.69. ${ }^{1} \mathrm{H}$ NMR spectrum of compounds 3.106a and 3.106b $\left(400 \mathrm{MHz}, \mathrm{CDCl}_{3}\right) \ldots \ldots \ldots \ldots 192$

Figure 4.70. ${ }^{13} \mathrm{C}$ NMR spectrum of compounds 3.106a and 3.106b $\left(101 \mathrm{MHz}, \mathrm{CDCl}_{3}\right) \ldots \ldots \ldots .193$

Figure 4.71. ${ }^{1} \mathrm{H}$ NMR spectrum of compound 3.107a and 3.107b $\left(400 \mathrm{MHz}, \mathrm{CDCl}_{3}\right) \ldots \ldots \ldots \ldots . . .196$

Figure 4.72. ${ }^{13} \mathrm{C}$ NMR spectrum of compound 3.107a and 3.107b $\left(101 \mathrm{MHz}, \mathrm{CDCl}_{3}\right) \ldots \ldots \ldots . .197$

Figure 4.73. ${ }^{1} \mathrm{H}$ NMR spectrum of a $2.2: 1$ mixture of compounds $3.108 \mathbf{a}$ and $\mathbf{3 . 1 0 8 b}(400 \mathrm{MHz}$,

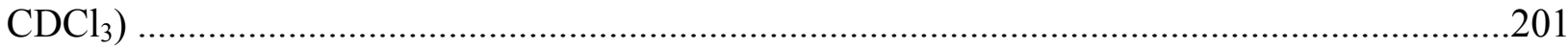


Figure 4.74. ${ }^{13} \mathrm{C}$ NMR spectrum of a 2.2:1 mixture of compounds $\mathbf{3 . 1 0 8 a}$ and $\mathbf{3 . 1 0 8 b}(101 \mathrm{MHz}$, $\left.\mathrm{CDCl}_{3}\right)$ .202

Figure 4.75. ${ }^{1} \mathrm{H}$ NMR spectrum of a 1:2.2 mixture of compounds $3.108 \mathbf{a}$ and $\mathbf{3 . 1 0 8 b}(400 \mathrm{MHz}$, $\left.\mathrm{CDCl}_{3}\right)$ .203

Figure 4.76. ${ }^{13} \mathrm{C}$ NMR spectrum of a 1:2.2 mixture of compounds 3.108a and 3.108b (101

$\left.\mathrm{MHz}, \mathrm{CDCl}_{3}\right)$ .204

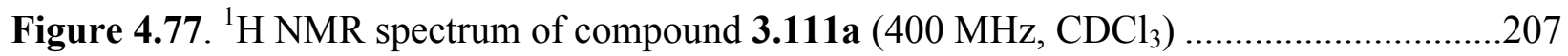

Figure 4.78. ${ }^{13} \mathrm{C}$ NMR spectrum of compound 3.111a $\left(101 \mathrm{MHz}, \mathrm{CDCl}_{3}\right) \ldots \ldots \ldots \ldots \ldots \ldots \ldots \ldots . . .208$

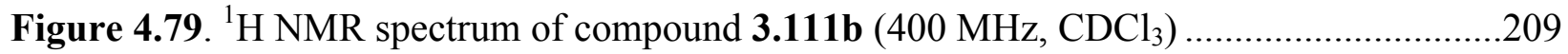

Figure 4.80. ${ }^{13} \mathrm{C}$ NMR spectrum of compound 3.111b $\left(101 \mathrm{MHz}, \mathrm{CDCl}_{3}\right) \ldots \ldots \ldots \ldots \ldots \ldots \ldots \ldots . . .210$

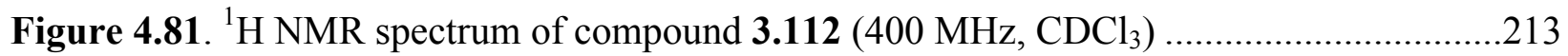

Figure 4.82. ${ }^{13} \mathrm{C}$ NMR spectrum of compound $3.112\left(101 \mathrm{MHz}, \mathrm{CDCl}_{3}\right)$...........................214

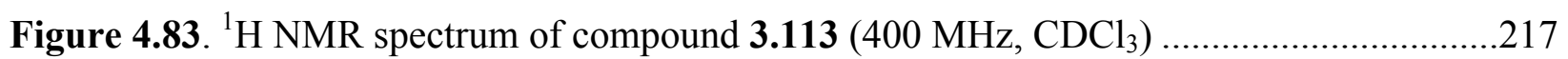

Figure 4.84. ${ }^{13} \mathrm{C}$ NMR spectrum of compound $3.113\left(101 \mathrm{MHz}, \mathrm{CDCl}_{3}\right) \ldots \ldots \ldots \ldots \ldots \ldots \ldots \ldots \ldots . . .218$ 


\section{LIST OF SCHEMES}

\section{Chapter 1}

Scheme 1.1. Proposed mechanism of DNA alkylation by saframycin A.....................................3

Scheme 1.2. Proposed mechanism of superoxide formation by quinocarcin...............................4

Scheme 1.3. Bioxalomycin $\alpha-2$ cross-linking adduct ..........................................................

Scheme 1.4. Naphthyridinomycin-derived alkylating intermediate proposed by Moore ...............5

Scheme 1.5. Bioxalomycin $\alpha-2$ cross-linking mechanism proposed by Williams .........................5

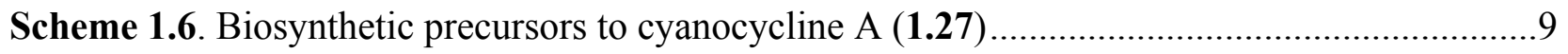

Scheme 1.7. Biosynthesis of 3-hydroxy-5-methyl- $O$-methyl-L-tyrosine (1.32) .........................10

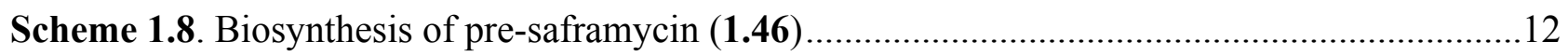

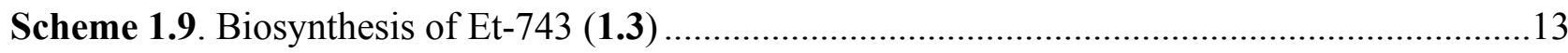

Scheme 1.10. Biosynthetic origin of the C-2 unit of naphthyridinomycin and quinocarcin............15

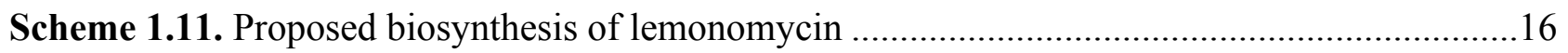

\section{Chapter 2}

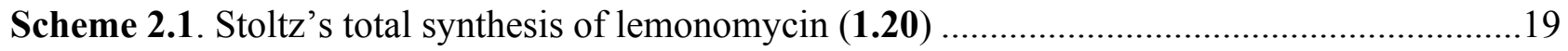

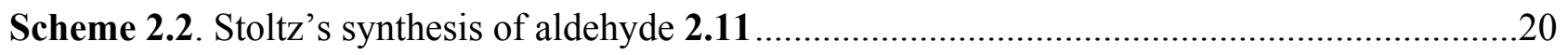

Scheme 2.3. Fukuyamas's total synthesis of lemonomycin $(\mathbf{1 . 2 0})$.......................................21

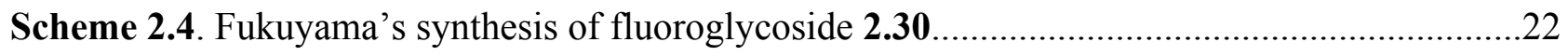

Scheme 2.5. Magnus' synthesis of lemonomycinone amide (2.52) ........................................24

Scheme 2.6. Zhu's asymmetric synthesis of lemonomycinone amide (2.52) ............................25 


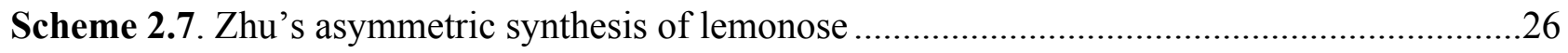

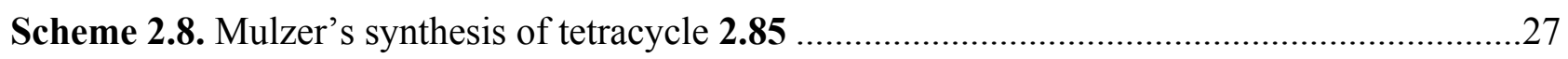

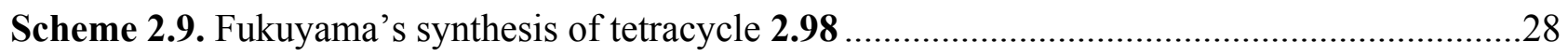

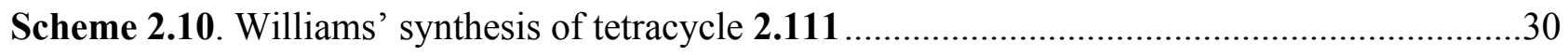

Scheme 2.11. Construction of the tetracyclic cores of quinocarcinamide and tetrazomine.............31

\section{Chapter 3}

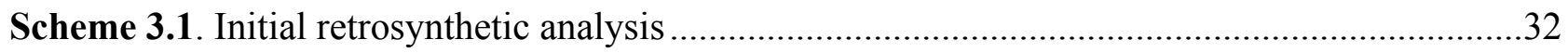

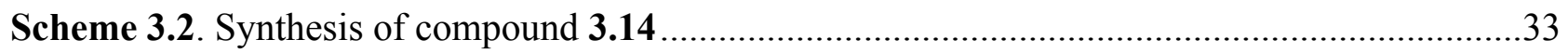

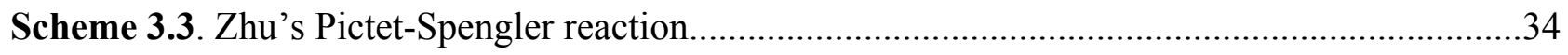

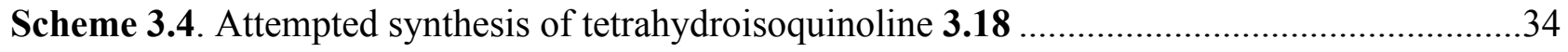

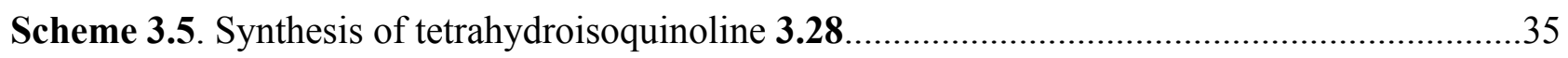

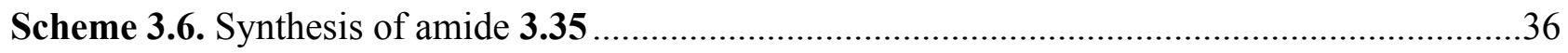

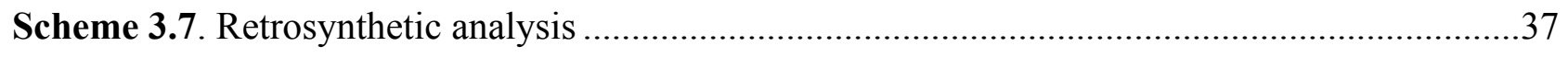

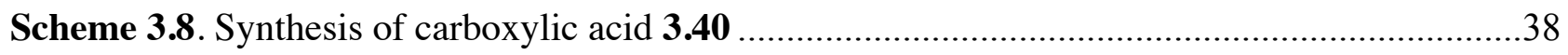

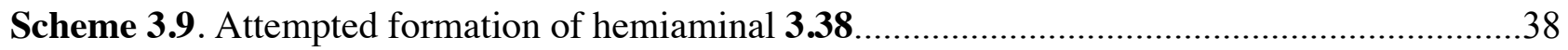

Scheme 3.10. Comparison of the hydrogenation substrates ..................................................40

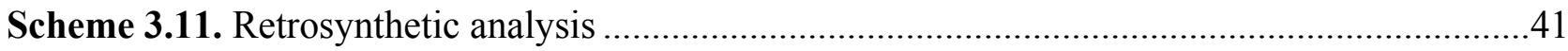

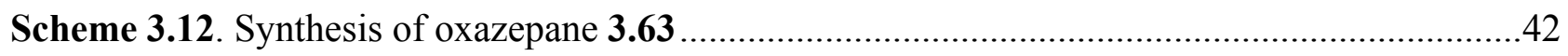

Scheme 3.13. Attempted formation of hemiaminal 3.68.................................................43

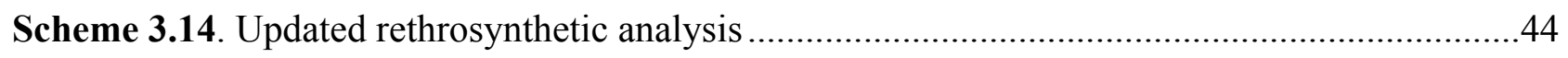

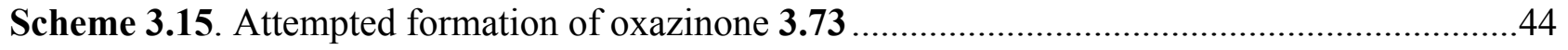

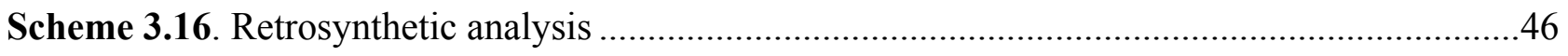


Scheme 3.17. Synthesis of tetrahydroisoquinolines 3.90a and 3.90b

Scheme 3.18. Preparation of aldehyde 3.85 48

Scheme 3.19. Formation of cycloadducts $3.102 \mathrm{a}$ and $3.102 \mathrm{~b}$. 49

Scheme 3.20. Synthesis of compounds 3.105a and 3.105b .51

Scheme 3.21. Synthesis of aldehydes 3.108a and 3.108b .53

Scheme 3.22. Proposed rationale for the chemoselective reduction of $\mathbf{3 . 1 0 6 a} / \mathbf{3 . 1 0 6 b}$. .53

Scheme 3.23. Reduction of the enamide double bond .55 


\section{CHAPTER 1}

\section{The tetrahydroisoquinoline family of antitumor antibiotics}

\subsection{Introduction}

The tetrahydroisoquinoline antitumor antibiotics are family of natural products and their synthetic analogs. ${ }^{1}$ Starting with the isolation of naphthyridinomycin (1.1) in $1974,{ }^{2}$ more than 70 natural products have been described in the literature. Structurally, their polycyclic skeleton contains tetrahydroisoquinoline moieties and 3,8-diazabicyclo[3.2.1]octane or 3,9diazabicyclo[3.3.8]nonane ring systems. They are classified into the naphthyridinomycin (1.1), saframycin (1.2) and quinocarcin (1.3) sub-families.

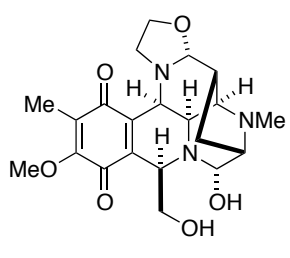

1.1

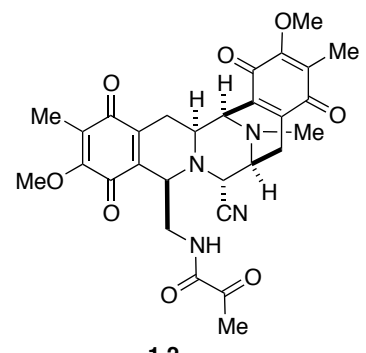

1.2

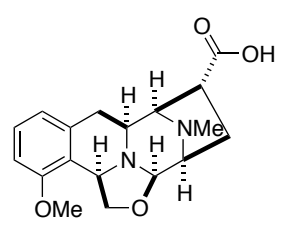

1.3

Figure 1.1. Representative members of the tetrahydroisoquinoline antitumor antibiotics

Several members of this family possess potent cytotoxic activities against tumor cells and bacteria. For instance, Ecteinascidin 743 (Et-743) (1.4), a compound isolated from the Caribbean tunicate Ecteinascidia turbinata, has been approved in Europe for the treatment of some types of advanced soft tissue sarcomas and platinum-resistant ovarian cancers. ${ }^{3}$ In addition, it is undergoing phase II clinical trials for the treatment of translocation related sarcomas ${ }^{4}$ and has shown antitumor activity against other malignancies, such as advanced breast cancer ${ }^{5}$ and 
prostate cancer. ${ }^{6}$ PM-01183 (1.5), a synthetic analog of Et-743 (1.4), is currently in clinical development for the treatment of solid tumors. ${ }^{7}$ Furthermore, the synthetic compound PM-00104 (1.6) is currently in phase II clinical trials for the treatment of multiple myeloma ${ }^{8}$ and advanced solid tumors. ${ }^{9}$

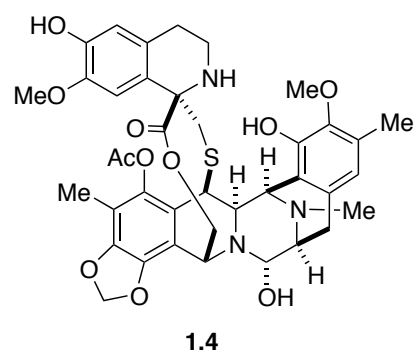

Figure 1.2. Structure of ecteinascidin 743 (1.4)

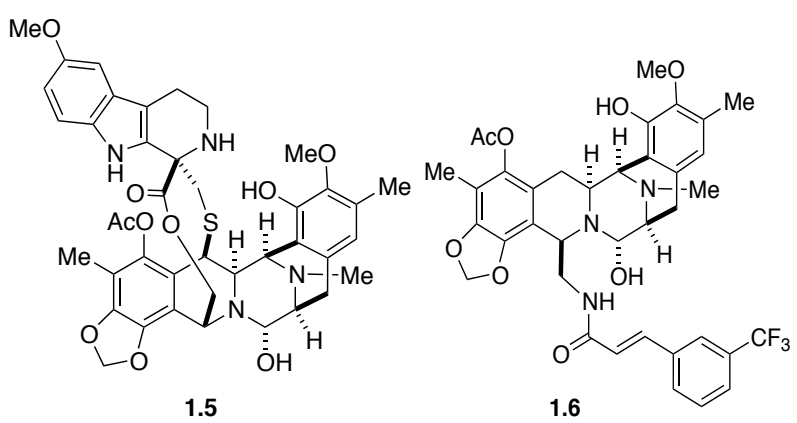

Figure 1.3. Structures of PM-01183 and PM-00104

\subsection{Mechanisms of action}

It has been shown that the tetrahydroisoquinoline antitumor antibiotics biological activities are the result of their interactions with cellular nucleic acids. The proposed mechanisms of action include DNA alkylation, DNA cross-linking and oxygen mediated DNA damage. ${ }^{1}$ In 1982, Lown and coworkers proposed a mechanism of covalent bonding between saframycin A (1.2) and DNA (Scheme 1.1). ${ }^{10}$ Upon protonation of the nitrile group connected to C-21, the lone pair of the adjacent nitrogen of intermediate $\mathbf{1 . 7}$ promotes the release of $\mathrm{HCN}$ and leads to the 
formation of iminium ion 1.8. This highly electrophilic species is attacked by the N-2 atom of guanine in the minor grooves of $\mathrm{G}+\mathrm{C}$ containing sequences, to generate covalently linked adducts such as 1.9. An analogous mechanism has been proposed for similar compounds bearing hydroxyl or alkoxy leaving groups connected to C-21.
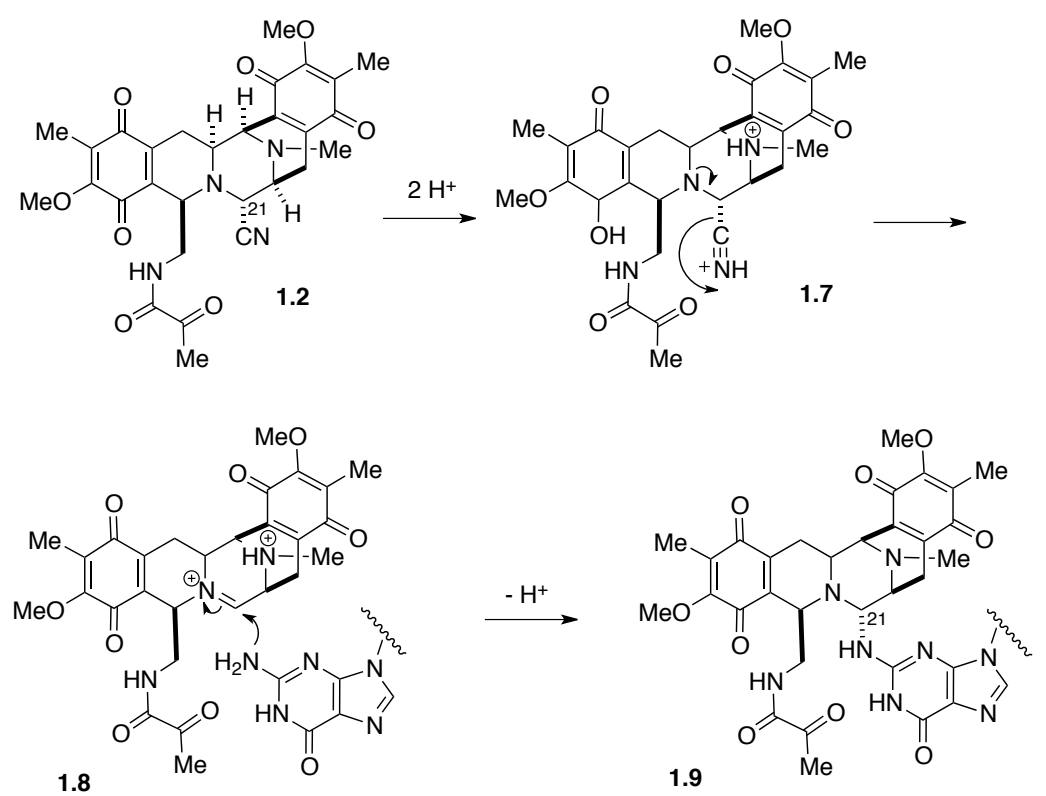

Scheme 1.1. Proposed mechanism of DNA alkylation by saframycin A

An additional DNA damaging mechanism was proposed for oxazolidine-containing members of the family. After an initial report of superoxide production by quinocarcin (1.3) made by Tomita and coworkers, ${ }^{11}$ a series of experiments conducted by Williams and coworkers led to the proposal that the oxygen-dependent DNA scission events are associated with the disproportionation reactions experienced by the oxazolidine-containing tetrahydroisoquinoline antitumor antibiotics. ${ }^{12,13}$ As outlined in Scheme 1.2, a single-electron transfer from $\mathbf{1 . 3}$ to the ring-opened tautomer 1.10, followed by the concomitant deprotonation event, would produce oxazolidinyl radical $\mathbf{1 . 1 1}$ and radical anion 1.12. Through a second single-electron oxidation, radical $\mathbf{1 . 1 1}$ generates oxazolidinium ion $\mathbf{1 . 1 3}$, which is converted to quinocarcinamide $\mathbf{1 . 1 4}$ by 
the addition of water. Radical anion $\mathbf{1 . 1 2}$ is the acceptor in a single electron transfer process that, with the concomitant protonation, leads to quinocarcinol 1.15. In addition, radical anion 1.12 can trap an oxygen molecule to produce peroxy radical anion 1.16. With the involvement of the lone electron pair of the adjacent nitrogen, 1.16 expels superoxide and regenerates 1.10. Through Haber-Weiss/Fenton cycling, superoxide gives rise to hydroxyl radicals and triggers to DNA damaging events. ${ }^{14,15,16}$

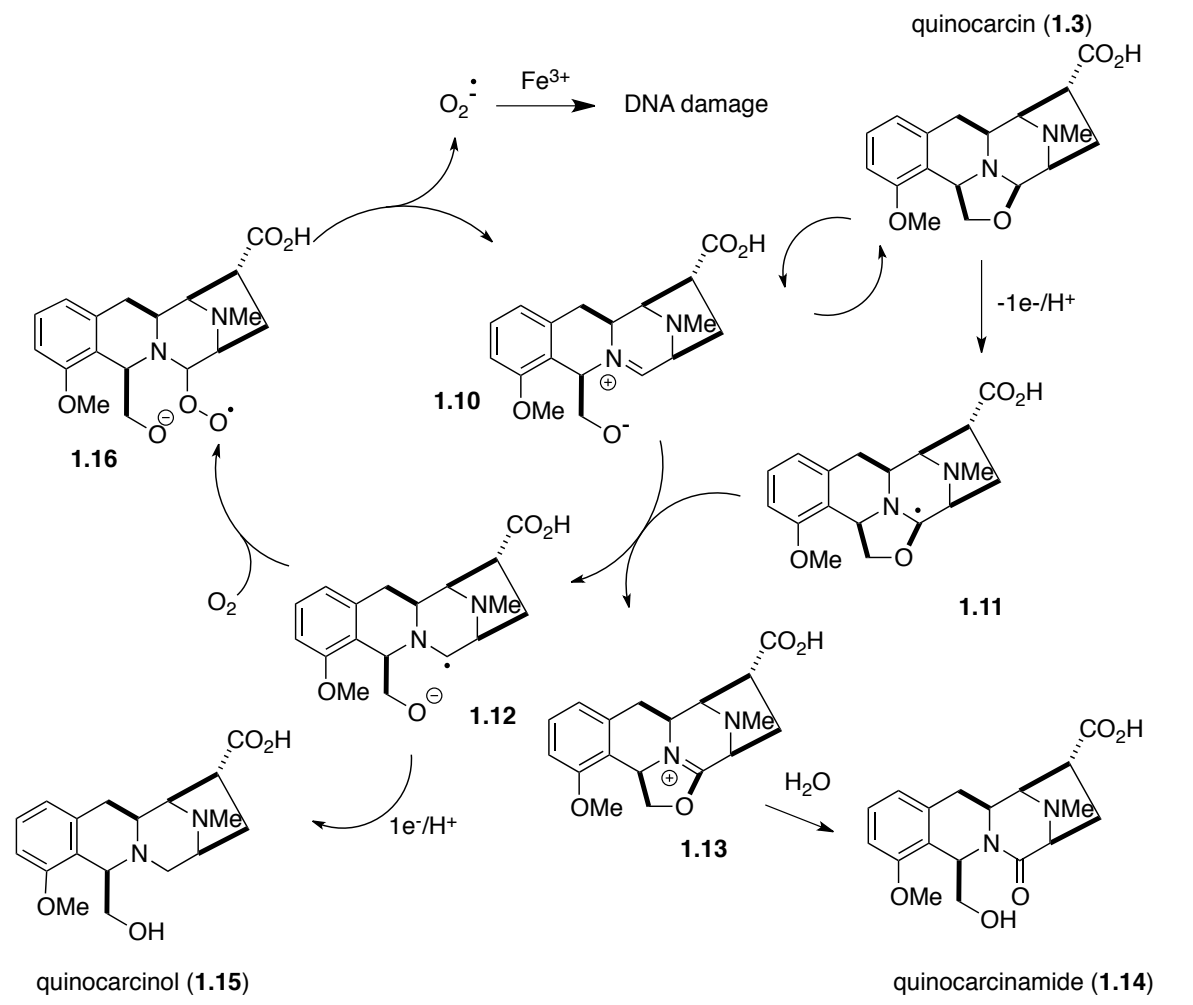

Scheme 1.2. Proposed mechanism of superoxide formation by quinocarcin

According to a series of experiments described by Williams, it was demonstrated that bioxalomycin $\alpha-2$ (1.17) is capable of cross-linking duplex DNA strands. ${ }^{17}$ The incubation at 37 ${ }^{\circ} \mathrm{C}$ of a buffered solution containing a $5{ }^{\prime}-{ }^{32} \mathrm{P}$-labelled oligonucleotide and bioxalomycin $\alpha-2$ led to the isolation of a cross-linked adduct (Scheme 1.3). It has been shown that the alkylation occurs in the exocyclic nitrogen of guanine and that the hydroquinone oxidation state is essential 
for this process. In spite of this, the exact structure of the DNA-bioxalomycin adduct remains unknown. In 1977, Moore suggested C-13b and C-9 as possible alkylation sites resulting from the formation of the o-quinone methide groups of 1.18, which could be derived from bioxalomycin $\alpha$-2 (1.17) (Scheme 1.4). Williams supported Moore's proposal for C-13b alkylation, and proposed a second alkylation site at C-7 instead of C-9 (Scheme 1.5). This assertion was based in the previous knowledge about the role of the $\alpha$-aminonitrile/hemiaminal functionality in the biological activity of other members of the tetrahydroisoquinoline family of antitumor antibiotics.

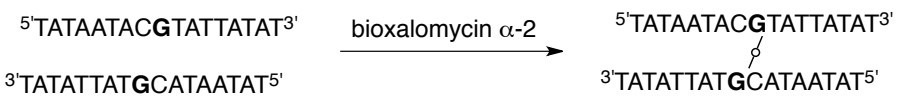

Scheme 1.3. Bioxalomycin $\alpha-2$ cross-linking adduct

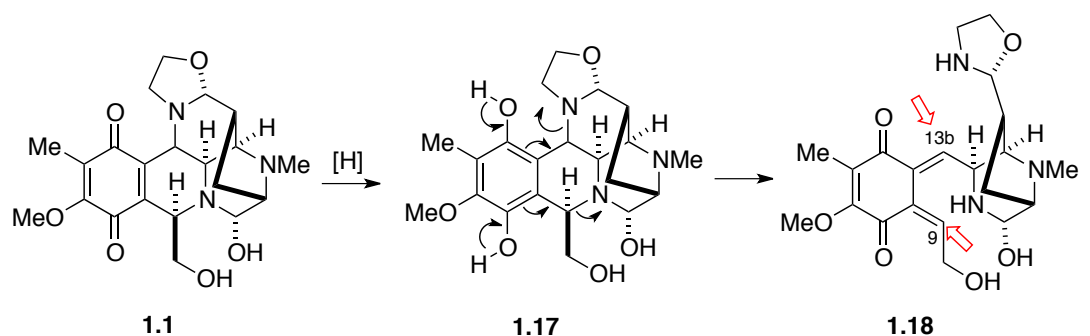

Scheme 1.4. Naphthyridinomycin-derived alkylating intermediate proposed by Moore
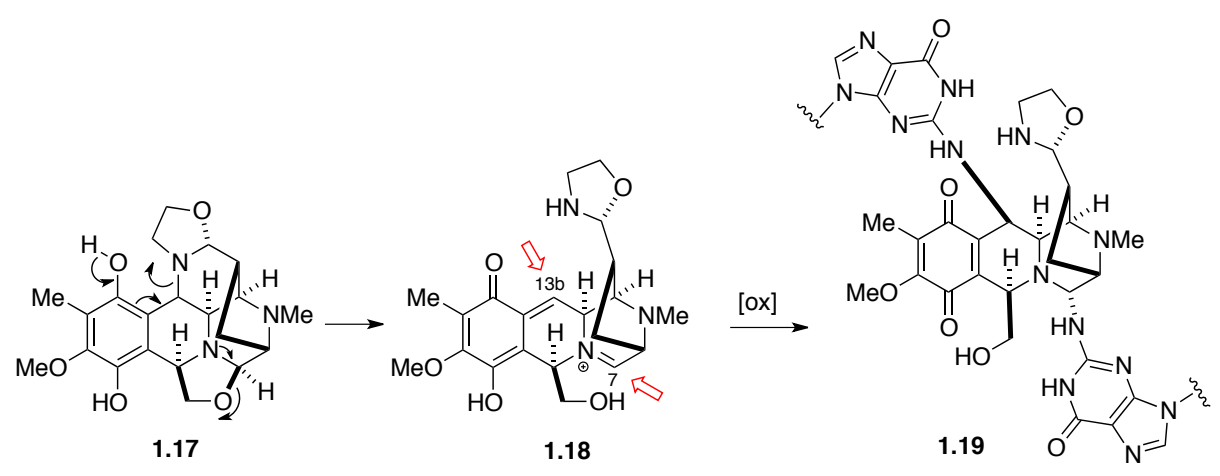

Scheme 1.5. Bioxalomycin $\alpha-2$ cross-linking mechanism proposed by Williams 


\subsection{Lemonomycin}

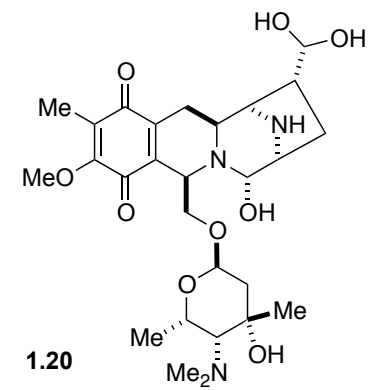

Figure 1.4. Structure of lemonomycin

Lemonomycin (1.20) is a member of the quinocarcin sub-family tetrahydroisoquinoline antitumor antibiotics. Its isolation from the fermentation broth of Streptomyces candidus (LLAP191) was described by Whaley and coworkers in $1964 .{ }^{18}$ The compound showed significant in vitro antimicrobial activities against both gram-negative and gram-positive bacteria (Table 1.1). In addition, in a series of assays it inhibited the bacterial growth in vitro at lower or similar concentrations, when compared to tetracycline, penicillin $\mathrm{G}$ and erythromycin (Table 1.2).

Table 1.1. In vitro antibacterial activities of lemonomycin

\begin{tabular}{lc}
\hline \multicolumn{1}{c}{ Organism } & $\begin{array}{c}\text { MIC } \\
(\mu \mathrm{g} / \mathrm{mL})\end{array}$ \\
\hline Mycobacterium smegmatis ATCC 607 & 6.2 \\
Staphylococcus aureus A TCC 6548P & 0.2 \\
Streptococcus faecalis ATCC 8043 & 0.4 \\
Bacillus subtilis ATCC 6633 & 0.05 \\
Pseudomonas fluorescens ATCC 12633 & 1.6 \\
Proteus vulgaris ATCC 9484 & 0.4 \\
Escherichia coli ATCC 9637 & 1.6 \\
Salmonella gallinarum (Lederle 604) & 0.8 \\
Clostridium sporogenes ATCC 7955 & $>100$ \\
\hline
\end{tabular}


Table 1.2. Comparison of antibacterial activities of lemonomycin (1.20), tetracycline (A), penicillin $\mathrm{G}(\mathrm{B})$ and erythromycin (C), against various staphylococci and streptococci

\begin{tabular}{|c|c|c|c|c|}
\hline \multirow{2}{*}{ Organism } & \multicolumn{4}{|c|}{$\mathrm{MIC}(\mu \mathrm{g} / \mathrm{mL})$} \\
\hline & 1.20 & A & $\mathrm{B}$ & $\mathrm{C}$ \\
\hline Staphylococcus aureus (Lederle 4050B-122-7) & 0.08 & 10 & $>100$ & 1.5 \\
\hline S. aureus (Lederle 4050B-122-10) & 0.15 & $>100$ & $>100$ & 3 \\
\hline S. aureus (Lederle 4050B-122-13) & 0.15 & 2.5 & 0.08 & 3 \\
\hline S. aureus (Lederle 4050B-122-14) & 0.15 & $>100$ & 0.04 & 3 \\
\hline S. aureus Rose ATCC 14154 & 0.15 & $>100$ & $>100$ & 12.5 \\
\hline S. aureus Smith & 0.04 & 2.5 & 0.8 & 1.5 \\
\hline Streptococcus faecalis ATCC 8043 & 0.4 & 2.5 & 2.5 & 0.4 \\
\hline S. pyogenes C203 & $<0.005$ & 1.2 & 0.001 & 0.2 \\
\hline S. pyogenes (Lederle 8053B-40-2) & 0.01 & 25 & 0.01 & 0.4 \\
\hline S. pyogenes (Lederle 8053B-40-3) & 0.01 & 100 & 0.01 & 0.4 \\
\hline S. pyogenes NY5 & $<0.005$ & 2.5 & 0.01 & 0.2 \\
\hline Streptococcus sp $\lambda$-Strep 11 & 5.0 & $>100$ & 2.5 & 1.5 \\
\hline Streptococcus sp. $\beta$-Strep 80 & 2.5 & $>100$ & 2.5 & 1.5 \\
\hline
\end{tabular}

The structure of lemonomycin was reported by He and coworkers in $2000,{ }^{19}$ which also confirmed the in vitro activity against susceptible strains of $S$. aureus and B. subtilis (MICs of 0.2 and $0.05 \mu \mathrm{g} / \mathrm{mL}$, respectively) and performed in vitro assays with methicillin resistant $S$. aureus and vancomycin resistant Enterococcus faecium (MICs of 0.4 and $0.2 \mu \mathrm{g} / \mathrm{mL}$, 
respectively). In addition to the antibacterial activity, $\mathbf{1 . 2 0}$ also showed in vitro activity against the human colon tumor cell line $\mathrm{HCT} 116\left(\mathrm{IC}_{50}=0.36 \mu \mathrm{g} / \mathrm{mL}\right)$.

Structurally, the compound contains the tetracyclic core found in quinocarcin ${ }^{20}$ which includes a 3,8-diazabicyclo ring system and a rare bis-desoxy aminosugar portion, which has only been found in a few natural products. ${ }^{21}$

\subsection{Proposed biosyntheses for the tetrahydroisoquinoline antitumor antibiotics}

The biosynthetic gene clusters of members of the three sub-families have been identified and the bioinformatics analyses revealed the polycyclic backbones are constructed by homologous nonribosomal peptide synthetases (NRPSs) (Figure 1.5). ${ }^{22,23}$ According to Oikawa and coworkers, the four systems share a unique $N$-terminal acyl ligase (AL) domain, which has been found in lipopeptide NRPSs. They proposed that the AL domain is involved in the activation of a fatty acid chain, which is incorporated into an $\mathrm{N}$-acyl dipeptidyl moiety with the involvement of the two condensation-adenylation-peptidyl carrier protein (C-A-PCP) tridomains. In addition, they suggested that a single module ( $\mathrm{SfmC}$ and its homologs) is responsible for the incorporation of a tyrosine derivative into its PCP domain and the assembly of the tetrahydroisoquinoline rings, with the involvement of the reductase (R) and PictetSpenglerase (PS) domains. The NRPSs of quinocarcin (1.3) and cyanocycline (1.27) include an additional module (Qcn19 and Cya17, respectively), which is proposed to be involved in the formation of the pyrrolidine rings found in these natural products. ${ }^{22}$ The detailed function of the NRPS modules will be discussed later. Finally, it has been proposed that a peptidase domain ( $\mathrm{SfmE}$ and its homologs) removes the fatty acid chain at a late stage of the biosynthesis. ${ }^{23}$ 


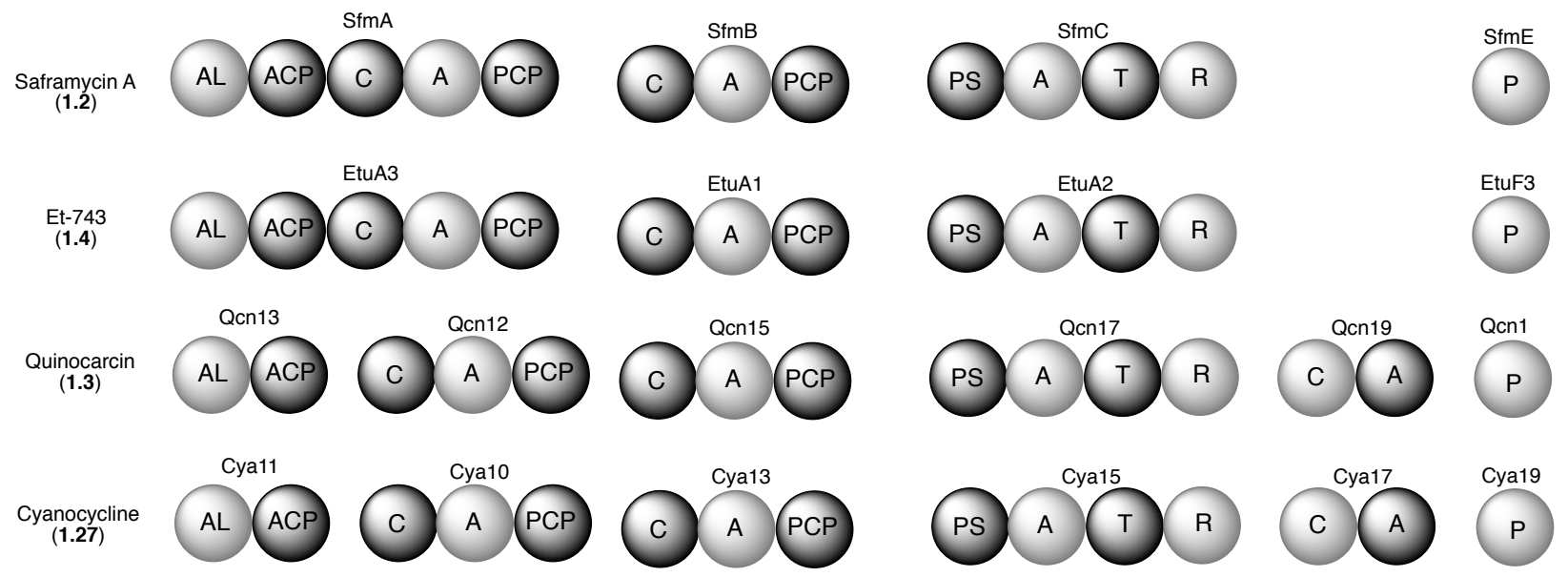

Figure 1.5. Domain organization of NRPSs for tetrahydroisoquinoline antitumor antibiotics biosynthesis. Abbreviations: A, adenylation domain; AL, acyl-CoA ligase domain; ACP, acyl carrier protein; C, condensation domain; PCP, peptidyl carrier protein; R, reductase domain; PS,

Pictet-Spenglerase domain; P, peptidase domain

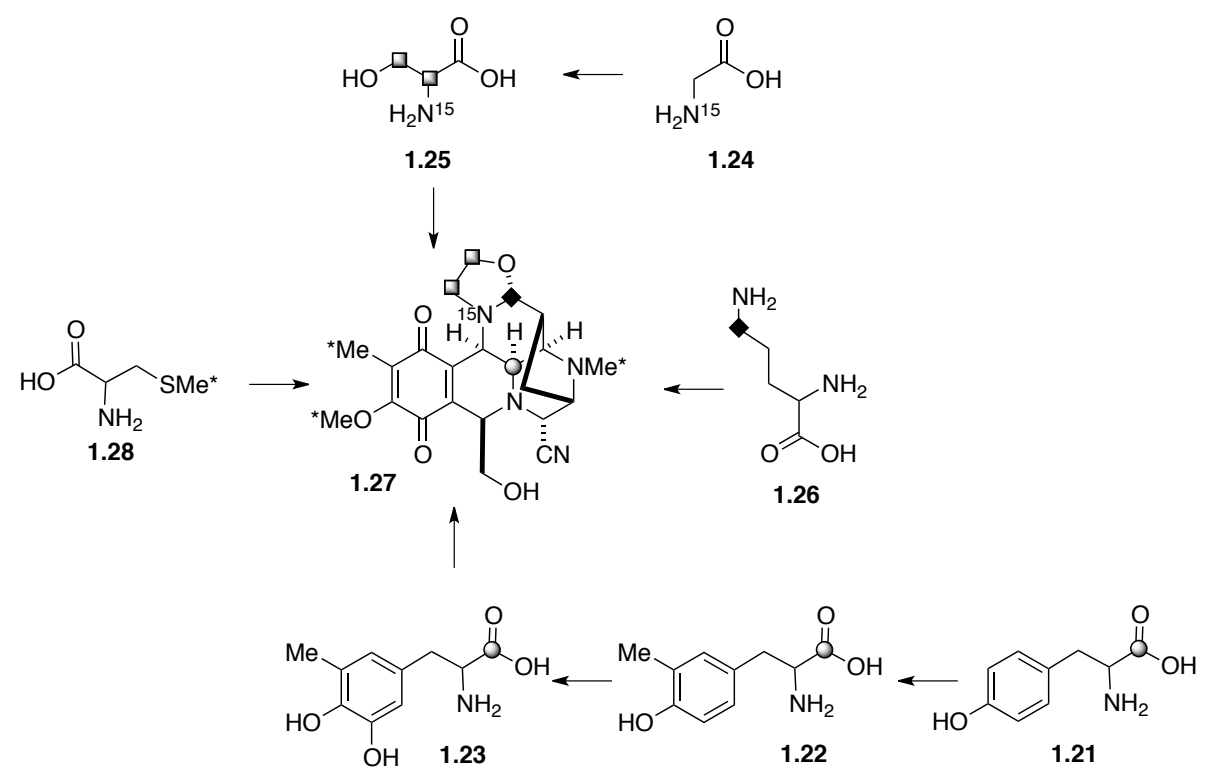

Scheme 1.6. Biosynthetic precursors to cyanocycline A (1.27) 

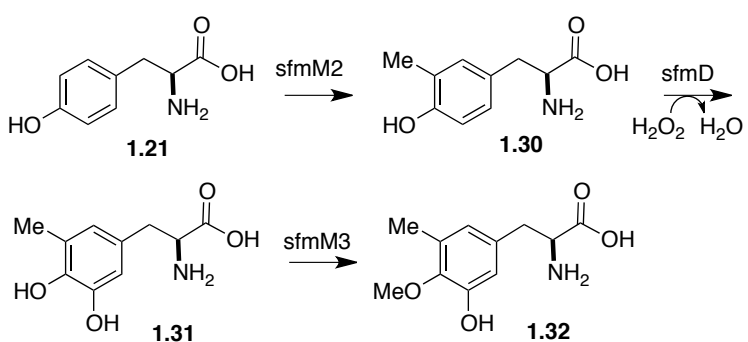

Scheme 1.7. Biosynthesis of 3-hydroxy-5-methyl- $O$-methyl-L-tyrosine (1.32)

The feeding studies conducted by Zmijewsky and coworkers demonstrated that tyrosine (1.21), glycine (1.24), serine (1.25) and ornithine (1.26) are incorporated into the polycyclic skeleton of cyanocycline A (1.27), and that methionine (1.28) is the source of the methyl groups (Scheme 1.6). ${ }^{24}$ In their studies on the biosynthesis of saframycin A from Streptomyces lavendulae, Tang and coworkers identified a gene cassette that encodes the proteins responsible for the conversion of L-tyrosine (1.21) into 3-hydroxy-5-methyl- $O$-methyl-L-tyrosine (1.32) (Scheme 1.7). ${ }^{25} \mathrm{SfmM} 2$ and SfmM3 were identified as a $C$-methyl and $O$-methyl transferases, respectively, ${ }^{25}$ and $\mathrm{SfmD}$ was characterized as a HEME-containing peroxidase that utilizes $\mathrm{H}_{2} \mathrm{O}_{2}$ as the oxidizing agent. ${ }^{26}$

A series of studies conducted by Oikawa and coworkers unveiled the role of the NRPS in the transformations that lead to the assembly of the pentacyclic core of saframycin $A . .^{22,23,27}$ As shown in Scheme 1.8, they proposed that the starter module of the NRPS (SfmA) includes an acyl ligase (AL) - thiolation (T) didomain, which loads a fatty acid unit into the SfmA module (1.33). The condensation-adenylation-thiolation (C-A-T) tridomain utilizes alanine (1.34) to build an $N$-acylalanine (1.35) unit. SfmB loads and activates a glycine fragment (1.36), which reacts with 1.35 to form an $N$-acylalanyl glycine unit (1.37). The thioester group is reduced by the reductase (R) module of $\mathrm{SfmC}$, to release the $N$-acyl dipeptide aldehyde (1.38) from $\mathrm{SfmB}$. The aldehyde reacts with $\mathrm{SfmC}$ loaded with the tyrosine derivative $\mathbf{1 . 3 9}$ in reaction catalyzed by 
the Pictet-Spenglerase (PS) domain to form tetrahydroisoquinoline 1.40. Then, aldehyde $\mathbf{1 . 4 2}$ is reductively released from the $\mathrm{T}$ domain, which is loaded with another unit of the tyrosine derivative. A second Pictet-Spengler reaction occurs between $\mathbf{1 . 4 2}$ and $\mathbf{1 . 3 9}$ to form intermediate 1.43, which is reductively released as aldehyde 1.44. The nitrogen of the southern tetrahydroisoquinoline ring attacks the aldehyde group to form the hemiaminal and complete the assembly of the pentacyclic core of saframycin A. Intermediate $\mathbf{1 . 4 5}$ is converted into presaframycin (1.46) through a series of transformations that include oxidations of the aromatic rings to $p$-quinones, an $N$-methylation, the hydrolysis of the $N$-acyl fragment by the peptidase module ( $\mathrm{SfmE})$ and the transamination of the alanine residue to form the pyruvyl fragment.
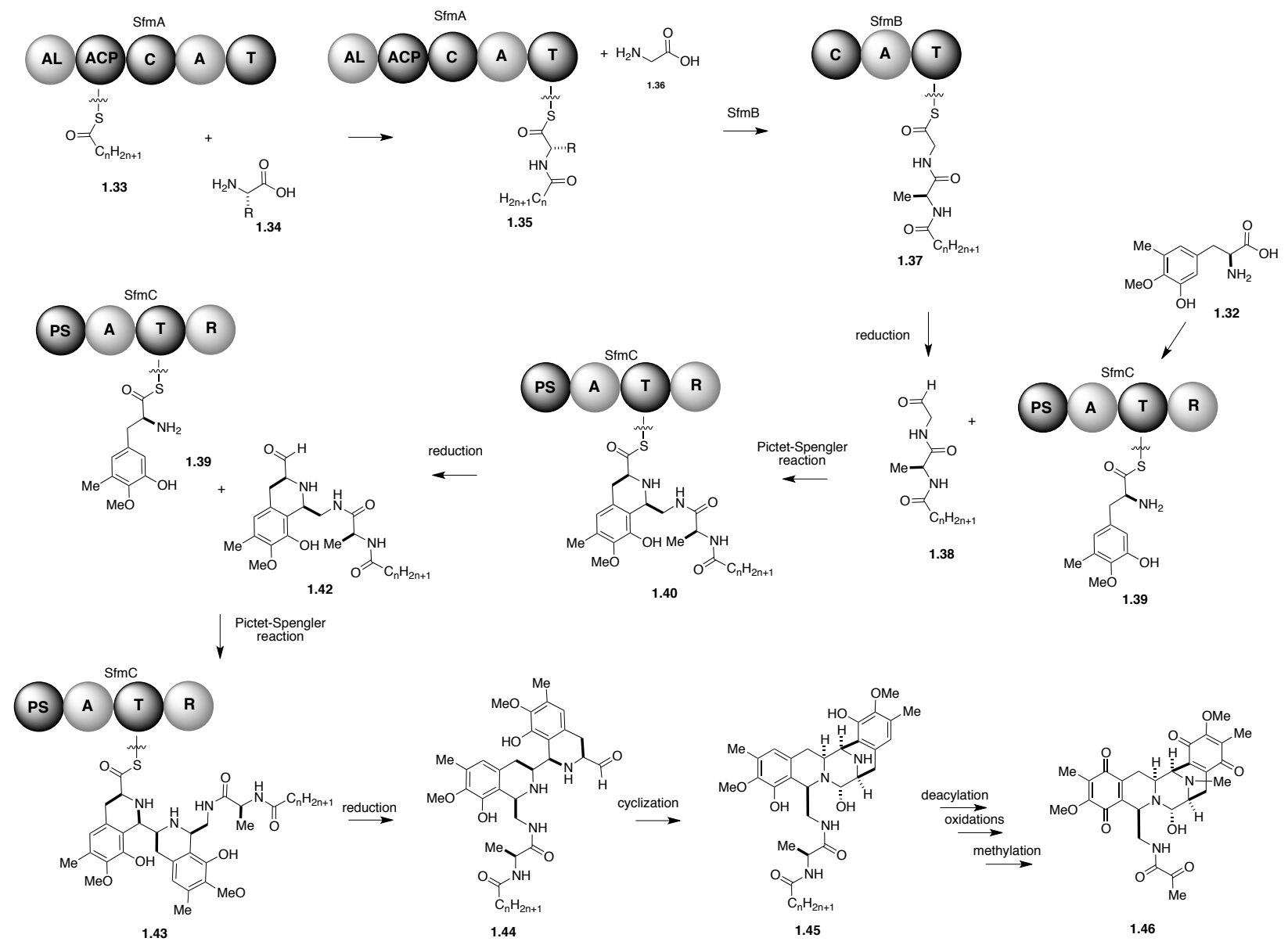

Scheme 1.8. Biosynthesis of pre-saframycin (1.46) 
Sherman and coworkers identified the $\gamma$-protobacterium Candidatus Endoecteinascidia frumentensis as the bacterial symbiont of E. turbinata that produces Et-743 (1.4) ${ }^{28}$ and proposed a biosynthetic pathway for this compound. They identified the genes encoding the enzymes EtuM1, EtuH and EtuM2, as homologues of SfmM2, SfmD and SfmM3, respectively, which are involved in the formation of 3-hydroxy-5-methyl-O-methyl-L-tyrosine (1.32) (vide supra). In addition, they identified the main modules of the NRPS as EtuA1, EtuA2 and EtuA3 and proposed the sequence outlined in Scheme 1.9. EtuA3 forms an $N$-acylcysteine fragment (1.49), which is combined by EtuA1 with a glycolic acid fragment (1.50) to build the T-loaded acylated depsipeptide $\mathbf{1 . 5 1}$

In accordance with Oikawa's proposed sequence (vide supra), intermediate $\mathbf{1 . 5 1}$ is reductively released by the $\mathrm{R}$ module of EtuA2 to form aldehyde $\mathbf{1 . 5 2}$. The tyrosine derivative 1.32 is loaded into EtuA2, to initiate the iterative Pictet-Spengler/reduction sequence that leads to the formation of intermediate $\mathbf{1 . 5 7}$, which cyclizes to produce pentacyclic intermediate $\mathbf{1 . 5 8}$. It has been proposed that EtuF3 is the peptidase involved the removal of the acyl chain and that a subsequent multi-step process, including the oxidation of the left hand side aromatic ring, the addition of the sulfhydryl group into a putative ortho-quinone methide intermediate and an acetylation, leads to the formation of 1.60. The compounds Et-583 (1.60), Et-597 (1.61), Et-596 (1.62) and Et-594 (1.63) have been isolated from E. turbinata. However, none of the enzymes involved in the transformation of 1.59 into Et-743 (1.4) have been identified. The proposed final steps of sequence involve the $N$-methylation of 1.60, a transamination step that gives rise to the $S$-substituted pyruvyl fragment of $\mathbf{1 . 6 2}$ and an oxidation that forms the methylenedioxy moiety of 1.63. Lastly, it was proposed that tyrosine derivative $\mathbf{1 . 6 4}$ is incorporated via a Pictet-Spengler 
reaction to form the northern tetrahydroisoquinoline ring and that the resulting enzyme bound intermediate is converted into Et-743 through an unknown mechanism.
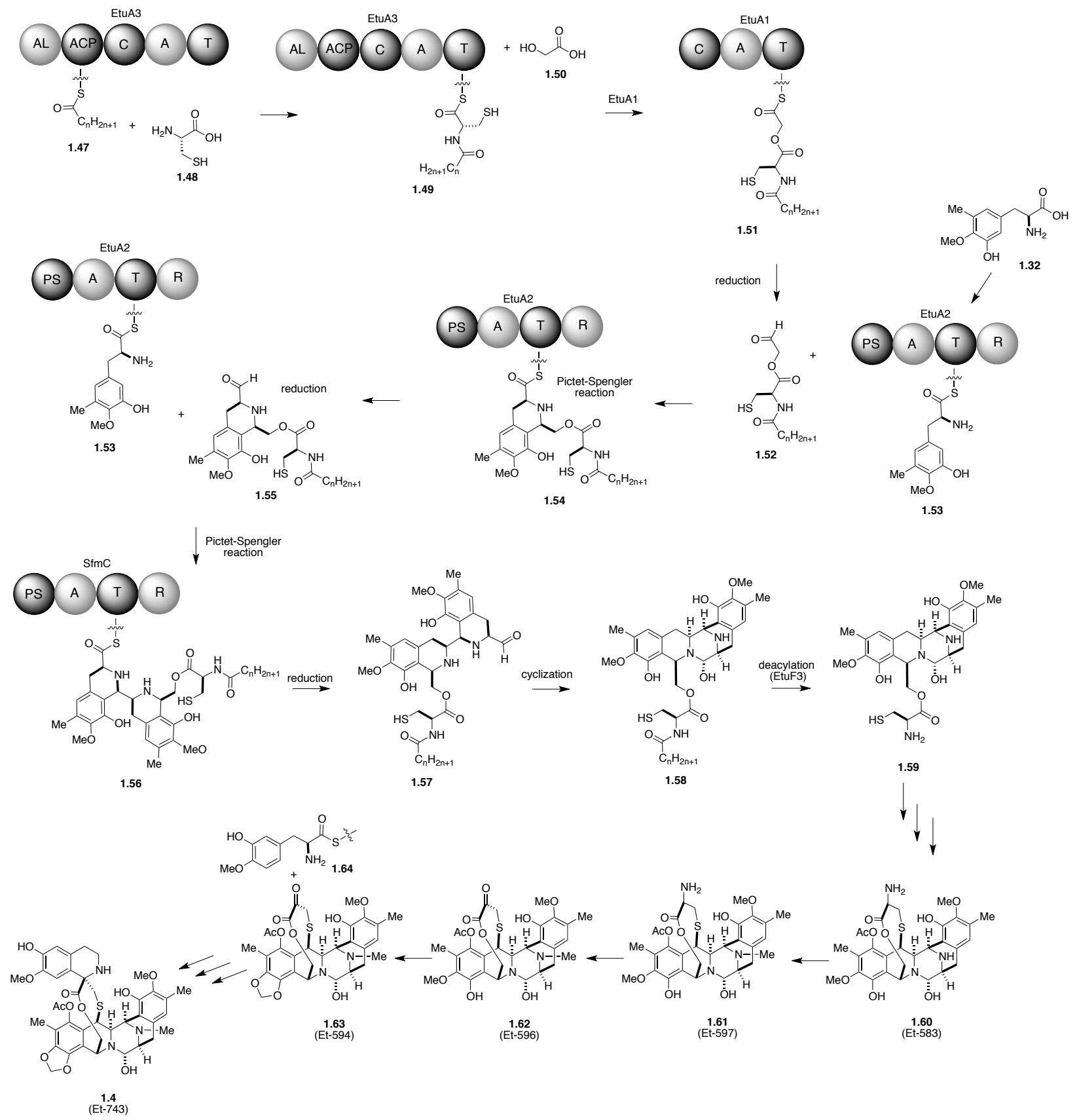

Scheme 1.9. Biosynthesis of Et-743 (1.3) 
A report from Tang and coworkers revealed the biosynthetic origin of the glycolyl unit that is loaded into the starting modules of the NRPSs for naphthyridinomycin (1.1), from Streptomyces lusitanus, and quinocarcin (1.3), Streptomyces melanovinaceus. In both cases, they identified two-component transketolase (Tkase)/acyl carrier protein (ACP) systems that utilize ketoses as substrates for the preparation of the glycolyl fragments. ${ }^{29}$ As shown in Scheme 1.10, the NapB/QncN modules utilize a ketose phosphate (1.65) to form a glycoaldehyde-ThDP unit (1.67). The C-2 fragment is transferred to a lipoyl fragment attached to NapD/QncL to form glycolyl lipoic acid intermediate 1.68. Then, the NapC/QcnM modules catalyze the transfer of the glycolyl unit to an acyl carrier protein (ACP), to form 1.70, which is utilized by the NRPSs for the incorporation of the $\mathrm{C}-2$ fragment into the tetrahydroisoquinoline ring system of naphthyridinomycin (1.1) and quinocarcin (1.3). The mechanism of the ThDP-dependent incorporation of the C-2 unit into $\mathrm{NapB} / \mathrm{QncN}$ starts with the attack of thiazolium ylide of thiamine diphosphate (ThDP) (1.71) into the carbonyl carbon of a ketose unit (1.72), to form intermediate 1.73. Then, the bond between $\mathrm{C}-2$ and $\mathrm{C}-3$ breaks in a process assisted by the imidazole moiety of a histidine residue (1.74), leading to the formation of the glycoaldehyde intermediate $\mathbf{1 . 7 6}$ and an aldose, such as D-gliceralehyde-3-phosphate (1.75).

In their study of the Et-743 producing organism, Sherman and coworkers reported several genes with unknown roles in the biosynthetic pathway, ${ }^{28}$ including two components of a possible pyruvate dehydrogenase complex (EtuP1 and EtuP2). ${ }^{28}$ Tang and coworkers identified these two proteins as homologs of the $\mathrm{NapB} / \mathrm{QcnN}$ and $\mathrm{NapD} / \mathrm{QcnL}$ systems and proposed that the biosynthetic origin of the glycolyl unit is the same for the three pathways. ${ }^{29}$ 

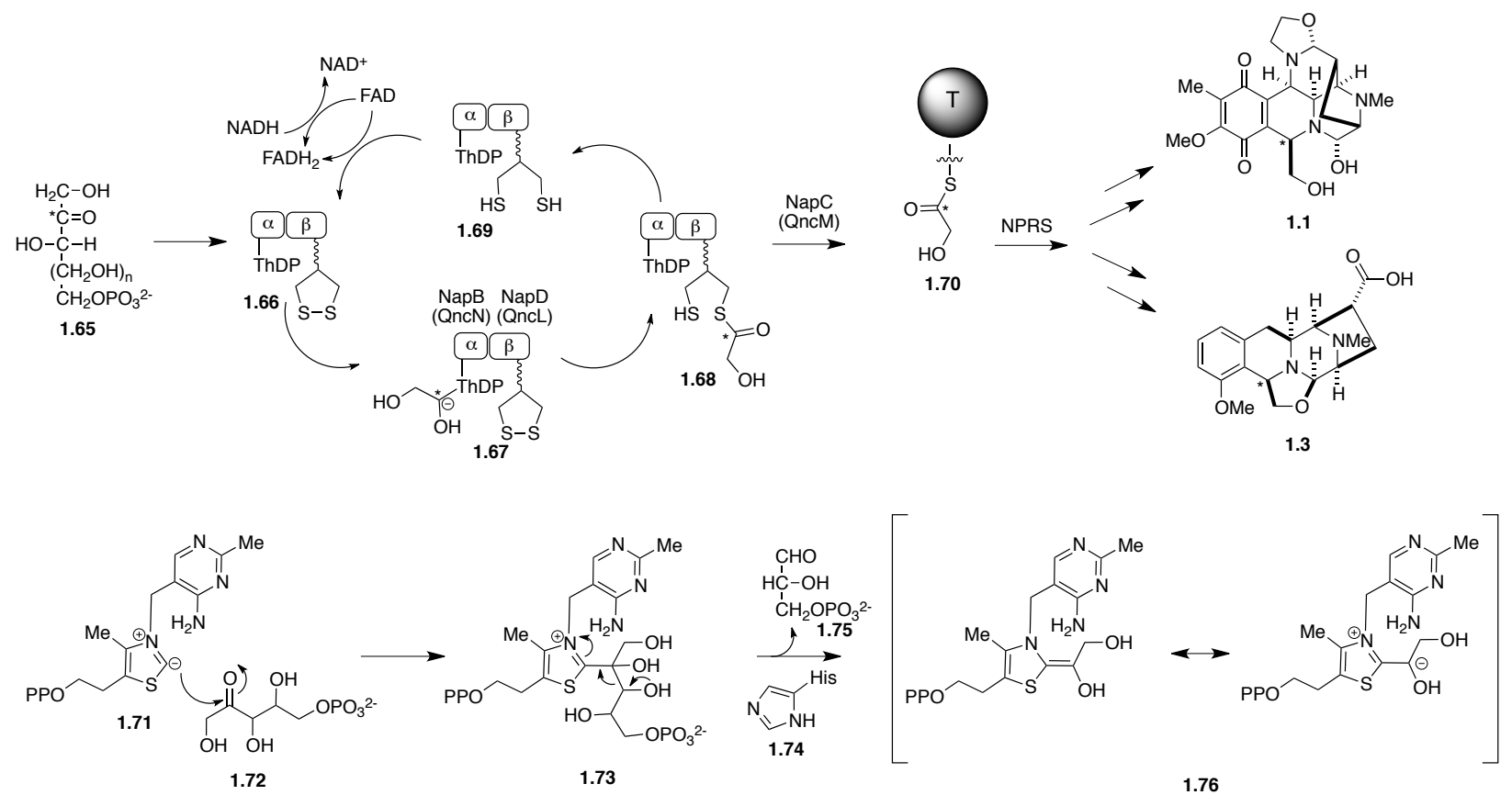

Scheme 1.10. Biosynthetic origin of the C-2 unit of naphthyridinomycin and quinocarcin

\subsection{Biosynthesis proposal for lemonomycin}

The biosynthesis of lemonomycin has not been studied. However, we expect that it would occur analogously to the biosynthesis of the other members of the tetrahydroisoquinoline family of antitumor antibiotics. Based on the information discussed in the previous section, we propose that the tetracyclic ring system of lemonomycin is constructed by a NRPS homologous to the NRPSs of quinocarcin (1.3) and naphtryridomycin (1.1). As shown in Scheme 1.11, our proposed sequence involves the assembly of a T-loaded $N$-acyldepsipeptide $\mathbf{1 . 8 0}$ utilizing a an acyl fragment loaded into the ACP of the first module 1.76, an unidentified amino acid 1.77 and a ketose-derived glycolyl unit $\mathbf{1 . 7 9}$ loaded into the third module. 


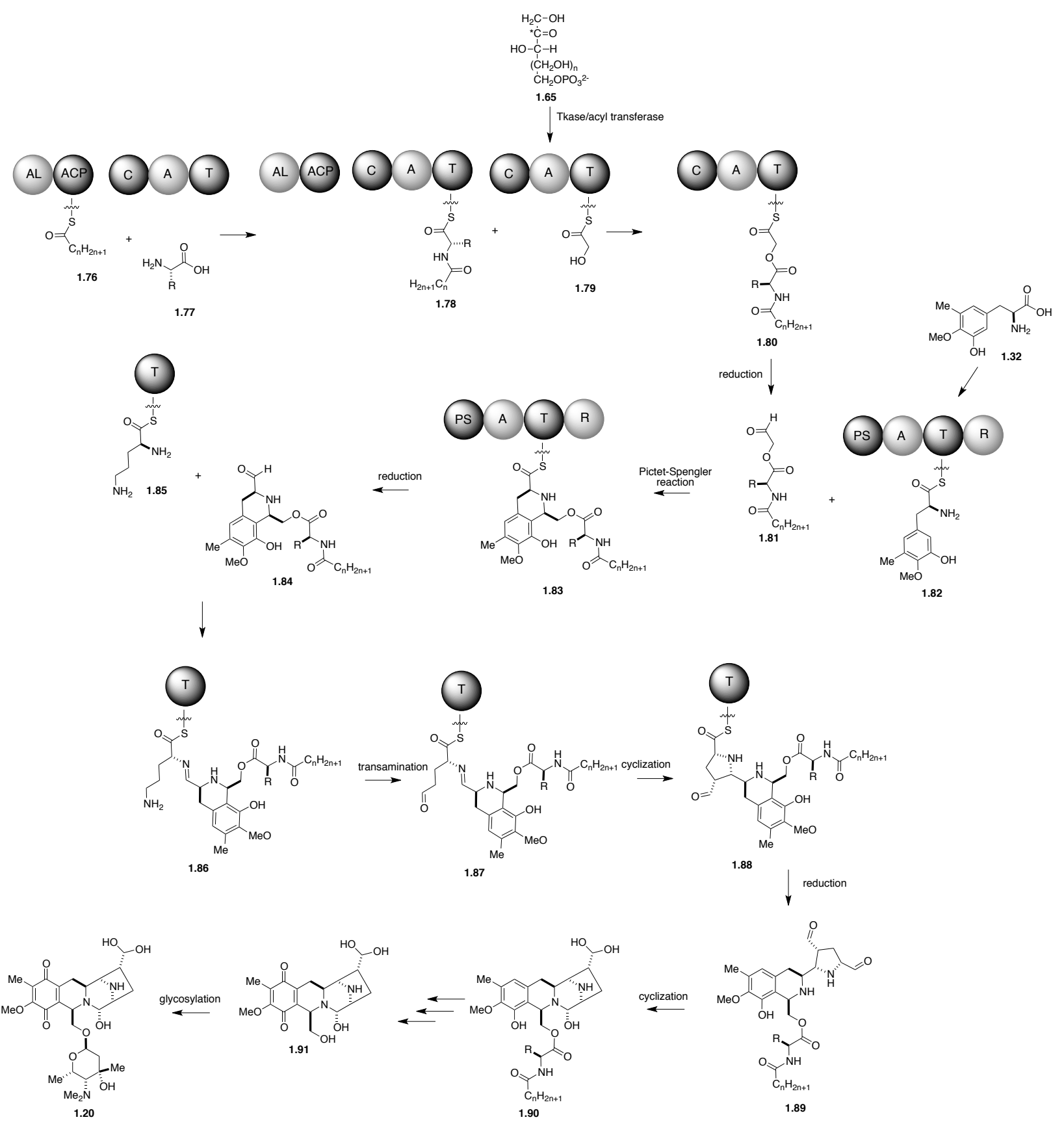

Scheme 1.11. Proposed biosynthesis of lemonomycin 
The $N$-acyldepsipeptide $\mathbf{1 . 8 0}$ is reductively released to afford aldehyde $\mathbf{1 . 8 1}$, which reacts with the tyrosine derivative unit loaded into the $\mathrm{T}$ domain of the fourth module (1.82) to give intermediate 1.83, in a reaction catalyzed by the Pictet-Spenglerase domain (PS). The reductase domain $(\mathrm{R})$ reduces the thioester group to release aldehyde $\mathbf{1 . 8 4}$, which reacts with the $\alpha$-amino group of an D-ornithine unit loaded into the T-domain of an different module (1.85), to form imine intermediate 1.86. The transamination of $\gamma$-amino group forms the aldehyde group of $\mathbf{1 . 8 7}$, which could react via an enol intermediate addition into the imine group, to form the pyrrolidine group of 1.88. In accordance with Oikawa's proposal, we submit that the formation of the pyrrolidine ring involves the participation of a module that is homologous to Qcn19 and Cya17. Then, the reduction of the thioester group would form dialdehyde $\mathbf{1 . 8 9}$, which could cyclize to form the hemiaminal moiety of $\mathbf{1 . 9 0}$. The hydrolyses of the peptide and ester groups and the oxidation of the aromatic ring would afford lemonomycin aglycon (1.91), which could be transformed into lemonomycin (1.20) via a glycosylation event. 


\section{CHAPTER 2}

\section{Previous synthetic work on lemonomycin}

\subsection{Introduction}

The structural complexity and biological activities of the tetrahydroisoquinoline antitumor antibiotics have made them attractive targets for the synthetic community. In this chapter we will discuss the synthetic work related to lemonomycin. To date, there are two total syntheses of lemonomycin by Stoltz ${ }^{30}$ and Fukuyama ${ }^{31,32}$ and synthetic studies by Magnus, ${ }^{33,34}$ Zhu, ${ }^{35,36}$ Mulzer $^{37}$ and our laboratory. ${ }^{38}$

\subsection{Stoltz's total synthesis}

In 2003, Stoltz and coworkers made the first report of the total synthesis of lemonomycin. ${ }^{30}$ Their concise and convergent approach involved a longest linear sequence of 15 steps. The synthetic sequence starts with a [3+2] dipolar cycloaddition between an Oppolzer's sultam-derived acrylamide (2.1) and oxidopyrazinium salt 2.2 (Scheme 2.1). The chiral auxiliary was removed under reductive conditions to afford primary alcohol 2.3. Protection of the hydroxyl with TIPSOTf, followed by a stereospecific iodination gave $Z$-iodoenamide $\mathbf{2 . 4}$, which was utilized in a Suzuki coupling with boronic ester 2.5 to form aryl enamide 2.6. The reduction of the double bond and the hydrogenolysis of the benzyl group provided 2.7 stereospecifically. The secondary amine was converted into the $\mathrm{Cbz}$ carbamate and the phenolic tosylate was cleaved with KOTMS to give 2.8. Then, the amide was converted into the Boc carbamate to facilitate the reduction of the carbonyl, and the acid-labile protecting groups were removed with methanolic $\mathrm{HCl}$ to give aminotriol 2.10. This compound was combined in a Pictet-Spengler reaction with aldehyde $\mathbf{2 . 1 1}$ (vide infra) to afford substituted tetrahydroisoquinoline $\mathbf{2 . 1 2}$. After 
removing the $\mathrm{Cbz}$ carbamate under hydrogenolysis conditions, an oxidation under Swern conditions $^{39}$ was used to transform the two primary hydroxyls into the hemiaminal and aldehyde hydrate groups. Finally, an oxidation with ceric ammonium nitrate gave (-)-lemonomycin (1.20).
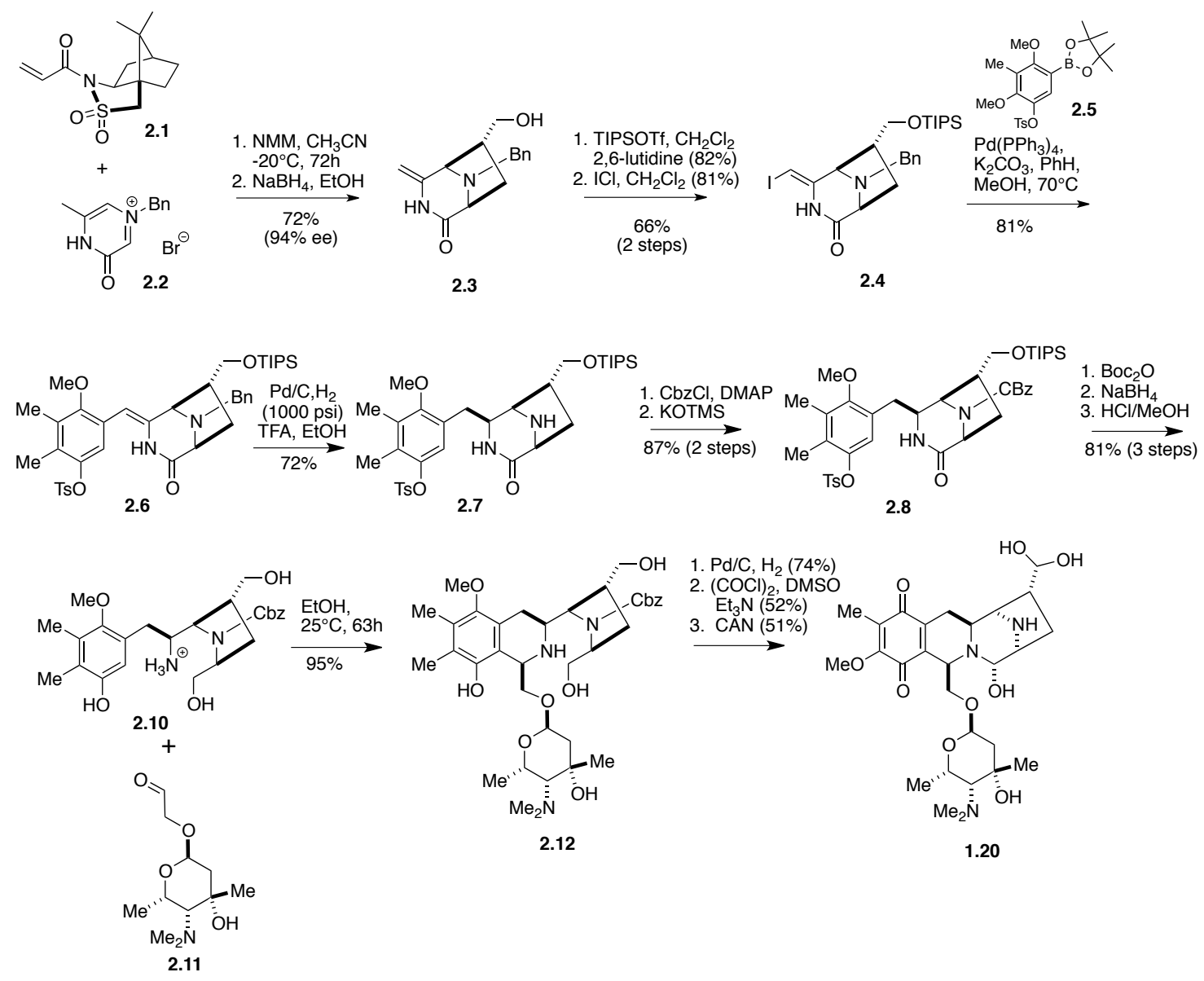

Scheme 2.1. Stoltz's total synthesis of lemonomycin (1.20)

The sequence for the preparation of aldehyde 2.11 started with the synthesis of ketone 2.14 from D-threonine (2.13) (Scheme 2.2). Felkin-controlled aldol addition of the lithium enolate of ethyl acetate into 2.14 gave 2.15 stereospecifically. ${ }^{40}$ Then, formation of a lactone through the acid-mediated cleavage of the oxazolidine ring, followed by reaction with dimethoxymethane and TMSOTf to form the fused oxazolidine ring, reduction to the lactol with DIBAL and protection with allyl bromide provided 2.16. Treatment with REDAL, which 
induced both the reduction of the hemiaminal ether and the cleavage of the benzenesulfonyl group, followed by a methylation under reductive amination conditions, and a Lemieux-Johnson oxidation, ${ }^{41}$ gave $\mathbf{2 . 1 1}$.

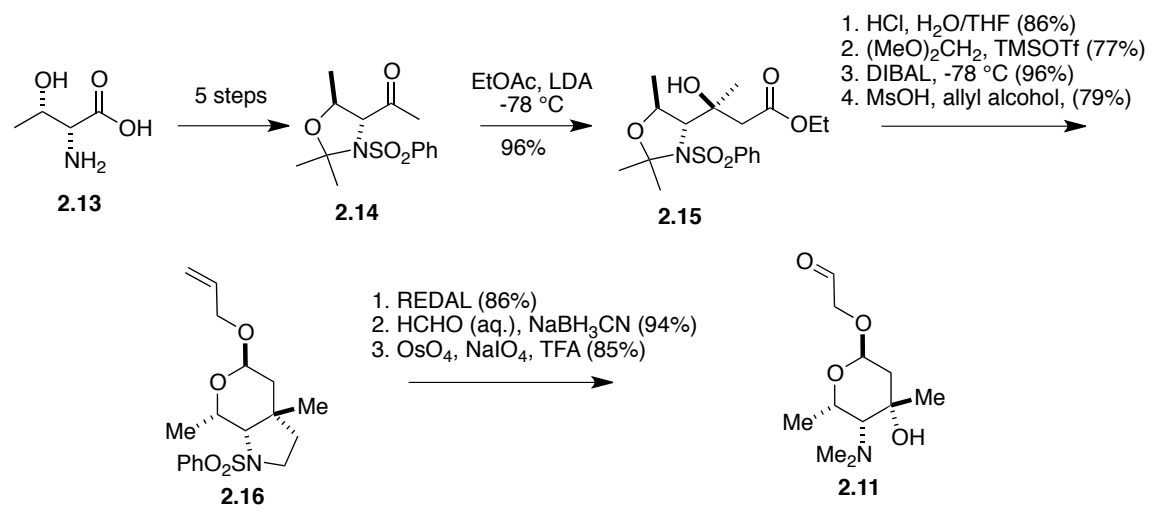

Scheme 2.2. Stoltz's synthesis of aldehyde $\mathbf{2 . 1 1}$

\subsection{Fukuyama's total synthesis}

In 2012, Fukuyama and coworkers published their total synthesis of lemonomycin. ${ }^{31}$ The first step in the sequence is the alkylation of Oppolzer's sultam derived glycinate $\mathbf{2 . 1 7}$ with iodopropargylsilane $\mathbf{2 . 1 8}$, followed by acid hydrolysis of the imine to provide $\mathbf{2 . 1 9}$ as a single diastereomer (Scheme 2.3). Coupling with $N$-Boc glycine, followed by reflux with formic acid and protection with Boc anhydride gave diketopiperazine 2.21. This compound was combined with aldehyde $\mathbf{2 . 2 2}$ in a Perkin-type condensation, ${ }^{42}$ to form $Z$-enamide $\mathbf{2 . 2 3}$ with high stereoselectivity. Partial reduction of the triple bond, followed by sodium borohydride reduction of the activated carbonyl gave 2.24. Then, a TFA-induced Hosomi-Sakurai reaction was employed to form the diazabicyclo[3.2.1]octane ring system of $\mathbf{2 . 2 5}$. The secondary amine was 

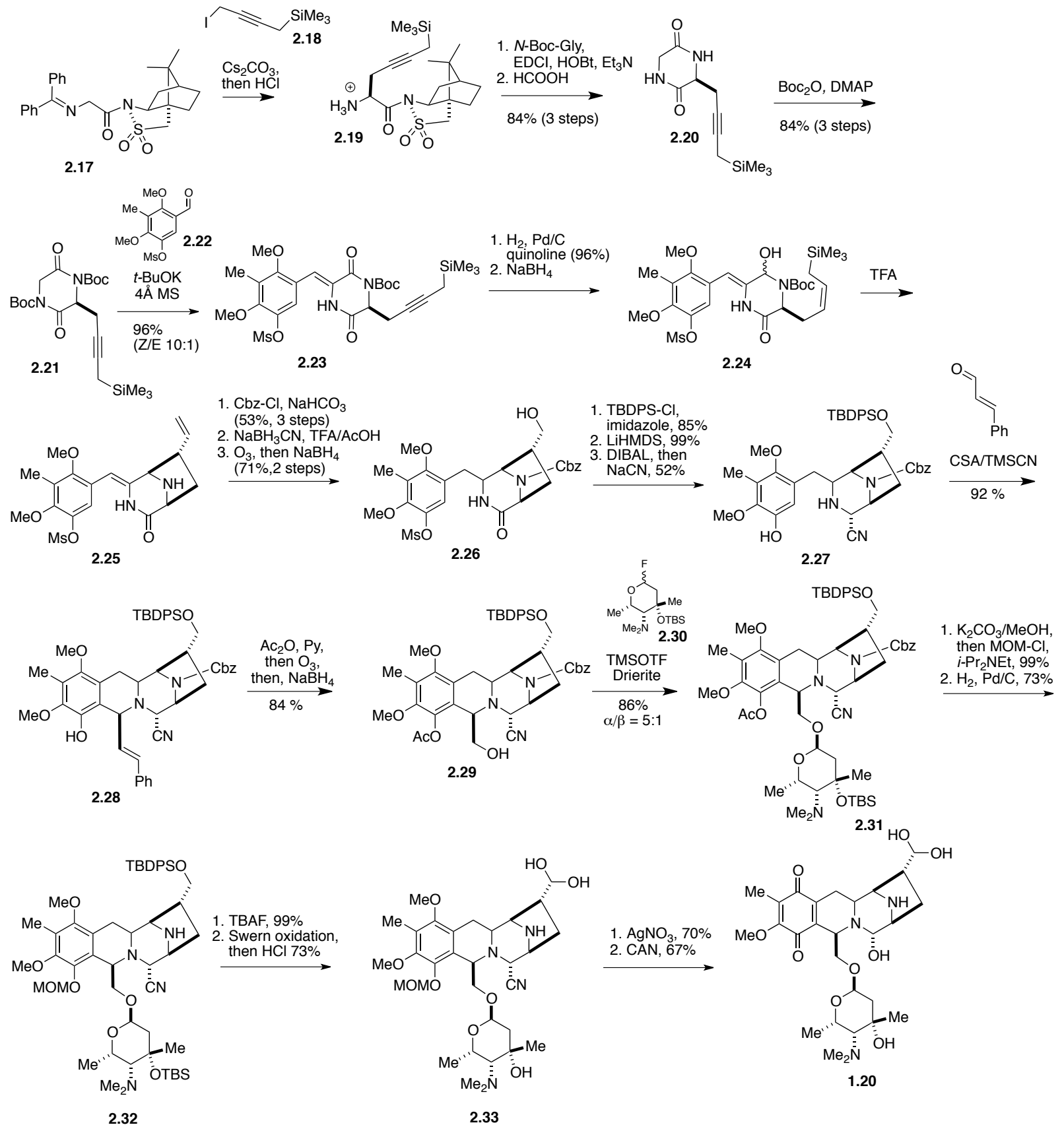

Scheme 2.3. Fukuyamas's total synthesis of lemonomycin (1.20)

converted into the $\mathrm{Cbz}$ carbamate and the enamide double bond was reduced with sodium cyanoborohydride under acidic conditions. Then, the resulting compound was treated with ozone followed by sodium borohydride, to afford 2.26. The primary hydroxyl was converted into the 
TBDPS silyl ether, the phenolic mesylate was removed with LiHMDS and the amide was treated with sodium cyanoborohydride and sodium cyanide to give aminonitrile $\mathbf{2 . 2 7}$. This compound was combined with cinnamaldehyde in a Pictet-Spengler reaction that provided tetracycle $\mathbf{2 . 2 8}$ stereospecifically. Acetylation of the phenolic hydroxyl, followed by ozonolysis and treatment with sodium borohydride, gave 2.29. A glycosylation reaction with fluoroglycoside $\mathbf{2 . 3 0}$ (vide infra) was employed to form 2.31. A one-pot approach was used to cleave the phenolic acetate and install the methoxymethyl ether, and the Cbz group was removed under hydrogenolysis conditions to provide $\mathbf{2 . 3 2}$. Then, removal of the silyl protecting groups with TBAF and oxidation of the primary alcohol under Swern conditions ${ }^{39}$ with an acidic workup provided compound 2.33. The completion of the synthesis was achieved by the conversion of the aminonitrile into the hemiaminal with $\mathrm{AgNO}_{3}$ and the oxidation of the aromatic ring to the $p$ quinone using ceric ammonium nitrate.

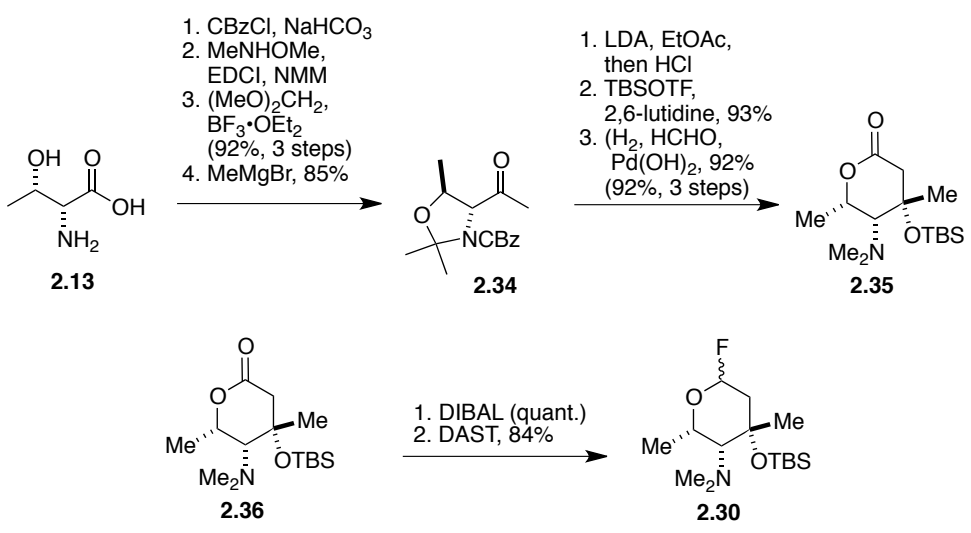

Scheme 2.4. Fukuyama's synthesis of fluoroglycoside $\mathbf{2 . 3 0}$

The synthesis of the glycosylation reagent $\mathbf{2 . 3 0}$ involves the preparation of ketone $\mathbf{2 . 3 4}$ from D-threonine (2.13), with a sequence comprising $\mathrm{Cbz}$ protection, conversion of the carboxylic acid into a Weinreb amide, formation of the oxazolidine ring and transformation into the methyl ketone with $\mathrm{MeMgBr}$ (Scheme 2.4). Then, Felkin controlled addition of the lithium 
enolate of EtOAc, ${ }^{40}$ followed by protection of the resulting tertiary alcohol as TBS ether and hydrogenolysis of the $\mathrm{Cbz}$ under reductive amination conditions gave lactone $\mathbf{2 . 3 5}$. The sequence was completed with a DIBAL reduction and the conversion of the resulting lactol into the fluoroglycoside with DAST. ${ }^{43}$

\subsection{Magnus's racemic synthesis of lemonomycinone amide}

In 2005, Magnus and Matthews reported a racemic synthesis of lemonomycinone amide (2.52), ${ }^{33}$ a putative natural product that is structurally related to lemonomycin aglycon. They built a quinoline system via a modification of the Larock isoquinoline synthesis ${ }^{44}$ that involved the sequential coupling of $o$-iodoimine $\mathbf{2 . 3 8}$ with alkyne $\mathbf{2 . 3 9}$ under Castro conditions ${ }^{45}$ and a copper-catalyzed ring closure (Scheme 2.5). The addition of benzyloxymethyllithium ${ }^{46}$ to $\mathbf{2 . 4 0}$, followed by treatment with methyl chloroformate gave isoquinoline 2.41. The deprotection of the primary alcohol with TBAF induced the formation of the oxazolidinone ring, and the stereoselective reduction of the double bond, followed by treatment with hydrazine and $\mathrm{KOH}$ provided cis-substituted tetrahydroisoquinoline $\mathbf{2 . 4 3}$. Then, conversion of the amino and hydroxyl groups into their silyl derivatives, followed by treatment with glycine derived mixed anhydride $\mathbf{2 . 4 4}$ provided amide $\mathbf{2 . 4 5}$. Hemiaminal thioeter $\mathbf{2 . 4 6}$ was obtained by oxidizing the primary alcohol and treating the resulting hemiaminal ether with tiophenol under acidic conditions. The alkylation of $\mathbf{2 . 4 6}$ with iodide $\mathbf{2 . 4 7}$, followed by inversion of the stereocenter with tert-BuLi and removal of the TIPS protecting group gave 2.49. Then, oxidation under Swern conditions ${ }^{39}$ and conversion of the resulting aldehyde into the silyl enol ether provided 2.50. The formation of the diazabicyclo[3.2.1] octane ring system was achieved by treatment with $\mathrm{AgBF}_{4}$, which triggers an $\mathrm{N}$-acyliminium ion cyclization. The final three steps of the sequence 
involve hydrogenolysis of the benzyl groups with Pearlman's catalyst, the removal of the $N$-Boc carbamate under acidic and the oxidation of the aromatic ring with ceric ammonium nitrate.
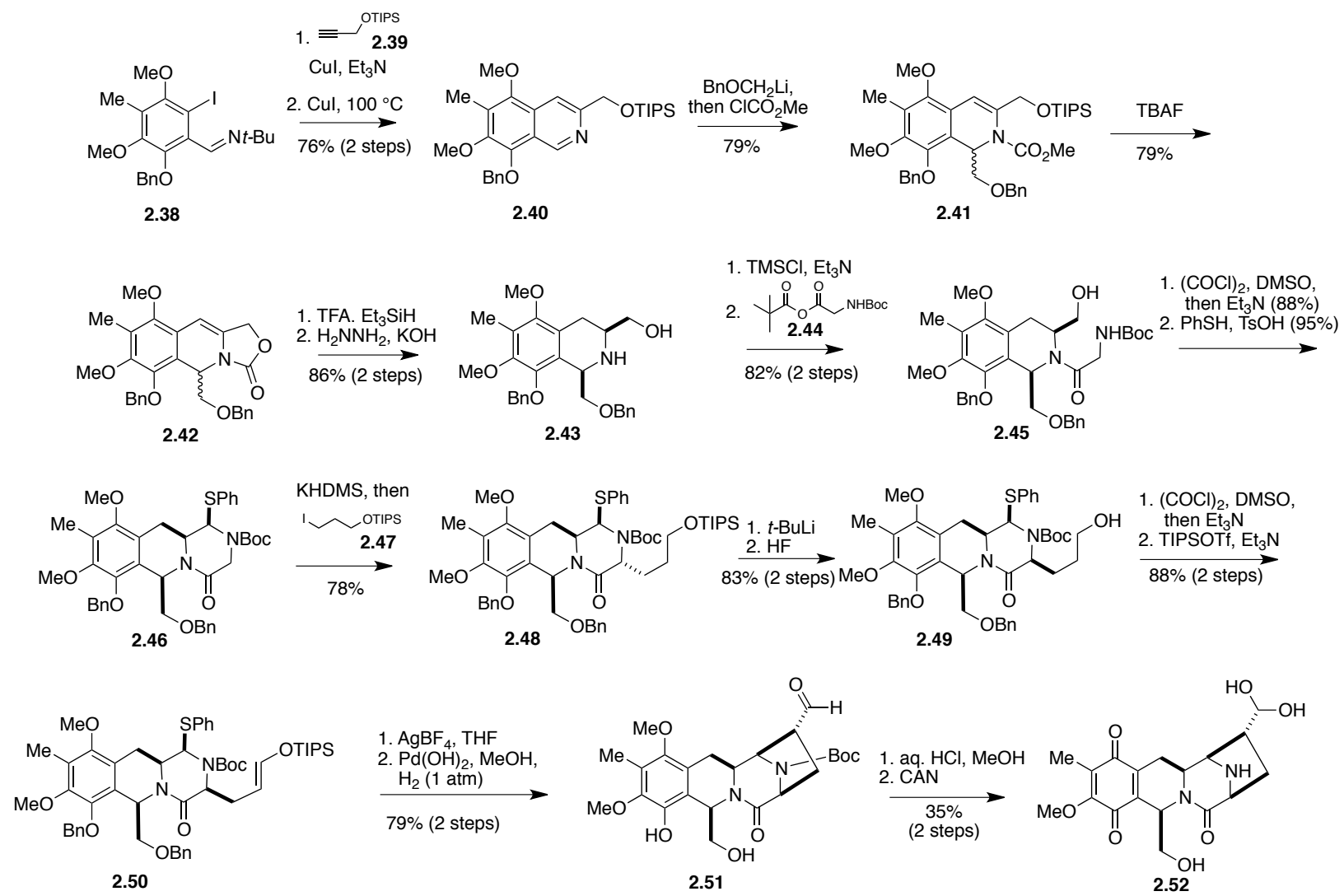

Scheme 2.5. Magnus' synthesis of lemonomycinone amide (2.52)

\subsection{Zhu's asymmetric synthesis of lemonomycinone amide}

In 2009, Zhu and coworkers published an asymmetric synthesis of lemonomycinone amide, which involved an overall strategy that replicated Magnus' approach for the construction of the diazabicyclo[3.2.1] octane ring system via a Lewis acid induced $N$-acyl iminium ion cyclization (vide supra). ${ }^{35 \mathrm{~b}}$ The synthesis of the cis-tetrahydroisoquinoline fragment started with the enantioselective alkylation of tert-butyl glycinate 2.53 with benzyl bromide 2.54 in the presence of Corey-Lygo's phase transfer catalyst $(\mathbf{2 . 5 5}),{ }^{47,48}$ followed by hydrolysis of the imine and removal of the phenolic TBS ether to give tyrosine derivative $\mathbf{2 . 5 6}$ (Scheme 2.6). Then, a 
Pictet-Spengler reaction between $\mathbf{2 . 5 6}$ and benzyloxyacetaldehyde provided cis-substituted tetrahydroisoquinoline 2.57. Protection of the secondary amino group as the Boc carbamate, followed by benzylation of the phenol and methanolic acidolysis of the tert-butyl ester furnished compound 2.58.

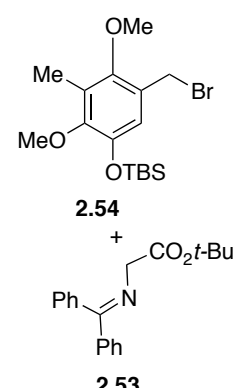

2.53

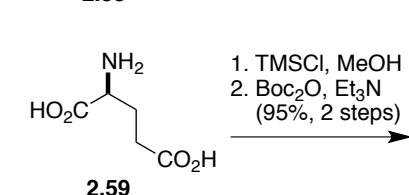

2.59
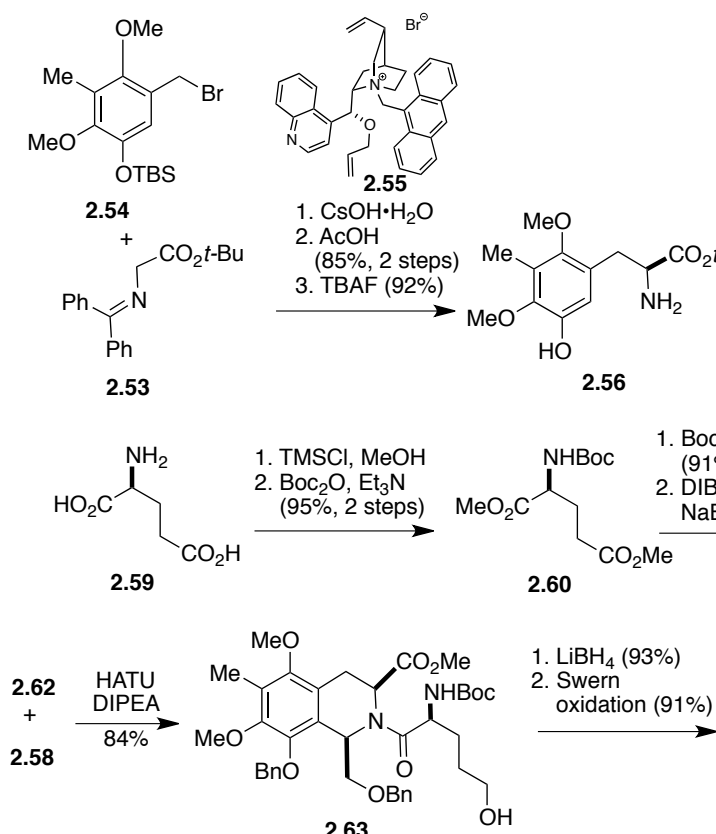
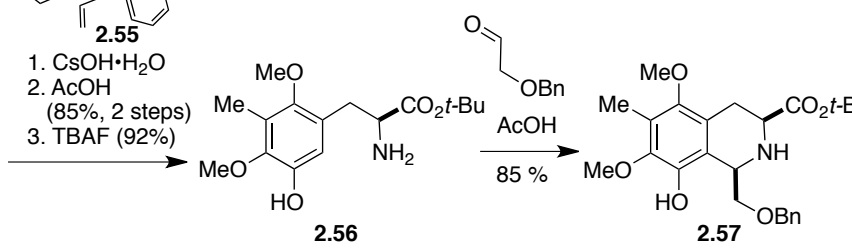

1. $\mathrm{Boc}_{2} \mathrm{O}$, DIPEA
$(90 \%)$
2. $\mathrm{BnBr}, \mathrm{Cs}_{2} \mathrm{CO}_{3}$,
$\mathrm{Nal}(98 \%)$

3. $\mathrm{SOCl}_{2}, \mathrm{MeOH}$

\begin{tabular}{c}
$(92 \%)$ \\
\hline
\end{tabular}

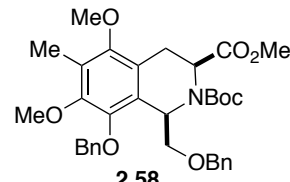

1. $\mathrm{CeCl}_{3} \cdot 7 \mathrm{H}_{2} \mathrm{O}, \mathrm{Nal}$

2. TBSCl, imidazole

(79\%, 2 steps)

3. $\mathrm{LiOH}(97 \%)$

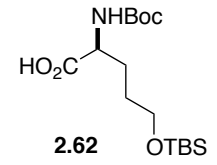

2.61
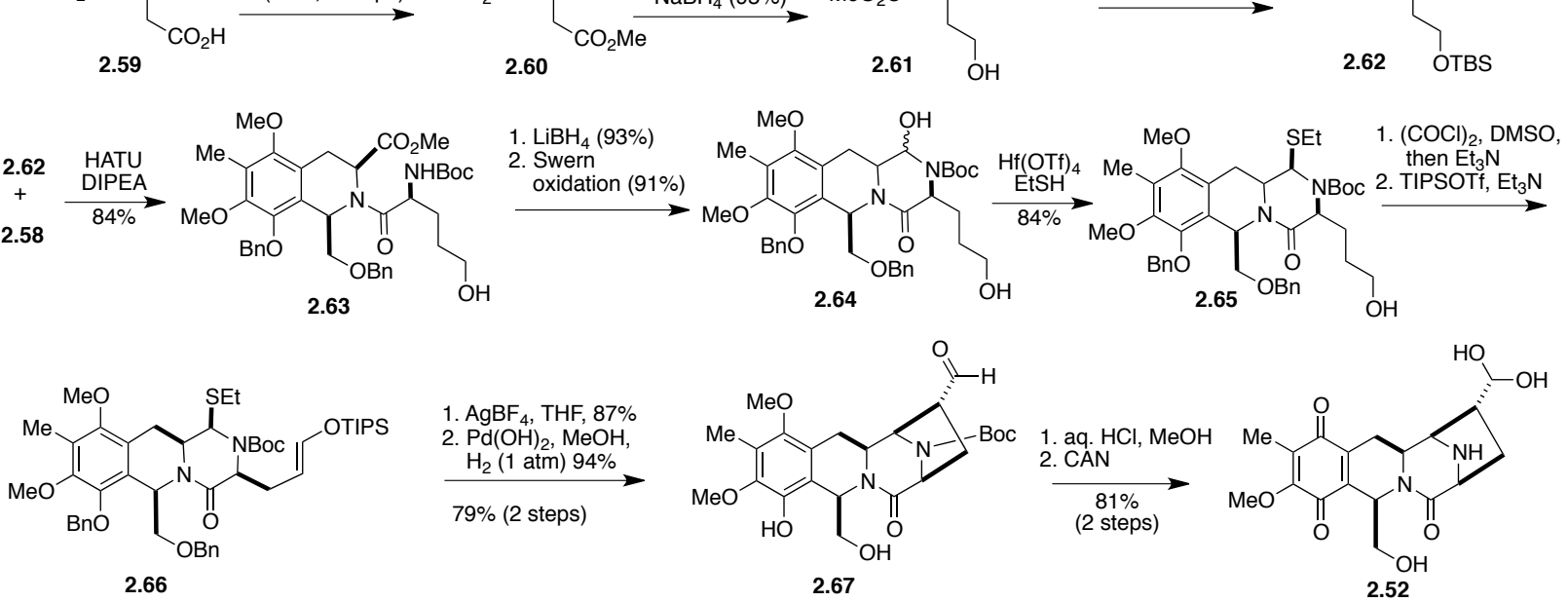

Scheme 2.6. Zhu's asymmetric synthesis of lemonomycinone amide (2.52)

The sequence used for the conversion of L-glutamic acid (2.59) into 2.61 comprises an esterification, two consecutive Boc protection steps, a regiospecific reduction of the less sterically hindered ester with DIBAL-H and a reduction with $\mathrm{NaBH}_{4}$ to form the primary alcohol. Then, removal of one of the $N$-Boc groups with cerium chloride, followed by TBS protection of the primary alcohol and hydrolysis of the ester with LiOH provided compound 2.62. Tetrahydroisoquinoline $\mathbf{2 . 5 8}$ and amino acid $\mathbf{2 . 6 2}$ were combined under peptide coupling 
conditions to provide amide 2.63. After the reduction of the methyl ester with lithium borohydride, the resulting primary alcohol was oxidized under Swern conditions ${ }^{39}$ to afford hemiaminal 2.64. Then, treatment with ethanothiol and hafnium triflate provided hemiaminal thioether 2.65. This compound was converted into (-)-lemonomycinone amide using the same 5step sequence employed by Magnus for the conversion of hemiaminal thioether 2.49 into $( \pm)$ lemonomycinone amide (vide supra).

\subsection{Zhu's asymmetric synthesis of lemonose}

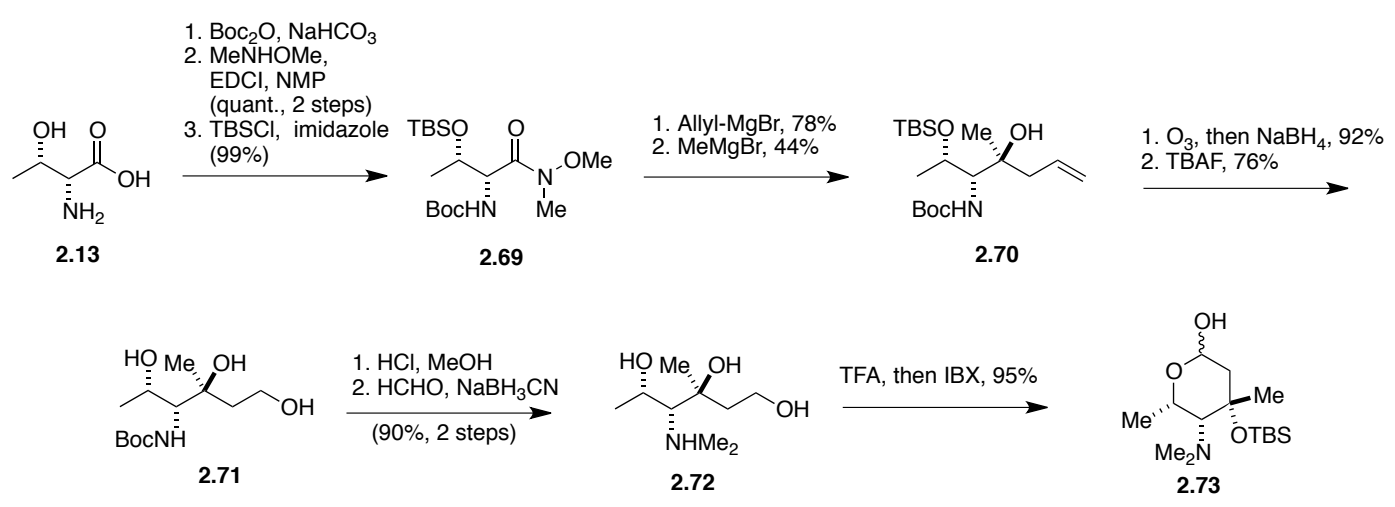

Scheme 2.7. Zhu's asymmetric synthesis of lemonose

In 2011, Zhu and coworkers published a synthesis of lemonose (2.73), the deoxyaminosugar found in lemonomycin. ${ }^{36}$ Their sequence starts with the conversion of Dthreonine (2.13) into Weinreb amide 2.69 (Scheme 2.7). Then, the treatment of allylmagnesium bromide, followed by a diastereoselective addition of methylmagnesium bromide provided tertiary alcohol 2.70. Ozonolysis of the double bond with sodium borohydride as reducing agent, followed by treatment with TBAF furnished compound 2.71. After removal of the Boc carbamate with methanolic $\mathrm{HCl}$, the resulting amine was bis-methylated under reductive amination conditions. The final step involved the regioselective oxidation of the primary alcohol, which was accomplished with the treatment of $\mathbf{2 . 7 2}$ with IBX under acidic conditions, to give lemonose (2.73). 


\subsection{Mulzer's asymmetric construction of the tetracyclic core}
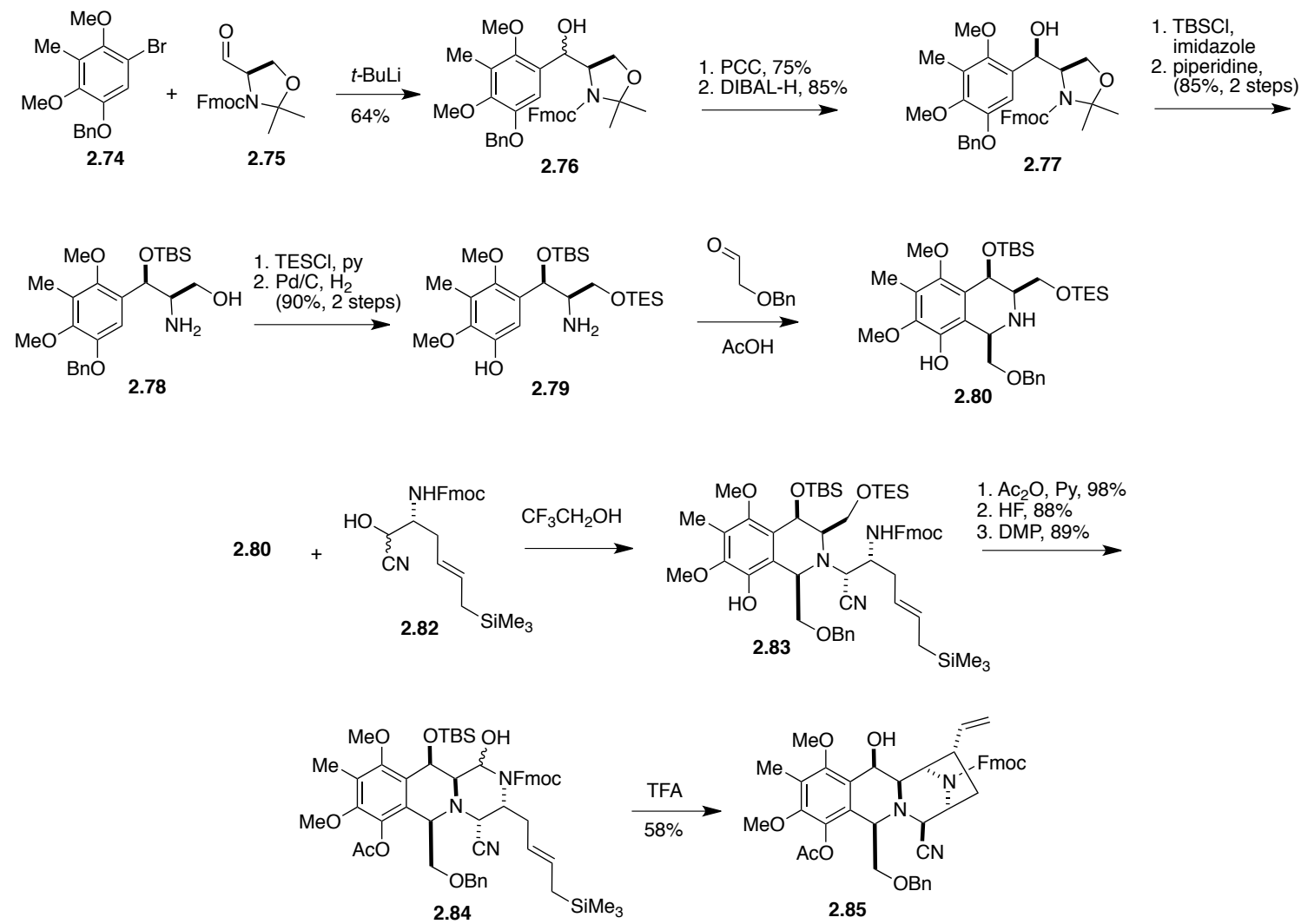

Scheme 2.8. Mulzer's synthesis of tetracycle $\mathbf{2 . 8 5}$

In 2008, Mulzer and co-workers published a report of the asymmetric construction of the tetracyclic core of lemonomycin. ${ }^{37}$ As shown in Scheme 2.8, their synthetic sequence started with the addition of the organolithium derivative of $\mathbf{2 . 7 4}$ into the Fmoc variant of (R)-Garner's aldehyde (2.75) ${ }^{49}$ to afford alcohol $\mathbf{2 . 7 6}$ as a mixture of diastereomers, which was subjected to an oxidation-reduction sequence to provide 2.77 stereoselectively. Then, protection of the secondary alcohol as the TBS ether, followed by treatment with piperidine to cleave the Fmoc carbamate and the oxazolidine ring furnished aminoalcohol 2.78. After protection of the primary alcohol as the TES ether and deprotection of the phenolic hydroxyl, the resulting aminophenol 2.79 was combined with benzyloxyacetaldehyde in a Pictet-Spengler reaction to form tetrahydroisoquinoline $\mathbf{2 . 8 0}$. This compound was combined with cyanohydrin $\mathbf{2 . 8 2}^{50}$ in 
trifluoroethanol to give compound $\mathbf{2 . 8 3}$ as a mixture of diastereomers, which were separable via column chromatography. Then, acetylation of the phenol of the major diastereomer, followed by selective deprotection of the primary hydroxyl with HF and oxidation with Dess-Martin periodinane ${ }^{51}$ provided hemiaminal $\mathbf{2 . 8 4}$. The completion of the sequence was achieved by treating 2.84 with TFA to induce the formation of an $\mathrm{N}$-acyl iminium ion that triggers the intramolecular Hosomi-Sakurai reaction, which leads to tetracycle $\mathbf{2 . 8 5}$.

\subsection{Fukuyama's asymmetric construction of the tetracyclic core}

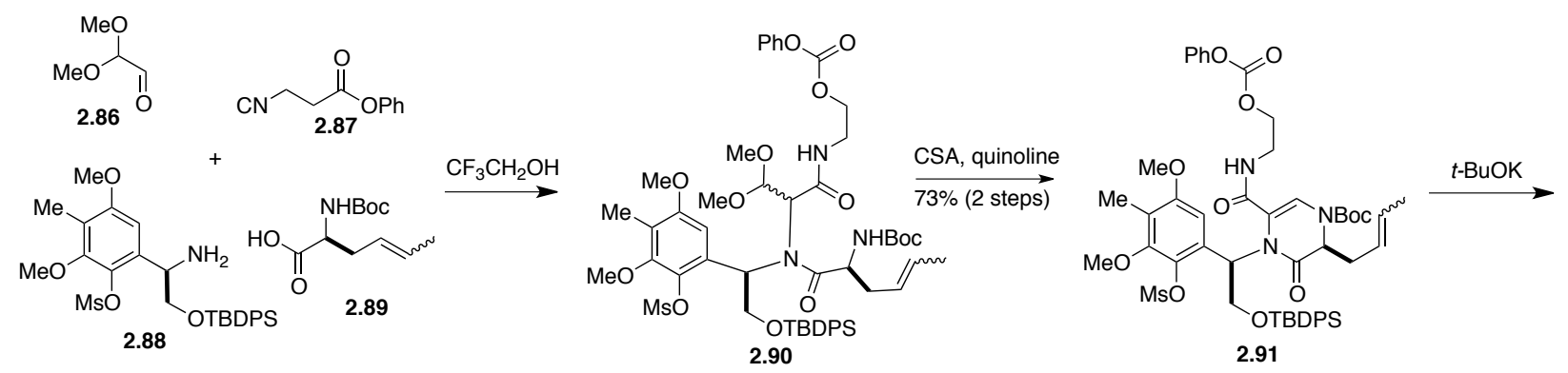

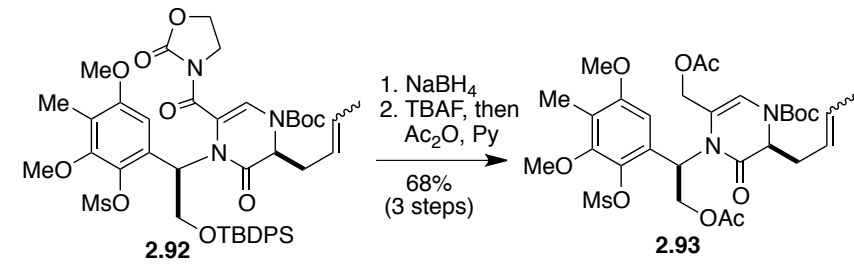
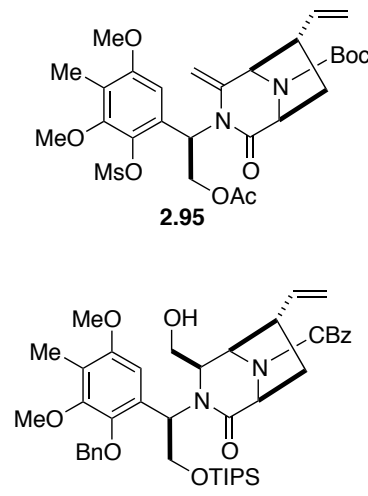

2.97
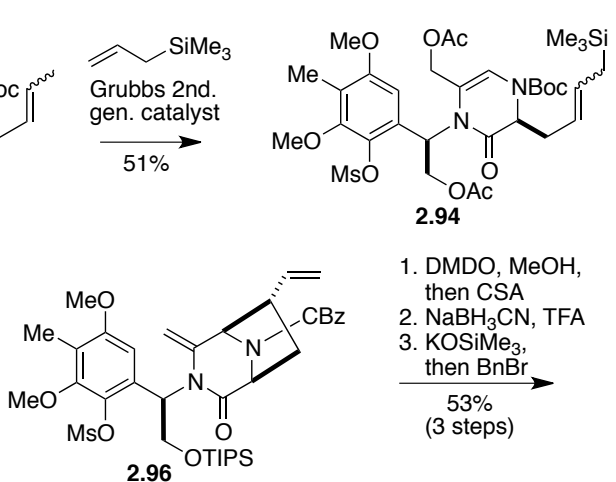

2. $\mathrm{CbzCl}$, DMAP

3. $\mathrm{K}_{2} \mathrm{CO}_{3}, \mathrm{MeOH}$

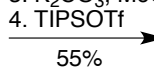

(4 steps)

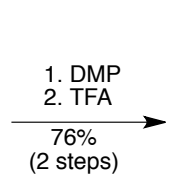

(2 steps)
2.94

1. DMDO, $\mathrm{MeOH}$,

then CSA

2. $\mathrm{NaBH}_{3} \mathrm{CN}$, TFA

3. $\mathrm{KOSiMe}_{3}$

then $\mathrm{BnB}$

Scheme 2.9. Fukuyama's synthesis of tetracycle $\mathbf{2 . 9 8}$ 
In 2005, a report from Fukuyama and coworkers described the assembly of the tetracyclic core of lemonomycin. ${ }^{32}$ Their sequence starts with an Ugi four-component reaction ${ }^{52}$ that forms peptide 2.90 (Scheme 2.9). Acid-promoted formation of the piperazinone, followed by treatment with potassium tert-butoxide provided compound 2.92. Then, reduction of the exocyclic amide with $\mathrm{NaBH}_{4}$, removal of the TBDPS protecting group and acetylation provided compound 2.93. This compound was combined with allyltrimethylsilane in a cross metathesis reaction using Grubbs second-generation catalyst, to furnish compound 2.94. Treatment with $\mathrm{BF}_{3}$ etherate induced the formation of a conjugated $\mathrm{N}$-acyl iminium ion, which underwent an intramolecular Hosomi-Sakurai reaction that formed the diazabicyclo[3.2.1]octane ring system of 2.95. A fourstep sequence was used to exchange the $N$-Boc and acetate groups for $N$-Cbz and TIPS groups, respectively, and form 2.96. Then, the sequential treatment of this compound with DMDO and camphorsulfonic acid, followed by a stereospecific reduction with $\mathrm{NaBH}_{3} \mathrm{CN}$ under acidic conditions and exchange of the mesylate group for a benzyl group provided compound 2.97. The sequence was completed with the oxidation of the primary alcohol with Dess-Martin periodinane ${ }^{51}$ and the cyclization of the resulting aldehyde in a Friedel-Crafts hydroxyalkylation reaction, to form the tetrahydroisoquinoline fragment and provide tetracycle $\mathbf{2 . 9 8}$.

\subsection{Williams' synthesis of the tetracyclic core}

In 2007, Williams and coworkers published an asymmetric approach for the construction

of the tetracyclic core of lemonomycin. ${ }^{38,53}$ As shown in Scheme 2.10, the sequence starts with the conversion of alcohol $\mathbf{2 . 1 0 0}{ }^{54}$ into iodide 2.101, which was coupled with $N$-Boc oxazinone $\mathbf{2 . 1 0 2}^{55}$ to provide intermediate $\mathbf{2 . 1 0 3}$. Then, selective hydrogenolysis of the lactone fragment, followed by conversion into a mixed anhydride and reduction with sodium borohydride furnished alcohol 2.104. The $N$-Boc group was cleaved with TFA and the primary alcohol was 
converted into the TBS ether to afford aminophenol $\mathbf{2 . 1 0 5}$, which was converted into tetrahydroisoquinoline $\mathbf{2 . 1 0 6}$ in a Pictet-Spengler reaction with ethyl glyoxalate. After conversion of the phenolic hydroxyl into an acetate and removal of the 1,2-diphenylethyl fragment, the resulting tetrahydroisoquinoline 2.107 was combined with $N$-Bn- $N$-Boc-Gly under peptide coupling conditions. Removal of the TBS ether and oxidation under Swern conditions ${ }^{39}$ provided aldehyde $\mathbf{2 . 1 0 9}$, which was treated with TFA and TEMPO under air to form conjugated iminium ion 2.110. Treatment with triethylamine formed an azomethine ylide, which underwent a [3+2] dipolar cycloaddition with tert-butyl acrylate to form tetracycle $\mathbf{2 . 1 1 1}$.
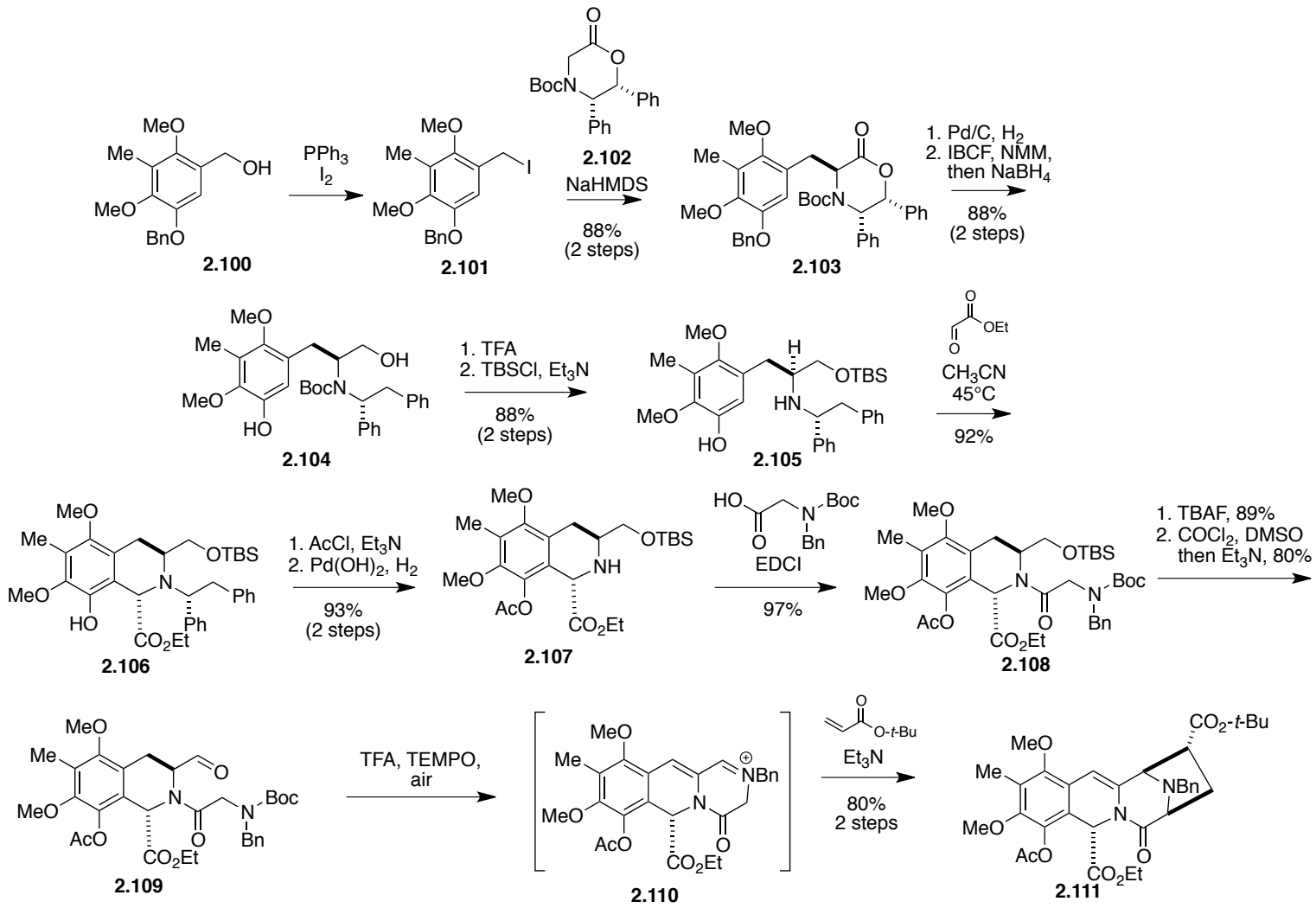

Scheme 2.10. Williams' synthesis of tetracycle 2.111 

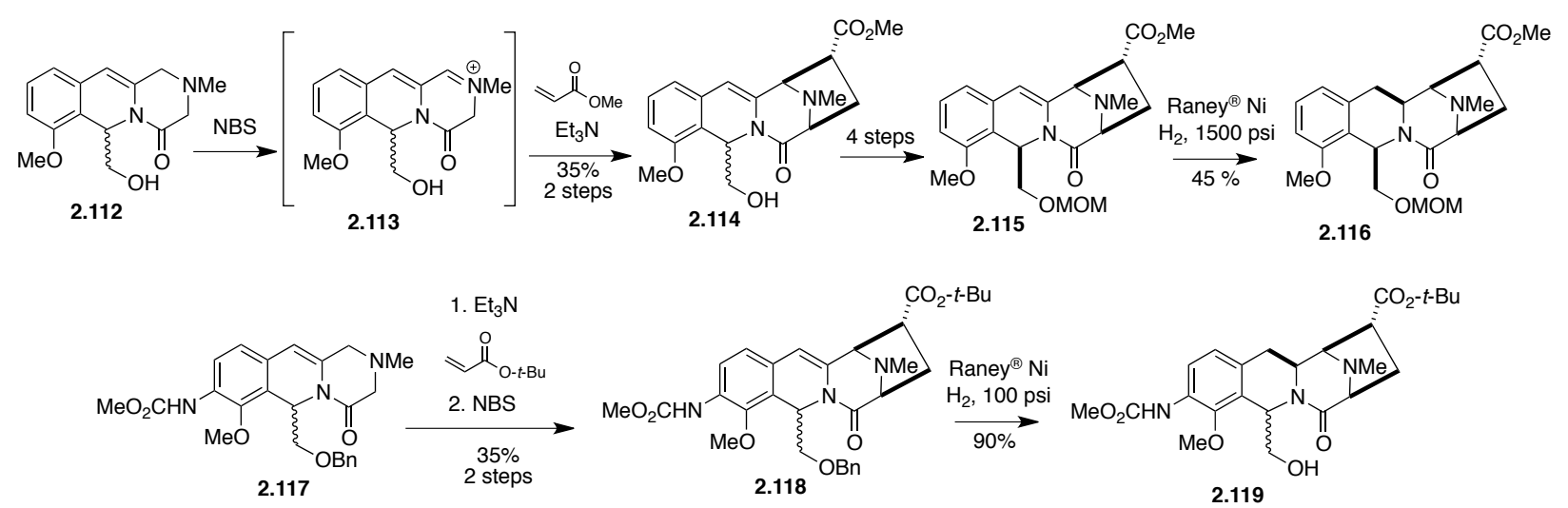

Scheme 2.11. Construction of the tetracyclic cores of quinocarcinamide and tetrazomine

A similar [3+2] dipolar cycloaddition strategy was used by Williams for the construction of the $[3,8]$-diazabicyclo ring system in the total syntheses of (-)-tetrazomine ${ }^{56}$ and $( \pm)$ quinocarcinamide. ${ }^{57}$ As shown in Scheme 2.11, the sequences involve the generation of an iminium ion via a NBS oxidation of a tricyclic allylic amine, followed by formation an azomethine ylide and its reaction with an acrylate ester. Both sequences required the reduction of the enamide double bond to complete the formation of the tetrahydroisoquinoline fragment found in the natural products. Treatment of 2.115 and 2.118 with $\mathrm{H}_{2}$ and Raney ${ }^{\circledR}$ Nickel provided compounds 2.116 and 2.119, respectively. However, in the synthetic sequence towards lemonomycin the attempts to effect a similar transformation were unsuccessful. ${ }^{58}$ Compound 2.111 proved to be unreactive under a number of hydrogenation conditions, which included multiple catalysts and elevated pressures. These findings prompted the preparation of several derivatives of $\mathbf{2 . 1 1 1}$, but all of the attempts to reduce the enamide double bond failed. The substrates and conditions of the attempted hydrogenation conditions are listed in Appendix 1. 


\section{CHAPTER 3}

\section{Studies towards the synthesis of lemonomycin}

\subsection{Synthetic goals}

The primary goal of the project was the development of a concise, novel and high yield route for the asymmetric synthesis of (-)-lemonomycin (1.20). In our initial strategy, we intended to explore the use of Williams' [3+2] dipolar cycloaddition approach, which was described in Section 2.8. Our plan involved the preparation of substrates that would prevent the formation of the enamide double bond, in an attempt to circumvent the problems encountered with its lack of reactivity under catalytic hydrogenation conditions.

\subsection{Dithiane approach}

\subsubsection{Retrosynthetic analysis}

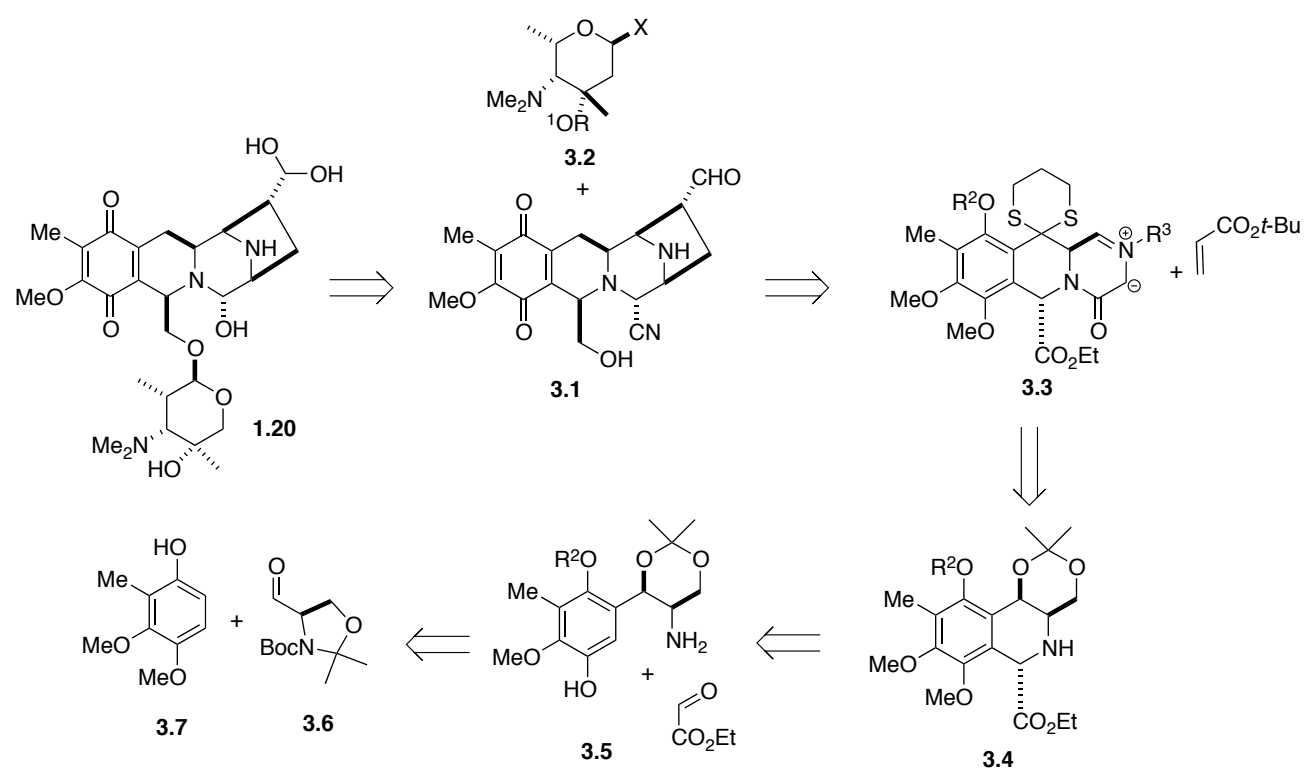

Scheme 3.1. Initial retrosynthetic analysis 
We envisioned lemonomycin as the result of a late stage glycosylation of tetracycle $\mathbf{3 . 1}$ using lemonose derivative 3.2 (Scheme 3.1). Compound 3.1 could be derived from the cycloadduct of tert-butyl acrylate and azomethine ylide 3.3. We expected that the presence of the dithiane moiety at the benzylic position of $\mathbf{3 . 3}$ would prevent the tautomerization process that leads to the formation of the enamide double bond. This intermediate could be prepared in several steps from tetrahydroisoquinoline 3.4, which in turn would be the product of a PictetSpengler reaction between aminophenol 3.5 and ethyl glyoxalate. Finally, 3.5 could be prepared form the coupling product of phenol 3.7 and (R)-Garner's aldehyde $3.6^{59}$ under modified Casiraghi conditions. ${ }^{60,61}$

\subsubsection{Synthesis of the first Pictet-Spengler substrate}
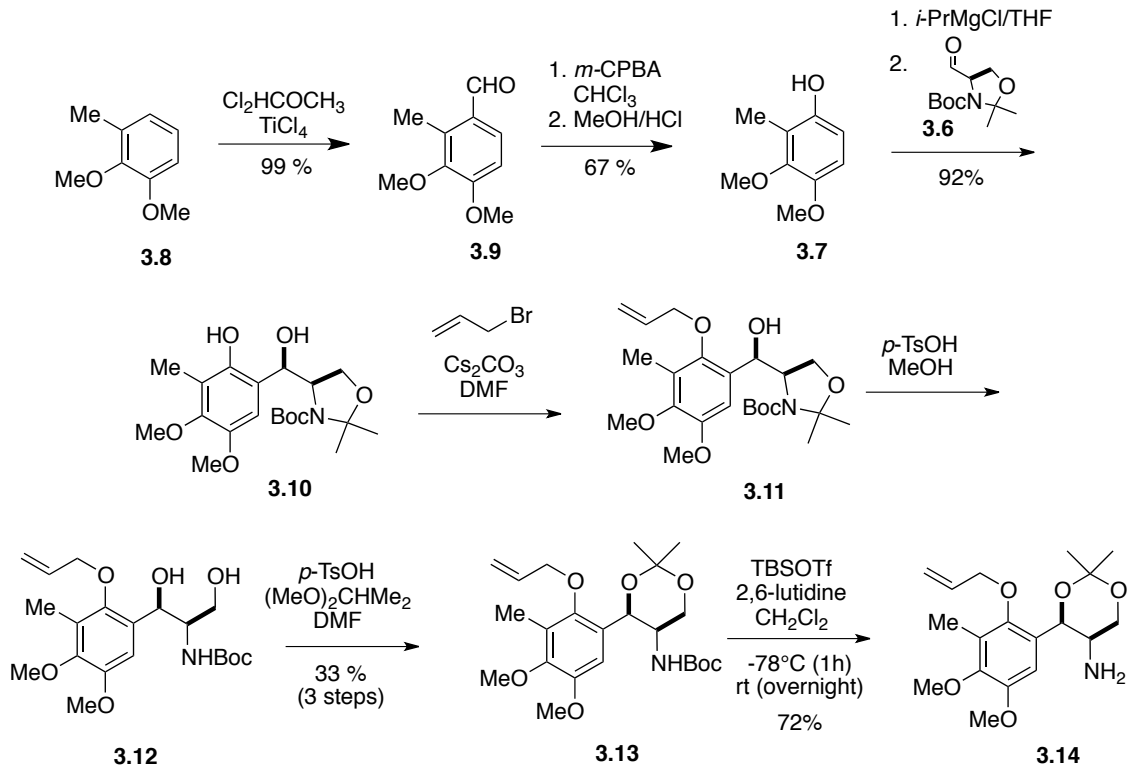

Scheme 3.2. Synthesis of compound 3.14

Commercially available 2,3-dimethoxytoluene (3.8) was formylated under Rieche-Gross conditions and the resulting aldehyde (3.9) was treated with $m$-CPBA to provide phenol 3.7 (Scheme 3.2). This compound was sequentially treated with $i$-PrMgCl and (R)-Garner's aldehyde 
3.6 to provide $\mathbf{3 . 1 0}$ in $92 \%$ yield. Allylation of the phenol, followed by acid-mediated methanolysis of the oxazolidine and conversion of the resulting diol into an acetonide afforded 3.13 in $33 \%$ yield. Then, the $N$-Boc carbamate was removed under Ohfune conditions ${ }^{62}$ to furnish compound $\mathbf{3 . 1 4}$ in $72 \%$ yield. The compound was treated with the conditions described by Zhu and coworkers for the conversion of amine 3.15 into tetrahydroisoquinoline $\mathbf{3 . 1 6}$ (Scheme 3.3). ${ }^{61}$ Intriguingly, despite the structural similarity between both compounds, $\mathbf{3 . 1 4}$ was not converted into the corresponding tetrahydroisoquinoline 3.18, and only imine 3.17 was observed in the reaction mixture (Scheme 3.4). The use of higher temperatures (i.e. 40, 80 and $120^{\circ} \mathrm{C}$ ) led to the decomposition the imine, and the use of an alternate Brønsted acid (i.e. BHT) gave similar results.

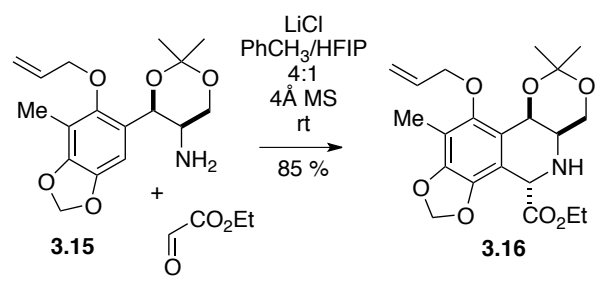

Scheme 3.3. Zhu's Pictet-Spengler reaction

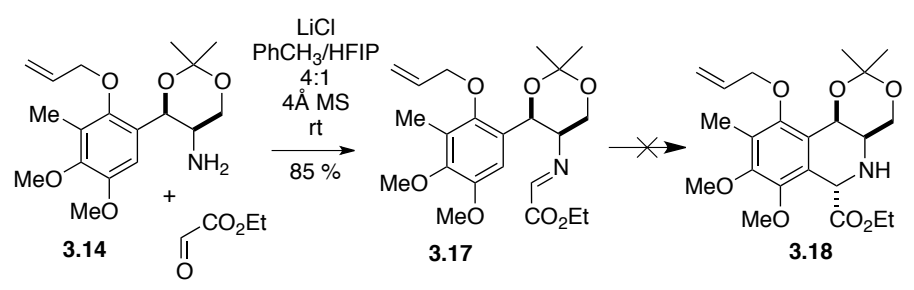

Scheme 3.4. Attempted synthesis of tetrahydroisoquinoline $\mathbf{3 . 1 8}$

\subsubsection{Formation of the tetrahydroisoquinoline system}

We decided to abandon the initial route in favor of a synthetic sequence involving a Pictet-Spengler substrate with a free hydroxyl ortho to the unsubstituted aromatic position. This required the preparation of phenol 3.22, which was accomplished in four steps from 
benzaldehyde 3.9 (Scheme 3.5). The sequence involved bis-demethylation, selective protection of the hydroxyl para to the formyl group, methylation and a Dakin oxidation. The treatment of 3.22 with EtMgBr and (R)-Garner's aldehyde, followed by selective methylation of the phenolic hydroxyl gave compound $\mathbf{3 . 2 4}$ in $95 \%$ yield. The oxazolidine was cleaved under acidic conditions and the resulting diol was transformed into the acetonide to give 3.25 in $77 \%$ yield. Then, hydrogenolysis of the benzyl group with Pearlman's catalyst and removal of the Boc group under Ohfune conditions ${ }^{62}$ gave aminophenol 3.27. A Pictet-Spengler reaction between 3.27 and ethyl glyoxalate provided tetrahydroisoquinoline $\mathbf{3 . 2 8}$.
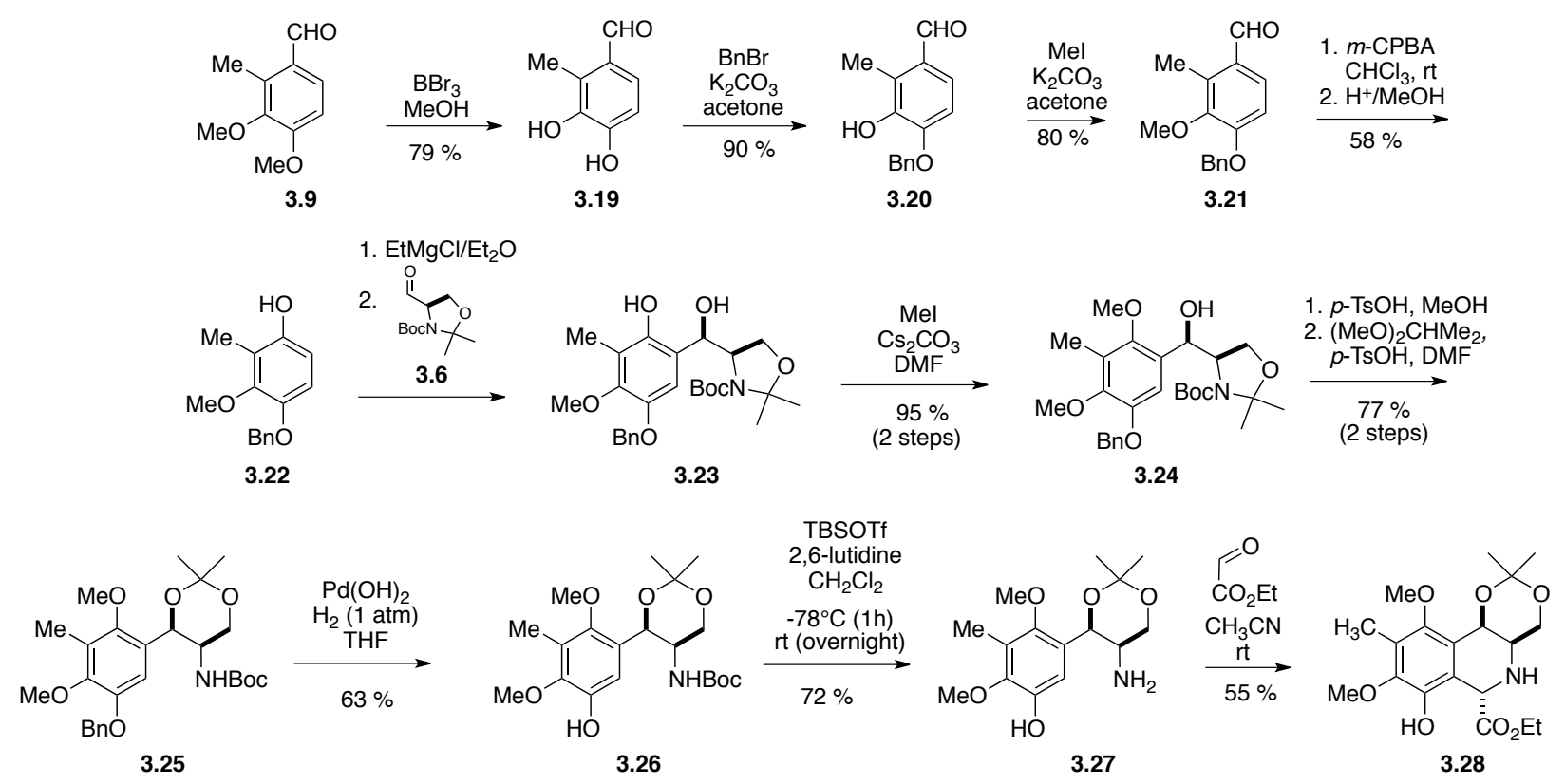

Scheme 3.5. Synthesis of tetrahydroisoquinoline 3.28

\subsubsection{Incorporation of the of the glycine fragment}

A three-step sequence was used to transform glycine ethyl ester (3.29) into $N$-Bn- $N$-NsGly (3.30) (Scheme 3.6). Then, treatment with oxalyl chloride provided acyl chloride $\mathbf{3 . 3 2}$, which was reacted with tetrahydroisoquinoline $\mathbf{3 . 2 8}$ to provide compound 3.33. Selective hydrolysis of the ester with lithium hydroxide, followed by conversion of the phenol into an allyl 
ether gave compound 3.35. Our original plan for this compound involved the removal the acetonide, the selective protection of the primary alcohol and the oxidation of the secondary alcohol to form a ketone, which eventually would have allowed the installation of a 1,3-dithiane protecting group. However, the conditions tested for the hydrolysis of the acetonide led to decomposition of the starting material. These results prompted the re-evaluation of the synthetic approach that revealed that the planned number of steps for the construction of the tetracyclic core was close to 40 and we decided to abandon this route in favor of a more concise and convergent approach.

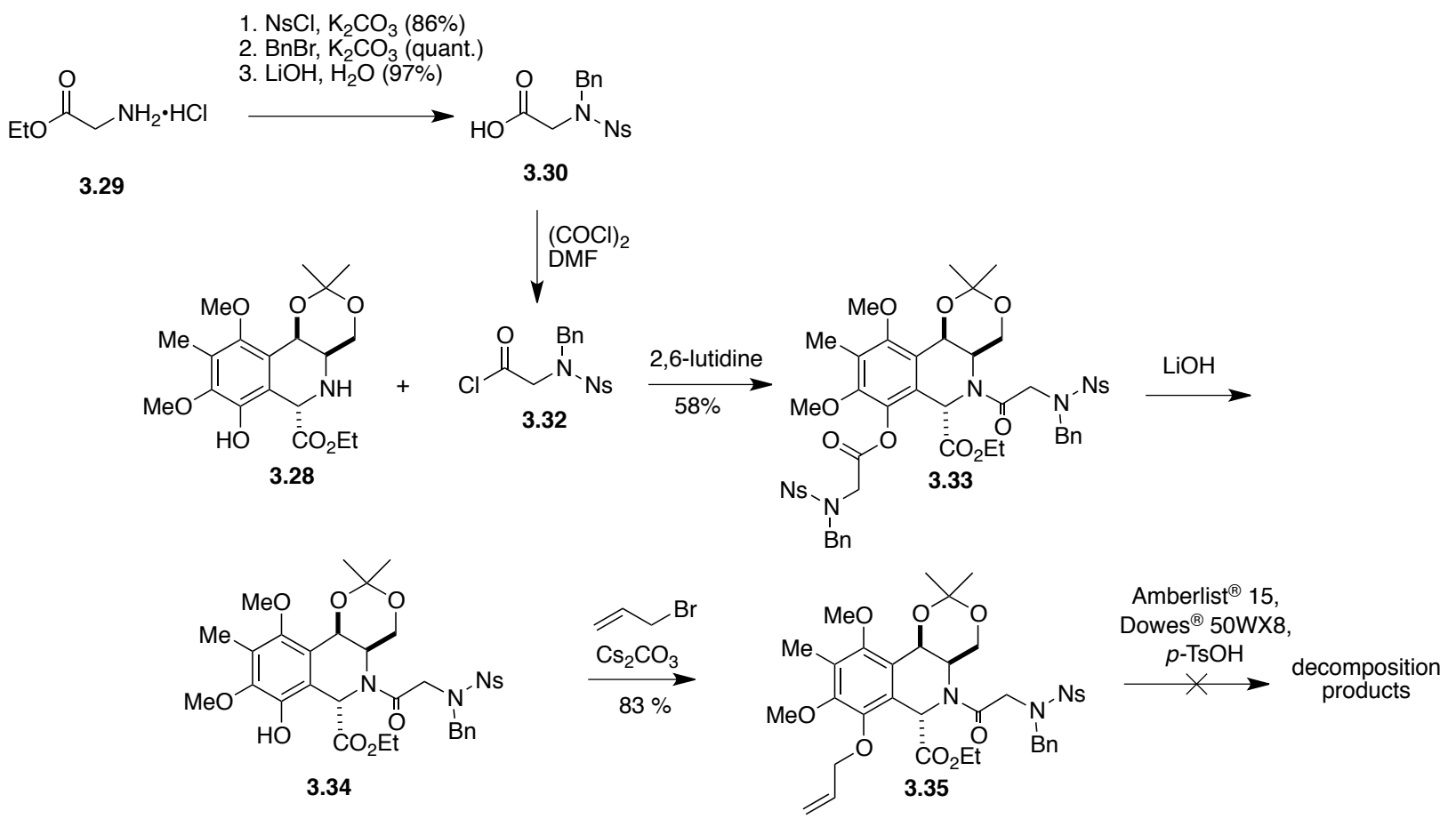

Scheme 3.6. Synthesis of amide 3.35 


\subsection{Hosomi-Sakurai approach}

\subsubsection{Retrosynthetic analysis}
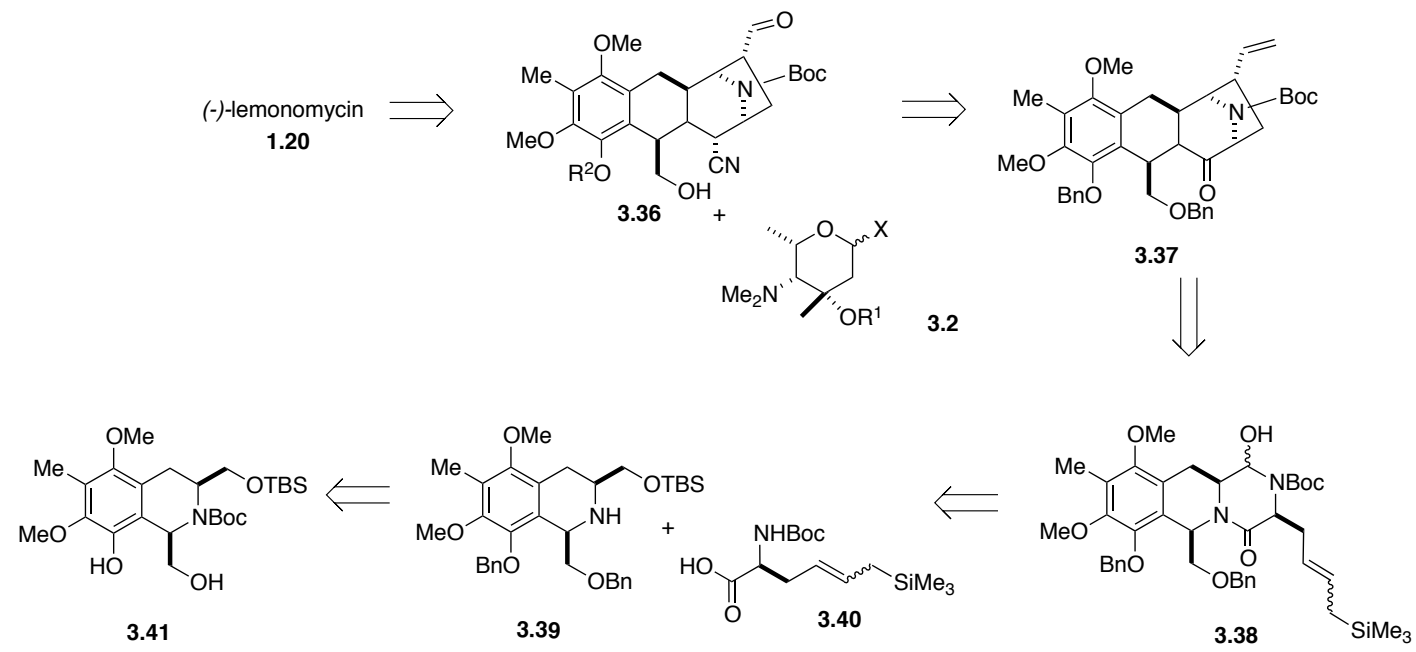

Scheme 3.7. Retrosynthetic analysis

As shown in Scheme 3.7, we envisioned lemonomycin as the result of the late stage glycosylation of tetracycle 3.36, which could be derived form compound 3.37. This compound could be obtained through an acid-catalyzed Hosomi-Sakurai reaction involving intermediate 3.38, which could be accessed through the coupling of $(S)-N$-Boc-allylglycine $\mathbf{3 . 4 0}$ and tetrahydroisoquinoline 3.39. This intermediate could be prepared from $\mathbf{3 . 4 1}$, which is a known compound..$^{53}$ 


\subsubsection{Synthesis of the allyltrimethylsilane glycine derivative}

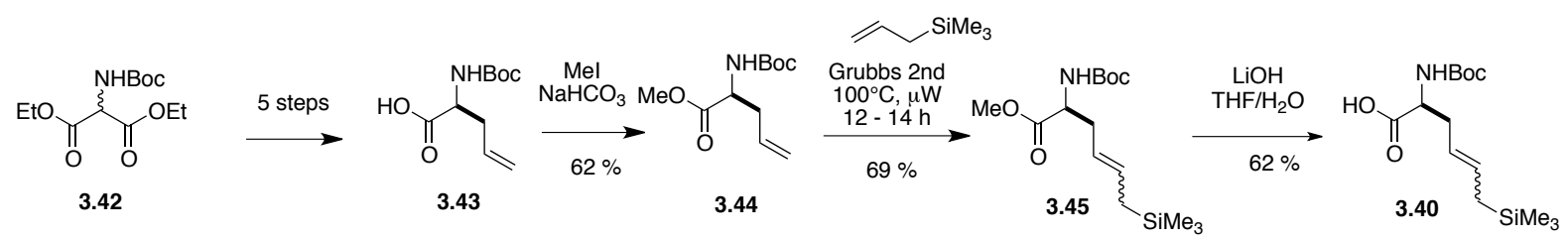

Scheme 3.8. Synthesis of carboxylic acid $\mathbf{3 . 4 0}$

The preparation of the first coupling partner started with the synthesis of $(S)-N$-Bocallylglycine (3.43) from diethylaminomalonate (3.42), using the 5-step sequence described by Berner and coworkers (Scheme 3.8). ${ }^{63}$ Acid 3.43 was esterified with methyl iodide and sodium bicarbonate to give compound 3.44. Treatment with allyltrimethylsilane and Grubbs secondgeneration catalyst under microwave irradiation gave $\mathbf{3 . 4 5}$, which was converted into the desired acid 3.40 through LiOH-mediated hydrolysis and acidification.

\subsubsection{Attempted formation of the cyclization precursor}

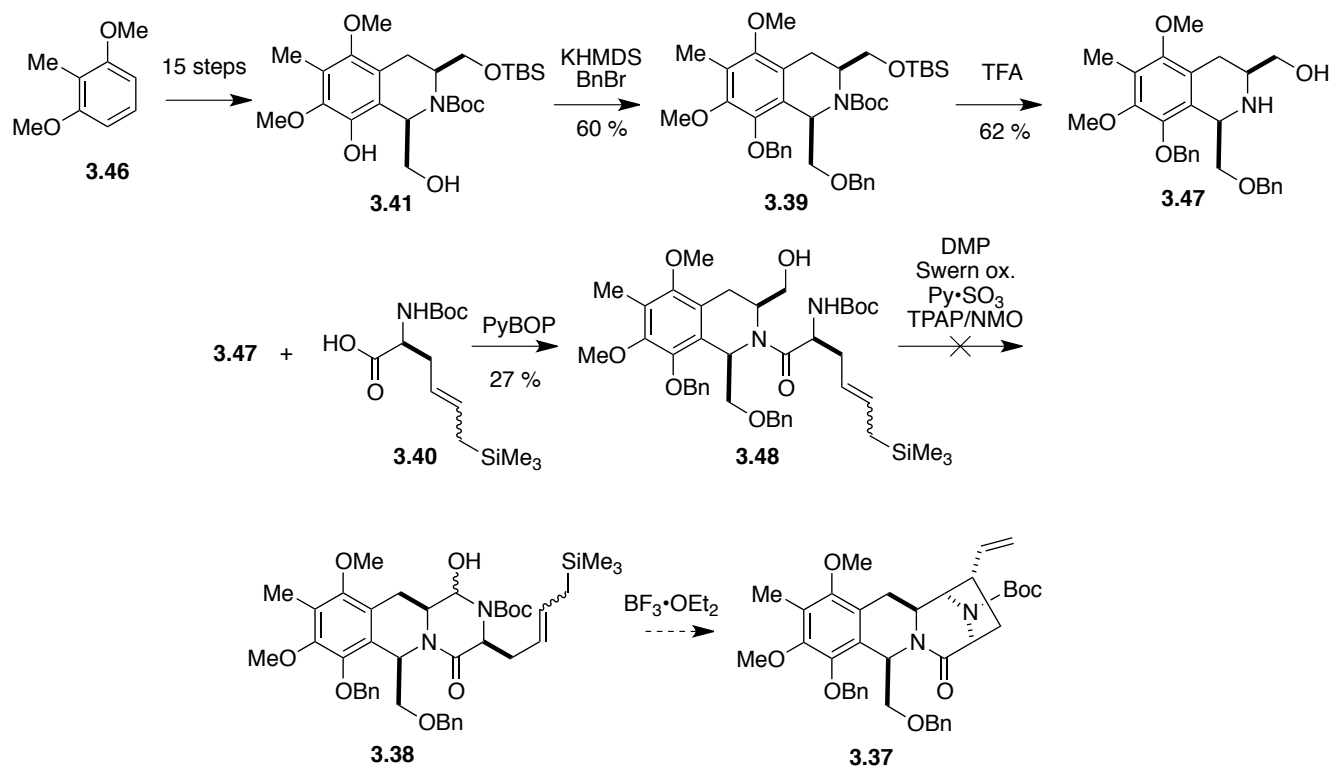

Scheme 3.9. Attempted formation of hemiaminal $\mathbf{3 . 3 8}$ 
As shown in Scheme 3.9, the preparation of the tetrahydroisoquinoline fragment started with the synthesis of compound 3.41, using a 15-step sequence from 2,6-dimethoxytoluene, which was described in a previous report from the Williams group. ${ }^{53}$ The synthesis of $\mathbf{3 . 4 7}$ was achieved by bis-benzylation of $\mathbf{3 . 4 1}$, followed by removal of the TBS and $N$-Boc protecting groups with trifluoroacetic acid. With compounds $\mathbf{3 . 4 7}$ and $\mathbf{3 . 4 0}$ in hand, we converted them in low yield into amide 3.48, using PyBOP as the coupling reagent. We made several unsuccessful attempts to transform 3.48 into 3.38 using multiple oxidation conditions, including Swern oxidation, ${ }^{39} \mathrm{TPAP} / \mathrm{NMO},{ }^{64} \mathrm{Py} \cdot \mathrm{SO}_{3}{ }^{65}$ and Dess-Martin periodinane. ${ }^{51}$ These results prompted a new evaluation of the synthetic strategy in light of the publication of Mulzer's synthetic approach (vide supra),${ }^{37}$ which involved a very similar overall strategy that comprised the initial formation of the tetrahydroisoquinoline ring system and a homologous Hosomi-Sakurai reaction for the construction of the diazabicyclo[3.2.1]octane ring system. At that point in time we decided to abandon this route and to explore alternate synthetic approaches.

\subsection{Redefinition of the synthetic strategy}

An evaluation of the results discussed in the previous section prompted a reconsideration of the [3+2] dipolar cycloaddition strategy for the construction of the tetracyclic core. However, such endeavor required the implementation of a plan for addressing the issue of the reduction of the enamide double bond, which was discussed in Section 2.8. As shown in Scheme 3.10, there is a clear reactivity difference between compounds 2.115 and 2.118, and compound 2.111 (Scheme 3.10) and its derivatives (Appendix 1). Our initial interpretation of these results was based on the apparent electronic differences between the aromatic rings of the two groups of compounds. We attributed the lack of reactivity of the enamide double bond to the higher number of electron donating aromatic substituents found in $\mathbf{2 . 1 1 1}$ and its derivatives. Therefore, 
we decided to implement a synthetic plan aimed at the generation of hydrogenation substrates with less electron-rich aromatic moieties than the ones found in the unreactive compounds.
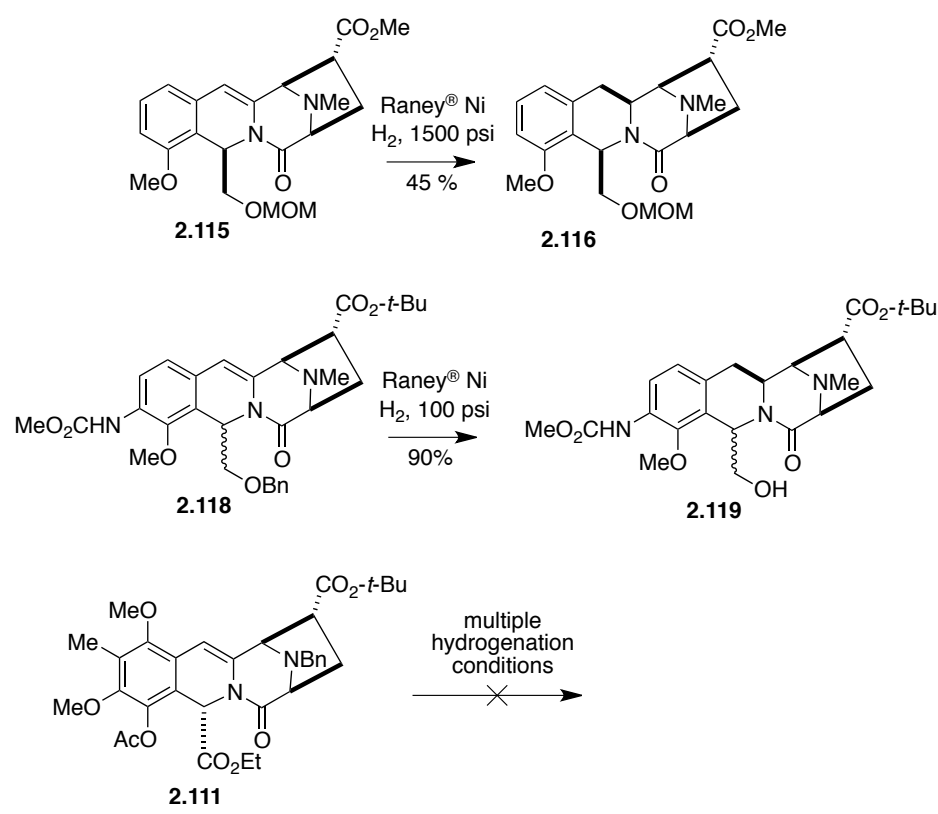

Scheme 3.10. Comparison of the hydrogenation substrates

\subsection{Attempted formation of alternate cycloaddition precursors}

\subsubsection{Retrosynthetic analysis}

In our updated synthetic plan, we envisioned that lemonomycin aglycon 3.49 could be derived from compound 3.50 through reduction of the double bond with three acetoxy susbstituents attached to the aromatic ring (Scheme 3.11). Compound $\mathbf{3 . 5 0}$ could be prepared with a sequence involving deacetylation, oxidation/cleavage of the methylenedioxy fragment, ${ }^{66}$ reduction and acetylation, starting from compound 3.51. This compound could be obtained as the product of a [3+2] dipolar cycloaddition involving tert-butyl acrylate and azomethine ylide $\mathbf{3 . 5 2}$. This intermediate could be prepared from tetrahydroisoquinoline 3.53, which could be formed with a Pictet-Spengler reaction between aminophenol 3.54 and ethyl glyoxalate. 

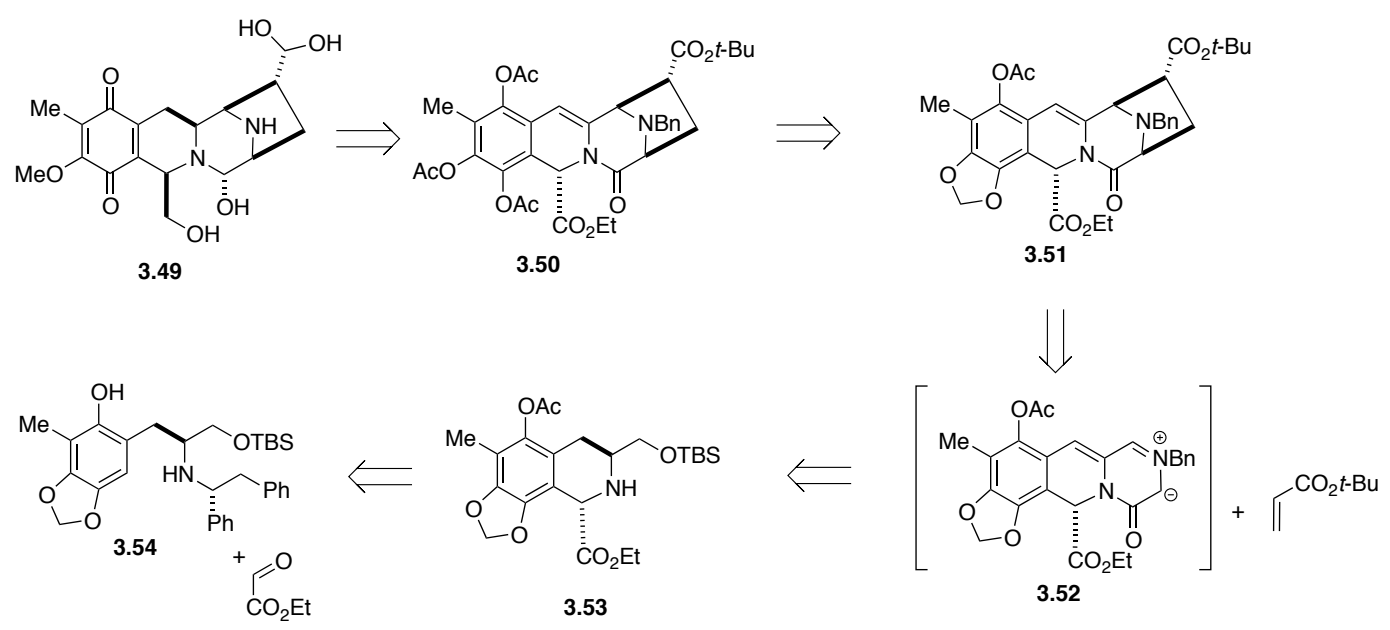

Scheme 3.11. Retrosynthetic analysis

\subsubsection{Attempted formation of the tetrahydroisoquinoline system}

We prepared aldehyde 3.56 using the 5-step sequence from sesamol (3.55) described by Saito and coworkers (Scheme 3.12). ${ }^{67}$ Benzylation of the phenol, followed by reduction with sodium borohydride provided alcohol 3.58. Then, we adapted the chemistry developed in the Williams group for the conversion of alcohol 2.100 into tetrahydroisoquinoline 2.106 (Scheme $2.10)^{38,53}$ to attempt the preparation of our desired tetrahydroisoquinoline system. Thus, alcohol 3.58 was transformed into the corresponding benzylic iodide (3.59), which was coupled with $N$ Boc oxazinone $\mathbf{2 . 1 0 2}$ to provide compound 3.60 in $99 \%$ yield. Selective hydrogenolysis of the lactone, followed by mixed anhydride formation and reduction with $\mathrm{NaBH}_{4}$ afforded compound 3.62, which was then converted into compound 3.54 after treatment with TFA to remove the $\mathrm{N}$ Boc group and protection of the primary alcohol as the TBS ether. Aminophenol 3.54 was reacted with ethyl glyoxalate to provide a single diastereomer of a compound that was tentatively identified as oxazepane 3.63. We submit that this result was caused by the nucleophilic attack of the phenolic oxygen onto the incipient imine. The obvious turnaround for this problem would involve the protection of the phenol and the use of Lewis or Brønsted acids to promote the 
Pictet-Spengler reaction. However, we decided to focus on other concurrent approaches and no further experimental work was done with this route.
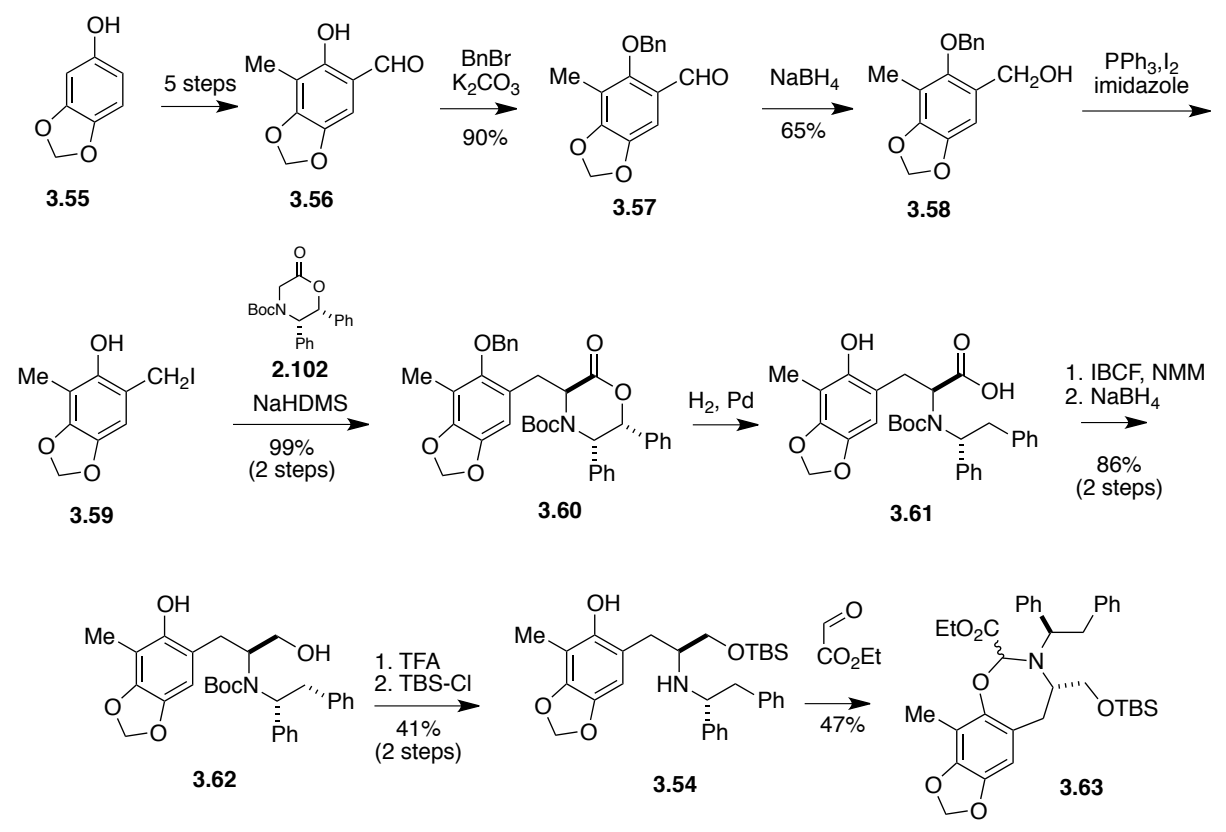

Scheme 3.12. Synthesis of oxazepane 3.63

\subsubsection{Attempted formation of a tricyclic hemiaminal}

In an attempt to gain rapid access to our desired cycloaddition precursors, we decided to prepare known methylendioxy-substituted tetrahydroisoquinoline compounds, which can be accessed using concise routes. Consequently, we used the 9-step sequence described by Zhu and coworkers $^{61}$ to prepare compound $\mathbf{3 . 1 5}$ (Scheme 3.13). The reaction of $\mathbf{3 . 1 5}$ with acyl chloride 3.64 provided amide 3.65 in $64 \%$ yield. Treatment with Dowex ${ }^{\circledR} 50 \mathrm{WX} 8$ in methanol, ${ }^{68}$ effected both the removal of the acetonide and the formation of the methyl ether to give compound 3.66. Oxidation of primary alcohol with Dess-Martin periodinane ${ }^{51}$ provided aldehyde 3.67. The removal of the $N$-Fmoc group with diethylamine formed a single compound that could not be 
identified as hemiaminal $\mathbf{3 . 6 8}$, thus precluding the preparation of the desired azomethine ylide intermediate (3.69). This result prompted the modification of the sequence to attempt the removal of the $N$-Fmoc group in an earlier stage of the sequence. However, the treatment of compound 3.65 with diethylamine induced the formation of diketopiperazine 3.70. At this stage we realized that the use of Fmoc as the protecting group in the glycine fragment was not compatible with our synthetic plan. However, our attempts to generate an analog of $\mathbf{3 . 6 5}$ with an $N$-Boc- $N$-Bn-glycyl fragment were unsuccessful. Therefore, we decided to focus on the other concurrent approaches that we were pursuing at that point in time and no further experimental work was done with this route.

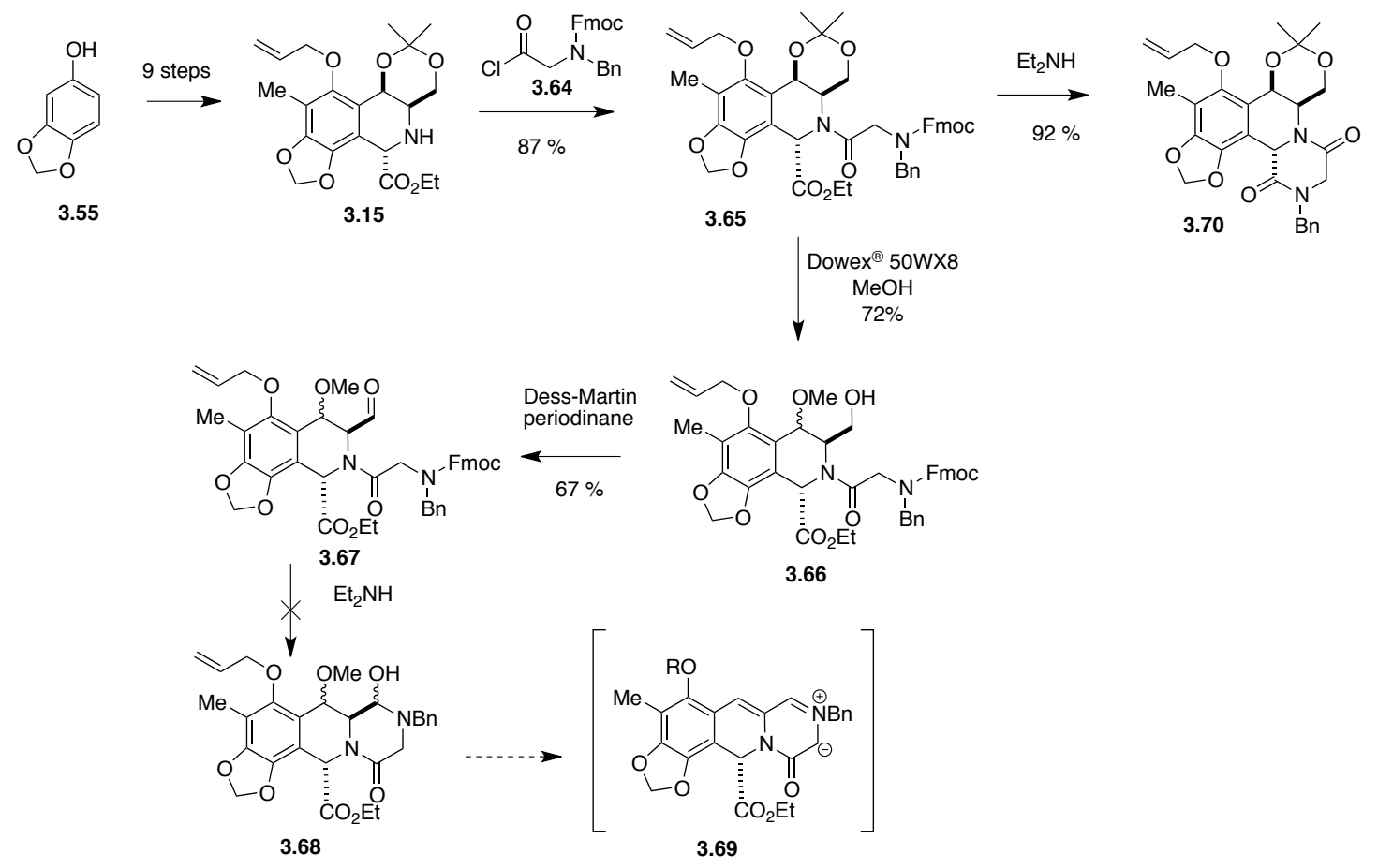

Scheme 3.13. Attempted formation of hemiaminal 3.68 


\subsubsection{Orthogonally protected aromatic fragment approach.}

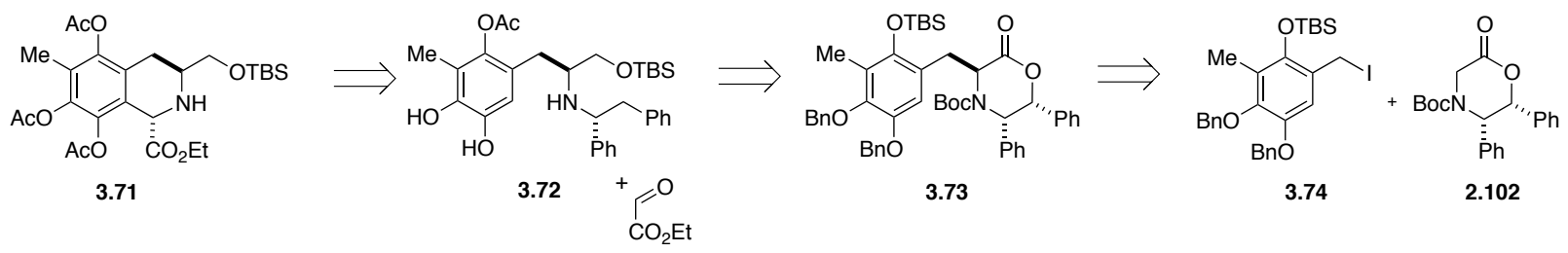

Scheme 3.14. Updated rethrosynthetic analysis

We decided to modify the synthetic strategy outlined in Scheme 3.11 , to attempt the formation of the tetrahydroisoquinoline using a Pictet-Spengler substrate that would include a hydroxyl group ortho to the unsubstituted aromatic position. As shown in Scheme 3.14, we envisioned that compound 3.71 could be accessed from aminocatechol 3.72 and ethyl glyoxalate. This compound could be derived from orthogonally protected oxazinone 3.73, which in turn could be the product of the alkylation of $N$-Boc oxazinone 2.102 with benzylic iodide 3.74. This plan mimics the strategy used for the preparation of compound 2.106 (Scheme 2.10) and the attempted formation of tetrahydroisoquinoline $\mathbf{3 . 5 3}$ (Schemes 3.11 and 3.12, vide supra).

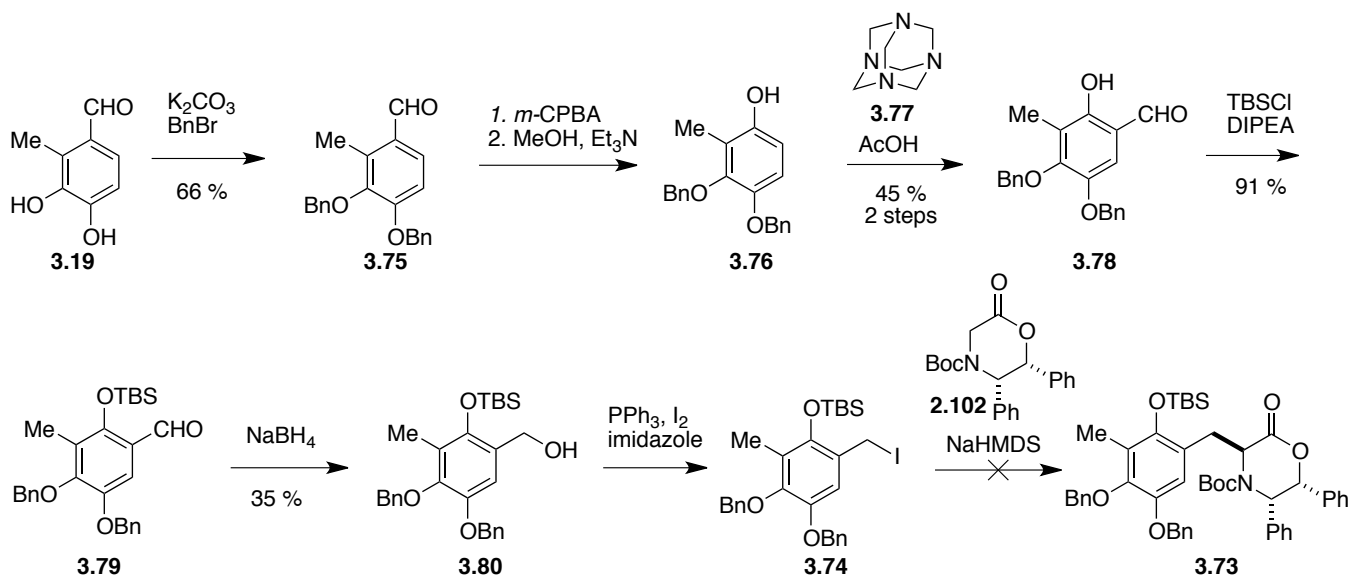

Scheme 3.15. Attempted formation of oxazinone 3.73 
As shown in Scheme 3.15, the sequence that gave access to the orthogonally protected benzyl alcohol started with the bis-benzylation of aldehyde 3.19 to give 3.75. A Dakin oxidation, followed by an ortho-formylation with hexamethylenetetramine in glacial acetic acid gave compound 3.78 in modest yield. Then, protection of the free phenol with TBSCl and DIPEA provided aldehyde 3.79, which was reduced with $\mathrm{NaBH}_{4}$ to give benzyl alcohol $\mathbf{3 . 8 0}$ in low yield. With this compound in hand, we unsuccessfully attempted its conversion into benzylic iodide 3.74 and the coupling with oxazinone 2.102. The separation of the reaction mixture allowed the recovery of intact $\mathbf{2 . 1 0 2}$, which was likely re-protonated during the aqueous quench, along with several unidentified products derived from 3.74. We suspect that this result was caused by the low solubility of $\mathbf{3 . 7 4}$ in the reaction mixture, thus preventing the alkylation from happening. We submit that the solubility issues are caused by the large size of the benzyl, TBS and iodo substituents. Once again, we decided to focus on the other concurrent approach that we were pursuing at that point in time and no further experimental work was done with this route.

\subsection{Construction of the tetracyclic core}

\subsubsection{Retrosynthetic analysis}

The unsatisfactory results discussed in previous sections forced a re-evaluation of the synthetic strategy and the exploration of alternative routes for the construction of the tetrahydroisoquinoline ring system. In our updated plan, we envisioned that lemonomycin could be accessed from compound 3.81, which could be prepared from bis-acetoxy-substituted tetracycle 3.82 through reduction of the enamide double bond and epimerization of the southern benzylic position and reduction of the ester (Scheme 3.16). Compound $\mathbf{3 . 8 2}$ could be formed from tetracycle $\mathbf{3 . 8 3}$ through oxidation of the aromatic ring to the para-quinone, followed by reduction to the hydroquinone and acetylation. The preparation of $\mathbf{3 . 8 3}$ would involve the use of 
the [3+2] dipolar cycloaddition involving azomethine ylide $\mathbf{3 . 8 4}$, which could be obtained from aldehyde 3.85. The tetrahydroisoquinoline system of $\mathbf{3 . 8 5}$ could be formed through a PictetSpengler reaction involving a derivative of bromotyrosinol 3.86, which is a known compound. ${ }^{69}$
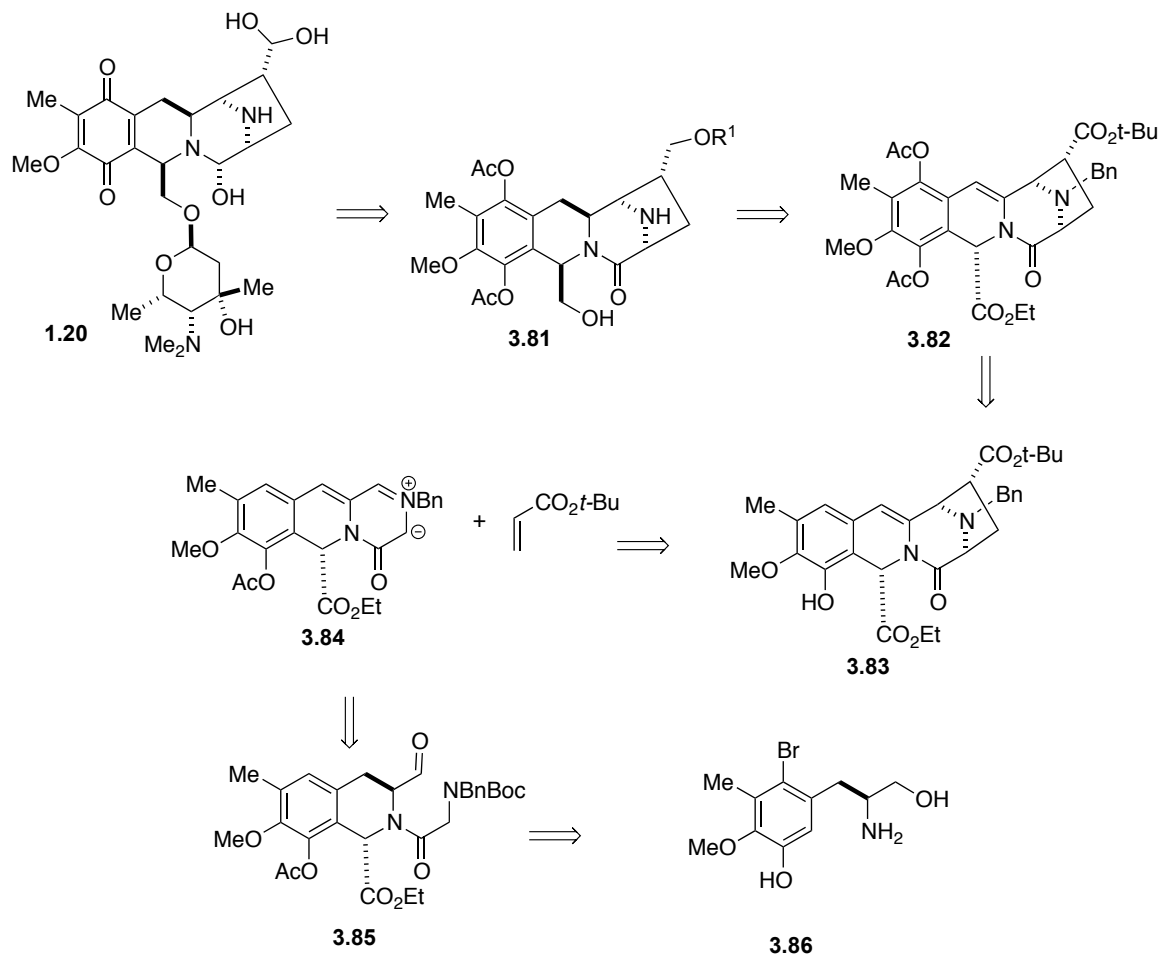

Scheme 3.16. Retrosynthetic analysis
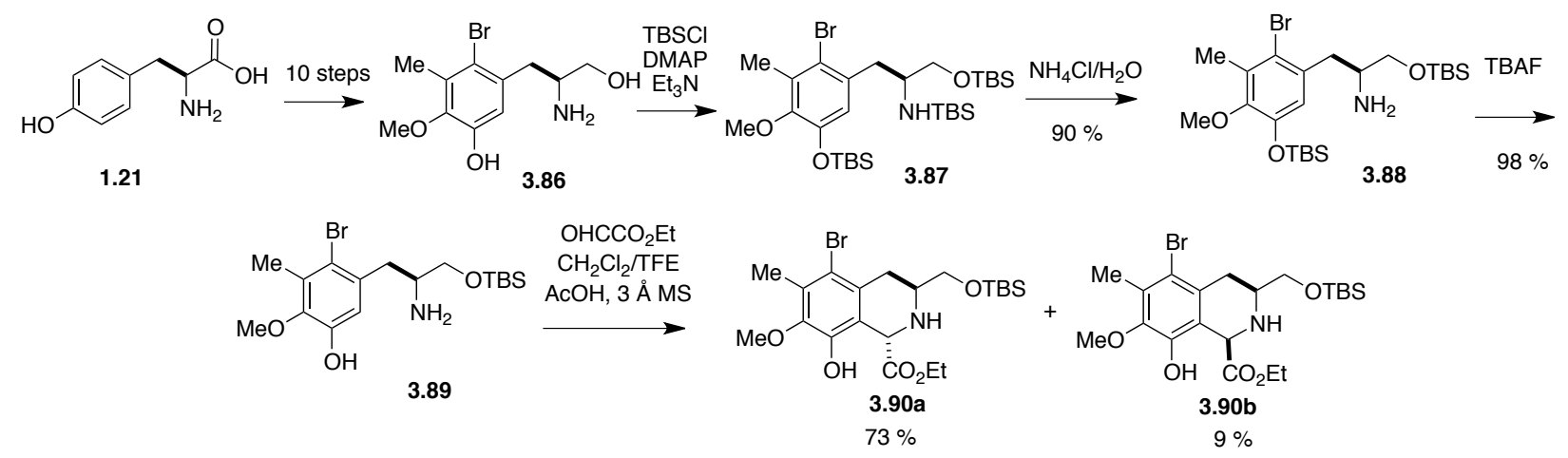

Scheme 3.17. Synthesis of tetrahydroisoquinolined 3.90a and 3.90b 


\subsubsection{Synthesis of the tetrahydroisoquinoline fragment}

The preparation of bromotyrosinol $\mathbf{3 . 8 6}$ (Scheme 3.17) was accomplished in 10 steps from L-tyrosine (1.21), using the method described by Liao. ${ }^{69}$ We initially attempted to perform the direct conversion of $\mathbf{3 . 8 6}$ into bis-silyl ether $\mathbf{3 . 8 8}$ using two equivalents of TBSCl, but the yields were inconsistent and low $(<30 \%)$. The lack of reactivity of the primary hydroxyl of $\mathbf{3 . 8 6}$ is consistent with the regioselectivity observed in the reactions between $\mathrm{TBSCl}$ and diols bearing a $\beta$-aminoalcohol motif. ${ }^{70}$ We concur with the explanation provided by the authors, which stated that the nucleophilicity of the primary hydroxyl is reduced by internal hydrogen bonding to the neighboring amino group. By increasing the relative amount of $\mathrm{TBSCl}$ to six equivalents, compound $\mathbf{3 . 8 6}$ was converted into the tris-silylated compound 3.87. Unexpectedly, the hydrolysis of the silylamine function required a prolonged vigorous stirring with aqueous $\mathrm{NH}_{4} \mathrm{Cl}$ at room temperature $(\sim 2 \mathrm{~h})$ to form the bis-silyl ether $\mathbf{3 . 8 8}$ in $90 \%$ yield. The phenolic silyl ether was selectively cleaved with one equivalent of TBAF at $0{ }^{\circ} \mathrm{C},{ }^{71}$ to afford compound $\mathbf{3 . 8 9}$ in $98 \%$ yield.

The next step entailed the formation of the trans-tetrahydroisoquinoline ring via a PictetSpengler reaction between 3.89 and ethyl glyoxalate. Previously, our group reported a similar transformation, which was performed by stirring a solution of the starting materials in acetonitrile for 3.5 days at $50{ }^{\circ} \mathrm{C}$, which afforded the trans- product stereospecifically. ${ }^{53} \mathrm{~A}$ similar report by Zhu and coworkers involved the use of $\mathrm{LiCl}$, hexafluorisopropanol and molecular sieves, and stirring the suspension in toluene at room temperature for $48 \mathrm{~h} .{ }^{61}$ Since none of these mild conditions led to the formation of the desired tetrahydroisoquinoline ring system, we decided to adapt the reaction conditions that were originally described by $\mathrm{Zhu}^{72}$ to our substrate. The amount of acetic acid was reduced from 2.5 equivalents to 0.2 equivalents to 
prevent cleavage of the $O$-TBS ether due to the prolonged exposure to the acid. In the present system, treatment of a solution of compound 3.89 and ethyl glyoxalate with $\mathrm{CF}_{3} \mathrm{CH}_{2} \mathrm{OH}, \mathrm{AcOH}$ (0.2 eq.) and $4 \AA$ MS afforded an 8:1 mixture of 3.90a and 3.90b in $82 \%$ yield. These two diastereomers were separated via flash chromatography

\subsubsection{Formation of the tetracyclic ring system}
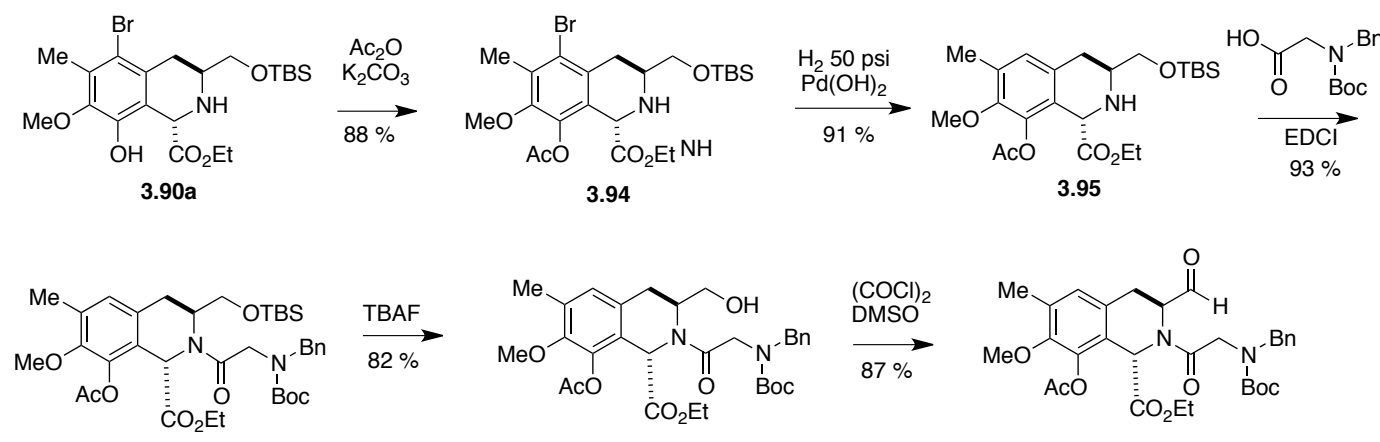

3.96
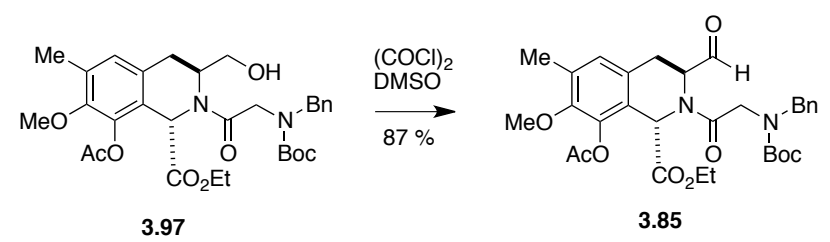

Scheme 3.18. Preparation of aldehyde $\mathbf{3 . 8 5}$

As shown in Scheme 3.18, selective acetylation of compound $3.90 \mathrm{a},{ }^{73}$ followed by hydrogenolysis of the $\mathrm{C}-\mathrm{Br}$ bond ${ }^{69}$ provided tetrahydroisoquinoline 3.95 (Scheme 3.18). Following the conditions described in the previous report form the Williams group, ${ }^{38}$ we converted compound $\mathbf{3 . 9 5}$ into aldehyde $\mathbf{3 . 8 5}$, which is the substrate required for the $[3+2]$ dipolar cycloaddition. Thus, tetrahydroisoquinoline 3.95 and $N$-Boc- $N$-Bn-Gly were coupled using EDCI, and the resulting amide was treated with TBAF to cleave the $O$-TBS ether and then oxidized under Swern conditions ${ }^{39}$ to afford aldehyde $\mathbf{3 . 8 5}$.

As illustrated in Scheme 3.19, aldehyde $\mathbf{3 . 8 5}$ was dissolved in $\mathrm{CHCl}_{3}$ and treated under aerobic conditions with $\operatorname{TFA}^{74,75,76}$ (50 eq.) and TEMPO (0.1 eq.), to generate iminium ion $\mathbf{3 . 9 8}$, which tautomerizes to form ammonium ion 3.99. This intermediate is autoxidized in situ to 
afford conjugated iminium ion 3.100, which was concentrated to dryness and taken up in $\mathrm{CHCl}_{3}$. Addition of triethylamine induces the formation of azomethine ylide 3.101, which is trapped in situ by tert-butyl acrylate to give a 2.4:1 mixture of tetracycles 3.102a and 3.102b in a combined $59 \%$ yield. We propose that the dipolarophile adds from the $R e$ face of the iminium ion carbon to form 3.102a, which epimerizes under the reaction conditions to form $\mathbf{3 . 1 0 2 b}$.

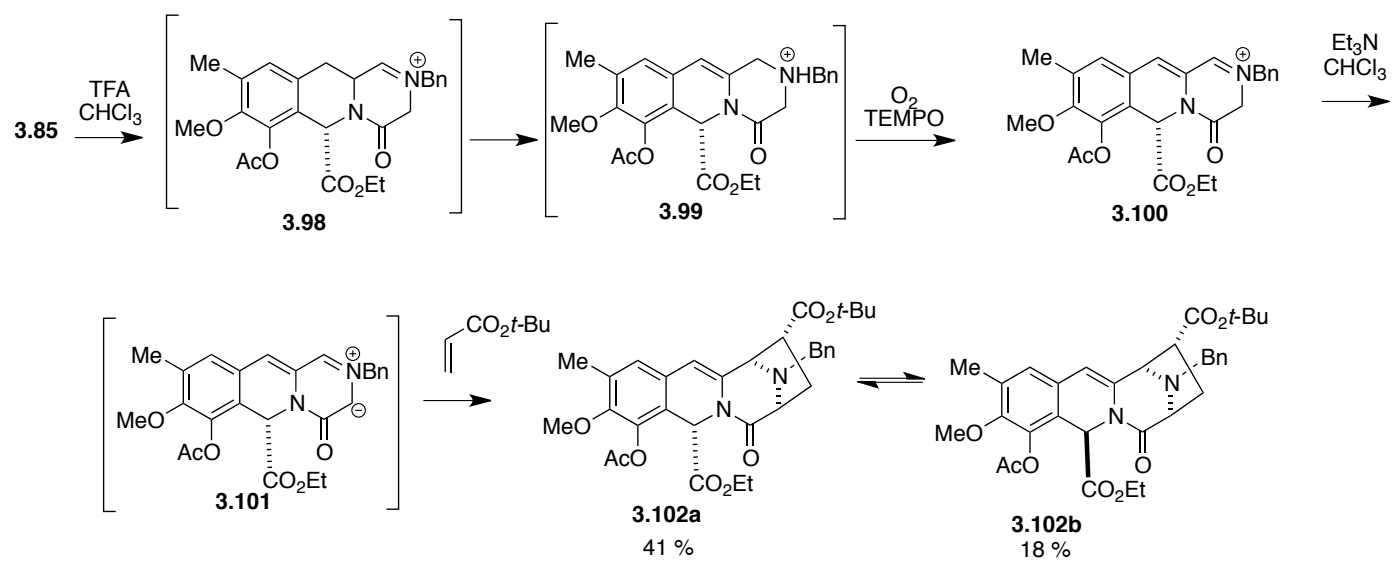

Scheme 3.19. Formation of cycloadducts 3.102a and 3.102b

\subsubsection{Redefinition of the synthetic strategy}

With compounds 3.102a and 3.102b in hand, we conducted a thorough examination of the previous related work, with the intention of choosing an optimal strategy for the reduction of the double bond. As part of such process, we built molecular models of the compounds that were successfully hydrogenated in the total syntheses of (-)-tetrazomine ${ }^{56}$ and $( \pm)$-quinocarcinamide, ${ }^{57}$ the newly synthesized tetracycles and some of the substrates that failed to undergo hydrogenation in the previous synthetic approach. ${ }^{58}$ As shown in Figure 3.1, compounds 2.115 and 2.118a have relatively small groups attached to the side of the tetracyclic structures that binds to the surface of the heterogeneous catalyst during the hydrogenation event. Moreover, we expect that an inversion of the configuration of the secondary amine nitrogen, which would 
allow the formation of a coordinate bond, might improve the binding of the molecule to the catalyst and facilitate the reaction. The evaluation of the structure of $\mathbf{2 . 1 1 1}$ revealed several key facts that were overlooked during our previous assessments. First, we concluded that the formation of a bonding interaction between the enamide double bond carbons and the metal surface is not possible with a benzyl group attached to the amino nitrogen.
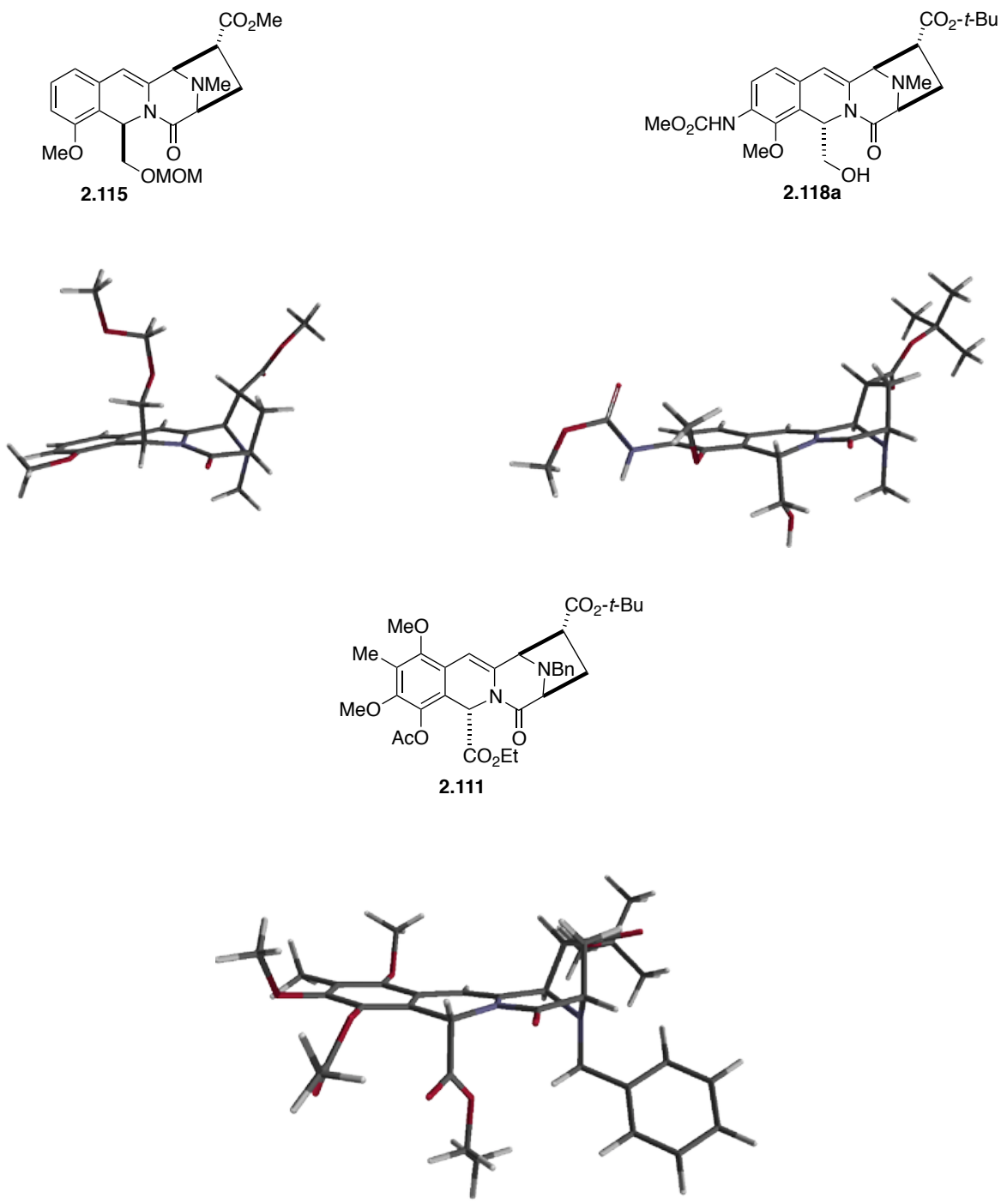

Figure 3.1. Representation of the calculated equilibrium geometry conformations ${ }^{77}$ of compounds 2.115, 2.118a and 2.111 
Furthermore, we submit that inversion of the nitrogen configuration is not possible, because it would require the benzyl and tert-butyl ester substituents to be in close proximity. We also concluded that the ester groups of $\mathbf{2 . 1 1 1}$ prevent the formation of bonding interactions between the catalyst and the reactive centers, which would be required for a successful hydrogenolysis of the benzyl group. Therefore, we concluded that the removal of the benzyl group in our system would require the conversion of at least one of the ester groups into a smaller substituent (e.g., hydroxymethyl) or the inversion of the configuration at the southern benzylic position of the tetrahydroisoquinoline moiety. Lastly, we concluded that the reduction of the enamide double bound would require the removal of the benzyl group, and the conversion of the ethyl ester into a hydroxymethyl group or the inversion of the southern benzylic stereocenter.

\subsubsection{Initial modification of the tetracyclic core}

With the mixture of compounds 3.102a and 3.102b in hand, we attempted the use of basic conditions to modify the diastereomeric ratio. However, were unable to detect a change in the ratio using $\mathrm{DBN}, \mathrm{DBU}, \mathrm{Cs}_{2} \mathrm{CO}_{3}$ and $\mathrm{Et}_{3} \mathrm{~N}$. The previous experiments conducted in the Williams group with similar systems indicated that reduction to the aldehyde is required for successful epimerization of the benzylic position. ${ }^{56-58}$

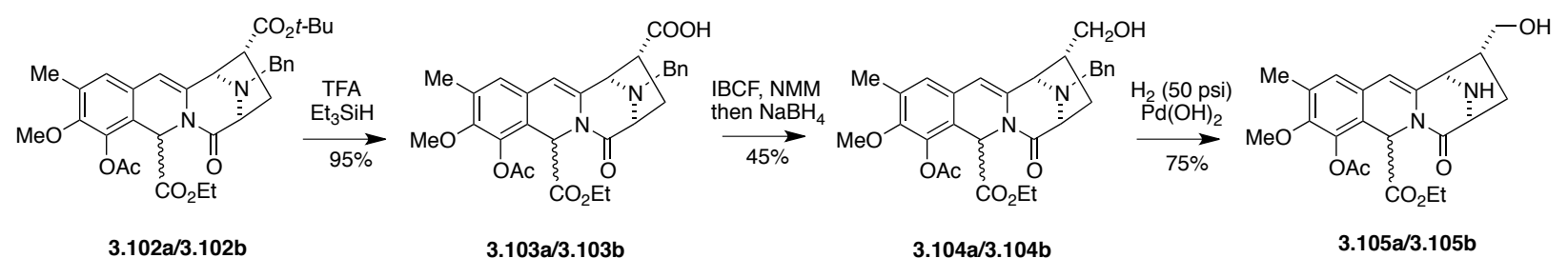

Scheme 3.20. Synthesis of compounds 3.105a and 3.105b 
Then, we turned our attention to the conversion of the tert-butyl ester into a hydroxymethyl group to attempt the debenzylation of the piperazinone amine. Thus, following Williams group precedent, ${ }^{58}$ treatment of 3.102a and 3.102b with TFA, followed by conversion into a mixed anhydride and reduction with sodium borohydride gave the desired mixture of epimeric alcohols 3.104a and 3.104b in moderate yield (Scheme 3.20). The use of standard conditions for the deprotection of tertiary benzylamines (Pearlman's catalyst, $\mathrm{H}_{2}$ at 50 psi, EtOH) effected the conversion into 3.105a and 3.105b in $75 \%$ yield. This result confirmed one of the predictions discussed in the previous section, in relation to the influence of the tert-butyl ester group on the reactivity towards debenzylation of our tetracyclic compounds. At this stage, we decided to adopt a strategy aimed at the initial epimerization of the southern benzylic position, which involved attempting the debenzylation and transformation of the tert-butyl ester at later stages of the sequence. With this decision we intended to reduce the total number of steps in our planned sequence, because the use of a route utilizing compounds $\mathbf{3 . 1 0 5} \mathbf{a}$ and $\mathbf{3 . 1 0 5} \mathbf{b}$ would have required the installation of additional protecting groups on both the primary alcohol and the secondary amine.

\subsubsection{Epimerization of the southern benzylic stereocenter}

Deacetylation of the $\mathbf{3 . 1 0 2 a} / \mathbf{3 . 1 0 2 b}$ mixture under standard methanolysis conditions provided a 5:1 mixture of 3.106a and 3.106b in 70\% yield (Scheme 3.21). We suggest that 3.106b decomposes under the reaction conditions at a higher rate than 3.106a, which provides an explanation for both the moderate yield and the change in the diastereomeric ratio. The chemoselective reduction of the ethyl esters with one equivalent of $\mathrm{LiAlH}_{4}$ at $-10{ }^{\circ} \mathrm{C}$, afforded a 3:1 mixture of aldehydes 3.107a and 3.107b in 55\% yield. As shown in Scheme 3.22, we propose that the observed chemoselectivity can be explained by the initial formation of a 
phenoxyaluminum hydride species (3.109), which upon delivery one hydride to the ester, forms a stable 7-membered ring alkoxy(phenoxy)aluminum hydride species (3.110) that does not undergo a second hydride addition. We submit that the partial epimerization seen in this step is promoted by the slightly basic workup conditions.

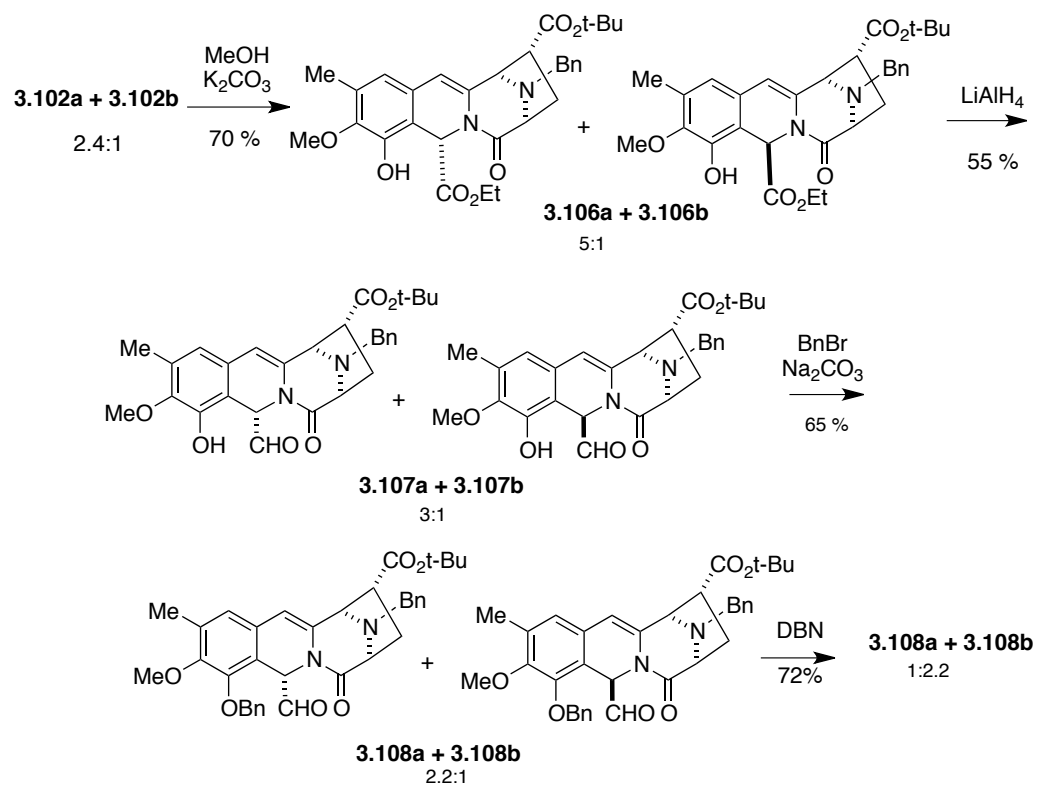

Scheme 3.21. Synthesis of aldehydes 3.108a and 3.108b
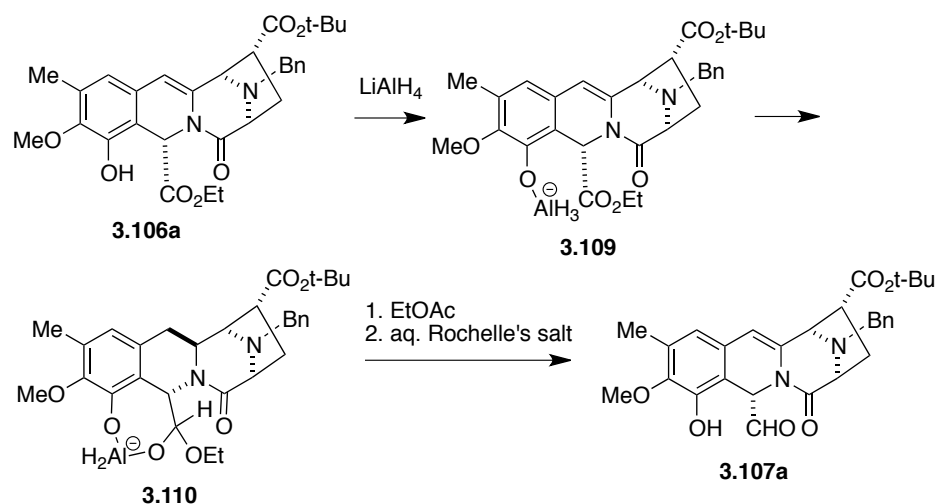

Scheme 3.22. Proposed rationale for the chemoselective reduction of $3.106 a / 3.106 b$

Then, treatment of 3.107a and 3.107b with $\mathrm{BnBr}$ and $\mathrm{Na}_{2} \mathrm{CO}_{3}$ formed the phenolic benzyl ethers and induced additional epimerization of the aldehyde's $\alpha$ carbon, to provide a 2.2:1 
mixture of 3.108a and 3.108b which was then reacted with DBN in THF to invert the epimeric ratio (Scheme 3.21). ${ }^{56-57,58}$ Since, these two compounds are very unstable to silica gel, we did not attempt their separation for the purpose of recycling of $\mathbf{3 . 1 0 8 a}$.

\subsubsection{Hydrogenation of the enamide double bond}

As shown in Scheme 3.23, the 1:2.2 mixture of aldehydes 3.108a and 3.108b was then treated with sodium borohydride to afford a mixture of alcohols 3.111a and 3.111b, which were separated via flash chromatography to give $\mathbf{3 . 1 1 1 b}$ in $65 \%$ yield. The sequence used to transform the 3.102a/3.102b mixture into 3.111b not only provided the desired configuration in the benzylic position but also furnished an unhindered substrate for the $N$-debenzylation of the piperazinone amine. With compound 3.111b in hand, we attempted the debenzylation reaction with the conditions used for the transformation of 3.104a/3.104b into 3.105a/3.105b (Pearlman's catalyst, $\mathrm{H}_{2}$ at 50 psi, EtOH, Scheme 3.20). Unfortunately, the desired product was formed only the first attempted reaction and all the subsequent attempts to reproduce this result were unsuccessful. We tentatively identified the unstable product formed in the subsequent attempts as the corresponding bis-debenzylated hemiaminal ether, which could result from the reduction of the amide and the incorporation of EtOH. We also made several attempts using $\mathrm{Pd}(\mathrm{OH})_{2}$ and aprotic solvents (e.g. THF, EtOAc), but only the $O$-debenzylation product was formed.

To our delight, the hydrogenolysis in glacial acetic acid $(10 \% \mathrm{Pd} / \mathrm{C}, 1 \mathrm{~atm})$ effected the bis-debenzylation of 3.111b to afford $\mathbf{3 . 1 1 2}$ in $92 \%$ yield. The removal of the $N$-benzyl group provided the desired unhindered substrate for the hydrogenation of the enamide double bond. Gratifyingly, the treatment of $\mathbf{3 . 1 1 2}$ with Raney ${ }^{\circledR}$ nickel and $\mathrm{H}_{2} 100 \mathrm{psi}^{56}$ provided compound 3.113 in $73 \%$ yield. These two results confirmed our hypotheses about the role of the steric 
factors in the outcome of both the debenzylation of the tertiary benzylamine and hydrogenation of the enamide double bond.
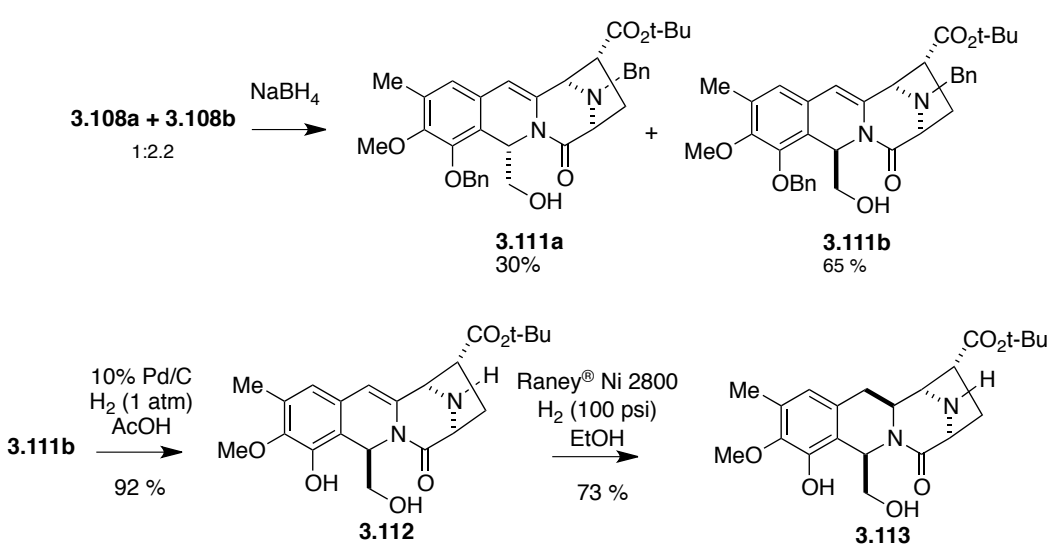

Scheme 3.23. Reduction of the enamide double bond

\subsection{Concluding remarks}

In summary, we have accomplished the asymmetric construction of the tetracyclic core of (-)-lemonomycin. An advanced tetracyclic intermediate was prepared from known bromotyrosinol $\mathbf{3 . 8 6}$ in sixteen steps. Efforts to gain access to (-)-lemonomycin through this advanced intermediate are currently under investigation. 


\section{REFERENCES}

1. Scott, J. D.; Williams, R. M., Chemistry and biology of the tetrahydroisoquinoline antitumor antibiotics. Chem. Rev. 2002, 102, 1669-1730.

2. Kluepfel, D.; Baker, H. A.; Piattoni, G.; Sehgal, S. N.; Sidorowicz, A.; Singh, K.; Vezina, C., Naphthyridinomycin, a New Broad-Spectrum Antibiotic. J. Antibiot. 1975, 28, 497-502.

3. J. Monk, B.; Dalton, H.; Benjamin, I.; Tanovic, A., Trabectedin as a new chemotherapy option in the treatment of relapsed platinum sensitive ovarian cancer. Current Pharmaceutical Design 2012, 18, 3754-3769.

4. $\quad$ Cesne, A. L.; Cresta, S.; Maki, R. G.; Blay, J. Y.; Verweij, J.; Poveda, A.; Casali, P. G.; Balaña, C.; Schöffski, P.; Grosso, F.; Lardelli, P.; Nieto, A.; Alfaro, V.; Demetri, G. D., A retrospective analysis of antitumour activity with trabectedin in translocation-related sarcomas. European Journal of Cancer 2012, 48, 3036-3044.

5. Delaloge, S.; Tedesco, K. L.; Blum, J.; Goncalves, A.; Lubinski, J.; Efrat, N.; Osborne, C.; Lebedinsky, C.; Tercero, J. C.; Holmes, F. A., Preliminary safety and activity results of trabectedin in a phase II trial dedicated to triple-negative (ER-, PR-, HER2-), HER2+++, or BRCA1/2 germ-line-mutated metastatic breast cancer (MBC) patients (pts). Journal of Clinical Oncology 2009, 27.

6. Michaelson, M. D.; Bellmunt, J.; Hudes, G. R.; Goel, S.; Lee, R. J.; Kantoff, P. W.; Stein, C. A.; Lardelli, P.; Pardos, I.; Kahatt, C.; Nieto, A.; Cullell-Young, M.; Lewis, N. L.; Smith, M. R., Multicenter phase II study of trabectedin in patients with metastatic castration-resistant prostate cancer. Annals of Oncology 2012, 23, 1234-1240.

7. Leal, J. F. M.; Martinez-Diez, M.; Garcia-Hernandez, V.; Moneo, V.; Domingo, A.; Bueren-Calabuig, J. A.; Negri, A.; Gago, F.; Guillen-Navarro, M. J.; Aviles, P.; Cuevas, C.; Garcia-Fernandez, L. F.; Galmarini, C. M., PM01183, a new DNA minor groove covalent binder with potent in vitro and in vivo anti-tumour activity. British Journal of Pharmacology 2010, 161, 1099-1110.

8. Ocio, E. M.; De La Rubia, J.; Oriol-Rocafiguera, A.; Blade, J.; Rodriguez, J.; Coronado, C.; Sanchez, J. M.; Teruel, A. I.; Hernandez-Maraver, D.; Prosper, F.; San-Miguel, J. F., Phase II Optimization, Open-Label Clinical Trial of Zalypsis (R) (PM00104) in Relapsed/Refractory Multiple Myeloma Patients. Blood 2012, 120.

9. $\quad$ Yap, T. A.; Cortes-Funes, H.; Shaw, H.; Rodriguez, R.; Olmos, D.; Lal, R.; Fong, P. C.; Tan, D. S.; Harris, D.; Capdevila, J.; Coronado, C.; Alfaro, V.; Soto-Matos, A.; FernándezTeruel, C.; Siguero, M.; Tabernero, J. M.; Paz-Ares, L.; de Bono, J. S.; López-Martin, J. A., First-in-man phase I trial of two schedules of the novel synthetic tetrahydroisoquinoline alkaloid PM00104 (Zalypsis) in patients with advanced solid tumours. British Journal of Cancer 2012, 106, 1379-1385. 
10. Lown, J. W.; Joshua, A. V.; Lee, J. S., Molecular mechanisms of binding and singlestrand scission of deoxyribonucleic-acid by the anti-tumor antibiotics saframycins A and C. Biochemistry 1982, 21, 421-428.

11. Tomita, F.; Takahashi, K.; Tamaoki, T., Quinocarcin, a novel antitumor antibiotic .3. Mode of action. J. Antibiot. 1984, 37, 1268-1272.

12. Williams, R. M.; Flanagan, M. E.; Tippie, T. N., $\mathrm{O}_{2}$-dependent cleavage of DNA by Tetrazomine. Biochemistry 1994, 33, 4086-4092.

13. Williams, R. M.; Glinka, T.; Flanagan, M. E.; Gallegos, R.; Coffman, H.; Pei, D. H., Cannizzaro-based $\mathrm{O}_{2}$-dependent cleavage of dna by quinocarcin. J. Am. Chem. Soc. 1992, 114, 733-740.

14. Henle, E. S.; Linn, S., Formation, prevention, and repair of DNA damage by iron hydrogen peroxide. J. Biol. Chem. 1997, 272, 19095-19098.

15. Wolkenberg, S. E.; Boger, D. L., Mechanisms of in situ activation for DNA-targeting antitumor agents. Chem. Rev. 2002, 102, 2477-2495.

16. Stubbe, J.; Kozarich, J. W., Mechanisms of bleomycin-Induced DNA-degradation. Chem. Rev. 1987, 87, 1107-1136.

17. Williams, R. M.; Herberich, B., DNA interstrand cross-link formation induced by bioxalomycin alpha(2). J. Am. Chem. Soc. 1998, 120, 10272-10273.

18. Whaley, H. A. P., E. L.; Dann, M.; Shay, A. J.; Porter, J. N. In Isolation and Characterization of Lemonomycin, a New Antibiotic, Proceedings of the Fourth Interscience Conference on Antimicrobial Agents and Chemotherapy, New York, N.Y., New York, N.Y., 1964; pp 83-86.

19. He, H. Y.; Shen, B.; Carter, G. T., Structural elucidation of lemonomycin, a potent antibiotic from Streptomyces candidus. Tetrahedron Lett. 2000, 41, 2067-2071.

20. Takahashi, K.; Tomita, F., Dc-52, a Novel anti-tumor antibiotic .2. Isolation, physicochemical characteristics and structure determination. J. Antibiot. 1983, 36, 468-470.

21. (a) Hegde, V. R.; Patel, M. G.; Das, P. R.; Pramanik, B.; Puar, M. S., A family of novel macrocyclic lactones, the saccharocarcins produced by Saccharothrix aerocolonigenes subsp antibiotica .2. Physico-chemical properties and structure determination. J. Antibiot. 1997, 50, 126-134; (b) Li, W. Y.; Leet, J. E.; Ax, H. A.; Gustavson, D. R.; Brown, D. M.; Turner, L.; Brown, K.; Clark, J.; Yang, H.; Fung-Tomc, J.; Lam, K. S., Nocathiacins, new thiazolyl peptide antibiotics from Nocardia sp I. Taxonomy, fermentation and biological activities. J. Antibiot. 2003, 56, 226-231; (c) Northcote, P. T.; Siegel, M.; Borders, D. B.; Lee, M. D., Glycothiohexide-alpha, a novel antibiotic produced by sebekia Sp, LL-14E605 .3. Structural elucidation. J. Antibiot. 1994, 47, 901-908; (d) Sasaki, T.; Otani, T.; Matsumoto, H.; Unemi, N.; Hamada, M.; Takeuchi, T.; Hori, M., MJ347-81F4 A \& B, novel antibiotics from Amycolatopsis sp.: Taxonomic characteristics, fermentation, and antimicrobial activity. J. Antibiot. 1998, 51, 
715-721; (e) Zhang, C. W.; Herath, K.; Jayasuriya, H.; Ondeyka, J. G.; Zink, D. L.; Occi, J.; Birdsall, G.; Venugopal, J.; Ushio, M.; Burgess, B.; Masurekar, P.; Barrett, J. F.; Singh, S. B., Thiazomycins, thiazolyl peptide antibiotics from Amycolatopsis fastidiosa. J. Nat. Prod. 2009, $72,841-847$.

22. Koketsu, K.; Minami, A.; Watanabe, K.; Oguri, H.; Oikawa, H., Pictet-Spenglerase involved in tetrahydroisoquinoline antibiotic biosynthesis. Curr. Opin. Chem. Biol. 2012, 16, 142-149.

23. Koketsu, K.; Minami, A.; Watanabe, K.; Oguri, H.; Oikawa, H., The Pictet-Spengler mechanism involved in the biosynthesis of tetrahydroisoquinoline antitumor antibiotics: a novel function for a nonribosomal peptide synthetase. Natural Product Biosynthesis by Microorganisms and Plants, Pt B 2012, 516, 79-98.

24. (a) Zmijewski, M. J., Biosynthetic origin of carbon-1 and carbon-2 of naphthyridinomycin. J. Antibiot. 1985, 38, 819-820; (b) Zmijewski, M. J.; Mikolajczak, M.; Viswanatha, V.; Hruby, V. J., Biosynthesis of the anti-tumor antibiotic naphthyridinomycin. $J$. Am. Chem. Soc. 1982, 104, 4969-4971; (c) Zmijewski, M. J.; Palaniswamy, V. A.; Gould, S. J., Studies of nitrogen-metabolism using C-13 NMR-Spectroscopy .4. Naphthyridinomycin biosynthesis - the involvement of ornithine and the origin of the oxazolidine nitrogen. Journal of the Chemical Society-Chemical Communications 1985, 1261-1262.

25. Li, L.; Deng, W.; Song, J.; Ding, W.; Zhao, Q. F.; Peng, C.; Song, W. W.; Tang, G. L.; Liu, W., Characterization of the saframycin a gene cluster from Streptomyces lavendulae NRRL 11002 revealing a nonribosomal peptide synthetase system for assembling the unusual tetrapeptidyl skeleton in an iterative manner. J. Bacteriol. 2008, 190, 251-263.

26. Tang, M. C.; Fu, C. Y.; Tang, G. L., Characterization of SfmD as a HEME peroxidase that catalyzes the regioselective hydroxylation of 3-methyltyrosine to 3-hydroxy-5methyltyrosine in saframycin A biosynthesis. J. Biol. Chem. 2012, 287, 5112-5121.

27. Koketsu, K.; Watanabe, K.; Suda, H.; Oguri, H.; Oikawa, H., Reconstruction of the saframycin core scaffold defines dual Pictet-Spengler mechanisms. Nature Chemical Biology 2010, 6, 408-410.

28. Rath, C. M.; Janto, B.; Earl, J.; Ahmed, A.; Hu, F. Z.; Hiller, L.; Dahlgren, M.; Kreft, R.; Yu, F. A.; Wolff, J. J.; Kweon, H. K.; Christiansen, M. A.; Hakansson, K.; Williams, R. M.; Ehrlich, G. D.; Sherman, D. H., Meta-omic characterization of the marine invertebrate microbial consortium that produces the chemotherapeutic natural product ET-743. ACS Chemical Biology 2011, 6, 1244-1256.

29. Peng, C.; Pu, J. Y.; Song, L. Q.; Jian, X. H.; Tang, M. C.; Tang, G. L., Hijacking a hydroxyethyl unit from a central metabolic ketose into a nonribosomal peptide assembly line. Proceedings of the National Academy of Sciences of the United States of America 2012, 109, 8540-8545.

30. Ashley, E. R.; Cruz, E. G.; Stoltz, B. M., The total synthesis of (-)-lemonomycin. J. Am. Chem. Soc. 2003, 125, 15000-15001. 
31. Yoshida, A.; Akaiwa, M.; Asakawa, T.; Hamashima, Y.; Yokoshima, S.; Fukuyama, T.; Kan, T., Total synthesis of (-)-lemonomycin. Chemistry-a European Journal 2012, 18, 1119211195 .

32. Rikimaru, K.; Mori, K.; Kan, T.; Fukuyama, T., Synthetic studies on (-)-lemonomycin: stereocontrolled construction of the 3,8-diazabicyclo[3.2.1] skeleton. Chem. Commun. 2005, 394-396.

33. Magnus, P.; Matthews, K. S., Synthesis of the tetrahydroisoquinoline alkaloid ( \pm )renieramycin $\mathrm{g}$ and a $( \pm$ )-lemonomycinone analogue from a common intermediate. J. Am. Chem. Soc. 2005, 127, 12476-12477.

34. Magnus, P.; Matthews, K. S., A divergent strategy for synthesis of the tetrahydroisoquinoline alkaloids renieramycin $\mathrm{G}$ and a lemonomycin analog. Tetrahedron 2012, 68, 6343-6360.

35. (a) Couturier, C.; Schlama, T.; Zhu, J. P., Synthetic studies towards (-)-lemonomycin, synthesis of fused tetracycles. Synlett 2006, 1691-1694; (b) Wu, Y. C.; Bernadat, G.; Masson, G.; Couturier, C.; Schlama, T.; Zhu, J. P., Synthetic studies on (-)-lemonomycin: an efficient asymmetric synthesis of lemonomycinone amide. J. Org. Chem. 2009, 74, 2046-2052.

36. Bernadat, G.; George, N.; Couturier, C.; Masson, G.; Schlama, T.; Zhu, J. P., asymmetric synthesis of 2,4,6-trideoxy-4-(dimethylamino)-3-c-methyl-L-lyxohexopyranose (lemonose). Synlett 2011, 576-578.

37. Siengalewicz, P.; Brecker, L.; Mulzer, J., Stereocontrolled synthesis of the tetracyclic core framework of (-)-lemonomycin. Synlett 2008, 2443-2446.

38. Vincent, G.; Chen, Y. Y.; Lane, J. W.; Williams, R. M., Formation of the C-3-C-4 unsaturated framework of cribrostatin 4 via dead-mediated oxidation of an allylic tertiary amine. Heterocycles 2007, 72, 385-398.

39. Mancuso, A. J.; Huang, S. L.; Swern, D., Oxidation of long-chain and related alcohols to carbonyls by dimethyl-sulfoxide activated by oxalyl chloride. J. Org. Chem. 1978, 43, 24802482 .

40. Evans, D. A.; Hu, E.; Tedrow, J. S., An aldol-based approach to the asymmetric synthesis of L-callipeltose, the deoxyamino sugar of L-callipeltoside A. Org. Lett. 2001, 3, 3133-3136.

41. Pappo, R.; Allen, J. D.; Lemieux, R.; Johnson, W., Osmium tetroxide-catalyzed periodate oxidation of olefinic bonds. J. Org. Chem. 1956, 21, 478-479.

42. Gallina, C.; Liberato.A, Condensation of 1,4-diacetylpiperazine-2,5-dione with aldehydes. Tetrahedron 1974, 30, 667-673.

43. Singh, R. P.; Shreeve, J. M., Recent advances in nucleophilic fluorination reactions of organic compounds using Deoxofluor and DAST. Synthesis-Stuttgart 2002, 2561-2578. 
44. Roesch, K. R.; Larock, R. C., Synthesis of isoquinolines and pyridines by the palladium/copper-catalyzed coupling and cyclization of terminal acetylenes and unsaturated imines: the total synthesis of decumbenine B. J. Org. Chem. 2002, 67, 86-94.

45. Castro, C. E.; Havlin, R.; Honwad, V. K.; Malte, A. M.; Moje, S. W., Copper(I) substitutions. Scope and mechanism of cuprous acetylide substitutions. J. Am Chem. Soc.1969, 91, 6464-6470.

46. Kaufman, T. S., Convenient one-pot synthesis of primary alpha-alkoxystannanes. Synlett 1997, 1377-1378.

47. Corey, E. J.; Xu, F.; Noe, M. C., A Rational approach to catalytic enantioselective enolate alkylation using a structurally rigidified and defined chiral quaternary ammonium salt under phase transfer conditions. J. Am. Chem. Soc. 1997, 119, 12414-12415.

48. (a) Lygo, B.; Wainwright, P. G., A new class of asymmetric phase-transfer catalysts derived from Cinchona alkaloids - Application in the enantioselective synthesis of $\alpha$-amino acids. Tetrahedron Lett. 1997, 38, 8595-8598; (b) Lygo, B.; Andrews, B. I., Asymmetric phasetransfer catalysis utilizing chiral quaternary ammonium salts: asymmetric alkylation of glycine imines. Acc. Chem. Res. 2004, 37, 518-525.

49. Rush, J.; Bertozzi, C. R., An $\alpha$-Formylglycine building block for fmoc-based solid-phase peptide synthesis. Org. Lett. 2006, 8, 131-134.

50. Myers, A. G.; Schnider, P.; Kwon, S.; Kung, D. W., Greatly simplified procedures for the synthesis of alpha-amino acids by the direct alkylation of pseudoephedrine glycinamide hydrate. J. Org. Chem. 1999, 64, 3322-3327.

51. Dess, D. B.; Martin, J. C., A Useful 12-I-5 Triacetoxyperiodinane (the Dess-Martin periodinane) for the selective oxidation of primary or secondary alcohols and a variety of related 12-I-5 species. J. Am. Chem. Soc. 1991, 113, 7277-7287.

52. Domling, A.; Ugi, I., Multicomponent reactions with isocyanides. Angewandte ChemieInternational Edition 2000, 39, 3169-3210.

53. Lane, J. W.; Chen, Y. Y.; Williams, R. M., Asymmetric total syntheses of (-)-jorumycin, (-)-renieramycin G, 3-epi jorumycin, and 3-epi-renieramycin G. J. Am. Chem. Soc. 2005, 127, 12684-12690.

54. Fukuyama, T.; Yang, L.; Ajeck, K. L.; Sachleben, R. A., Total synthesis of (+/-)saframycin-A. J. Am. Chem. Soc. 1990, 112, 3712-3713.

55. (a) Bender, D. M.; Williams, R. M., An efficient synthesis of (S)-m-tyrosine. J. Org. Chem. 1997, 62, 6690-6691; (b) Dastlik, K. A.; Sundermeier, U.; Johns, D. M.; Chen, Y.; Williams, R. M., An improved synthesis of optically pure 4-Boc-5,6-diphenylmorpholin-2-one and 4-Cbz-5,6-diphenylmorpholin-2-one. Synlett 2005, 693-696; (c) Williams, R. M.; Im, M. N., Asymmetric-synthesis of alpha-amino-acids - comparison of enolate vs cation functionalization of N-Boc-5,6-diphenyl-2,3,5,6-tetrahydro-4h-1,4-oxazin-2-ones. Tetrahedron Lett. 1988, 29, 
6075-6078; (d) Williams, R. M.; Im, M. N., Asymmetric-synthesis of monosubstituted and alpha,alpha-disubstituted alpha-amino-acids via diastereoselective glycine enolate alkylations. $J$. Am. Chem. Soc. 1991, 113, 9276-9286; (e) Williams, R. M., Asymmetric syntheses of alphaaminoacids. Aldrichimica Acta 1992, 25, 11-25.

56. Scott, J. D.; Williams, R. M., Total synthesis of (-)-tetrazomine and determination of its stereochemistry. Angewandte Chemie-International Edition 2001, 40, 1463-1465.

57. Flanagan, M. E.; Williams, R. M., Synthetic studies on quinocarcin - total synthesis of (+/-)-quinocarcinamide via dipole cycloaddition of an azomethine ylide generated by NBS oxidation. J. Org. Chem. 1995, 60, 6791-6797.

58. Chen, Y. Studies towards the total synthesis of (-)-lemonomycin Colorado State University, 2005.

59. (a) Garner, P.; Park, J. M.; Malecki, E., A Stereodivergent synthesis of D-erythrosphingosine and d-threo-sphingosine from L-serine. J. Org. Chem. 1988, 53, 4395-4398; (b) Garner, P.; Park, J. M., An Asymmetric-synthesis of 5-O-Carbamoylpolyoxamic acid from DSerine. J. Org. Chem. 1988, 53, 2979-2984; (c) Garner, P.; Park, J. M., The synthesis and configurational stability of differentially protected beta-hydroxy-alpha-amino aldehydes. J. Org. Chem. 1987, 52, 2361-2364.

60. Casiraghi, G.; Cornia, M.; Rassu, G., Synthesis of 1-(2-hydroxyaryl)-1,2,3-propanetriol and 1-(2-hydroxyaryl)-2-amino-1,3-propanediol derivatives of either threo or erythro configuration. J. Org. Chem. 1988, 53, 4919-4922.

61. Chen, X. C.; Chen, J. C.; De Paolis, M.; Zhu, J. P., Synthetic studies toward ecteinascidin 743. J. Org. Chem. 2005, 70, 4397-4408.

62. Sakaitani, M.; Ohfune, Y., Syntheses and reactions of silyl carbamates. 1. Chemoselective transformation of amino protecting groups via tert-butyldimethylsilyl carbamates. The Journal of Organic Chemistry 1990, 55, 870-876.

63. Schneider, H.; Sigmund, G.; Schricker, B.; Thirring, K.; Berner, H., Synthesis of Modified Partial Structures of the Bacterial-Cell Wall .1. Lipopeptides containing nonproteinogenic amino-acids. J. Org. Chem. 1993, 58, 683-689.

64. Ley, S. V.; Norman, J.; Griffith, W. P.; Marsden, S. P., Tetrapropylammonium perruthenate, $\mathrm{Pr}_{4} \mathrm{~N}^{+} \mathrm{RuO}_{4}^{-}$, Tpap - a Catalytic oxidant for organic-synthesis. Synthesis-Stuttgart 1994, 639-666.

65. Parikh, J. R.; Doering, W. V. E., Sulfur trioxide in oxidation of alcohols by dimethyl sulfoxide. J. Am. Chem. Soc. 1967, 89, 5505-\&.

66. Martinez, E. J.; Corey, E. J., Enantioselective synthesis of saframycin A and evaluation of antitumor activity relative to ecteinascidin/saframycin hybrids. Org. Lett. 1999, 1, 75-77. 
67. Saito, N.; Tashiro, K.; Maru, Y.; Yamaguchi, K.; Kubo, A., Synthetic approaches toward ecteinascidins .1. Preparation of an (E)-2-arylidene-3-benzyl-1,5-imino-3-benzazocin-4-one having a protected phenol in the E-ring. Journal of the Chemical Society-Perkin Transactions 1 1997, 53-69.

68. Fishlock, D.; Willlams, R. M., Synthetic Studies on Et-743. Assembly of the pentacyclic core and a formal total synthesis. J. Org. Chem. 2008, 73, 9594-9600.

69. Liao, X. W.; Liu, W.; Dong, W. F.; Guan, B. H.; Chen, S. Z.; Liu, Z. Z., Total synthesis of (-)-renieramycin G from L-tyrosine. Tetrahedron 2009, 65, 5709-5715.

70. Sales, M.; Charette, A. B., A Diels-Alder approach to the stereoselective synthesis of 2,3,5,6-tetra- and 2,3,4,5,6-pentasubstituted piperidines. Org. Lett. 2005, 7, 5773-5776.

71. Frie, J. L.; Jeffrey, C. S.; Sorensen, E. J., A Hypervalent iodine-induced double annulation enables a concise synthesis of the pentacyclic core structure of the cortistatins. Org. Lett. 2009, 11, 5394-5397.

72. Chen, J. C.; Chen, X. C.; Bois-Choussy, M.; Zhu, J. P., Total synthesis of ecteinascidin 743. J. Am. Chem. Soc. 2006, 128, 87-89.

73. Fukuyama, T.; Nunes, J. J., Stereocontrolled total synthesis of (+/-)-quinocarcin. J. Am. Chem. Soc. 1988, 110, 5196-5198.

74. Vishnetskaya, M. V.; Yakimova, I. Y.; Sidorenkova, I. A., The catalytic oxidation of organic compounds in superacids. Russian Journal of Physical Chemistry 2006, 80, 176-180.

75. Vishnetskaya, M. V.; Yakimova, I. Y.; Sidorenkova, I. A., Superacids as catalysts of the oxidation of inorganic substrates. Russian Journal of Physical Chemistry 2006, 80, 173-175.

76. Vishnetskaya, M. V.; Ivanova, M. S.; Solkan, V. N.; Zhidomirov, G. M.; Mel'nikov, M. Y., Activation of molecular oxygen in trifluoroacetic acid. Russian Journal of Physical Chemistry A 2012, 86, 889-891.

77. The equilibrium geometry conformations were calculated with Spartan'10, using the Hartree-Fock/3-21G model. Spartan'10, Wavefunction Inc. Irvine, CA. 


\section{CHAPTER 4}

\section{Experimental procedures}

\subsection{General conditions}

Unless otherwise noted, all materials were obtained from commercial sources and used without purification. All reactions requiring anhydrous conditions were performed under a positive pressure of argon using flame-dried glassware. Organic solvents were degassed with argon and dried through a solvent purification system (Pure Process Technology). Flash chromatography was performed on silica gel grade $60(230 \times 400$ mesh $)$ from Sorbent Technologies. Thin layer chromatography was performed on glass plates coated with silica gel grade 60, from Merck. Melting points were measured in open-end capillary tubes and are

uncorrected. ${ }^{1} \mathrm{H}$ NMR and ${ }^{13} \mathrm{C}$ NMR spectra were recorded on Varian 300 or $400 \mathrm{MHz}$ spectrometers as indicated. Proton spectra in $\mathrm{CDCl}_{3}$ were referenced to residual $\mathrm{CHCl}_{3}$ at 7.26 ppm. Carbon spectra in $\mathrm{CDCl}_{3}$ were referenced to $77.16 \mathrm{ppm}$. Proton spectra in $\mathrm{CD}_{3} \mathrm{OD}$ were referenced to residual $\mathrm{CHD}_{2} \mathrm{OD}$ at $3.34 \mathrm{ppm}$. Proton spectra in DMSO- $d_{6}$ were referenced to residual $\mathrm{CD}_{3} \mathrm{SOCD}_{2} \mathrm{H}$ at $2.50 \mathrm{ppm}$. Infrared spectra were recorded on a Bruker Tensor FT-IR spectrometer. High-resolution mass spectra were obtained using a TOF spectrometer using simultaneous electrospray (ESI) and atmospheric pressure chemical ionization (APCI). Optical rotations were recorded on a Rudolph Research Autopol polarimeter, at a wavelength of $589 \mathrm{~nm}$. 


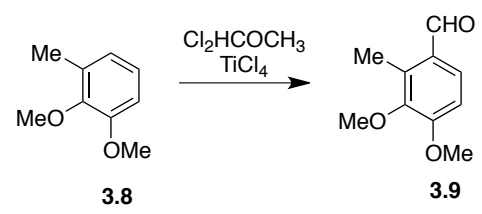

\subsection{3,4-dimethoxy-2-methylbenzaldehyde (3.9)}

To a stirred solution of 2,3-dimethoxytoluene (3.8) (40.7g, $0.27 \mathrm{~mol}, 1$ eq.) in $\mathrm{CH}_{2} \mathrm{Cl}_{2}(250 \mathrm{~mL})$, at $0^{\circ} \mathrm{C}$ under $\mathrm{Ar}$, was added $\mathrm{TiCl}_{4}(47 \mathrm{~mL}, 0.43 \mathrm{~mol}, 1.6$ eq. $)$ followed by a dropwise addition of a solution of $\mathrm{Cl}_{2} \mathrm{HCOCH}_{3}\left(25 \mathrm{~mL}, 0.28 \mathrm{~mol}, 1.05\right.$ eq.) in $\mathrm{CH}_{2} \mathrm{Cl}_{2}(125 \mathrm{~mL})$. The mixture was stirred at $0^{\circ} \mathrm{C}$ for $15 \mathrm{~min}$ and then at $\mathrm{RT}$ for $2 \mathrm{~h}$. The reaction was poured over crushed ice, stirred overnight, the phases separated and the organic layer was rinsed with $5 \% \mathrm{NaHCO}_{3}$, dried $\left(\mathrm{Na}_{2} \mathrm{SO}_{4}\right)$, filtered and concentrated under reduced pressure. The resulting oil was seeded with crystals from a previous batch to afford the title compound as a crystalline solid (47.0 g, 99\%).

${ }^{1} \mathrm{H}-\mathrm{NMR}\left(300 \mathrm{MHz} ; \mathrm{CDCl}_{3}\right): \delta 10.11(\mathrm{~s}, 1 \mathrm{H}), 7.59(\mathrm{~d}, J=8.6 \mathrm{~Hz}, 1 \mathrm{H}), 6.89(\mathrm{~d}, J=8.6 \mathrm{~Hz}, 1 \mathrm{H})$, $3.94(\mathrm{~s}, 3 \mathrm{H}), 3.79(\mathrm{~s}, 3 \mathrm{H}), 2.59(\mathrm{~s}, 3 \mathrm{H})$. 


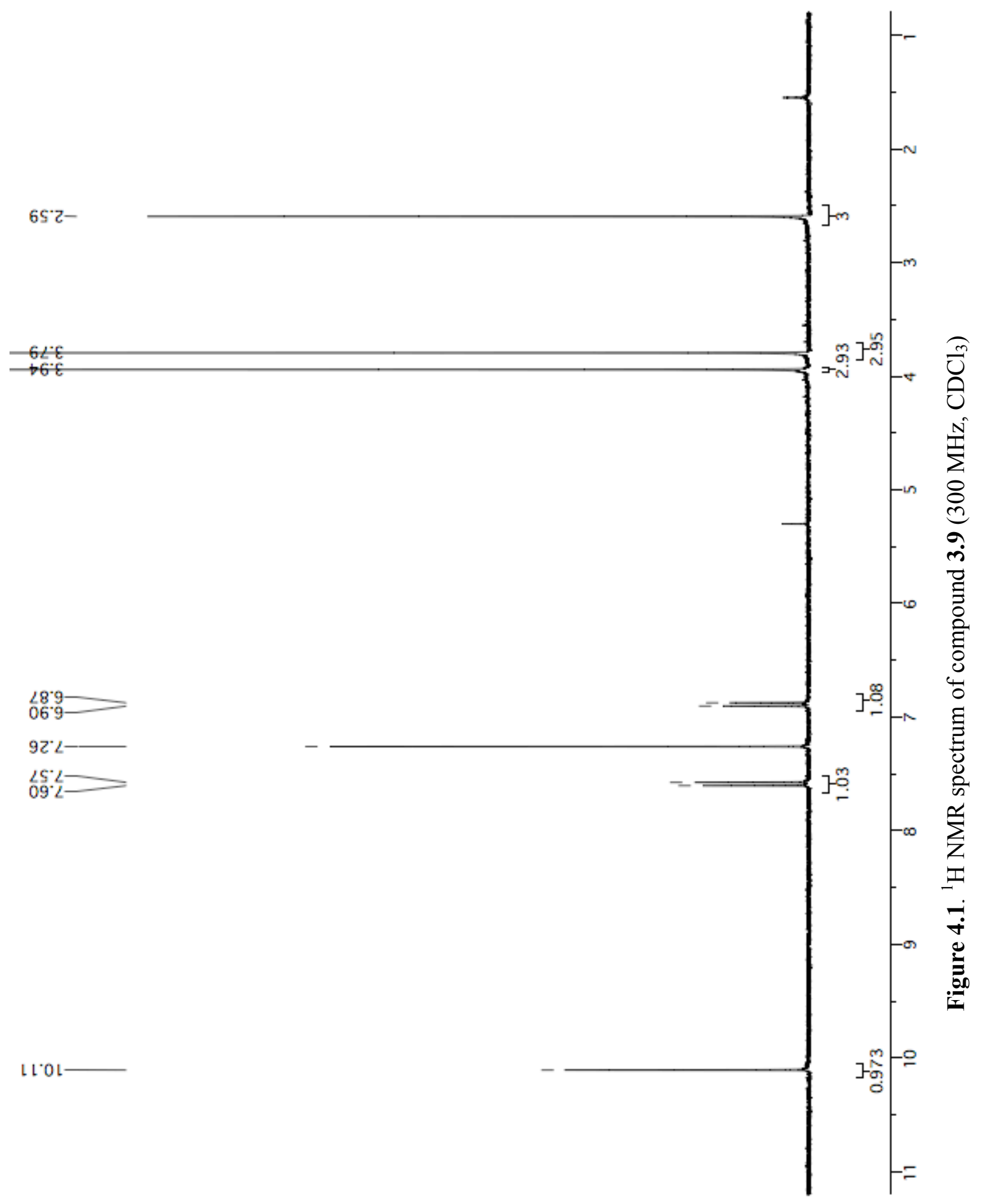




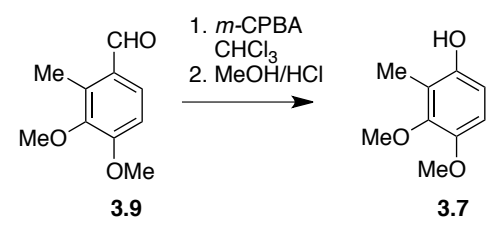

\subsection{3,4-dimethoxy-2-methylphenol (3.7)}

To a stirred solution of 3,4-dimethoxy-2-methylbenzaldehyde (3.9) $(7.81 \mathrm{~g}, 43.4 \mathrm{mmol}, 1$ eq.) in $\mathrm{CHCl}_{3}(200 \mathrm{~mL})$ at $0^{\circ} \mathrm{C}$ was added $m$-CPBA $(20.38 \mathrm{~g}, 130 \mathrm{mmol}, 3.0$ eq.). The solution was warmed to RT, stirred for $10 \mathrm{~min}$. and then refluxed for $3 \mathrm{~h}$. The resulting mixture was washed with $10 \% \mathrm{NaS}_{2} \mathrm{O}_{3}(2 \times 100 \mathrm{~mL}), \mathrm{NaHCO}_{3}(3 \times 50 \mathrm{~mL})$ and brine $(2 \times 50 \mathrm{~mL})$. The organic phase was concentrated under reduced pressure, diluted with $\mathrm{MeOH}(50 \mathrm{~mL})$, cooled to $0^{\circ} \mathrm{C}$, acidified with conc. $\mathrm{HCl}(1 \mathrm{~mL}, 12 \mathrm{mmol})$ and stirred at $\mathrm{RT}$ for $12 \mathrm{~h}$ and then concentrated under reduced pressure. The residue was purified by flash chromatography with 5:1 hexanes/EtOAc to provide the title compound as a yellow solid $(4.88$ g., $67 \%) . \mathrm{R}_{\mathrm{f}}=0.4\left(4: 1\right.$ hexanes/EtOAc); ${ }^{1} \mathrm{H}-\mathrm{NMR}$ $\left(300 \mathrm{MHz} ; \mathrm{CDCl}_{3}\right): \delta 6.64(\mathrm{~d}, J=8.8 \mathrm{~Hz}, 1 \mathrm{H}), 6.51(\mathrm{~d}, J=8.8 \mathrm{~Hz}, 1 \mathrm{H}), 4.44(\mathrm{~s}, 1 \mathrm{H}), 3.81(\mathrm{~s}$, $3 \mathrm{H}), 3.80(\mathrm{~s}, 3 \mathrm{H}), 2.18(\mathrm{~s}, 3 \mathrm{H})$. 


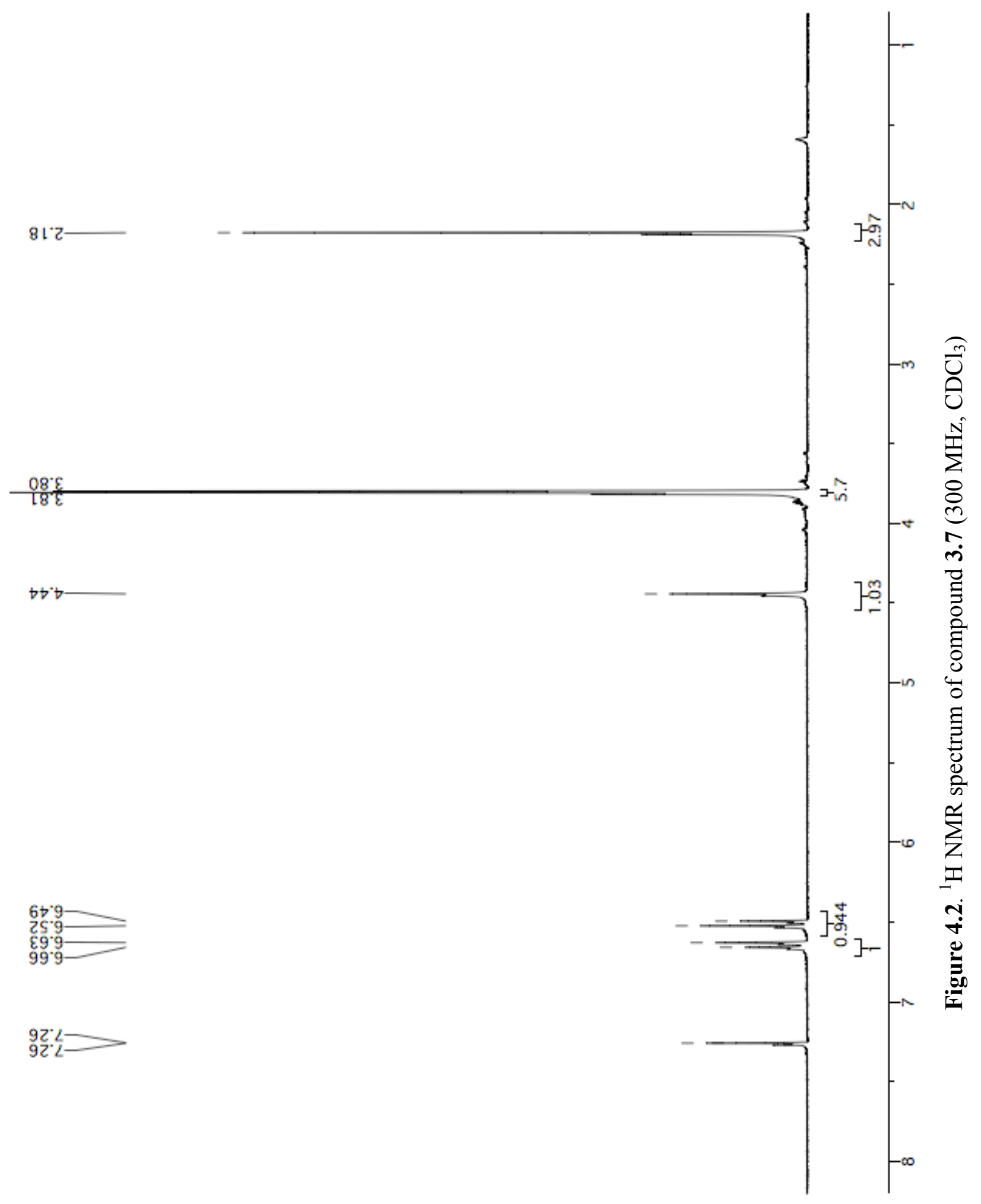




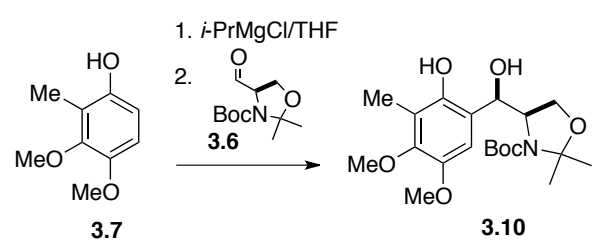

\section{$4.4 \quad(R)$-tert-butyl 4-((R)-hydroxy(2-hydroxy-4,5-dimethoxy-3-methylphenyl)methyl)-2,2- dimethyloxazolidine-3-carboxylate (3.10)}

To a solution of 3,4-dimethoxy-2-methylphenol (3.7) ( $0.22 \mathrm{~g}, 1.3 \mathrm{mmol}, 1.0 \mathrm{eq}$.) in dry THF (3.0 $\mathrm{mL})$, under $\mathrm{Ar}$ atmosphere, was added $i-\mathrm{PrMgCl}(2.0 \mathrm{M}$ in THF, $700 \mu \mathrm{L}, 1.4 \mathrm{mmol}, 1.08$ eq. $)$ at RT. After 5 min. of stirring, a solution of (R)-tert-butyl 4-formyl-2,2-dimethyloxazolidine-3carboxylate ( $R$-Garner's aldehyde) $\left(320 \mathrm{mg}, 1.4 \mathrm{mmol}, 1.8\right.$ eq.) in $\mathrm{CH}_{2} \mathrm{Cl}_{2}(3 \mathrm{~mL})$ was added dropwise and the resulting mixture was stirred overnight. The reaction was quenched with sat. aq. $\mathrm{NH}_{4} \mathrm{Cl}(10 \mathrm{~mL})$, the phases were separated, the organic layer was rinsed with brine $(10 \mathrm{~mL})$, filtered and concentrated under reduced pressure. The crude was purified by flash chromatography with 5:1 hexanes/EtOAc to afford the title compound $(0.34 \mathrm{~g}, 66 \%) ; \mathrm{R}_{\mathrm{f}}=0.3$ (4:1 hexanes/EtOAc) ${ }^{1} \mathrm{H}-\mathrm{NMR}\left(300 \mathrm{MHz} ; \mathrm{CD}_{3} \mathrm{OD}\right)$ : mixture of rotamers, $\delta 6.56(\mathrm{~s}, 1 \mathrm{H}), 4.29-$ $4.22(\mathrm{~m}, 1 \mathrm{H}), 4.09-4.00(\mathrm{~m}, 1 \mathrm{H}), 3.89$ (dd, $J=9.4,6.3 \mathrm{~Hz}, 1 \mathrm{H}), 3.77$ (s, 3H), 3.73 (br s, 3H), $2.10(\mathrm{~s}, 3 \mathrm{H}), 1.52$ (br s, 9H), 1.44 (br s, 3H), 1.29 (br s, 3H). HRMS (FAB+) calcd. for $\mathrm{C}_{20} \mathrm{H}_{31} \mathrm{NO}_{7}\left(\mathrm{M}^{+}\right):(\mathrm{m} / \mathrm{z})$ 397.2101; found (m/z) 397.2095. 


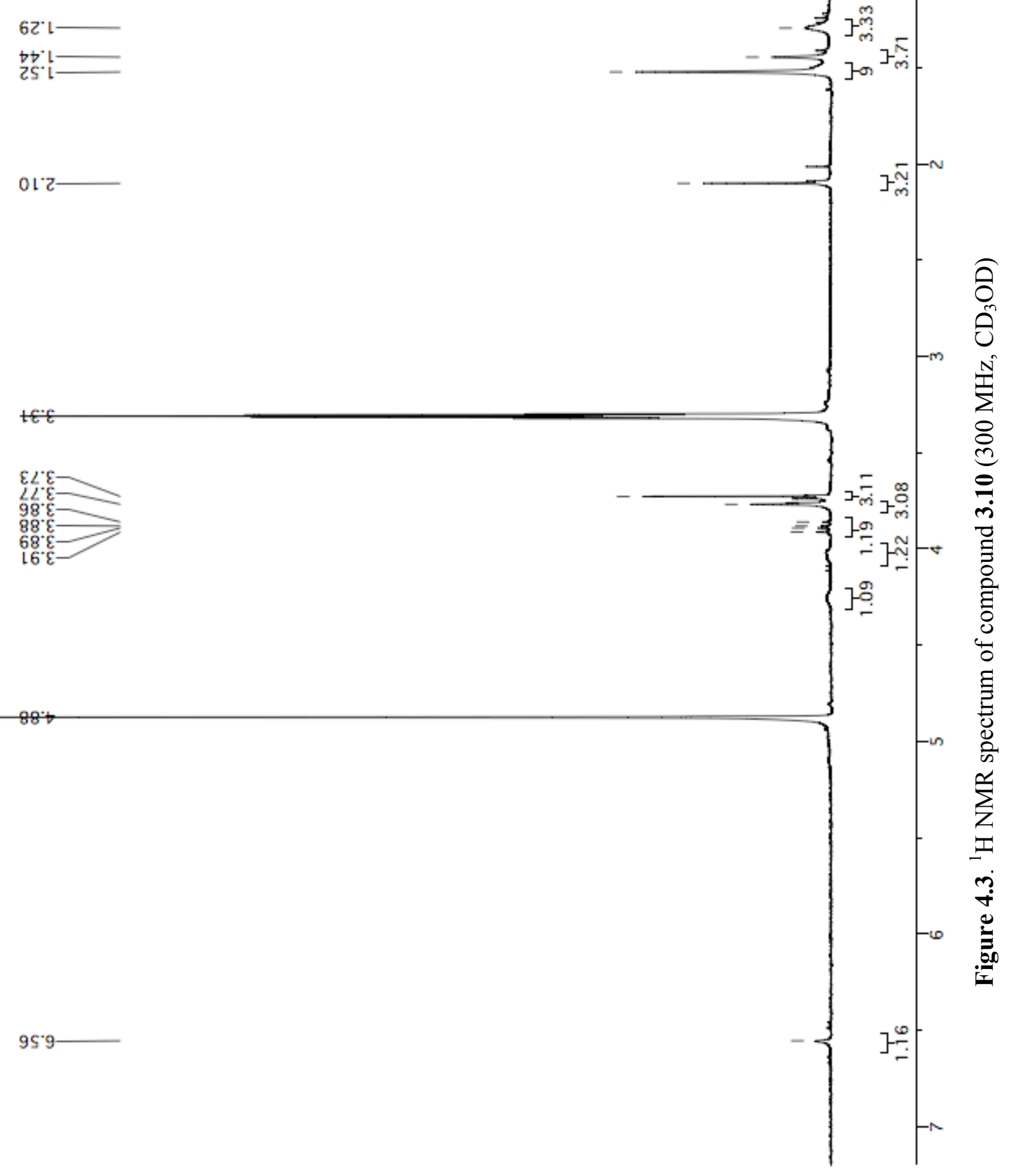




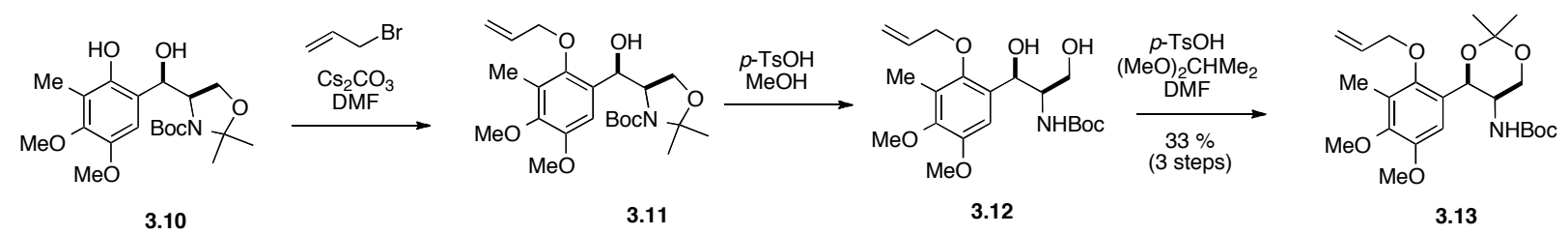

\subsection{Tert-butyl ((4R,5R)-4-(2-(allyloxy)-4,5-dimethoxy-3-methylphenyl)-2,2-dimethyl-1,3- dioxan-5-yl)carbamate (3.13)}

\section{(R)-tert-butyl 4-((R)-(2-(allyloxy)-4,5-dimethoxy-3-methylphenyl)(hydroxy)methyl)-2,2-} dimethyloxazolidine-3-carboxylate (3.11)

A solution of compound $\mathbf{3 . 1 0}(0.34 \mathrm{~g}, 0.86 \mathrm{mmol}, 1.0$ eq.) in dry DMF $(8.0 \mathrm{~mL})$ was added $\mathrm{Cs}_{2} \mathrm{CO}_{3}(0.56 \mathrm{~g}, 1.7 \mathrm{mmol}, 2.0$ eq.) followed by allyl bromide ( $450 \mathrm{~mL}, 5.2 \mathrm{mmol}, 6.0$ eq.). The solution was stirred under Ar atmosphere for $2 \mathrm{~h}$ and NMR analysis revealed the consumption of the starting material. The reaction was diluted with $\mathrm{H}_{2} \mathrm{O}(15 \mathrm{~mL})$, extracted with diethyl ether (3 $\times 10 \mathrm{~mL})$ and the organic layer was rinsed with $\mathrm{H}_{2} \mathrm{O}(10 \mathrm{~mL})$, brine $(10 \mathrm{~mL})$, dried $\left(\mathrm{Na}_{2} \mathrm{SO}_{4}\right)$, filtered and concentrated under reduced pressure to afford the title compound as a yellow oil. This material was used in the following step without further purification. HRMS (FAB+) calcd. for $\mathrm{C}_{23} \mathrm{H}_{35} \mathrm{NO}_{7}:\left(\mathrm{M}^{+}\right):(\mathrm{m} / \mathrm{z}) 437.2414$; found $(\mathrm{m} / \mathrm{z}) 437.2414$.

Tert-butyl ((1R,2R)-1-(2-(allyloxy)-4,5-dimethoxy-3-methylphenyl)-1,3-dihydroxypropan-2yl)carbamate (3.12)

To a solution of crude $3.11(0.86 \mathrm{mmol}, 1.0$ eq. $)$ in $\mathrm{MeOH}(15 \mathrm{~mL})$ at $0^{\circ} \mathrm{C}$ was added $p$-TsOH (15 mg, $0.09 \mathrm{mmol}, 0.1$ eq.). The reaction was warmed to RT and stirred for $2 \mathrm{~h}$ until TLC analysis revealed absence of starting material and a new strong spot at $R_{f}=0$. The reaction was diluted with $\mathrm{H}_{2} \mathrm{O}(15 \mathrm{~mL})$ and extracted with $\mathrm{CH}_{2} \mathrm{Cl}_{2}(4 \times 5 \mathrm{~mL})$. The combined organic layers 
were rinsed with $5 \% \mathrm{NaHCO}_{3}(10 \mathrm{~mL})$ and brine $(10 \mathrm{~mL})$, dried $\left(\mathrm{Na}_{2} \mathrm{SO}_{4}\right)$, filtered and concentrated under reduced pressure to afford the title compound of a yellow oil. This material was used in the following step without further purification. MS (FAB+) calcd. for $\mathrm{C}_{20} \mathrm{H}_{32} \mathrm{NO}_{7}$ : $\left(\mathrm{MH}^{+}\right):(\mathrm{m} / \mathrm{z}) 398.2$; found $(\mathrm{m} / \mathrm{z}) 398.2$.

Tert-butyl ((4R,5R)-4-(2-(allyloxy)-4,5-dimethoxy-3-methylphenyl)-2,2-dimethyl-1,3dioxan-5-yl)carbamate (3.13)

To a solution of crude 3.12 (261 mg, $0.66 \mathrm{mmol}, 1.0$ eq.) in dry DMF (5 mL) under Ar atmosphere were added $p$-TsOH (10 mg, $0.05 \mathrm{mmol}$ ) and 2,2-dimethoxypropane (300 $\mathrm{mL}, 3.4$ mmol, 2.0 eq.). The reaction stirred for $48 \mathrm{~h}$, quenched with $5 \% \mathrm{NaHCO}_{3}(10 \mathrm{~mL})$, diluted with $\mathrm{H}_{2} \mathrm{O}(15 \mathrm{~mL})$ and extracted with EtOAc $(3 \times 5 \mathrm{~mL})$. The combined organic layers were rinsed with $5 \% \mathrm{NaHCO}_{3}(10 \mathrm{~mL})$ and brine $(10 \mathrm{~mL})$, dried $\left(\mathrm{MgSO}_{4}\right)$, filtered and concentrated under reduced pressure. The crude material was purified by flash chromatography with 5:1 hexanes/EtOAc to afford the title compound ( $125 \mathrm{mg}, 33 \%, 3$ steps). $\mathrm{R}_{\mathrm{f}}=0.30 ;{ }^{1} \mathrm{H}-\mathrm{NMR}(300$ $\left.\mathrm{MHz} ; \mathrm{CD}_{3} \mathrm{OD}\right):$ mixture of rotamers, $\delta 6.89(\mathrm{br} \mathrm{s}, 1 \mathrm{H}), 6.21-6.06(\mathrm{~m}, 1 \mathrm{H}), 5.55-5.39(\mathrm{~m}, 2 \mathrm{H})$, 5.37-5.23 (m, 1H), 4.49-4.25 (m, 3H), 4.09 (q, $J=7.1 \mathrm{~Hz}, 1 \mathrm{H}), 3.88-3.80(\mathrm{~m}, 3 \mathrm{H}), 3.77-3.68(\mathrm{~m}$, 5H), $2.16(\mathrm{~s}, 3 \mathrm{H}), 1.55$ (br s, 3H), 1.49 (br s, 3H), $1.24(\mathrm{~s}, 9 \mathrm{H})$. HRMS (FAB+) calcd. for $\mathrm{C}_{23} \mathrm{H}_{35} \mathrm{NO}_{7}:\left(\mathrm{MH}^{+}\right):(\mathrm{m} / \mathrm{z})$ 437.2414; found $(\mathrm{m} / \mathrm{z}) 437.2414$. 


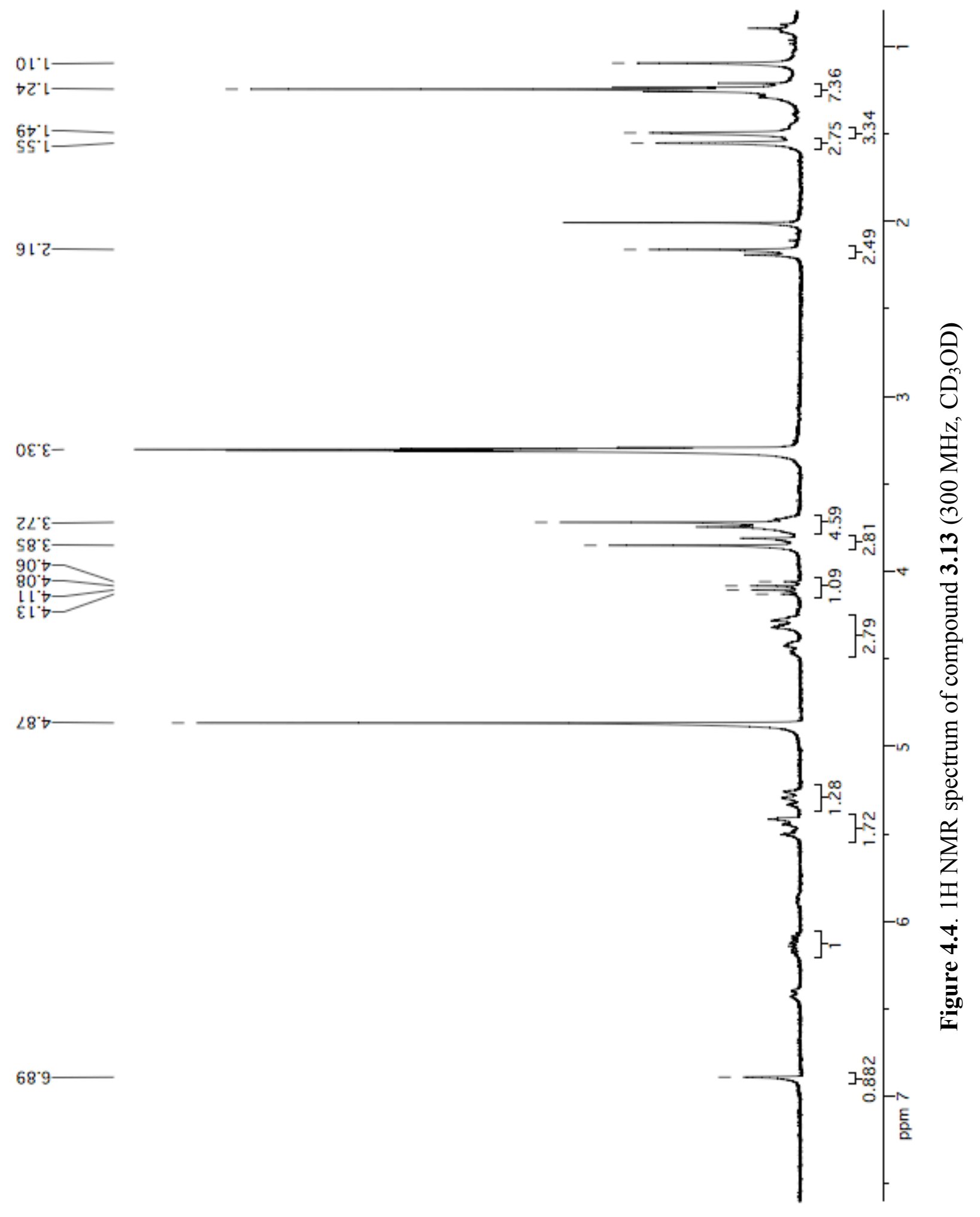



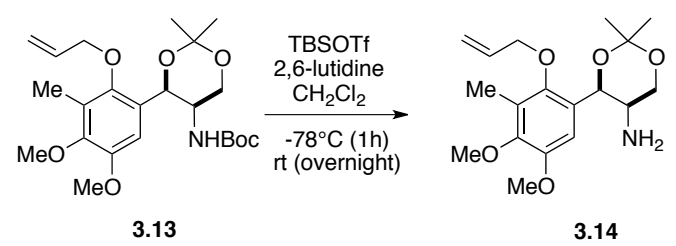

\section{6 (4R,5R)-4-(2-(allyloxy)-4,5-dimethoxy-3-methylphenyl)-2,2-dimethyl-1,3-dioxan-5- amine (3.14)}

To a solution of $\mathbf{3 . 1 3}$ (90 mg, $0.21 \mathrm{mmol}, 1.0$ eq.) in dry $\mathrm{CH}_{2} \mathrm{Cl}_{2}(5 \mathrm{~mL})$ was added 2,6-lutidine (150 $\mu \mathrm{L}, 1.3 \mathrm{mmol}, 6.2$ eq.). The solution was cooled to $-78^{\circ} \mathrm{C}$ and TBSOTf $(160 \mu \mathrm{L}, 0.70$ mmol, 3.4 eq.) was added dropwise. The reaction was stirred at this temperature for $1 \mathrm{~h}$, warmed to $\mathrm{RT}$ and stirred for $12 \mathrm{~h}$. The reaction was quenched with $\mathrm{MeOH}(5 \mathrm{~mL})$ and $\mathrm{KF} \cdot 2 \mathrm{H}_{2} \mathrm{O}(75 \mathrm{mg}$, $1.2 \mathrm{mmol}, 6.0$ eq.) was added with vigorous stirring. After $15 \mathrm{~min}$. the solution was diluted with $\mathrm{CH}_{2} \mathrm{Cl}_{2}(5 \mathrm{~mL})$, rinsed with $5 \% \mathrm{NaHCO}_{3}(5 \mathrm{~mL})$ and brine $(5 \mathrm{~mL})$, dried $\left(\mathrm{MgSO}_{4}\right)$, filtered and concentrated under reduced pressure. The crude material was purified by flash chromatography with 4:1:0.1 EtOAc/hexanes/Et $3 \mathrm{~N}$ to afford the title compound $(51 \mathrm{mg}, 72 \%) . \mathrm{R}_{\mathrm{f}}=0.22(4: 1: 0.1$ EtOAc/hexanes/Et $\left.{ }_{3} \mathrm{~N}\right) ;{ }^{1} \mathrm{H}-\mathrm{NMR}\left(300 \mathrm{MHz} ; \mathrm{CD}_{3} \mathrm{OD}\right): \delta$ 7.09-6.85 $(\mathrm{m}, 1 \mathrm{H}), 6.18-6.11(\mathrm{~m}, 1 \mathrm{H})$, 5.64-5.22 (m, 1H), 4.56-4.16 (m, 1H), 3.92-3.82 (m, 3H), $3.85(\mathrm{~s}, 3 \mathrm{H}), 3.78(\mathrm{~s}, 3 \mathrm{H}), 2.19(\mathrm{~s}, 3 \mathrm{H})$, $1.55(\mathrm{~s}, 3 \mathrm{H}), 1.51(\mathrm{~s}, 3 \mathrm{H})$. HRMS (FAB+) calcd. for $\mathrm{C}_{18} \mathrm{H}_{28} \mathrm{NO}_{5}:\left(\mathrm{MH}^{+}\right):(\mathrm{m} / \mathrm{z}) 338.1923$; found (m/z) 338.1967. 
IS ${ }_{9}^{\circ}$

$61^{\circ} 2$

$\left\llcorner\mathcal{E}^{*} \varepsilon-\right.$

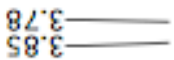

76.9

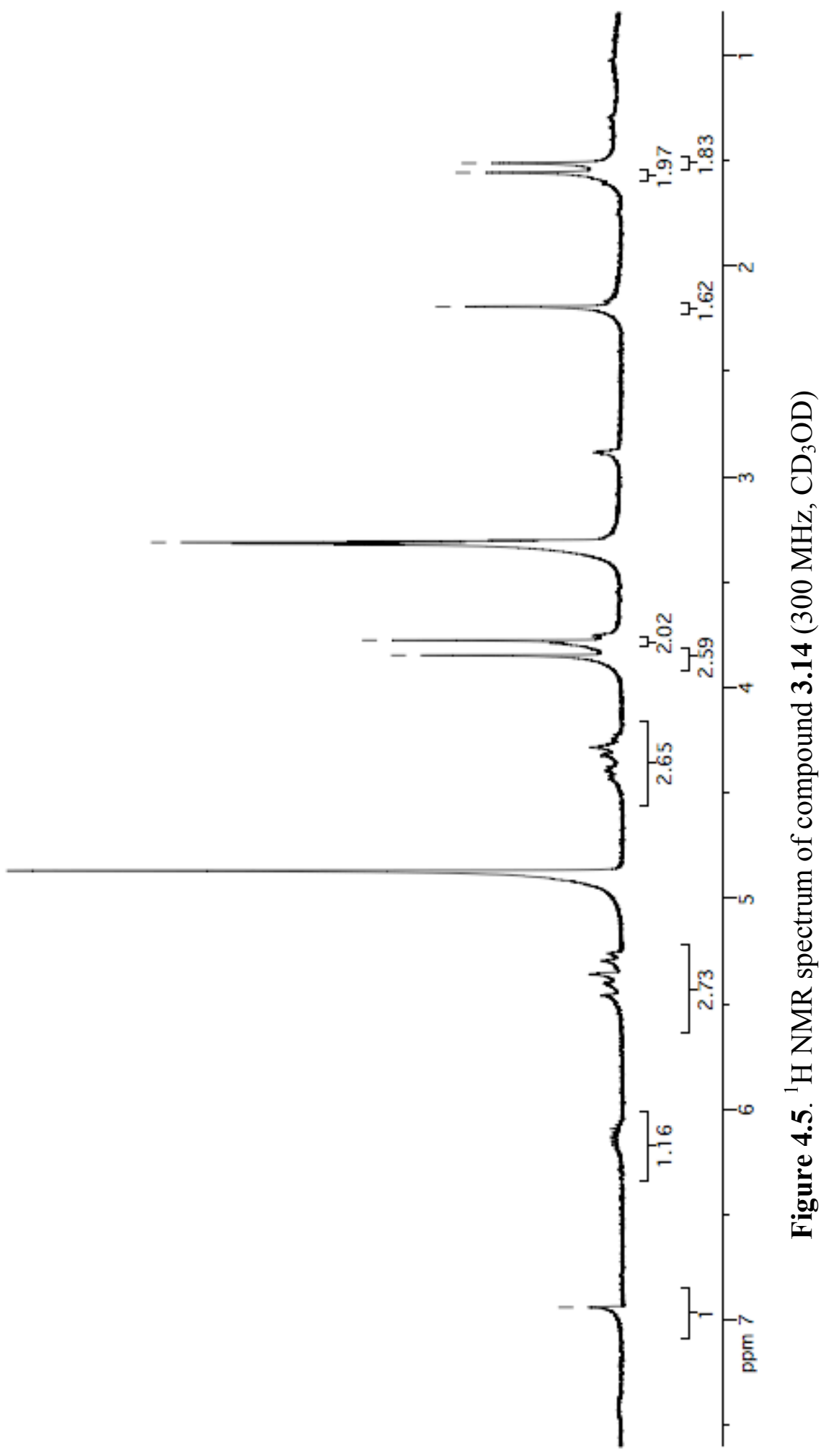




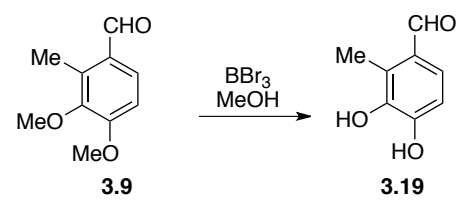

\subsection{3,4-dihydroxy-2-methylbenzaldehyde (3.19)}

To a stirred solution of 3,4-dimethoxy-2-methylbenzaldehyde (3.9) in (8.5 g, $47 \mathrm{mmol}, 1$ eq.) in $\mathrm{CHCl}_{3}(100 \mathrm{~mL})$ at $-78^{\circ} \mathrm{C}$ was added dropwise $\mathrm{BBr}_{3}(10 \mathrm{~mL}, 100 \mathrm{mmol}, 2.0$ eq.). The solution was stirred at this temperature for $15 \mathrm{~min}$ and then at RT for $1.5 \mathrm{~h}$, cooled to $-78^{\circ} \mathrm{C}$ and quenched with $\mathrm{MeOH}(40 \mathrm{~mL})$. The purple solution was diluted with brine $(40 \mathrm{~mL})$ and $\mathrm{H}_{2} \mathrm{O}(40 \mathrm{~mL})$. The aqueous phase was extracted with ether $(3 \times 50 \mathrm{~mL})$. The combined organic phases were rinsed with brine, dried $\left(\mathrm{Na}_{2} \mathrm{SO}_{4}\right)$, filtered, and concentrated under reduced pressure to afford a dark purple solid. This material was eluted through a silica plug and the solvent evaporated to afford the title compound as a brown solid (5.65 g, $79 \%$ ). This material was used in the next step without further purification. ${ }^{1} \mathrm{H}-\mathrm{NMR}\left(300 \mathrm{MHz} ; \mathrm{CDCl}_{3}\right): \delta 10.11(\mathrm{~m}, 1 \mathrm{H}), 7.35(1 / 2 \mathrm{AB}, J=8.4$ $\mathrm{Hz}, 1 \mathrm{H}), 6.86(1 / 2 \mathrm{AB}, J=8.4 \mathrm{~Hz}, 1 \mathrm{H}), 6.00(\mathrm{~s}, 1 \mathrm{H}), 2.59(\mathrm{~s}, 3 \mathrm{H})$. 


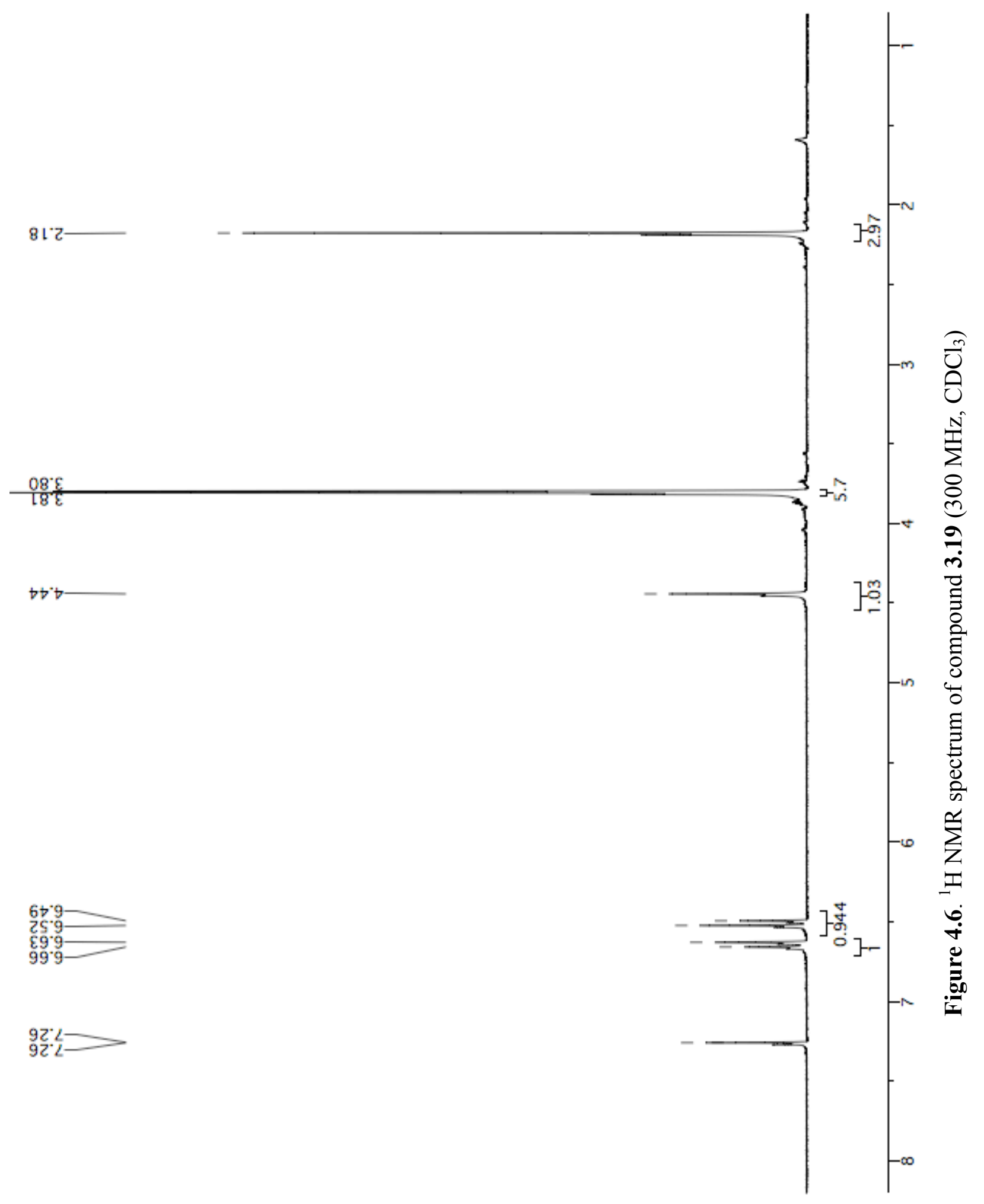




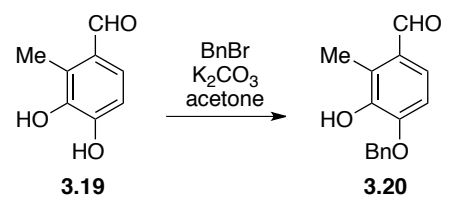

\subsection{4-benzyloxy-3-hydroxy-2-methylbenzaldehyde (3.20)}

To a solution of 3,4-dihydroxy-2-methylbenzaldehyde (3.19) (10.00 g, $65 \mathrm{mmol}, 1$ eq.) in acetone $(100 \mathrm{~mL})$ was added $\mathrm{K}_{2} \mathrm{CO}_{3}(8.97 \mathrm{~g}, 65 \mathrm{mmol}, 1$ eq.) and benzyl bromide $(7.7 \mathrm{~mL}, 65$ mmol, 1 eq.). The mixture was stirred under reflux for $48 \mathrm{~h}$, concentrated under reduced pressure, suspended in $\mathrm{CHCl}_{3}$, cooled to $0^{\circ} \mathrm{C}$, filtered and concentrated to afford the title compound as a brown solid (11.95 $\mathrm{g}, 76 \%)$. This material was used without further purification. $\mathrm{R}_{\mathrm{f}}=0.45\left(4: 1\right.$ hexanes/EtOAc); ${ }^{1} \mathrm{H}-\mathrm{NMR}\left(300 \mathrm{MHz} ; \mathrm{CDCl}_{3}\right): \delta 10.11(\mathrm{~s}, 1 \mathrm{H}), 7.42-7.35(\mathrm{~m}$, 7H), $6.91(1 / 2 \mathrm{AB}, J=8.4 \mathrm{~Hz}, 1 \mathrm{H}), 5.86(\mathrm{~s}, 1 \mathrm{H}), 5.20(\mathrm{~s}, 2 \mathrm{H}), 2.58(\mathrm{~s}, 3 \mathrm{H})$. 
$85^{2} 2$

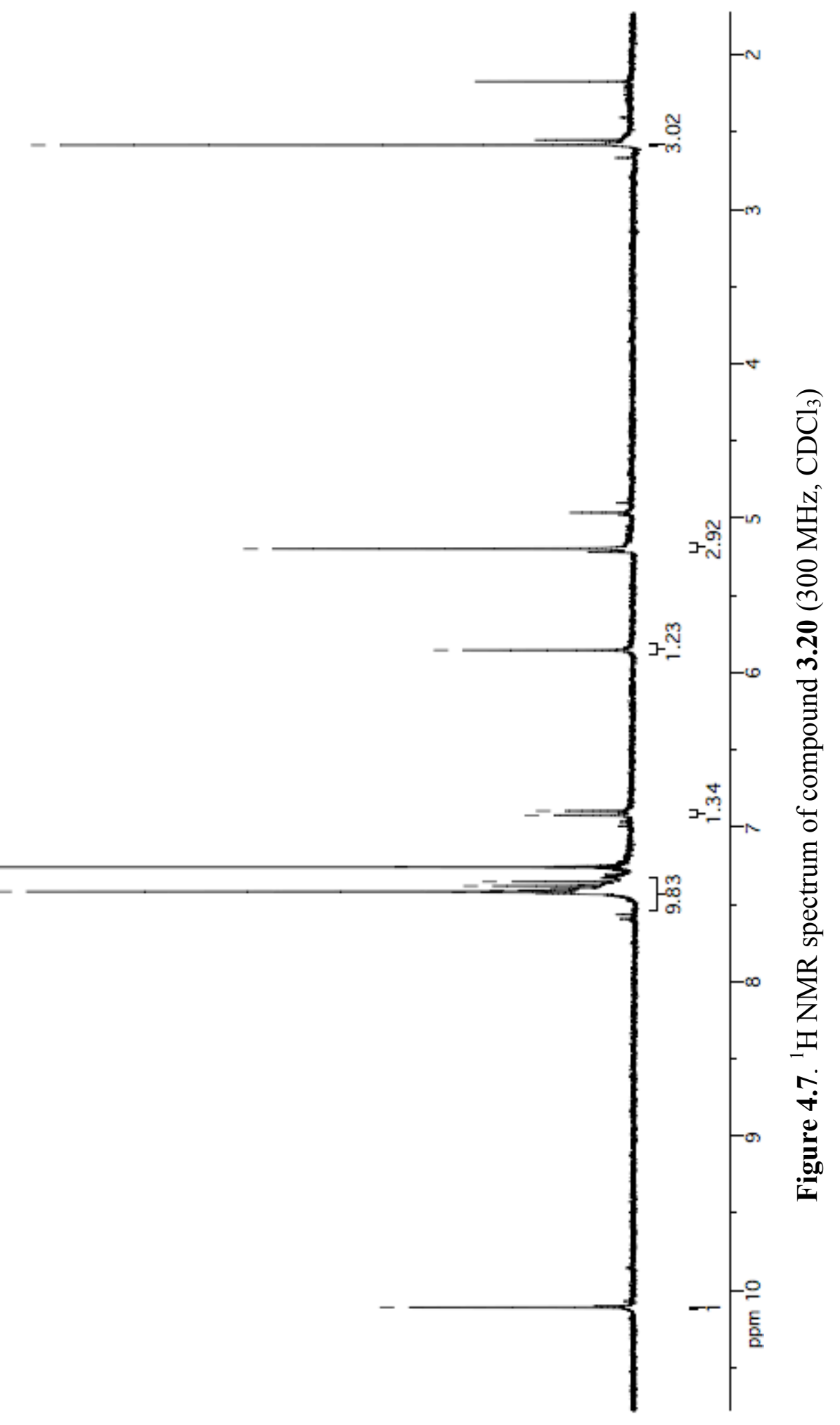




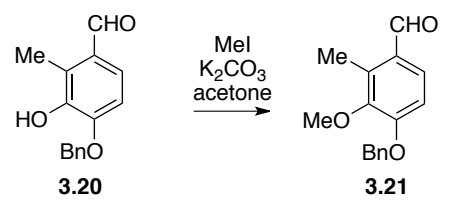

\subsection{4-benzyloxy-3-methoxy-2-methylbenzaldehyde (3.21)}

To a solution of 4-benzyloxy-3-hydroxy-2-methylbenzaldehyde (3.20) (11.95 g, 49 mmol, 1 eq.) in acetone $(125 \mathrm{~mL})$ was added $\mathrm{K}_{2} \mathrm{CO}_{3}(20.7 \mathrm{~g}, 150 \mathrm{mmol}, 3$ eq. $)$ and methyl iodide $(9.3 \mathrm{~mL}, 150$ mmol, 3 eq.). The mixture was stirred at RT for $24 \mathrm{~h}$, filtered and concentrated under reduced pressure. The crude material was purified by flash chromatography with $8: 1$ hexanes/EtOAc to afford the title compound as a yellow solid (10.0 g, 80\%). $\mathrm{R}_{\mathrm{f}}=0.50$ (4:1 hexanes/EtOAc); ${ }^{1} \mathrm{H}-$ $\operatorname{NMR}\left(300 \mathrm{MHz} ; \mathrm{CDCl}_{3}\right): \delta 10.10(\mathrm{~s}, 1 \mathrm{H}), 7.54(1 / 2 \mathrm{AB}, J=8.6 \mathrm{~Hz}, 1 \mathrm{H}), 7.46-7.34(\mathrm{~m}, 7 \mathrm{H})$, $6.93(1 / 2 \mathrm{AB}, J=8.6 \mathrm{~Hz}, 1 \mathrm{H}), 5.21(\mathrm{~s}, 2 \mathrm{H}), 3.84(\mathrm{~s}, 3 \mathrm{H}), 2.60(\mathrm{~s}, 3 \mathrm{H})$. 


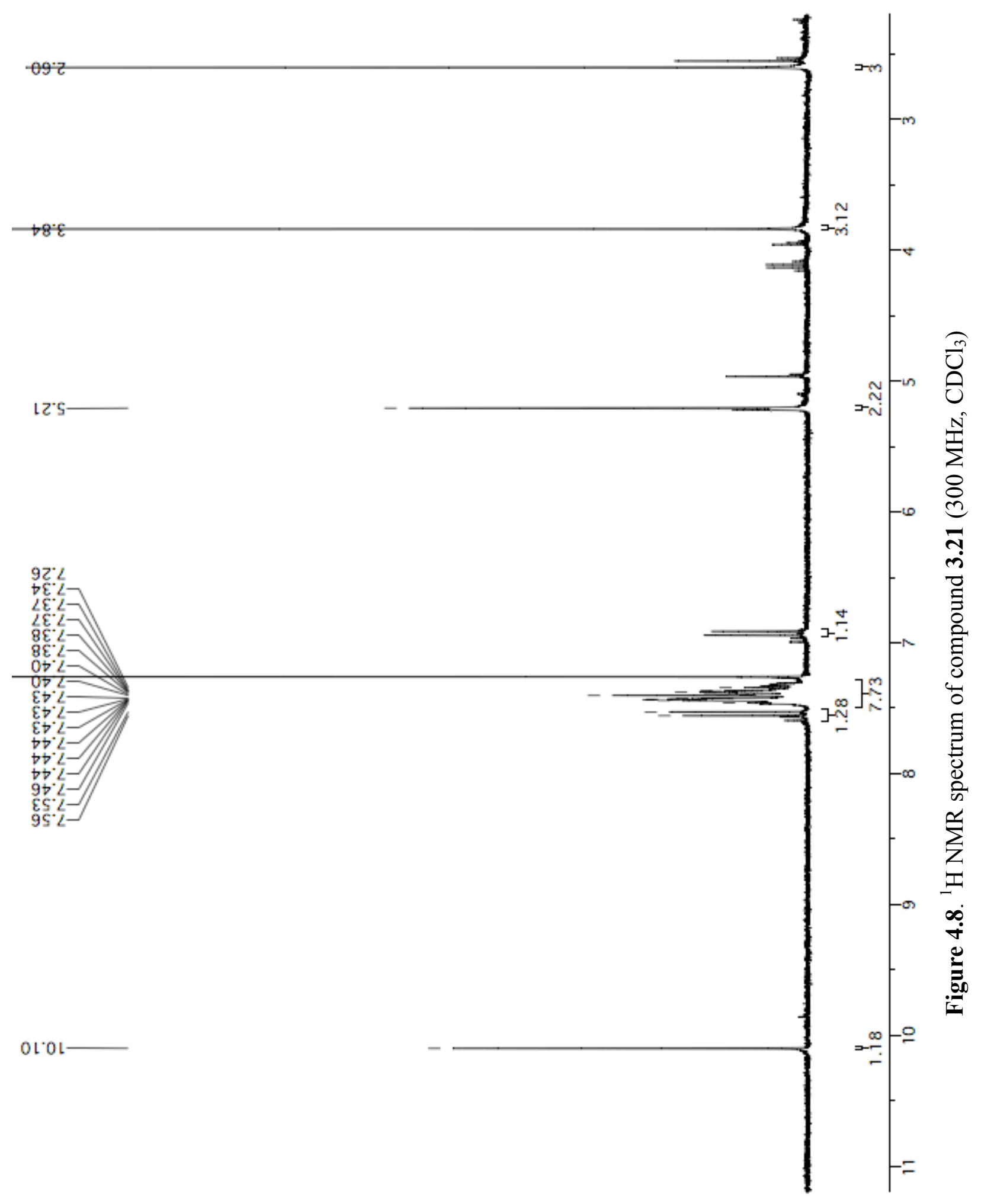




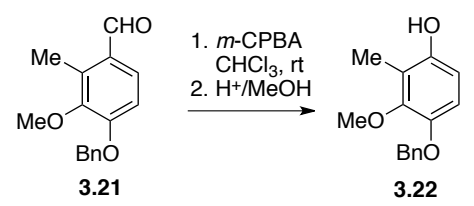

\subsection{4-benzyloxy-3-methoxy-2-methylphenol (3.22)}

To a stirred solution of 4-benzyloxy-3-methoxy-2-methylbenzaldehyde (3.21) (10.00 g, 39 mmol, 1 eq.) in $\mathrm{CHCl}_{3}(300 \mathrm{~mL})$ at $0^{\circ} \mathrm{C}$ was added $m$-CPBA $(13.40 \mathrm{~g}, 78 \mathrm{mmol}, 2.0$ eq.). The solution was warmed to RT and stirred for $8 \mathrm{~h}$. The resulting mixture was washed with $10 \%$ $\mathrm{NaS}_{2} \mathrm{O}_{3}(2 \times 100 \mathrm{~mL}), \mathrm{NaHCO}_{3}(3 \times 50 \mathrm{~mL})$ and brine $(2 \times 50 \mathrm{~mL})$. The organic phase was concentrated under reduced pressure, diluted with $\mathrm{MeOH}(50 \mathrm{~mL})$, cooled to $0^{\circ} \mathrm{C}$, acidified with conc. $\mathrm{HCl}(1 \mathrm{~mL}, 12 \mathrm{mmol})$ and stirred at $\mathrm{RT}$ for $12 \mathrm{~h}$ and then concentrated under reduced pressure. The residue was purified by flash chromatography with 5:1 hexanes/EtOAc to provide the title compound as a yellow solid $(4.88 \mathrm{~g}, 58 \%) . \mathrm{R}_{\mathrm{f}}=0.50$ (4:1 hexanes/EtOAc); ${ }^{1} \mathrm{H}-\mathrm{NMR}$ $\left(300 \mathrm{MHz} ; \mathrm{CDCl}_{3}\right): \delta 7.45-7.33(\mathrm{~m}, 8 \mathrm{H}), 6.68(1 / 2 \mathrm{AB}, J=8.7 \mathrm{~Hz}, 1 \mathrm{H}), 6.47(\mathrm{~d}, J=8.8 \mathrm{~Hz}, 1 \mathrm{H})$, $5.05(\mathrm{~s}, 2 \mathrm{H}), 3.85$ (s, 3H), $2.19(\mathrm{~s}, 3 \mathrm{H})$. 


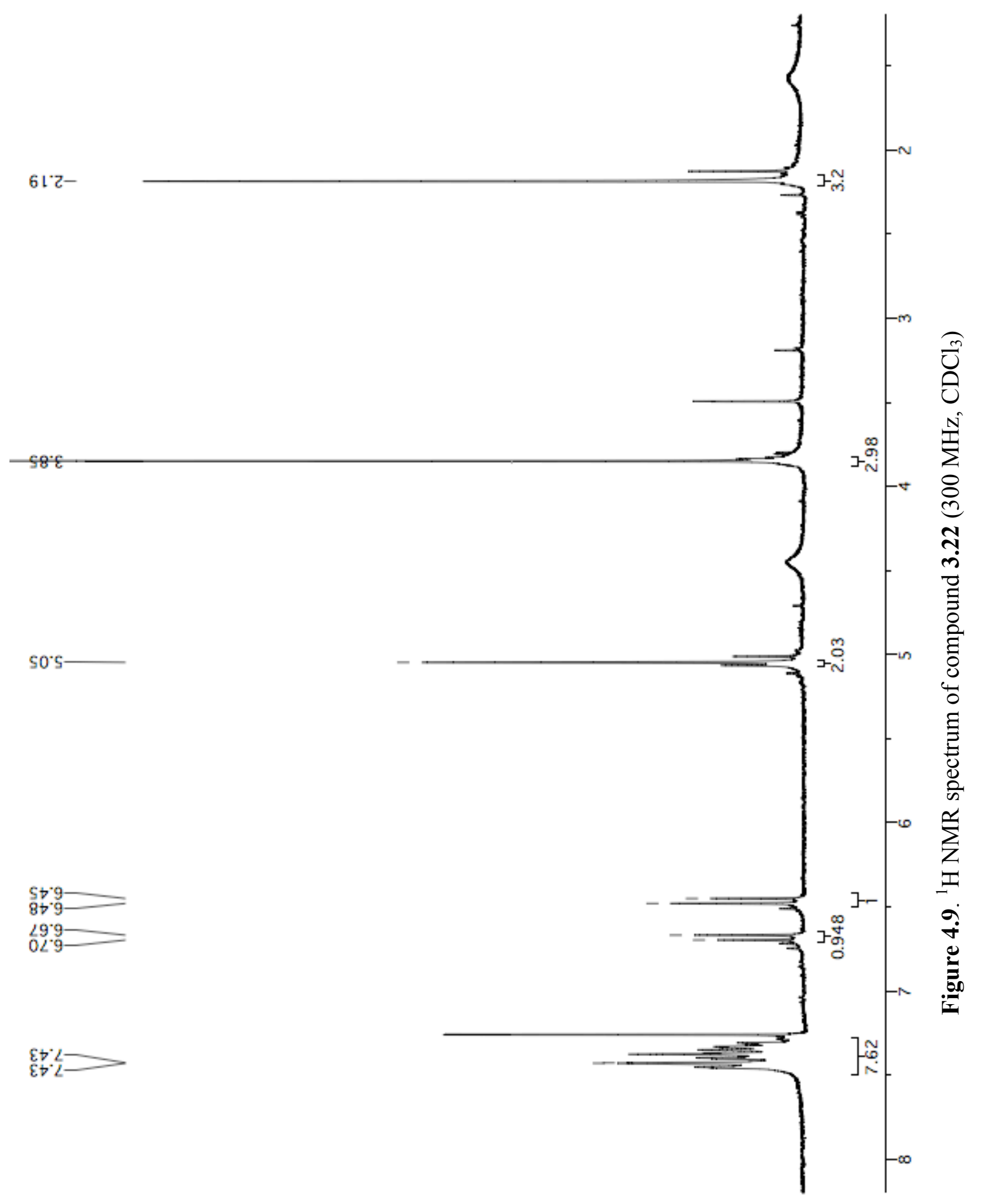




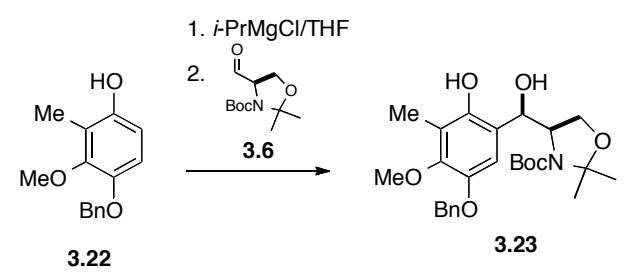

\subsection{1 (R)-tert-butyl 4-((R)-(5-(benzyloxy)-2-hydroxy-4-methoxy-3-} methylphenyl)(hydroxy)methyl)-2,2-dimethyloxazolidine-3-carboxylate (3.23)

To a solution of 4-benzyloxy-3-methoxy-2-methylphenol (3.22) (231 mg, 0.95 mmol, 1.0 eq.) in dry THF (2.0 mL), under Ar atmosphere, was added EtMgBr (3.0 M in $\mathrm{Et}_{2} \mathrm{O}, 330 \mu \mathrm{L}, 1.0 \mathrm{mmol}$, 1.05 eq.) at rt. After $5 \mathrm{~min}$. of stirring, a solution of (R)-tert-butyl 4-formyl-2,2dimethyloxazolidine-3-carboxylate ( $R$-Garner's aldehyde) (300 mg, $1.0 \mathrm{mmol}, 1.05$ eq.) in $\mathrm{CH}_{2} \mathrm{Cl}_{2}(2 \mathrm{~mL})$ was added dropwise and the resulting mixture was stirred overnight. The reaction was quenched with sat. aq. $\mathrm{NH}_{4} \mathrm{Cl}(10 \mathrm{~mL})$, the phases were separated, the organic layer was rinsed with brine, filtered and concentrated under reduced pressure to afford the title compound (292 mg, 66\%), which was used without further purification. ${ }^{1} \mathrm{H}-\mathrm{NMR}\left(300 \mathrm{MHz} ; \mathrm{CDCl}_{3}\right)$ : mixture of rotamers, $\delta 7.41-7.34(\mathrm{~m}, 5 \mathrm{H}), 6.45(\mathrm{~s}, 1 \mathrm{H}), 5.02(\mathrm{~s}, J=4.1 \mathrm{~Hz}, 2 \mathrm{H}), 4.69-4.65(\mathrm{~m}$, 1H), 4.36-4.34 (m, 1H), $3.84(\mathrm{~s}, 3 \mathrm{H}), 2.16(\mathrm{~s}, 3 \mathrm{H}), 1.60(\mathrm{~s}, 3 \mathrm{H}), 1.53(\mathrm{~s}, 9 \mathrm{H}), 1.50(\mathrm{~s}, 3 \mathrm{H}) . \mathrm{HRMS}$ (FAB+) calcd. for $\mathrm{C}_{26} \mathrm{H}_{35} \mathrm{NO}_{7}:\left(\mathrm{M}^{+}\right):(\mathrm{m} / \mathrm{z})$ 473.2414; found (m/z) 473.2414. 


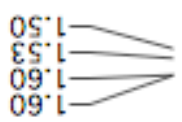

$\rightarrow 0$

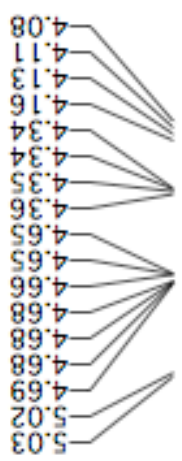

$\mathrm{S} \nabla \cdot 9$

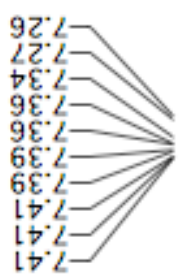

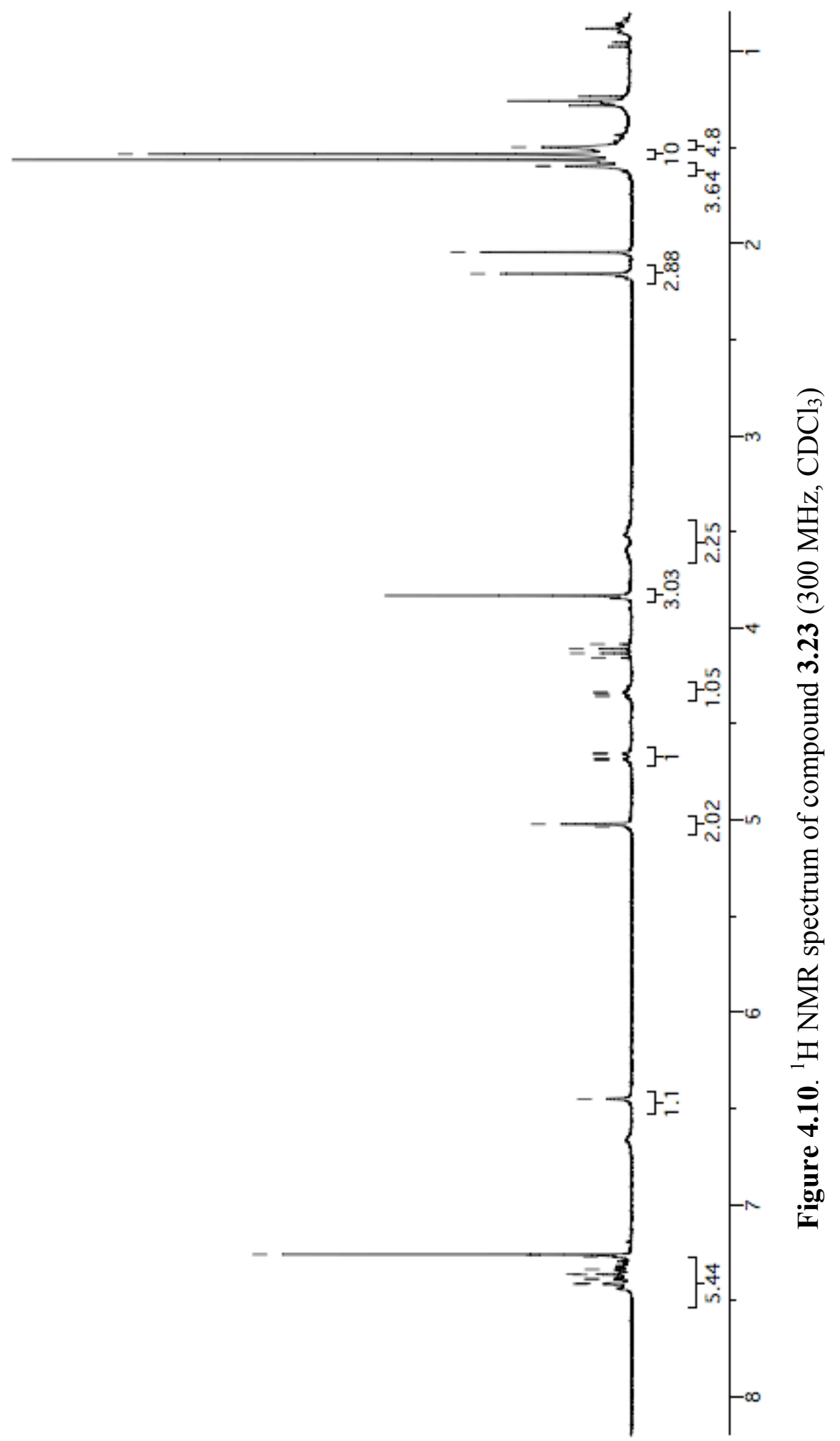




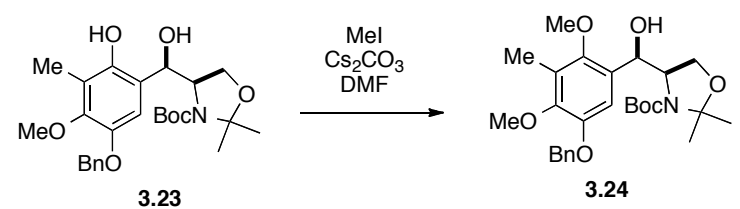

\subsection{2 (R)-tert-butyl 4-((R)-(5-(benzyloxy)-2,4-dimethoxy-3-methylphenyl)-(hydroxy)-} methyl)-2,2-dimethyloxazolidine-3-carboxylate (3.24)

A solution of $\mathbf{3 . 2 3}$ (9.2 g, $19 \mathrm{mmol}, 1.0$ eq.) in acetone $(100 \mathrm{~mL})$ was added $\mathrm{Cs}_{2} \mathrm{CO}_{3}(5.24 \mathrm{~g}, 38$ mmol, 2.0 eq.) followed by methyl iodide $(3.53 \mathrm{~mL}, 56 \mathrm{mmol}, 3.0$ eq.). The solution was stirred under $\mathrm{Ar}$ atmosphere for $16 \mathrm{~h}$. The suspension was concentrated to dryness, diluted with $\mathrm{H}_{2} \mathrm{O}$ (40 $\mathrm{mL})$, extracted with diethyl ether $(3 \times 150 \mathrm{~mL})$ and the organic layer was rinsed with $\mathrm{H}_{2} \mathrm{O}(100$ $\mathrm{mL})$, brine $(100 \mathrm{~mL})$, dried $\left(\mathrm{MgSO}_{4}\right)$, filtered and concentrated under reduced pressure. The crude was purified by flash chromatography with 5:1 hexanes/EtOAc to afford of the title compound $(8.33 \mathrm{~g}, 89 \%) . \mathrm{R}_{\mathrm{f}}=0.1\left(5: 1\right.$ hexanes/EtOAc); ${ }^{1} \mathrm{H}-\mathrm{NMR}\left(300 \mathrm{MHz} ; \mathrm{CDCl}_{3}\right)$ : mixture of carbamate rotamers, $\delta 7.46-7.31(\mathrm{~m}, 3 \mathrm{H}), 6.89(\mathrm{~s}, 1 \mathrm{H}), 5.47(\mathrm{~s}, 1 \mathrm{H}), 5.07(\mathrm{AB}, J=9.1 \mathrm{~Hz}, 2 \mathrm{H})$, $4.25(\mathrm{t}, J=11.3 \mathrm{~Hz}, 1 \mathrm{H}), 3.82(\mathrm{~s}, 3 \mathrm{H}), 3.75(\mathrm{~s}, 3 \mathrm{H}), 3.64-3.55(\mathrm{~m}, 3 \mathrm{H}), 2.22(\mathrm{~s}, 3 \mathrm{H}), 1.65(\mathrm{~s}, 3 \mathrm{H})$, $1.56(\mathrm{~s}, 9 \mathrm{H}), 1.50(\mathrm{~s}, 3 \mathrm{H}) \cdot \mathrm{HRMS}(\mathrm{FAB}+)$ calcd. for $\mathrm{C}_{27} \mathrm{H}_{37} \mathrm{NO}_{7}:\left(\mathrm{M}^{+}\right):(\mathrm{m} / \mathrm{z})$ 487.2570; found $(\mathrm{m} / \mathrm{z}) 487.2570$. 


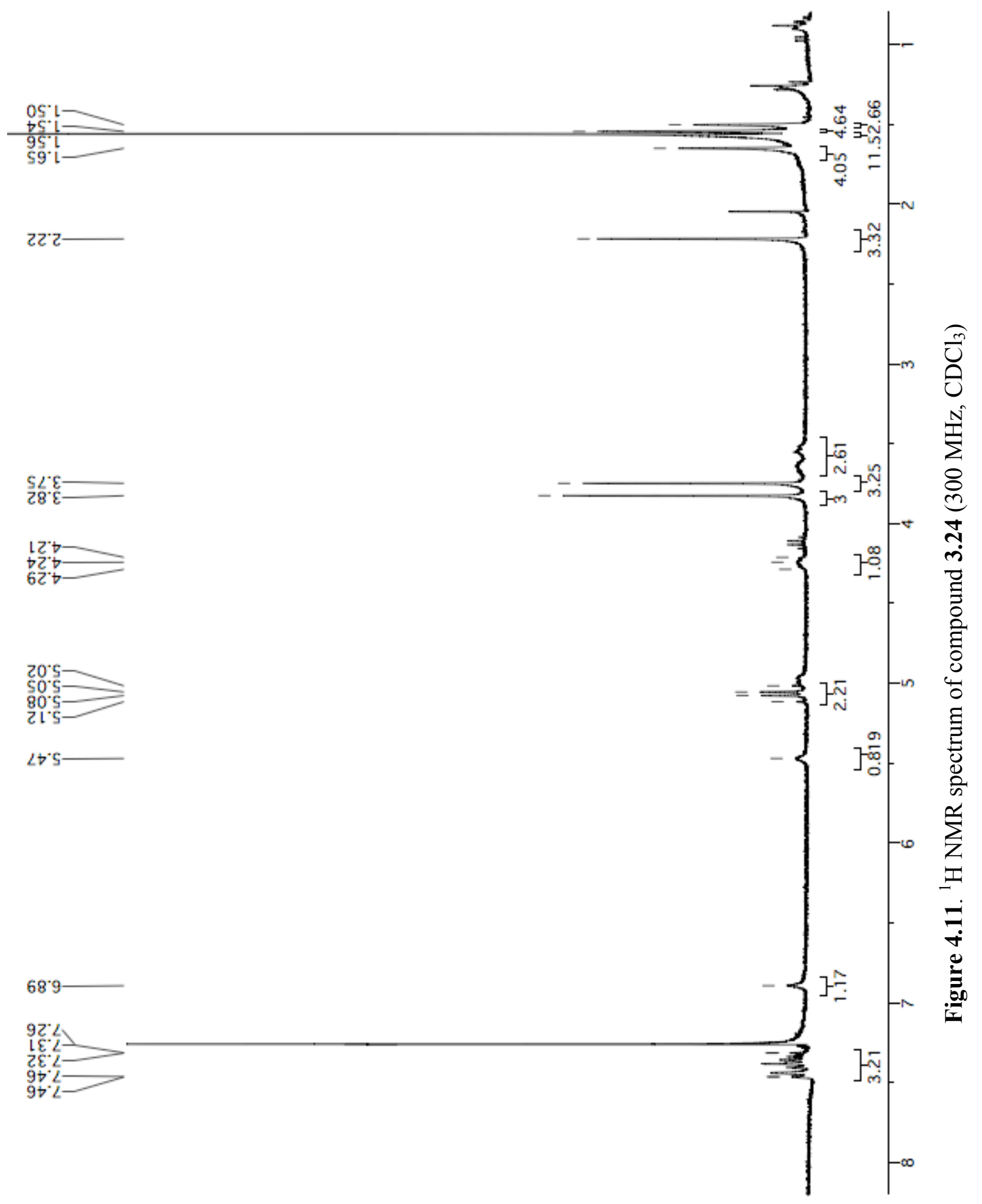




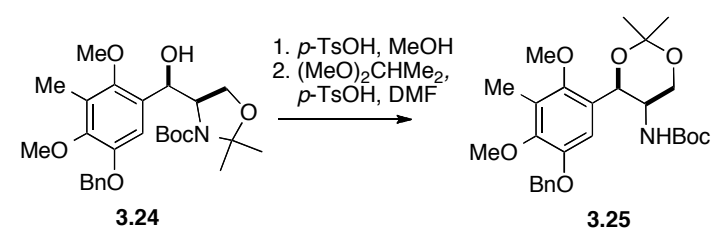

\subsection{3 tert-butyl ((4R,5R)-4-(5-(benzyloxy)-2,4-dimethoxy-3-methylphenyl)-2,2-dimethyl-}

\section{1,3-dioxan-5-yl)carbamate (3.25)}

To a solution of compound $\mathbf{3 . 2 4}$ (130 mg, $0.26 \mathrm{mmol}, 1.0$ eq.) in $\mathrm{MeOH}(5 \mathrm{~mL})$ at $0^{\circ} \mathrm{C}$ was added $p$-TsOH ( $5 \mathrm{mg}, 0.03 \mathrm{mmol}, \sim 0.1$ eq.). The reaction was warmed to $\mathrm{RT}$ and stirred for $2 \mathrm{~h}$ until TLC analysis revealed absence of starting material and a new strong spot at $R_{f}=0$. The reaction was concentrated and the residue was dissolved in DMF ( $5 \mathrm{~mL})$ under Ar atmosphere. To the solution was added 2,2-dimethoxypropane $(300 \mu \mathrm{L}, 3.4 \mathrm{mmol}, 13 \mathrm{eq}$.$) and the reaction$ was stirred for $24 \mathrm{~h}$, quenched with $5 \% \mathrm{NaHCO}_{3}(10 \mathrm{~mL})$ and diluted with $\mathrm{H}_{2} \mathrm{O}(15 \mathrm{~mL})$, extracted with EtOAc $(3 \times 5 \mathrm{~mL})$. The combined organic layers were rinsed with $5 \% \mathrm{NaHCO}_{3}$ $(10 \mathrm{~mL})$ and brine $(10 \mathrm{~mL})$, dried $\left(\mathrm{MgSO}_{4}\right)$, filtered and concentrated under reduced pressure. The crude material was purified by flash chromatography with 5:1 hexanes/EtOAc to afford the title compound $(100 \mathrm{mg}, 77 \%) . \mathrm{R}_{\mathrm{f}}=0.2$ (5:1 hexanes/EtOAc); ${ }^{1} \mathrm{H}-\mathrm{NMR}\left(300 \mathrm{MHz} ; \mathrm{CDCl}_{3}\right)$ : mixture of carbamate rotamers, $\delta 7.50-7.33(\mathrm{~m}, 6 \mathrm{H}), 6.89(\mathrm{~s}, 1 \mathrm{H}), 5.37-5.25(\mathrm{~m}, 2 \mathrm{H}), 5.09(\mathrm{~s}$, 2H), 4.33-4.25 (m, 1H), 3.85-3.80 (m, 3H), $3.78(\mathrm{~s}, 3 \mathrm{H}), 3.77(\mathrm{~s}, 3 \mathrm{H}), 2.21(\mathrm{~s}, 3 \mathrm{H}), 1.58(\mathrm{~s}, 3 \mathrm{H})$, $1.51(\mathrm{~s}, 3 \mathrm{H}), 1.26(\mathrm{~s}, 9 \mathrm{H})$. HRMS (FAB+) calcd. for $\mathrm{C}_{27} \mathrm{H}_{37} \mathrm{NO}_{7}:\left(\mathrm{M}^{+}\right)$: $(\mathrm{m} / \mathrm{z})$ 487.2570; found (m/z) 487.2570. 


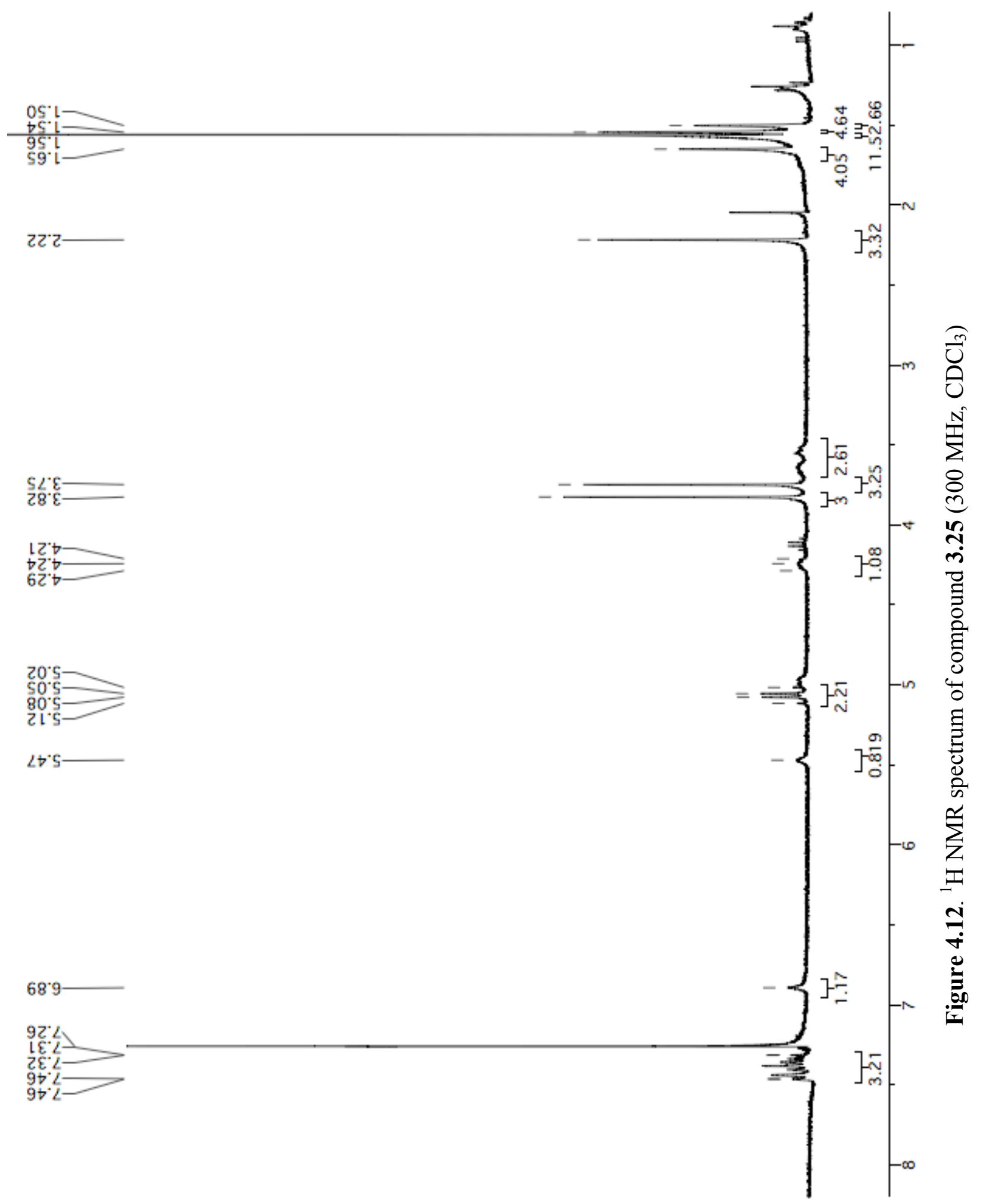



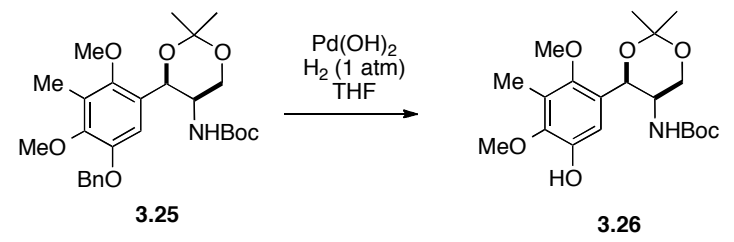

\subsection{4 tert-butyl ((4R,5R)-4-(5-hydroxy-2,4-dimethoxy-3-methylphenyl)-2,2-dimethyl-1,3- dioxan-5-yl)carbamate (3.26)}

To a solution of compound $\mathbf{3 . 2 5}(100 \mathrm{mg}, 0.20 \mathrm{mmol}, 1.0$ eq. $)$ in $\mathrm{THF}(15 \mathrm{~mL})$ at $0^{\circ} \mathrm{C}$ was added $\mathrm{Pd}(\mathrm{OH})_{2}(20 \mathrm{mg}, 0.14 \mathrm{mmol}, \sim 0.6$ eq. $)$. The reaction was evacuated and filled with $\mathrm{H}_{2}(1 \mathrm{~atm})$ three times and resulting suspension was stirred under $\mathrm{H}_{2}$ for $4 \mathrm{~h}$, filtered through Celite ${ }^{\circledR}$ using EtOAc, concentrated under reduced pressure, and purified by flash chromatography $(5: 1$, then 4:1 hexanes/EtOAc) to afford the title compound (52 mg, 63\%). $\mathrm{R}_{\mathrm{f}}=0.2(4: 1$ hexanes/EtOAc); ${ }^{1} \mathrm{H} \mathrm{NMR} \mathrm{CDCl}_{3}(\delta, \mathrm{ppm}):{ }^{1} \mathrm{H}-\mathrm{NMR}\left(300 \mathrm{MHz} ; \mathrm{CDCl}_{3}\right): \delta 6.89(\mathrm{~s}, 1 \mathrm{H}), 5.34(\mathrm{~s}, 3 \mathrm{H}), 4.32-4.27$ $(\mathrm{m}, 2 \mathrm{H}), 3.85-3.78(\mathrm{~m}, 3 \mathrm{H}), 2.23(\mathrm{~s}, 3 \mathrm{H}), 1.51(\mathrm{~s}, 3 \mathrm{H}), 1.26(\mathrm{~s}, 9 \mathrm{H})$. HRMS (FAB+) calcd. for $\mathrm{C}_{20} \mathrm{H}_{31} \mathrm{NO}_{7}:\left(\mathrm{M}^{+}\right):(\mathrm{m} / \mathrm{z}) 397.2101$; found $(\mathrm{m} / \mathrm{z}) 397.2101$. 


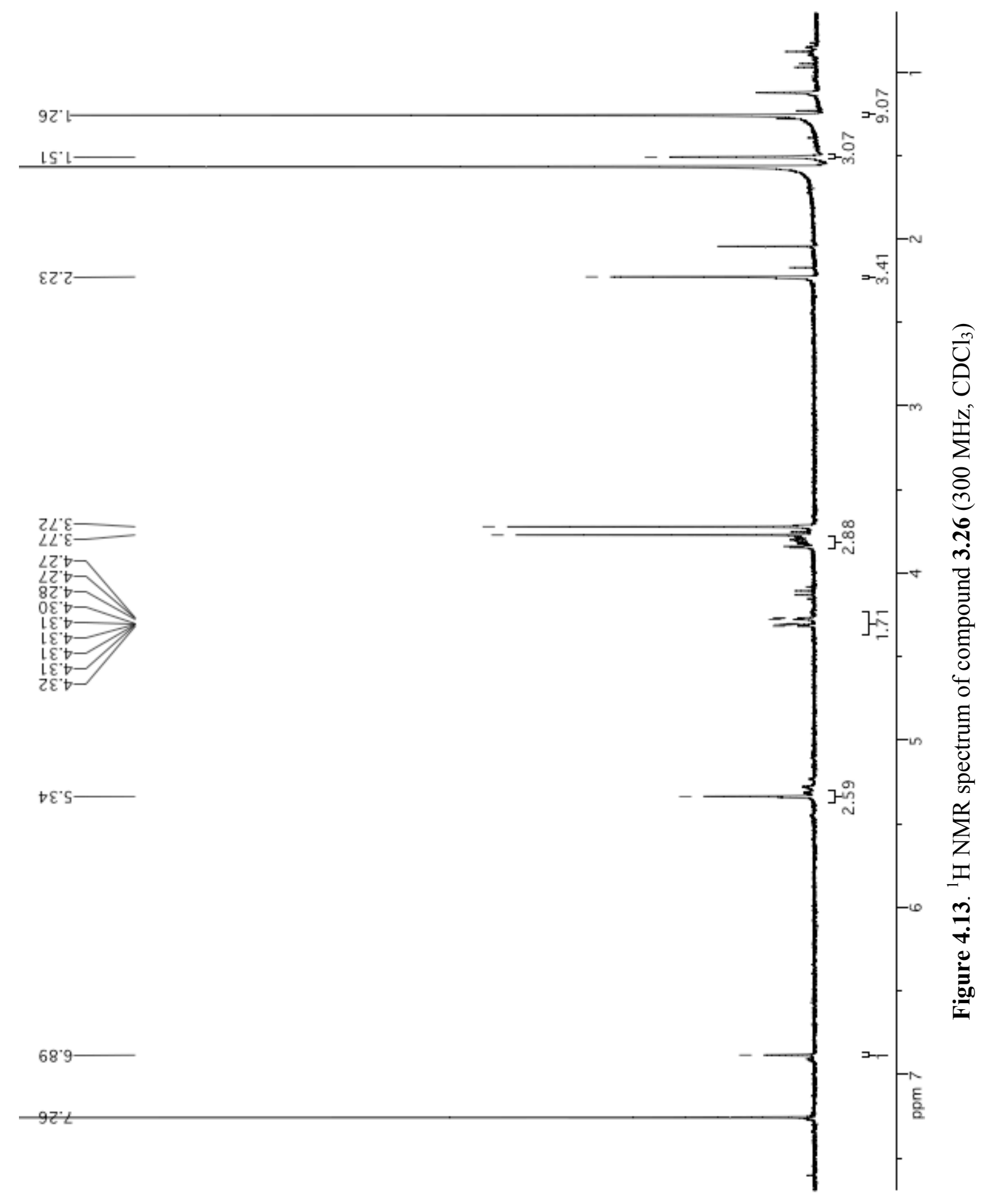




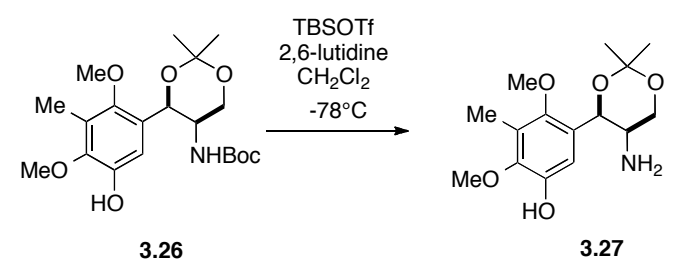

\subsection{5-((4R,5R)-5-amino-2,2-dimethyl-1,3-dioxan-4-yl)-2,4-dimethoxy-3-methylphenol}

To a solution of compound 3.26 (1.55 mg, $3.9 \mathrm{mmol}, 1.0$ eq.) in dry $\mathrm{CH}_{2} \mathrm{Cl}_{2}(40 \mathrm{~mL})$ was added 2,6-lutidine (1.55 mL, $13.3 \mathrm{mmol}, 3.4$ eq.). The solution was cooled to $-78^{\circ} \mathrm{C}$ and TBSOTf $(2.9$ $\mathrm{mL}, 12.5 \mathrm{mmol}, 3.2$ eq.) was added dropwise. The reaction was stirred at this temperature for 1 $\mathrm{h}$, warmed to RT and stirred for $12 \mathrm{~h}$. The reaction was quenched with $\mathrm{MeOH}(1 \mathrm{~mL})$ and $\mathrm{KF} \cdot 2 \mathrm{H}_{2} \mathrm{O}$ (4 eq.) was added with vigorous stirring. After $15 \mathrm{~min}$. the solution was diluted with $\mathrm{CH}_{2} \mathrm{Cl}_{2}(50 \mathrm{~mL})$, rinsed with $5 \% \mathrm{NaHCO}_{3}(50 \mathrm{~mL})$ and brine $(50 \mathrm{~mL})$, dried $\left(\mathrm{MgSO}_{4}\right)$, filtered and concentrated under reduced pressure. The crude material was purified by flash chromatography with 4:1:0.1 EtOAc/hexanes/Et ${ }_{3} \mathrm{~N}$ to afford the title compound (820 mg, $72 \%$ ). $\mathrm{R}_{\mathrm{f}}=0.1$ 4:1:0.1 EtOAc/hexanes/Et $3 \mathrm{~N} ;{ }^{1} \mathrm{H}-\mathrm{NMR}\left(300 \mathrm{MHz} ; \mathrm{CDCl}_{3}\right): \delta 6.94(\mathrm{~s}, 1 \mathrm{H}), 5.27(\mathrm{~s}, 1 \mathrm{H})$, $4.30(1 / 2 \mathrm{ABX}, J=11.7,2.3 \mathrm{~Hz}, 1 \mathrm{H}), 3.86(1 / 2 \mathrm{ABX}, J=11.7,1.8 \mathrm{~Hz}, 1 \mathrm{H}), 3.78$ (s, 3H), 3.70 (s, 3H), $2.81(\mathrm{q}, J=1.9 \mathrm{~Hz}, 1 \mathrm{H}), 2.24(\mathrm{~s}, 3 \mathrm{H}), 1.56(\mathrm{~s}, 3 \mathrm{H}), 1.52(\mathrm{~s}, 3 \mathrm{H})$. MS (FAB+) calcd. for $\mathrm{C}_{15} \mathrm{H}_{23} \mathrm{NO}_{5}:\left(\mathrm{MH}^{+}\right):(\mathrm{m} / \mathrm{z}) 298.2$; found $(\mathrm{m} / \mathrm{z}) 298.2$. 


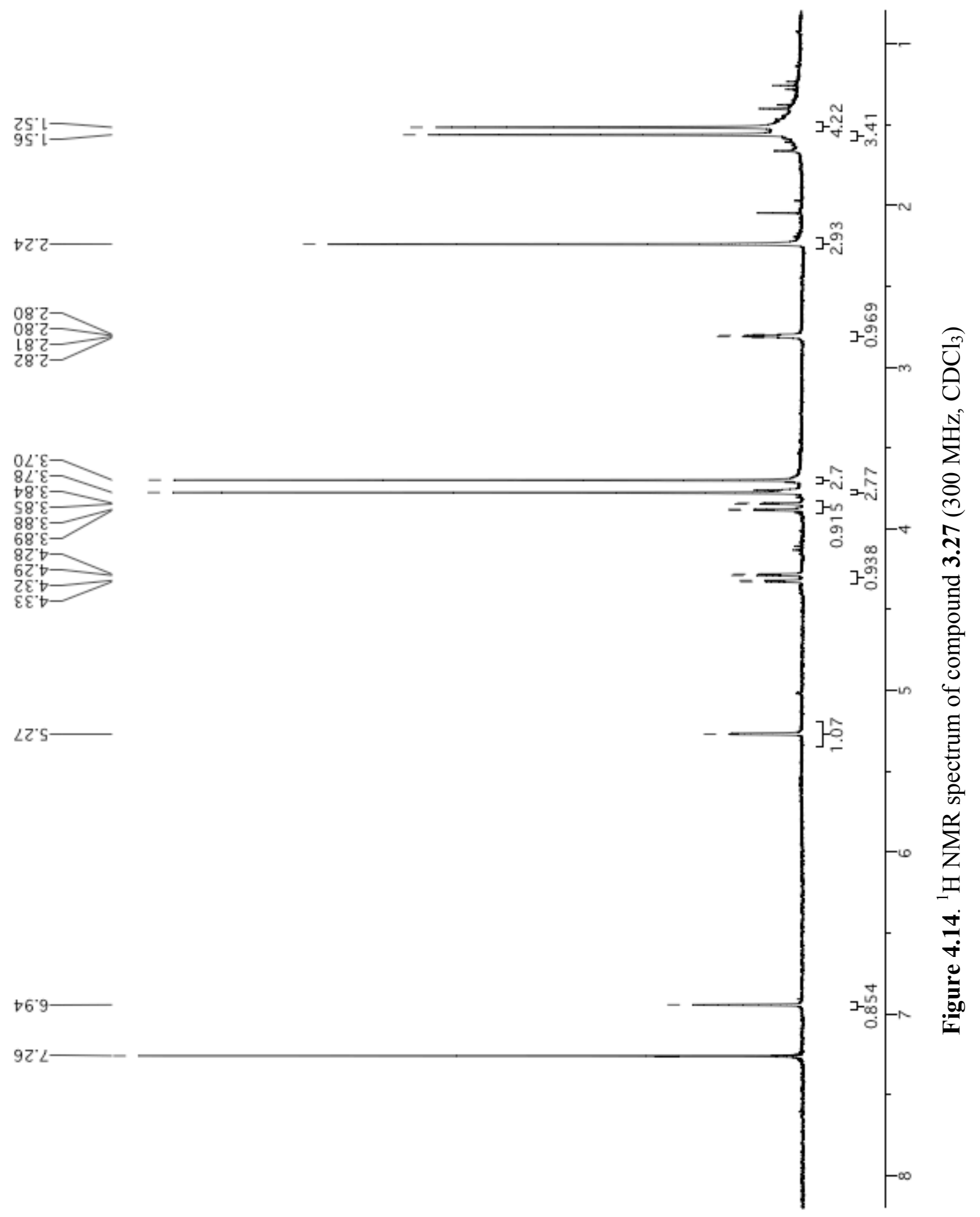




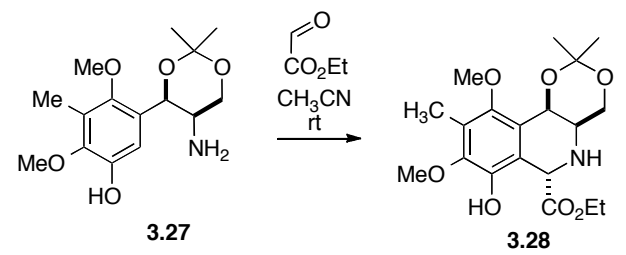

\subsection{6 (4aR,6S,10bR)-ethyl 7-hydroxy-8,10-dimethoxy-2,2,9-trimethyl-4a,5,6,10b- tetrahydro-4H-[1,3]dioxino[5,4-c]isoquinoline-6-carboxylate (3.28)}

A solution of compound 3.27 (1.00 g, $3.36 \mathrm{mmol}, 1.0$ eq.) and ethyl glyoxalate (734 $\mu \mathrm{L}$ of a $50 \%$ solution in toluene, 0.04 mmol, 4 eq.) in dry $\mathrm{CH}_{3} \mathrm{CN}(70 \mathrm{~mL})$ was prepared in a vial containing $4 \AA \mathrm{MS}(1.00 \mathrm{~g})$. The solution was stirred under Ar atmosphere for $24 \mathrm{~h}$, filtered through Celite ${ }^{\circledR}$ and concentrated under reduced pressure. The crude material was purified by flash chromatography with 19:1 $\mathrm{CH}_{2} \mathrm{Cl}_{2} / \mathrm{MeOH}$ to afford the title compound (704 mg, $55 \%$ ). $\mathrm{R}_{\mathrm{f}}=0.5$ 19:1 $\left.\mathrm{CH}_{2} \mathrm{Cl}_{2} / \mathrm{MeOH}\right) ;{ }^{1} \mathrm{H}-\mathrm{NMR}\left(300 \mathrm{MHz} ; \mathrm{CDCl}_{3}\right): \delta 6.28(\mathrm{~s}, 1 \mathrm{H}), 5.11(\mathrm{~d}, J=1.4 \mathrm{~Hz}, 1 \mathrm{H}), 4.80$ (br s, 1H), 4.36-4.30, (m, 4H), 3.98-3.93 (m, 1H), $3.80(\mathrm{~d}, \mathrm{~s}, 3 \mathrm{H}), 3.77(\mathrm{~s}, 3 \mathrm{H}), 2.95-2.82(\mathrm{~m}$, 1H), 2.51 (br s, 1H), $2.22(\mathrm{~s}, 3 \mathrm{H}), 1.65(\mathrm{~m}, 3 \mathrm{H}), 1.43(\mathrm{~m}, 3 \mathrm{H}), 1.34(\mathrm{t}, 7.1 \mathrm{~Hz}, 3 \mathrm{H}), 6 . \mathrm{MS}$ (FAB+) calcd. for $\mathrm{C}_{19} \mathrm{H}_{27} \mathrm{NO}_{7}:\left(\mathrm{MH}^{+}\right):(\mathrm{m} / \mathrm{z}) 382.2$; found $(\mathrm{m} / \mathrm{z}) 382.2$. 

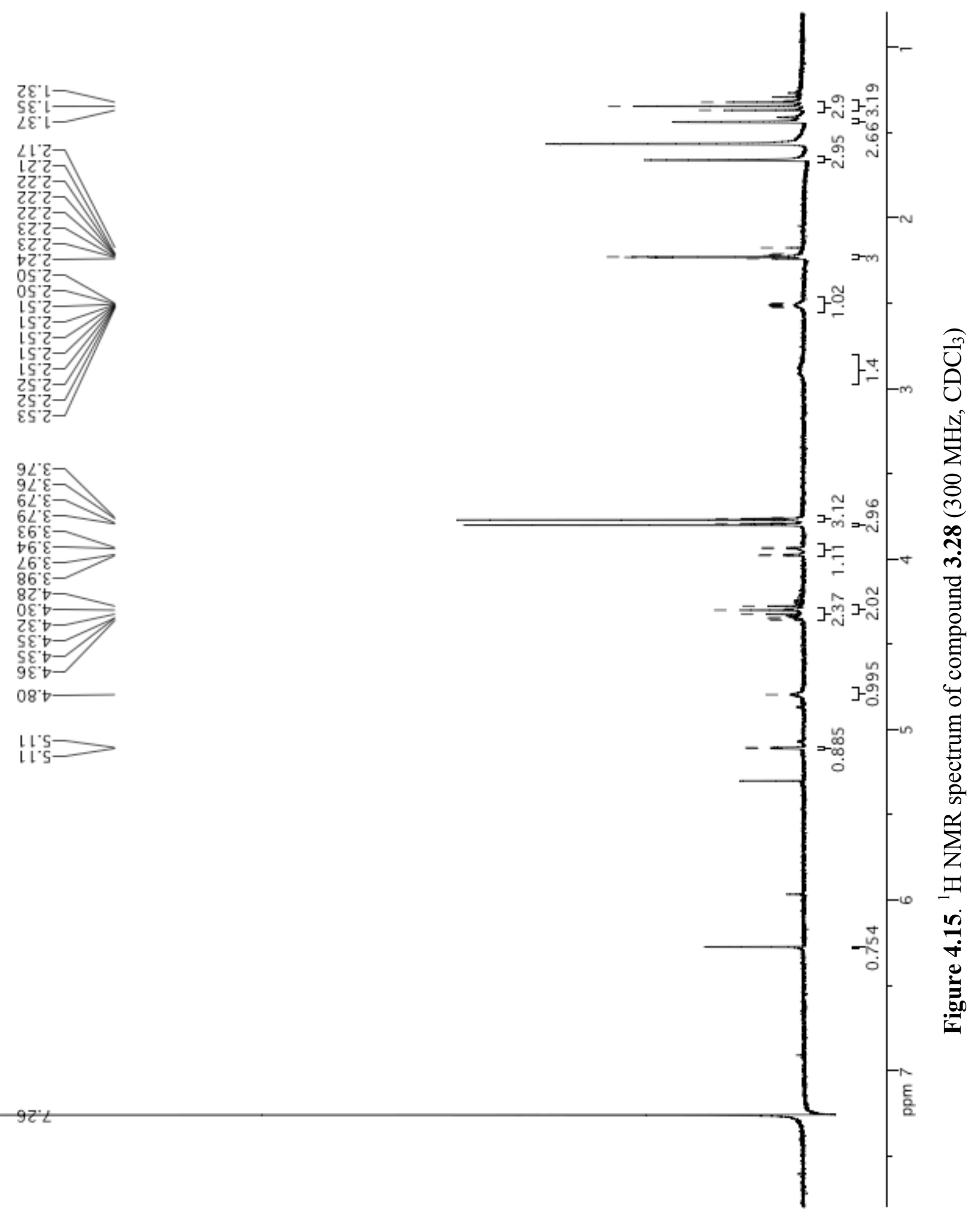


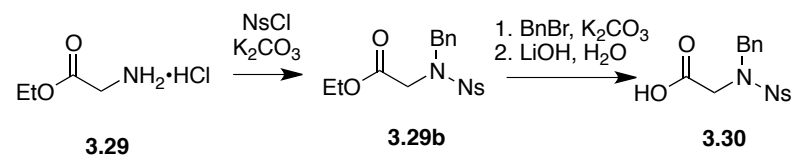

\subsection{2-(N-benzyl-4-nitrophenylsulfonamido)acetic acid (3.30)}

\section{Ethyl 2-(4-nitrophenylsulfonamido)acetate (3.29b)}

To a stirred suspension of GlyOEt $\bullet \mathrm{HCl}\left(7.00 \mathrm{~g}, 50 \mathrm{mmol}, 1.0\right.$ eq.) and $\mathrm{K}_{2} \mathrm{CO}_{3}(14.50 \mathrm{~g}, 100$ mmol, 1.0 eq. $)$ in water $(40 \mathrm{~mL})$ and dioxane $(40 \mathrm{~mL})$ at $0^{\circ} \mathrm{C}$ was added $\mathrm{NsCl}(11.08 \mathrm{~g}, 50$ mmol, 1.0 eq.) in one portion. The reaction was stirred at RT for $48 \mathrm{~h}$, the dioxane evaporated, the residue partitioned between water and ethyl acetate/dichlorometane $4: 1(125 \mathrm{~mL})$, and the organic phase rinsed with sat. aq. $\mathrm{NaHCO}_{3}(3 \times 25 \mathrm{~mL})$, water $(50 \mathrm{~mL})$ and brine $(50 \mathrm{~mL})$. The organic phase was dried $\left(\mathrm{MgSO}_{4}\right)$, filtered, concentrated under reduced pressure to afford the title compound as yellow oil (12.38 g, 86\%), which was used in the next step without further purification. ${ }^{1} \mathrm{H}-\mathrm{NMR}\left(300 \mathrm{MHz} ; \mathrm{CDCl}_{3}\right): \delta 8.11-8.08(\mathrm{~m}, 1 \mathrm{H}), 7.96-7.92(\mathrm{~m}, 1 \mathrm{H}), 7.76-7.73(\mathrm{~m}$, 2H), 4.05 (q, $J=7.2 \mathrm{~Hz}, 2 \mathrm{H}), 4.00$ (s, 2H), 1.16 (t, $J=7.2 \mathrm{~Hz}, 3 \mathrm{H})$.

\section{2-(N-benzyl-4-nitrophenylsulfonamido)acetic acid (3.30)}

A suspension of N-Ns-Gly-OEt (12.38g 43 mmol, 1.0 eq.), BnBr (5.28 mL, $44 \mathrm{mmol}, 1.0$ eq) and $\mathrm{K}_{2} \mathrm{CO}_{3}\left(18.3 \mathrm{~g}, 133 \mathrm{mmol}, 3.1\right.$ eq.) in $\mathrm{CH}_{3} \mathrm{CN}(450 \mathrm{~mL})$ was stirred under argon for $16 \mathrm{~h}$. The reaction was concentrated under reduced pressure, partitioned between water $(200 \mathrm{~mL})$ and ethyl acetate $(200 \mathrm{~mL})$, the aqueous phase was rinsed with ethyl acetate $(2 \times 50 \mathrm{~mL})$ and the combined organic layers were rinsed with brine, dried $\left(\mathrm{Na}_{2} \mathrm{SO}_{4}\right)$, filtered and concentrated to afford the title compound as a yellow oil (16.5 g, quant.). The material was used in the next step without further purification. 
To a stirred solution of N-Ns-Gly-OEt $(2.06 \mathrm{~g}, 5.0 \mathrm{mmol})$ in $\mathrm{THF} / \mathrm{H}_{2} \mathrm{O} / \mathrm{MeOH}$ 3:2:1 (18 mL) was added $\mathrm{LiOH} \cdot 2 \mathrm{H}_{2} \mathrm{O}(630 \mathrm{mg}, 15 \mathrm{mmol})$. The reaction was stirred for $3 \mathrm{~h}$, quenched with $1 \mathrm{M}$ $\mathrm{HCl}(30 \mathrm{~mL})$, extracted with EtOAc $(2 \times 30 \mathrm{~mL})$, rinsed with water $(30 \mathrm{~mL})$ and brine $(30 \mathrm{~mL})$, dried $\left(\mathrm{Na}_{2} \mathrm{SO}_{4}\right)$, filtered and concentrated to afford the title compound as a yellow solid (1.70 g, 97\%). The solid was dried under vacuum overnight and used in the next step without further purification. ${ }^{1} \mathrm{H}-\mathrm{NMR}\left(300 \mathrm{MHz}\right.$; DMSO-d $\left.\mathrm{d}_{6}\right): \delta 8.15-7.80(\mathrm{~m}, 5 \mathrm{H}), 7.33-7.19(\mathrm{~m}, 5 \mathrm{H}), 4.58(\mathrm{~s}$, $2 \mathrm{H}), 3.92(\mathrm{~d}, J=0.5 \mathrm{~Hz}, 2 \mathrm{H})$. 


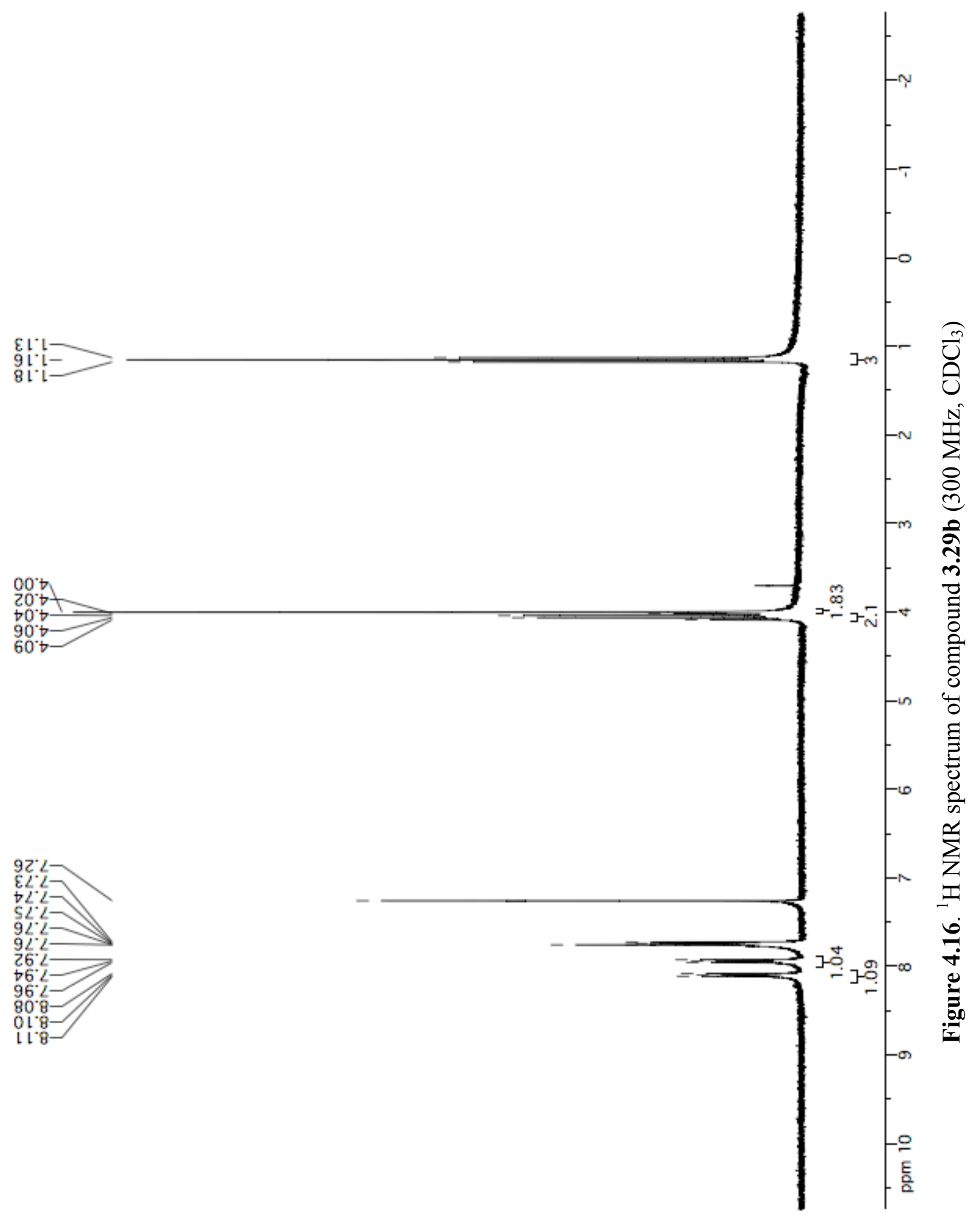




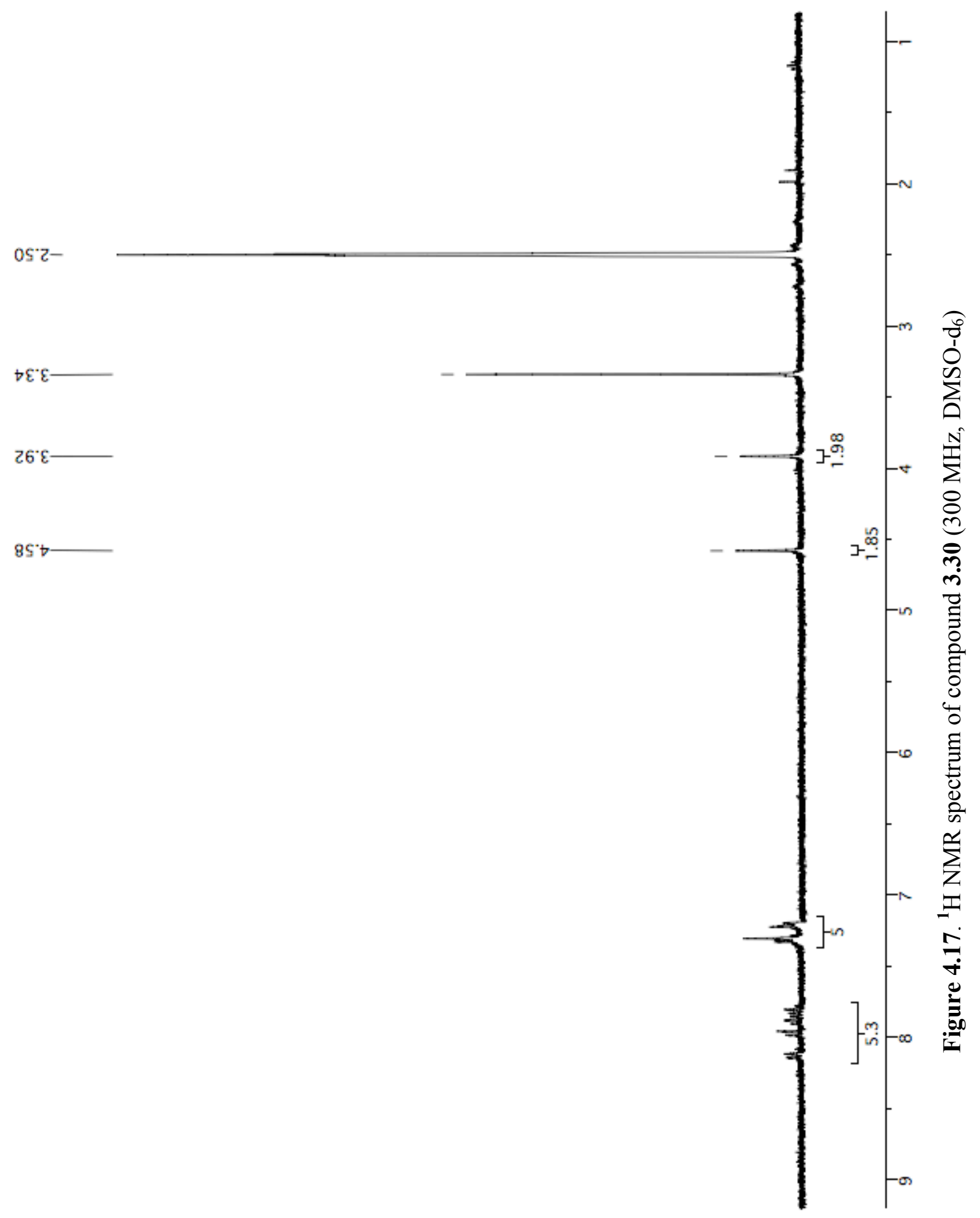




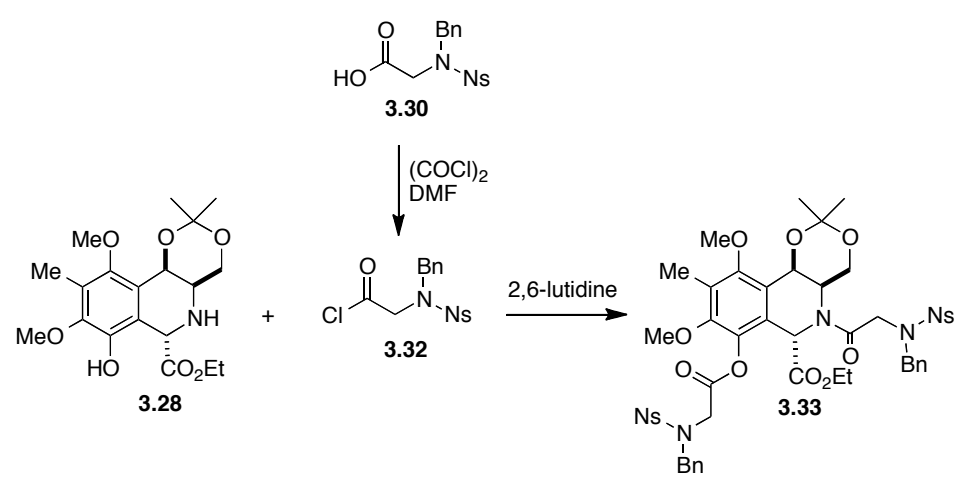

\subsection{8 (4a R,6S,10bR)-ethyl 7-(2-(N-benzyl-4-nitrophenylsulfonamido)acetoxy)-5-(2-(N- benzyl-4-nitrophenylsulfonamido)acetyl)-8,10-dimethoxy-2,2,9-trimethyl-4a,5,6,10b- tetrahydro-4H-[1,3]dioxino[5,4-c]isoquinoline-6-carboxylate (3.33)}

Compounds $\mathbf{3 . 2 8}$ and $\mathbf{3 . 3 0}$ were azeotropically dried with toluene prior to use. To a solution of 3.30 (203 $\mathrm{mg}, 0.580 \mathrm{mmol}$ ) in $3 \mathrm{~mL}$ of $\mathrm{CH}_{2} \mathrm{Cl}_{2}$ at $\mathrm{RT}$ under argon atmosphere was added $3.6 \mathrm{~mL}$ of oxalyl chloride, after which DMF $(6.6 \mu \mathrm{L})$ was added to the stirring solution. The reaction was stirred for $20 \mathrm{~min}$, after which the mixture was concentrated using the rotary evaporator to afford the corresponding crude acid chloride. The acid chloride was azeotropically dried with toluene to remove residual oxalyl chloride, and was then re-dissolved in $3 \mathrm{~mL}$ of $\mathrm{CH}_{2} \mathrm{Cl}_{2}$ at $\mathrm{RT}$ under argon atmosphere and cooled to $0{ }^{\circ} \mathrm{C}$. A solution comprised of compound $\mathbf{3 . 2 8}(110 \mathrm{mg}$, $0.29 \mathrm{mmol})$ and 2,6-lutidine $(37 \mu \mathrm{L}, 0.318 \mathrm{mmol})$ in $3 \mathrm{~mL}$ of $\mathrm{CH}_{2} \mathrm{Cl}_{2}$ was added via cannula. The reaction was stirred at $0{ }^{\circ} \mathrm{C}$ for $45 \mathrm{~min}$, after which the mixture was quenched with sat. aq. $\mathrm{NH}_{4} \mathrm{Cl}(20 \mathrm{~mL})$. The mixture was diluted with $\mathrm{CH}_{2} \mathrm{Cl}_{2}(50 \mathrm{~mL})$, the phases were separated and the aqueous phase was extracted with $\mathrm{CH}_{2} \mathrm{Cl}_{2}(2 \times 25 \mathrm{~mL})$. The combined organic phases were dried $\left(\mathrm{Na}_{2} \mathrm{SO}_{4}\right)$, filtered and concentrated. The residue was purified by flash chromatography (EtOAc/hexanes 4:1) to afford the title compound as a colorless oil (120 mg, 58\%). The ${ }^{1} \mathrm{H}$ NMR 
spectrum revealed the presence of a complex mixture of carbamate rotamers. (See Figure 4.18)

HRMS(ESI/APCI+) for $\mathrm{C}_{49} \mathrm{H}_{52} \mathrm{~N}_{5} \mathrm{O}_{17} \mathrm{~S}_{2}:\left(\mathrm{MH}^{+}\right)$: calc. (m/z) 1046.2800; found (m/z) 1046.2784 


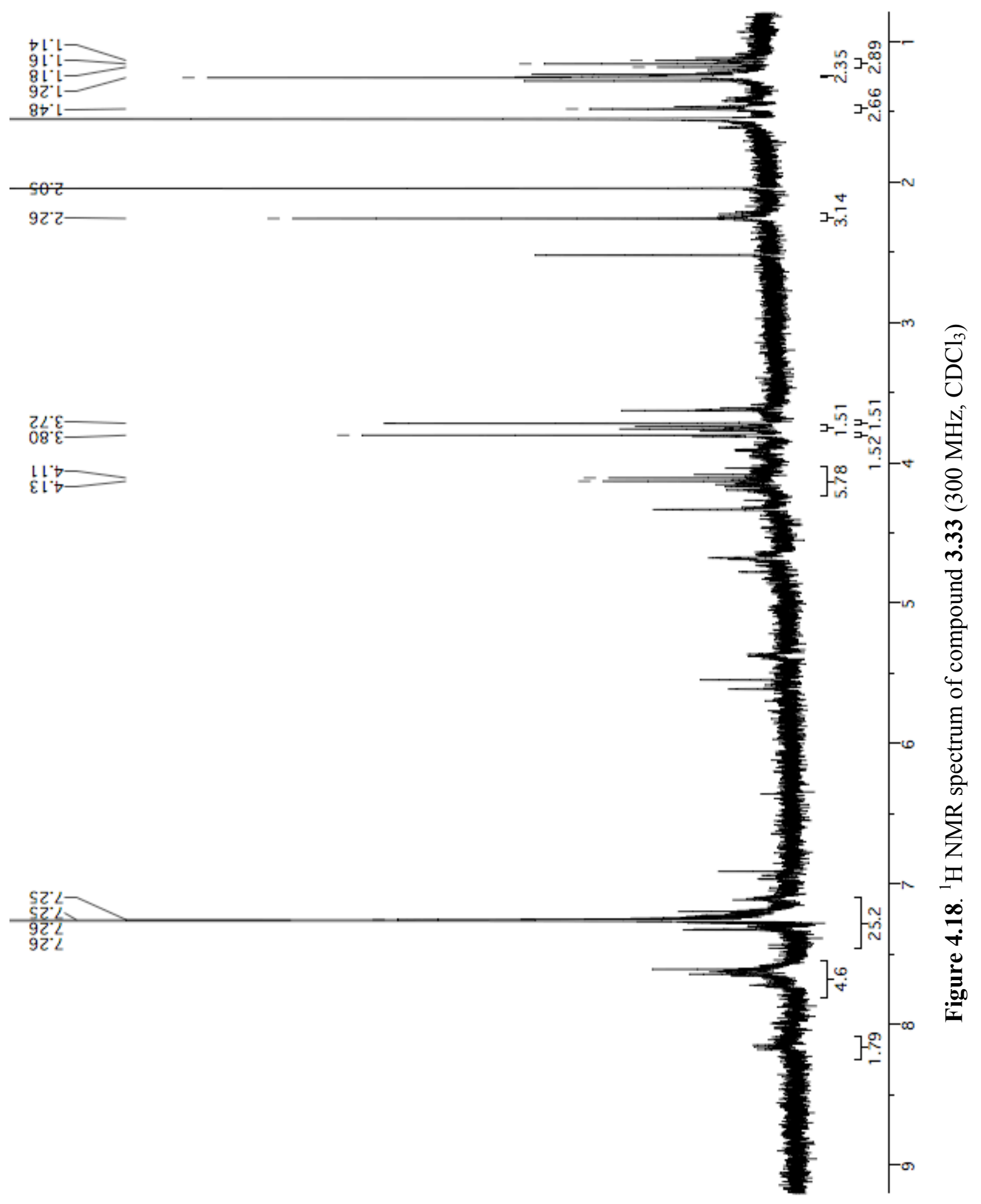




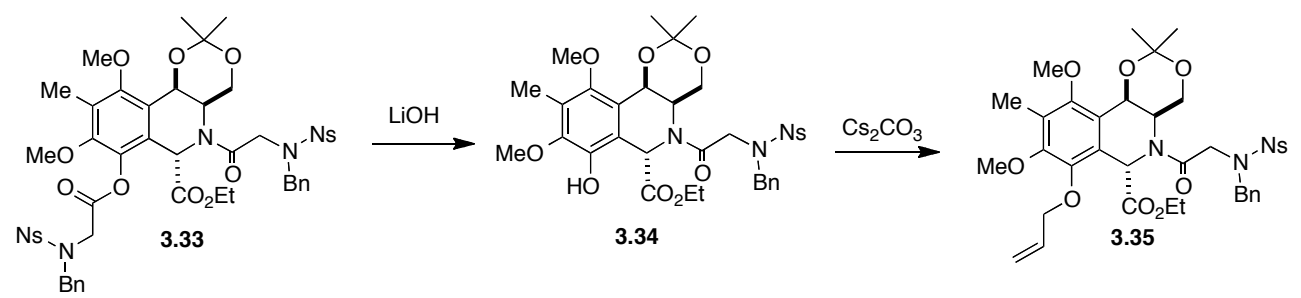

\section{$4.19(4 \mathrm{a} R, 6 S, 10 \mathrm{~b} R)-$ ethyl 7-(allyloxy)-5-(2-( $N$-benzyl-4-nitrophenylsulfonamido)acetyl)-} 8,10-dimethoxy-2,2,9-trimethyl-4a,5,6,10b-tetrahydro-4H-[1,3]dioxino[5,4-c]isoquinoline-6carboxylate (3.35)

(4a $R, 6 S, 10 \mathrm{~b} R)$-ethyl 5-(2-( $N$-benzyl-4-nitrophenylsulfonamido)acetyl)-7-hydroxy-8,10dimethoxy-2,2,9-trimethyl-4a,5,6,10b-tetrahydro-4H-[1,3] dioxino[5,4-c]isoquinoline-6carboxylate (3.34)

To a solution of Compound $\mathbf{3 . 3 3}(5 \mathrm{mg}, 0.005 \mathrm{mmol})$ in $\mathrm{H}_{2} \mathrm{O} / \mathrm{EtOH} / \mathrm{THF}(2: 2: 1,500 \mu \mathrm{L})$ was added $\mathrm{LiOH} \cdot 2 \mathrm{H}_{2} \mathrm{O}(0.3 \mathrm{mg}, 0.007 \mathrm{mmol})$ and the reaction was stirred for 10 minutes. The mixture was acidified with $\mathrm{NH}_{4} \mathrm{Cl}(1 \mathrm{~mL})$, concentrated under reduced pressure and extracted with EtOAc $(3 \times 2 \mathrm{~mL})$, rinsed with brine $(5 \mathrm{~mL})$, dried $\left(\mathrm{Na}_{2} \mathrm{SO}_{4}\right)$, filtered and concentrated to give the title compound. The material was used in the next step without further purification. HRMS(ESI/APCI+) for $\mathrm{C}_{34} \mathrm{H}_{39} \mathrm{~N}_{3} \mathrm{O}_{12} \mathrm{SNa}:\left(\mathrm{MNa}^{+}\right)$: calc $(\mathrm{m} / \mathrm{z}) 736.2147$; found $(\mathrm{m} / \mathrm{z}) 736.2146$ (4aR,6S,10bR)-ethyl 7-(allyloxy)-5-(2-( $N$-benzyl-4-nitrophenylsulfonamido)acetyl)-8,10dimethoxy-2,2,9-trimethyl-4a,5,6,10b-tetrahydro-4H-[1,3]dioxino[5,4-c]isoquinoline-6carboxylate (3.35)

A suspension of compound $\mathbf{3 . 3 4}$ (crude from previous step, $0.05 \mathrm{mmol}$ ), allyl bromide $(3 \mu \mathrm{L}, 0.1$ $\mathrm{mmol})$ and $\mathrm{Cs}_{2} \mathrm{CO}_{3}(5 \mathrm{mg}, 0.015 \mathrm{mmol})$ in $(500 \mu \mathrm{L})$ was stirred under Ar for $12 \mathrm{~h}$. The solvent was evaporated and the residue was partitioned between water $(5 \mathrm{~mL})$ and EtOAc $(5 \mathrm{~mL})$. The organic phase was rinsed with brine $(2 \mathrm{~mL})$, dried $\left(\mathrm{Na}_{2} \mathrm{SO}_{4}\right)$, filtered and concentrated by flash 
chromatography (EtOAc/hex 1:1) to give the title compound as a colorless oil ( $3 \mathrm{mg}, 83 \%) .{ }^{1} \mathrm{H}$ NMR (300 MHz; $\left.\mathrm{CDCl}_{3}\right): \delta 8.17(\mathrm{dt}, J=4.7,2.3 \mathrm{~Hz}, 1 \mathrm{H}), 7.65-7.61(\mathrm{~m}, 3 \mathrm{H}), 7.29-7.27(\mathrm{~m}, 5 \mathrm{H})$, 5.94-5.85 (m, 1H), $5.57(\mathrm{~s}, 1 \mathrm{H}), 5.37(\mathrm{~d}, J=4.2 \mathrm{~Hz}, 1 \mathrm{H}), 5.26-5.19(\mathrm{~m}, 1 \mathrm{H}), 5.10-5.05(\mathrm{~m}, 1 \mathrm{H})$, $4.82(\mathrm{~s}, 1 \mathrm{H}), 4.68(\mathrm{~s}, 1 \mathrm{H}), 4.55-4.42(\mathrm{~m}, 3 \mathrm{H}), 4.37(\mathrm{~s}, 1 \mathrm{H}), 4.26(\mathrm{~s}, 1 \mathrm{H}), 4.21-4.11(\mathrm{~m}, 2 \mathrm{H}), 3.93-$ $3.87(\mathrm{~m}, 2 \mathrm{H}), 3.81(\mathrm{~s}, 3 \mathrm{H}), 3.73(\mathrm{~s}, 3 \mathrm{H}), 2.21(\mathrm{~s}, 3 \mathrm{H}), 1.48(\mathrm{~s}, 3 \mathrm{H}), 1.25(\mathrm{~s}, 3 \mathrm{H}), 1.15(\mathrm{t}, J=7.1$ $\mathrm{Hz}, 3 \mathrm{H})$. 


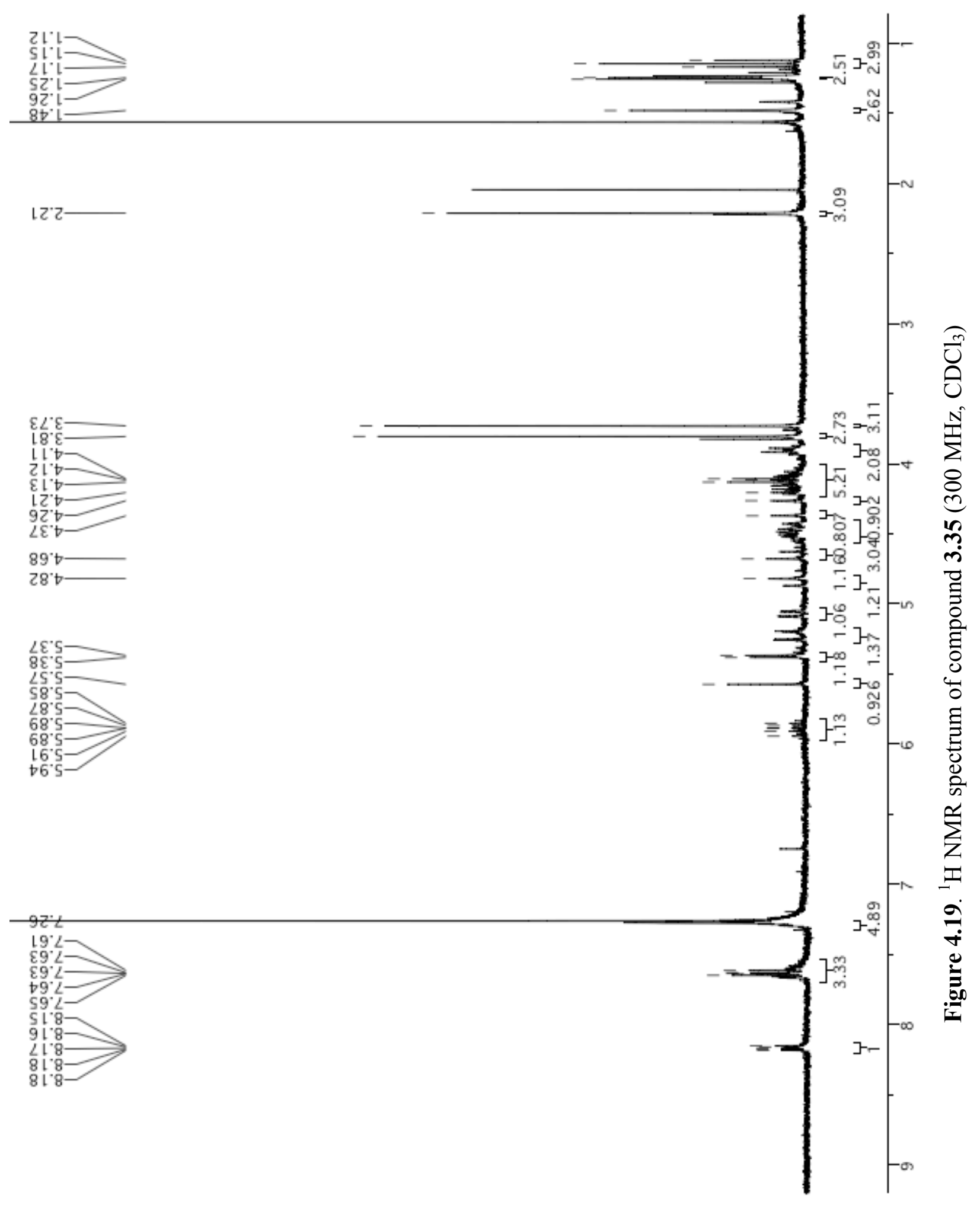




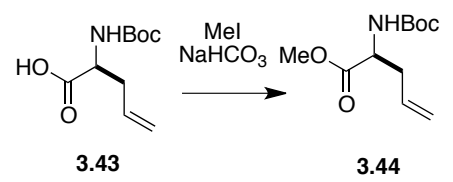

\subsection{0 (S)-methyl 2-((tert-butoxycarbonyl)amino)pent-4-enoate (3.44)}

(S)-Boc-allylglycine (3.43) (302 mg, $1 \mathrm{mmol})$ and $\mathrm{NaHCO}_{3}(252 \mathrm{mg}, 2 \mathrm{mmol})$ were suspended in DMF $(6 \mathrm{~mL})$ under $\mathrm{Ar}$ atmosphere. Iodomethane $(286 \mu \mathrm{L}, 3 \mathrm{mmol})$ was added and the reaction was stirred for $24 \mathrm{~h}$, poured over $25 \mathrm{~mL}$ of water, the phases separated, the aqueous phase extracted with EtOAc $(2 \times 25 \mathrm{~mL})$ and the combined organic phases rinsed with water $(25$ $\mathrm{mL})$ and brine $(25 \mathrm{~mL})$, dried $\left(\mathrm{Na}_{2} \mathrm{SO}_{4}\right)$, filtered and concentrated. The resulting oil was purified by flash chromatography $(9: 1$ hexanes/EtOAc) to give the title compound as a clear colorless oil $(199 \mathrm{mg}, 62 \%) . \mathrm{R}_{\mathrm{f}}=0.2\left(6: 1\right.$ hexanes/EtOAc); ${ }^{1} \mathrm{H}-\mathrm{NMR}\left(300 \mathrm{MHz} ; \mathrm{CDCl}_{3}\right): \delta$ 5.71-5.57 (m, 1H), 5.10-5.05 (m, 3H), 4.35-4.29 (m, 1H), 3.65 (s, 3H), 2.54-2.37 (m, 2H), 1.35 (s, 9H). 


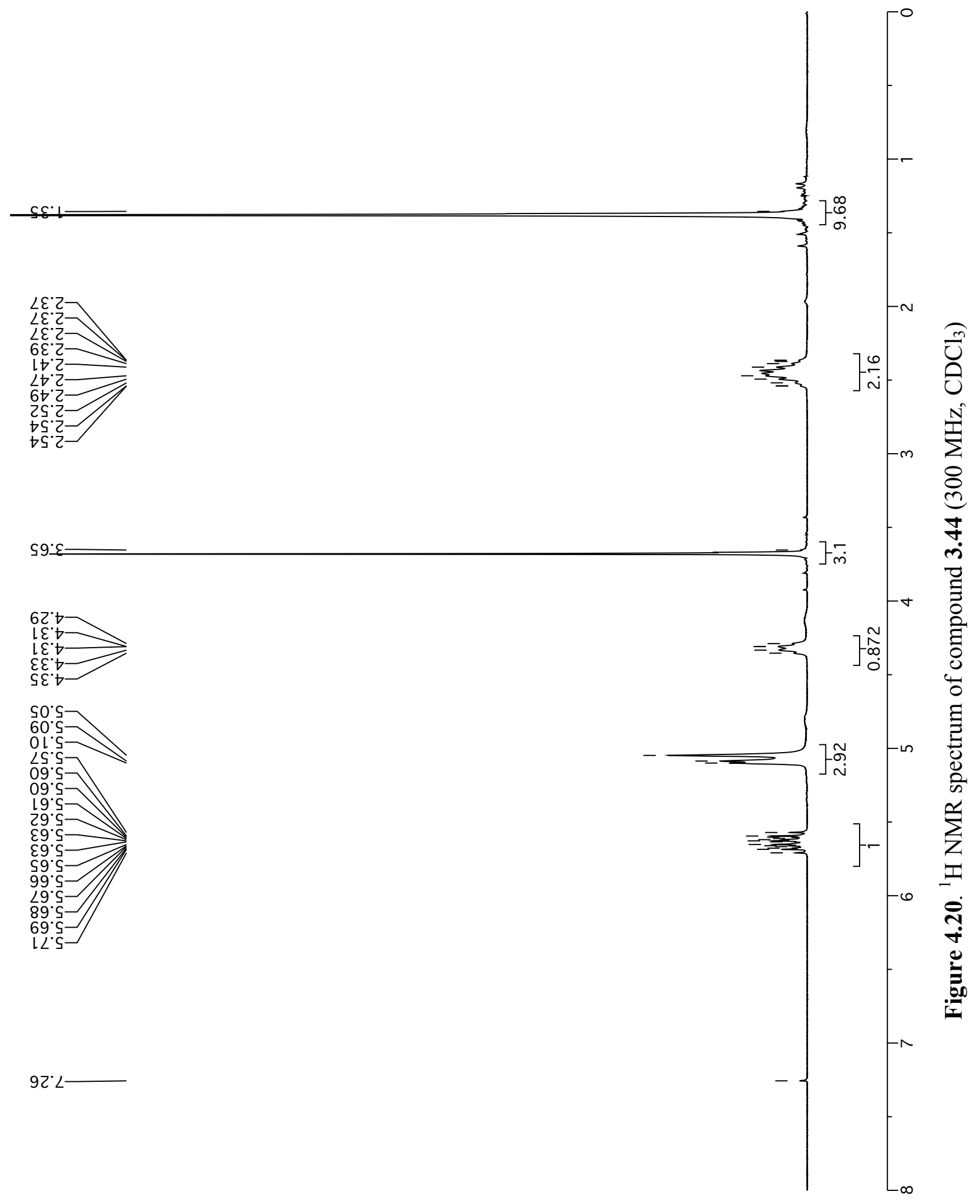




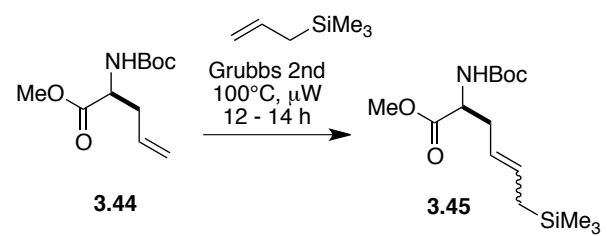

\subsection{1 (S)-methyl 2-((tert-butoxycarbonyl)amino)-6-(trimethylsilyl)hex-4-enoate (3.45)}

Compound (3.44) (199 mg, $0.86 \mathrm{mmol})$ and Grubbs $2^{\text {nd }}$ generation catalyst (40 mg, $0.047 \mathrm{mmol}$, $5.5 \mathrm{~mol} \%)$ were dissolved in DCM $(8 \mathrm{~mL})$ in a microwave reaction vessel and the resulting solution was degassed with Ar for $5 \mathrm{~min}$. and placed in a microwave reactor (maximum power $=$ $100 \mathrm{~W}, 100^{\circ} \mathrm{C}$ for $\left.12 \mathrm{~h}\right)$. The reaction mixture was concentrated under vacuum and the resulting solid was purified by flash chromatography (9:1 hexanes/EtOAc) to afford the title compound as a colorless oil $(188 \mathrm{mg}, 69 \%) . \mathrm{R}_{\mathrm{f}}=0.5\left(6: 1\right.$ hexanes/EtOAc); ${ }^{1} \mathrm{H}-\mathrm{NMR}\left(300 \mathrm{MHz} ; \mathrm{CDCl}_{3}\right): \delta$ 5.56-5.45 (m, 1H), 5.14-4.96 (m, 1H), $3.73(\mathrm{~s}, 3 \mathrm{H}), 2.53-2.38(\mathrm{~m}, 2 \mathrm{H}), 1.43(\mathrm{~s}, 9 \mathrm{H}), 1.43(\mathrm{~s}, 9 \mathrm{H})$, $-0.01(\mathrm{~s}, 6 \mathrm{H})$. 


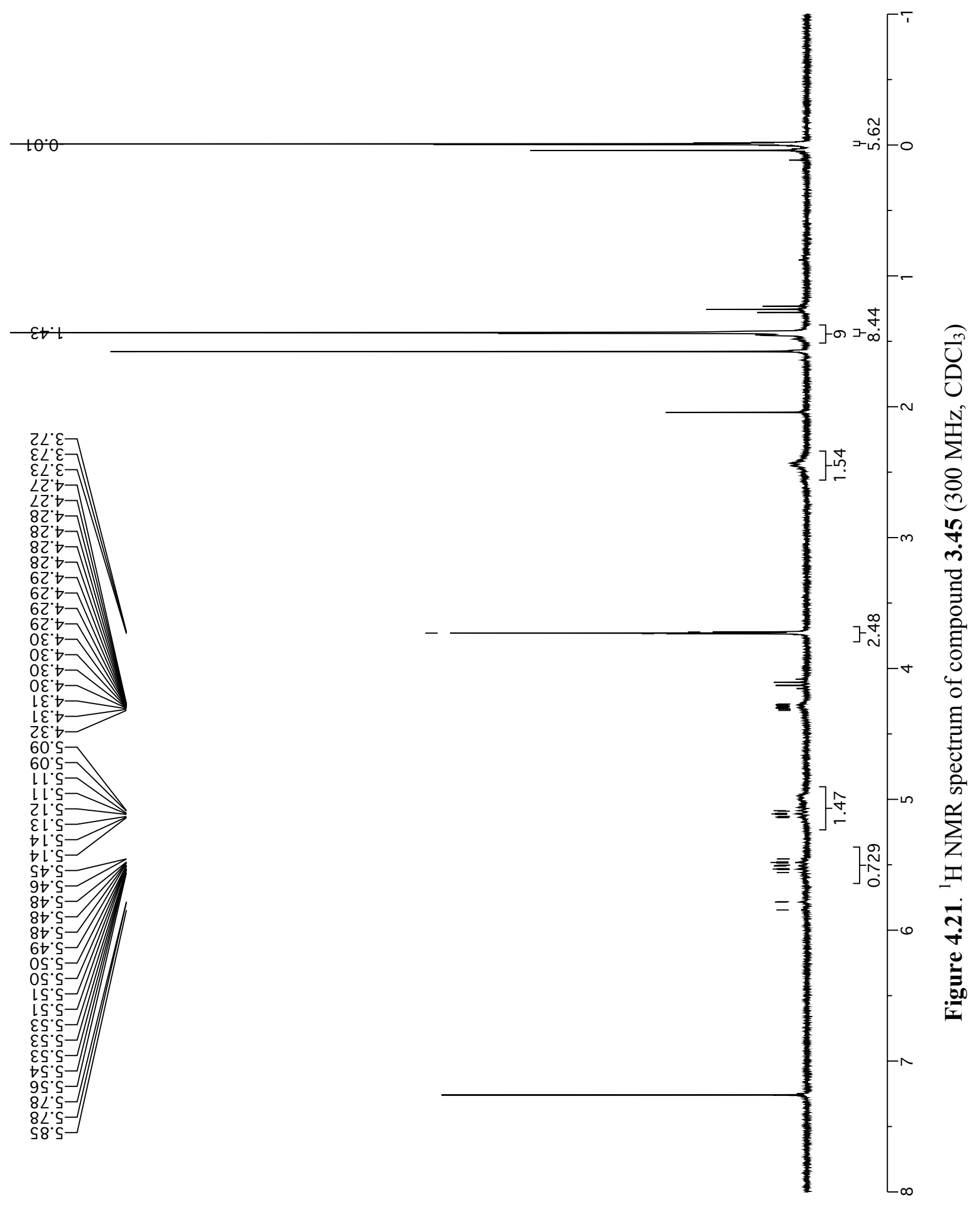




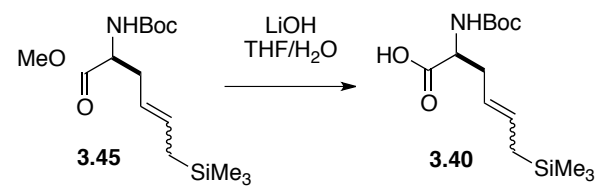

\subsection{2 (S)-2-((tert-butoxycarbonyl)amino)-6-(trimethylsilyl)hex-4-enoic acid (3.40)}

To a solution of compound $\mathbf{3 . 4 5}(188 \mathrm{mg}, 0.60 \mathrm{mmol})$ in THF $(8 \mathrm{~mL})$ were added water $(1.6 \mathrm{~mL})$ and $\mathrm{LiOH} \cdot \mathrm{H}_{2} \mathrm{O}(100 \mathrm{mg}, 2.4 \mathrm{mmol})$ and the resulting suspension was stirred for $2 \mathrm{~h}$, diluted with water $(20 \mathrm{~mL})$, acidified to $\mathrm{pH}=4$ with $1 \mathrm{~N} \mathrm{HCl}$ and diluted with EtOAc $(20 \mathrm{~mL})$. The phases were separated and the aqueous phase was extracted with EtOAc $(2 \times 20 \mathrm{~mL})$ and the combined organic phases were rinsed with brine $(20 \mathrm{~mL})$ dried $\left(\mathrm{Na}_{2} \mathrm{SO}_{4}\right)$, filtered and concentrated. The resulting oil was purified by flash chromatography (1:1 hexanes/EtOAc) to afford the title compound as a clear colorless oil $(120 \mathrm{mg}, 62 \%) . \mathrm{R}_{\mathrm{f}}=0.1\left(1: 1\right.$ hexanes/EtOAc); ${ }^{1} \mathrm{H}-\mathrm{NMR}\left(300 \mathrm{MHz} ; \mathrm{CDCl}_{3}\right)$ : $\delta$ 5.55-5.50 (m, 1H), 5.19-5.05 (m, 2H), $4.15(\mathrm{~s}, 1 \mathrm{H}), 2.51-2.44(\mathrm{~m}, 2 \mathrm{H}), 1.46-1.39(\mathrm{~m}, 9 \mathrm{H})$. 


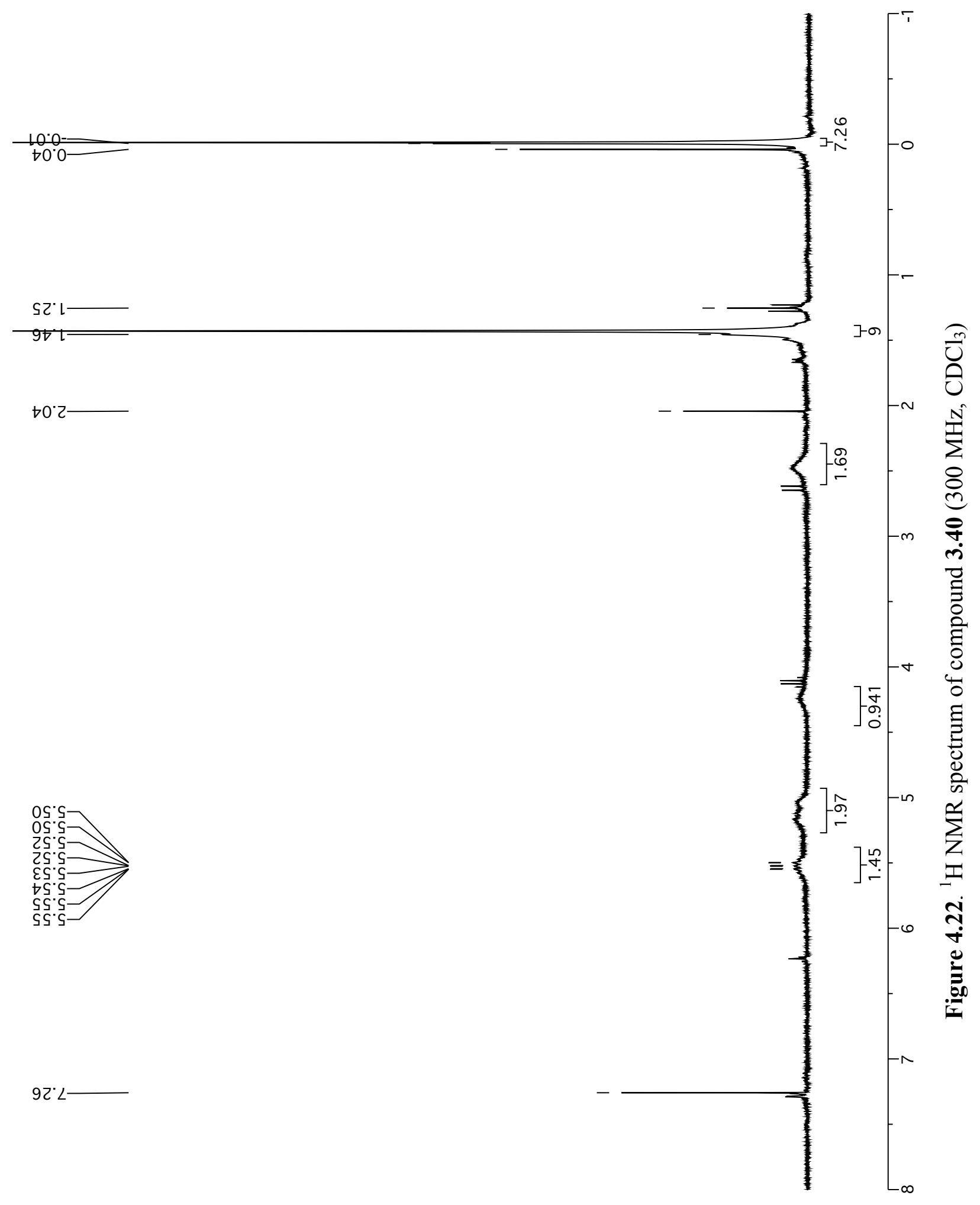



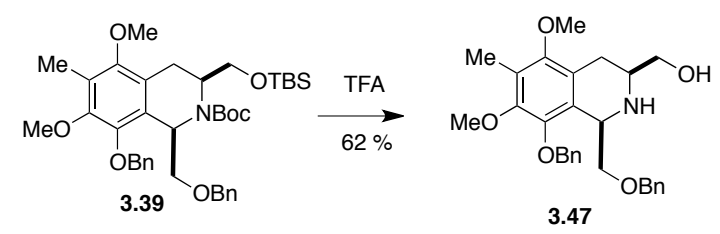

\subsection{3 ((1R,3S)-8-(benzyloxy)-1-((benzyloxy)methyl)-5,7-dimethoxy-6-methyl-1,2,3,4- tetrahydroisoquinolin-3-yl)methanol (3.47)}

To a solution of compound $3.39(220 \mathrm{mg})$ in $\mathrm{CH}_{2} \mathrm{Cl}_{2}(3.25 \mathrm{~mL})$ was added TFA $(0.964 \mathrm{~mL}, 40$ eq) and the resulting mixture was stirred for $2 \mathrm{~h}$ (until TLC revealed absence of SM). The reaction was diluted with water $(20 \mathrm{~mL})$, the TFA quenched with $\mathrm{NaHCO}_{3}$ sat., the phases separated and the aqueous phase was extracted with $\mathrm{CH}_{2} \mathrm{Cl}_{2}(2 \times 20 \mathrm{~mL})$ and the combined organic phases were rinsed with brine $(20 \mathrm{~mL})$ dried $\left(\mathrm{Na}_{2} \mathrm{SO}_{4}\right)$, filtered and concentrated. The resulting oil was purified by flash chromatography (1:1 hexanes/EtOAc followed by EtOAc) to afford the title compound as a clear colorless oil $(120 \mathrm{mg}, 62 \%) . \mathrm{R}_{\mathrm{f}}=0.1\left(\right.$ EtOAc); ${ }^{1} \mathrm{H}-\mathrm{NMR}$ $\left(300 \mathrm{MHz} ; \mathrm{CDCl}_{3}\right): \delta 7.43-7.17(\mathrm{~m}, 5 \mathrm{H}), 5.03(\mathrm{~d}, J=5.7 \mathrm{~Hz}, 2 \mathrm{H}), 4.40(\mathrm{~d}, J=2.9 \mathrm{~Hz}, 2 \mathrm{H}), 3.80$ (s, 3H), $3.69(\mathrm{~s}, 3 \mathrm{H}), 3.56-3.53(\mathrm{~m}, 3 \mathrm{H}), 3.30-3.23(\mathrm{~m}, 3 \mathrm{H}), 2.96-2.90(\mathrm{~m}, 3 \mathrm{H}), 2.24(\mathrm{~s}, 3 \mathrm{H})$. 

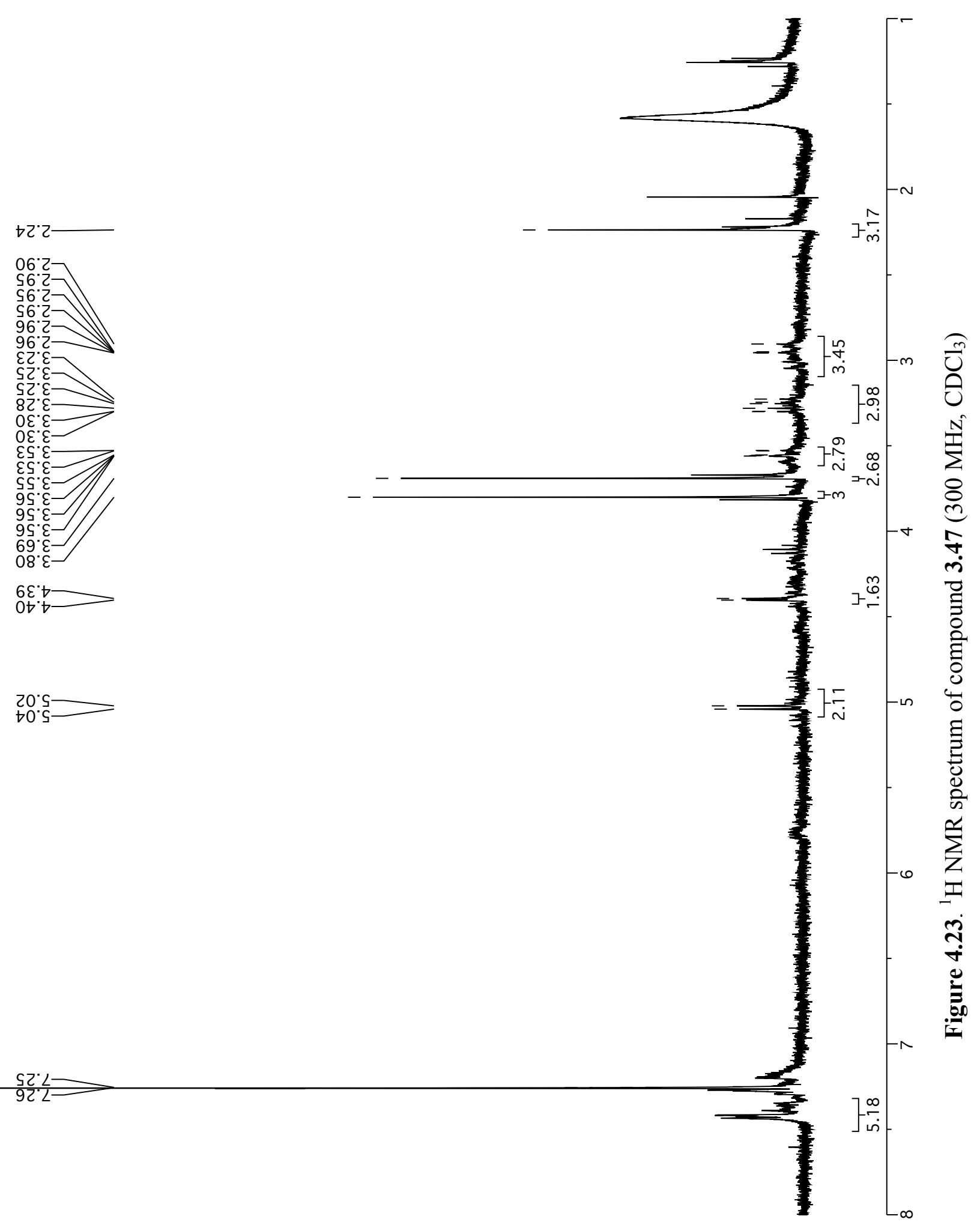


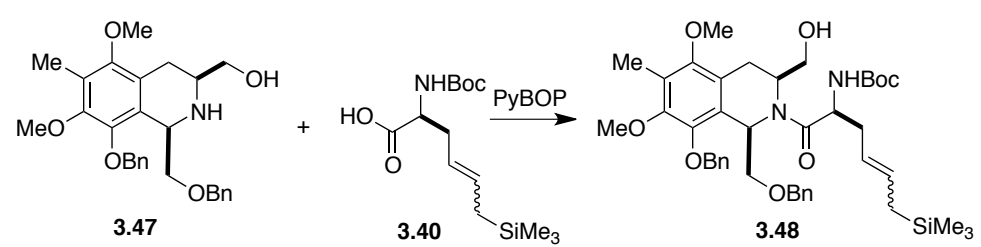

\subsection{Tert-butyl ((S)-1-((1R,3S)-8-(benzyloxy)-1-((benzyloxy)methyl)-3-(hydroxymethyl)-} 5,7-dimethoxy-6-methyl-3,4-dihydroisoquinolin-2(1H)-yl)-1-oxo-6-(trimethylsilyl)hex-4-en-

\section{2-yl)carbamate (3.48)}

A solution of compound $3.47(70 \mathrm{mg}, 0.15 \mathrm{mmol})$, PyBOP $(84 \mathrm{mg}, 0.16 \mathrm{mmol})$ and compound 3.40 (45 mg, $0.15 \mathrm{mmol})$ in $\mathrm{CH}_{2} \mathrm{Cl}_{2}(700 \mu \mathrm{L})$ was stirred for $24 \mathrm{~h}$ and diluted with $\mathrm{CH}_{2} \mathrm{Cl}_{2}(5$ $\mathrm{mL})$ and sat. aq. $\mathrm{NH}_{4} \mathrm{Cl}(5 \mathrm{~mL})$. The phases were separated and the aqueous phase was rinsed with $\mathrm{CH}_{2} \mathrm{Cl}_{2}(2 \times 5 \mathrm{~mL})$. The combined organic phases were rinsed with brine $(5 \mathrm{~mL})$, dried $\left(\mathrm{Na}_{2} \mathrm{SO}_{4}\right)$, filtered and concentrated. The resulting oil was purified by flash chromatography (3:1 hexanes/EtOAc) to afford the title compound ( $30 \mathrm{mg}, 27 \%)$ as a clear colorless oil. $\mathrm{R}_{\mathrm{f}}=0.15(3: 1$ hexanes/EtOAc); ${ }^{1} \mathrm{H}-\mathrm{NMR}\left(300 \mathrm{MHz} ; \mathrm{CDCl}_{3}\right): \delta 7.38-7.23(\mathrm{~m}, 5 \mathrm{H}), 5.04(\mathrm{~d}, J=11.0 \mathrm{~Hz}, 2 \mathrm{H})$, $4.83(\mathrm{~d}, J=10.9 \mathrm{~Hz}, 1 \mathrm{H}), 4.30(\mathrm{~d}, J=4.6 \mathrm{~Hz}, 1 \mathrm{H}), 4.20-4.13(\mathrm{~m}, 2 \mathrm{H}), 3.81-3.78(\mathrm{~m}, 2 \mathrm{H}), 3.68$ (s, 3H), 3.54 (s, 1H), 2.91-2.85 (m, 2H), 2.45-2.42 (m, 2H), 2.21 (s, 3H), 1.43 (s, 9H), -0.02 (s, $6 \mathrm{H})$. 


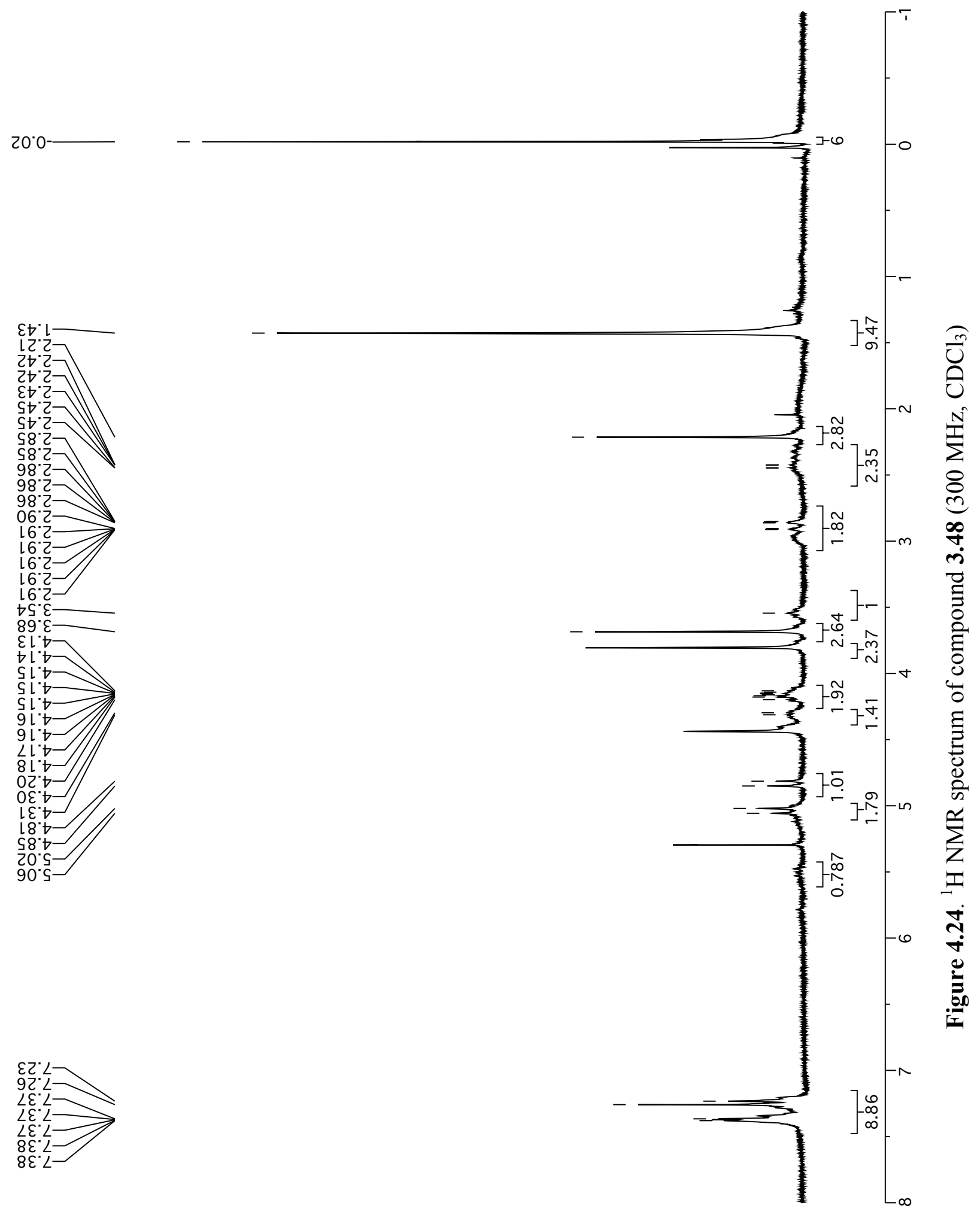




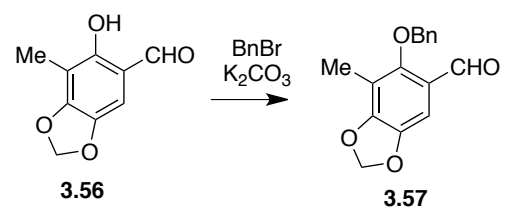

\subsection{6-(benzyloxy)-7-methylbenzo $[d][1,3]$ dioxole-5-carbaldehyde (3.57)}

To a suspension of aldehyde $\mathbf{3 . 5 6}$ (500 mg, $2.78 \mathrm{mmol})$ and $\mathrm{K}_{2} \mathrm{CO}_{3}(1.5 \mathrm{~g}, 8.33 \mathrm{mmol})$ in acetone (30 $\mathrm{mL})$ was added $\mathrm{BnBr}(400 \mu \mathrm{L}, 3.36 \mathrm{mmol})$. The reaction was stirred for $24 \mathrm{~h}$, diluted with water $(30 \mathrm{~mL})$, concentrated under vacuum and the aqueous phase extracted with EtOAc $(2 \times 25$ $\mathrm{mL})$. The combined organic phases were concentrated, dried $\left(\mathrm{Na}_{2} \mathrm{SO}_{4}\right)$, filtered and evaporated under vacuum. The resulting solid was purified by flash chromatography ( $3: 1$ hexanes/EtOAc) to afford the title compound as yellow solid $(680 \mathrm{mg}, 90 \%) . \mathrm{R}_{\mathrm{f}}=0.4\left(3: 1\right.$ hexanes/EtOAc); ${ }^{1} \mathrm{H}-$ NMR (300 MHz; $\left.\mathrm{CDCl}_{3}\right): \delta 10.07$ (s, 1H), $7.40(\mathrm{~s}, 5 \mathrm{H}), 7.12(\mathrm{~s}, 1 \mathrm{H}), 6.05(\mathrm{~s}, 2 \mathrm{H}), 4.93(\mathrm{~s}, 1 \mathrm{H})$, $2.21(\mathrm{~s}, 3 \mathrm{H})$. 


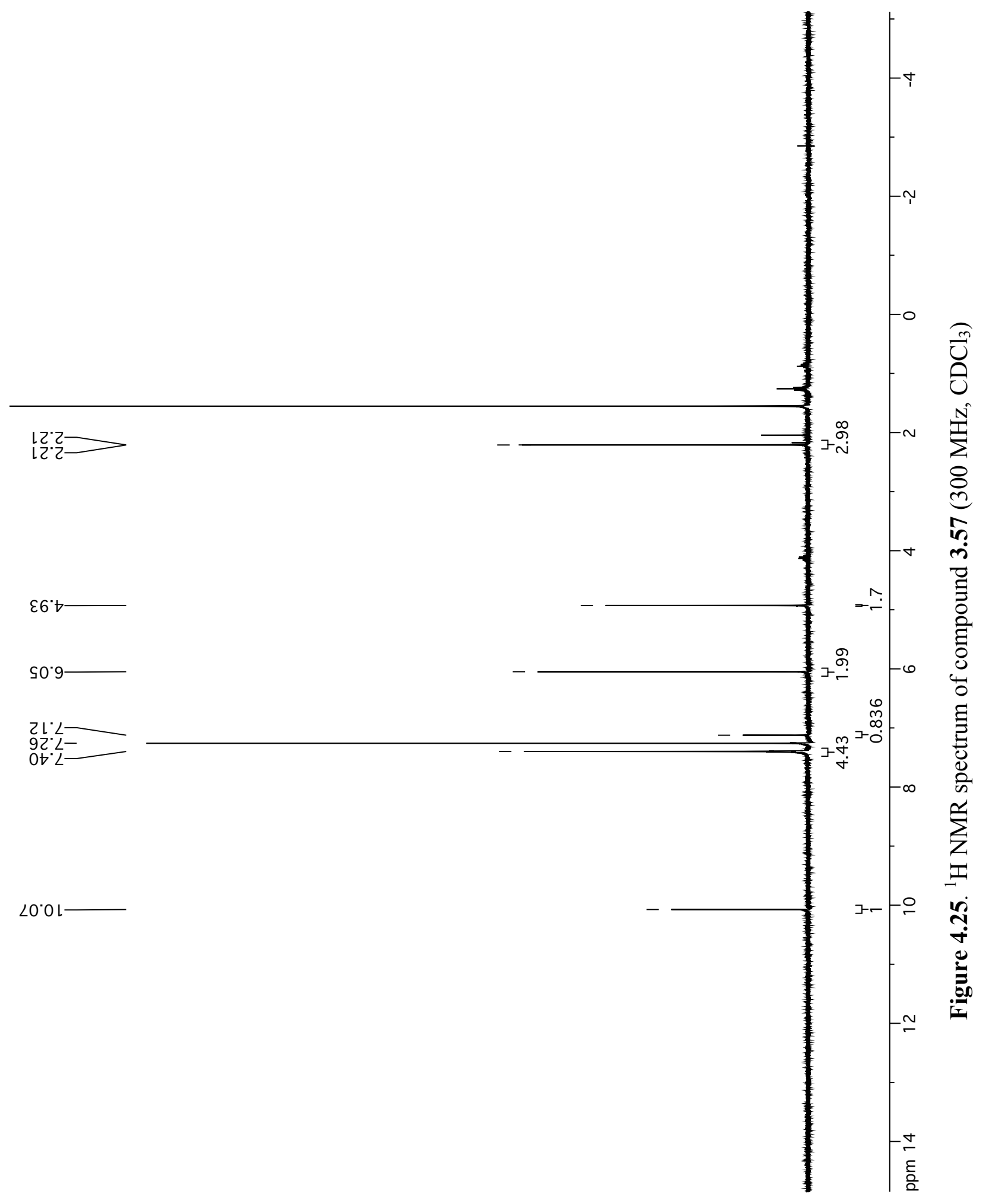




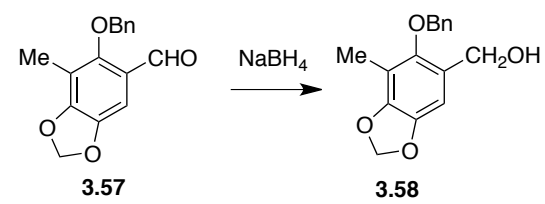

\subsection{6-(hydroxymethyl)-4-methylbenzo[d][1,3] dioxol-5-ol (3.58)}

To a solution of aldehyde $3.57(680 \mathrm{mg}, 2.5 \mathrm{mmol})$ in $\mathrm{EtOH}(15 \mathrm{~mL})$ was added $\mathrm{NaBH}_{4}(38 \mathrm{mg}$, $1 \mathrm{mmol})$. The reaction was stirred for $3 \mathrm{~h}$, quenched with $1 \mathrm{~N} \mathrm{HCl}(15 \mathrm{~mL})$ and concentrated under vacuum. The aqueous phase extracted with EtOAc $(2 \times 25 \mathrm{~mL})$. The combined organic phases were concentrated under, dried $\left(\mathrm{Na}_{2} \mathrm{SO}_{4}\right)$, filtered and evaporated. The resulting solid was purified by flash chromatography (3:1 hexanes/EtOAc) to afford the title compound as a white solid (450 mg, $65 \%) . \mathrm{R}_{\mathrm{f}}=0.2$ (3:1 hexanes/EtOAc); ${ }^{1} \mathrm{H}-\mathrm{NMR}\left(300 \mathrm{MHz} ; \mathrm{CDCl}_{3}\right): \delta$ 7.39-7.33 (m, 6H), $6.73(\mathrm{~s}, 1 \mathrm{H}), 5.92(\mathrm{~s}, 2 \mathrm{H}), 4.76(\mathrm{~s}, 2 \mathrm{H}), 4.48(\mathrm{~s}, 2 \mathrm{H}), 2.17(\mathrm{~s}, 3 \mathrm{H})$. 


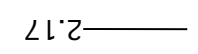

$6 t^{\circ} \varepsilon$

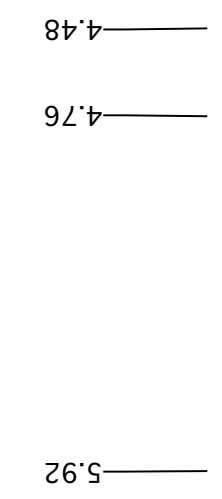

$\varepsilon\llcorner\cdot 9$

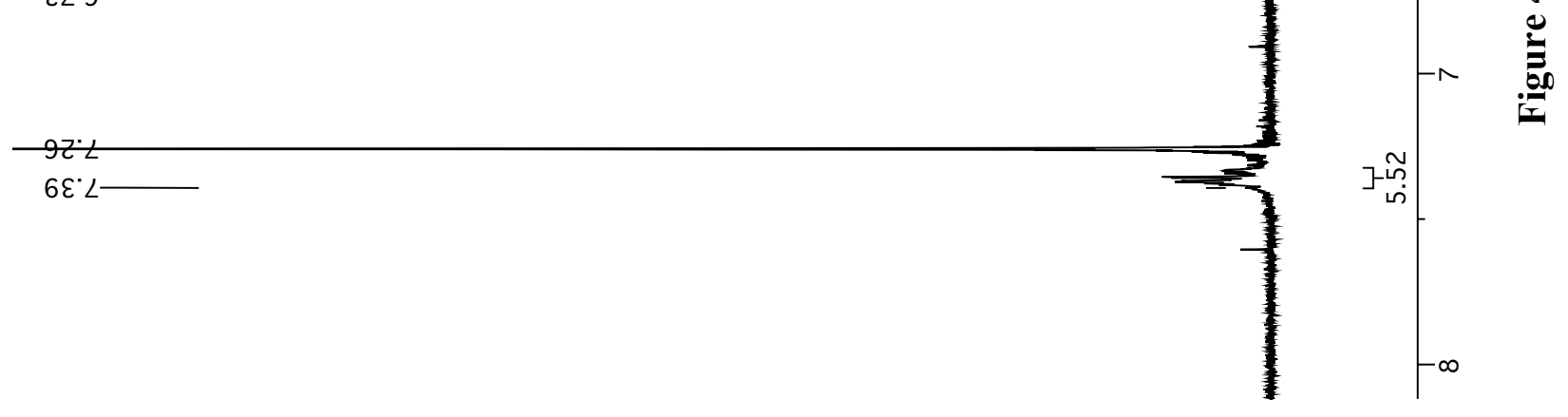




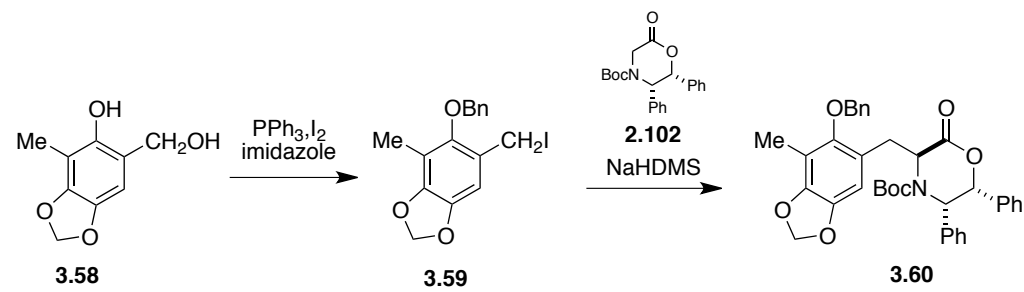

\subsection{7 (3S,5S,6R)-tert-butyl 3-((6-(benzyloxy)-7-methylbenzo[d][1,3]dioxol-5-yl)methyl)-2-} oxo-5,6-diphenylmorpholine-4-carboxylate (3.60)

To a solution of $\mathrm{PPh}_{3}(5.51 \mathrm{~g}, 21 \mathrm{mmol})$ in $100 \mathrm{~mL}$ of dry $\mathrm{CH}_{2} \mathrm{Cl}_{2}$ at $0^{\circ} \mathrm{C}$ under $\mathrm{Ar}$ atmosphere, was added $\mathrm{I}_{2}(5.32 \mathrm{~g}, 21 \mathrm{mmol})$ in several small portions over $1 \mathrm{~min}$. The mixture was stirred for 5 min, after which a solution consisting of benzyl alchohol 3.58 (3.812 g, $14 \mathrm{mmol})$ and imidazole $(2.85 \mathrm{mg}, 42 \mathrm{mmol})$ in $150 \mathrm{~mL}$ of dry $\mathrm{CH}_{2} \mathrm{Cl}_{2}$ was added dropwise over 5 min by cannula. The mixture was stirred at $0^{\circ} \mathrm{C}$ for 45 minutes and quenched with $100 \mathrm{~mL}$ of $5 \%$ $\mathrm{NaHSO}_{3}$. The phases were separated, the aqueous phase was extracted with $\mathrm{CH}_{2} \mathrm{Cl}_{2}(2 \times 75 \mathrm{~mL})$ and the combined organic layers were dried $\left(\mathrm{Na}_{2} \mathrm{SO}_{4}\right)$, filtered and concentrated under reduced pressure to afford a pale-yellow solid. The crude material was kept under vacuum and covered with aluminum foil for $12 \mathrm{~h}$ (to avoid exposure to light) and used in the following step without further purification.

Tert-butyl (2R,3S)-6-oxo-2,3-diphenyl-4-morpholinecarboxylate (3.102) (4.94 mg, 14 mmol, 1.0 eq.) was dissolved in $140 \mathrm{~mL}$ of anhydrous THF under Ar atmosphere and the mixture was cooled to $-78^{\circ} \mathrm{C}$. NaHDMS (1.0 M in THF, $16 \mathrm{~mL}, 16 \mathrm{mmol}, 1.15$ eq.) was added dropwise over 5 minutes and the mixture was stirred for $45 \mathrm{~min}$, after which a solution of crude benzyl iodide (12) in $140 \mathrm{~mL}$ of dry THF was added over 5 minutes by cannula. The reaction was stirred for 4h at $-78^{\circ} \mathrm{C}$, quenched with $10 \mathrm{~mL}$ of sat. aq. $\mathrm{NH}_{4} \mathrm{Cl}$, allowed to warm to $\mathrm{RT}$, and diluted with $250 \mathrm{~mL}$ of EtOAc. The phases were separated and the aqueous phase was extracted with EtOAc $(3 \times 100 \mathrm{~mL})$. The combined organic phases were rinsed with brine $\left(100 \mathrm{~mL}\right.$ and dried $\left(\mathrm{Na}_{2} \mathrm{SO}_{4}\right)$, 
filtered and concentrated under reduced pressure and the crude material was purified with flash chromatography (hexanes/EtOAc 4:1) to give the title compound as a white crystalline solid (8.45 mg, 99\%). $\mathrm{R}_{\mathrm{f}}=0.3$ (hexanes/EtOAc 4:1); ${ }^{1} \mathrm{H}$ NMR: mixture of rotamers, ${ }^{1} \mathrm{H}-\mathrm{NMR}(300$ $\left.\mathrm{MHz} ; \mathrm{CDCl}_{3}\right): \delta$ 7.42-7.34 (m, 2H), 7.23-7.01 (s, 10H), $6.74(\mathrm{~s}, 1 \mathrm{H}), 6.69-6.64(\mathrm{~m}, 2 \mathrm{H}), 6.51(\mathrm{t}$, $J=6.6 \mathrm{~Hz}, 2 \mathrm{H}), 5.97-5.92(\mathrm{~d}, \mathrm{~m}, 2 \mathrm{H}), 5.57(\mathrm{~d}, J=3.1 \mathrm{~Hz}, 1 \mathrm{H}), 5.35(\mathrm{~d}, J=3.0 \mathrm{~Hz}, 1 \mathrm{H}), 5.24-$ $5.19(\mathrm{~m}, 1 \mathrm{H}), 5.06-5.00(\mathrm{~m}, 1 \mathrm{H}), 3.39(\mathrm{dd}, J=13.4,8.5 \mathrm{~Hz}, 1 \mathrm{H}), 3.28-3.20(\mathrm{~m}, 2 \mathrm{H}), 2.21(\mathrm{~s}$, $3 \mathrm{H}), 2.20(\mathrm{~s}, 3 \mathrm{H}), 1.57$ (s, 9H). 


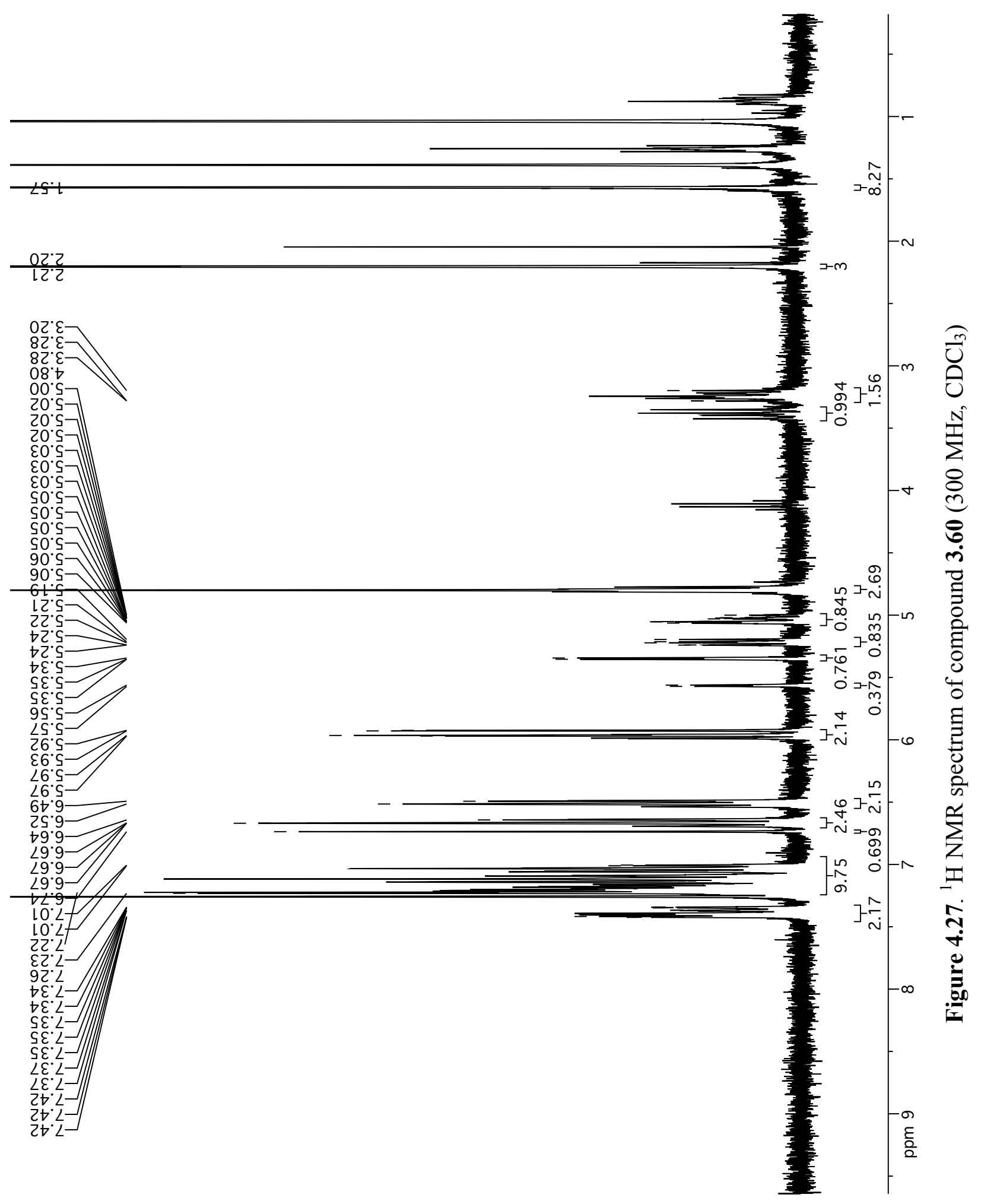




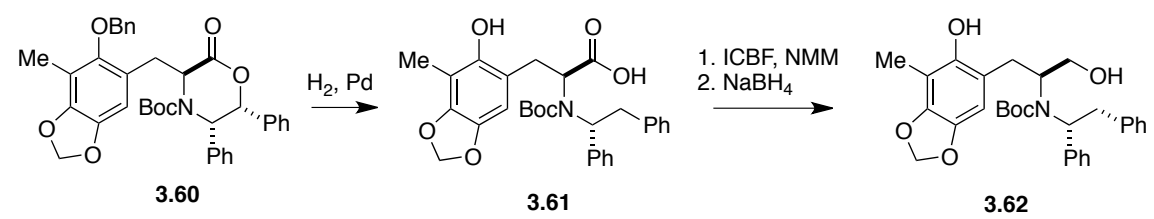

\subsection{Tert-butyl ((R)-1,2-diphenylethyl)((S)-1-hydroxy-3-(6-hydroxy-7-}

methylbenzo $[d][1,3]$ dioxol-5-yl)propan-2-yl)carbamate (3.62)

Compound 3.60 (300 mg, $0.5 \mathrm{mmol})$ was dissolved in $\mathrm{MeOH}(8 \mathrm{~mL})$ and THF $(8 \mathrm{~mL}) .80 \mathrm{mg}$ of $10 \% \mathrm{Pd} / \mathrm{C}$ were added and the resulting suspension was evacuated three times and filled with $\mathrm{H}_{2}$

(1 atm), and stirred under $\mathrm{H}_{2}(1 \mathrm{~atm})$ for $24 \mathrm{~h}$. The reaction was filtered through Celite ${ }^{\circledR}$ using EtOAc to transfer the material and the filtrate was evaporated to give an oil. The crude material was dissolved in $10 \mathrm{~mL}$ of dry THF under Ar atmosphere and NMM (76 $\mu \mathrm{L}, 0.69 \mathrm{mmol}, 1.2 \mathrm{eq})$ was added dropwise over $30 \mathrm{~s}$., followed by isobutyl chloroformate (91 $\mu \mathrm{L}, 0.69 \mathrm{mmol}, 1.2 \mathrm{eq})$. The reaction was stirred at RT for 30 min and the resulting suspension was loaded into a short column of Celite ${ }^{\circledR}$ (previously rinsed with anhydrous THF). Using vacuum, the solution was transferred to a flask containing $\mathrm{NaBH}_{4}\left(380 \mathrm{mg}, 7 \mathrm{mmol}, 10\right.$ eq.) dissolved in $\mathrm{H}_{2} \mathrm{O}(10 \mathrm{~mL})$ at $0^{\circ} \mathrm{C}$, using $6 \mathrm{~mL}$ of THF to rinse the flask. The reaction was stirred at $0^{\circ} \mathrm{C}$ for $2 \mathrm{~h}$ and quenched by adding $\mathrm{AcOH} / \mathrm{H}_{2} \mathrm{O}(1: 1)(500 \mu \mathrm{L})$ dropwise over 1 minute. The reaction was immediately diluted with EtOAc $(10 \mathrm{~mL})$ and $\mathrm{H}_{2} \mathrm{O}(10 \mathrm{~mL})$. The phases were separated and the aqueous phase was extracted with EtOAc $(2 \times 10 \mathrm{~mL})$. The combined organic phases were dried, filtered and concentrated. The resulting crude was purified by flash chromatography (hexanes/EtOAc 4:1) to afford the title compound a as a colorless oil $(235 \mathrm{mg}, 86 \%) . \mathrm{R}_{\mathrm{f}}=0.38$ (hexanes/EtOAc 4:1); ${ }^{1} \mathrm{H}-\mathrm{NMR}\left(300 \mathrm{MHz} ; \mathrm{CDCl}_{3}\right.$ ): mixture of carbamate rotamers, low solubility, $\delta$ 7.51-7.48 (m, 5H), 7.28-7.20 (m, 10H), 5.80-5.76 (m, 2H), 3.44-3.22 (m, 3H), 3.17-3.00 (m, 2H), $2.06(\mathrm{~s}$, $3 \mathrm{H}), 1.35(\mathrm{~s}, 9 \mathrm{H})$. 


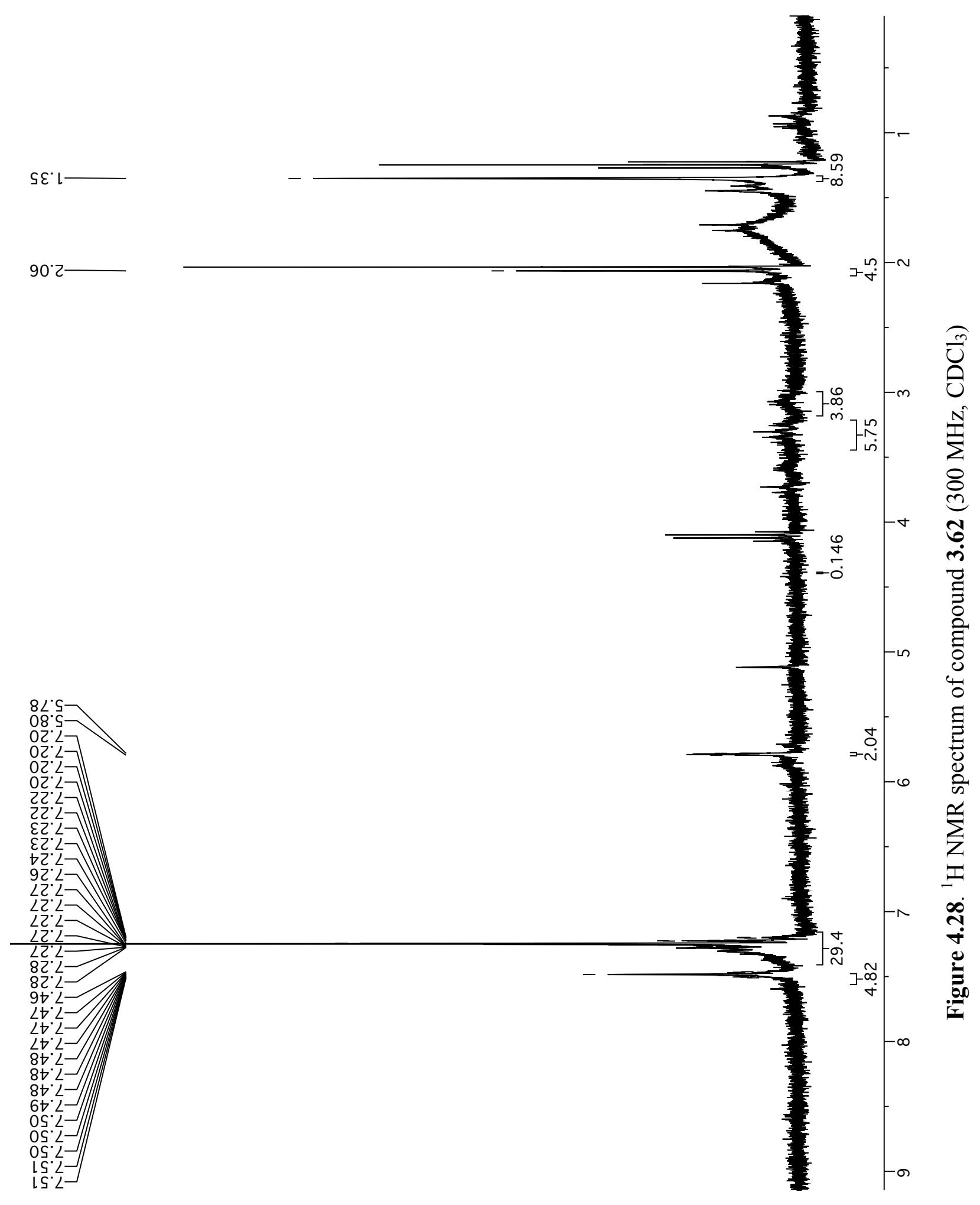




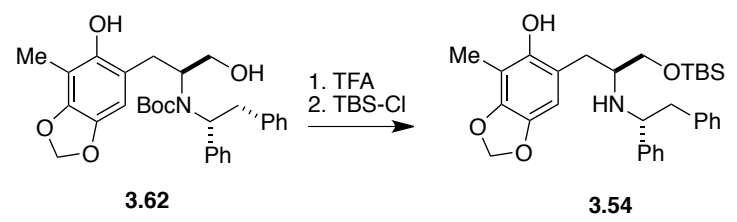

\subsection{Tert-butyl ((R)-1,2-diphenylethyl)((S)-1-hydroxy-3-(6-hydroxy-7-methyl- benzo $[d][1,3]$ dioxol-5-yl)propan-2-yl)carbamate (3.54)}

To a solution of compound $3.62\left(235 \mathrm{mg}, 0.47 \mathrm{mmol}, 1.0\right.$ eq.) in dry $\mathrm{CH}_{2} \mathrm{Cl}_{2}(20 \mathrm{~mL})$ under $\mathrm{Ar}$ atmosphere, were added $600 \mu \mathrm{L}$ of TFA $(8 \mathrm{mmol})$. The solution was stirred at RT for $2 \mathrm{~h}$, diluted with $5 \mathrm{~mL}$ of $\mathrm{CH}_{2} \mathrm{Cl}_{2}$ and $5 \mathrm{~mL}$ of aq. $\mathrm{NaHCO}_{3}$. The phases were separated and the organic phase was rinsed with $5 \%$ aq. $\mathrm{NaHCO}_{3}(10 \mathrm{~mL})$ and brine $(10 \mathrm{~mL})$, dried $\left(\mathrm{Na}_{2} \mathrm{SO}_{4}\right)$, filtered and concentrated under reduced pressure to afford the crude aminoalcohol (177 $\mathrm{mg}, 0.44 \mathrm{mmol})$. The crude material was dissolved in dry $\mathrm{CH}_{2} \mathrm{Cl}_{2}(43 \mathrm{~mL})$ under Ar atmosphere and then TBS-Cl (131 $\mathrm{mg}, 0.88,2$ eq.) was added. The reaction mixture was stirred for $16 \mathrm{~h}$, poured over $10 \mathrm{~mL}$ of water and the aqueous phase was extracted with EtOAc $(3 \times 10 \mathrm{~mL})$. The combined organic phases were rinsed with brine and dried $\left(\mathrm{Na}_{2} \mathrm{SO}_{4}\right)$, filtered and concentrated under reduced pressure. The crude was purified with flash chromatography (hexanes/EtOAc 6:1) to afford the title compound as a colorless oil $(100 \mathrm{mg}, 41 \%) . \mathrm{R}_{\mathrm{f}}=0.5$ (hexanes/EtOAc 6:1); ${ }^{1} \mathrm{H}-\mathrm{NMR}(300$ $\left.\mathrm{MHz} ; \mathrm{CDCl}_{3}\right): \delta$ 7.23-7.05 (m, 8H), 6.86-6.83 (m, 2H), $6.25(\mathrm{~s}, 1 \mathrm{H}), 5.87(\mathrm{AB}, J=1.5 \mathrm{~Hz}, 2 \mathrm{H})$, 4.07-4.01 (m, 2H), 3.45-2.77 (m, 5H), $2.20(\mathrm{~s}, 3 \mathrm{H}), 0.81(\mathrm{~s}, 9 \mathrm{H}),-0.07(\mathrm{~d}, J=5.5 \mathrm{~Hz}, 6 \mathrm{H})$. 


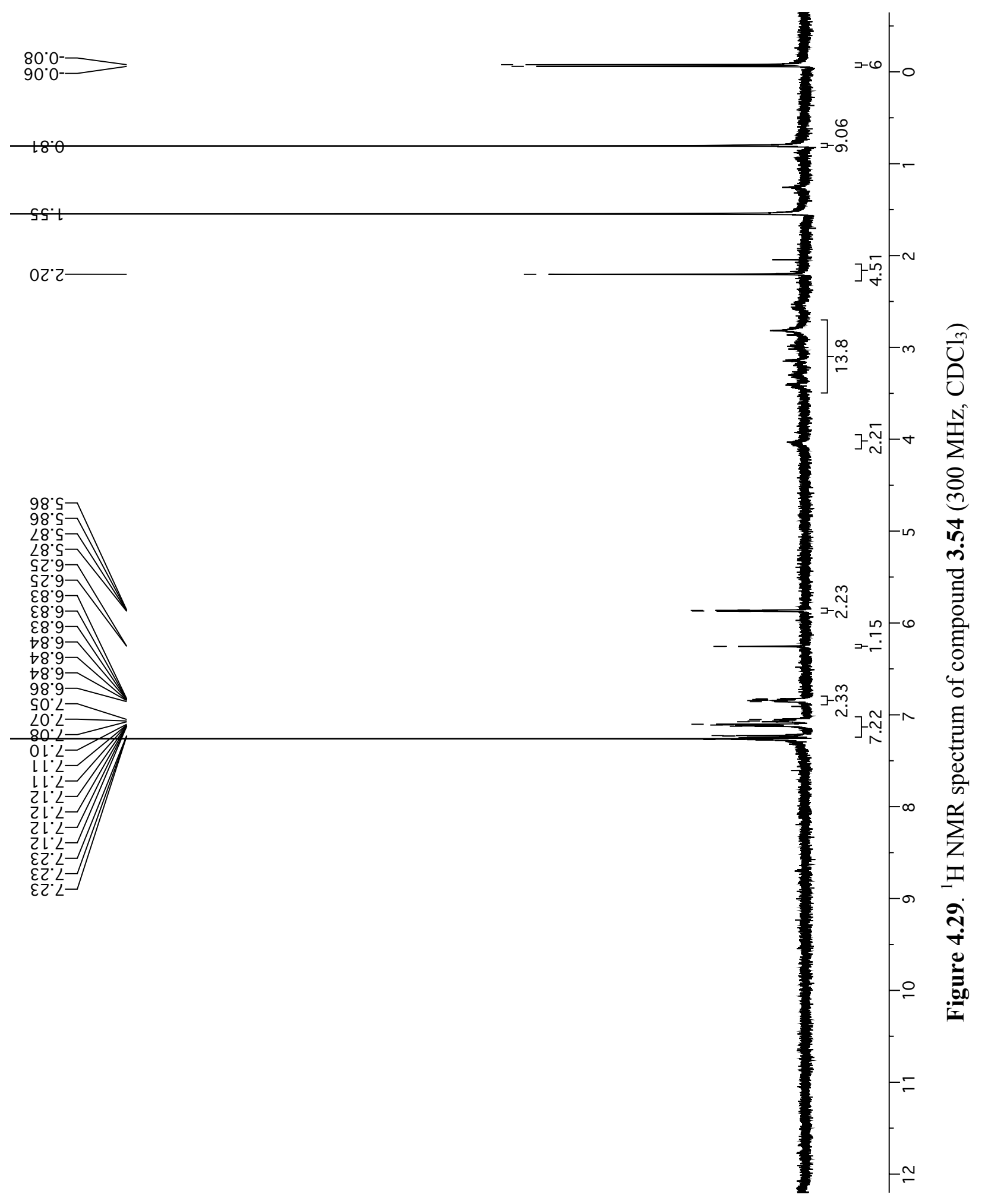




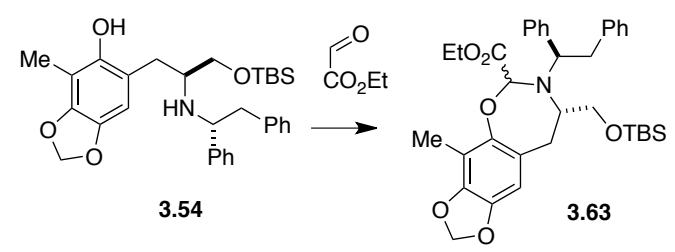

\subsection{0 (8S)-ethyl 8-(((tert-butyldimethylsilyl)oxy)methyl)-7-((R)-1,2-diphenylethyl)-4-} methyl-6,7,8,9-tetrahydro-[1,3]dioxolo $[4 ', 5 '$ ':4,5]benzo[1,2-f][1,3]oxazepine-6-carboxylate (3.63)

To a solution of compound 3.54 (100 mg, $0.19 \mathrm{mmol}, 1.0$ eq.) in $2.00 \mathrm{~mL}$ of acetonitrile under Ar atmosphere, was added of 50\% ethyl glyoxalate in toluene ( $56 \mu \mathrm{L}, 0.26 \mathrm{mmol}, 1.4$ eq.). The reaction was stirred at $45^{\circ} \mathrm{C}$ for 3 days. After cooling to RT, the mixture was filtered through Celite $^{\circledR}$ using EtOAc to transfer the material. The solvents were evaporated and the resulting crude was purified by flash chromatography (hexanes/EtOAc 6:1) to afford the title compound as pale yellow solid (55 mg, 47\%); $\mathrm{R}_{\mathrm{f}}=0.25$ (hexanes/EtOAc 6:1); ${ }^{1} \mathrm{H}-\mathrm{NMR}\left(300 \mathrm{MHz} ; \mathrm{CDCl}_{3}\right.$ ): $\delta$ 7.22-6.94 (m, 10H), $5.78(\mathrm{~d}, J=4.3 \mathrm{~Hz}, 2 \mathrm{H}), 5.77(\mathrm{~s}, 1 \mathrm{H}), 4.15-4.05(\mathrm{~m}, 2 \mathrm{H}), 3.96-3.85(\mathrm{~m}, 1 \mathrm{H})$, 3.44-3.33 (m, 3H), $3.24(\mathrm{dd}, J=13.0,3.9 \mathrm{~Hz}, 1 \mathrm{H}), 3.12-3.04(\mathrm{~m}, 1 \mathrm{H}), 2.33-2.26(\mathrm{~m}, 1 \mathrm{H}), 1.96-$ $1.91(\mathrm{~m}, 1 \mathrm{H}), 1.87(\mathrm{~s}, 3 \mathrm{H}), 1.08(\mathrm{t}, J=7.1 \mathrm{~Hz}, 3 \mathrm{H}), 0.79(\mathrm{~s}, 9 \mathrm{H}),-0.10(\mathrm{~d}, J=5.0 \mathrm{~Hz}, 6 \mathrm{H})$. 


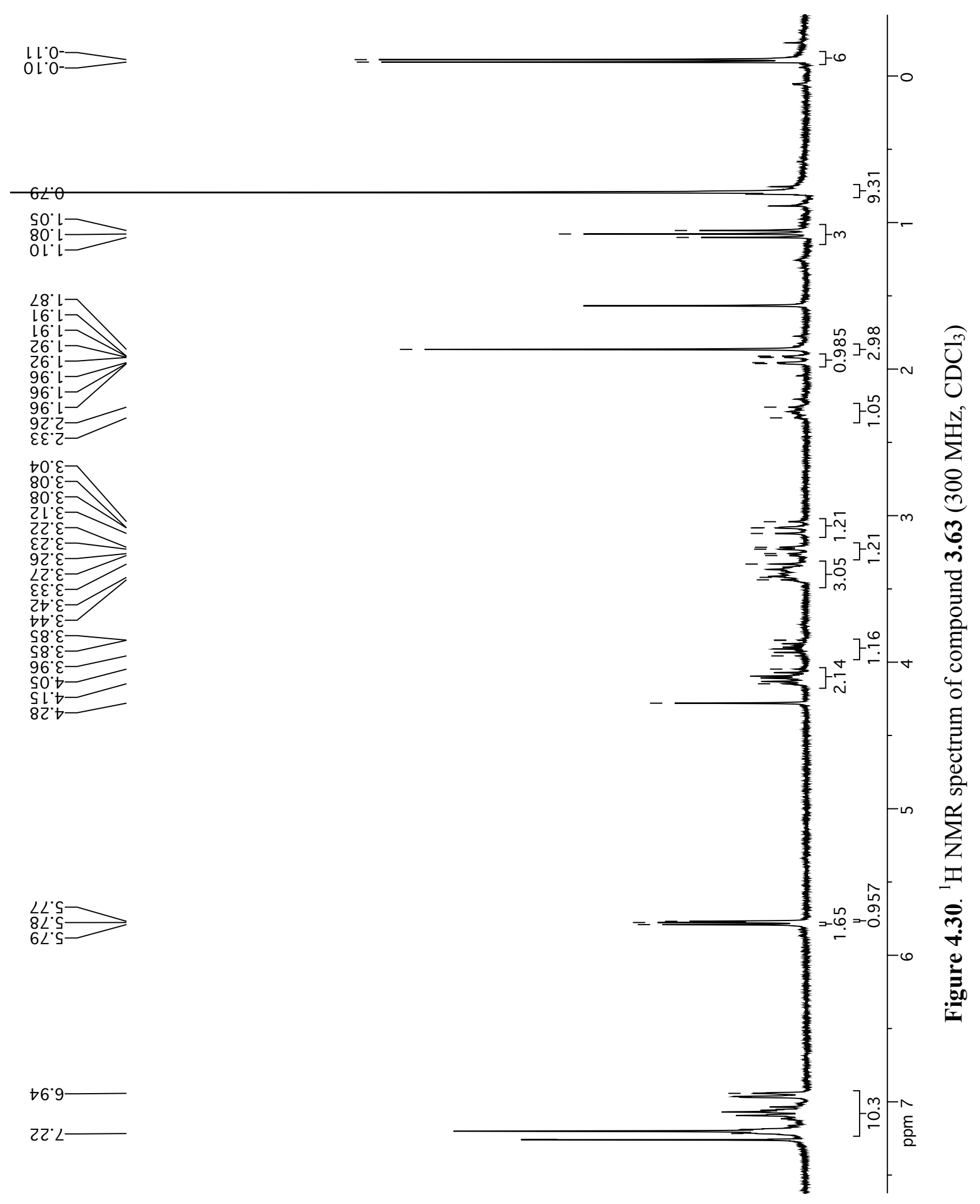




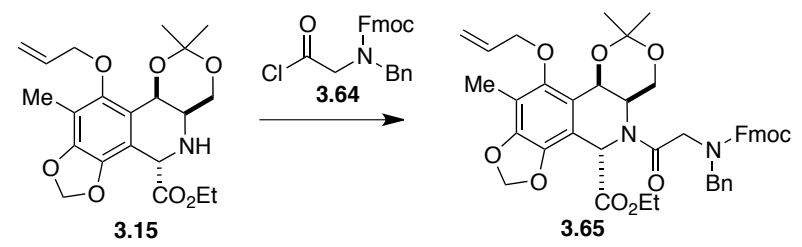

\section{$4.31 \quad(4 S, 5 \mathrm{a} R, 9 \mathrm{a} R)-\mathrm{ethyl} \mathrm{5-(2-((((9H-fluoren-9-}$}

yl)methoxy)carbonyl)(benzyl)amino)acetyl)-10-(allyloxy)-8,8,11-trimethyl-5,5a,6,9atetrahydro-4H-[1,3] dioxino[5,4-c][1,3] dioxolo[4,5-h]isoquinoline-4-carboxylate $(3.65)$

To a solution of $N$-Bn- $N$-Fmoc-Gly (347 mg, $0.900 \mathrm{mmol}, 1.2 \mathrm{eq})$ in $\mathrm{CH}_{2} \mathrm{Cl}_{2}(8 \mathrm{~mL})$ was added oxalyl chloride $(2.0 \mathrm{~mL}, \sim 30 \mathrm{eq})$ at RT under Ar, to which was added dry DMF (6 $\mu \mathrm{L})$ dropwise. After stirring for $1 \mathrm{~h}$, the solution was concentrated, and then concentrated from dry toluene and dried under vacuum. The acid chloride was dissolved in $\mathrm{CH}_{2} \mathrm{Cl}_{2}(5 \mathrm{~mL})$ and cooled to $0^{\circ} \mathrm{C}$. To this was added a solution compound 3.15 (303 $\mathrm{mg}, 0.748 \mathrm{mmol})$ and 2,6-lutidine (95 $\mu \mathrm{L}, 1.1 \mathrm{eq})$ in $\mathrm{CH}_{2} \mathrm{Cl}_{2}(5 \mathrm{~mL})$ dropwise. The reaction was stirred $20 \mathrm{~h}$, and then quenched with aq. $\mathrm{NH}_{4} \mathrm{Cl}$ (25 mL). The aqueous phase was extracted with $\mathrm{CH}_{2} \mathrm{Cl}_{2}(4 \times 25 \mathrm{~mL})$. The organic phase was dried $\left(\mathrm{Na}_{2} \mathrm{SO}_{4}\right)$, filtered and concentrated. Flash chromatography (3:1 hexanes:EtOAc) provided the title compound (507 mg, 64\%). $\mathrm{R}_{\mathrm{f}}=0.30$ (2:1 hexanes:EtOAc) ${ }^{1} \mathrm{H}-\mathrm{NMR}\left(300 \mathrm{MHz} ; \mathrm{CDCl}_{3}\right)$ : mixture of rotamers $\delta$ 7.72-7.13 $(\mathrm{m}, 12 \mathrm{H}), 6.04-6.01(\mathrm{~m}, 1 \mathrm{H}), 6.01-5.82(\mathrm{~m}, 4 \mathrm{H}), 5.38-5.22(\mathrm{~m}$, 3H), 5.10-5.08 (m, 1H), 4.66-4.02 (m, 9H), 3.70-3.66 (m, 2H), $2.13(\mathrm{~s}, 3 \mathrm{H}), 1.57(\mathrm{~s}, 6 \mathrm{H}), 1.21(\mathrm{t}$, $J=7.7 \mathrm{~Hz}, 3 \mathrm{H}), 1.10(\mathrm{t}, J=6.8 \mathrm{~Hz}, 3 \mathrm{H})$. 


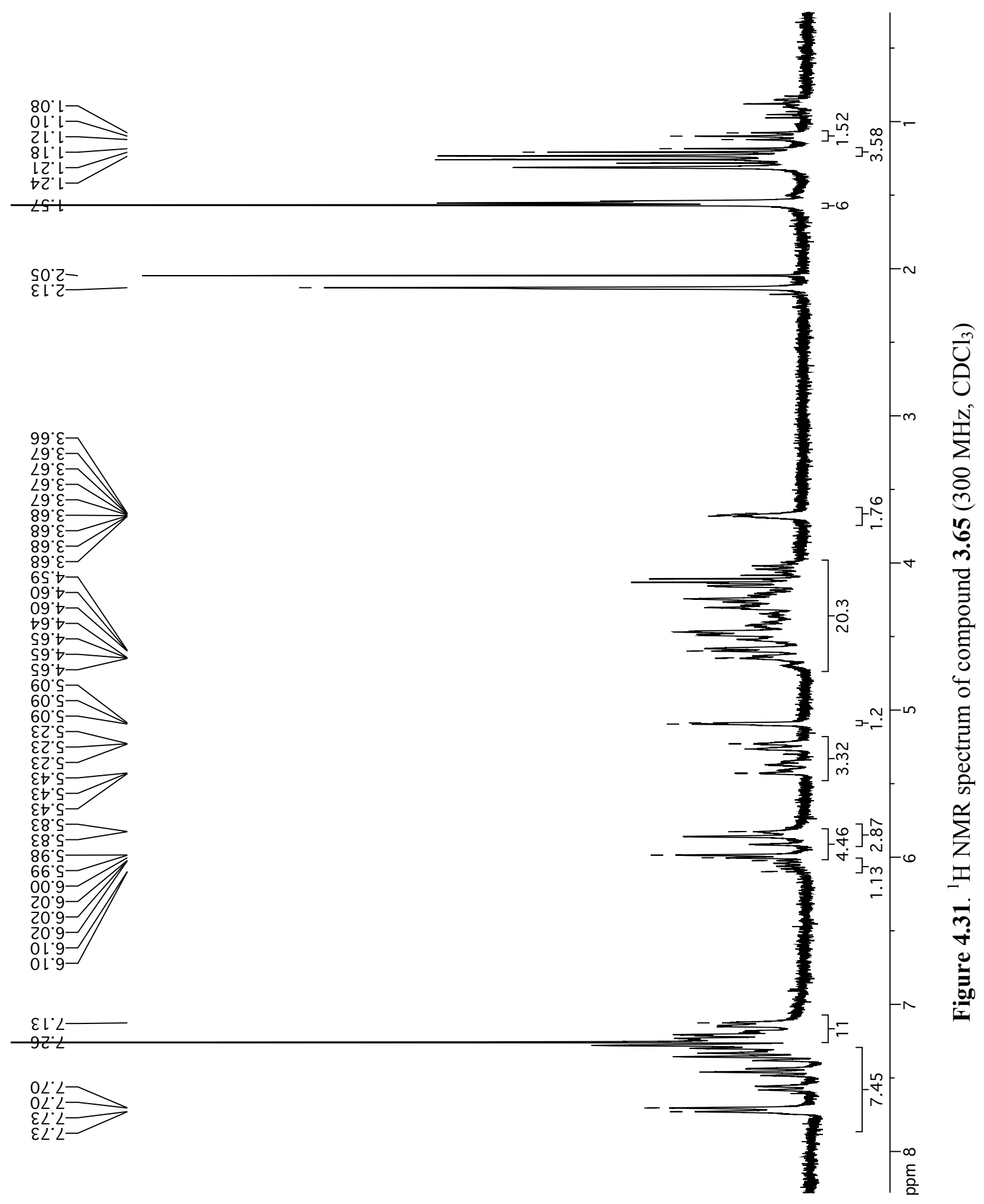




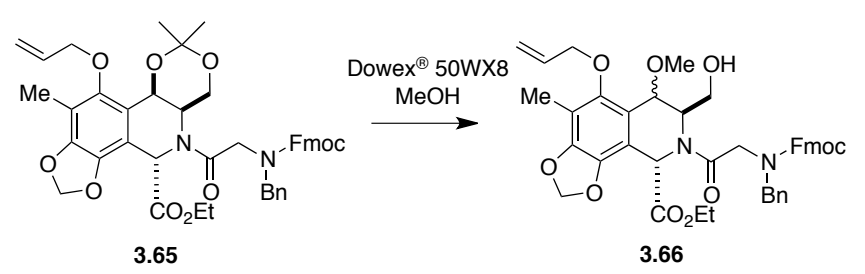

\subsection{2 (7R,9S)-ethyl 8-(2-((((9H-fluoren-9-yl)methoxy)carbonyl)(benzyl)amino)acetyl)-5-} (allyloxy)-7-(hydroxymethyl)-6-methoxy-4-methyl-6,7,8,9-tetrahydro-[1,3]dioxolo[4,5h]isoquinoline-9-carboxylate (3.66)

Compound 3.65 (50 mg, $0.65 \mathrm{mmol}$ ) was dissolved in dry $\mathrm{MeOH}(2.5 \mathrm{~mL})$, and Dowex ${ }^{\circledR}$ 50WX8 cationic resin $(50 \mathrm{mg})$ was added (the resin was rinsed with dry $\mathrm{MeOH}$ and dried under a steam of Ar). The reaction was stirred under Ar for $72 \mathrm{~h}$, filtered through a pad of Celite ${ }^{\circledR}$ using $\mathrm{MeOH}$ and $\mathrm{CH}_{2} \mathrm{Cl}_{2}$ to transfer the material. The filtrate was evaporated and the residue was purified with flash chromatography (1:1 hexanes:EtOAc) to give the title compound (35 $\mathrm{mg}$ $72 \%) . \mathrm{R}_{\mathrm{f}}=0.15\left(1: 1\right.$ hexanes:EtOAc). ${ }^{1} \mathrm{H}-\mathrm{NMR}\left(300 \mathrm{MHz} ; \mathrm{CDCl}_{3}\right)$ : mixture of rotamers $\delta 7.75-$ $7.73(\mathrm{~m}, 2 \mathrm{H}), 7.60-7.11(\mathrm{~m}, 11 \mathrm{H}), 6.16-5.77(\mathrm{~m}, 4 \mathrm{H}), 5.50-5.18(\mathrm{~m}, 3 \mathrm{H})$, 5.06-4.64 (m, 3H), 3.10 (s, 3H), $1.19(\mathrm{t}, 3 \mathrm{H}, 7.2 \mathrm{~Hz}), 1.13-1.08(\mathrm{t}, 3 \mathrm{H}, 7.2 \mathrm{~Hz})$. 
$0 L^{\circ} L-$
$92 \cdot L-$
S0'2-
$6 L^{\circ} 2-$

$60^{\circ} \varepsilon-$

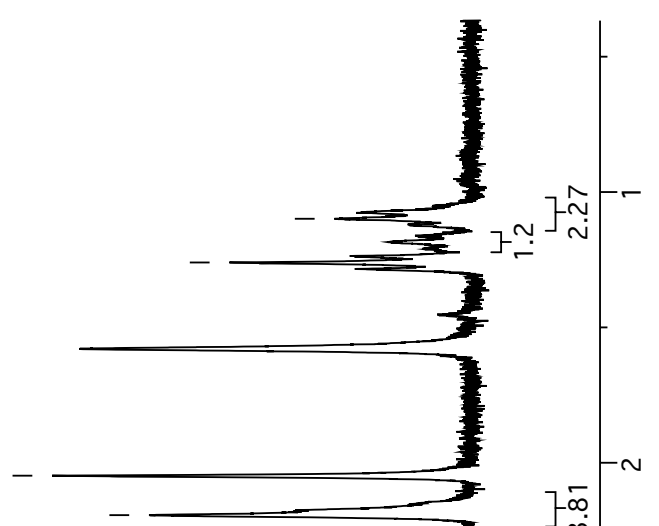

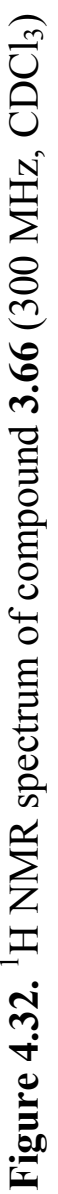

$9 Z^{\circ} L-$

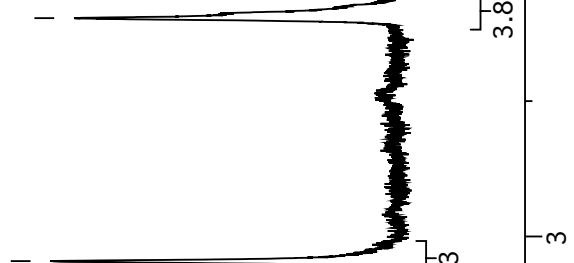




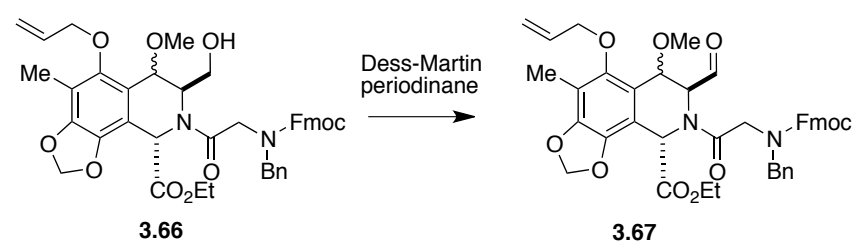

\subsection{3 (7S,9S)-ethyl 8-(2-(((9H-fluoren-9-yl)methoxy)carbonyl)(benzyl)amino)acetyl)-5-} (allyloxy)-7-formyl-6-methoxy-4-methyl-6,7,8,9-tetrahydro-[1,3]dioxolo[4,5- $h]$ isoquinoline-

\section{9-carboxylate (3.67)}

To suspension of compound $\mathbf{3 . 6 6}(90 \mathrm{mg}, 0.12 \mathrm{mmol})$ and $\mathrm{NaHCO}_{3}(141 \mathrm{mg}, 1.68 \mathrm{mmol}, 14$ eq.) in $\mathrm{CH}_{2} \mathrm{Cl}_{2}(9 \mathrm{~mL})$, was added Dess-Martin periodinane (77 mg, $0.18 \mathrm{mmol}, 1.5$ eq.). The mixture was stirred at RT for $2 \mathrm{~h}$ and the reaction was quenched with sat. aq. $\mathrm{NaHCO}_{3}$, the aqueous phase was extracted with $\mathrm{CH}_{2} \mathrm{Cl}_{2}$, and the organic phase was rinsed with brine, dried $\left(\mathrm{Na}_{2} \mathrm{SO}_{4}\right)$, filtered and concentrated. The resulting oil was purified with flash chromatography (4:1 hexanes:EtOAc) to give the title compound $(60 \mathrm{mg}, 72 \%) ; \mathrm{R}_{\mathrm{f}}=0.15\left(1: 1\right.$ Hexanes:EtOAc); ${ }^{1} \mathrm{H}-\mathrm{NMR}(300 \mathrm{MHz}$; $\left.\mathrm{CDCl}_{3}\right): \quad \delta 9.01(\mathrm{~s}, 1 \mathrm{H}), 8.96-8.93(\mathrm{~m}),, 7.80-7.67(\mathrm{~m}, 3 \mathrm{H}), 7.55-7.29(\mathrm{~m}, 8 \mathrm{H})$, 7.22-7.08 (m, $3 \mathrm{H}), 6.11-5.86(\mathrm{~m}, 4 \mathrm{H}), 5.65-5.57(\mathrm{~m}, 1 \mathrm{H}), 5.52-5.22(\mathrm{~m}, 4 \mathrm{H}), 5.10-4.83(\mathrm{~m}, 4 \mathrm{H}), 3.07(\mathrm{~s}, 3 \mathrm{H})$, $2.15(\mathrm{~s}, 3 \mathrm{H}), 1.11(\mathrm{t}, J=9.2 \mathrm{~Hz}, 3 \mathrm{H})$. 


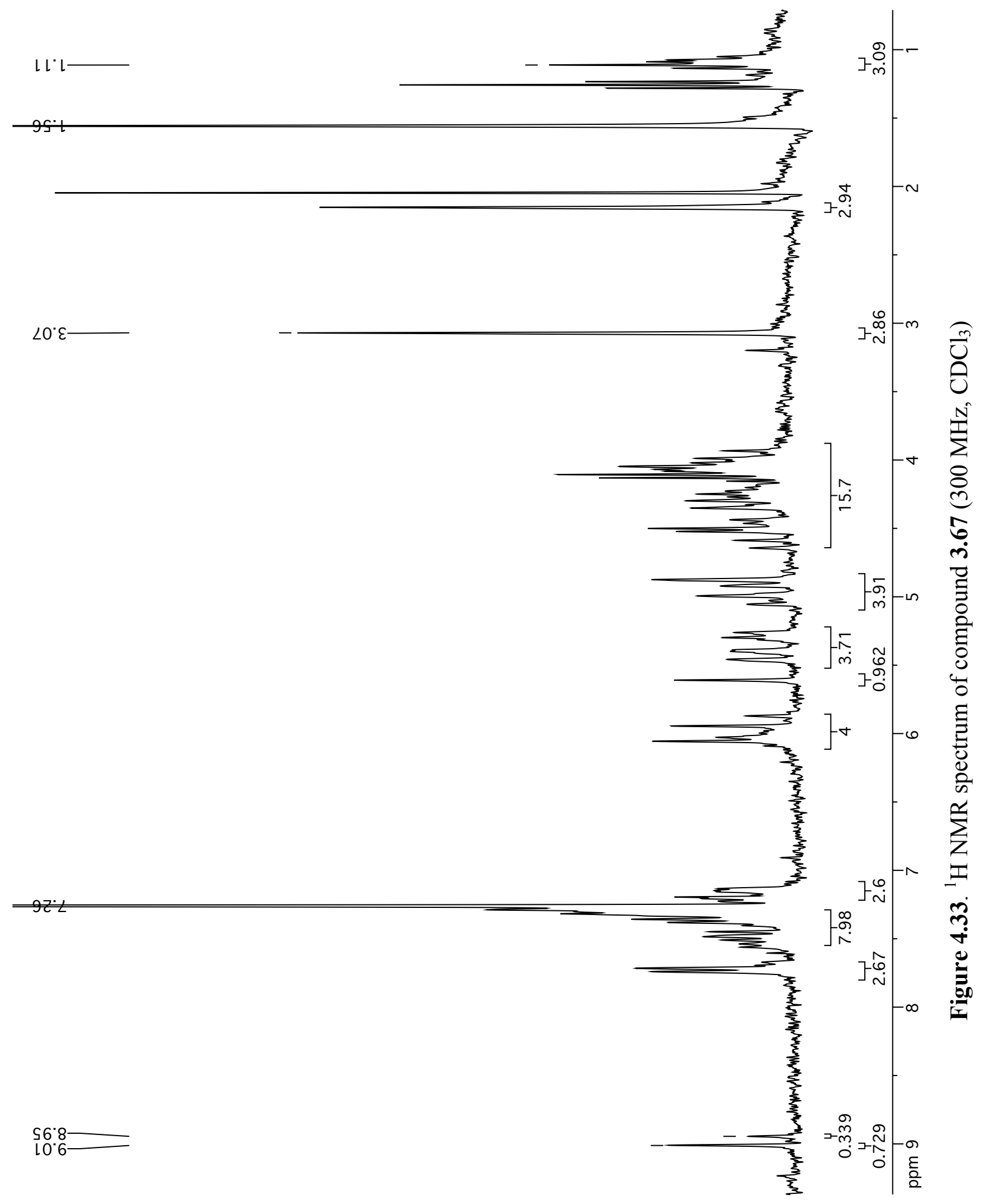




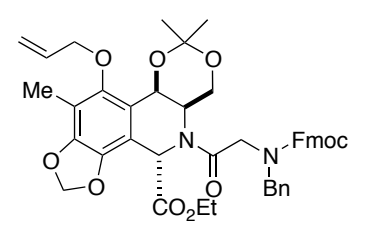

3.65

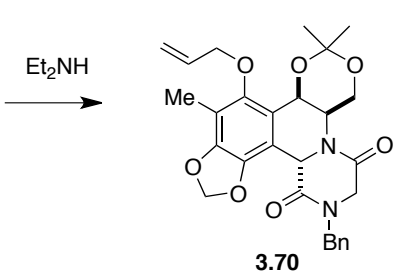

\subsection{4 (4aR,9cS,14aR)-5-(allyloxy)-11-benzyl-3,3,6-trimethyl-1,11,12,14a-tetrahydro-}

$[1,3]$ dioxino $[5,4-c][1,3]$ dioxolo $[4,5-h]$ pyrazino $[2,1-a]$ isoquinoline-10,13(4a $H, 9 \mathrm{cH})$-dione

A solution of compound $\mathbf{3 . 6 5}$ (in $10 \mathrm{mg} 0.13 \mathrm{mmol})$ in $\mathrm{CH}_{2} \mathrm{Cl}_{2}(1 \mathrm{~mL})$ and $\mathrm{Et}_{2} \mathrm{NH}(1 \mathrm{~mL})$ was stirred under Ar for $1 \mathrm{~h}$. The reaction was concentrated and the residue was purified by flash chromatography (3:1 hexanes:EtOAc) to give the title compound as a yellow solid (6 mg, 92\%). $\mathrm{R}_{\mathrm{f}}=0.50$ (2:1 hexanes:EtOAc); ${ }^{1} \mathrm{H}-\mathrm{NMR}\left(300 \mathrm{MHz} ; \mathrm{CDCl}_{3}\right): \delta$ 7.40-7.31 (m, 5H), 6.12-6.03 (m, 1H), 6.01-6.00 (m, 1H), $5.92(\mathrm{~s}, 1 \mathrm{H}), 5.83(\mathrm{~d}, J=1.4 \mathrm{~Hz}, 1 \mathrm{H}), 5.54-5.53(\mathrm{~m}, 1 \mathrm{H}), 5.41(\mathrm{dq}, J$ $=17.1,1.5 \mathrm{~Hz}, 1 \mathrm{H}), 5.31-5.26(\mathrm{~m}, 1 \mathrm{H}), 5.06(\mathrm{~d}, J=14.4 \mathrm{~Hz}, 1 \mathrm{H}), 4.37(\mathrm{~d}, J=14.4 \mathrm{~Hz}, 2 \mathrm{H})$, 4.33-4.22 (m, 2H), 4.20-4.11 (m, 2H), 4.06-3.98 (m, 2H), 3.90-3.75 (m, 3H), 2.13 (s, 3H), 1.57 $(\mathrm{s}, 3 \mathrm{H}), 1.43(\mathrm{~s}, 3 \mathrm{H})$. 


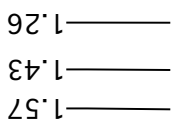

$\varepsilon l \cdot Z$
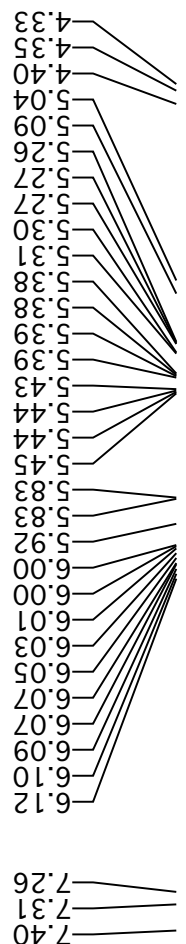

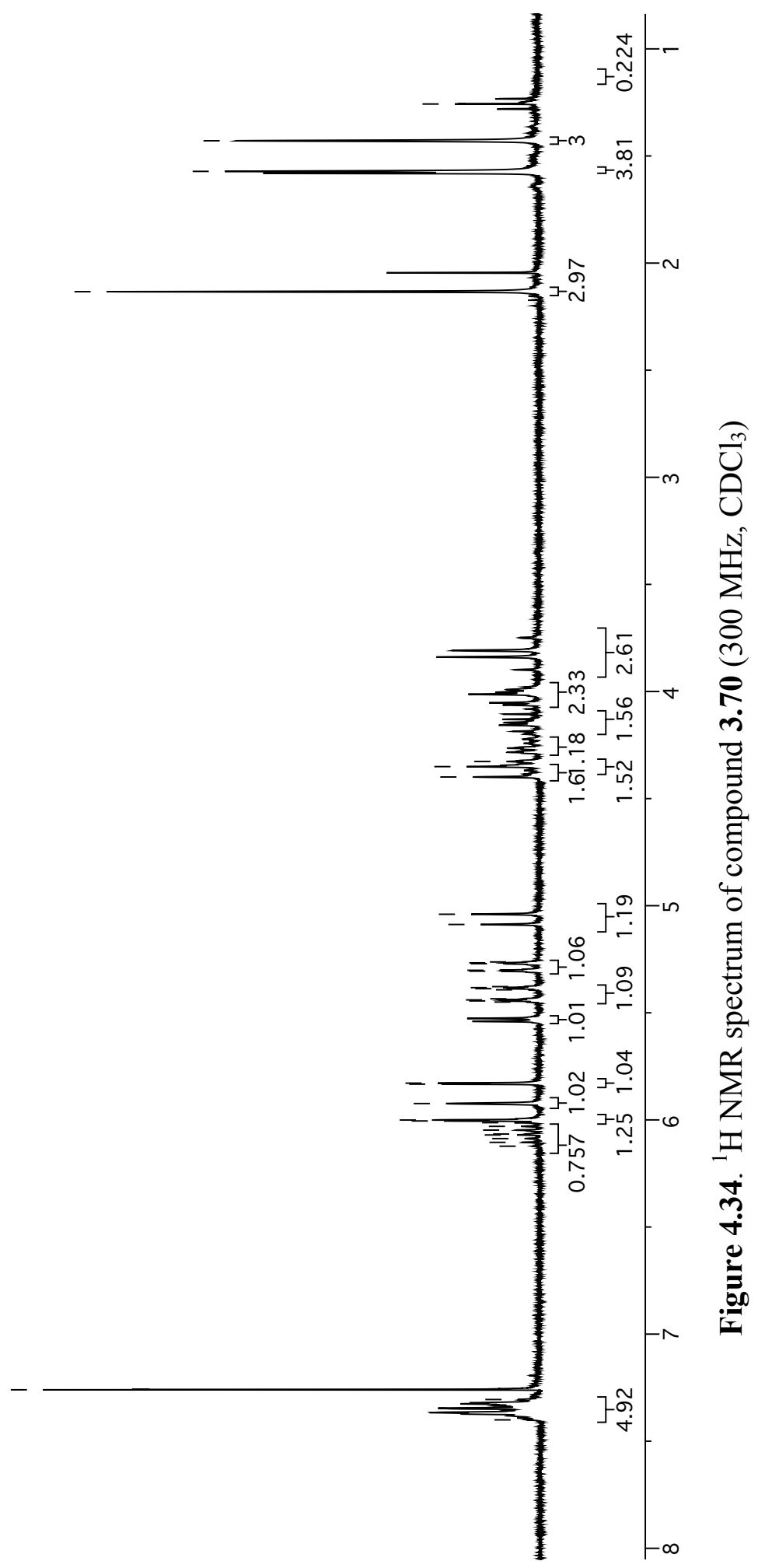




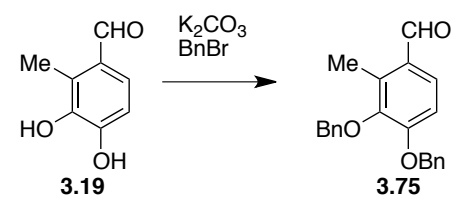

\subsection{3,4-bis(benzyloxy)-2-methylbenzaldehyde (3.75)}

To a solution of 3,4-dihydroxy-2-methylbenzaldehyde (3.19) (1.25 g, 8.26 mmol, 1 eq.) in DMF (14 mL) was added $\mathrm{K}_{2} \mathrm{CO}_{3}$ (2.28 g, $16.5 \mathrm{mmol}, 2$ eq.) and $\mathrm{BnBr}$ (2.5 mL, 2. mmol, 1 eq.). The mixture was stirred under argon for $48 \mathrm{~h}$, filtered, concentrated under reduced pressure, and purified by flash chromatography (4:1 hexanes/EtOAc) to afford $(1.80 \mathrm{~g}, 66 \%)$ of the title compound as a white solid. $\mathrm{R}_{\mathrm{f}}=0.40\left(4: 1\right.$ hexanes/EtOAc); ${ }^{1} \mathrm{H}-\mathrm{NMR}\left(300 \mathrm{MHz} ; \mathrm{CDCl}_{3}\right): \delta$ $10.10(\mathrm{~s}, 1 \mathrm{H}), 7.58(\mathrm{~d}, J=8.5 \mathrm{~Hz}, 1 \mathrm{H}), 7.48-7.31(\mathrm{~m}, 10 \mathrm{H}), 6.99-6.97(\mathrm{~d}, 1 \mathrm{H}, J=8.5 \mathrm{~Hz}, 1 \mathrm{H})$, $5.22(\mathrm{~s}, 2 \mathrm{H}), 4.96(\mathrm{~s}, 2 \mathrm{H}), 2.55(\mathrm{~s}, 3 \mathrm{H})$ 


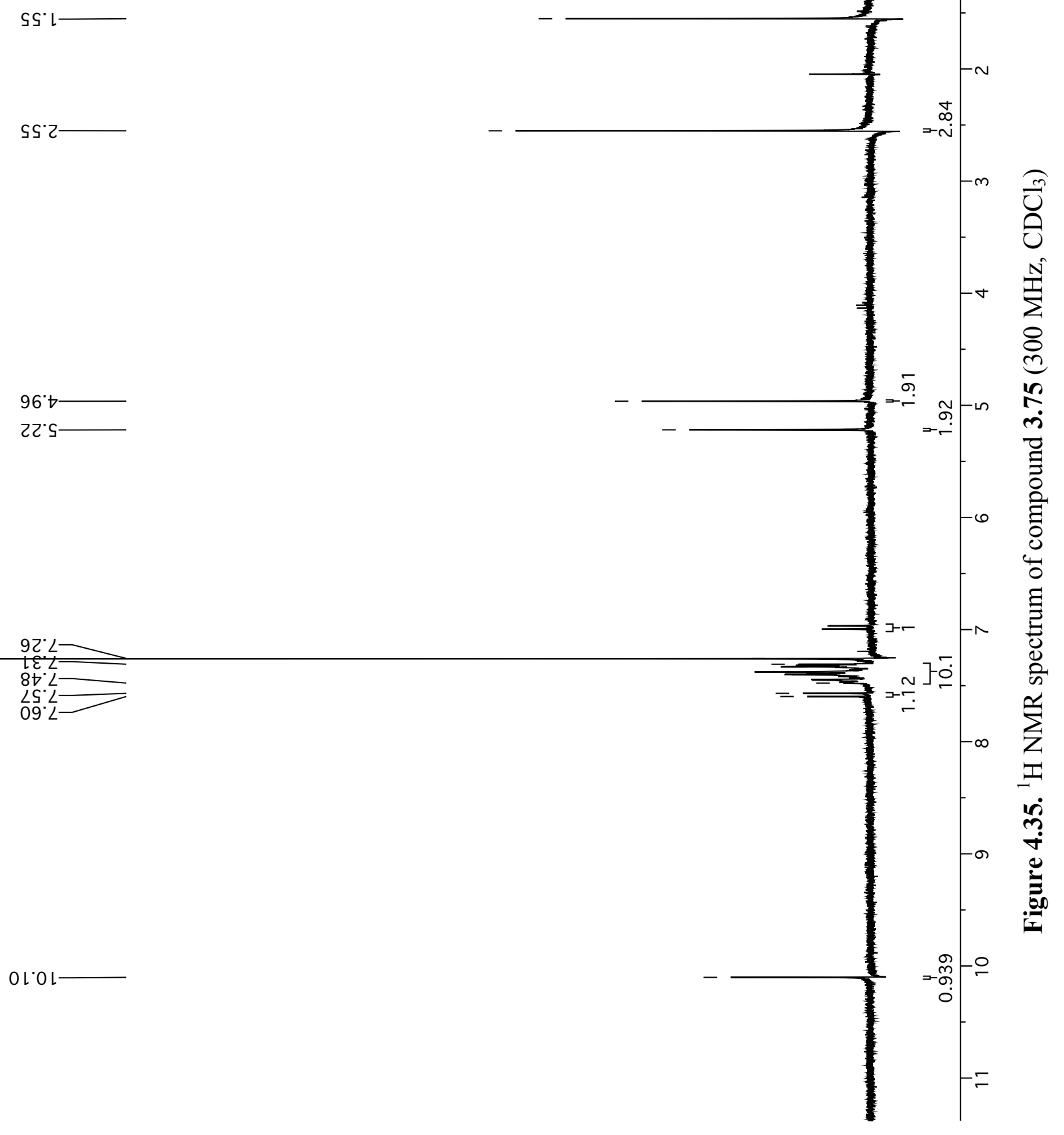




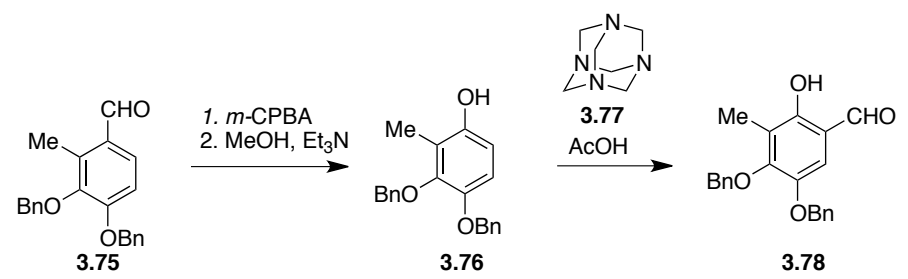

\subsection{4,5-bis(benzyloxy)-2-hydroxy-3-methylbenzaldehyde (3.78)}

To a stirred solution of 3,4-benzyloxy-2-methylbenzaldehyde (3.75) (3.50 g, 10.5 mmol, 1 eq.) in $\mathrm{CHCl}_{3}(105 \mathrm{~mL})$ was added $m$-CPBA $(3.62 \mathrm{~g}, 21.0 \mathrm{mmol}, 2.0$ eq.). The solution was stirred at RT for $12 \mathrm{~h}$. The resulting mixture was washed with $10 \% \mathrm{NaS}_{2} \mathrm{O}_{3}(2 \times 50 \mathrm{~mL}), \mathrm{NaHCO}_{3}(3 \times 50$ $\mathrm{mL})$ and brine $(2 \times 50 \mathrm{~mL})$, dried $\left(\mathrm{Na}_{2} \mathrm{SO}_{4}\right)$, filtered and concentrated under vacuum. To a solution of the resulting oil in $\mathrm{CH}_{2} \mathrm{Cl}_{2} / \mathrm{MeOH} 1: 1(105 \mathrm{~mL})$ was added triethylamine $(1.40 \mathrm{~mL}$, $10.1 \mathrm{mmol}, 1.25 \mathrm{eq})$ and the reaction was stirred under $\mathrm{Ar}$ for $4 \mathrm{~h}$, concentrated under vacuum to give 3,4-bis(benzyloxy)-2-methylphenol (3.76) as a brown solid (3.02 g, 90\%), which was used without further purification. ${ }^{1} \mathrm{H}-\mathrm{NMR}\left(300 \mathrm{MHz} ; \mathrm{CDCl}_{3}\right): \delta 7.46-7.30(\mathrm{~m}, 11 \mathrm{H}), 6.73(\mathrm{~d}, J=8.7$ $\mathrm{Hz}, 1 \mathrm{H}), 6.50(\mathrm{~d}, J=8.7 \mathrm{~Hz}, 1 \mathrm{H}), 5.06(\mathrm{~s}, 2 \mathrm{H}), 5.01(\mathrm{~s}, 2 \mathrm{H}), 2.12(\mathrm{~s}, 3 \mathrm{H})$.

A solution of 3,4-bis(benzyloxy)-2-methylphenol (3.76) $(0.92 \mathrm{~g}, 2.87 \mathrm{mmol})$ and hexamethylenetetramine $(2.40 \mathrm{~g}, 17.2 \mathrm{mmol}, 6 \mathrm{eq})$ in $\mathrm{AcOH}(30 \mathrm{~mL})$ was heated under reflux for 3h. The reaction was allowed to cool to RT, quenched with $\mathrm{H}_{2} \mathrm{O}(60 \mathrm{~mL})$, the aqueous phase was rinsed extracted with EtOAc $(3 \times 25 \mathrm{~mL})$ and the combined organic phases were rinsed with $\mathrm{H}_{2} \mathrm{O}$ (25 mL) brine $(25 \mathrm{~mL})$, dried $\left(\mathrm{Na}_{2} \mathrm{SO}_{4}\right)$, filtered, concentrated under vacuum and purified by flash chromatography (hexanes/EtOAc 6:1) to give 4,5-bis(benzyloxy)-2-hydroxy-3methylbenzaldehyde (3.78) as a light yellow solid $(0.50 \mathrm{~g}, 50 \%)$. $\mathrm{R}_{\mathrm{f}}=0.3$ (hexanes/EtOAc 6:1); ${ }^{1} \mathrm{H}-\mathrm{NMR}\left(300 \mathrm{MHz} ; \mathrm{CDCl}_{3}\right): \delta 11.29(\mathrm{~s}, 1 \mathrm{H}), 9.71(\mathrm{~s}, 1 \mathrm{H}), 7.46-7.32(\mathrm{~m}, 11 \mathrm{H}), 6.95(\mathrm{~s}, 1 \mathrm{H})$, $5.14(\mathrm{~s}, 2 \mathrm{H}), 5.10(\mathrm{~s}, 2 \mathrm{H}), 2.11(\mathrm{~s}, 3 \mathrm{H})$. 


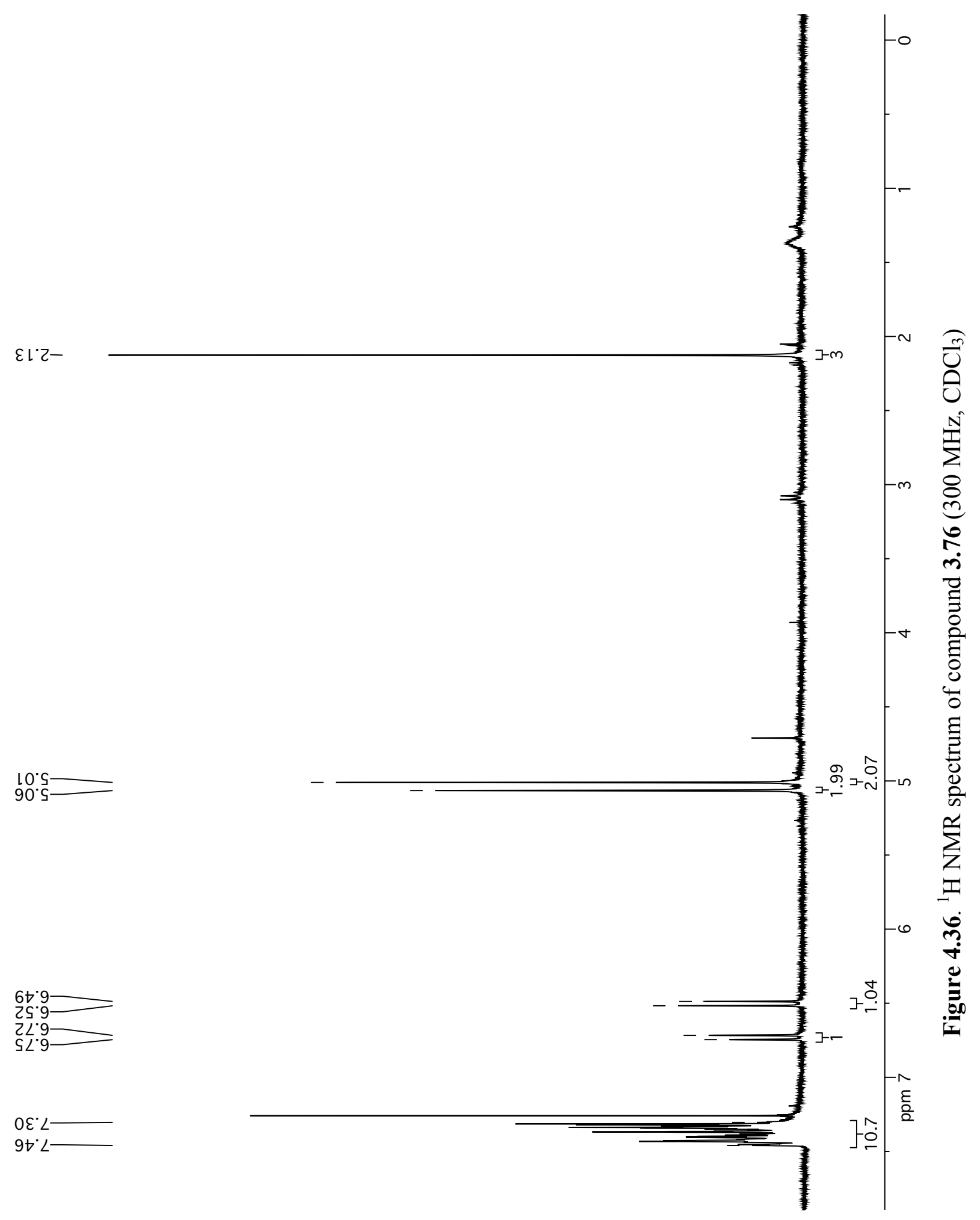




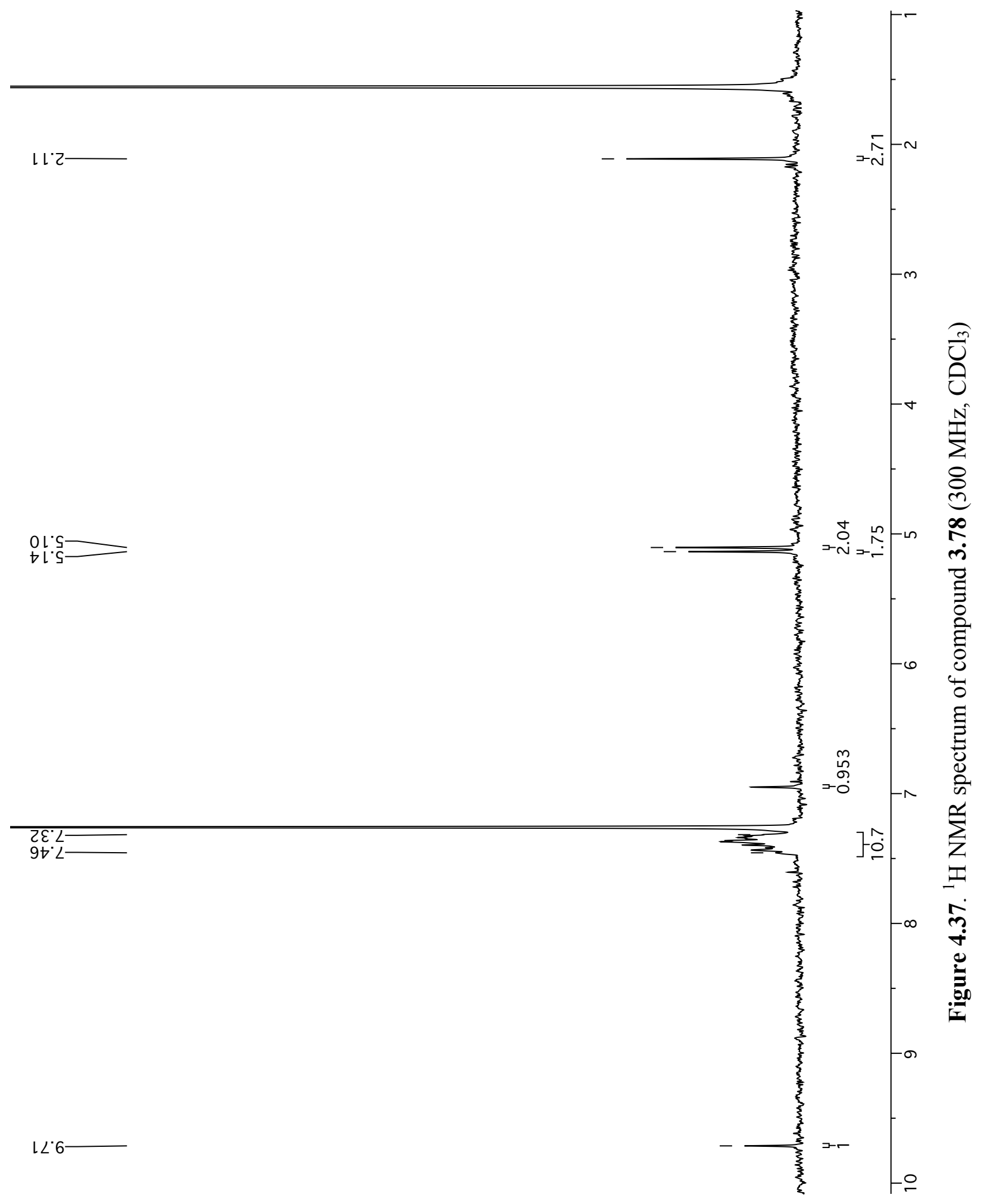




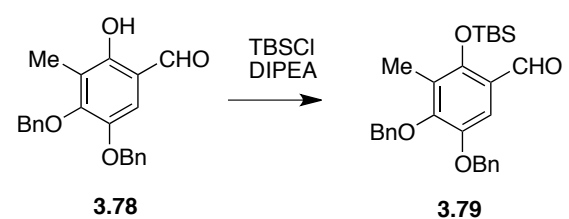

\subsection{4,5-bis(benzyloxy)-2-((tert-butyldimethylsilyl)oxy)-3-methylbenzaldehyde (3.79)}

To a solution of compound 3.78 (1.438 g, $4.13 \mathrm{mmol}, 1$ eq.) and TBS-Cl (1.247 g, $8.26 \mathrm{mmol}$, 2.0 eq.) in DMF $(16 \mathrm{~mL})$ was added DIPEA $(2.16 \mathrm{~mL}, 12.4 \mathrm{mmol}, 3.0$ eq). The reaction was stirred under $\mathrm{Ar}$ for $2 \mathrm{~h}$, quenched with $1 \mathrm{~N} \mathrm{HCl}(50 \mathrm{~mL})$ and the resulting aqueous phase was extracted with $\mathrm{CH}_{2} \mathrm{Cl}_{2}(3 \times 25 \mathrm{~mL})$. The combined organic phases were rinsed with brine $(25 \mathrm{~mL})$, dried $\left(\mathrm{Na}_{2} \mathrm{SO}_{4}\right)$, filtered, concentrated under vacuum and purified by flash chromatography (hexanes/EtOAc 9:1) to afford the title compound as a light yellow solid (1.75 g, 92\%). $R_{\mathrm{f}}=0.5$ (hexanes/EtOAc 6:1); ${ }^{1} \mathrm{H}-\mathrm{NMR}\left(300 \mathrm{MHz} ; \mathrm{CDCl}_{3}\right): \delta 10.20(\mathrm{~s}, 1 \mathrm{H}), 7.48-7.29(\mathrm{~m}, 10 \mathrm{H}), 5.12(\mathrm{~s}$, 2H), $5.11(\mathrm{~s}, 2 \mathrm{H}), 2.04(\mathrm{~s}, 3 \mathrm{H}), 1.04(\mathrm{~s}, 9 \mathrm{H}), 0.10(\mathrm{~s}, 6 \mathrm{H})$. 


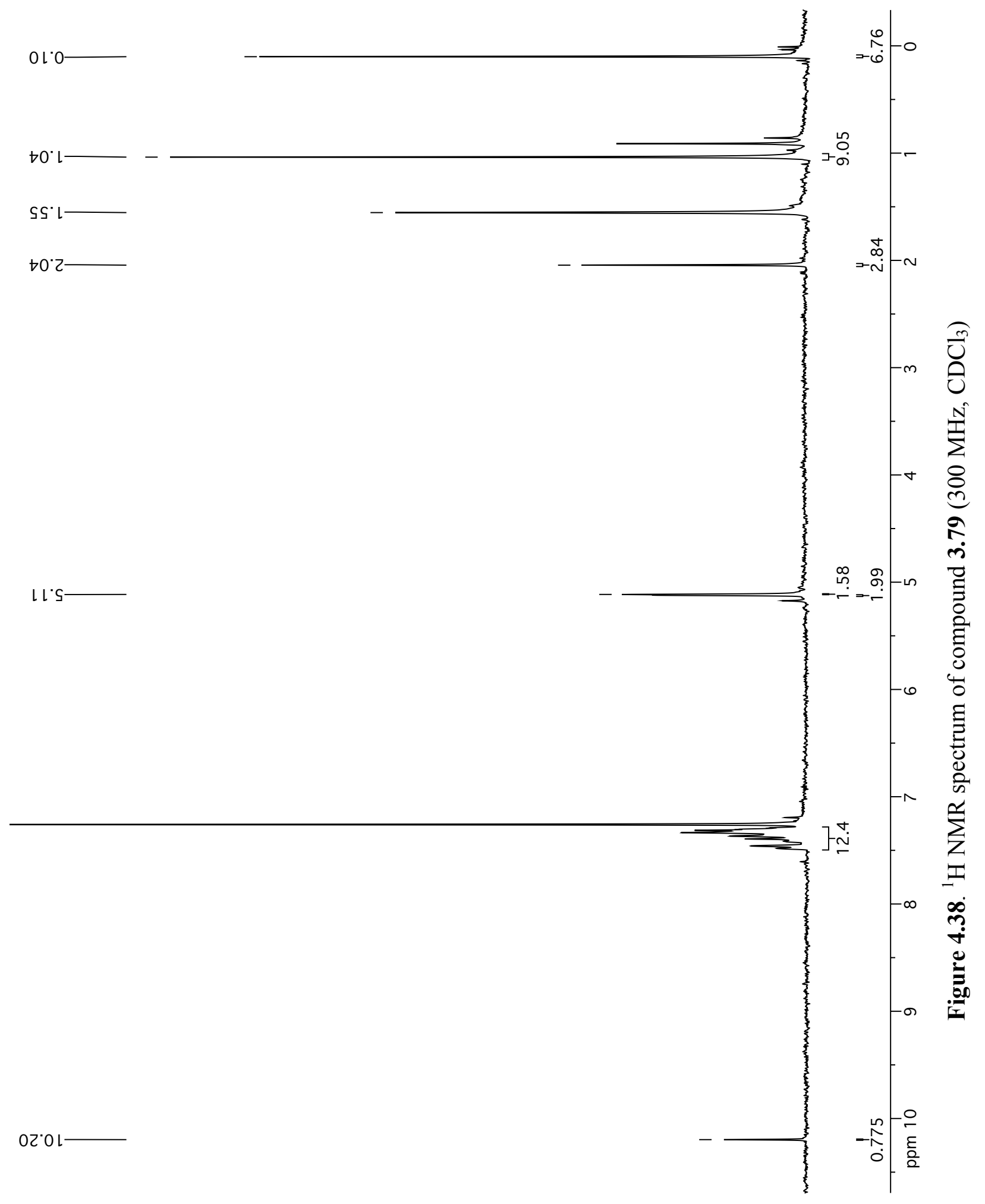




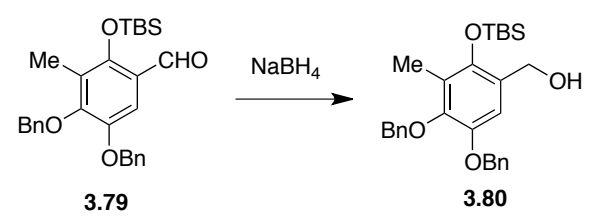

\subsection{8 (4,5-bis(benzyloxy)-2-((tert-butyldimethylsilyl)oxy)-3-methylphenyl)methanol (3.80)}

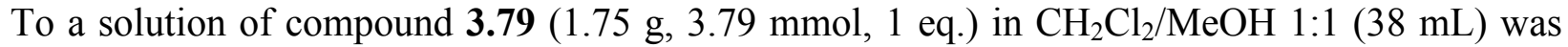
added $\mathrm{NaBH}_{4}(720 \mathrm{mg}, 19 \mathrm{mmol}, 5.0 \mathrm{eq})$. The reaction was stirred under Ar for $2 \mathrm{~h}$, quenched with sat. aq. $\mathrm{NH}_{4} \mathrm{Cl}(50 \mathrm{~mL})$ and the resulting aqueous phase was extracted with $\mathrm{CH}_{2} \mathrm{Cl}_{2}(3 \times 25$ $\mathrm{mL})$. The combined organic phases were rinsed with brine $(25 \mathrm{~mL})$, dried $\left(\mathrm{Na}_{2} \mathrm{SO}_{4}\right)$, filtered, concentrated under vacuum and purified by flash chromatography (hexanes/EtOAc, 9:1 to 6:1) to afford the title compound as a colorless oil $(625 \mathrm{mg}, 35 \%) . \mathrm{R}_{\mathrm{f}}=0.1$ (hexanes/EtOAc 6:1); ${ }^{1} \mathrm{H}-$ NMR (300 MHz; $\left.\mathrm{CDCl}_{3}\right): \delta$ 7.46-7.30 (m, 10H), $6.91(\mathrm{~s}, 1 \mathrm{H}), 5.10(\mathrm{~s}, 2 \mathrm{H}), 5.00(\mathrm{~s}, 2 \mathrm{H}), 4.62(\mathrm{~s}$, 2H), 2.07 (s, 3H), $1.02(\mathrm{~s}, 9 \mathrm{H}), 0.14(\mathrm{~s}, 6 \mathrm{H})$. 


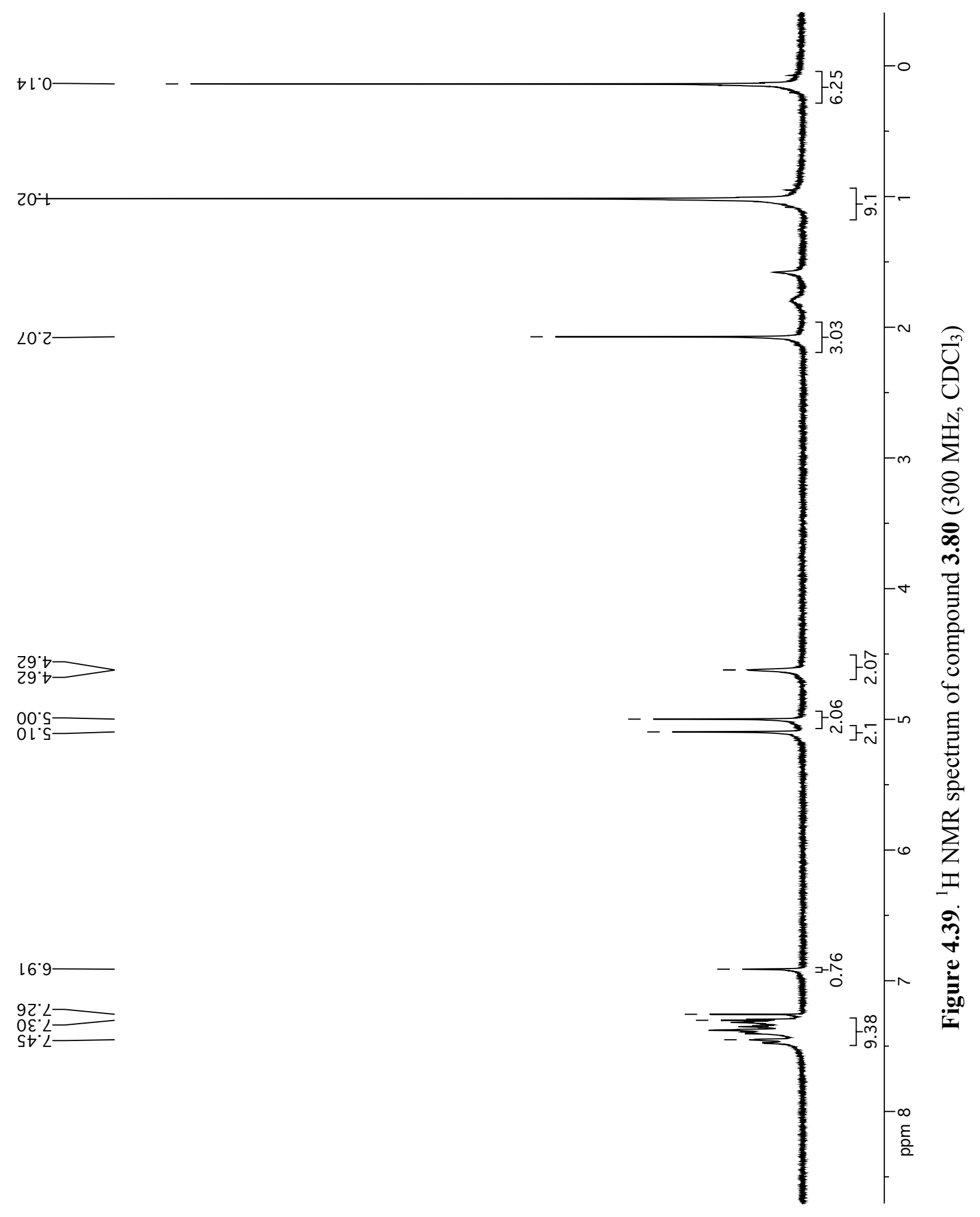




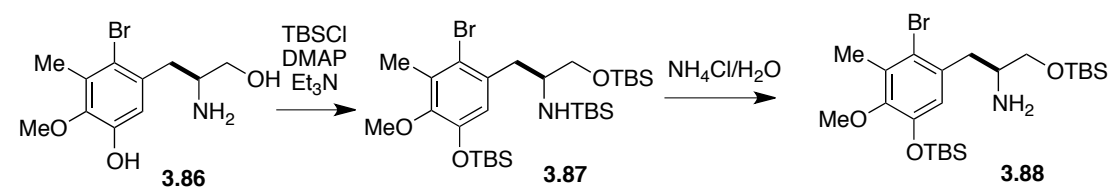

\subsection{9 (S)-1-(2-bromo-5-((tert-butyldimethylsilyl)oxy)-4-methoxy-3-methylphenyl)-3-((tert- butyldimethylsilyl)oxy)propan-2-amine (3.88)}

To a stirred solution of compound $\mathbf{3 . 8 6}$ (1.55 g, $5.36 \mathrm{mmol}, 1$ eq.) in $\mathrm{CH}_{2} \mathrm{Cl}_{2}(90 \mathrm{~mL}, 0.06 \mathrm{M})$, were added DMAP (327 mg, $2.68 \mathrm{mmol}, 0.5$ eq.), $\mathrm{Et}_{3} \mathrm{~N}$ (4.48 mL, $32.2 \mathrm{mmol}, 6.00$ eq.) and TBS-Cl (4.86 g, $32.2 \mathrm{mmol}, 6$ eq.). The reaction was stirred under Ar for $3 \mathrm{~h}$ at RT, and then sat. aq. $\mathrm{NH}_{4} \mathrm{Cl}(50 \mathrm{~mL})$ was added and the mixture was stirred for $2 \mathrm{~h}$. The phases were separated, the aqueous layer was extracted with $\mathrm{CH}_{2} \mathrm{Cl}_{2}(2 \times 50 \mathrm{~mL})$ and the combined organic layers were rinsed with brine $(50 \mathrm{~mL})$, dried $\left(\mathrm{Na}_{2} \mathrm{SO}_{4}\right)$, filtered, and concentrated under vacuum. The crude material was purified by flash chromatography (silica gel, hexane/EtOAc 5:1) to give the title compound $3.88(2.50 \mathrm{~g}, 90 \%)$ as a colorless oil. ${ }^{1} \mathrm{H}-\mathrm{NMR}\left(400 \mathrm{MHz} ; \mathrm{CDCl}_{3}\right): \delta 6.65(\mathrm{~s}, 1 \mathrm{H})$, $3.72(\mathrm{~s}, 3 \mathrm{H}), 3.61(1 / 2 \mathrm{ABX}, J=9.7,4.1 \mathrm{~Hz}, 1 \mathrm{H}), 3.47(1 / 2 \mathrm{ABX}, J=9.7,6.5 \mathrm{~Hz}, 1 \mathrm{H}), 3.20-$ $3.14(\mathrm{~m}, 1 \mathrm{H}), 2.87(1 / 2 \mathrm{ABX}, J=13.4,5.4 \mathrm{~Hz}, 1 \mathrm{H}), 2.57(1 / 2 \mathrm{ABX}, J=13.4,8.0 \mathrm{~Hz}, 1 \mathrm{H}), 2.35$ (s, 3H), 1.00 (s, 9H), 0.91 (s, 9H), 0.17 (s, 6H), 0.07 (s, 3H), 0.06 (s, 3H); ${ }^{13} \mathrm{C}-\mathrm{NMR}(101 \mathrm{MHz}$ $\left.\mathrm{CDCl}_{3}\right): \delta 148.8,147.6,134.6,133.1,121.3,119.4,67.6,60.2,52.9,41.3,26.1,25.8,18.4,18.4$, 17.2, -4.4, -5.2; $\mathrm{R}_{\mathrm{f}}\left(\mathrm{SiO}_{2}, 2: 1\right.$ hexanes/EtOAc) $0.35 ;[\alpha]_{\mathrm{D}}^{25}=+0.9^{\circ}\left(\mathrm{c}=0.35, \mathrm{CHCl}_{3}\right)$; IR (film, $\left.\mathrm{CH}_{2} \mathrm{Cl}_{2}\right), \quad v_{\max }$ 2996, 2930, 2858, 2471, $839 \mathrm{~cm}^{-1} ;$ HRMS $\left(\mathrm{MH}^{+}\right)$, found 520.2103. $\mathrm{C}_{23} \mathrm{H}_{45} \mathrm{BrNO}_{3} \mathrm{Si}_{2}$ requires 520.2101. 


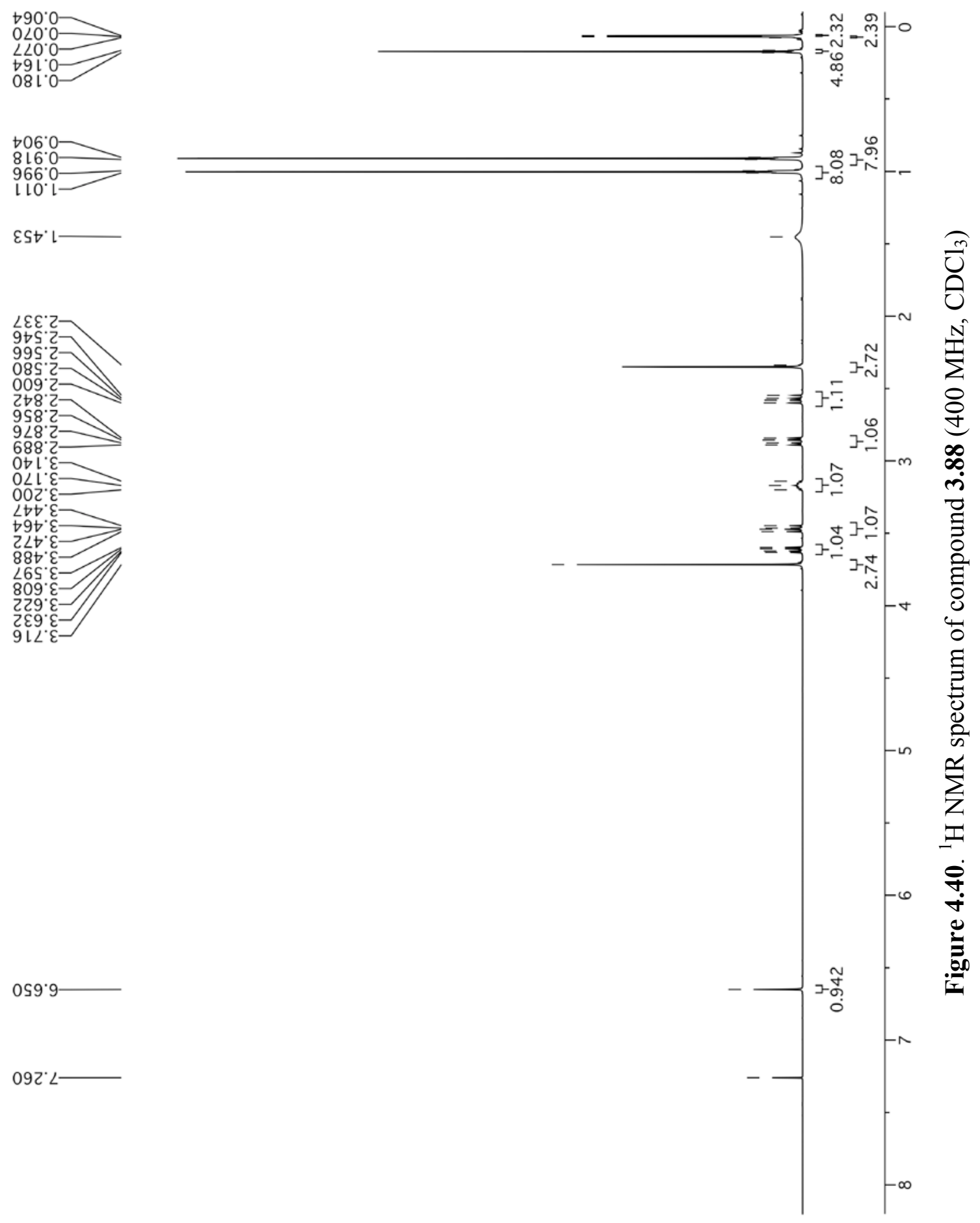



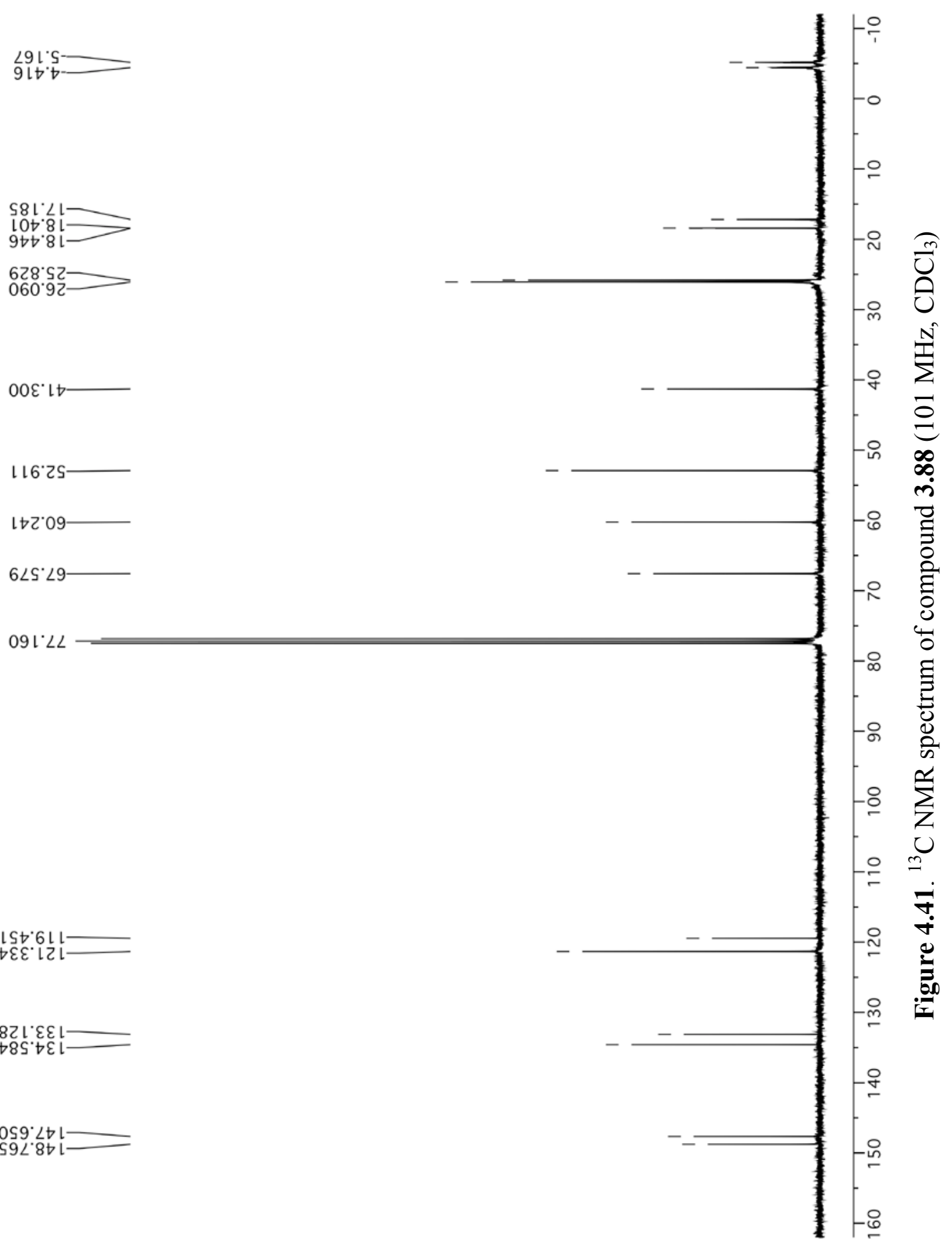


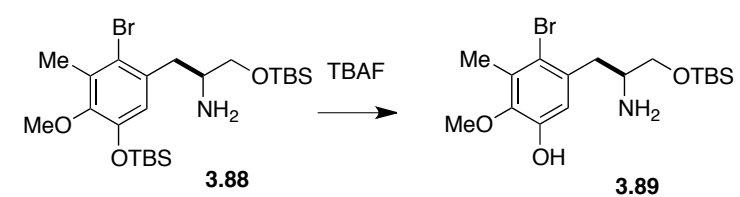

\subsection{0 (S)-5-(2-amino-3-((tert-butyldimethylsilyl)oxy)propyl)-4-bromo-2-methoxy-3- methylphenol (3.89)}

To a stirred solution of compound 3.88 (1.59 g, $3.05 \mathrm{mmol}, 1$ eq.) in THF (100 mL, $0.03 \mathrm{M})$, under $\mathrm{Ar}$, at $0{ }^{\circ} \mathrm{C}$, was added a 1.0 solution $\mathrm{M}$ of TBAF in THF ( $3.05 \mathrm{~mL}, 3.05 \mathrm{mmol}$,, 1 eq.). The reaction was stirred for 25 minutes and quenched with sat. aq. $\mathrm{NH}_{4} \mathrm{Cl}(50 \mathrm{~mL})$. The phases were allowed to warm to RT, the aqueous phase was extracted with EtOAc $(2 \times 50 \mathrm{~mL})$ and the combined organic layers were rinsed with brine $(50 \mathrm{~mL})$, dried $\left(\mathrm{Na}_{2} \mathrm{SO}_{4}\right)$, filtered, and concentrated under vacuum. The crude material was purified by flash chromatography (silica gel, $\mathrm{CHCl}_{3} / \mathrm{MeOH}$ 10:1) to give the title compound 3.89 (1.23 g, 98\%) as a colorless oil. ${ }^{1} \mathrm{H}-\mathrm{NMR}$ (400 MHz; $\left.\mathrm{CDCl}_{3}\right): \delta 6.77(\mathrm{~s}, 1 \mathrm{H}), 3.73(\mathrm{~s}, 3 \mathrm{H}), 3.71-3.66(\mathrm{~m}, 1 \mathrm{H}), 3.56-3.50(\mathrm{~m}, 1 \mathrm{H}), 3.27-3.24$ (m, 1H), $2.92(1 / 2 \mathrm{ABX}, J=13.5,4.6 \mathrm{~Hz}, 1 \mathrm{H}), 2.62(1 / 2 \mathrm{ABX}, J=13.5,9.0 \mathrm{~Hz}, 1 \mathrm{H}), 2.34(\mathrm{~s}$, 3H), 0.92 (s, 9H), 0.09 (s, 3H), 0.08 (s, 3H); ${ }^{13} \mathrm{C}-\mathrm{NMR}\left(101 \mathrm{MHz}, \mathrm{CDCl}_{3}\right): \delta$ 148.4, 145.0, 134.6, $132.2,117.2,116.1,67.1,60.8,52.9,52.7,40.5,26.1,18.4,17.2,-5.2,-5.2 . \mathrm{R}_{\mathrm{f}}\left(\mathrm{SiO}_{2}\right.$ $\mathrm{CH}_{2} \mathrm{Cl}_{2} / \mathrm{MeOH}$ 10:1) 0.4; $[\alpha]_{\mathrm{D}}^{25}=+8.3^{\circ}\left(\mathrm{c}=0.41, \mathrm{CHCl}_{3}\right) ;$ IR (film, $\left.\mathrm{CH}_{2} \mathrm{Cl}_{2}\right), v_{\max } 3263$ (br), 2954, 2928, 2856, 1578, 1471, $1092 \mathrm{~cm}^{-1}$; HRMS $\left(\mathrm{MH}^{+}\right)$, found 406.1233. $\mathrm{C}_{17} \mathrm{H}_{31} \mathrm{BrNO}_{3} \mathrm{Si}$ requires 406.1236 


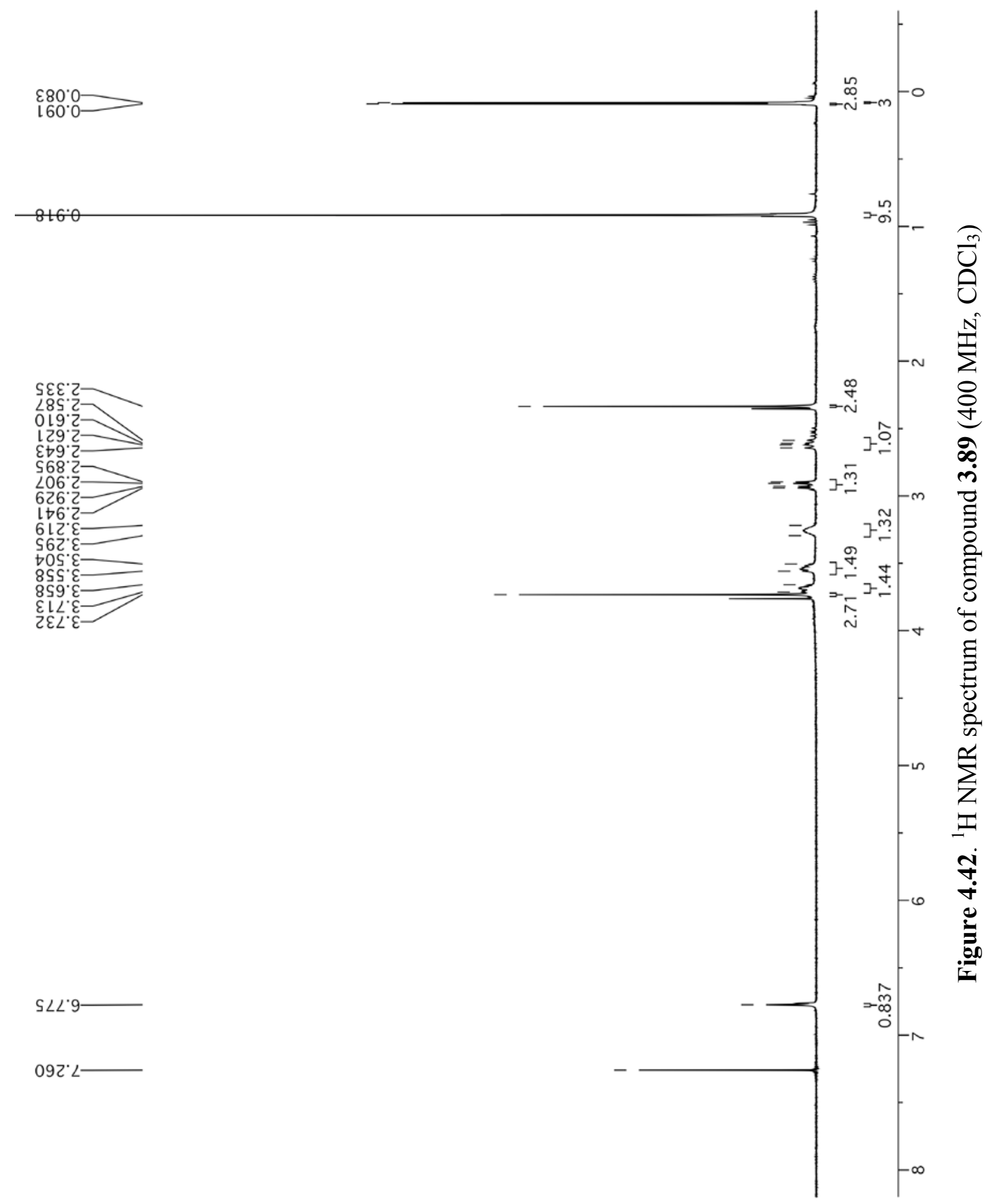




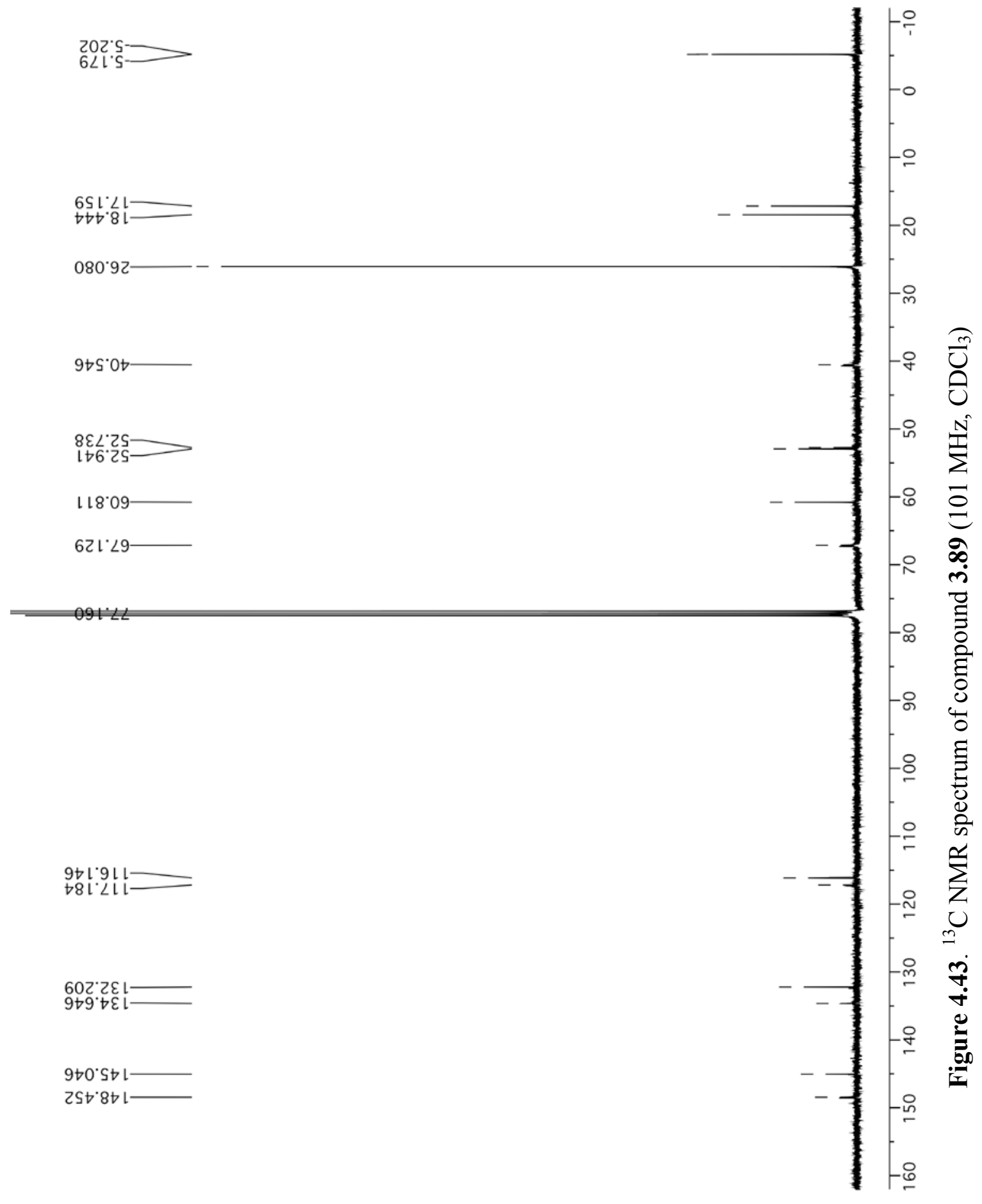




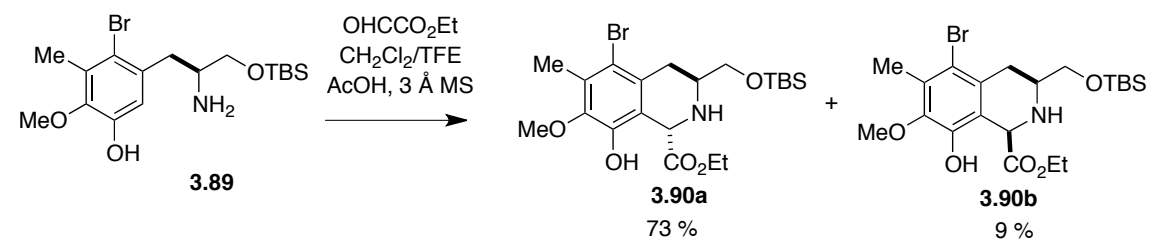

4.42 (1S,3S)-ethyl 5-bromo-3-((tert-butyldimethylsilyl)oxy)-methyl)-8-hydroxy-7methoxy-6-methyl-1,2,3,4-tetrahydro-isoquinoline-1-carboxylate (3.90a) and (1R,3S)-ethyl 5-bromo-3-(((tert-butyldimethylsilyl)oxy)methyl)-8-hydroxy-7-methoxy-6-methyl-1,2,3,4tetrahydroisoquinoline-1-carboxylate (3.90b)

To a stirred solution of compound 3.89 (5.43 g, 13.4 mmol, 1.0 eq.) in $\mathrm{CH}_{2} \mathrm{Cl}_{2}(134 \mathrm{~mL}, 0.10 \mathrm{M})$, under Ar, were added, $4 \AA$ molecular sieves $(2.72 \mathrm{~g}), \mathrm{CF}_{3} \mathrm{CH}_{2} \mathrm{OH}(13.4 \mathrm{~mL}), \mathrm{AcOH}(153 \mu \mathrm{L}$, $2.68 \mathrm{mmol}, 0.20$ eq.) and ethyl glyoxalate (50\% solution in $\mathrm{PhCH}_{3}, 2.93 \mathrm{~mL}, 14.8 \mathrm{mmol}, 1.1$ eq.). The reaction was stirred overnight, diluted with $\mathrm{CH}_{2} \mathrm{Cl}_{2}(50 \mathrm{~mL})$, filtered through Celite ${ }^{\circledR}$ and concentrated under vacuum. The crude material was purified by flash chromatography (silica gel, hexanes/EtOAc 5:1) to give compound 3.90a $(4.78 \mathrm{~g}, 73 \%)$ as a white solid and compound 3.90b (610 mg, 9\%) as a white solid. Compound 3.90a: ${ }^{1} \mathrm{H}-\mathrm{NMR}\left(400 \mathrm{MHz} ; \mathrm{CDCl}_{3}\right): \delta 6.25$ (br s, 1H), 4.89 (s, 1H), 4.26-4.18 (m, 2H), 3.82 (1/2 ABX, $J=9.8,3.5 \mathrm{~Hz}, 1 \mathrm{H}), 3.76(\mathrm{~s}, 3 \mathrm{H}), 3.54$ $(1 / 2 \mathrm{ABX}, J=9.8,8.5 \mathrm{~Hz}, 1 \mathrm{H}), 3.13-3.07(\mathrm{~m}, 1 \mathrm{H}), 2.71(1 / 2 \mathrm{ABX}, J=16.9,4.1 \mathrm{~Hz}, 1 \mathrm{H}), 2.35$ (s, 3H), 2.27 (1/2 ABX, $J=16.9,11.3 \mathrm{~Hz}, 1 \mathrm{H}), 1.29$ (t, $J=7.1 \mathrm{~Hz}, 3 \mathrm{H}), 0.93$ (s, 9H), 0.10 (s, 3H), $0.09(\mathrm{~s}, 3 \mathrm{H}) ;{ }^{13} \mathrm{C}-\mathrm{NMR}\left(101 \mathrm{MHz}, \mathrm{CDCl}_{3}\right): \delta 172.9,145.6,144.3,130.8,130.7,120.0$, $118.4,66.9,61.7,61.2,55.6,51.6,32.7,26.0,18.4,17.0,16.9,14.4,14.4,-5.1,-5.2,-5.2,-5.3$; m.p. $=47^{\circ} \mathrm{C} ; \mathrm{R}_{\mathrm{f}}\left(\mathrm{SiO}_{2}\right.$, hexanes/EtOAc 4:1) 0.40; $[\alpha]_{\mathrm{D}}{ }^{25}=-24.3^{\circ}\left(\mathrm{c}=0.885, \mathrm{CHCl}_{3}\right)$; IR (film, $\mathrm{CH}_{2} \mathrm{Cl}_{2}$ ), $v_{\max } 3284$ (br), 2955, 2931, 2857, 1739, 1462, $1178 \mathrm{~cm}^{-1}$; HRMS $\left(\mathrm{MH}^{+}\right)$, found 490.1446. $\mathrm{C}_{21} \mathrm{H}_{35} \mathrm{BrNO}_{5} \mathrm{Si}$ requires 490.1447. Compound 3.90b: ${ }^{1} \mathrm{H}-\mathrm{NMR}\left(400 \mathrm{MHz} ; \mathrm{CDCl}_{3}\right): \delta$ 5.86 (br s, 1H), $4.78(\mathrm{~s}, 1 \mathrm{H}), 4.30-4.15(\mathrm{~m}, 2 \mathrm{H}), 3.80(1 / 2 \mathrm{ABX}, \mathrm{J}=9.9,4.1 \mathrm{~Hz}, 1 \mathrm{H}), 3.74(\mathrm{~s}$, 
3H), $3.68(1 / 2 \mathrm{ABX}, \mathrm{J}=9.9,6.6 \mathrm{~Hz}, 1 \mathrm{H}), 2.95-2.89(\mathrm{~m}, 1 \mathrm{H}), 2.77(1 / 2 \mathrm{ABX}, \mathrm{J}=16.6,3.1 \mathrm{~Hz}$ 1H), $2.44(1 / 2 \mathrm{ABX}, \mathrm{J}=16.6,8.5 \mathrm{~Hz}, 2 \mathrm{H}), 2.36(\mathrm{~s}, 3 \mathrm{H}), 1.27(\mathrm{t}, \mathrm{J}=7.1 \mathrm{~Hz}, 3 \mathrm{H}), 0.92(\mathrm{~s}, 9 \mathrm{H})$, 0.09 (s, $6 \mathrm{H}) . ;{ }^{13} \mathrm{C}-\mathrm{NMR}\left(101 \mathrm{MHz}, \mathrm{CDCl}_{3}\right): \delta 172.8,145.1,143.9,132.0,130.4,120.3,118.4$, $66.7,61.5,61.4,58.4,54.5,33.0,26.1,26.0,18.5,17.0,14.2,-5.1,-5.2 ; \mathrm{m} . \mathrm{p} .=95{ }^{\circ} \mathrm{C} ; \mathrm{R}_{\mathrm{f}}\left(\mathrm{SiO}_{2}\right.$ hexanes/EtOAc 4:1) $0.37 ;[\alpha]_{\mathrm{D}}^{25}=-36.7^{\circ}\left(\mathrm{c}=0.600, \mathrm{CHCl}_{3}\right)$; IR (film, CH2Cl2), $v_{\max } 3314$ (br), 2955, 2931, 2858, 1738, 1463, $1257 \mathrm{~cm}^{-1}$; HRMS $\left(\mathrm{MH}^{+}\right)$, found 490.1456. $\mathrm{C}_{21} \mathrm{H}_{35} \mathrm{BrNO}_{5} \mathrm{Si}$ requires 490.1447. 


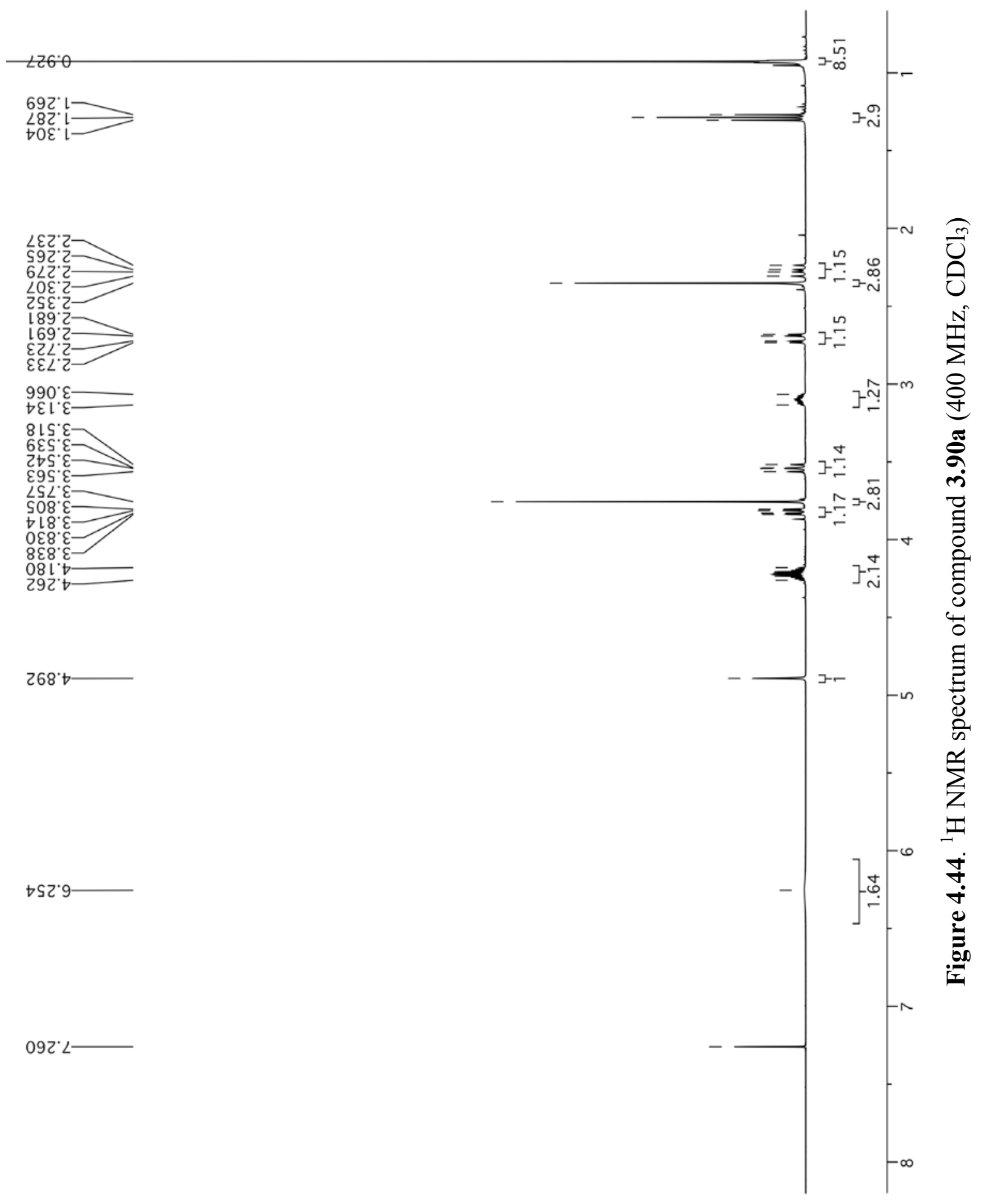




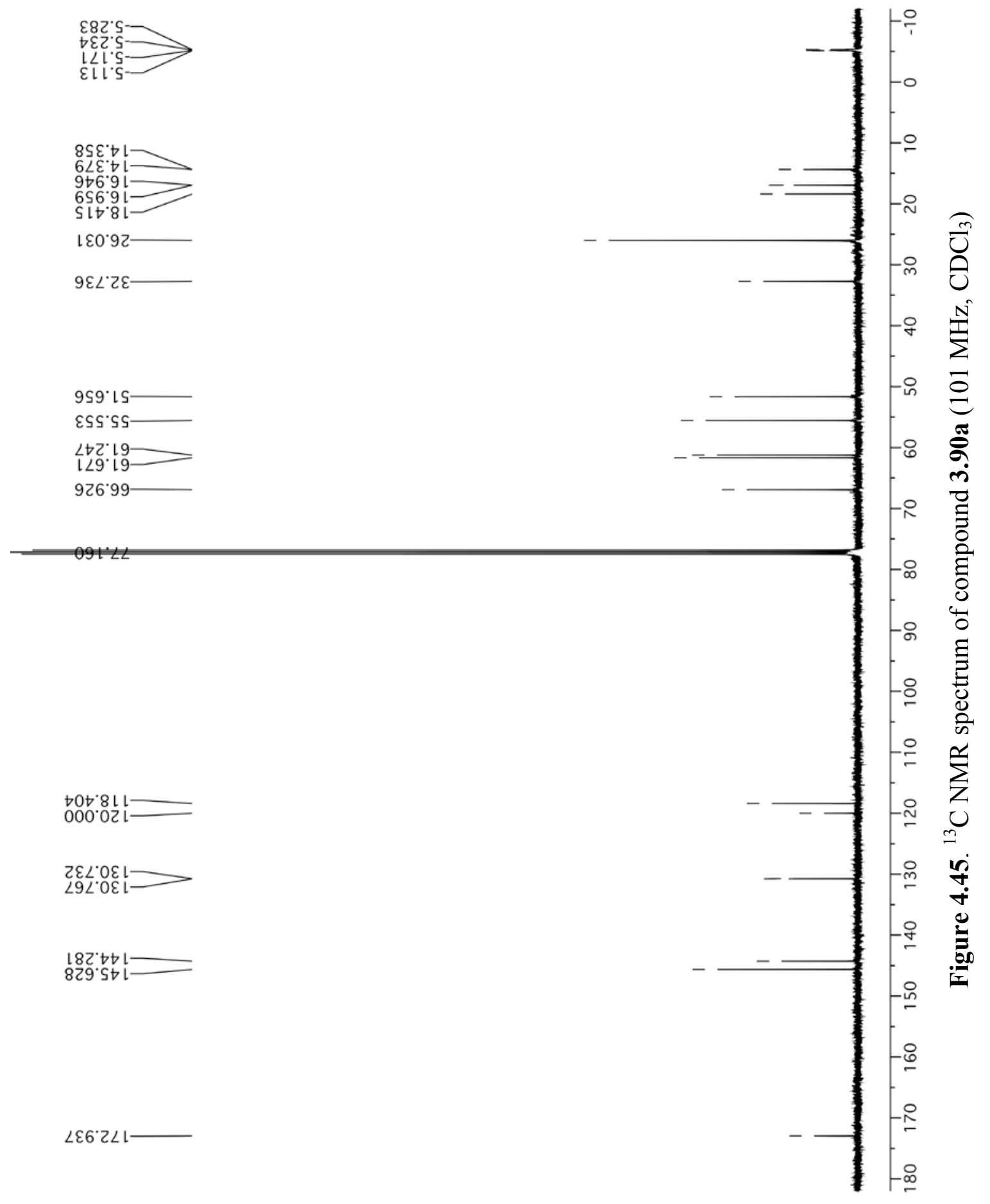




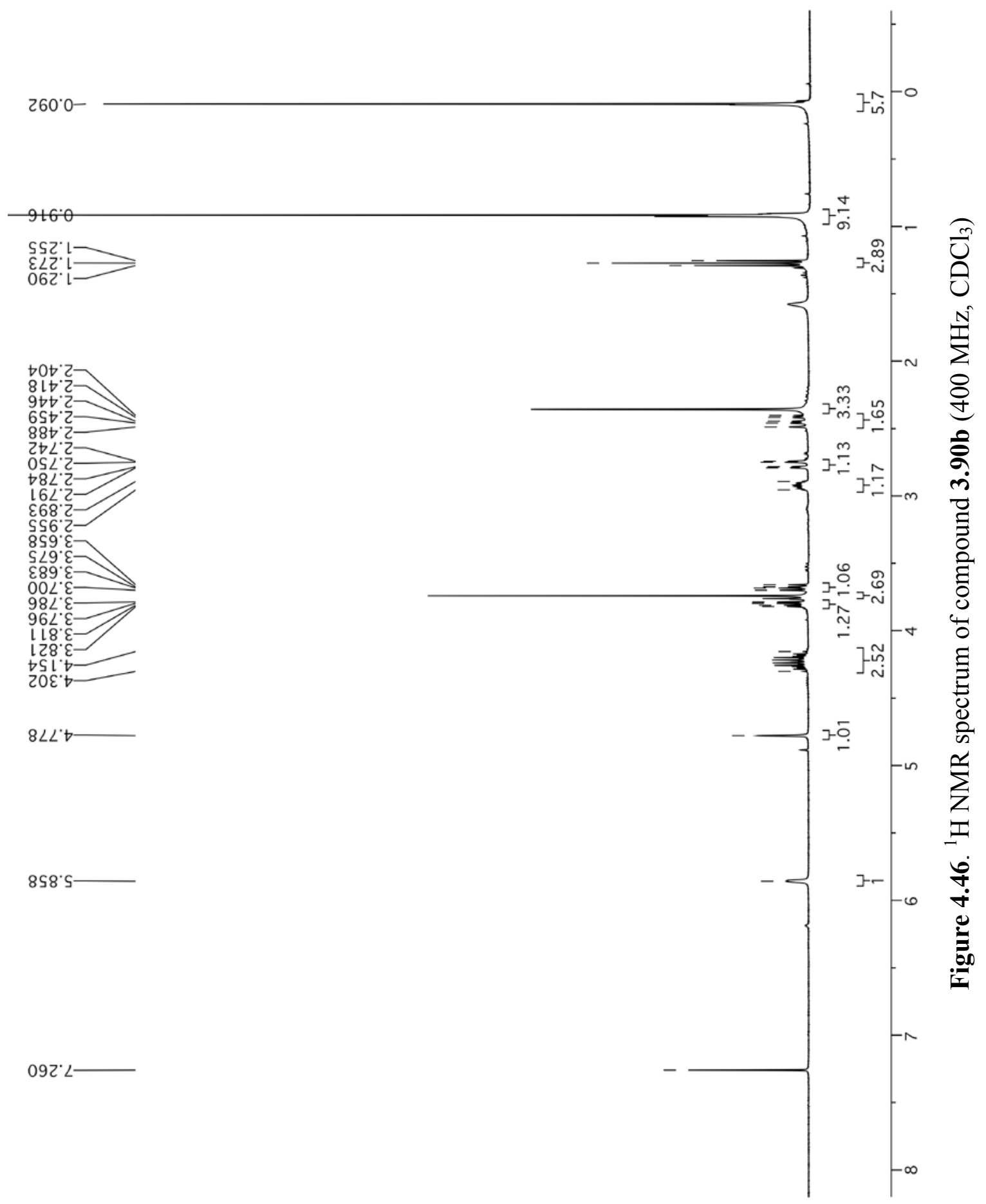




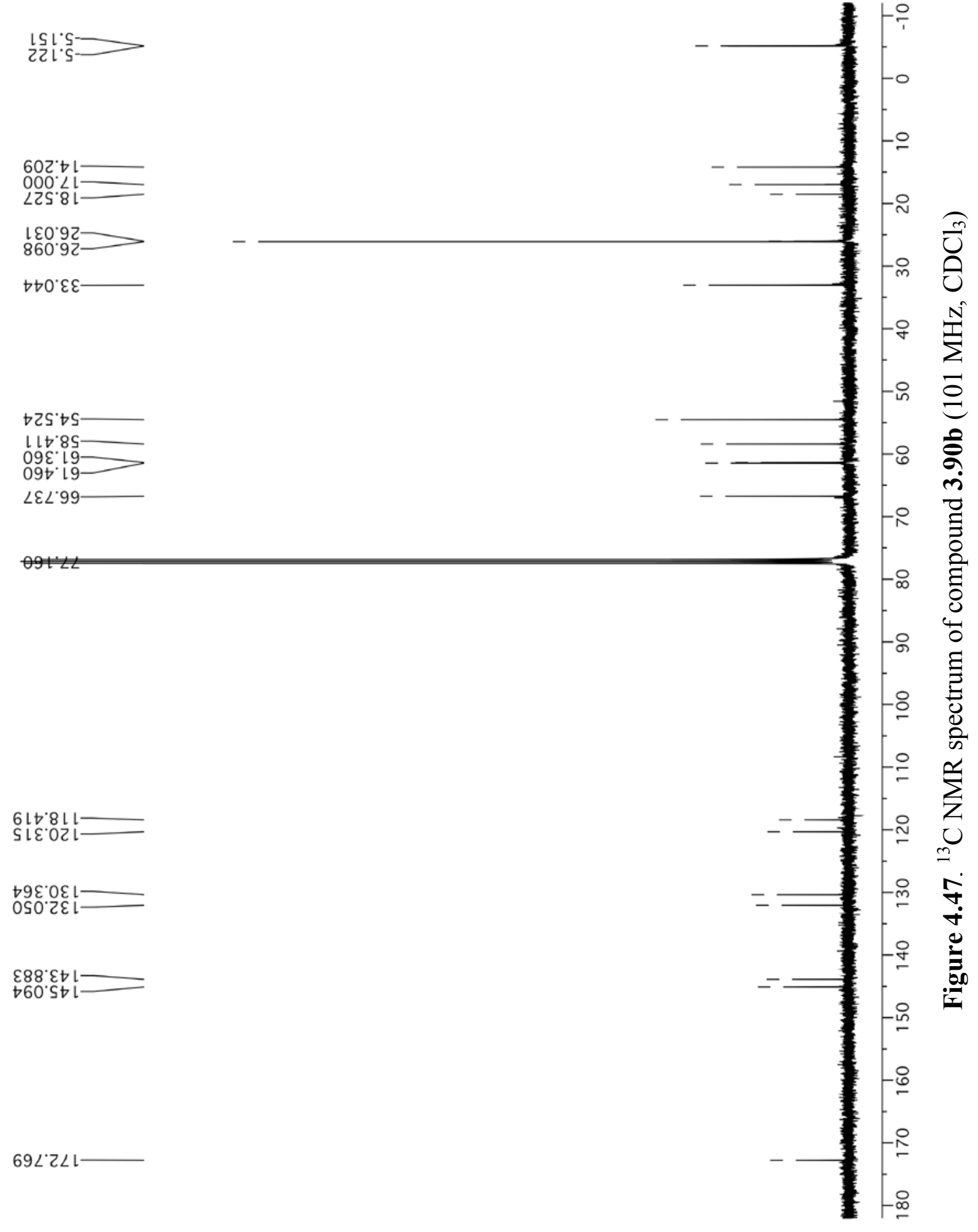




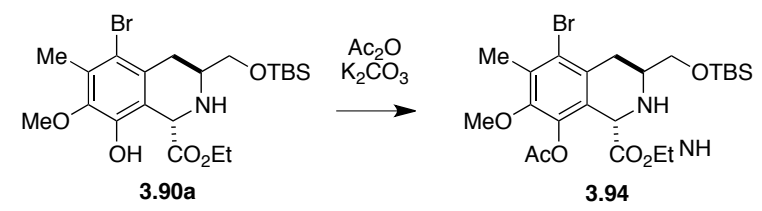

\subsection{3 (1S,3S)-ethyl 8-acetoxy-5-bromo-3-((tert-butyldimethyl-silyl)oxy)methyl)-7-}

\section{methoxy-6-methyl-1,2,3,4-tetrahydro-isoquinoline-1-carboxylate (3.94)}

To a stirred solution of compound $\mathbf{3 . 9 0 a}(840 \mathrm{mg}, 1.72 \mathrm{mmol}, 1.0$ eq.) in acetone ( $34 \mathrm{~mL}, 0.05$ $\mathrm{M})$, under $\mathrm{Ar}$, were added $\mathrm{K}_{2} \mathrm{CO}_{3}(1.20 \mathrm{~g}, 8.64 \mathrm{mmol}, 5.0$ eq.) and acetic anhydride $(162 \mu \mathrm{L}$, $1.72 \mathrm{mmol}, 1.0$ eq.). The suspension was stirred overnight, the solvent was evaporated and the residue was partitioned between water $(25 \mathrm{~mL})$ and EtOAc $(25 \mathrm{~mL})$. The aqueous phase was extracted with EtOAc $(2 \times 25 \mathrm{~mL})$ and the combined organic layers were rinsed with brine $(50$ $\mathrm{mL})$, dried $\left(\mathrm{Na}_{2} \mathrm{SO}_{4}\right)$, filtered, and concentrated under vacuum. The crude material was purified by flash chromatography (silica gel, hexanes/EtOAc 5:1) to give the title compound 3.94 (800 mg, 88\%) as a colorless oil. ${ }^{1} \mathrm{H}-\mathrm{NMR}\left(400 \mathrm{MHz} ; \mathrm{CDCl}_{3}\right): \delta 4.66(\mathrm{~s}, 1 \mathrm{H}), 4.18$ (q, $J=7.1 \mathrm{~Hz}$, 2H), $3.81(1 / 2 \mathrm{ABX}, J=9.8,3.5 \mathrm{~Hz}, 1 \mathrm{H}), 3.70(\mathrm{~s}, 3 \mathrm{H}), 3.55(1 / 2 \mathrm{ABX}, J=9.8,7.6 \mathrm{~Hz}, 1 \mathrm{H})$, 3.22-3.16 (m, 1H), $2.74(1 / 2 \mathrm{ABX}, J=16.9,4.1 \mathrm{~Hz}, 2 \mathrm{H}), 2.38(\mathrm{~s}, 3 \mathrm{H}), 2.37-2.33(\mathrm{~m}, 1 \mathrm{H}), 2.29$ $(\mathrm{s}, 3 \mathrm{H}), 1.27(\mathrm{t}, J=7.1 \mathrm{~Hz}, 3 \mathrm{H}), 0.921(\mathrm{~s}, 9 \mathrm{H}), 0.10(\mathrm{~s}, 3 \mathrm{H}), 0.07(\mathrm{~s}, 3 \mathrm{H}) ;{ }^{13} \mathrm{C}-\mathrm{NMR}(101 \mathrm{MHz}$, $\left.\mathrm{CDCl}_{3}\right): \delta 171.8,167.9,148.6,141.0,132.5,131.5,125.9,125.8,66.7,61.5,61.1,55.8,51.0$ 32.6, 26.0, 20.6, 18.4, 17.1, 14.4, -5.2, -5.3. $\mathrm{R}_{\mathrm{f}}\left(\mathrm{SiO}_{2}\right.$, hexanes/EtOAc 4:1) 0.45; $[\alpha]_{\mathrm{D}}^{25}=-21.1^{\circ}$ $\left(\mathrm{c}=1.10, \mathrm{CHCl}_{3}\right.$ ); IR (film, $\mathrm{CH}_{2} \mathrm{Cl}_{2}$ ), $v_{\max } 2956,2932,2856,1780,1737,1462,1192 \mathrm{~cm}^{-1}$; HRMS $\left(\mathrm{MH}^{+}\right)$, found 532.1561. $\mathrm{C}_{23} \mathrm{H}_{37} \mathrm{BrNO}_{6}$ Si requires 530.1574 


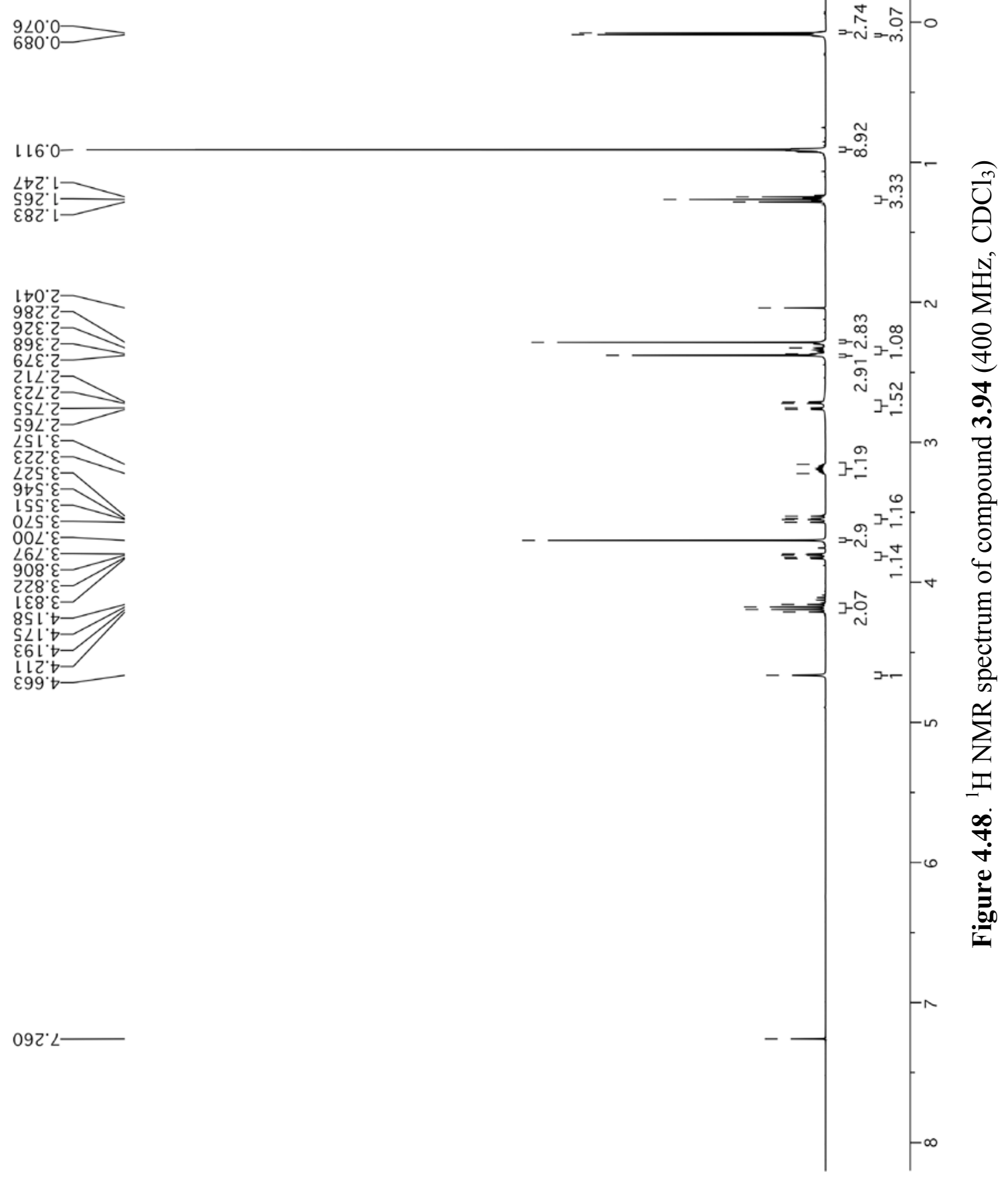




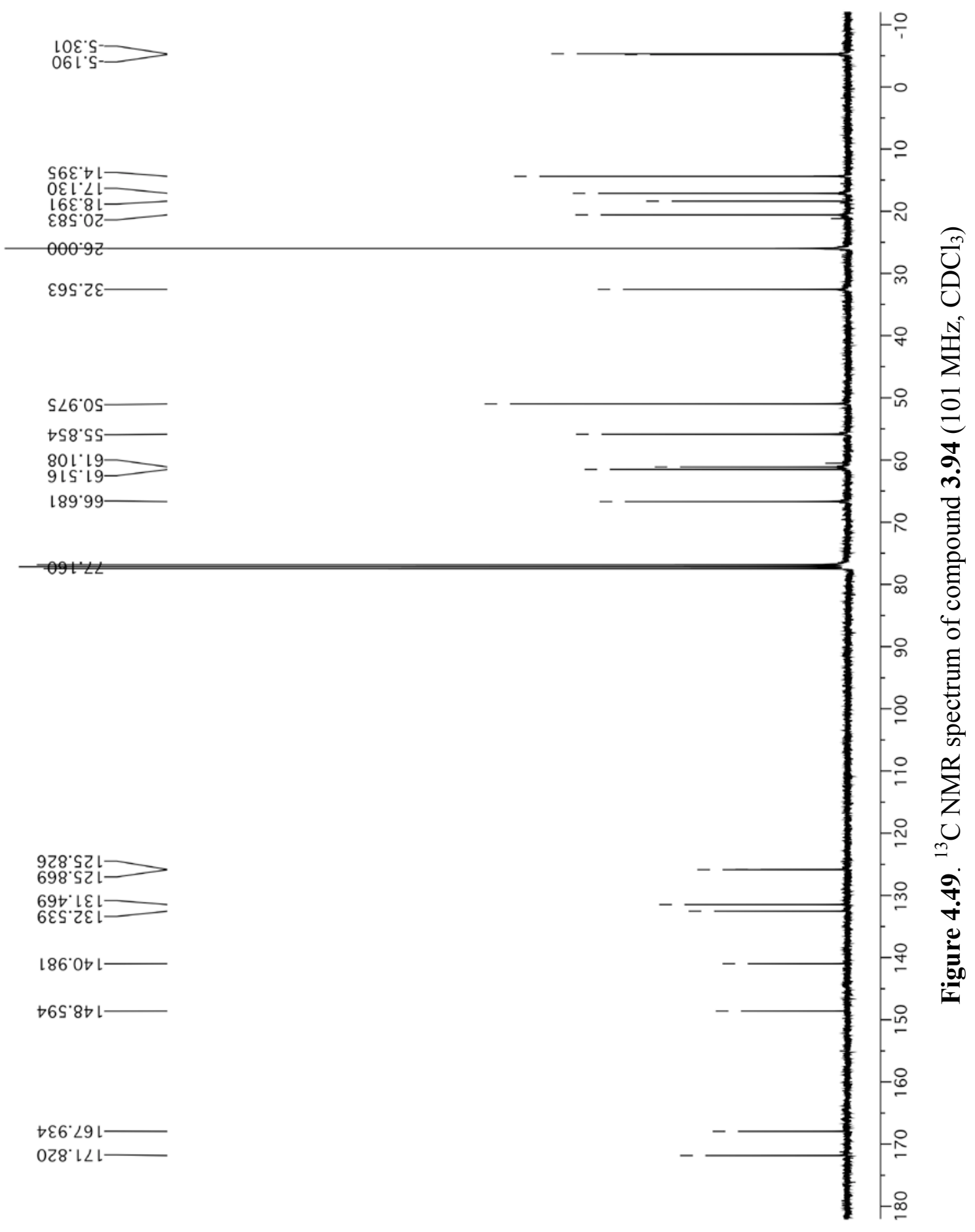




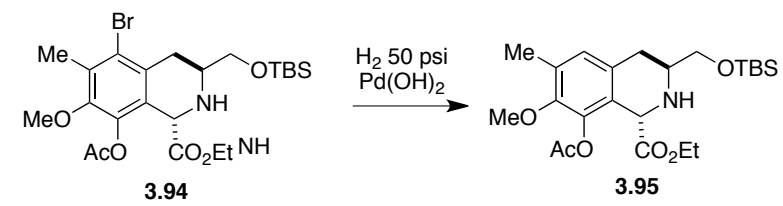

\subsection{4 (1S,3S)-ethyl 8-acetoxy-3-(((tert-butyldimethylsilyl)oxy)-methyl)-7-methoxy-6- methyl-1,2,3,4-tetrahydroisoquinoline-1-carboxylate (3.95)}

A solution of compound $3.94(2.90 \mathrm{~g}, 5.46 \mathrm{mmol})$ in $\mathrm{MeOH}(110 \mathrm{~mL}, 0.05 \mathrm{M})$, and Pearlman's catalyst $\left(20 \% \mathrm{Pd}(\mathrm{OH})_{2} / \mathrm{C}, 580 \mathrm{mg}\right)$ were placed in a Fisher-Porter bottle, under Ar. The mixture was sparged with Ar for 5 minutes and the vessel was filled with hydrogen gas at 50 psi. The reaction was vigorously stirred overnight and then filtered through Celite ${ }^{\circledR}$ and the vessel was rinsed with $\mathrm{MeOH}(50 \mathrm{~mL})$ and EtOAc $(50 \mathrm{~mL})$. The solution was concentrated under vacuum to dryness and partitioned between sat. aq. $\mathrm{NaHCO}_{3}(75 \mathrm{~mL})$ and EtOAc $(75 \mathrm{~mL})$. The aqueous phase was extracted with EtOAc $(2 \times 75 \mathrm{~mL})$ and the combined organic layers were rinsed with brine $(50 \mathrm{~mL})$, dried $\left(\mathrm{Na}_{2} \mathrm{SO}_{4}\right)$, filtered, and concentrated under vacuum. The crude material was purified by flash chromatography (silica gel, hexanes/EtOAc 5:1, 4:1 and 3:1) to give the title compound $3.95(2.25 \mathrm{~g}, 91 \%)$ as a colorless oil. ${ }^{1} \mathrm{H}-\mathrm{NMR}\left(400 \mathrm{MHz} ; \mathrm{CDCl}_{3}\right): \delta 6.85(\mathrm{~s}, 1 \mathrm{H})$, $4.65(\mathrm{~s}, 1 \mathrm{H}), 4.17(\mathrm{q}, J=7.1 \mathrm{~Hz}, 2 \mathrm{H}), 3.73(1 / 2 \mathrm{ABX}, J=9.8,3.7 \mathrm{~Hz}, 1 \mathrm{H}), 3.70(\mathrm{~s}, 3 \mathrm{H}), 3.52$ $(1 / 2 \mathrm{ABX}, J=9.8,7.2 \mathrm{~Hz}, 1 \mathrm{H}), 3.28-3.22(\mathrm{~m}, 1 \mathrm{H}), 2.59(1 / 2 \mathrm{ABX}, J=16.1,4.2 \mathrm{~Hz}, 1 \mathrm{H}), 2.50$ $(1 / 2 \mathrm{ABX}, J=16.1,10.7 \mathrm{~Hz}, 1 \mathrm{H}), 2.28(\mathrm{~s}, 3 \mathrm{H}), 2.27(\mathrm{~s}, 3 \mathrm{H}), 1.26(\mathrm{t}, J=7.1 \mathrm{~Hz}, 3 \mathrm{H}), 0.90(\mathrm{~s}$, 9H), $0.07(\mathrm{~s}, 3 \mathrm{H}), 0.06(\mathrm{~s}, 2 \mathrm{H}) .{ }^{13} \mathrm{C}-\mathrm{NMR}\left(101 \mathrm{MHz}, \mathrm{CDCl}_{3}\right): \delta$ 172.2, 168.3, 148.2, 141.6, $131.5,131.1,129.2,124.0,66.7,61.3,60.6,55.6,50.7,30.2,26.0,20.6,18.4,16.0,14.4,-5.2$, 5.3. $\mathrm{R}_{\mathrm{f}}\left(\mathrm{SiO}_{2}\right.$, hexanes/EtOAc 4:1) 0.42; $[\alpha]_{\mathrm{D}}{ }^{25}=-17^{\circ}\left(\mathrm{c}=0.42, \mathrm{CHCl}_{3}\right)$; IR (film, $\left.\mathrm{CH}_{2} \mathrm{Cl}_{2}\right), v_{\max }$ 2954, 2929, 2857, 1775, 1737, $1197 \mathrm{~cm}^{-1}$; HRMS $\left(\mathrm{MH}^{+}\right)$, found 452.244. $\mathrm{C}_{23} \mathrm{H}_{38} \mathrm{NO}_{6} \mathrm{Si}$ requires 452.2468 . 


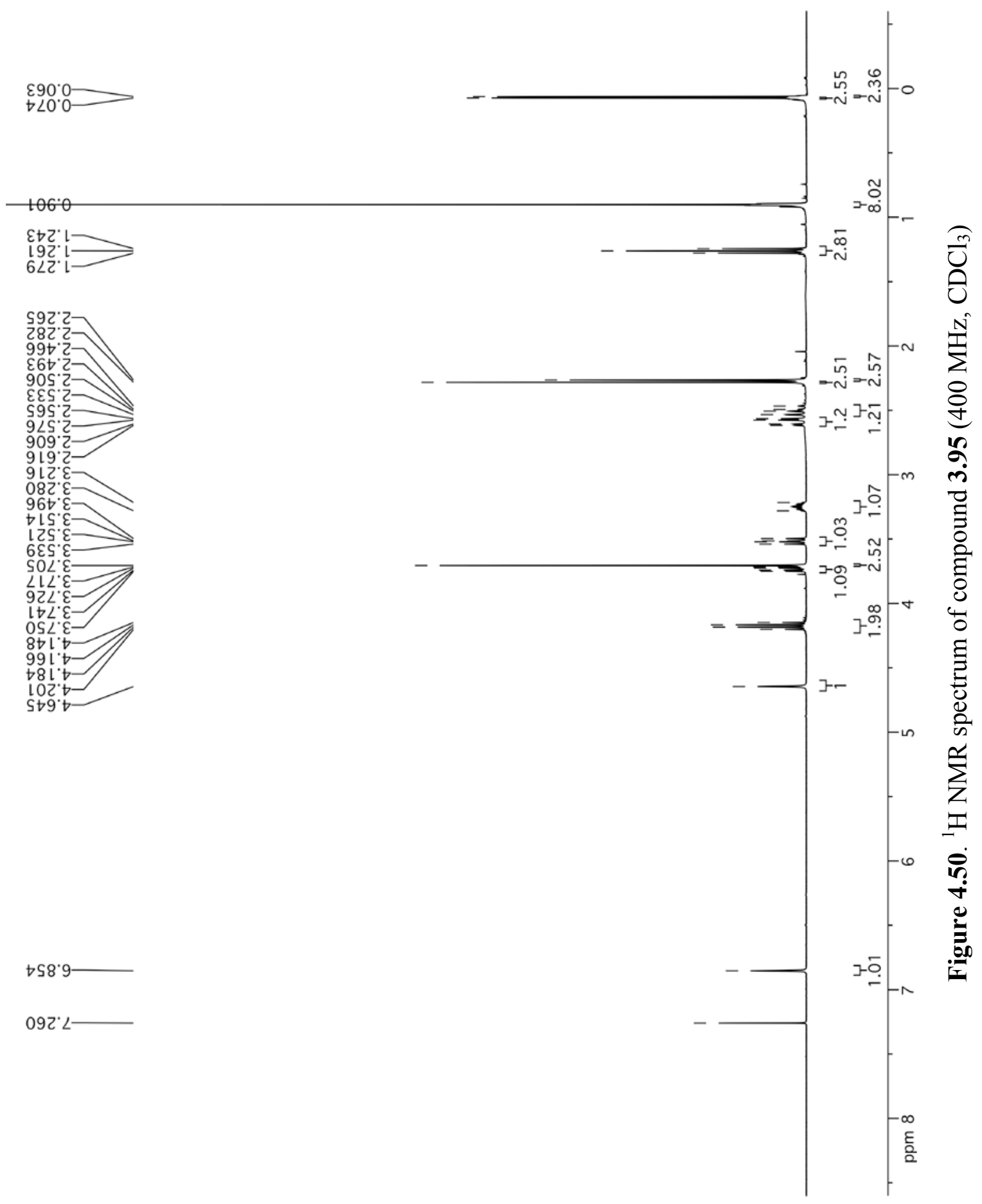




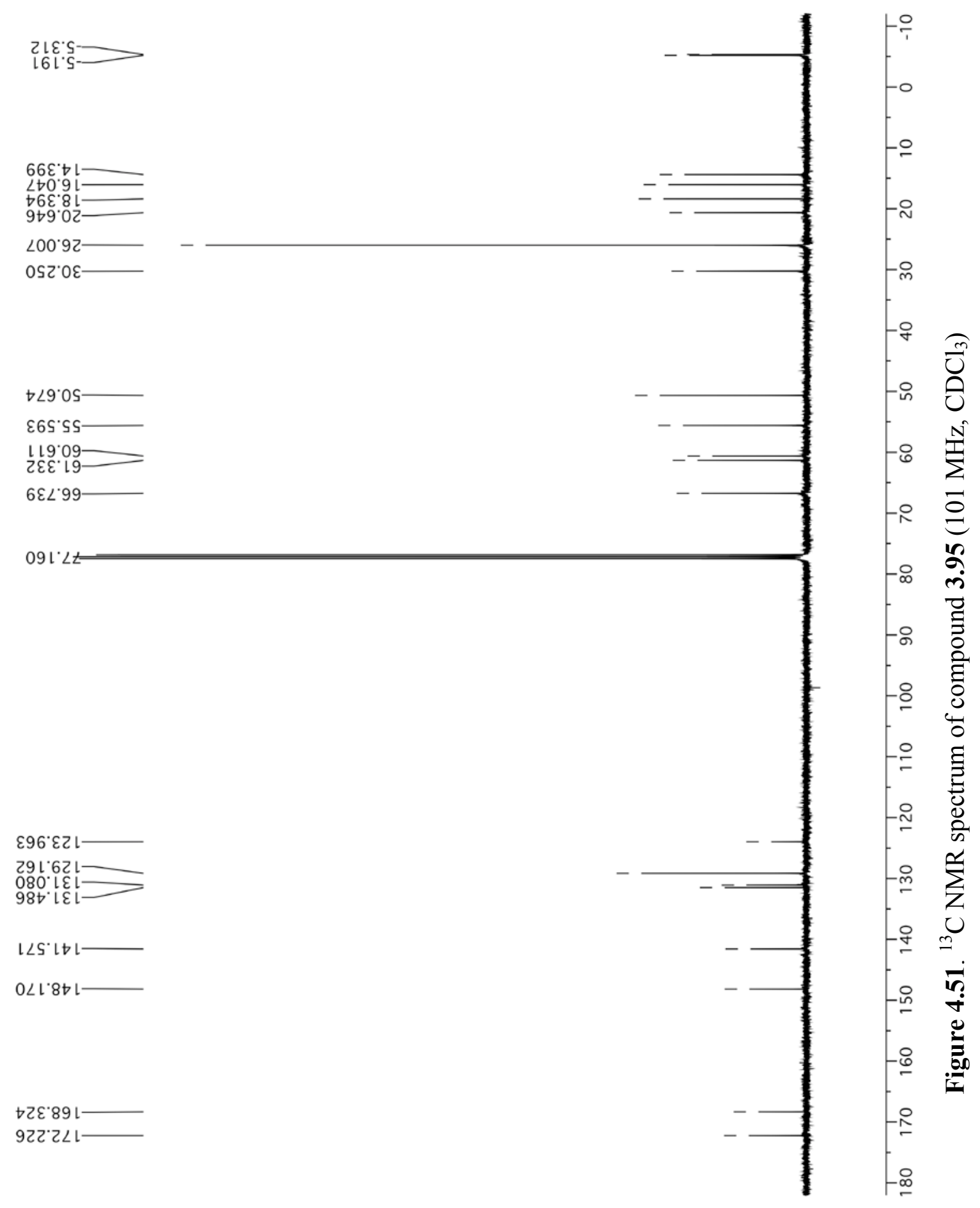




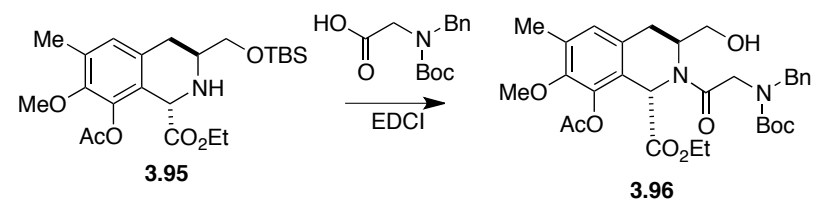

\subsection{5 (1S,3S)-ethyl 8-acetoxy-2-(2-(benzyl(tert-butoxycarbonyl)-amino)acetyl)-3-((tert- butyldimethylsilyl)oxy)methyl)-7-methoxy-6-methyl-1,2,3,4-tetrahydroisoquinoline-1- carboxylate (3.96)}

A solution of compound 3.95 (2.20 g, $4.87 \mathrm{mmol}, 1.0 \mathrm{eq}$.), $N$-Bn- $N$-Boc-glycine (2.58 g, 9.74 mmol, 2.0 eq.) and EDCI (1.40 g, $7.31 \mathrm{mmol}, 1.5$ eq.) in $\mathrm{CH}_{2} \mathrm{Cl}_{2}(2.5 \mathrm{~mL}, 2 \mathrm{M})$, under $\mathrm{Ar}$, was stirred for 2.5 days. The reaction was diluted with EtOAc $(200 \mathrm{~mL})$, and the solution was extracted with water $(100 \mathrm{~mL})$, sat. aq. $\mathrm{NaHCO}_{3}(2 \times 100 \mathrm{~mL})$ and brine $(100 \mathrm{~mL})$, dried $\left(\mathrm{Na}_{2} \mathrm{SO}_{4}\right)$, filtered, and concentrated under vacuum. The crude material was purified by flash chromatography (silica gel, hexanes/EtOAc 4:1, 3:1 and 2:1) to give the title compound $\mathbf{3 . 9 6}$ (3.15 g, 93\%) as a colorless oil. ${ }^{1} \mathrm{H}-\mathrm{NMR}\left(300 \mathrm{MHz}\right.$; DMSO- $d_{6}, 393 \mathrm{~K}$, mixture of rotamers): $\delta$ 7.36-7.24 (m, 5H), $6.94(\mathrm{~s}, 1 \mathrm{H}), 6.88(\mathrm{~s}, 1 \mathrm{H}$, minor rotamer), $5.48(\mathrm{~s}, 1 \mathrm{H}), 4.49(1 / 2 \mathrm{AB}, J=15.6$ $\mathrm{Hz}, 1 \mathrm{H}), 4.39(1 / 2 \mathrm{AB}, J=15.6 .0 \mathrm{~Hz}, 1 \mathrm{H}), 4.33-4.27(\mathrm{~m}, 2 \mathrm{H}), 4.13-3.87(\mathrm{~m}, 3 \mathrm{H}), 3.69(\mathrm{~s}, 3 \mathrm{H})$, $3.66(\mathrm{~s}, 1 \mathrm{H}$, minor rotamer), 3.34-3.10 (br m, 2H), 3.07-2.91 (br m, 2H), $2.33(\mathrm{~s}, 3 \mathrm{H}), 2.24(\mathrm{~s}$, $3 \mathrm{H}), 2.23(\mathrm{~s}, 3 \mathrm{H}$, minor rotamer), $2.23(\mathrm{~s}, 1 \mathrm{H}$, minor rotamer), $1.41(\mathrm{~s}, 9 \mathrm{H}), 1.21(\mathrm{t}, J=7.0 \mathrm{~Hz}$, $3 \mathrm{H}$, minor rotamer), $1.12(\mathrm{t}, J=7.1 \mathrm{~Hz}, 3 \mathrm{H}), 0.92(\mathrm{~d}, J=0.6 \mathrm{~Hz}, 2 \mathrm{H}), 0.79(\mathrm{~s}, 9 \mathrm{H}), 0.08(\mathrm{~s}, 3 \mathrm{H}$, minor rotamer), $0.04(\mathrm{~s}, 3 \mathrm{H}$, minor rotamer), $0.03(\mathrm{~m}, 3 \mathrm{H}$, minor rotamer), $-0.11(\mathrm{~s}, 3 \mathrm{H}),-0.14(\mathrm{~s}$, 3H). ${ }^{13} \mathrm{C}-\mathrm{NMR}\left(101 \mathrm{MHz}, \mathrm{CDCl}_{3}\right.$, mixture of rotamers): $\delta 170.1,169.7,168.1,168.0,156.1$, 149.6, 129.2, 129.1, 128.7, 128.4, 127.8, 127.5, 127.5, 127.4, 121.6, 80.5, 80.4, 71.6, 61.9, 61.3, $60.7,53.6,53.6,53.5,53.0,53.0,52.9,52.9,50.9,47.7,29.5,28.5,28.4,26.0,26.0,25.9,20.9$, $18.3,16.1,16.0,14.0,13.9,-5.3,-5.4,-5.4,-5.7 . \mathrm{R}_{\mathrm{f}}\left(\mathrm{SiO}_{2}\right.$, hexanes/EtOAc 3:1) 0.30; $[\alpha]_{\mathrm{D}}{ }^{25}=$ 
$+26.8^{\circ}\left(\mathrm{c}=0.995, \mathrm{CHCl}_{3}\right) ; \mathrm{IR}\left(\right.$ film, $\left.\mathrm{CH}_{2} \mathrm{Cl}_{2}\right), v_{\max } 2956,2931,2857,1781,1743,1703,1668$, $1199 \mathrm{~cm}^{-1}$; HRMS $\left(\mathrm{MH}^{+}\right)$, found 699.3666. $\mathrm{C}_{37} \mathrm{H}_{55} \mathrm{~N}_{2} \mathrm{O}_{9}$ Si requires 699.3677. 


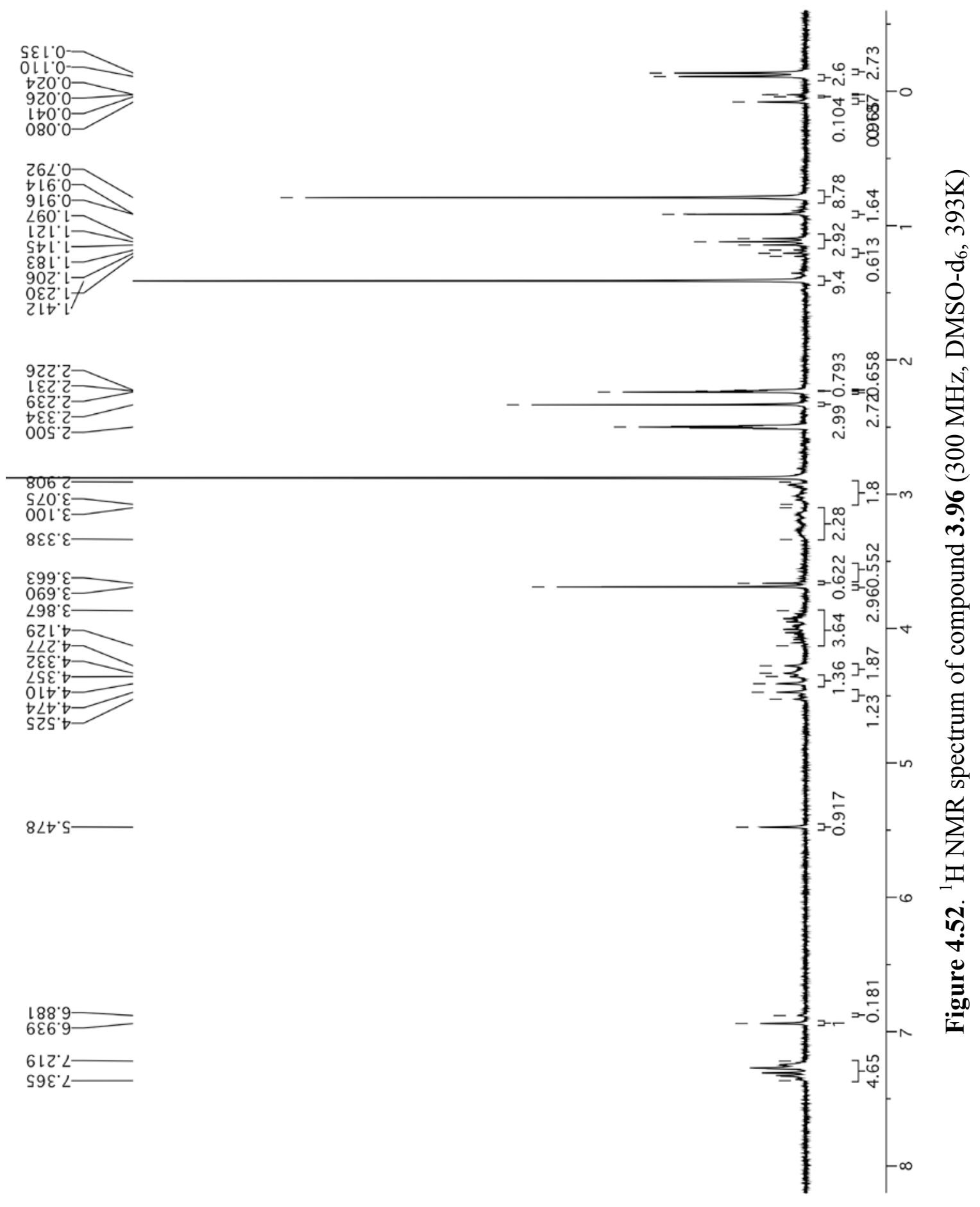




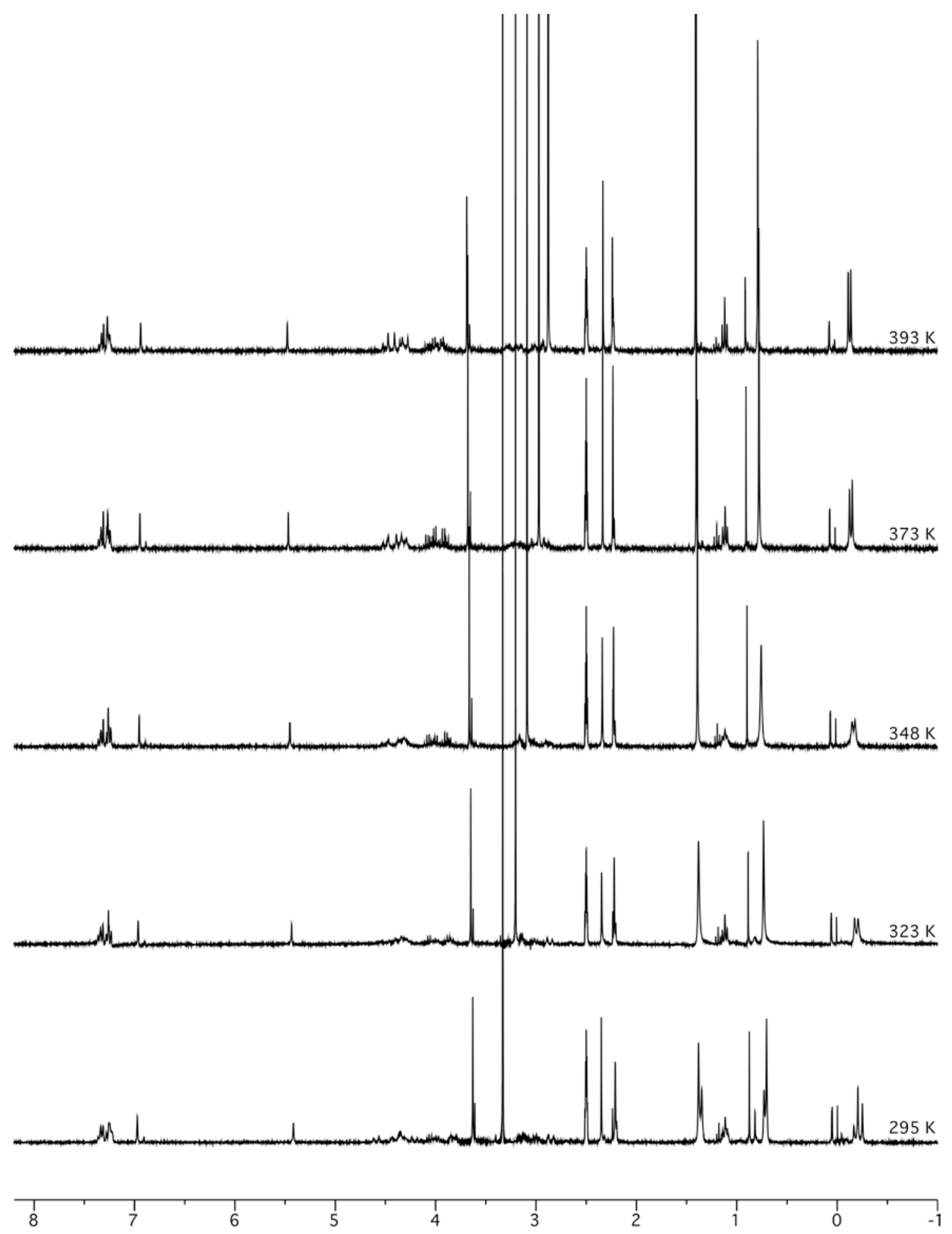

Figure 4.53. ${ }^{1} \mathrm{H}-\mathrm{NMR}$ spectra of compound $\mathbf{3 . 9 6}$ (300 MHz, DMSO-d 6 , 295, 323, 348, 373 and 393K) 


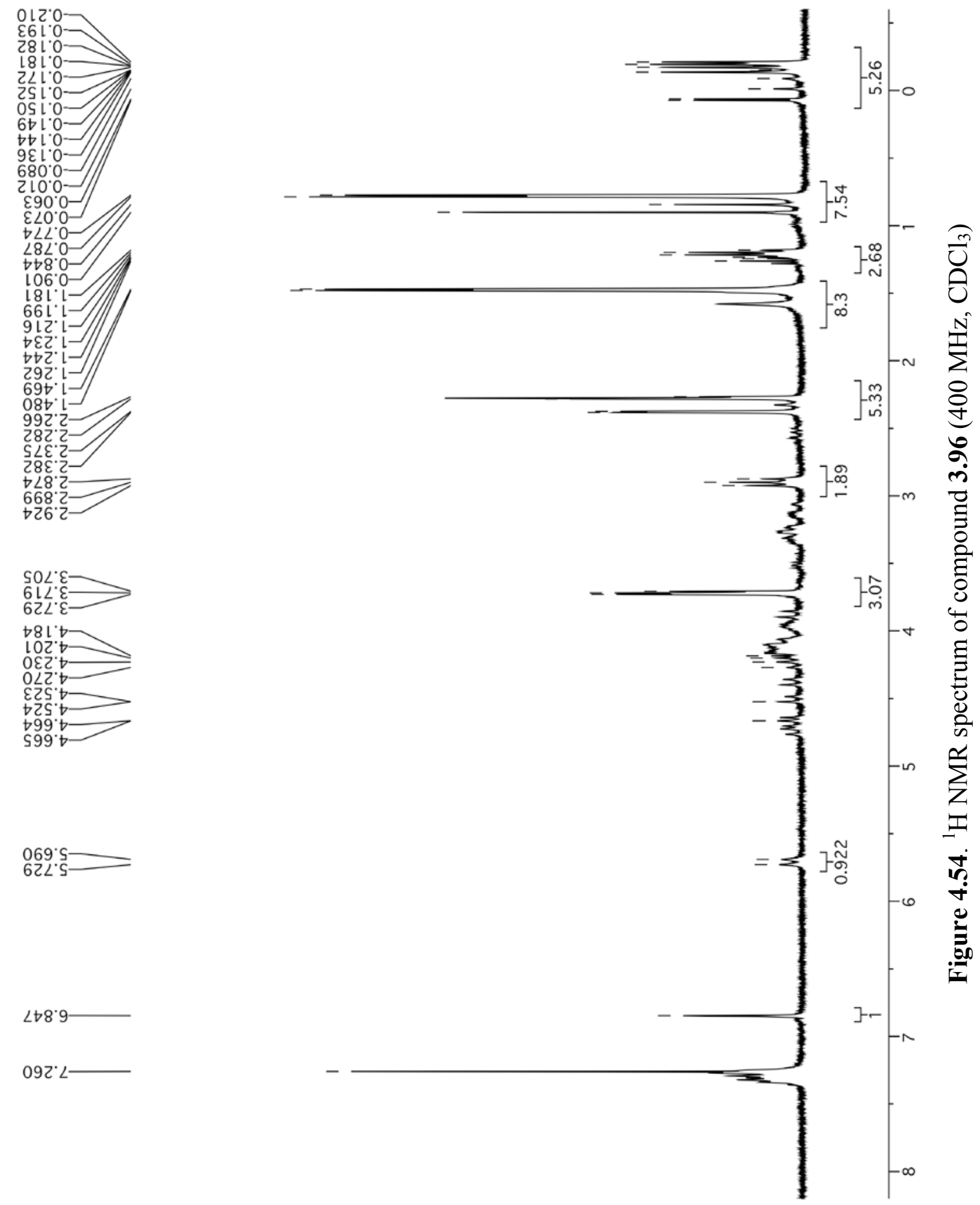



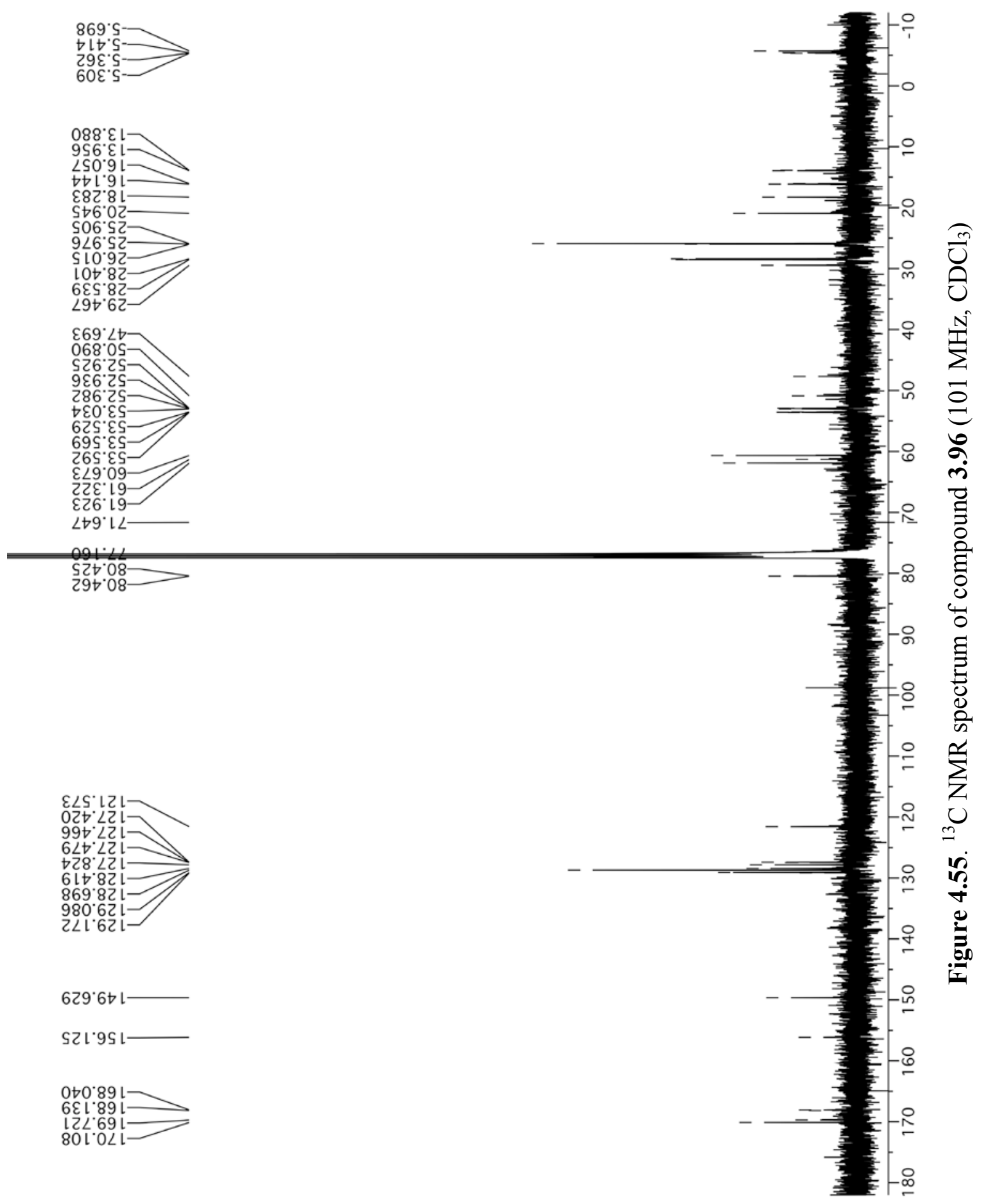


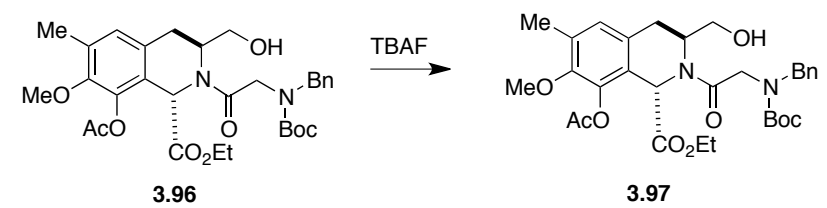

\subsection{6 (1S,3S)-ethyl 2-(2-(benzyl(tert-butoxycarbonyl)amino)acetyl)-8-hydroxy-3-} (hydroxymethyl)-7-methoxy-6-methyl-1,2,3,4-tetrahydroisoquinoline-1-carboxylate (3.97)

To a solution of compound 3.96 (765 mg, $1.09 \mathrm{mmol}, 1.0$ eq.) in THF (10 mL, $0.11 \mathrm{M})$, under Ar, were added $\mathrm{MeOH}(625 \mu \mathrm{L})$ and TBAF (1.0 M solution in THF, $2.18 \mathrm{~mL}, 2.0$ eq.). The reaction was stirred overnight and quenched with sat. aq. $\mathrm{NH}_{4} \mathrm{Cl}(50 \mathrm{~mL})$ and then diluted with EtOAc $(100 \mathrm{~mL})$. The phases were separated, the aqueous phase was extracted with EtOAc $(2 \times 25 \mathrm{~mL})$ and the combined organic layers were rinsed with brine $(50 \mathrm{~mL})$, dried $\left(\mathrm{Na}_{2} \mathrm{SO}_{4}\right)$, filtered, and concentrated under vacuum. The crude material was dissolved in the minimal amount of $\mathrm{CH}_{2} \mathrm{Cl}_{2}$ and purified by flash chromatography (silica gel, hexanes/EtOAc 2:1, then 1:1) to give the title compound 3.97 as a white amorphous solid (525 mg, 82\%). ${ }^{1} \mathrm{H}-\mathrm{NMR}$ (300 MHz; DMSO- $d_{6}, 393$ K): $\delta$ 7.36-7.26 (m, 5H), 6.96 (s, 1H), 5.50 (s, 1H), 4.49-4.40 (br m, 2H), 4.27-4.17 (br m, 2H), 4.07-3.89 (m, 3H), 3.70 (s, 3H), 3.19-3.03 (br m, 2H), 2.94-2.81 (m, 2H, overlapped with $\mathrm{H}_{2} \mathrm{O}$ signal), $2.34(\mathrm{~s}, 3 \mathrm{H}), 2.25(\mathrm{~s}, 3 \mathrm{H}), 1.41(\mathrm{~s}, 9 \mathrm{H}), 1.13(\mathrm{t}, J=7.1 \mathrm{~Hz}, 3 \mathrm{H})$; ${ }^{13} \mathrm{C}-\mathrm{NMR}\left(101 \mathrm{MHz}, \mathrm{CDCl}_{3}\right.$, mixture of rotamers): $\delta 170.2,170.1,168.0,168.0,156.4,154.8$, $152.8,149.7,145.0,141.7,141.5,138.1,138.1,138.0,132.9,132.8,130.2,130.0,128.7,128.5$ $128.4,128.3,128.1,127.8,127.8,127.7,127.5,127.5,127.1,124.2,121.2,80.9,80.4,65.1,63.8$, $62.0,60.6,53.7,53.5,52.7,52.0,51.0,47.9,30.6,30.0,29.5,28.5,28.4,20.9,16.2,13.8 ;$ m.p. $80^{\circ} \mathrm{C} ; \mathrm{R}_{\mathrm{f}}\left(\mathrm{SiO}_{2}\right.$, hexanes/EtOAc 1:1) 0.35; $[\alpha]_{\mathrm{D}}^{25}=+78^{\circ}\left(\mathrm{c}=0.44, \mathrm{CHCl}_{3}\right)$; IR (film, $\mathrm{CH}_{2} \mathrm{Cl}_{2}$ ), $v_{\max } 3455$ (br), 2977, 2935, 1780, 1742, 1698, 1663, $1200 \mathrm{~cm}^{-1}$; HRMS $\left(\mathrm{MH}^{+}\right)$, found 585.2816. $\mathrm{C}_{31} \mathrm{H}_{41} \mathrm{~N}_{2} \mathrm{O}_{9}$ requires 585.2812 . 


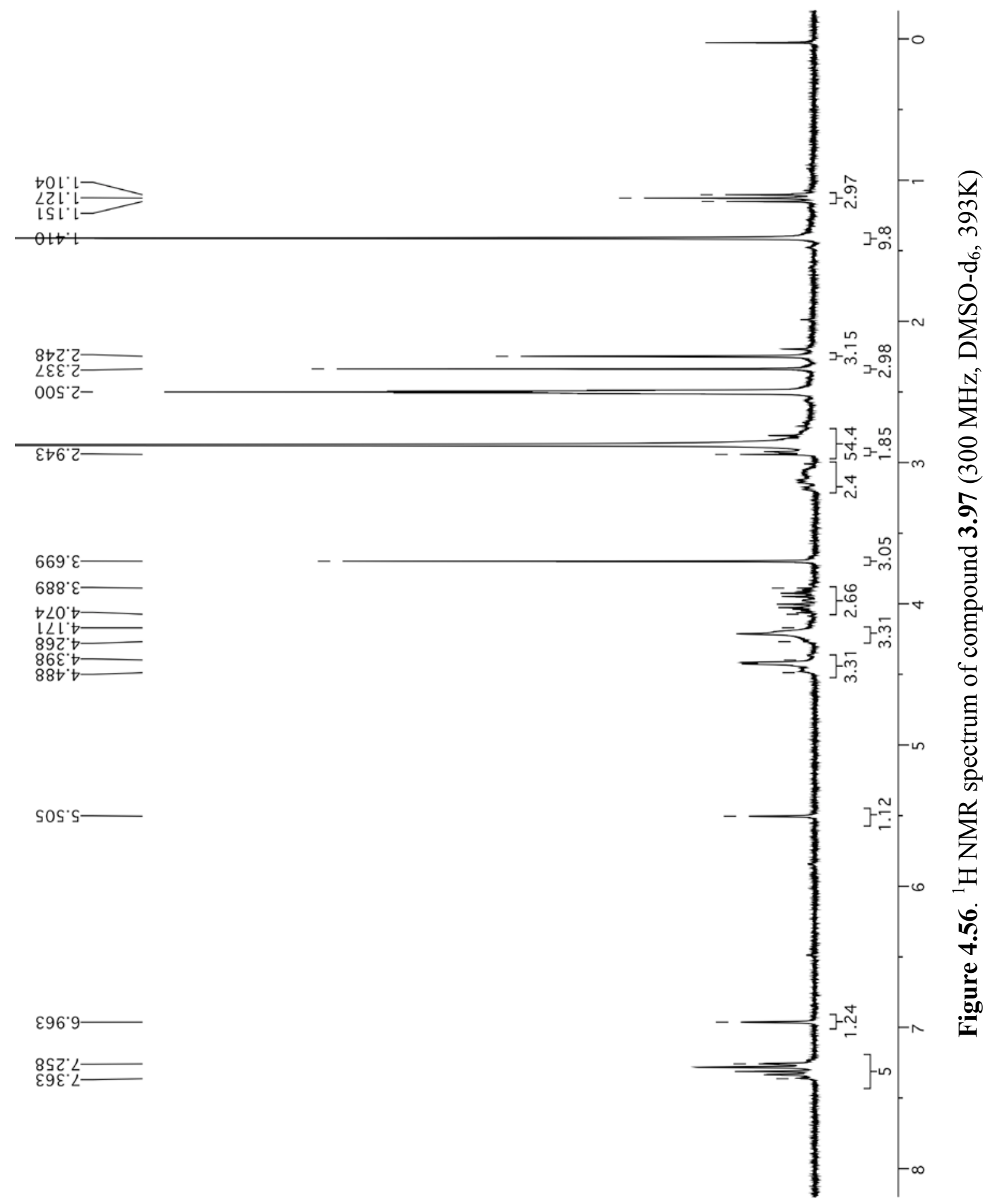



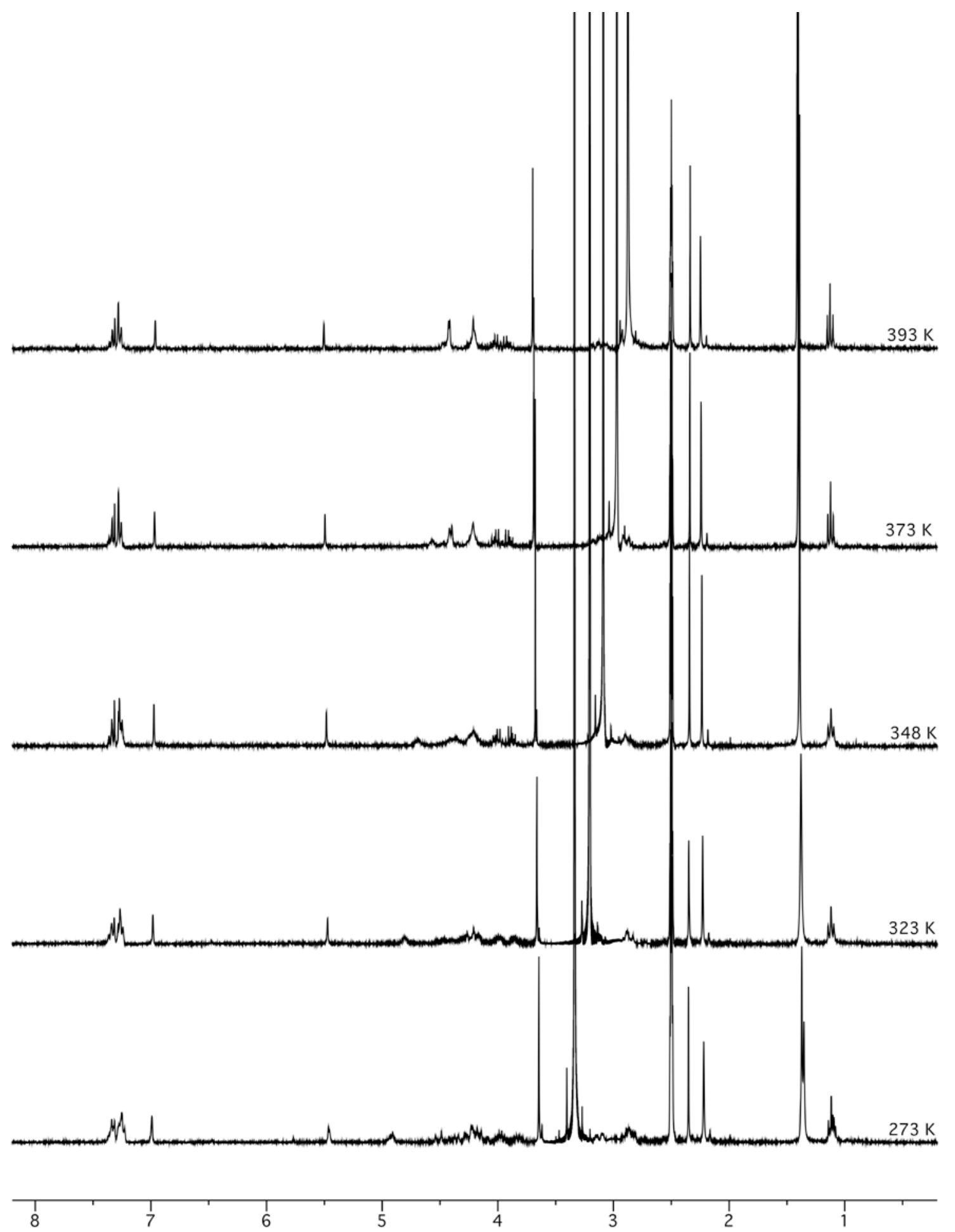

Figure 4.57. ${ }^{1} \mathrm{H}-\mathrm{NMR}$ spectra of compound 3.97 (300 MHz, DMSO-d $\mathrm{d}_{6}, 295,323,348$, 373 and $393 \mathrm{~K})$ 


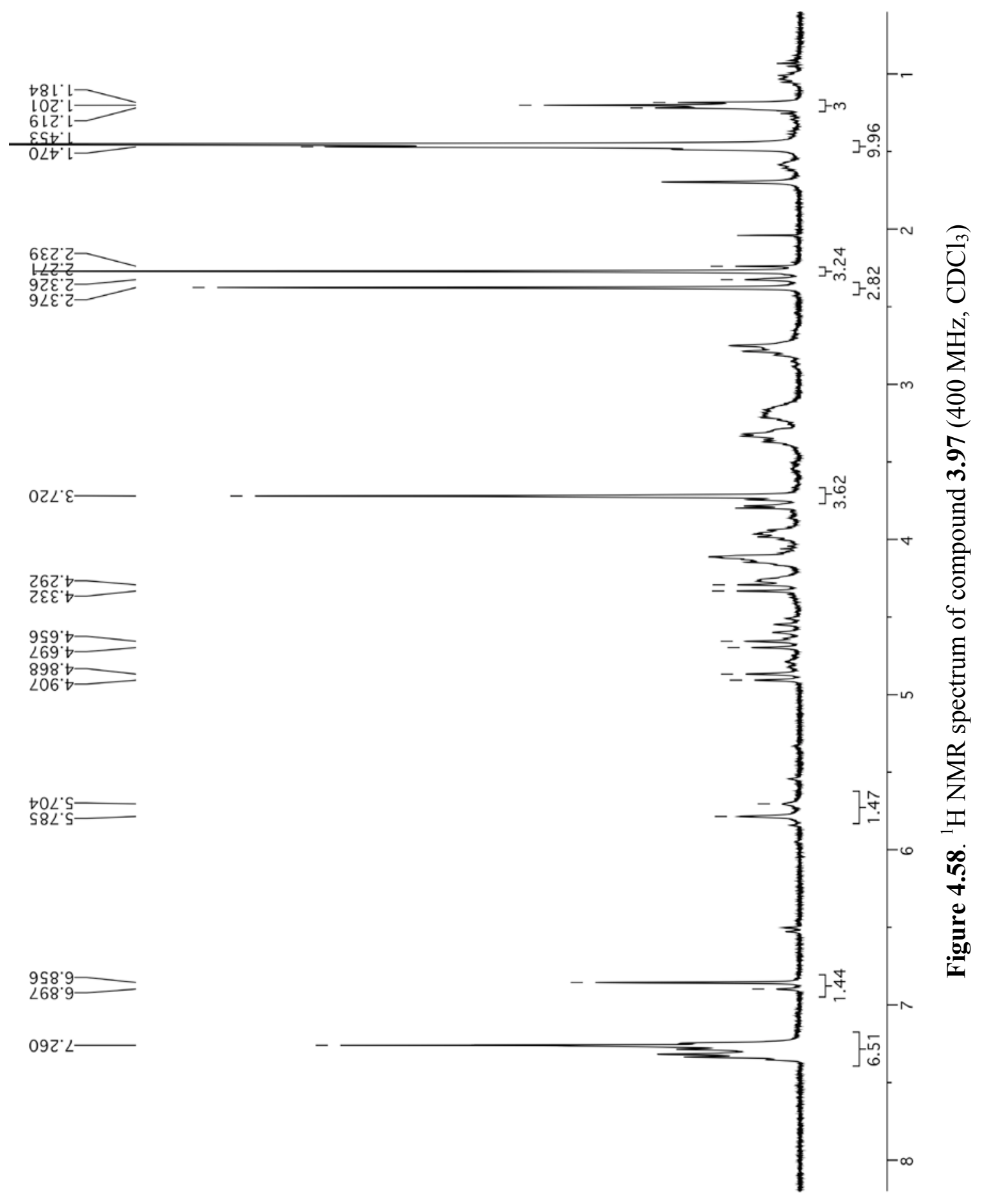




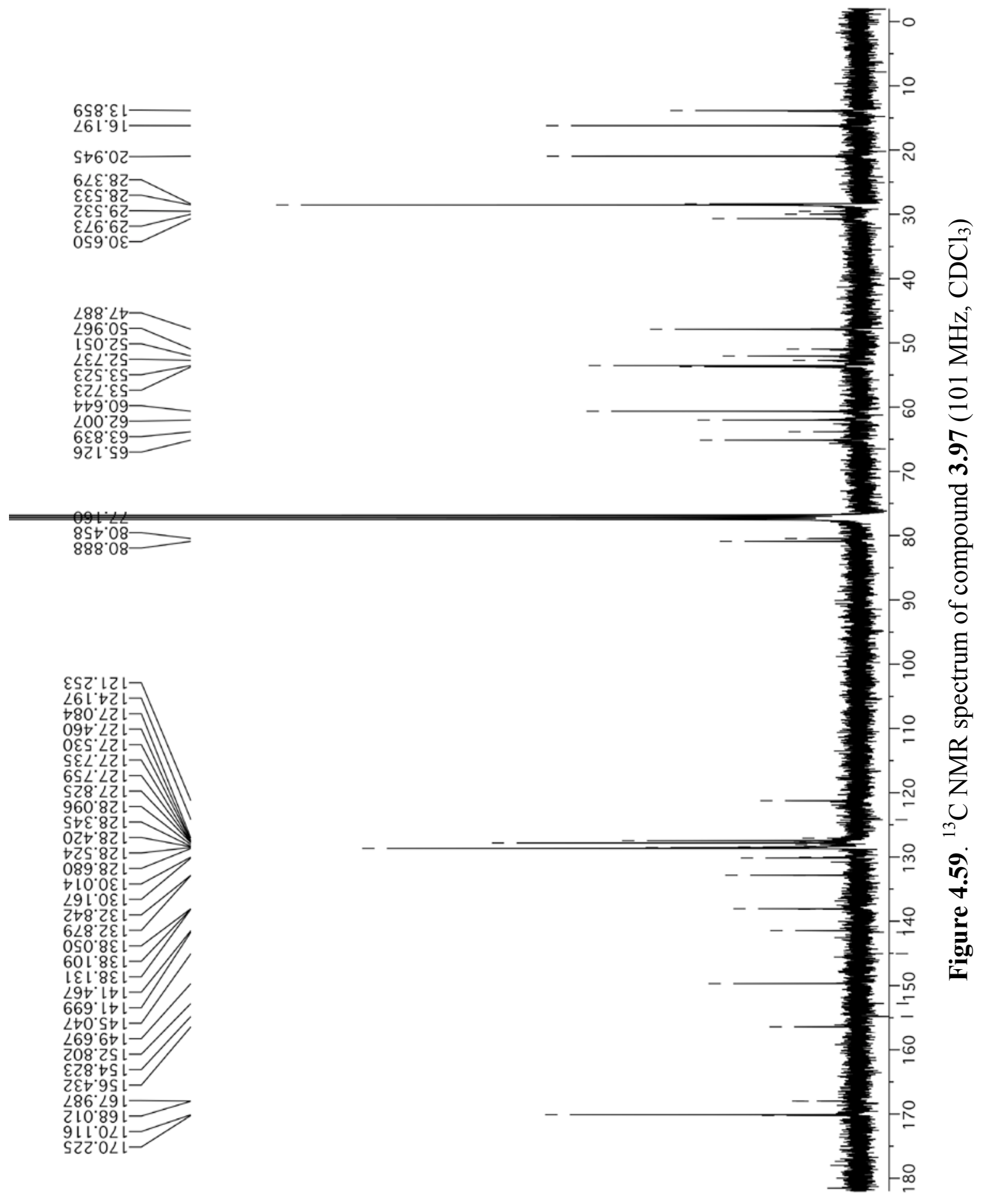




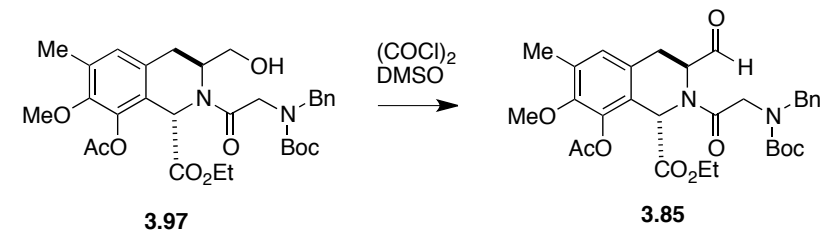

\subsection{7 (1S,3S)-ethyl 2-(2-(benzyl(tert-butoxycarbonyl)amino)-acetyl)-3-formyl-8-hydroxy- 7-methoxy-6-methyl-1,2,3,4-tetrahydroisoquinoline-1-carboxylate (3.85)}

A solution of oxalyl chloride ( $825 \mu \mathrm{L}, 9.75 \mathrm{mmol}, 3.0$ eq.) in $\mathrm{CH}_{2} \mathrm{Cl}_{2}(22.5 \mathrm{~mL})$, under $\mathrm{Ar}$, was cooled to $-78 \mathrm{C}$, and DMSO (921 $\mu \mathrm{L}, 13.0 \mathrm{mmol}, 4.0$ eq.) was added dropwise. The resulting mixture was stirred an additional $30 \mathrm{~min}$ at $-78^{\circ} \mathrm{C}$. A solution of compound $3.97(1.90 \mathrm{mg}, 3.25$ mmol, 1.0 eq. $)$ in $\mathrm{CH}_{2} \mathrm{Cl}_{2}(10 \mathrm{~mL})$ at $\mathrm{RT}$ was then added slowly by cannula, and the mixture continued to stir at $-78{ }^{\circ} \mathrm{C}$ for $30 \mathrm{~min}$. Triethylamine $(4.50 \mathrm{~mL}, 32.5 \mathrm{mmol}, 10$ eq. $)$ was then added dropwise, and the solution was stirred for $15 \mathrm{~min}$ at $-78{ }^{\circ} \mathrm{C}$ and an additional $30 \mathrm{~min}$ at 0 ${ }^{\circ} \mathrm{C}$. The reaction was quenched with sat. aq. $\mathrm{NH}_{4} \mathrm{Cl}(50 \mathrm{~mL})$ and allowed to warm to $\mathrm{RT}$. The layers were separated, the aqueous phase was extracted with $\mathrm{CH}_{2} \mathrm{Cl}_{2}(3 \times 50 \mathrm{~mL})$ and the combined organic layers were rinsed with brine $(50 \mathrm{~mL})$, dried $\left(\mathrm{Na}_{2} \mathrm{SO}_{4}\right)$, filtered, and concentrated under vacuum. The crude material was purified by flash chromatography (silica gel, hexanes/EtOAc 2:1, then 1:1) to give the title compound $3.85(1.65 \mathrm{~g}, 87 \%)$ as a colorless oil, which solidifies upon standing to afford a colorless amorphous solid. ${ }^{1} \mathrm{H}-\mathrm{NMR}$ (300 MHz; DMSO- $d_{6}, 373 \mathrm{~K}$, mixture of rotamers): $\delta 9.54(\mathrm{~s}, 1 \mathrm{H}$, minor rotamer), $9.28(\mathrm{~s}, 1 \mathrm{H}), 7.35-7.23$ $(\mathrm{m}, 5 \mathrm{H}), 7.08(\mathrm{~s}, 1 \mathrm{H}$, minor rotamer), $7.01(\mathrm{~s}, 1 \mathrm{H}), 6.94(\mathrm{~s}, 1 \mathrm{H}$, minor rotamer), $6.91(\mathrm{~s}, 1 \mathrm{H}$, minor rotamer), $5.70(\mathrm{~s}, 1 \mathrm{H}), 5.10-4.88(\mathrm{~m}, 1 \mathrm{H}), 4.52-4.28(\mathrm{~m}, 3 \mathrm{H}), 4.26-4.14(\mathrm{~m}, 1 \mathrm{H}), 4.13-3.98$ $(\mathrm{m}, 2 \mathrm{H}), 3.97-3.86(\mathrm{~m}, 1 \mathrm{H}), 3.69(\mathrm{~s}, 3 \mathrm{H}$, minor rotamer), $3.68(\mathrm{~s}, 3 \mathrm{H}$, minor rotamer), $3.67(\mathrm{~s}$, $3 \mathrm{H}), 3.38-3.27(\mathrm{~m}, 1 \mathrm{H}), 2.34(\mathrm{~s}, 3 \mathrm{H}), 2.32(\mathrm{~s}, 3 \mathrm{H}$, minor rotamer), $2.25(\mathrm{~s}, 3 \mathrm{H}$, minor rotamer), $2.24(\mathrm{~s}, 3 \mathrm{H}$, minor rotamer), $2.22(\mathrm{~s}, 3 \mathrm{H}), 1.41(\mathrm{~s}, 9 \mathrm{H}$, minor rotamer $), 1.40(\mathrm{~s}, 9 \mathrm{H}), 1.36(\mathrm{~s}, 9 \mathrm{H}$, 
minor rotamer), $1.34\left(\mathrm{~s}, 9 \mathrm{H}\right.$, minor rotamer), $1.12(\mathrm{t}, J=7.2 \mathrm{~Hz}, 3 \mathrm{H}) \cdot{ }^{13} \mathrm{C}-\mathrm{NMR}(101 \mathrm{MHz}$, $\mathrm{CDCl}_{3}$, mixture of rotamers): $\delta 201.2,199.6,199.2,169.9,167.8,155.9,155.8,150.2,149.7$, $141.5,141.0,137.6,137.5,137.5,133.6,133.3,128.6,128.6,128.5,128.5,128.4,128.1,128.0$, $127.9,122.6,122.1,81.0,80.8,62.7,62.2,60.9,60.6,60.6,60.2,53.7,53.5,53.3,50.9,47.8$, 47.6, 47.1, 29.6, 28.5, 28.5, 28.4, 28.2, 20.9, 16.2, 13.8; m.p. $78{ }^{\circ} \mathrm{C} ; \mathrm{R}_{\mathrm{f}}\left(\mathrm{SiO}_{2}\right.$, hexanes/EtOAc 1:1) $0.40 ;[\alpha]_{\mathrm{D}}{ }^{25}=+35^{\circ}\left(\mathrm{c}=0.23, \mathrm{CHCl}_{3}\right)$; IR (film, $\left.\mathrm{CH}_{2} \mathrm{Cl}_{2}\right), v_{\max } 2978,2937,1780,1742$, 1699, 1673, $1200 \mathrm{~cm}^{-1}$; HRMS $\left(\mathrm{MH}^{+}\right)$, found 583.2654. $\mathrm{C}_{31} \mathrm{H}_{39} \mathrm{~N}_{2} \mathrm{O}_{9}$ requires 583.2656. 


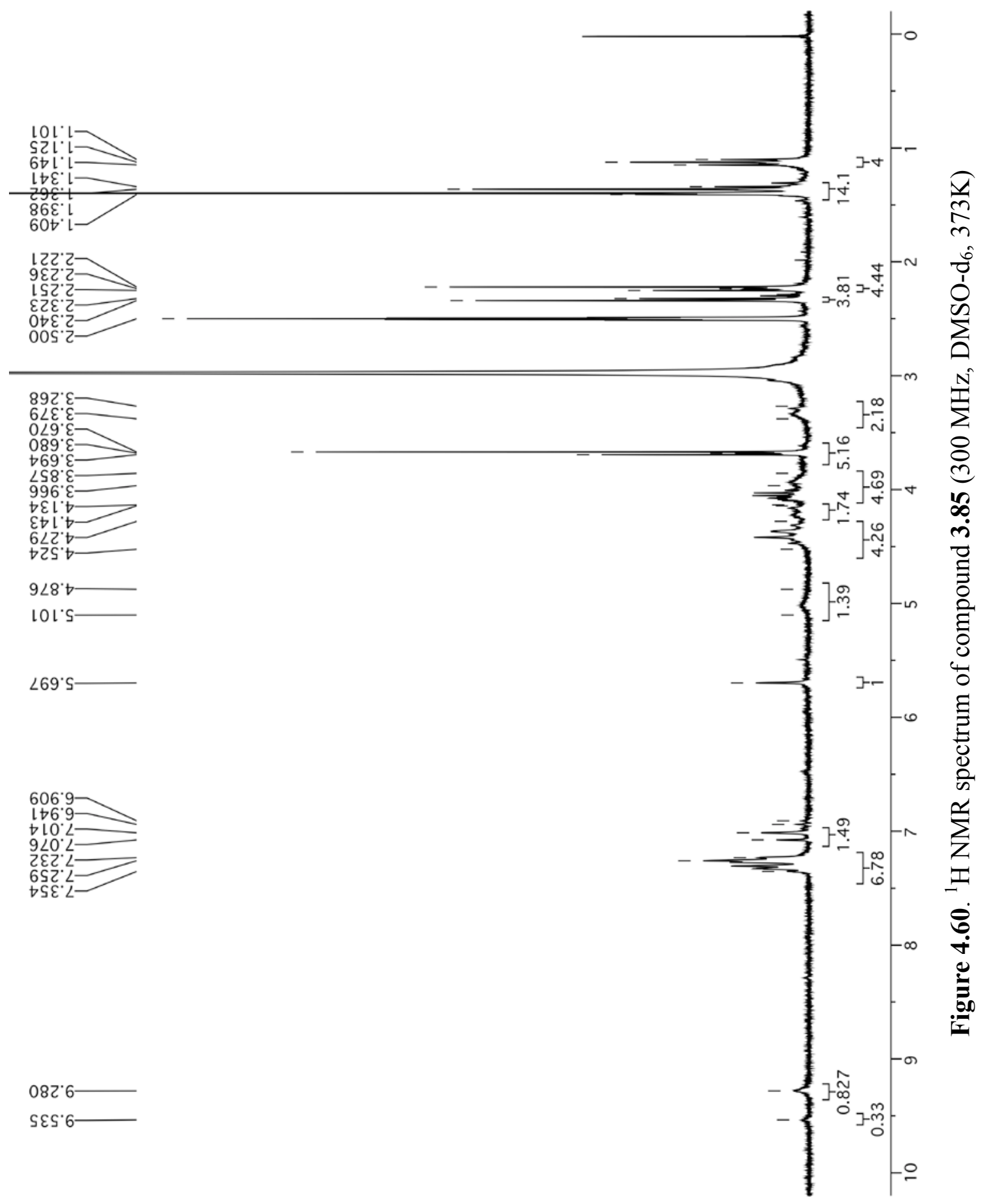




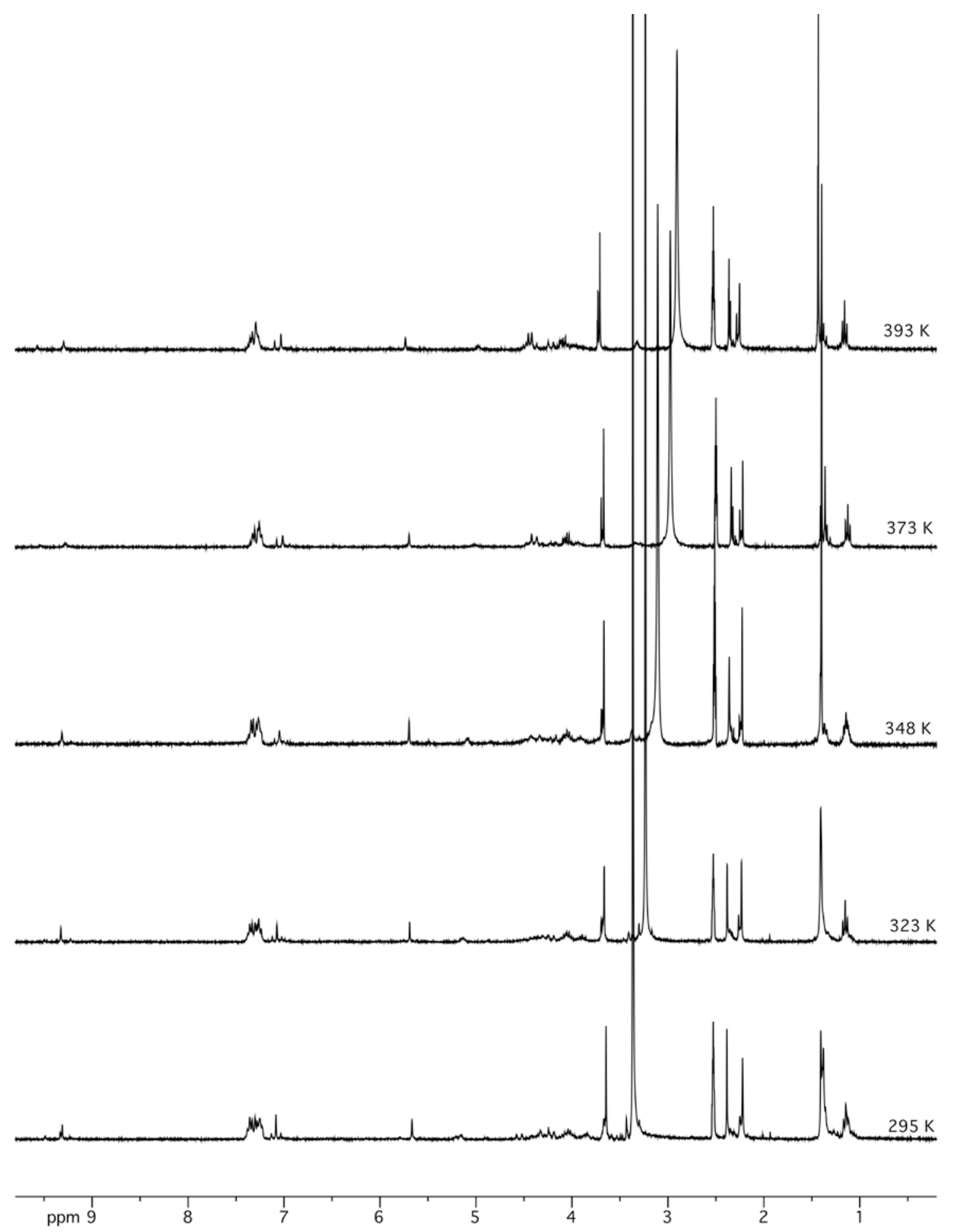

Figure 4.61. ${ }^{1} \mathrm{H}-\mathrm{NMR}$ spectra of compound $\mathbf{3 . 8 5}$

(300 MHz, DMSO-d 6 , 295, 323, 348, 373 and 393K) 


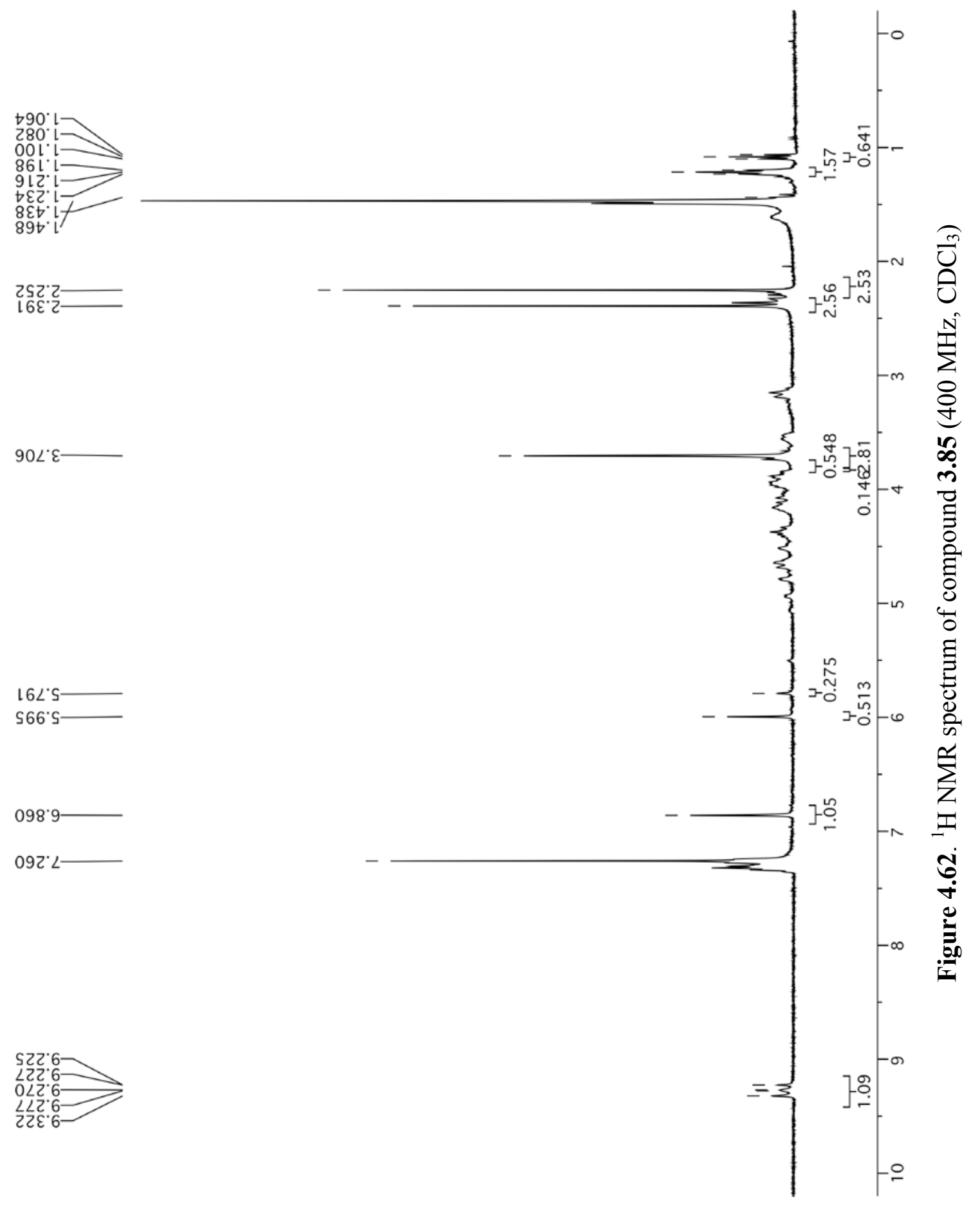




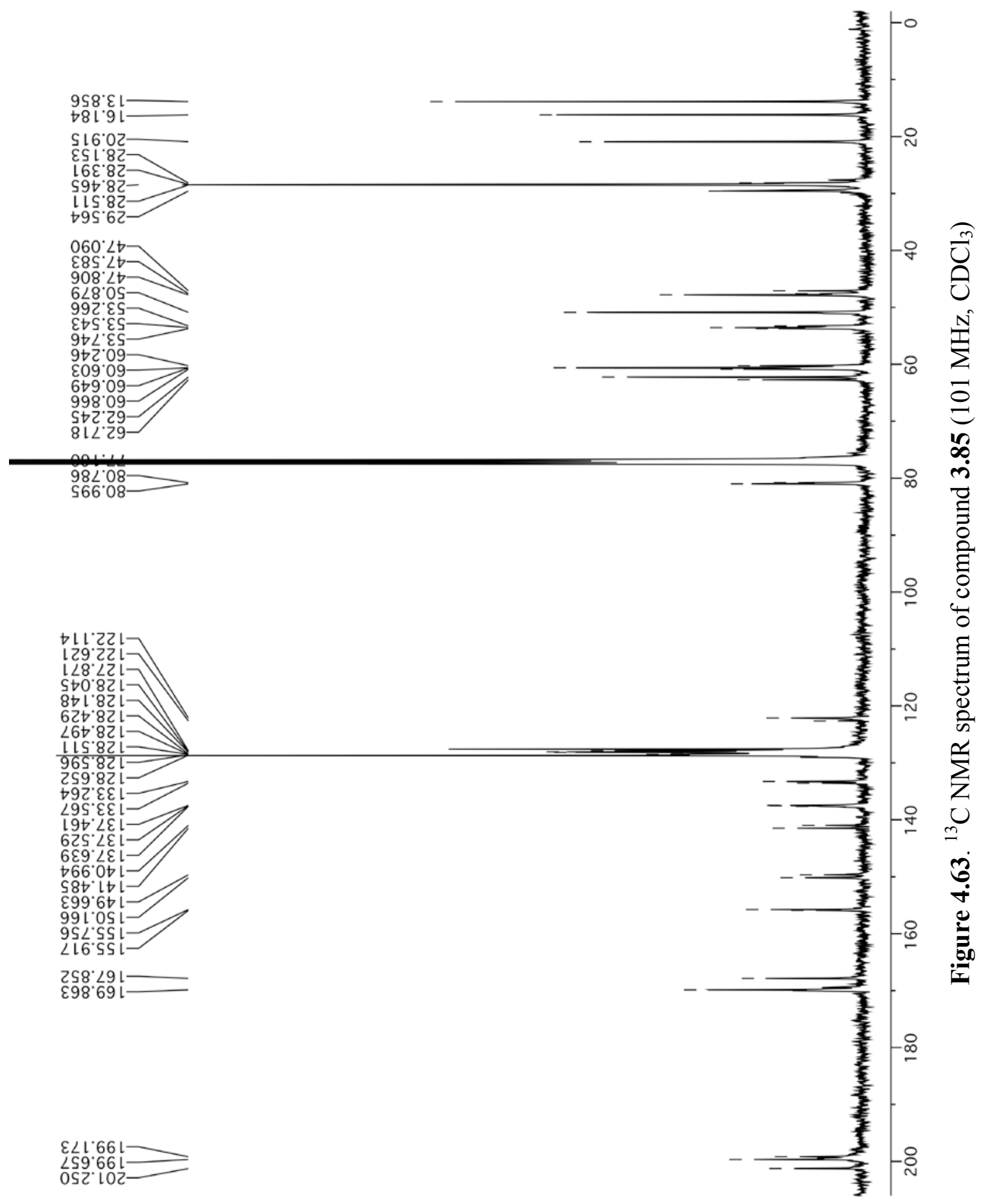



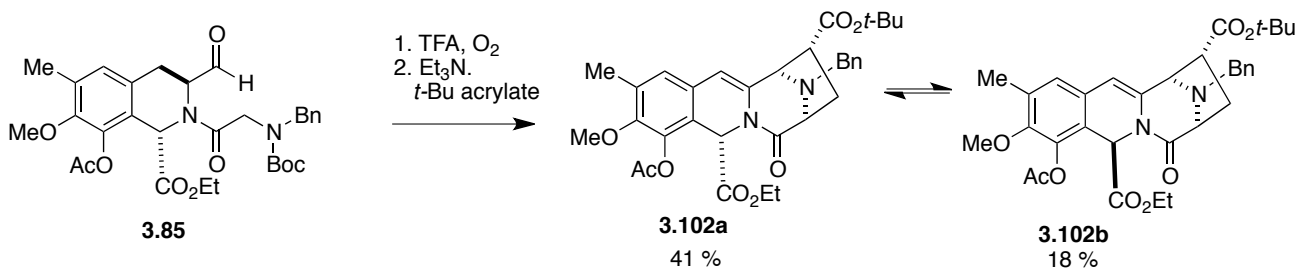

\section{$4.48(5 S, 8 S, 10 R, 11 S)$-10-tert-butyl 5-ethyl 4-acetoxy-13-benzyl-3-methoxy-2-methyl-7- oxo-5,7,8,9,10,11-hexahydro-8,11-epiminoazepino[1,2-b] isoquinoline-5,10-dicarboxylate} (3.102a) and $(5 R, 8 S, 10 R, 11 S)$-10-tert-butyl 5-ethyl 4-acetoxy-13-benzyl-3-methoxy-2methyl-7-oxo-5,7,8,9,10,11-hexahydro-8,11-epiminoazepino[1,2-b]isoquinoline-5,10dicarboxylate (3.102b)

To solution of compound 3.85 (1.65 g, $2.83 \mathrm{mmol}, 1.0$ eq.) in $\mathrm{CHCl}_{3}(28 \mathrm{~mL}, 0.1 \mathrm{M})$, under air, were added TEMPO (44 mg, $0.28 \mathrm{mmol}, 0.10$ eq.), and trifluoroacetic acid (10.8 mL, $142 \mathrm{mmol}$, 50 eq.) and the flask was loosely capped with a Teflon ${ }^{\circledR}$ stopper. The solution was stirred for $4 \mathrm{~h}$, the solvent was evaporated to dryness under vacuum and the residue was taken up in $\mathrm{CHCl}_{3}$. The solution was cooled to $0{ }^{\circ} \mathrm{C}$ and then tert-butyl acrylate $(8.20 \mathrm{~mL}, 56.6 \mathrm{mmol}, 20$ eq.) and triethylamine (3.95 mL, $28.3 \mathrm{mmol}, 10$ eq.) were added. The reaction was allowed to warm to RT and stirred overnight. The solution was diluted with EtOAc $(200 \mathrm{~mL})$, rinsed with sat. aq. $\mathrm{NH}_{4} \mathrm{Cl}(50 \mathrm{~mL})$ and brine $(50 \mathrm{~mL})$, dried $\left(\mathrm{Na}_{2} \mathrm{SO}_{4}\right)$, filtered, and concentrated under vacuum. The crude material was purified by flash chromatography (silica gel, hexanes/EtOAc 4:1, 3:1) to afford a 2.4:1 mixture of the title compounds 3.102a and 3.102b (985 mg, 59\%) as a yellow oil, which was used in the next step without further purification. ${ }^{1} \mathrm{H}-\mathrm{NMR}\left(400 \mathrm{MHz} ; \mathrm{CDCl}_{3}\right): \delta$ 7.41-7.22 $(\mathrm{m}, 5 \mathrm{H}), 6.74(\mathrm{~s}, 1 \mathrm{H}$, minor diastereomer), $6.73(\mathrm{~s}, 1 \mathrm{H}), 6.36(\mathrm{~s}, 1 \mathrm{H}$, minor diastereomer), $6.27(\mathrm{~s}, 1 \mathrm{H}), 5.51(\mathrm{~s}, 1 \mathrm{H}$, minor diastereomer), $5.50(\mathrm{~s}, 1 \mathrm{H}), 4.28-3.96(\mathrm{~m}, 6 \mathrm{H})$, 3.89-3.71 (m, 2H), 3.75 (s, 3H, minor diastereomer), $3.72(\mathrm{~s}, 3 \mathrm{H}), 2.80-2.67$ (m, 2H), 2.45 (dd, $J$ $=13.0,9.8 \mathrm{~Hz}, 1 \mathrm{H}$, minor diastereomer), $2.40(\mathrm{~s}, 3 \mathrm{H}), 2.39(\mathrm{~s}, 3 \mathrm{H}$, minor diastereomer $), 2.28(\mathrm{~s}$, 
3H, minor diastereomer), $2.26(\mathrm{~s}, 3 \mathrm{H}), 2.13(\mathrm{dd}, J=13.3,9.5 \mathrm{~Hz}, 1 \mathrm{H}), 1.46(\mathrm{~s}, 9 \mathrm{H}$, minor diastereomer), $1.42(\mathrm{~s}, 9 \mathrm{H}), 1.24(\mathrm{t}, J=7.1 \mathrm{~Hz}, 3 \mathrm{H}), 1.20(\mathrm{t}, J=7.2 \mathrm{~Hz}, 3 \mathrm{H}$, minor diastereomer); ${ }^{13} \mathrm{C}-\mathrm{NMR}\left(101 \mathrm{MHz}, \mathrm{CDCl}_{3}\right): \delta 172.4,171.7,168.7,167.9,149.9,141.6,133.1$, 129.0, 128.6, 128.4, 128.4, 127.4, 127.3, 126.6, 125.0, 124.8, 117.3, 116.7, 104.6, 103.1, 81.4, 81.3, 65.1, 64.1, 63.1, 62.6, 62.4, 62.3, 60.7, 60.6, 52.7, 51.8, 51.3, 50.7, 50.0, 48.0, 34.3, 31.9, $31.7,28.2,22.8,21.0,16.1,14.2,14.0 ; \mathrm{R}_{\mathrm{f}}\left(\mathrm{SiO}_{2}\right.$, hexanes/EtOAc $\left.3: 1\right) 0.5 ;[\alpha]_{\mathrm{D}}{ }^{25}=-65.0^{\circ}(\mathrm{c}=$ 0.320, $\mathrm{CH}_{2} \mathrm{Cl}_{2}$ ); IR (film, $\mathrm{CH}_{2} \mathrm{Cl}_{2}$ ), $v_{\max } 2980,2936,1781,1741,1693,1651 \mathrm{~cm}^{-1}$; HRMS $\left(\mathrm{MH}^{+}\right)$, found 591.2712. $\mathrm{C}_{33} \mathrm{H}_{39} \mathrm{~N}_{2} \mathrm{O}_{8}$ requires 591.2706. 


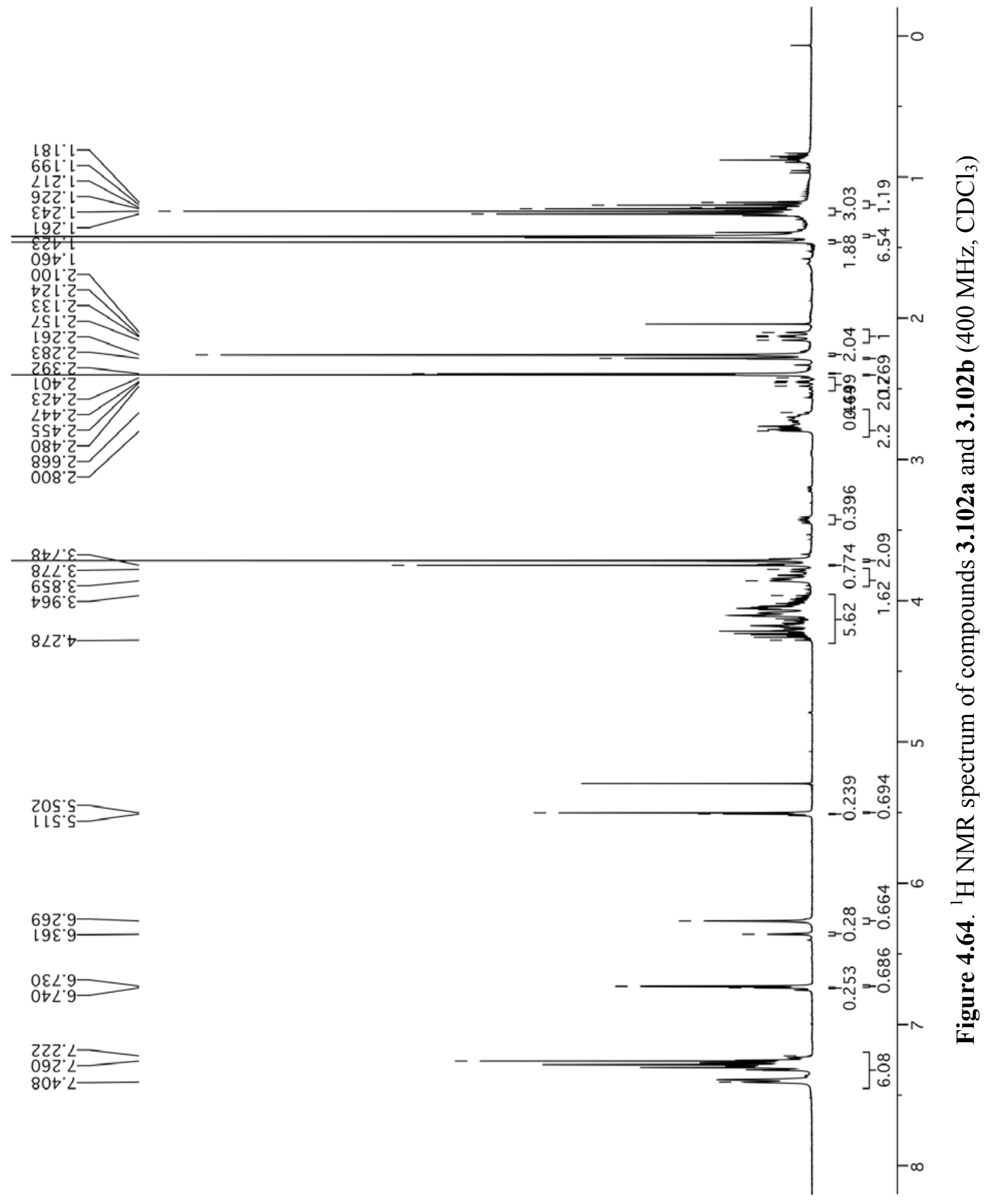




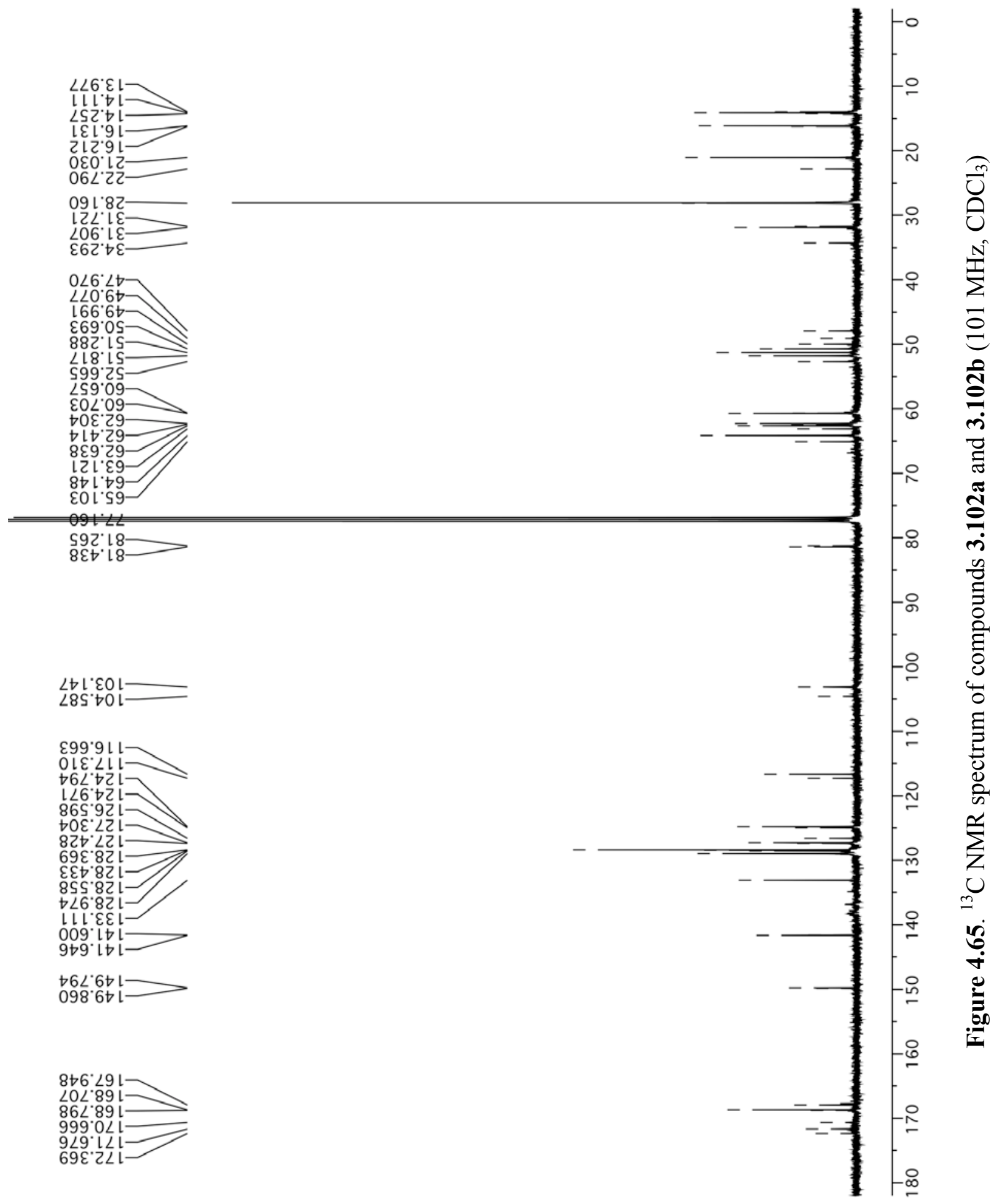




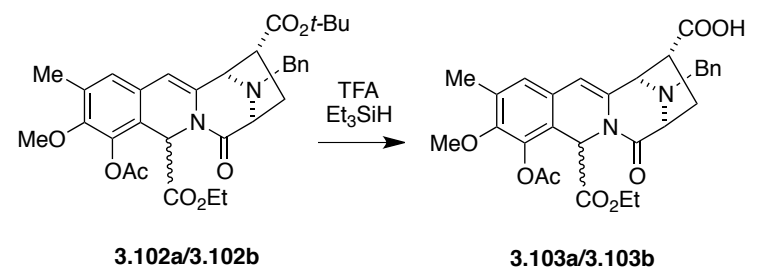

4.49 (8S,10R,11S)-4-acetoxy-13-benzyl-5-(ethoxycarbonyl)-3-methoxy-2-methyl-7-oxo5,7,8,9,10,11-hexahydro-8,11-epiminoazepino[1,2-b]isoquinoline-10-carboxylic acid

\section{(3.103a/3.103b)}

To a solution of a mixture of compounds 3.102a and 3.102b (110 mg, $0.186 \mathrm{mmol})$ in $\mathrm{CH}_{2} \mathrm{Cl}_{2}$ $(600 \mu \mathrm{L})$ at $0^{\circ} \mathrm{C}$, was added $\mathrm{Et}_{\mathrm{x}} \mathrm{SiH}(240 \mu \mathrm{L}, 1.5$ mmol, 8 eq.), followed by TFA $(600 \mu \mathrm{L}, 7.84$ mmol, 42 eq.). The resulting mixture was cooled to $5^{\circ} \mathrm{C}$. After $24 \mathrm{~h}$, the reaction concentrated to dryness and partitioned between $\mathrm{H}_{2} \mathrm{O}(10 \mathrm{~mL})$ and $\mathrm{CH}_{2} \mathrm{Cl}_{2}(25 \mathrm{~mL})$. The organic phase was washed with sat. aq. $\mathrm{NaHCO}_{3}(10 \mathrm{~mL})$, brine $(10 \mathrm{~mL})$, dried $\left(\mathrm{Na}_{2} \mathrm{SO}_{4}\right)$ and concentrated under vacuum. The resulting residue was purified by flash chromatography (hexanes:EtOAc 1:1 to 1:2) to provide a mixture of compounds $\mathbf{3 . 1 0 3 a} / \mathbf{3 . 1 0 3 b}$ as a colorless oil $(0.38 \mathrm{~g}, 95 \%$ yield $) . \mathrm{R}_{\mathrm{f}}=0.1$ (hexanes:EtOAc 1:2); ${ }^{1} \mathrm{H}-\mathrm{NMR}\left(300 \mathrm{MHz} ; \mathrm{CDCl}_{3}\right): \delta$ 7.41-7.32 (m, 5H), 6.83-6.81 (s, 1H), 6.78 $(\mathrm{s}, 1 \mathrm{H}), 6.38(\mathrm{~s}, 1 \mathrm{H}), 6.30(\mathrm{~s}, 1 \mathrm{H}), 5.66(\mathrm{~m}, 1 \mathrm{H}), 4.42-3.88(\mathrm{~m}, 13 \mathrm{H}), 3.76(\mathrm{~s}, 1 \mathrm{H}), 3.74(\mathrm{~s}, 3 \mathrm{H})$, $2.41(\mathrm{~s}, 3 \mathrm{H}), 2.31(\mathrm{~s}, 3 \mathrm{H}), 2.29(\mathrm{~s}, 3 \mathrm{H})$. 


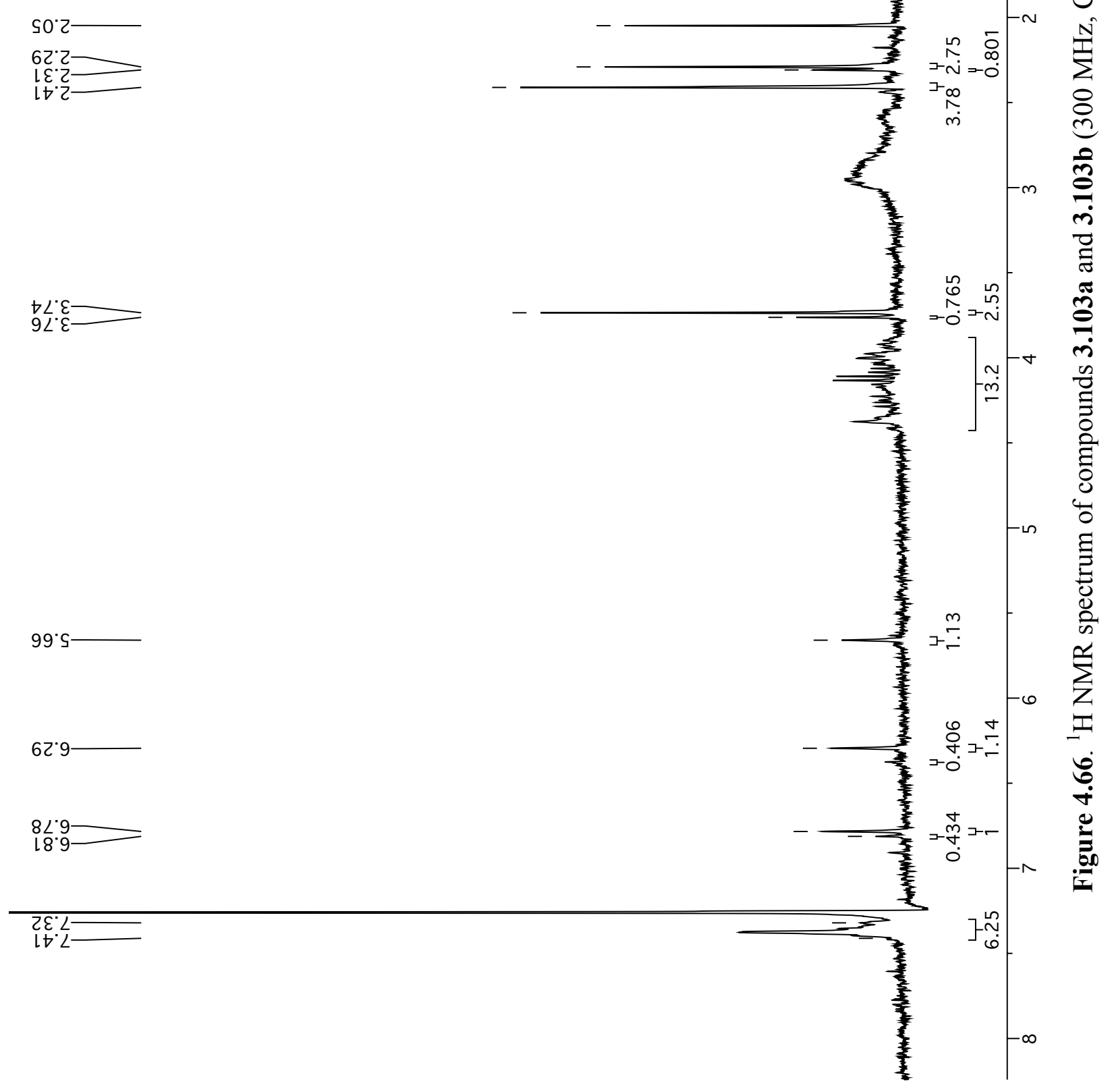




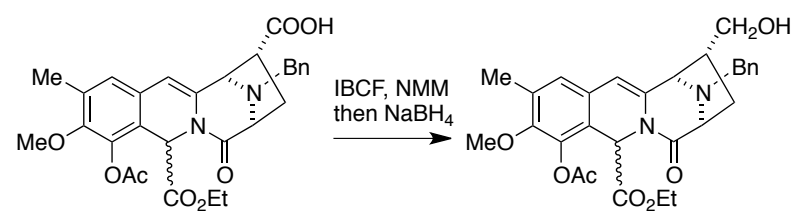

3.103a/3.103b

3.104a/3.104b

$4.50(8 S, 10 R, 11 S)$-ethyl 4-acetoxy-13-benzyl-10-(hydroxymethyl)-3-methoxy-2-methyl-7oxo-5,7,8,9,10,11-hexahydro-8,11-epiminoazepino[1,2-b]isoquinoline-5-carboxylate

\section{(3.104a/3.104b)}

To a solution of a mixture of compounds 3.103a and 3.103b (96 mg, $0.18 \mathrm{mmol})$ in THF (4 mL) at $0{ }^{\circ} \mathrm{C}$ was added $\mathrm{NMM}(27 \mu \mathrm{L}, 0.22 \mathrm{mmol}, 1.2$ eq.), followed by isobutyl chloroformate (29 $\mu \mathrm{L}, 0.25 \mathrm{mmol}, 1.4$ eq.). The reaction was then warmed to room temperature and after $20 \mathrm{~min}$ was filtered through Celite ${ }^{\circledR}$ and added to an ice-cold suspension of $\mathrm{NaBH}_{4}(68 \mathrm{mg}, 1.8 \mathrm{mmol}$, 10 eq.) in water $(4 \mathrm{~mL})$. The reaction mixture was stirred at $0{ }^{\circ} \mathrm{C}$ for 20 minutes and then quenched with $2 \mathrm{~N} \mathrm{HCl}(2 \mathrm{~mL})$. The resulting mixture was stirred for another 30 minutes at $0{ }^{\circ} \mathrm{C}$ and then diluted with water $(25 \mathrm{~mL})$, extracted with EtOAc $(3 \times 10 \mathrm{~mL})$, washed with brine $(25$ $\mathrm{mL})$, dried $\left(\mathrm{Na}_{2} \mathrm{SO}_{4}\right)$ and concentrated under vacuum. The resulting residue was purified by flash chromatography (hexanes:EtOAc 1:1) to give a mixture of compounds 3.104a and 3.104b as a colorless oil (42 mg, 45\%). $\mathrm{R}_{\mathrm{f}}=0.3$ (hexanes:EtOAc 1:1); ${ }^{1} \mathrm{H}-\mathrm{NMR}\left(300 \mathrm{MHz} ; \mathrm{CDCl}_{3}\right): \delta$ 7.37$7.29(\mathrm{~m}, 5 \mathrm{H}), 6.76(\mathrm{~s}, 1 \mathrm{H}), 6.72(\mathrm{~s}, 1 \mathrm{H}), 6.28(\mathrm{~s}, 1 \mathrm{H}), 5.50(\mathrm{~s}, 1 \mathrm{H}), 4.29-3.98(\mathrm{~m}, 6 \mathrm{H}), 3.83-3.74$ $(\mathrm{m}, 5 \mathrm{H}), 3.73(\mathrm{~s}, 3 \mathrm{H}), 3.57(\mathrm{dd}, J=10.2,5.3 \mathrm{~Hz}, 1 \mathrm{H}), 2.41(\mathrm{~s}, 3 \mathrm{H}), 2.27(\mathrm{~s}, 3 \mathrm{H}), 1.24(\mathrm{~d}, J=7.1$ $\mathrm{Hz}, 3 \mathrm{H}),(\mathrm{d}, J=7.1 \mathrm{~Hz}, 3 \mathrm{H})$. 


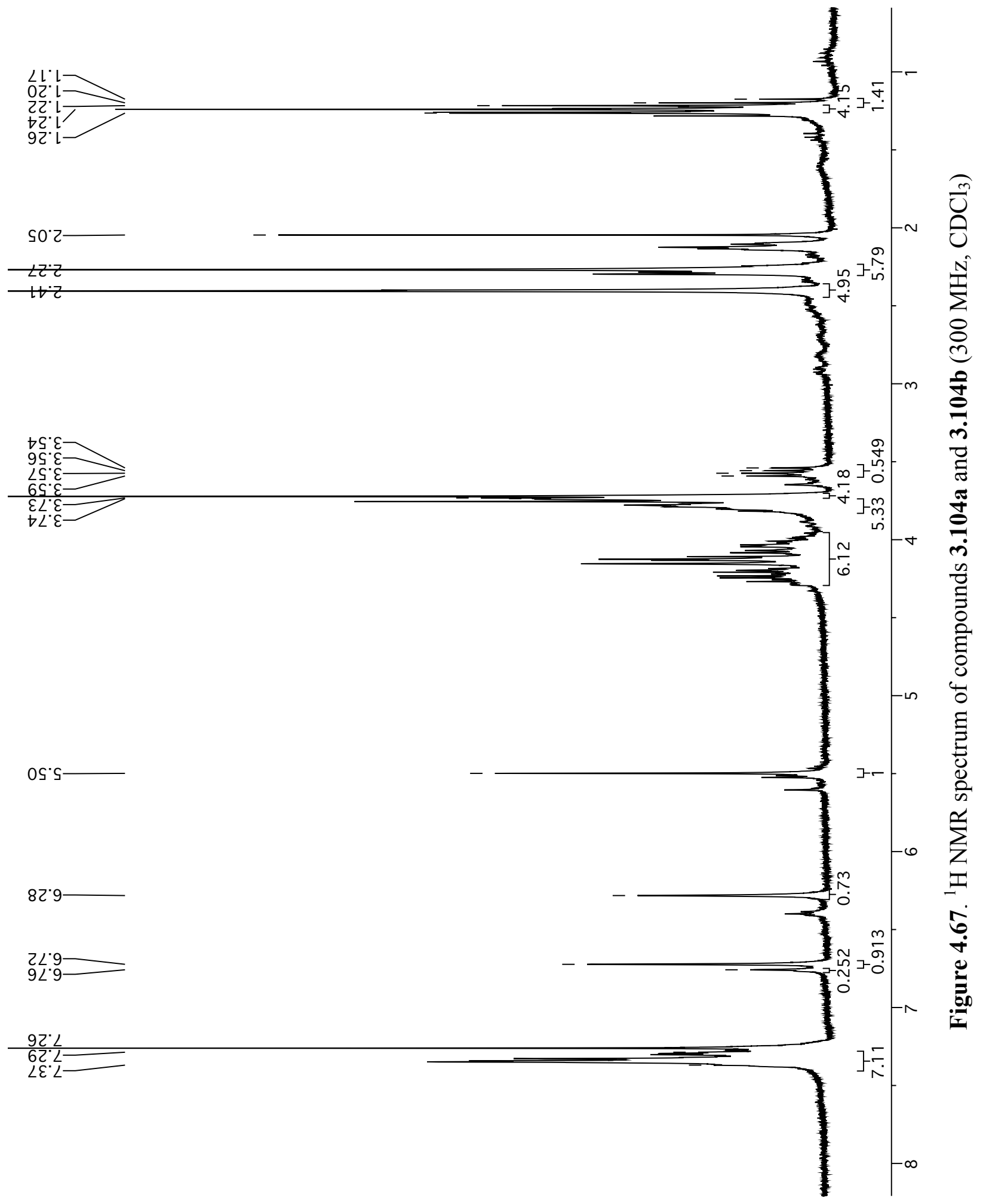




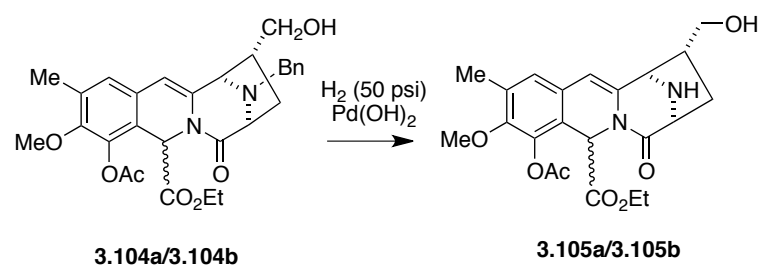

4.51 (8S,10R,11R)-ethyl 4-acetoxy-10-(hydroxymethyl)-3-methoxy-2-methyl-7-oxo-

\section{5,7,8,9,10,11-hexahydro-8,11-epiminoazepino[1,2-b]isoquinoline-5-carboxylate}

\section{(3.105a/3.105b)}

To a solution of a mixture of compounds 3.104a and 3.104b (10 mg, $0.019 \mathrm{mmol})$ in $\mathrm{MeOH}$ (1 $\mathrm{mL})$ in a $5 \mathrm{~mL}$ vial, was added Pearlman's catalyst $\left(20 \% \mathrm{Pd}(\mathrm{OH})_{2} / \mathrm{C}\right)$. The vial was placed in a Fisher-Porter bottle, under Ar, the suspension was sparged with Ar for 5 minutes and the vessel was filled with hydrogen gas at 50 psi. The reaction was vigorously stirred overnight and then suspension was filtered through Celite ${ }^{\circledR}$, using $\mathrm{MeOH}$ and EtOAc to transfer the material. The filtrate was concentrated under vacuum. The crude material was purified by flash chromatography (silica gel, $\mathrm{CHCl}_{3} / \mathrm{MeOH} 98: 2$ ) to afford a mixture of compounds 3.105a and 3.105b $(6 \mathrm{mg}, 75 \%)$ as a colorless oil. $\mathrm{R}_{\mathrm{f}}=0.2\left(\mathrm{CHCl}_{3} / \mathrm{MeOH} 95: 5\right) ;{ }^{1} \mathrm{H}-\mathrm{NMR}(300 \mathrm{MHz}$; $\left.\mathrm{CDCl}_{3}\right): \delta 6.72(\mathrm{~s}, 1 \mathrm{H}), 6.21(\mathrm{~s}, 1 \mathrm{H}), 5.57(\mathrm{~s}, 1 \mathrm{H}), 5.55(\mathrm{~s}, 1 \mathrm{H}), 4.18-3.83(\mathrm{~m}, 5 \mathrm{H}), 3.71(\mathrm{~s}, 3 \mathrm{H})$, 3.61-3.56 (m, 1H), 3.09-2.92 (m, 2H), $2.39(\mathrm{~s}, 3 \mathrm{H}), 2.26(\mathrm{~s}, 4 \mathrm{H}), 1.22-1.14(\mathrm{~m}, 3 \mathrm{H})$. 
92'て—

$6 \varepsilon \cdot 2$

$L L \mathcal{E}$

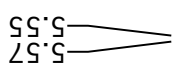

$12 \cdot 9$

$2 L 9$

$92^{\circ} \angle$

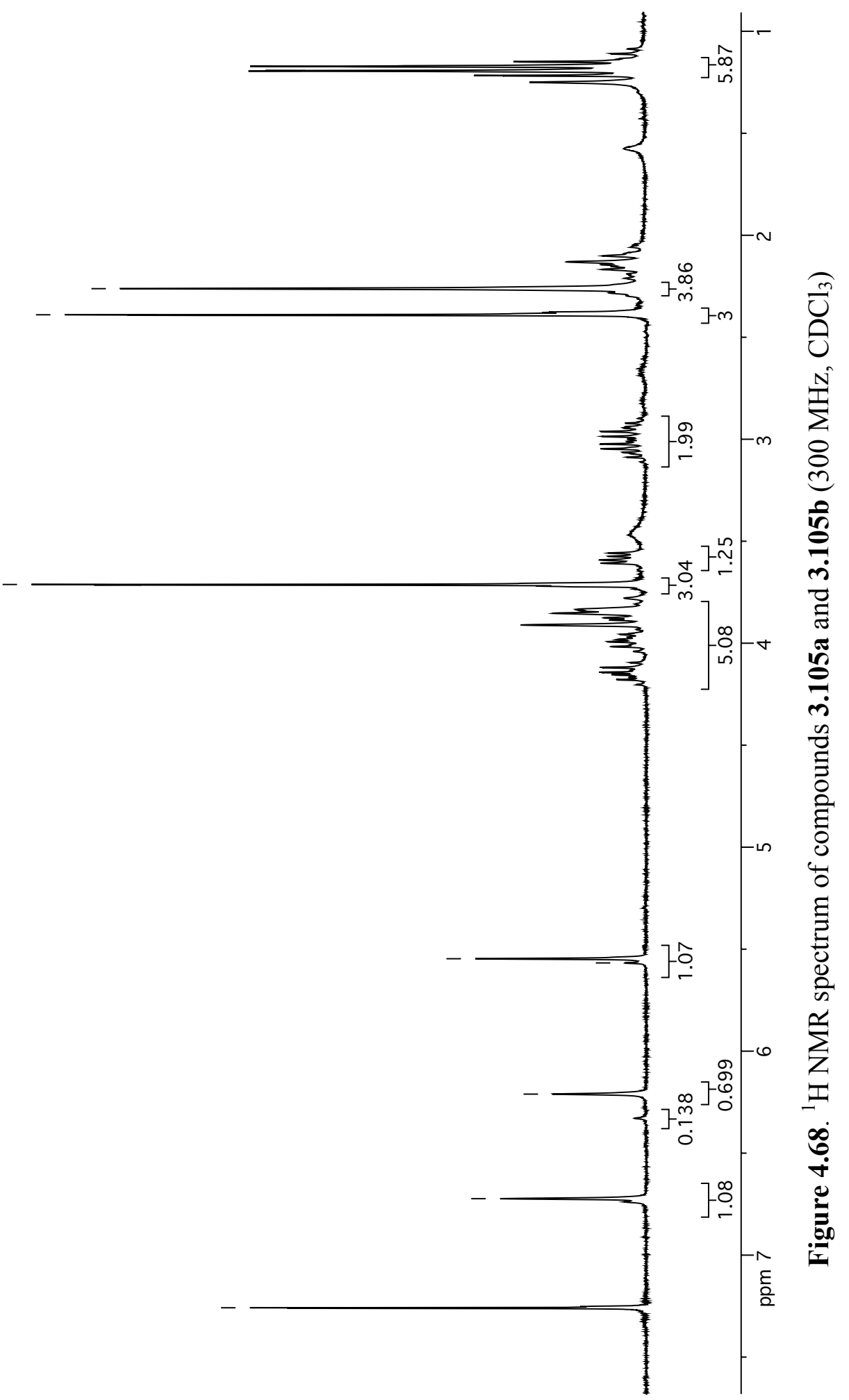




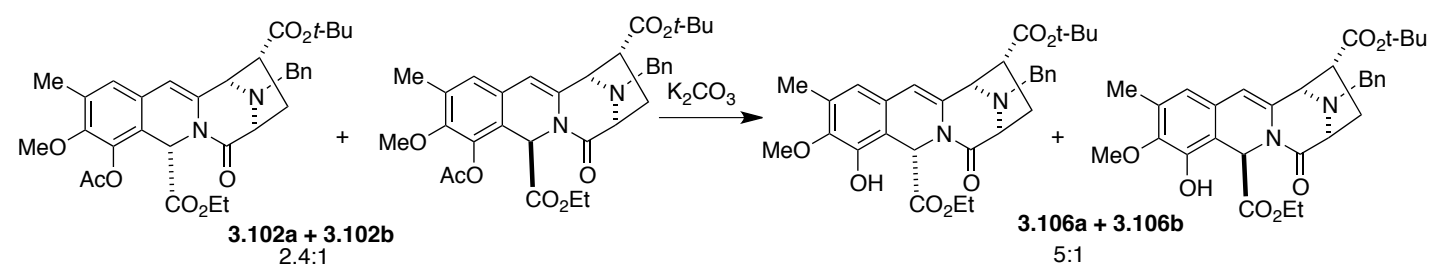

\subsection{2 (5S,8S,10R,11S)-10-tert-butyl 5-ethyl 13-benzyl-4-hydroxy-3-methoxy-2-methyl-7- oxo-5,7,8,9,10,11-hexahydro-8,11-epiminoazepino $[1,2-b]$ isoquinoline-5,10-dicarboxylate} (3.106a) and $(5 R, 8 S, 10 R, 11 S)$-10-tert-butyl 5-ethyl 13-benzyl-4-hydroxy-3-methoxy-2methyl-7-oxo-5,7,8,9,10,11-hexahydro-8,11-epiminoazepino[1,2-b]isoquinoline-5,10dicarboxylate (3.106b)

To a stirred solution of a 2.6:1 mixture of compounds 3.102a and 3.102b (410 mg, $0.695 \mathrm{mmol}$, 1.0 eq.) in THF/MeOH 1:1 (14 mL, $0.05 \mathrm{M})$, under $\mathrm{Ar}$, was added $\mathrm{K}_{2} \mathrm{CO}_{3}(192 \mathrm{mg}, 1.39 \mathrm{mmol}$, 2.0 eq.). The suspension was stirred for $2.5 \mathrm{~h}$, the solvent was evaporated and the residue was partitioned between phosphate buffer $(0.1 \mathrm{M}, \mathrm{pH}=7.5,50 \mathrm{~mL})$ and EtOAc $(33 \mathrm{~mL})$. The aqueous phase was extracted with EtOAc $(2 \times 33 \mathrm{~mL})$ and the combined organic layers were rinsed with brine $(50 \mathrm{~mL})$, dried $\left(\mathrm{Na}_{2} \mathrm{SO}_{4}\right)$, filtered, and concentrated under vacuum. The crude material was purified by flash chromatography (silica gel, hexanes/EtOAc 4:1) to afford a 5:1 mixture of the title compounds 3.106a and 3.106b (255 mg, 67\%) as a pale yellow oil, which was used in the next step without further purification. ${ }^{1} \mathrm{H}-\mathrm{NMR}\left(400 \mathrm{MHz} ; \mathrm{CDCl}_{3}\right): \delta$ 7.38-7.24 $(\mathrm{m}, 5 \mathrm{H}), 6.76(\mathrm{~s}, 1 \mathrm{H}), 6.63(\mathrm{~s}, 1 \mathrm{H}$, minor diastereomer), $6.49(\mathrm{~s}, 1 \mathrm{H}$, minor diastereomer), 6.43 $(\mathrm{s}, 1 \mathrm{H}$, minor diastereomer), $6.42(\mathrm{~s}, 1 \mathrm{H}), 6.39(\mathrm{~s}, 5 \mathrm{H}), 5.46(\mathrm{~s}, 1 \mathrm{H}$, minor diastereomer), $5.45(\mathrm{~s}$, 1H. minor diastereomer), $4.24(\mathrm{q}, J=7.1 \mathrm{~Hz}, 2 \mathrm{H}), 4.19-3.9(\mathrm{~m}, 5 \mathrm{H}), 4.07(\mathrm{~s}, 1 \mathrm{H}), 3.86(\mathrm{~d}, J=$ $7.5 \mathrm{~Hz}, 1 \mathrm{H}), 3.84(\mathrm{~s}, 1 \mathrm{H}$, minor diastereomer), $3.82(\mathrm{~s}, 3 \mathrm{H}), 3.31(\mathrm{dd}, J=9.8,6.0 \mathrm{~Hz}, 1 \mathrm{H}$, minor diastereomer), $2.79(\mathrm{dd}, J=9.5,4.6 \mathrm{~Hz}, 1 \mathrm{H}), 2.74-2.66(\mathrm{~m}, 1 \mathrm{H}), 2.46(\mathrm{dd}, J=13.0,9.9 \mathrm{~Hz}, 1 \mathrm{H}$, 
minor diastereomer), 2.26 (s, 3H, minor diastereomer), 2.24 (s, 3H), 2.13 (dd, $J=13.4,9.6 \mathrm{~Hz}$, 6H), 1.46 (s, 9H, minor diastereomer), $1.42(\mathrm{~s}, 9 \mathrm{H}), 1.27(\mathrm{t}, J=7.1 \mathrm{~Hz}, 3 \mathrm{H}), 1.24$ (t, $J=7.2 \mathrm{~Hz}$, $3 \mathrm{H}$, minor diastereomer); ${ }^{13} \mathrm{C}-\mathrm{NMR}\left(101 \mathrm{MHz}, \mathrm{CDCl}_{3}\right): \delta 172.4,171.9,170.7,170.6,170.4$, $168.9,146.9,146.8,146.2,138.5,138.0,136.1,134.2,131.9,131.7,128.5,127.4,127.3,126.6$, $126.0,119.1,119.1,110.8,103.4,81.3,64.3,62.7,62.6,60.8,60.8,52.2,52.2,52.1,51.5,50.8$, $48.2,32.1,28.2,28.1,22.8,15.9,14.3 ; \mathrm{R}_{\mathrm{f}}\left(\mathrm{SiO}_{2}\right.$, hexanes/EtOAc $\left.2: 1\right) 0.45 ;[\alpha]_{\mathrm{D}}^{25}=-73.6^{\circ}(\mathrm{c}=$ 0.282, $\mathrm{CH}_{2} \mathrm{Cl}_{2}$ ); IR (film, $\mathrm{CH}_{2} \mathrm{Cl}_{2}$ ), $v_{\max } 3374$ (br), 2980, 2938, 1736, 1689, 1647, $1154 \mathrm{~cm}^{-1}$; HRMS $\left(\mathrm{MH}^{+}\right)$, found 549.2606. $\mathrm{C}_{31} \mathrm{H}_{37} \mathrm{~N}_{2} \mathrm{O}_{7}$ requires 549.2601. 


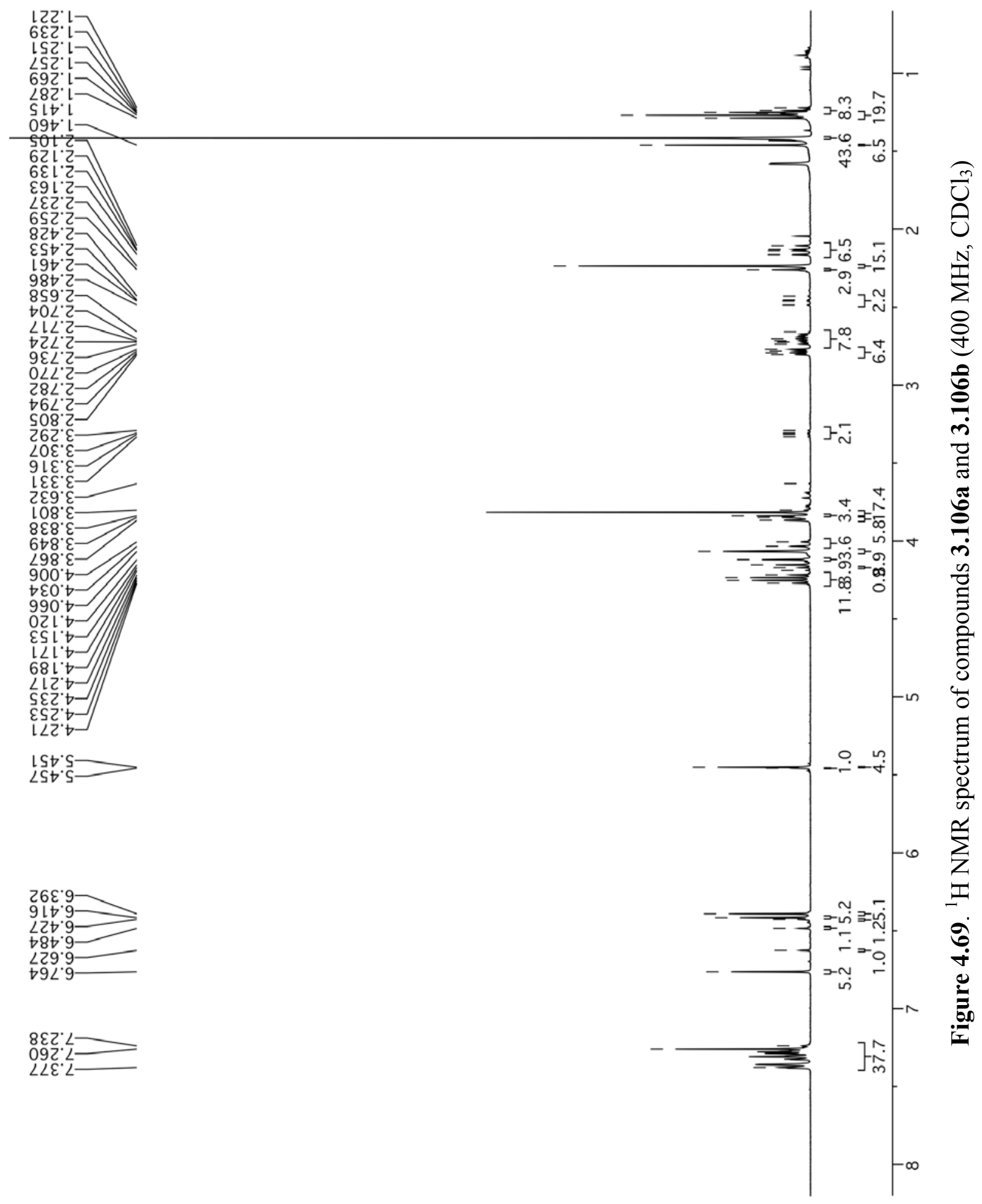




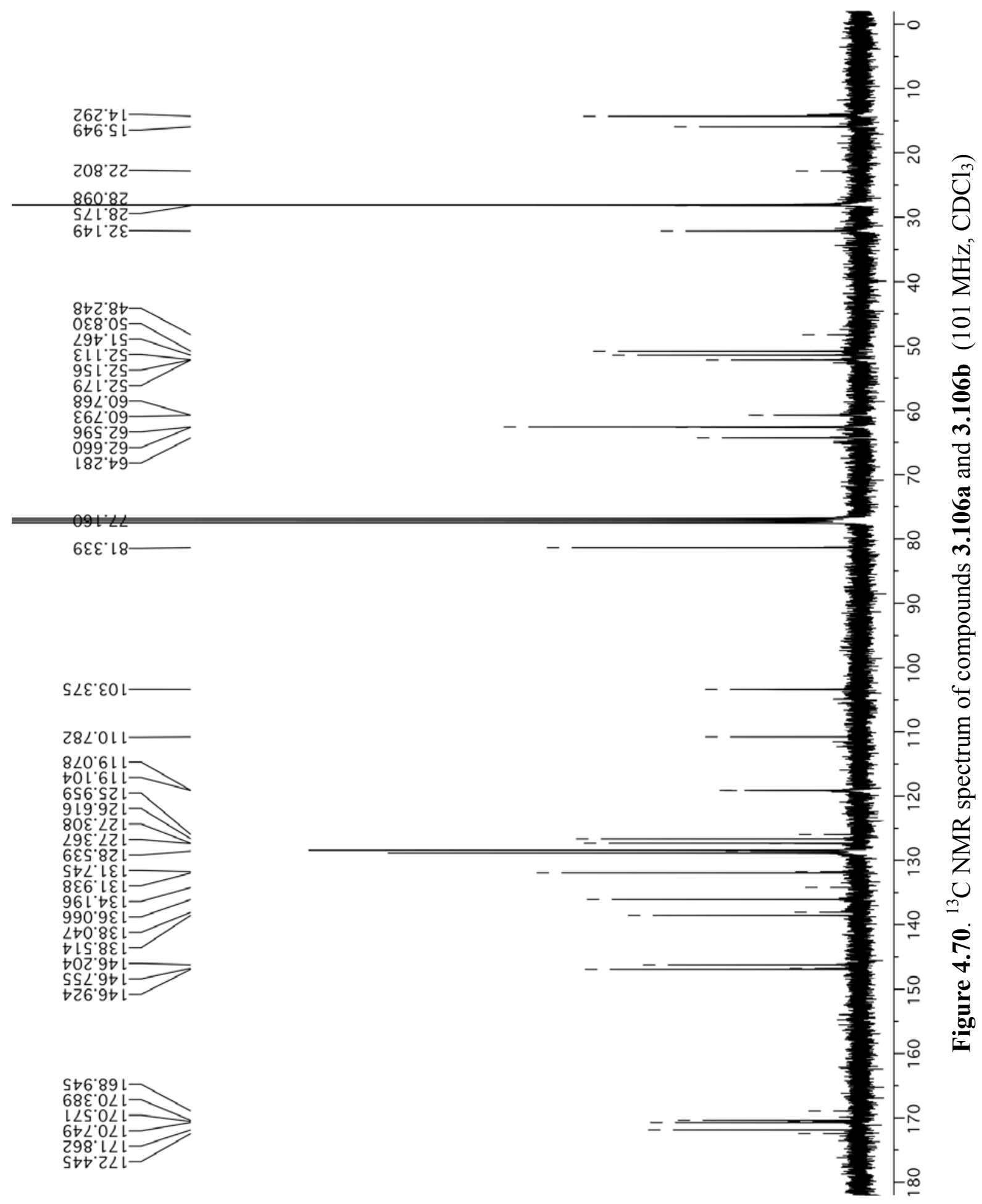




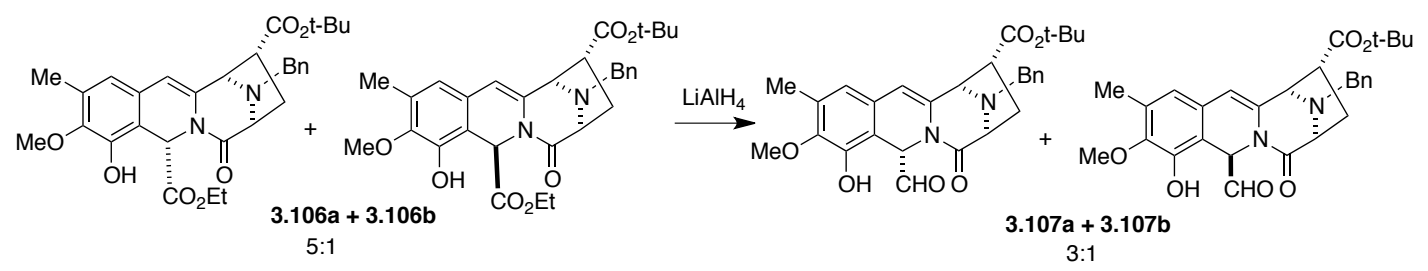

4.53 (5S,8S,10R,11S)-tert-butyl 13-benzyl-5-formyl-4-hydroxy-3-methoxy-2-methyl-7oxo-5,7,8,9,10,11-hexahydro-8,11-epimino-azepino[1,2-b]isoquinoline-10-carboxylate (3.107a) and (5R,8S,10R,11S)-tert-butyl 13-benzyl-5-formyl-4-hydroxy-3-methoxy-2methyl-7-oxo-5,7,8,9,10,11-hexahydro-8,11-epiminoazepino[1,2-b]isoquinoline-10carboxylate $(3.107 b)$

A solution of $\mathrm{LiAlH}_{4}$ in THF $(1.0 \mathrm{M}, 447 \mu \mathrm{L}, 0.447 \mathrm{mmol}, 1.0$ eq.) was added dropwise to a solution of a 5:1 mixture of compounds $\mathbf{3 . 1 0 6 a}$ and $\mathbf{3 . 1 0 6 b}$ (245 $\mathrm{mg}, 0.447 \mathrm{mmol}, 1.0$ eq.) in THF ( $9 \mathrm{~mL}, 0.05 \mathrm{M})$, under Ar, at $-10^{\circ} \mathrm{C}$. The solution was stirred for 10 minutes at this temperature, quenched with EtOAc $(12 \mathrm{~mL})$ and sat. aq. Rochelle's salt $(12 \mathrm{~mL})$ and allowed to warm to RT. The flask was covered with aluminum foil and stirred overnight under a stream of Ar. The solution was diluted with phosphate buffer $(0.1 \mathrm{M}, \mathrm{pH}=7.5,50 \mathrm{~mL})$, the phases were separated and aqueous phase was extracted with EtOAc $(3 \times 33 \mathrm{~mL})$ and the combined organic layers were rinsed with brine $(25 \mathrm{~mL})$, dried $\left(\mathrm{Na}_{2} \mathrm{SO}_{4}\right)$, filtered, and concentrated under vacuum. The crude material was purified by flash chromatography (silica gel, hexanes/EtOAc $4: 1$ ) to afford a 3:1 mixture of the title compounds 3.107a and 3.107b (124 mg, 55\%) as a pale yellow oil, which was used in the next step without further purification. ${ }^{1} \mathrm{H}-\mathrm{NMR}\left(400 \mathrm{MHz} ; \mathrm{CDCl}_{3}\right): \delta$ $9.48(\mathrm{~s}, 1 \mathrm{H}), 9.38(\mathrm{~s}, 1 \mathrm{H}$, minor diastereomer $), 7.41-7.23(\mathrm{~m}, 5 \mathrm{H}), 6.58(\mathrm{~s}, 1 \mathrm{H}), 6.57(\mathrm{~s}, 1 \mathrm{H}$, minor diastereomer), $6.43(\mathrm{~s}, 1 \mathrm{H}$, minor diastereomer $), 6.41(\mathrm{~s}, 1 \mathrm{H}), 6.18(\mathrm{~s}, 1 \mathrm{H}$, minor diastereomer), $6.17(\mathrm{~s}, 1 \mathrm{H}$, minor diastereomer $), 4.25(1 / 2 \mathrm{AB}, J=13.5 \mathrm{~Hz}, 1 \mathrm{H}), 4.18(1 / 2 \mathrm{AB}, J$ $=13.5 \mathrm{~Hz}, 1 \mathrm{H}), 4.07(\mathrm{~s}, 1 \mathrm{H}), 4.00(\mathrm{~s}, 1 \mathrm{H}$, minor diastereomer $), 3.83(\mathrm{~s}, 3 \mathrm{H}$, minor diastereomer $)$, 
3.81 (s, 3H, minor diastereomer), 3.40 (dd, $J=9.7,6.0 \mathrm{~Hz}, 1 \mathrm{H}$, minor diastereomer), 2.81 (dd, $J$ $=9.5,4.7 \mathrm{~Hz}, 1 \mathrm{H}), 2.73-2.67(\mathrm{~m}, 1 \mathrm{H}), 2.59(\mathrm{dd}, J=13.0,9.8 \mathrm{~Hz}, 1 \mathrm{H}$, minor diastereomer), 2.28 (s, 3H, minor diastereomer), $2.26(\mathrm{~s}, 3 \mathrm{H}), 2.15(\mathrm{dd}, J=13.4,9.6 \mathrm{~Hz}, 1 \mathrm{H}), 1.48(\mathrm{~s}, 9 \mathrm{H}$, minor diastereomer), $1.46(\mathrm{~s}, 9 \mathrm{H}) ;{ }^{13} \mathrm{C}-\mathrm{NMR}\left(101 \mathrm{MHz}, \mathrm{CDCl}_{3}\right): \delta 192.1,191.3,172.5,171.9,170.1$, $145.7,144.6,138.6,138.0,136.6,135.3,131.5,128.8,128.4,127.5,127.2,119.4,119.2,107.3$ $104.0,102.7,102.6,81.4,64.1,64.0,62.9,62.8,61.2,61.1,58.6,58.5,51.6,50.8,48.8,34.7$, 32.4, 31.7, 29.8, 28.1, 22.8, 16.0, 14.3; $\mathrm{Rf}\left(\mathrm{SiO}_{2}\right.$, hexanes/EtOAc 2:1) $0.42 ;[\alpha]_{\mathrm{D}}^{25}=-64.8^{\circ}(\mathrm{c}=$ 0.250, $\mathrm{CH}_{2} \mathrm{Cl}_{2}$ ); IR (film, $\mathrm{CH}_{2} \mathrm{Cl}_{2}$ ), $v_{\max } 3331$ (br), 2977, 2935, 1733, 1679, 1642, $1154 \mathrm{~cm}^{-1}$; HRMS $\left(\mathrm{MH}^{+}\right)$, found 505.2345. $\mathrm{C}_{29} \mathrm{H}_{33} \mathrm{~N}_{2} \mathrm{O}_{6}$ requires 505.2339. 


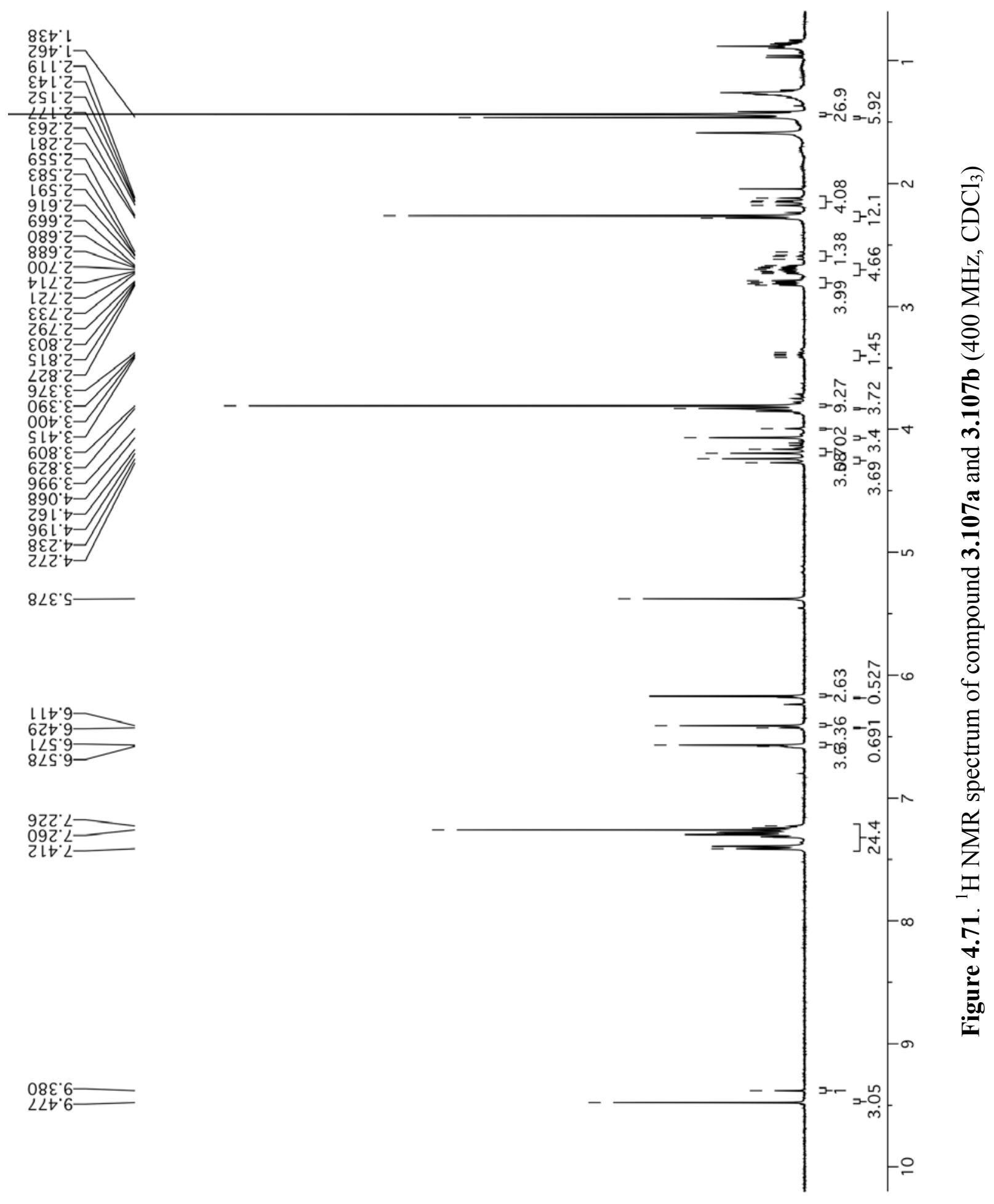




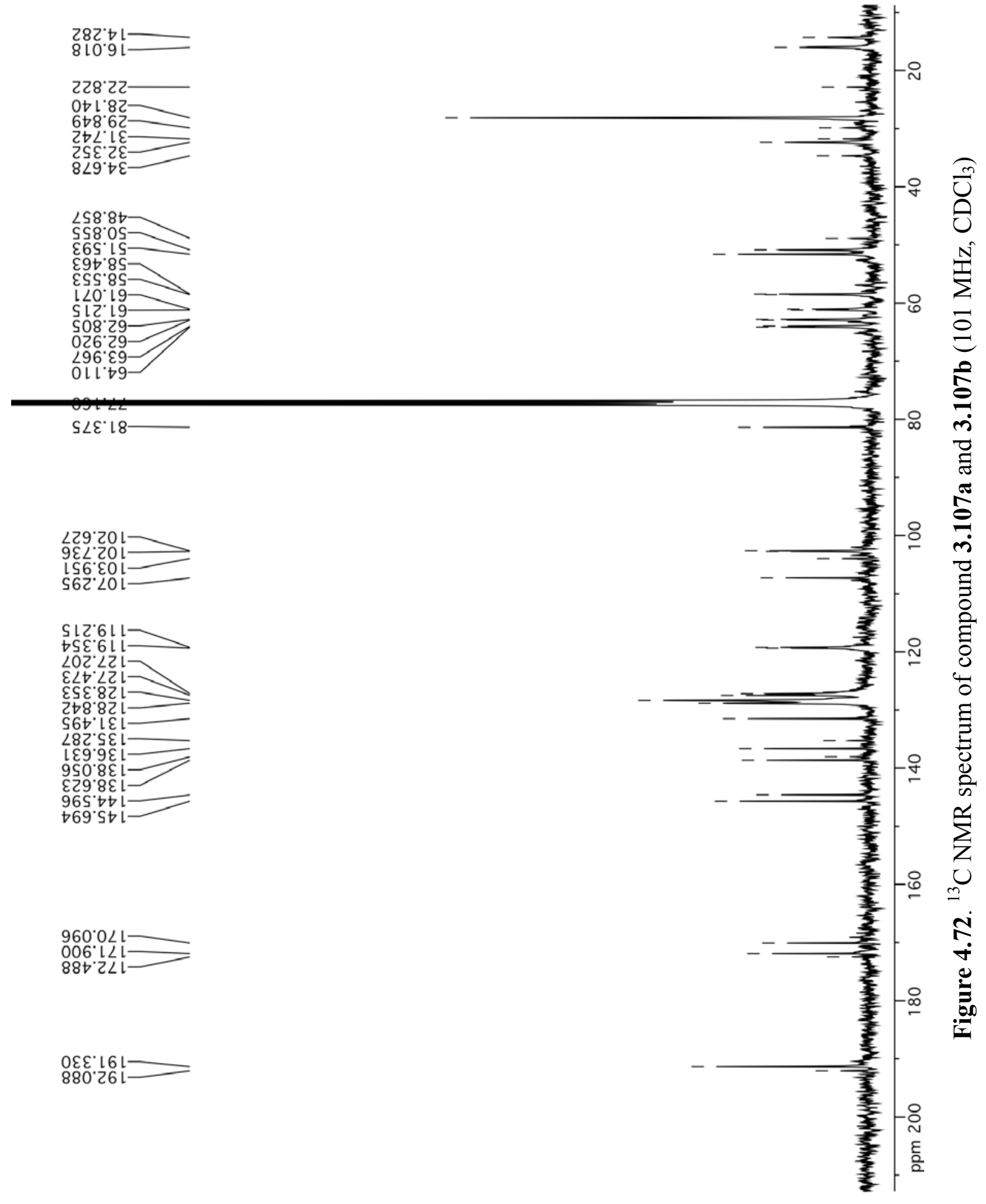




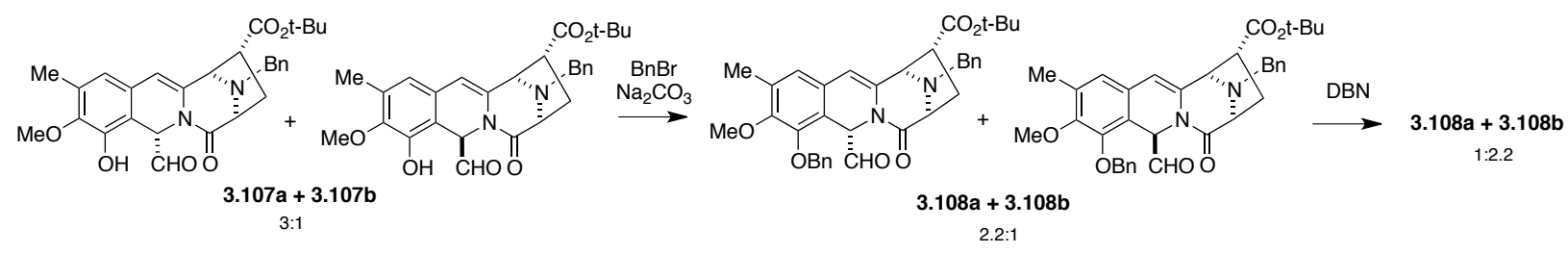

\section{$4.54(5 S, 8 S, 10 R, 11 S)$-tert-butyl 13-benzyl-4-(benzyloxy)-5-formyl-3-methoxy-2-methyl-7- oxo-5,7,8,9,10,11-hexahydro-8,11-epiminoazepino[1,2-b]isoquinoline-10-carboxylate} (3.108a) and $(5 R, 8 S, 10 R, 11 S)$-tert-butyl 13-benzyl-4-(benzyloxy)-5-formyl-3-methoxy-2methyl-7-oxo-5,7,8,9,10,11-hexahydro-8,11-epiminoazepino[1,2-b]isoquinoline-10carboxylate (5R,8S,10R,11S)-tert-butyl 13-benzyl-4-(benzyloxy)-5-formyl-3-methoxy-2methyl-7-oxo-5,7,8,9,10,11-hexahydro-8,11-epiminoazepino[1,2-b]isoquinoline-10carboxylate (3.108b)

To a stirred solution of a 3:1 mixture of compounds 3.107a and 3.107b $(115 \mathrm{mg}, 0.228 \mathrm{mmol}$, 1.0 eq.) and benzyl bromide (108 $\mu \mathrm{L}, 0.912 \mathrm{mmol}, 4.0$ eq.) in DMF (7.6 mL, $0.03 \mathrm{M})$, under Ar, were added tetrabutylammonium iodide $(9.0 \mathrm{mg}, 0.023 \mathrm{mmol}, 0.10 \mathrm{eq}$.$) and finely ground$ anhydrous $\mathrm{Na}_{2} \mathrm{CO}_{3}(241 \mathrm{mg}, 2.28 \mathrm{mmol}, 10$ eq.). The mixture was vigorously stirred for $2 \mathrm{~h}$ and diluted with water $(25 \mathrm{~mL})$ and phosphate buffer $(0.1 \mathrm{M}, \mathrm{pH}=7.5,25 \mathrm{~mL})$. The aqueous phase was extracted with EtOAc $(3 \times 33 \mathrm{~mL})$ and the combined organic layers were rinsed with brine $(25 \mathrm{~mL})$, dried $\left(\mathrm{Na}_{2} \mathrm{SO}_{4}\right)$, filtered, and concentrated under vacuum. The crude material was purified by flash chromatography (silica gel, hexanes/EtOAc 6:1, 4:1) to afford a 2.2:1 mixture of compounds 3.108a and 3.108b ( $88 \mathrm{mg}, 65 \%$ ) as a pale yellow oil, which was used in the next step without further purification. ${ }^{1} \mathrm{H}-\mathrm{NMR}\left(400 \mathrm{MHz} ; \mathrm{CDCl}_{3}\right)$ : $\delta 9.32(\mathrm{~s}, 1 \mathrm{H}), 9.19$ (s, $1 \mathrm{H}$ minor diastereomer), 7.48-7.22 (m, 10H), $6.63(\mathrm{~s}, 1 \mathrm{H}$, minor diastereomer), $6.62(\mathrm{~s}, 1 \mathrm{H}), 6.38(\mathrm{~s}, 1 \mathrm{H}$, minor diastereomer), $6.36(\mathrm{~s}, 1 \mathrm{H}), 5.37(\mathrm{~s}, 1 \mathrm{H}), 5.36$ (s, minor diastereomer), $5.28(1 / 2 \mathrm{AB}, J=$ 
$11.1 \mathrm{~Hz}, 1 \mathrm{H}$, minor diastereomer), $5.26(1 / 2 \mathrm{AB}, J=11.1 \mathrm{~Hz}, 2 \mathrm{H}), 5.20(1 / 2 \mathrm{AB}, J=11.1 \mathrm{~Hz}$, $1 \mathrm{H}$, minor diastereomer), $5.14(1 / 2 \mathrm{AB}, J=11.1 \mathrm{~Hz}, 1 \mathrm{H}), 4.20(1 / 2 \mathrm{AB}, J=13.5 \mathrm{~Hz}, 1 \mathrm{H}), 4.14$ $(1 / 2 \mathrm{AB}, J=13.5 \mathrm{~Hz}, 1 \mathrm{H}), 4.05(\mathrm{~s}, 1 \mathrm{H}), 3.97(\mathrm{~s}, 1 \mathrm{H}$, minor diastereomer), $3.86(\mathrm{~s}, 3 \mathrm{H}$, minor diastereomer), $3.84(\mathrm{~s}, 3 \mathrm{H}), 3.80(1 / 2 \mathrm{AB}, J=13.5 \mathrm{~Hz}, 1 \mathrm{H}) 3.79(\mathrm{~d}, J=7.4 \mathrm{~Hz}, 1 \mathrm{H}), 3.75(\mathrm{~d}, J=$ $6.9 \mathrm{~Hz}$, minor diastereomer), $3.68(1 / 2 \mathrm{AB}, J=13.5 \mathrm{~Hz}, 1 \mathrm{H}$, minor diastereomer), 3.37 (dd, $J=$ 9.7, $6.1 \mathrm{~Hz}, 1 \mathrm{H}$, minor diastereomer), $2.78(\mathrm{dd}, J=9.6,4.7 \mathrm{~Hz}, 1 \mathrm{H}), 2.71-2.64(\mathrm{~m}, 2 \mathrm{H}), 2.53(1 / 2$ ABX, $J=13.1,9.9 \mathrm{~Hz}, 1 \mathrm{H}$, minor diastereomer), 2.28 (s, 3H, minor diastereomer), $2.26(\mathrm{~s}, 3 \mathrm{H})$, $2.10(\mathrm{dd}, J=13.3,9.7 \mathrm{~Hz}, 1 \mathrm{H}), 1.45\left(\mathrm{~s}, 9 \mathrm{H}\right.$ minor diastereomer), $1.44(\mathrm{~s}, 9 \mathrm{H}) ;{ }^{13} \mathrm{C}-\mathrm{NMR}(101$ $\left.\mathrm{MHz}, \mathrm{CDCl}_{3}\right): \delta 192.5,191.7,171.9,169.8,168.8,150.4,150.3,148.3,148.1,138.6,138.1$, $136.9,136.9,136.6,135.3,133.7,128.9,128.8,128.8,128.6,128.6,128.5,128.5,128.4,128.3$, $127.4,127.2,126.9,123.1,122.8,115.0,114.6,103.9,102.5,81.4,81.2,75.0,75.0,65.0,63.9$, $63.1,62.8,60.5,58.8,57.3,52.8,51.6,48.8,34.7,32.2,28.2,16.0,16.0 ; \mathrm{R}_{\mathrm{f}}\left(\mathrm{SiO}_{2}\right.$ hexanes/EtOAc 4:1) 0.45; $[\alpha]_{\mathrm{D}}{ }^{25}=-64^{\circ}\left(\mathrm{c}=0.32, \mathrm{CH}_{2} \mathrm{Cl}_{2}\right)$; IR (film, $\left.\mathrm{CH}_{2} \mathrm{Cl}_{2}\right), v_{\max } 3030,2976$, 2934, 1733, 1688, 1646, $1154 \mathrm{~cm}^{-1}$; HRMS $\left(\mathrm{MH}^{+}\right)$, found 595.2801. $\mathrm{C}_{36} \mathrm{H}_{39} \mathrm{~N}_{2} \mathrm{O}_{6}$ requires 595.2808 .

To a stirred solution of a 2.2:1 mixture of compounds 3.108a and 3.108b ( $88 \mathrm{mg}, 0.15 \mathrm{mmol}, 1.0$ eq.) in THF ( $2 \mathrm{~mL}, 0.08 \mathrm{M})$, under $\mathrm{Ar}$, was added DBN (19 $\mu \mathrm{L}, 0.15 \mathrm{mmol}, 1.0$ eq.). The mixture was stirred for 30 minutes and then diluted with phosphate buffer $(0.1 \mathrm{M}, \mathrm{pH}=7.5,50$ $\mathrm{mL})$ and water $(50 \mathrm{~mL})$. The aqueous phase was extracted with EtOAc $(3 \times 33 \mathrm{~mL})$ and the combined organic layers were rinsed with brine $(25 \mathrm{~mL})$, dried $\left(\mathrm{Na}_{2} \mathrm{SO}_{4}\right)$, filtered, and concentrated under vacuum. The crude material was dissolved in the minimal amount of EtOAc purified by flash chromatography (silica gel, hexanes/EtOAc 4:1) to afford a 1:2.2 mixture of compounds 3.108a and 3.108b (64 mg, 72\%) as a pale yellow oil, which was used in the next 
step without further purification. ${ }^{1} \mathrm{H}-\mathrm{NMR}\left(400 \mathrm{MHz} ; \mathrm{CDCl}_{3}\right): \delta 9.32$ (s, $1 \mathrm{H}$, minor diastereomer), $9.19(\mathrm{~s}, 1 \mathrm{H}), 7.48-7.24(\mathrm{~m}, 10 \mathrm{H}), 6.63(\mathrm{~s}, 1 \mathrm{H}), 6.62(\mathrm{~s}, 1 \mathrm{H}$, minor diastereomer), $6.38(\mathrm{~s}, 1 \mathrm{H}), 6.36(\mathrm{~s}, 1 \mathrm{H}$, minor diastereomer), $5.37(\mathrm{~s}, 1 \mathrm{H}$, minor diastereomer), $5.36(\mathrm{~s}, 1 \mathrm{H})$, $5.28(1 / 2 \mathrm{AB}, J=11.1 \mathrm{~Hz}, 1 \mathrm{H}), 5.26(1 / 2 \mathrm{AB}, J=11.1 \mathrm{~Hz}, 1 \mathrm{H}$, minor diastereomer $), 5.19(1 / 2$ $\mathrm{AB}, J=11.1 \mathrm{~Hz}, 1 \mathrm{H}), 5.13(1 / 2 \mathrm{AB}, J=11.2 \mathrm{~Hz}, 2 \mathrm{H}$, minor diastereomer $), 4.20(1 / 2 \mathrm{AB}, J=$ 13.4 Hz, $1 \mathrm{H}$, minor diastereomer), $4.14(1 / 2 \mathrm{AB}, J=13.5 \mathrm{~Hz}, 1 \mathrm{H}$ minor diastereomer), 4.05 (s, $1 \mathrm{H}$, minor diastereomer), $3.97(\mathrm{~s}, 1 \mathrm{H}), 3.86(\mathrm{~s}, 3 \mathrm{H}$, minor diastereomer), $3.84(\mathrm{~s}, 3 \mathrm{H}$, minor diastereomer), $3.81(1 / 2 \mathrm{AB}, J=13.6 \mathrm{~Hz}, 1 \mathrm{H}), 3.79(\mathrm{~d}, J=6.2 \mathrm{~Hz}, 4 \mathrm{H}), 3.75(\mathrm{~d}, J=6.6 \mathrm{~Hz}, 3 \mathrm{H})$, $3.68(1 / 2 \mathrm{AB}, J=13.4 \mathrm{~Hz}, 3 \mathrm{H}), 3.37(\mathrm{dd}, J=9.8,6.0 \mathrm{~Hz}, 1 \mathrm{H}), 2.78(\mathrm{dd}, J=9.5,4.7 \mathrm{~Hz}, 1 \mathrm{H}$, minor diastereomer), 2.71-2.65 (m, 2H), $2.53(1 / 2 \mathrm{ABX}, J=13.0,9.9 \mathrm{~Hz}, 3 \mathrm{H}), 2.28(\mathrm{~s}, 3 \mathrm{H}), 2.26$ (s, 3H, minor diastereomer), $2.10(\mathrm{dd}, J=13.4,9.5 \mathrm{~Hz}, 1 \mathrm{H}$, minor diastereomer), $1.45(\mathrm{~s}, 9 \mathrm{H})$, 1.44 (s, 9H, minor diastereomer); ${ }^{13} \mathrm{C}-\mathrm{NMR}\left(101 \mathrm{MHz}, \mathrm{CDCl}_{3}\right): \delta 192.5,191.7,172.5,171.9$, $168.8,150.4,148.1,138.0,136.9,135.3,133.7,128.9,128.8,128.8,128.6,128.5,128.4,128.3$, $127.4,127.2,126.9,123.1,122.8,115.0,114.6,103.9,102.5,81.4,81.2,75.0,75.0,65.0,63.9$, $63.1,62.7,60.4,58.8,57.3,52.7,51.6,50.9,48.8,34.7,32.2,28.2,28.1,16.0,16.0 ; \mathrm{R}_{\mathrm{f}}\left(\mathrm{SiO}_{2}\right.$ hexanes/EtOAc ); $[\alpha]_{\mathrm{D}}{ }^{25}=+27^{\circ}\left(\mathrm{c}=0.22, \mathrm{CHCl}_{3}\right)$; IR (film, $\left.\mathrm{CH}_{2} \mathrm{Cl}_{2}\right), v_{\max } 3029,2969,2935$, 1732, 1688, 1647, $1154 \mathrm{~cm}^{-1}$; HRMS $\left(\mathrm{MH}^{+}\right)$, 595.2789. $\mathrm{C}_{36} \mathrm{H}_{39} \mathrm{~N}_{2} \mathrm{O}_{6}$ requires 595.2808. 


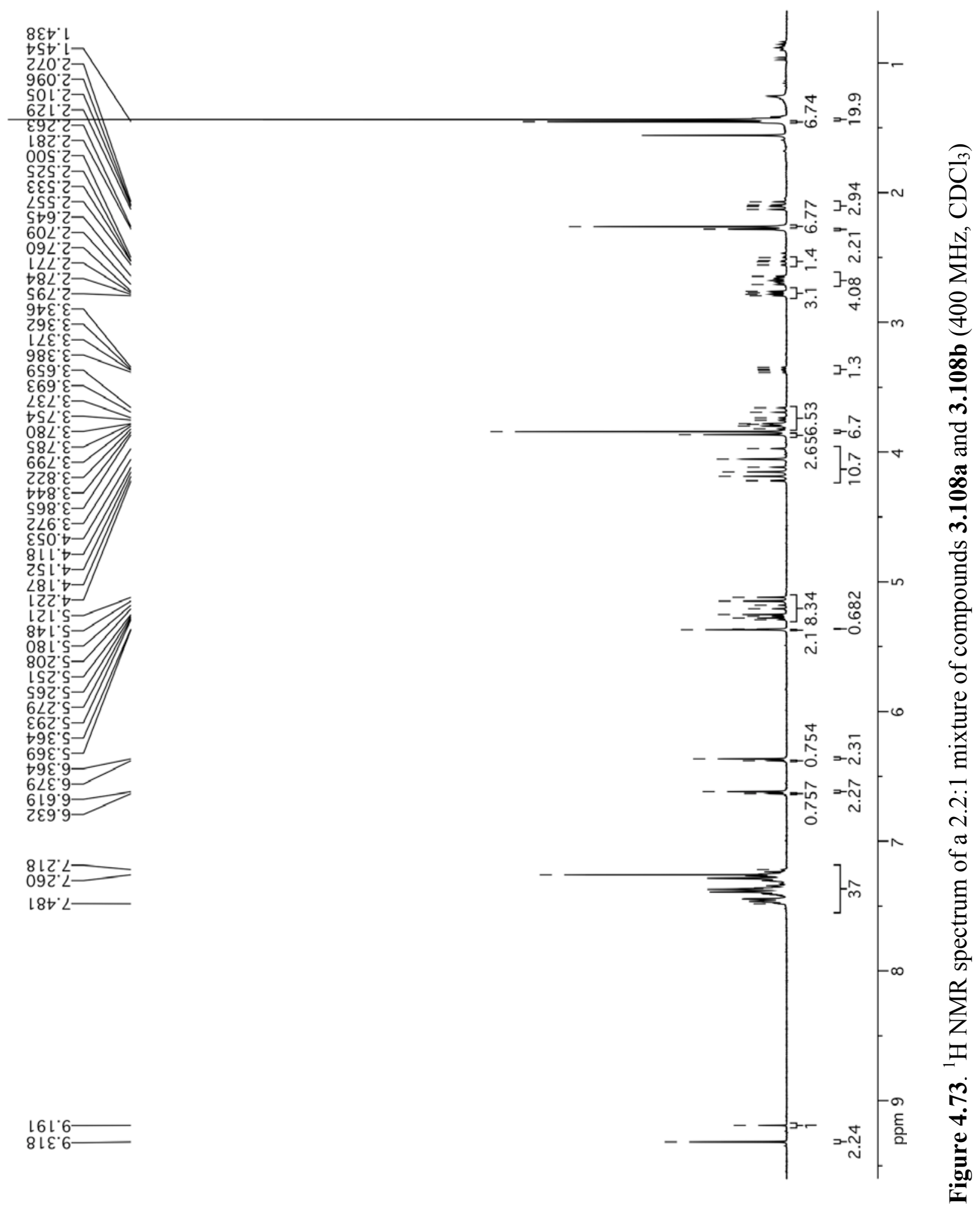




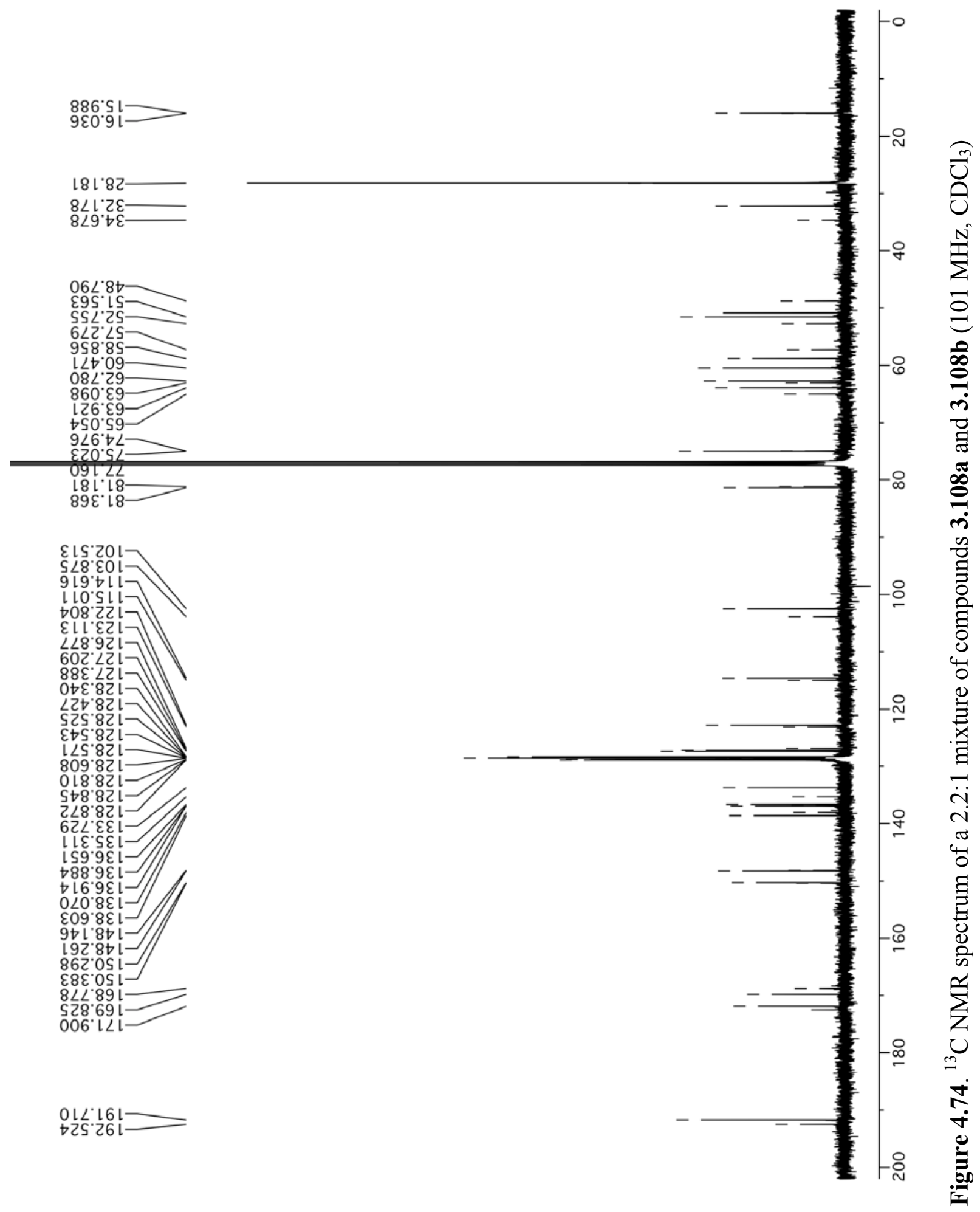




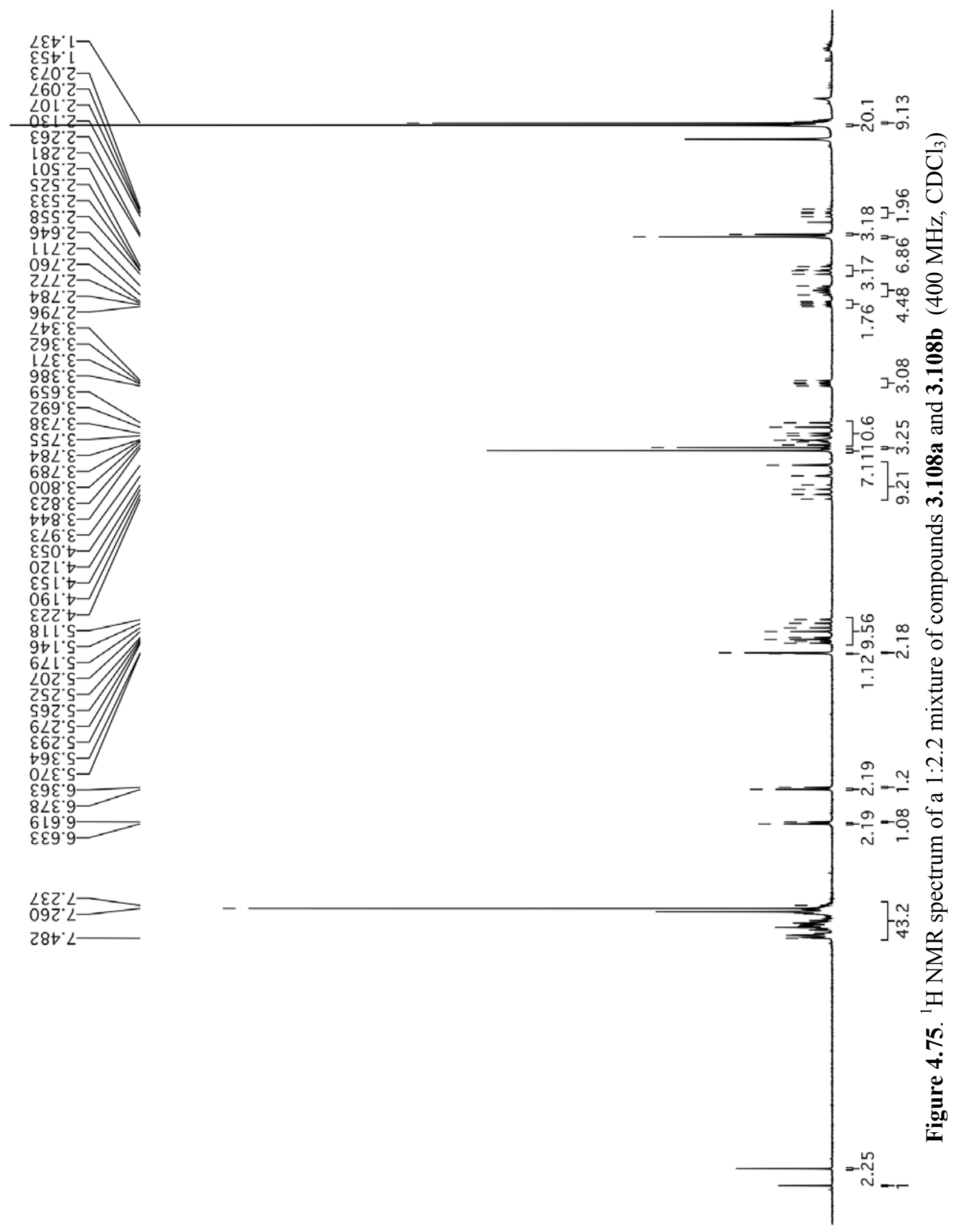



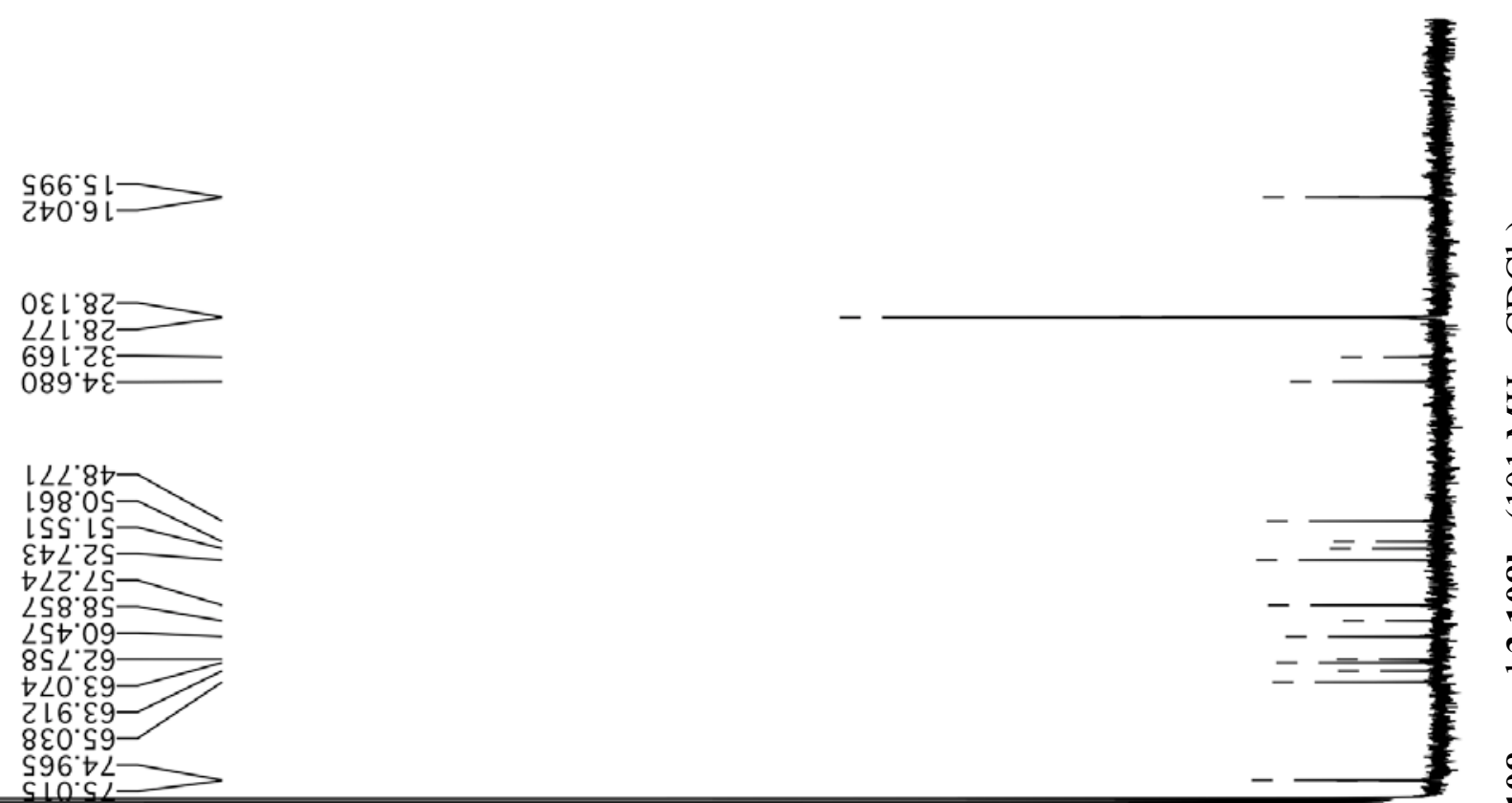

$0 \varepsilon L L^{\circ} 82=$

L2L ' 82

$089^{\circ} \downarrow \varepsilon$
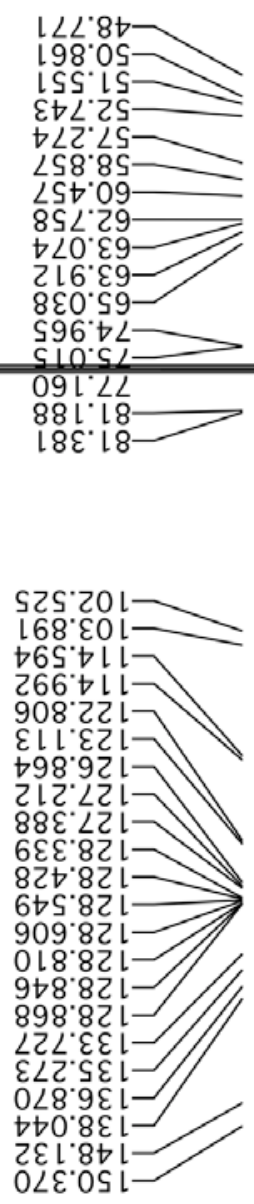

$\varepsilon 9 \angle 889 \mathrm{l}$

E68.
L $85^{\circ} \mathrm{LLL}-$

$70 L 161=$
$615.261-$

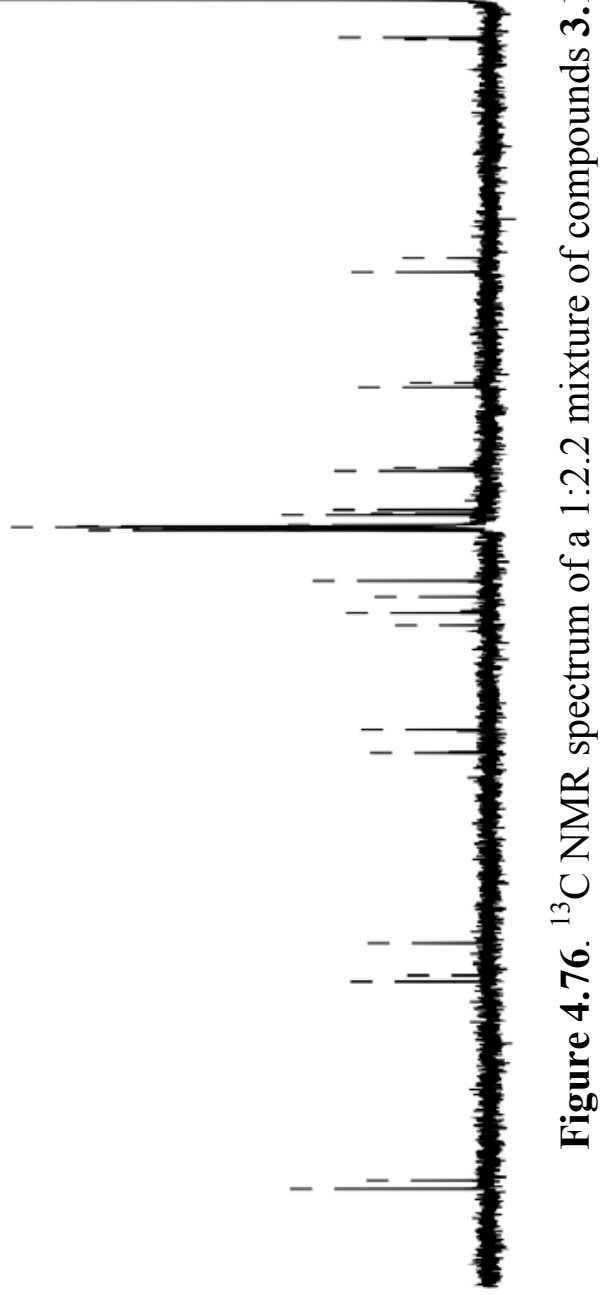




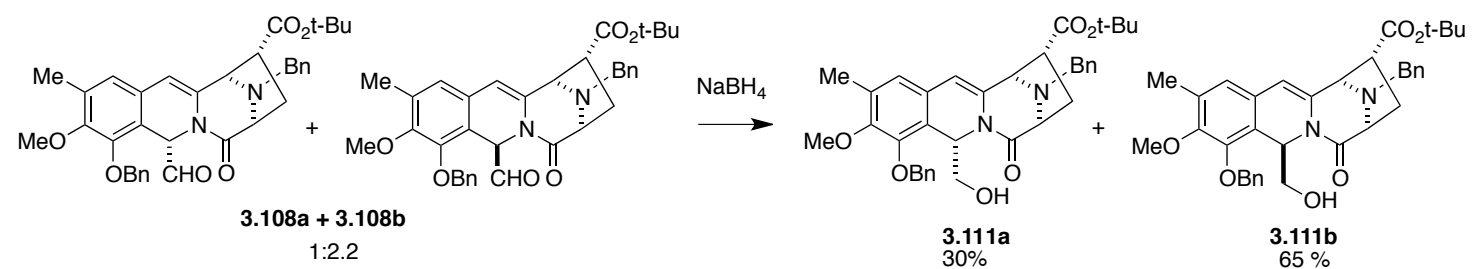

\section{$4.55(5 S, 8 S, 10 R, 11 S)$-tert-butyl 13-benzyl-4-(benzyloxy)-5-(hydroxymethyl)-3-methoxy-2- methyl-7-oxo-5,7,8,9,10,11-hexahydro-8,11-epiminoazepino[1,2-b]isoquinoline-10- carboxylate (3.111a) and (5R,8S,10R,11S)-tert-butyl 13-benzyl-4-(benzyloxy)-5- (hydroxymethyl)-3-methoxy-2-methyl-7-oxo-5,7,8,9,10,11-hexahydro-8,11- epiminoazepino[1,2-b]isoquinoline-10-carboxylate (3.111b)}

To a stirred solution of a mixture of compounds 3.108a and 3.108b (60 mg, $0.10 \mathrm{mmol})$ in EtOH ( $5 \mathrm{~mL}, 0.20 \mathrm{M})$, at $0{ }^{\circ} \mathrm{C}$, under $\mathrm{Ar}$, was added $\mathrm{NaBH}_{4}(30 \mathrm{mg}, 0.80 \mathrm{mmol} 8.0$ eq.). The reaction was stirred at RT for 2 hours, quenched with $1 \mathrm{~N} \mathrm{HCl}(2.4 \mathrm{~mL}, 2.40 \mathrm{mmol}, 24$ eq. $)$ and diluted with phosphate buffer $(0.1 \mathrm{M}, \mathrm{pH}=7.5,50 \mathrm{~mL})$. The aqueous phase was extracted with EtOAc $(3 \times 25 \mathrm{~mL})$ and the combined organic layers were rinsed with brine $(25 \mathrm{~mL})$, dried $\left(\mathrm{Na}_{2} \mathrm{SO}_{4}\right)$, filtered, and concentrated under vacuum. The crude material was purified by flash chromatography (silica gel, hexanes/EtOAc 4:1) to afford the title compounds $\mathbf{3 . 1 1 1 a}$ (18 mg, $30 \%$ ) as a colorless oil and compound $\mathbf{3 . 1 1 1 b}(38 \mathrm{mg}, 65 \%)$ as a colorless oil. Compound 3.111a: ${ }^{1} \mathrm{H}-\mathrm{NMR}\left(400 \mathrm{MHz} ; \mathrm{CDCl}_{3}\right): \delta$ 7.50-7.22 (m, 10H), $6.62(\mathrm{~s}, 1 \mathrm{H}), 6.14(\mathrm{t}, J=6.1 \mathrm{~Hz}$, $1 \mathrm{H}), 5.48(\mathrm{~s}, 1 \mathrm{H}), 5.18(1 / 2 \mathrm{AB}, J=11.1 \mathrm{~Hz}, 1 \mathrm{H}), 5.09(1 / 2 \mathrm{AB}, J=11.1 \mathrm{~Hz}, 1 \mathrm{H}), 4.10(\mathrm{~s}, 1 \mathrm{H})$, $3.97(1 / 2 \mathrm{AB}, J=13.3 \mathrm{~Hz}, 1 \mathrm{H}), 3.87(1 / 2 \mathrm{AB}, J=13.3 \mathrm{~Hz}, 1 \mathrm{H}), 3.79(\mathrm{~d}, J=7.7 \mathrm{~Hz}, 1 \mathrm{H}), 3.73(\mathrm{~s}$, 1H), $2.69(\mathrm{ddt}, J=27.0,9.0,4.6 \mathrm{~Hz}, 2 \mathrm{H}), 2.25(\mathrm{~s}, 3 \mathrm{H}), 2.06(\mathrm{dd}, J=13.3,9.5 \mathrm{~Hz}, 1 \mathrm{H}), 1.90(\mathrm{br} \mathrm{t}$, $6.0 \mathrm{~Hz}, 1 \mathrm{H}), 1.44(\mathrm{~s}, 9 \mathrm{H}) ;{ }^{13} \mathrm{C}-\mathrm{NMR}\left(101 \mathrm{MHz}, \mathrm{CDCl}_{3}\right): \delta 171.9,171.7,150.5,148.2,138.3$, $137.2,135.6,132.6,128.7,128.5,128.4,128.4,127.6,127.3,122.1,120.1,103.7,81.3,75.1$, 
65.4, 64.2, 62.7, 60.4, 51.7, 51.3, 50.7, 31.6, 28.1, 28.1, 15.9, 14.3; $\mathrm{R}_{\mathrm{f}}\left(\mathrm{SiO}_{2}\right.$, hexanes/EtOAc 4:1) 0.12; $[\alpha]_{\mathrm{D}}^{25}=-60.0^{\circ}\left(\mathrm{c}=0.895, \mathrm{CHCl}_{3}\right)$; IR (film, $\left.\mathrm{CH}_{2} \mathrm{Cl}_{2}\right), v_{\max } 3447$ (br), 3063, 3030, 2934, 2870, 1730, 1676, 1636, $1154 \mathrm{~cm}^{-1}$; HRMS $\left(\mathrm{MH}^{+}\right)$, found 597.2971. $\mathrm{C}_{36} \mathrm{H}_{41} \mathrm{~N}_{2} \mathrm{O}_{6}$ requires 597.2965. Compound 3.111b: ${ }^{1} \mathrm{H}-\mathrm{NMR}\left(400 \mathrm{MHz} ; \mathrm{CDCl}_{3}\right)$ : $\delta 6.62$ (s, 1H), 6.09 (dd, $J=8.4,4.4$ $\mathrm{Hz}, 1 \mathrm{H}), 5.45(\mathrm{~s}, 1 \mathrm{H}), 5.17(1 / 2 \mathrm{AB}, J=11.1 \mathrm{~Hz}, 1 \mathrm{H}), 5.14(1 / 2 \mathrm{AB}, J=11.1 \mathrm{~Hz}, 1 \mathrm{H}), 3.95(\mathrm{~s}$, 1H), $3.83(\mathrm{~s}, 3 \mathrm{H}), 3.78(\mathrm{~d}, J=13.5 \mathrm{~Hz}, 1 \mathrm{H}), 3.73(\mathrm{~d}, J=6.6 \mathrm{~Hz}, 1 \mathrm{H}), 3.63(\mathrm{~d}, J=13.4 \mathrm{~Hz}, 1 \mathrm{H})$, 3.63-3.50 (m, 1H), $3.15(\mathrm{dd}, J=9.8,6.1 \mathrm{~Hz}, 1 \mathrm{H}), 2.63(\mathrm{dt}, J=12.8,6.5 \mathrm{~Hz}, 1 \mathrm{H}), 2.45(\mathrm{dd}, J=$ 13.0, $9.8 \mathrm{~Hz}, 1 \mathrm{H}), 1.77-1.74(\mathrm{br} \mathrm{m}, 1 \mathrm{H}), 1.45(\mathrm{~s}, 9 \mathrm{H}) ;{ }^{13} \mathrm{C}-\mathrm{NMR}\left(101 \mathrm{MHz}, \mathrm{CDCl}_{3}\right): \delta 172.3$, $170.4,150.6,147.9,138.1,137.2,134.0,132.5,128.7,128.7,128.6,128.6,128.5,128.5,128.4$, $128.4,127.3,126.5,122.8,122.7,120.6,105.3,105.3,81.3,75.0,65.5,65.5,63.1,63.0,60.4$, $52.7,49.4,49.4,48.4,34.8,28.2,16.0,16.0 ; \mathrm{R}_{\mathrm{f}}\left(\mathrm{SiO}_{2}\right.$, hexanes/EtOAc 4:1) $0.10 ;[\alpha]_{\mathrm{D}}{ }^{25}=+64^{\circ}(\mathrm{c}$ $=0.31, \mathrm{CHCl}_{3}$ ); IR (film, $\mathrm{CH}_{2} \mathrm{Cl}_{2}$ ), $v_{\max } 3444$ (br), 3062, 3029, 2970, 2927, 1729, 1682, 1639, $1154 \mathrm{~cm}^{-1}$; HRMS $\left(\mathrm{MH}^{+}\right)$, found 597.2974. $\mathrm{C}_{36} \mathrm{H}_{41} \mathrm{~N}_{2} \mathrm{O}_{6}$ requires 597.2965. 


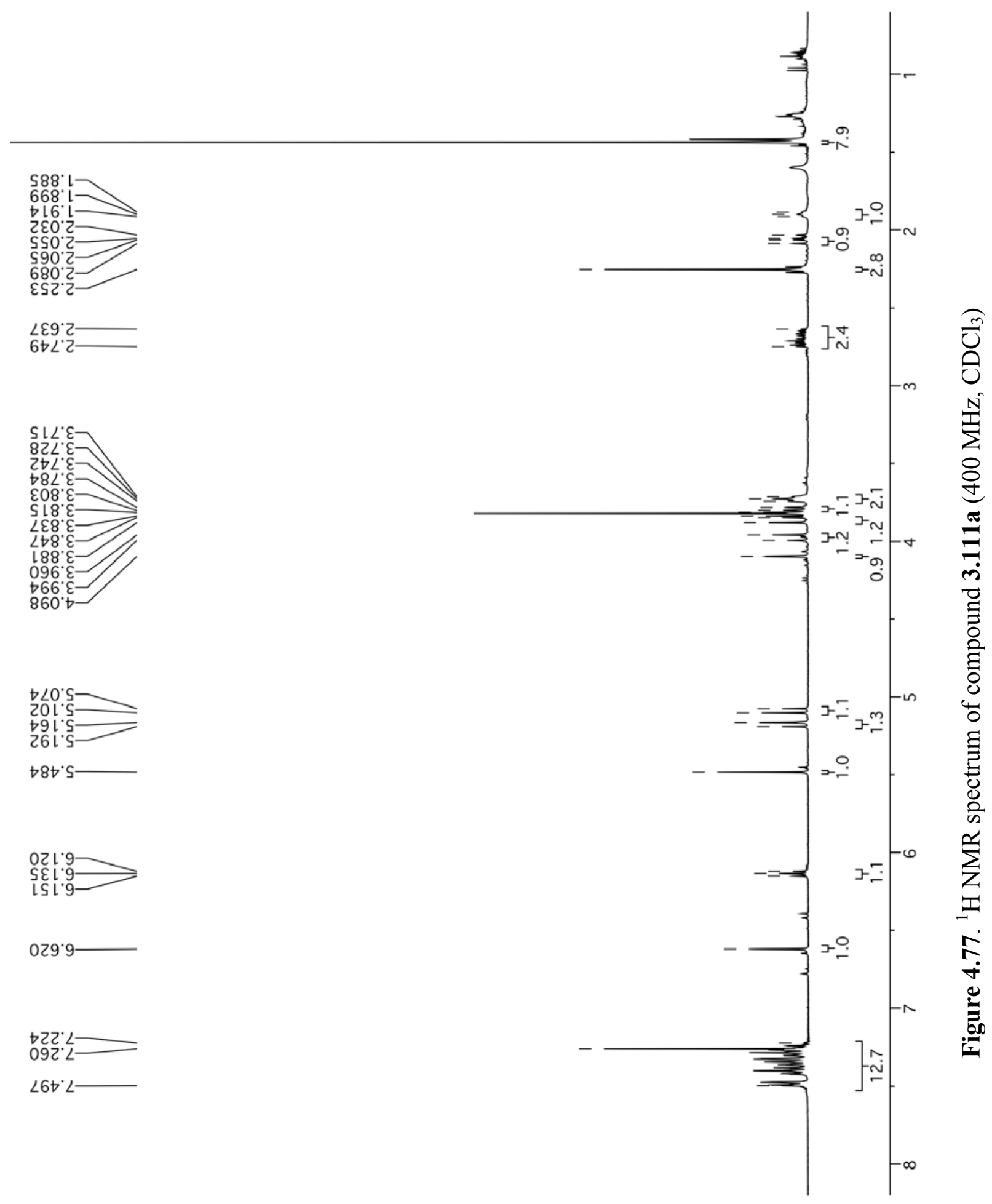




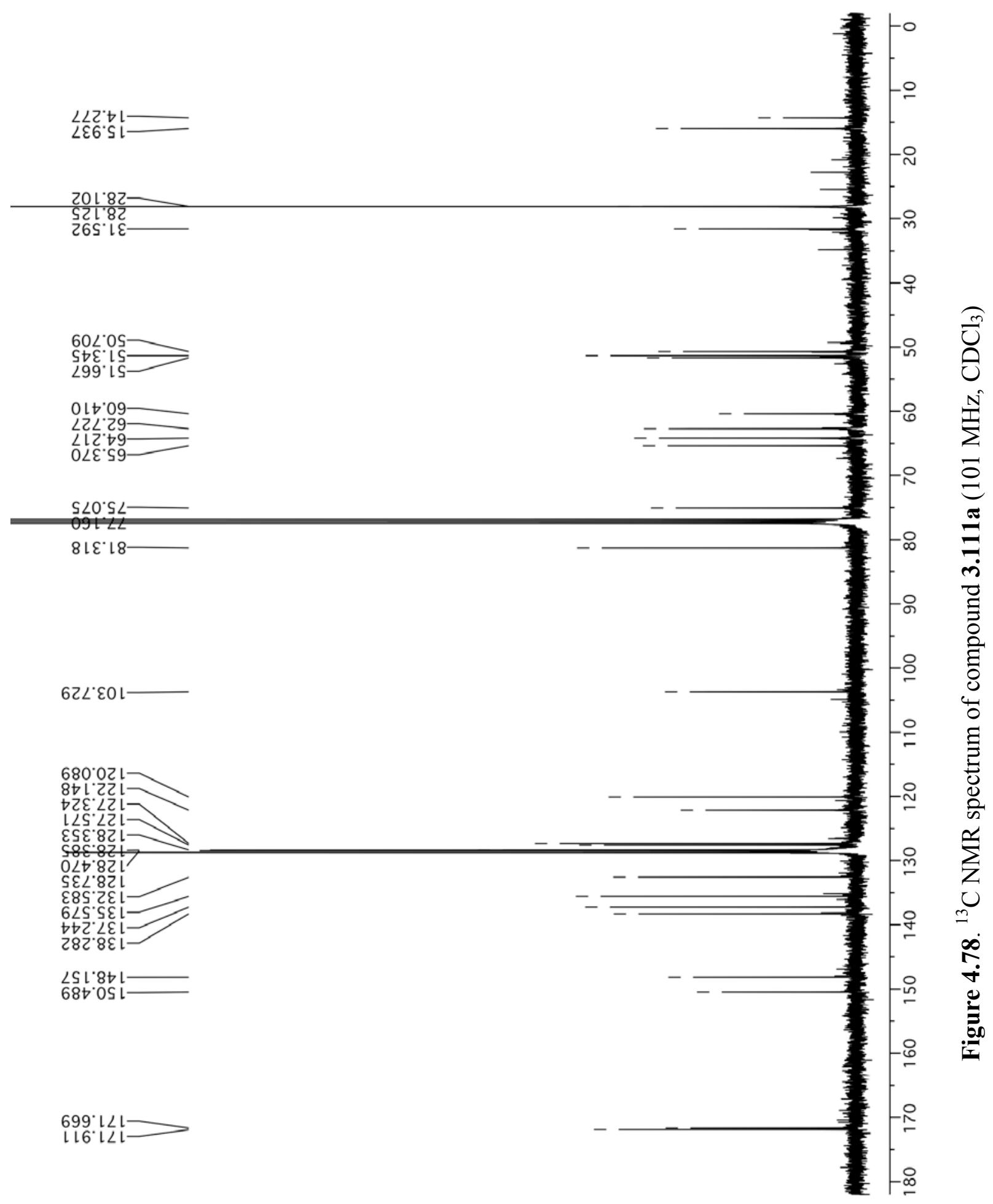




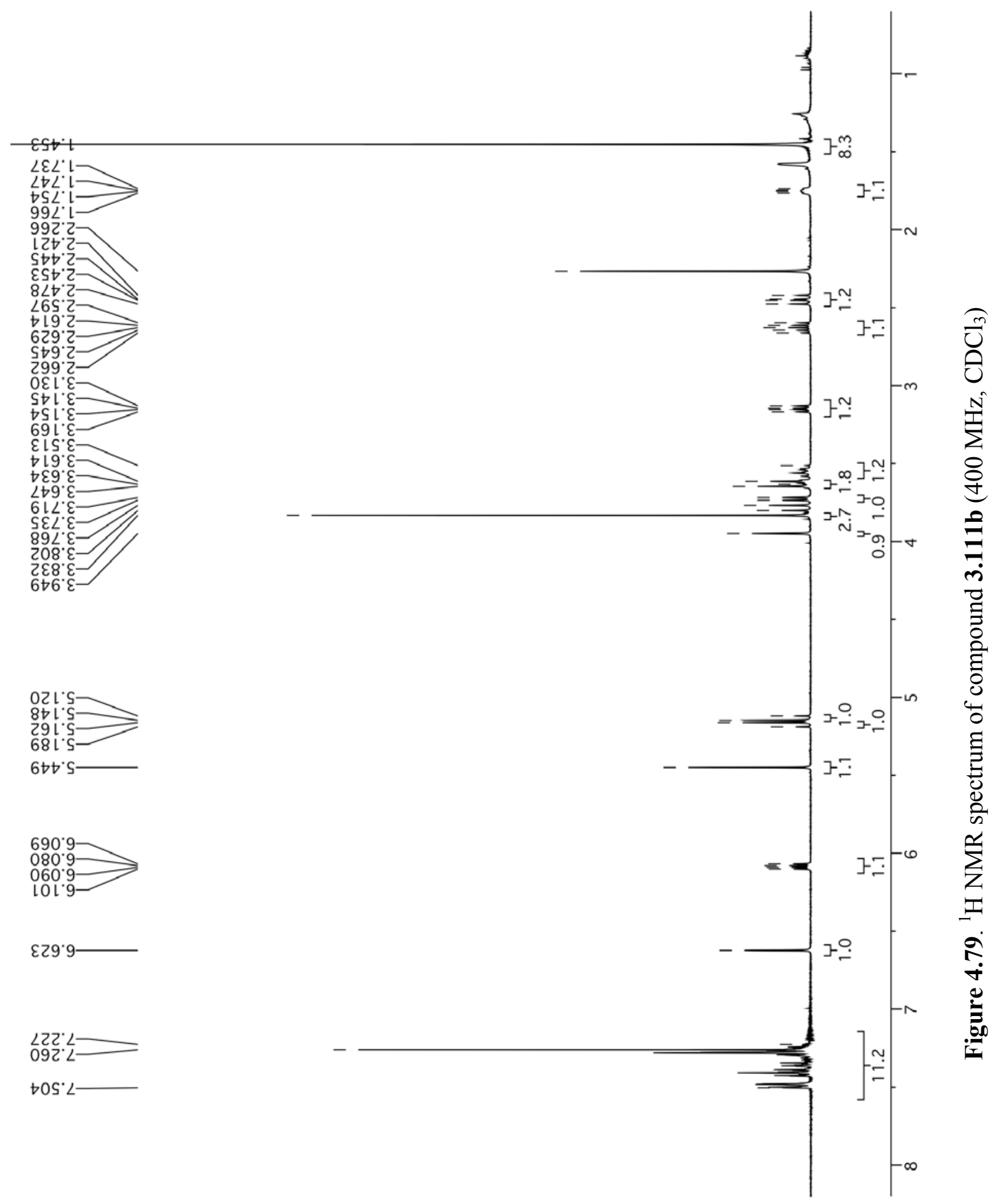




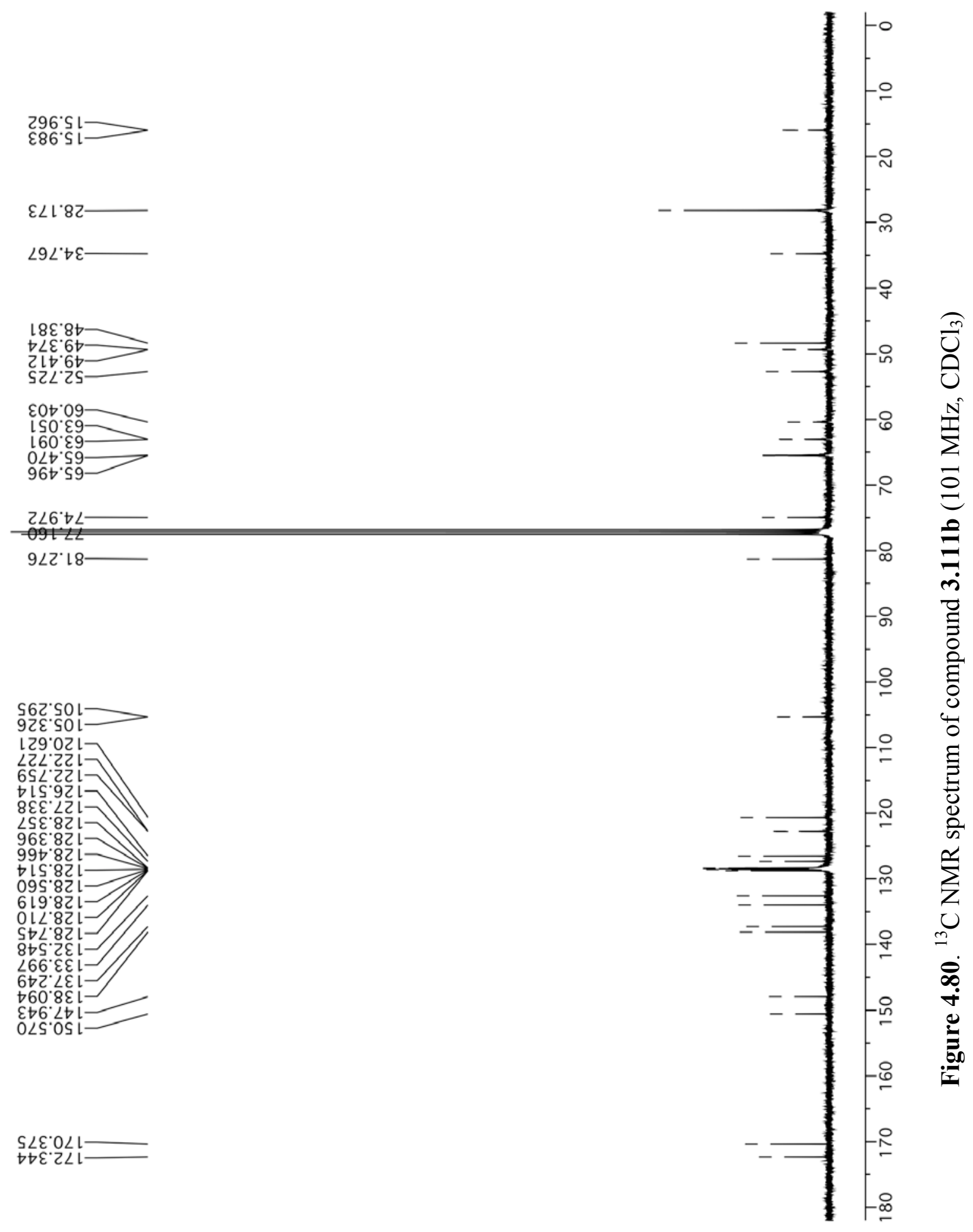




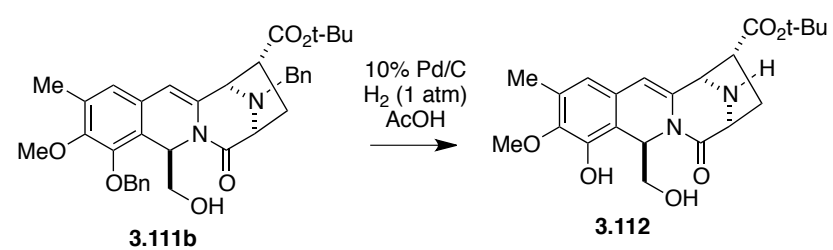

\section{$4.56(5 R, 8 S, 10 R, 11 S)$-tert-butyl 4-hydroxy-5-(hydroxymethyl)-3-methoxy-2-methyl-7-} oxo-5,7,8,9,10,11-hexahydro-8,11-epimino-azepino[1,2-b]isoquinoline-10-carboxylate

\section{(3.112)}

A solution of compound 3.111b $(7.0 \mathrm{mg}, 0.012 \mathrm{mmol})$ in glacial acetic acid $(1 \mathrm{~mL})$ and $10 \%$ $\mathrm{Pd} / \mathrm{C}(7 \mathrm{mg})$ were placed in round bottom flask and sparged with Ar for 5 minutes. The vessel was evacuated and filled with hydrogen three times. The reaction was vigorously stirred overnight under hydrogen (1 atm). The suspension was diluted with $\mathrm{CH}_{2} \mathrm{Cl}_{2}(25 \mathrm{~mL})$ and then filtered through Celite ${ }^{\circledR}$ and the flask was rinsed with $\mathrm{CH}_{2} \mathrm{Cl}_{2}(3 \times 5 \mathrm{~mL})$. The solution was extracted with sat. aq. $\mathrm{NaHCO}_{3}(3 \times 15 \mathrm{~mL})$. The combined aqueous layers were diluted with phosphate buffer $(0.1 \mathrm{M}, \mathrm{pH}=7.5,25 \mathrm{~mL})$ and extracted with $\mathrm{CH}_{2} \mathrm{Cl}_{2}(3 \times 15 \mathrm{~mL})$. The combined organic layers were rinsed with brine $(50 \mathrm{~mL})$, dried $\left(\mathrm{Na}_{2} \mathrm{SO}_{4}\right)$, filtered, and concentrated under vacuum. The crude material was purified by flash chromatography (silica gel, $\mathrm{CHCl}_{3} / \mathrm{MeOH}$ 97:3) to afford compound 3.112 (4.6 mg, $92 \%)$ as a colorless oil. ${ }^{1} \mathrm{H}-\mathrm{NMR}$ (400 MHz; $\mathrm{CDCl}_{3}$ ): $\delta$ $6.40(\mathrm{~s}, 1 \mathrm{H}), 6.05(\mathrm{dd}, J=7.9,4.1 \mathrm{~Hz}, 1 \mathrm{H}), 5.53(\mathrm{~s}, 1 \mathrm{H}), 4.30(\mathrm{~s}, 1 \mathrm{H}), 4.09$ (d, $J=6.7 \mathrm{~Hz}, 1 \mathrm{H})$, 3.78-3.74 (m, 2H), $3.76(\mathrm{~s}, 3 \mathrm{H}), 3.65-3.60(\mathrm{~m}, 1 \mathrm{H}), 3.17(\mathrm{dd}, J=9.3,6.2 \mathrm{~Hz}, 1 \mathrm{H}), 2.61(\mathrm{dd}, J=$ 13.1, 9.4 Hz, 1H), $2.32(\mathrm{dt}, J=13.2,6.6 \mathrm{~Hz}, 1 \mathrm{H}) 2.24(\mathrm{~s}, 3 \mathrm{H}), 1.47(\mathrm{~s}, 9 \mathrm{H}) ;{ }^{13} \mathrm{C}-\mathrm{NMR}(101 \mathrm{MHz}$ $\left.\mathrm{CDCl}_{3}\right): \delta 173.4,171.1,145.2,144.7,144.7,136.9,136.8,130.3,127.1,119.1,112.9,112.9$, $102.7,81.6,65.1,62.4,61.8,61.0,49.5,48.1,37.0,29.8,29.8,28.2,15.9 ; \mathrm{R}_{\mathrm{f}}\left(\mathrm{SiO}_{2}\right.$ $\mathrm{CHCl}_{3} / \mathrm{MeOH}$ 95:5) 0.17; $[\alpha]_{\mathrm{D}}^{25}=+4.3^{\circ}\left(\mathrm{c}=0.23, \mathrm{CHCl}_{3}\right)$; IR (film, $\left.\mathrm{CH}_{2} \mathrm{Cl}_{2}\right), v_{\max } 3262(\mathrm{br})$, 
2969, 2925, 2854, 1719, 1683, 1646, $1154 \mathrm{~cm}^{-1}$; HRMS $\left(\mathrm{MH}^{+}\right)$, found 417.2033. $\mathrm{C}_{22} \mathrm{H}_{29} \mathrm{~N}_{2} \mathrm{O}_{6}$ requires 417.2026. 


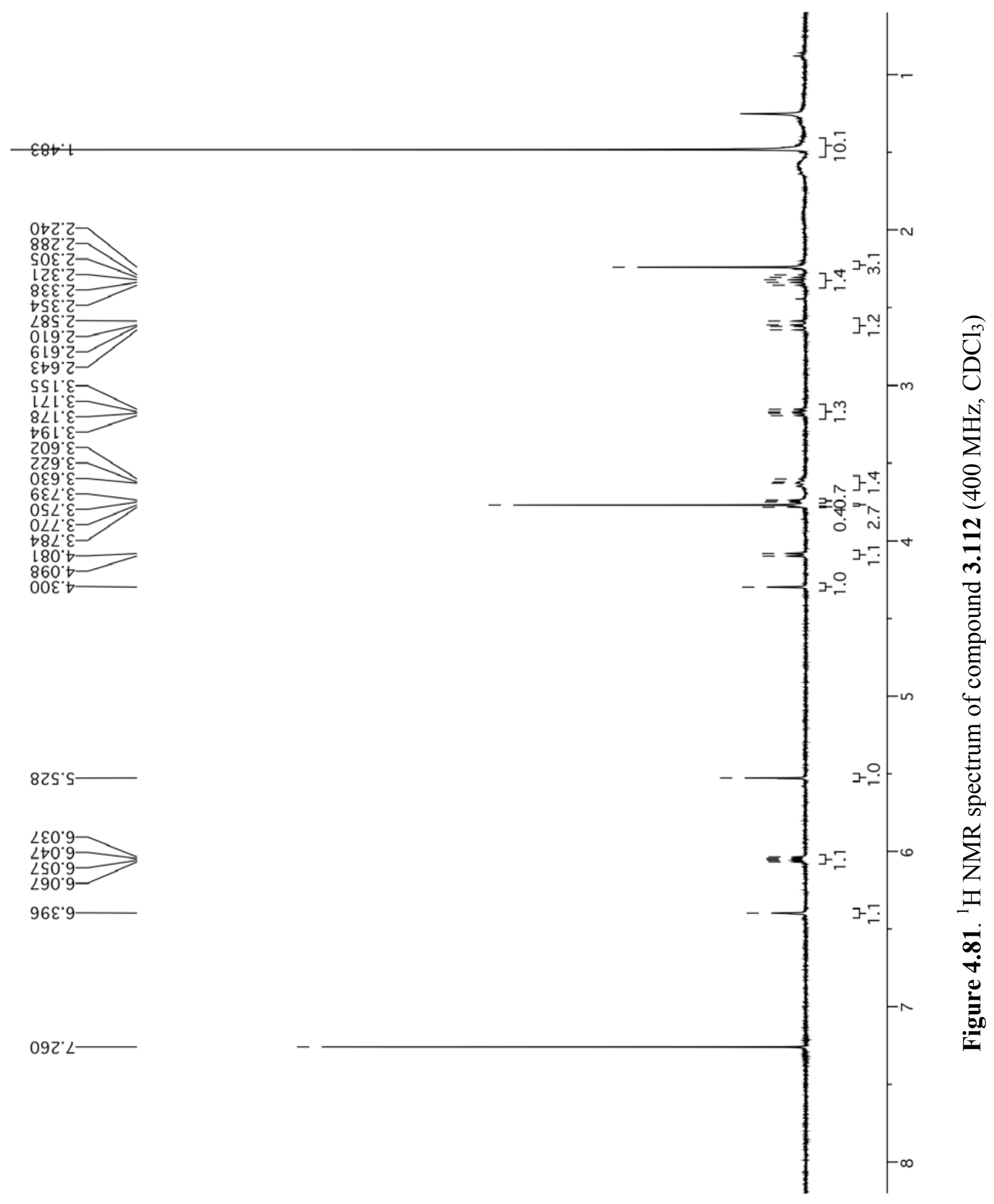




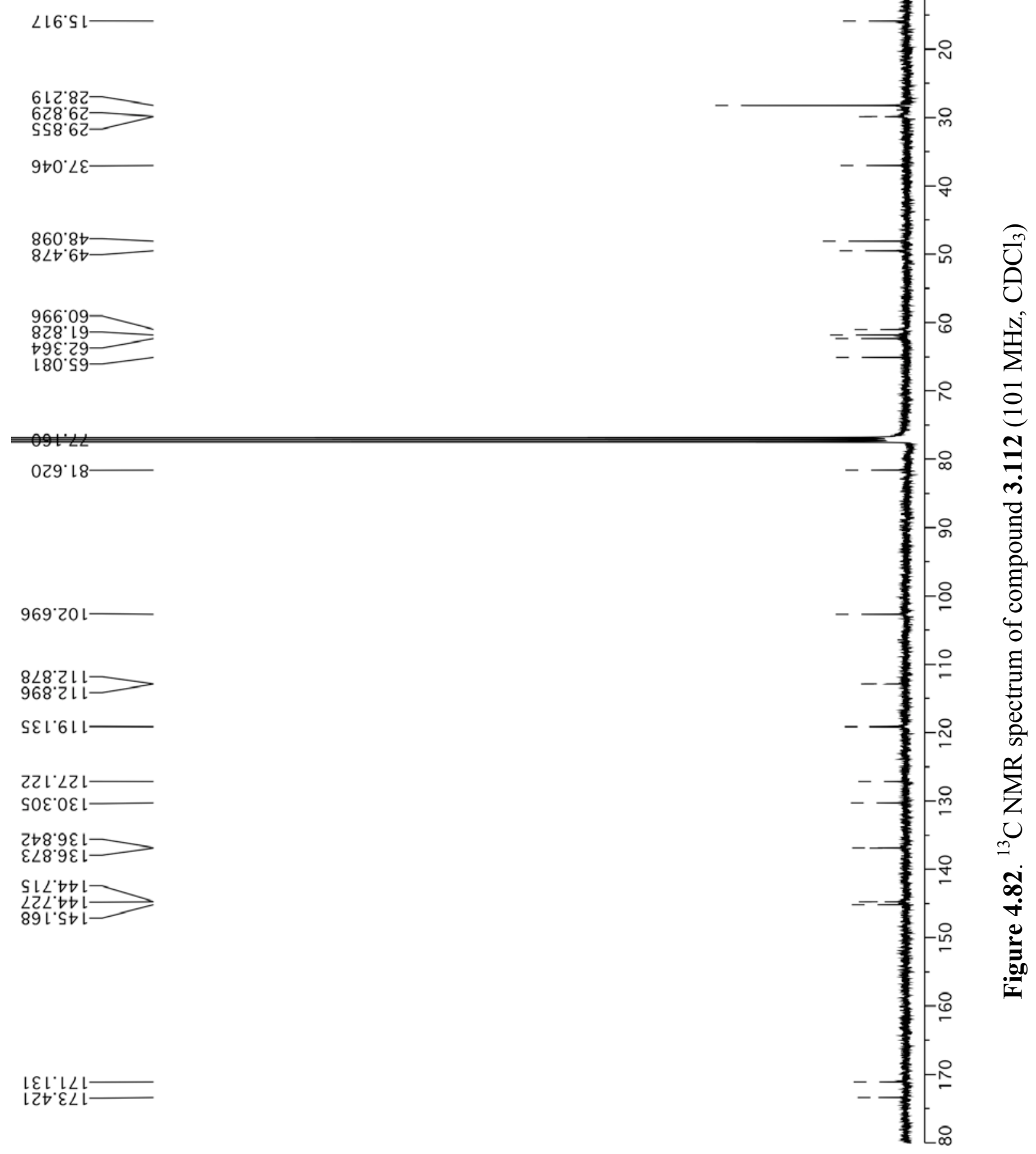




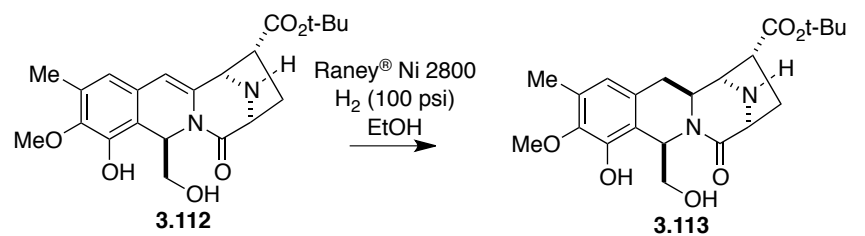

\section{$4.57(5 R, 8 \mathrm{~S}, 10 R, 11 S, 11 \mathrm{aS})$-tert-butyl 4-hydroxy-5-(hydroxymethyl)-3-methoxy-2-methyl- 7-oxo-5,7,8,9,10,11,11a, 12- octahydro-8,11-epiminoazepino[1,2- $b]$ isoquinoline-10- carboxylate (3.113)}

To a solution of compound $3.112(4.6 \mathrm{mg}, 0.011 \mathrm{mmol})$ in $\mathrm{EtOH}(1 \mathrm{~mL})$ in a $5 \mathrm{~mL}$ vial, was added a slurry of Raney ${ }^{\circledR}$ nickel $2800(500 \mu \mathrm{L}$ of commercially available water slurry, washed with $\mathrm{EtOH}(3 \times 1 \mathrm{~mL})$ and suspended in $\mathrm{EtOH}(1 \mathrm{~mL}))$. The vial was placed in a Fisher-Porter bottle, under Ar, the suspension was sparged with Ar for 5 minutes and the vessel was filled with hydrogen gas at 100 psi. The reaction was vigorously stirred overnight, diluted with EtOAc (10 $\mathrm{mL})$ and sat. aq. Rochelle's salt $(10 \mathrm{~mL})$, and stirred vigorously for $2 \mathrm{~h}$. The biphasic suspension was filtered through Celite ${ }^{\circledR}$, the phases separated and the aqueous phase extracted with EtOAc $(3 \times 10 \mathrm{~mL})$. The combined organic phases were rinsed with brine $(25 \mathrm{~mL})$, dried $\left(\mathrm{Na}_{2} \mathrm{SO}_{4}\right)$, filtered, and concentrated under vacuum. The crude material was purified by flash chromatography (silica gel, $\mathrm{CHCl}_{3} / \mathrm{MeOH}$ 97:3) to afford compound $\mathbf{3 . 1 1 3}(3.4 \mathrm{mg}, 74 \%)$ as a colorless oil. ${ }^{1} \mathrm{H}-\mathrm{NMR}\left(400 \mathrm{MHz} ; \mathrm{CDCl}_{3}\right): \delta 6.51(\mathrm{~s}, 1 \mathrm{H}), 5.59(\mathrm{dd}, J=5.6,3.4 \mathrm{~Hz}, 1 \mathrm{H}), 3.96(\mathrm{~d}$, $J=6.1 \mathrm{~Hz}, 1 \mathrm{H}), 3.88(\mathrm{dd}, J=10.9,3.2 \mathrm{~Hz}, 1 \mathrm{H}), 3.78(\mathrm{~s}, 3 \mathrm{H}), 3.77-3.76(\mathrm{~m}, 1 \mathrm{H}), 3.67(\mathrm{dt}, J=$ 12.4, $2.6 \mathrm{~Hz}, 1 \mathrm{H}), 3.61(\mathrm{dd}, J=11.1,5.8 \mathrm{~Hz}, 1 \mathrm{H}), 3.16(\mathrm{dd}, J=9.0,6.4 \mathrm{~Hz}, 1 \mathrm{H}), 2.84(\mathrm{t}, J=13.5$ $\mathrm{Hz}, 1 \mathrm{H}), 2.54(\mathrm{dd}, J=14.7,2.2 \mathrm{~Hz}, 1 \mathrm{H}), 2.50(\mathrm{dd}, J=13.2,9.0 \mathrm{~Hz}, 1 \mathrm{H}), 2.27$ (s, 3H), $2.18(\mathrm{dt}, J$ $=13.2,6.6 \mathrm{~Hz}, 1 \mathrm{H}), 1.53-1.45(\mathrm{~m}, 9 \mathrm{H}) ;{ }^{13} \mathrm{C}-\mathrm{NMR}\left(101 \mathrm{MHz}, \mathrm{CDCl}_{3}\right): \delta 174.4,172.4,145.7$, $132.0,129.7,121.2,120.2,118.0,81.5,67.8,63.0,62.2,61.0,60.8,52.6,42.8,38.8,32.1,29.9$, 28.2, 15.9; $\mathrm{R}_{\mathrm{f}}\left(\mathrm{SiO}_{2}, \mathrm{CHCl}_{3} / \mathrm{MeOH} 95: 5\right) 0.20 ;[\alpha]_{\mathrm{D}}{ }^{25}=-36^{\circ}\left(\mathrm{c}=0.080, \mathrm{CHCl}_{3}\right)$; IR (film, 
$\left.\mathrm{CH}_{2} \mathrm{Cl}_{2}\right), v_{\max } 3286(\mathrm{br}), 2958,2925,2855,1729,1652,1456 \mathrm{~cm}^{-1}$; HRMS $\left(\mathrm{MH}^{+}\right)$, found 419.2174. $\mathrm{C}_{22} \mathrm{H}_{31} \mathrm{~N}_{2} \mathrm{O}_{6}$ requires 419.2182. 


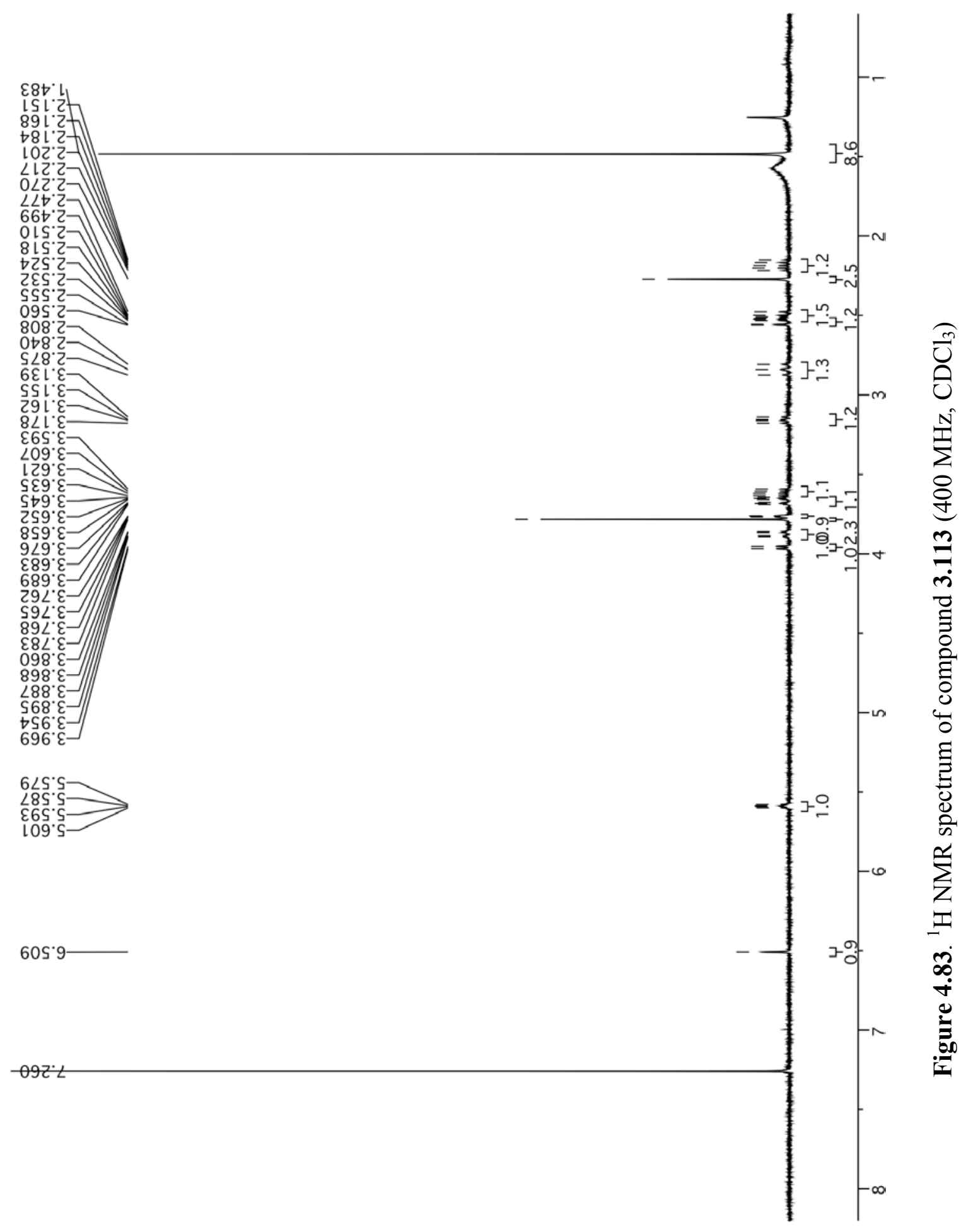




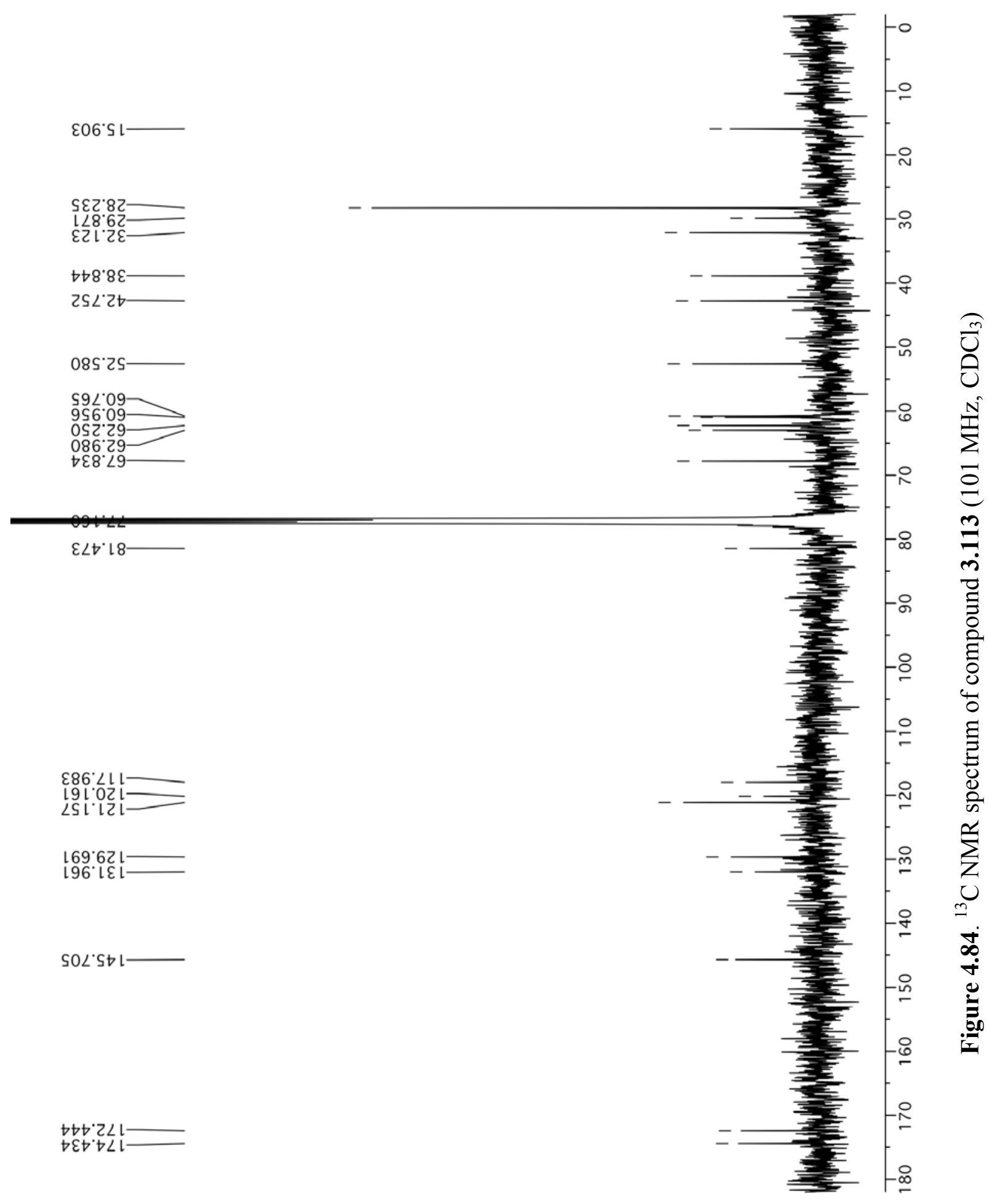




\section{APPENDIX 1}

Substrates and conditions of the enamide hydrogenation attempts listed in reference 58 


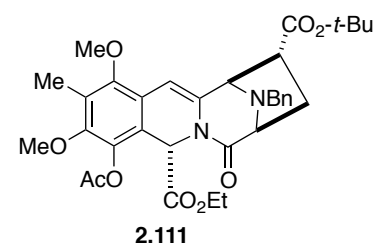

\begin{tabular}{|c|c|c|c|}
\hline Catalyst & $\mathrm{H}_{2}$ pressure $/ \mathrm{psi}$ & Temperature & Result \\
\hline Raney Ni & 1500 & r.t. & S.M. \\
\hline $\mathrm{Rh} / \mathrm{C}$ & 1300 & r.t. & S.M. \\
\hline $\mathrm{Rh} / \mathrm{Alumina}$ & 1300 & r.t. & S.M. \\
\hline $\mathrm{Rh}(\mathrm{OAc})_{2}$ & 1500 & r.t. & S.M. \\
\hline $\mathrm{RhCl}_{3}$ & 1500 & r.t. & S.M. \\
\hline Wilkinson's cat. & 1500 & r.t. & S.M. \\
\hline $\mathrm{Ir} / \mathrm{C}$ & 1300 & r.t. & S.M. \\
\hline Crabtree's cat. & 1500 & r.t. & S.M. \\
\hline $\mathrm{Pd} / \mathrm{C}$ & 1300 & r.t. & S.M. \\
\hline $\mathrm{PdCl}{ }_{2}$ & 1300 & r.t. & S.M. \\
\hline $\mathrm{Pd}(\mathrm{OH})_{2}$ & 1300 & r.t. & S.M. \\
\hline $\mathrm{Raney} \mathrm{Ni}$ & 2000 & r.t. & de-Bn + S.M. \\
\hline $\mathrm{Rh} / \mathrm{Alumina}$ & 2000 & $65^{\circ} \mathrm{C}$ & de-Bn + S.M. \\
\hline $\mathrm{Raney} \mathrm{Ni}$ & 1500 & $65^{\circ} \mathrm{C}$ & Unidentified product \\
\hline
\end{tabular}

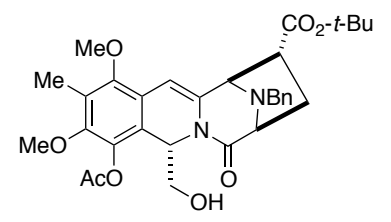

\begin{tabular}{|c|c|c|c|}
\hline A1-335 & Temperature & S.M. \\
\hline Catalyst & $\mathrm{H}_{2}$ pressure $/$ psi & r.t. & S.M. \\
\hline $\mathrm{Raney} \mathrm{Ni}$ & 1300 & $65^{\circ} \mathrm{C}$ & S.M. \\
\hline $\mathrm{Rh} / \mathrm{C}$ & 1500 & $65^{\circ} \mathrm{C}$ & S.M. \\
\hline $\mathrm{Pd}(\mathrm{OH})_{2}$ & 1500 & $65^{\circ} \mathrm{C}$ & S.M. \\
\hline $\mathrm{Ir} / \mathrm{C}$ & 1500 & r.t/ & \\
\hline
\end{tabular}

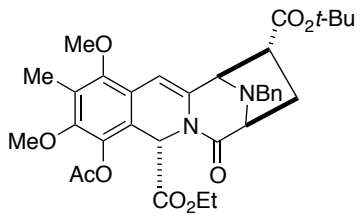

\begin{tabular}{|c|c|c|c|}
\hline Catalyst & $\mathrm{H}_{2}$ pressure $/ \mathrm{psi}$ & Temperature & Result \\
\hline Wilkinson's cat. & 1500 & r.t. & Show vinyl proton \\
\hline
\end{tabular}




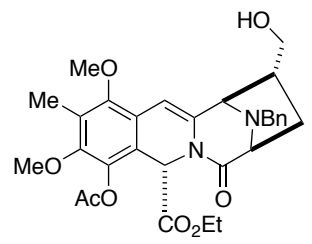

\begin{tabular}{|c|c|c|c|}
\hline \multicolumn{5}{|c|}{ A1-337 } \\
\hline Catalyst & $\mathrm{H}_{2}$ pressure $/ \mathrm{psi}$ & Temperature & Result \\
\hline $\mathrm{Rh} / \mathrm{C}$ & 1500 & $65^{\circ} \mathrm{C}$ & S.M. \\
\hline $\mathrm{RhCl}{ }_{3}$ & 1500 & $65^{\circ} \mathrm{C}$ & S.M. \\
\hline $\mathrm{Pd}(\mathrm{OH})_{2}$ & 1500 & $65^{\circ} \mathrm{C}$ & S.M. \\
\hline $\mathrm{Pd} / \mathrm{C}, \mathrm{TFA}$ & 1300 & r.t. & Removal of $N$-Bn \\
\hline
\end{tabular}

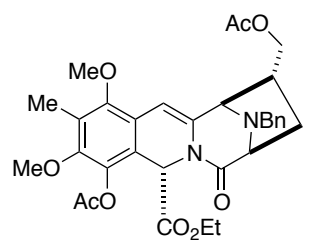

\begin{tabular}{|c|c|c|c|}
\hline Catalyst & $\mathrm{H}_{2}$ pressure $/ \mathrm{psi}$ & Temperature & Result \\
\hline $\mathrm{Pd} / \mathrm{C}$, TFA & 1300 & r.t. & Removal of $N$-Bn \\
\hline
\end{tabular}

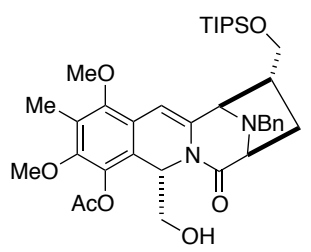

\begin{tabular}{|c|c|c|c|}
\hline A1-325 \\
\hline Catalyst & $\mathrm{H}_{2}$ pressure $/ \mathrm{psi}$ & Temperature & Result \\
\hline Pd/C, TFA & 1300 & r.t. & Removal of $N$-Bn \\
\hline Wilkinson's cat. & 2000 & $65^{\circ} \mathrm{C}$ & SM \\
\hline Ru black & 2000 & $65^{\circ} \mathrm{C}$ & SM \\
\hline Raney Ni & 2000 & $65^{\circ} \mathrm{C}$ & Unidentified product \\
\hline
\end{tabular}

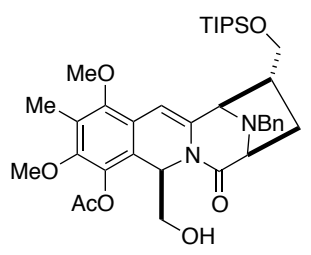

\begin{tabular}{|c|c|c|c|}
\hline Catalyst & $\mathrm{H}_{2}$ pressure $/ \mathrm{psi}$ & Temperature & Result \\
\hline $\mathrm{Pd} / \mathrm{C}, \mathrm{TFA}$ & 1300 & r.t. & Removal of $N$-Bn \\
\hline Raney Ni & 2000 & r.t. & $\begin{array}{c}\text { Removal of } N \text {-Bn, } \\
\text { S.M. }\end{array}$ \\
\hline Raney Ni & 2000 & $65^{\circ} \mathrm{C}$ & Unidentified product \\
\hline
\end{tabular}




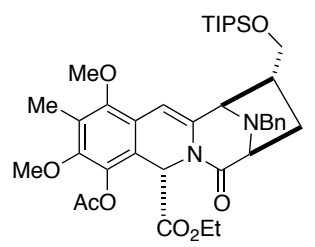

\begin{tabular}{|c|c|c|c|}
\hline \multicolumn{4}{|c|}{ A1-322 } \\
\hline Catalyst & $\mathrm{H}_{2}$ pressure $/ \mathrm{psi}$ & Temperature & Result \\
\hline $\mathrm{PdCl}_{2}$ & 1800 & $65^{\circ} \mathrm{C}$ & Removal of $N$-Bn \\
\hline
\end{tabular}


APPENDIX 2

Publications 


\title{
Synthetic studies on lemonomycin: construction of the tetracyclic core
}

\author{
Alberto Jiménez-Somarribas ${ }^{\mathrm{a}}$, Robert M. Williams ${ }^{\mathrm{a}, \mathrm{b}, *}$ \\ ${ }^{a}$ Department of Chemistry, Colorado State University, Fort Collins, CO 80523-1872, United States \\ ${ }^{\mathrm{b}}$ University of Colorado Cancer Center, Aurora, CO 80045, United States
}

\section{A R T I C L E I N F O}

\section{Article history:}

Received 9 December 2012

Received in revised form 4 May 2013

Accepted 6 May 2013

Available online $\mathrm{xxx}$

Keywords:

(-)-Lemonomycin

Tetrahydroisoquinoline antitumor

antibiotics

Pictet-Spengler reaction

[3+2] Dipolar cycloaddition

\begin{abstract}
A B S T R A C T
A substrate-induced stereocontrol strategy was used to gain access to the tetracyclic core of (-)-lemonomycin. An advanced intermediate was prepared from a known substituted tyrosinol through a 16 -step sequence, which involved a Pictet-Spengler reaction, a [3+2] dipolar cycloaddition and an enamide hydrogenation.
\end{abstract}

(c) 2013 Published by Elsevier Ltd.

\section{Introduction}

Lemonomycin (1) is a member of the tetrahydroisoquinoline (THIQ) family of antitumor antibiotics. ${ }^{1}$ It was isolated from the fermentation broth of Streptomyces candidus (LL-AP191) in 1964,,$^{2,3}$ and its structure was reported by He and co-workers in $2000 .{ }^{4}$ This compound showed significant in vitro antimicrobial activities against both gram-negative and gram-positive bacteria, including antibiotic-resistant strains, as well as against the human colon tumor cell line HCT116. ${ }^{2-4}$ Structurally, the compound contains the tetracyclic core found in quinocarcin ${ }^{5}$ and tetrazomine, ${ }^{6}$ which includes a 3,8-diazabicyclo ring system and a rare bis-desoxy aminosugar portion, which has only been found in a few natural products. $^{7-11}$ The structural complexity and biological activities of this substance have made lemonomycin an attractive target for the synthetic community. To date, there are two total syntheses by Stoltz ${ }^{12}$ and Fukuyama ${ }^{13}$ and synthetic studies by Magnus, ${ }^{14,15}$ $\mathrm{Zhu}^{16-18}{ }^{18}$ Mulzer, ${ }^{19}$ and our laboratory. ${ }^{20}$

As shown in Scheme 1, we envisioned that the final steps in the synthesis of lemonomycin (1) would involve a late-stage glycosylation reaction, and the formation of the quinone, hemiaminal, and aldehyde hydrate functional groups. Compound $\mathbf{2}$ could be accessed through the epimerization of the southern benzylic position and the reduction of the enamide double bond found in tetracycle 3. This key intermediate could be prepared from

* Corresponding author. Tel.: +1 970491 6747; fax: +1 970491 3944; e-mail address: rmw@lamar.colostate.edu (R.M. Williams). aldehyde 5 via azomethine ylide 4, using a [3+2] dipolar cycloaddition approach previously developed by our group. ${ }^{20}$ This key reaction was also used for the construction of the [3,8]-diazabicyclo ring system in our total syntheses of (-)-tetrazomine ${ }^{21}$ and $( \pm)$-quinocarcinamide. ${ }^{22}$ The tetrahydroisoquinoline system of $\mathbf{5}$ could be formed through a Pictet-Spengler reaction involving a derivative of compound $\mathbf{6}$, which is a known compound. ${ }^{23}$

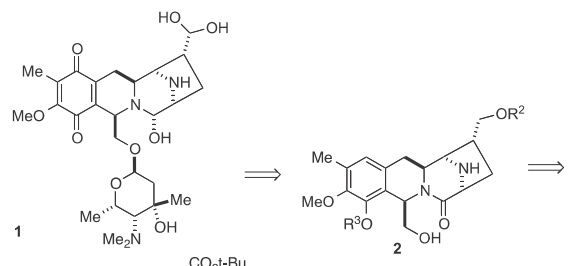

$$
\begin{aligned}
& \Longrightarrow \\
& \text { C }
\end{aligned}
$$

Scheme 1. Retrosynthetic analysis.

0040-4020/\$ - see front matter ๔ 2013 Published by Elsevier Ltd. http://dx.doi.org/10.1016/j.tet.2013.05.009

Please cite this article in press as: Jiménez-Somarribas, A.; Williams, R. M., Tetrahedron (2013), http://dx.doi.org/10.1016/j.tet.2013.05.009 


\section{Results and discussion}

Our synthetic sequence starts with substituted tyrosinol $\mathbf{6}$, which can be prepared from commercially available L-tyrosine methyl ester according to the procedure described by Liao. ${ }^{23}$ We initially attempted to perform the direct conversion of $\mathbf{6}$ into bissilyl ether 8 using 2 equiv of TBS- $\mathrm{Cl}$, but the yields were inconsistent and low $(<30 \%){ }^{24,25}$ By increasing the relative amount of TBS-Cl to 6 equiv, compound $\mathbf{6}$ was converted into the trissilylated compound 7. Unexpectedly, the hydrolysis of the silylamine function required a prolonged vigorous stirring with aq $\mathrm{NH}_{4} \mathrm{Cl}$ at $\mathrm{rt}(\sim 2 \mathrm{~h})$ to form the bis-silyl ether 8 in $90 \%$ yield. The phenolic silyl ether was selectively cleaved with 1 equiv of TBAF at $0{ }^{\circ} \mathrm{C},{ }^{26}$ to afford compound $\mathbf{9}$ in $98 \%$ yield (Scheme 2 ).

$$
\text { (c) }
$$

Scheme 2. Tetrahydroisoquinoline ring formation.

The next step entailed the formation of the trans-tetrahydroisoquinoline ring via a Pictet-Spengler reaction between 9 and ethyl glyoxalate. Previously, our group reported a similar transformation, which was performed by stirring a solution of the starting materials in acetonitrile for 3.5 days at $50{ }^{\circ} \mathrm{C}$, which afforded the trans-product stereospecifically. ${ }^{27} \mathrm{~A}$ similar report by Zhu and co-workers involved the use of $\mathrm{LiCl}$, hexafluoroisopropanol and molecular sieves, and stirring the suspension in toluene at $\mathrm{rt}$ for $48 \mathrm{~h}$. Since none of these mild conditions led to the formation of the desired tetrahydroisoquinoline ring system, we decided to adapt the reaction conditions that were originally described by $\mathrm{Zhu}^{28,29}$ to our substrate. The amount of acetic acid was reduced from 2.5 equiv to 0.2 equiv to prevent cleavage of the $O$-TBS ether due to the prolonged exposure to the acid. In the present system, treatment of a solution of compound $\mathbf{9}$ and ethyl glyoxylate with $\mathrm{CF}_{3} \mathrm{CH}_{2} \mathrm{OH}, \mathrm{AcOH}$ ( 0.2 equiv), and $4 \AA \mathrm{MS}$ afforded an $8: 1$ mixture of 10a and 10b in $82 \%$ yield. These two diastereomers were separated via flash chromatography and 10a was subjected to selective acetylation, ${ }^{30}$ followed by hydrogenolysis of the $\mathrm{C}-\mathrm{Br}$ bond ${ }^{23}$ to afford compound 12 (Scheme 3).

Following the conditions described in our previous report, ${ }^{20}$ we converted THIQ 12 into the [3+2] dipolar cycloaddition adducts 20a and 20b. Thus, THIQ 12 and $N$-Boc- $N$-Bn-Gly were coupled using $\mathrm{EDCI}$, and the resulting amide was treated with TBAF to cleave the $O$-TBS ether, followed by a Swern oxidation ${ }^{31}$ to afford aldehyde $\mathbf{1 5}$ (Scheme 3).

As illustrated in Scheme 4, aldehyde $\mathbf{1 5}$ was dissolved in $\mathrm{CHCl}_{3}$ and treated under aerobic conditions with TFA ${ }^{32-34}$ (50 equiv) and TEMPO ( 0.1 equiv), to generate iminium ion $\mathbf{1 6}$, which tautomerizes to form ammonium ion 17. This intermediate is autoxidized in situ to afford conjugated iminium ion $\mathbf{1 8}$, which was concentrated to dryness and taken up in $\mathrm{CHCl}_{3}$. Addition of triethylamine induces the formation of azomethine ylide 19, which is trapped in situ by tert-butyl acrylate to give a 2.4:1 mixture of tetracycles 20a and 20b in a combined $59 \%$ yield. ${ }^{35}$

$$
\text { (c) }
$$

Scheme 3. Preparation of aldehyde 15.
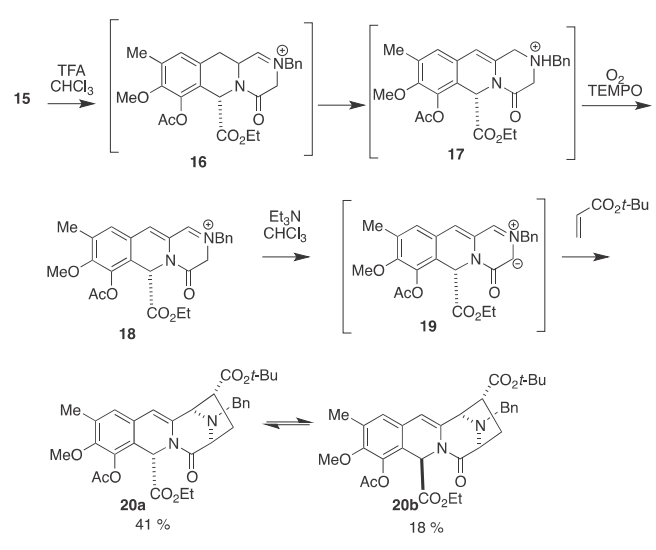

Scheme 4. Formation of cycloadducts 20a and 20b.

The deacetylation of the $\mathbf{2 0 a} / \mathbf{2 0 b}$ mixture under standard methanolysis conditions provided a 5:1 mixture of 21a and 21b in 70\% yield (Scheme 5). We suggest that 21b decomposes under the reaction conditions at a higher rate than 21a, which provides an explanation for both the moderate yield and the change in the diastereomeric ratio. The chemoselective reduction of the ethyl esters with 1 equiv of $\mathrm{LiAlH}_{4}$ at $-10{ }^{\circ} \mathrm{C}$, afforded a $3: 1$ mixture of aldehydes 22a and 22b in 55\% yield. ${ }^{36}$ We submit that the partial
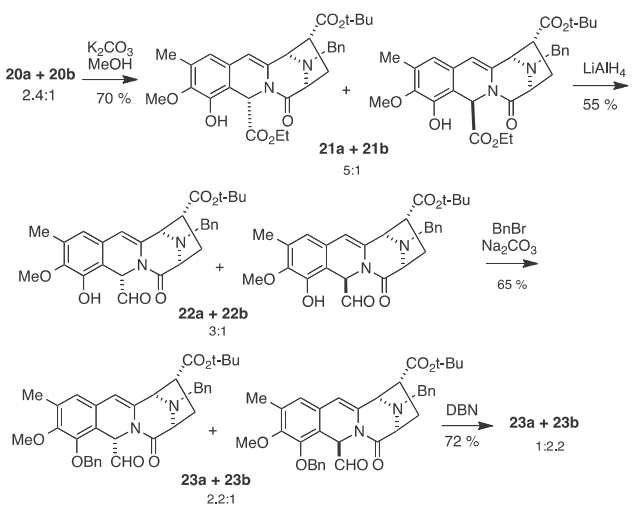

Scheme 5. Synthesis of aldehydes $23 \mathbf{a}$ and $\mathbf{2 3 b}$ 
epimerization seen in this step is promoted by the slightly basic workup conditions. Treatment with $\mathrm{BnBr}$ and $\mathrm{Na}_{2} \mathrm{CO}_{3}$ formed the phenolic benzyl ethers and induced additional epimerization of the aldehyde's $\alpha$ carbon, to provide a 2.2:1 mixture of 23a and $\mathbf{2 3} \mathbf{b} \mathbf{b}^{37}$ which was then reacted with DBN in THF to invert the epimeric ratio. ${ }^{21,22}$

The 1:2.2 mixture of aldehydes $\mathbf{2 3} \mathbf{a}$ and $\mathbf{2 3} \mathbf{b}$ was then treated with sodium borohydride to afford a mixture of alcohols $\mathbf{2 4 a}$ and $\mathbf{2 4 b}$, which were separated via flash chromatography to afford $\mathbf{2 4 \mathbf { b }}$ in 65\% yield (Scheme 6). The sequence used to transform the 20a/ 20b mixture into $\mathbf{2 4 b}$ not only provided the desired configuration in the benzylic position but also furnished an unhindered substrate for the $\mathrm{N}$-debenzylation of the piperazinone amine. Thus, hydrogenolysis of $\mathbf{2 4 b}$ in glacial acetic acid (10\% Pd/C, $1 \mathrm{~atm})$ effected the bis-debenzylation to afford $\mathbf{2 5}$ in $92 \%$ yield. Similarly, the removal of the $N$-benzyl group also provided an unhindered substrate for the hydrogenation of the enamide double bond from the Re face of C-3 (lemonomycin numbering). Gratifyingly, the hydrogenation of 25 with Raney ${ }^{\circledR}$ nickel at $100 \mathrm{psi}^{21}$ provided compound 26 in $73 \%$ yield.

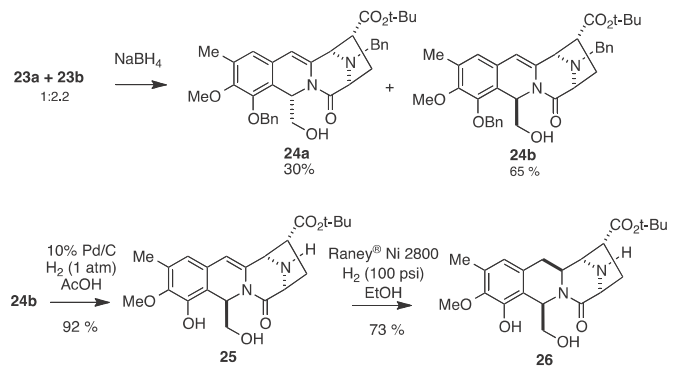

Scheme 6. Synthesis of compound 26.

\section{Conclusion}

In summary, we have accomplished the construction of the tetracyclic core of (-)-lemonomycin. Compound $\mathbf{2 6}$ was prepared from known bromotyrosinol $\mathbf{6}$ in 16 steps. Efforts to gain access to (-)-lemonomycin through this advanced intermediate are currently under investigation.

\section{Experimental section}

\subsection{General methods}

Unless otherwise noted, all materials were obtained from commercial sources and used without purification. All reactions requiring anhydrous conditions were performed under a positive pressure of argon using flame-dried glassware. Organic solvents were degassed with argon and dried through a solvent purification system (Pure Process Technology). Flash chromatography was performed on silica gel grade $60(230 \times 400$ mesh $)$ from Sorbent Technologies. Thin layer chromatography was performed on glass plates coated with silica gel grade 60, from Merck. ${ }^{1} \mathrm{H}$ NMR and ${ }^{13} \mathrm{C}$ NMR spectra were recorded on Varian 300 or $400 \mathrm{MHz}$ spectrometers as indicated. Proton spectra in $\mathrm{CDCl}_{3}$ were referenced to residual $\mathrm{CHCl}_{3}$ at $7.26 \mathrm{ppm}$. Carbon spectra in $\mathrm{CDCl}_{3}$ were referenced to $77.16 \mathrm{ppm}$. Proton spectra in DMSO- $d_{6}$ were referenced to residual $\mathrm{CD}_{3} \mathrm{SOCD}_{2} \mathrm{H}$ at $2.50 \mathrm{ppm}$. Infrared spectra were recorded on a Bruker Tensor FT-IR spectrometer. High-resolution mass spectra were obtained using a TOF spectrometer using simultaneous electrospray (ESI) and atmospheric pressure chemical ionization (APCI). Optical rotations were recorded on a Rudolph Research Autopol polarimeter, at a wavelength of $589 \mathrm{~nm}$.

4.2. (S)-1-(2-Bromo-5-((tert-butyldimethylsilyl)oxy)-4methoxy-3-methylphenyl)-3-((tert-butyldimethylsilyl)oxy) propan-2-amine (8)

To a stirred solution of compound $\mathbf{6}$ ( $1.55 \mathrm{~g}, 5.36 \mathrm{mmol}, 1$ equiv) (6) in $\mathrm{CH}_{2} \mathrm{Cl}_{2}(90 \mathrm{~mL}, 0.06 \mathrm{M})$, were added DMAP (327 mg, $2.68 \mathrm{mmol}, 0.5$ equiv), $\mathrm{Et}_{3} \mathrm{~N}$ ( $4.48 \mathrm{~mL}, 32.2 \mathrm{mmol}, 6.00$ equiv), and TBS-Cl ( $4.86 \mathrm{~g}, 32.2 \mathrm{mmol}, 6$ equiv). The reaction was stirred under $\mathrm{Ar}$ for $3 \mathrm{~h}$ at $\mathrm{rt}$, and then satd aq $\mathrm{NH}_{4} \mathrm{Cl}(50 \mathrm{~mL})$ was added and the mixture was stirred for $2 \mathrm{~h}$. The phases were separated, the aqueous layer was extracted with $\mathrm{CH}_{2} \mathrm{Cl}_{2}(2 \times 50 \mathrm{~mL})$ and the combined organic layers were rinsed with brine $(50 \mathrm{~mL})$, dried $\left(\mathrm{Na}_{2} \mathrm{SO}_{4}\right)$, filtered, and concentrated under vacuum. The crude material was purified by flash chromatography (silica gel, hexane/EtOAc $5: 1$ ) to give the title compound $\mathbf{8}(2.50 \mathrm{~g}, 90 \%)$ as a colorless oil. ${ }^{1} \mathrm{H}$ NMR $\left(400 \mathrm{MHz} ; \mathrm{CDCl}_{3}\right): \delta 6.65(\mathrm{~s}, 1 \mathrm{H}), 3.72(\mathrm{~s}, 3 \mathrm{H}), 3.61(1 / 2 \mathrm{ABX}, J=9.7$, $4.1 \mathrm{~Hz}, 1 \mathrm{H}), 3.47(1 / 2 \mathrm{ABX}, J=9.7,6.5 \mathrm{~Hz}, 1 \mathrm{H}), 3.20-3.14(\mathrm{~m}, 1 \mathrm{H}), 2.87$ (1/2 ABX, $J=13.4,5.4 \mathrm{~Hz}, 1 \mathrm{H}), 2.57(1 / 2 \mathrm{ABX}, J=13.4,8.0 \mathrm{~Hz}, 1 \mathrm{H}), 2.35$ (s, 3H), 1.00 (s, 9H), $0.91(\mathrm{~s}, 9 \mathrm{H}), 0.17(\mathrm{~s}, 6 \mathrm{H}), 0.07(\mathrm{~s}, 3 \mathrm{H}), 0.06(\mathrm{~s}$, $3 \mathrm{H}) ;{ }^{13} \mathrm{C}$ NMR (101 MHz, $\left.\mathrm{CDCl}_{3}\right): \delta 148.8,147.6,134.6,133.1,121.3$, 119.4, 67.6, 60.2, 52.9, 41.3, 26.1, 25.8, 18.4, 18.4, 17.2, -4.4, - 5.2; $R_{f}$ $\left(\mathrm{SiO}_{2}, 2: 1\right.$ hexanes/EtOAc) $0.35 ;[\alpha]_{\mathrm{D}}^{25}+0.9\left(\mathrm{c} 0.35, \mathrm{CHCl}_{3}\right)$; IR (film, $\left.\mathrm{CH}_{2} \mathrm{Cl}_{2}\right), \nu_{\max } 2996,2930,2858,2471,839 \mathrm{~cm}^{-1}$; HRMS $\left(\mathrm{MH}^{+}\right)$, found 520.2103. $\mathrm{C}_{23} \mathrm{H}_{45} \mathrm{BrNO}_{3} \mathrm{Si}_{2}$ requires 520.2101.

4.3. (S)-5-(2-Amino-3-((tert-butyldimethylsilyl)oxy)propyl)4-bromo-2-methoxy-3-methylphenol (9)

To a stirred solution of compound 8 ( $1.59 \mathrm{~g}, 3.05 \mathrm{mmol}, 1$ equiv) in THF ( $100 \mathrm{~mL}, 0.03 \mathrm{M})$, under $\mathrm{Ar}$, at $0{ }^{\circ} \mathrm{C}$, was added a 1.0 solution $\mathrm{M}$ of TBAF in THF (3.05 mL, $3.05 \mathrm{mmol}, 1$ equiv). The reaction was stirred for $25 \mathrm{~min}$ and quenched with satd aq $\mathrm{NH}_{4} \mathrm{Cl}(50 \mathrm{~mL})$. The phases were allowed to warm to rt, the aqueous phase was extracted with EtOAc $(2 \times 50 \mathrm{~mL})$ and the combined organic layers were rinsed with brine $(50 \mathrm{~mL})$, dried $\left(\mathrm{Na}_{2} \mathrm{SO}_{4}\right)$, filtered, and concentrated under vacuum. The crude material was purified by flash chromatography (silica gel, $\mathrm{CHCl}_{3} / \mathrm{MeOH} 10: 1$ ) to give the title compound 9 (1.23 g, 98\%) as a colorless oil. ${ }^{1} \mathrm{H}$ NMR $(400 \mathrm{MHz}$; $\left.\mathrm{CDCl}_{3}\right): \delta 6.77(\mathrm{~s}, 1 \mathrm{H}), 3.73(\mathrm{~s}, 3 \mathrm{H}), 3.71-3.66(\mathrm{~m}, 1 \mathrm{H}), 3.56-3.50(\mathrm{~m}$, $1 \mathrm{H}), 3.27-3.24(\mathrm{~m}, 1 \mathrm{H}), 2.92(1 / 2 \mathrm{ABX}, J=13.5,4.6 \mathrm{~Hz}, 1 \mathrm{H}), 2.62(1 / 2$ ABX, J=13.5, 9.0 Hz, 1H), 2.34 (s, 3H), 0.92 (s, 9H), 0.09 (s, 3H), 0.08 $(\mathrm{s}, 3 \mathrm{H}) ;{ }^{13} \mathrm{C}$ NMR $\left(101 \mathrm{MHz}, \mathrm{CDCl}_{3}\right): \delta 148.4,145.0,134.6,132.2,117.2$, 116.1, 67.1, 60.8, 52.9, 52.7, 40.5, 26.1, 18.4, 17.2, -5.2, -5.2. $R_{f}\left(\mathrm{SiO}_{2}\right.$, $\left.\mathrm{CH}_{2} \mathrm{Cl}_{2} / \mathrm{MeOH} 10: 1\right) 0.4 ;[\alpha]_{\mathrm{D}}^{25}+8.3\left(c 0.41, \mathrm{CHCl}_{3}\right.$ ); IR (film, $\mathrm{CH}_{2} \mathrm{Cl}_{2}$ ), $\nu_{\max } 3263$ (br), 2954, 2928, 2856, 1578, 1471, $1092 \mathrm{~cm}^{-1}$; HRMS $\left(\mathrm{MH}^{+}\right)$, found 406.1233. $\mathrm{C}_{17} \mathrm{H}_{31} \mathrm{BrNO}_{3} \mathrm{Si}$ requires 406.1236 .

4.4. (1S,3S)-Ethyl 5-bromo-3-(((tert-butyldimethylsilyl)oxy)methyl)-8-hydroxy-7-methoxy-6-methyl-1,2,3,4tetrahydroisoquinoline-1-carboxylate (10a) and (1R,3S)-ethyl 5-bromo-3-(((tert-butyldimethylsilyl)oxy)methyl)-8-hydroxy7-methoxy-6-methyl-1,2,3,4-tetrahydroisoquinoline-1carboxylate (10b)

To a stirred solution of compound 9 (5.43 g, $13.4 \mathrm{mmol}$, 1.0 equiv) in $\mathrm{CH}_{2} \mathrm{Cl}_{2}(134 \mathrm{~mL}, 0.10 \mathrm{M})$, under $\mathrm{Ar}$, were added, $4 \mathrm{~A}$ molecular sieves (2.72 g), $\mathrm{CF}_{3} \mathrm{CH}_{2} \mathrm{OH}(13.4 \mathrm{~mL}), \mathrm{AcOH}(153 \mu \mathrm{L}$, $2.68 \mathrm{mmol}, 0.20$ equiv), and ethyl glyoxalate ( $50 \%$ solution in $\mathrm{PhCH}_{3}, 2.93 \mathrm{~mL}, 14.8 \mathrm{mmol}, 1.1$ equiv). The reaction was stirred overnight, diluted with $\mathrm{CH}_{2} \mathrm{Cl}_{2}(50 \mathrm{~mL})$, filtered through Celite ${ }^{\circledR}$, and concentrated under vacuum. The crude material was purified by flash chromatography (silica gel, hexanes/EtOAc $5: 1$ ) to give 
compound 10a (4.78 g, 73\%) as a white solid and compound 10b (610 mg, 9\%) as a white solid. Compound 10a: ${ }^{1} \mathrm{H}$ NMR $(400 \mathrm{MHz}$; $\left.\mathrm{CDCl}_{3}\right): \delta 6.25$ (br s, $\left.1 \mathrm{H}\right), 4.89(\mathrm{~s}, 1 \mathrm{H}), 4.26-4.18(\mathrm{~m}, 2 \mathrm{H}), 3.82(1 / 2$ $\mathrm{ABX}, J=9.8,3.5 \mathrm{~Hz}, 1 \mathrm{H}), 3.76$ (s, 3H), $3.54(1 / 2 \mathrm{ABX}, J=9.8,8.5 \mathrm{~Hz}$, 1H), 3.13-3.07 (m, 1H), $2.71(1 / 2 \mathrm{ABX}, J=16.9,4.1 \mathrm{~Hz}, 1 \mathrm{H}), 2.35$ (s, $3 \mathrm{H}), 2.27(1 / 2 \mathrm{ABX}, J=16.9,11.3 \mathrm{~Hz}, 1 \mathrm{H}), 1.29(\mathrm{t}, J=7.1 \mathrm{~Hz}, 3 \mathrm{H}), 0.93(\mathrm{~s}$, 9H), $0.10(\mathrm{~s}, 3 \mathrm{H}), 0.09(\mathrm{~s}, 3 \mathrm{H}) ;{ }^{13} \mathrm{C}$ NMR $\left(101 \mathrm{MHz}, \mathrm{CDCl}_{3}\right): \delta 172.9$, 145.6, 144.3, 130.8, 130.7, 120.0, 118.4, 66.9, 61.7, 61.2, 55.6, 51.6, 32.7, 26.0, 18.4, 17.0, 16.9, 14.4, 14.4, -5.1, -5.2, -5.2, -5.3; $\mathrm{mp}=47^{\circ} \mathrm{C} ; R_{f}\left(\mathrm{SiO}_{2}\right.$, hexanes/EtOAc 4:1) 0.40; $[\alpha]_{\mathrm{D}}^{25}-24.3(c 0.885$, $\mathrm{CHCl}_{3}$ ); IR (film, $\mathrm{CH}_{2} \mathrm{Cl}_{2}$ ), $\nu_{\max } 3284$ (br), 2955, 2931, 2857, 1739, 1462, $1178 \mathrm{~cm}^{-1}$; HRMS $\left(\mathrm{MH}^{+}\right)$, found $490.1446 . \mathrm{C}_{21} \mathrm{H}_{35} \mathrm{BrNO}_{5} \mathrm{Si}$ requires 490.1447. Compound 10b: ${ }^{1} \mathrm{H}$ NMR (400 $\mathrm{MHz} ; \mathrm{CDCl}_{3}$ ): $\delta 5.86$ (br s, 1H), 4.78 (s, 1H), 4.30-4.15 (m, 2H), 3.80 (1/2 ABX, $J=9.9,4.1 \mathrm{~Hz}, 1 \mathrm{H}), 3.74(\mathrm{~s}, 3 \mathrm{H}), 3.68(1 / 2 \mathrm{ABX}, J=9.9,6.6 \mathrm{~Hz}, 1 \mathrm{H})$, $2.95-2.89(\mathrm{~m}, 1 \mathrm{H}), 2.77(1 / 2 \mathrm{ABX}, J=16.6,3.1 \mathrm{~Hz}, 1 \mathrm{H}), 2.44(1 / 2 \mathrm{ABX}$ $J=16.6,8.5 \mathrm{~Hz}, 2 \mathrm{H}), 2.36(\mathrm{~s}, 3 \mathrm{H}), 1.27$ (t, $J=7.1 \mathrm{~Hz}, 3 \mathrm{H}), 0.92(\mathrm{~s}, 9 \mathrm{H})$, 0.09 (s, 6H); ${ }^{13} \mathrm{C}$ NMR (101 MHz, $\left.\mathrm{CDCl}_{3}\right): \delta 172.8,145.1,143.9,132.0$ 130.4, 120.3, 118.4, 66.7, 61.5, 61.4, 58.4, 54.5, 33.0, 26.1, 26.0, 18.5 $17.0,14.2,-5.1,-5.2 ; \mathrm{mp}=95{ }^{\circ} \mathrm{C} ; R_{f}\left(\mathrm{SiO}_{2}\right.$, hexanes/EtOAc 4:1) 0.37; $[\alpha]_{\mathrm{D}}^{25}-36.7\left(c 0.600, \mathrm{CHCl}_{3}\right)$; IR (film, $\left.\mathrm{CH}_{2} \mathrm{Cl}_{2}\right), \nu_{\max } 3314$ (br), 2955, 2931, 2858, 1738, 1463, $1257 \mathrm{~cm}^{-1}$; HRMS $\left(\mathrm{MH}^{+}\right)$, found 490.1456 . $\mathrm{C}_{21} \mathrm{H}_{35} \mathrm{BrNO}_{5} \mathrm{Si}$ requires 490.1447 .

\section{5. (1S,3S)-Ethyl 8-acetoxy-5-bromo-3-(((tert-butyldime- thylsilyl)oxy)methyl)-7-methoxy-6-methyl-1,2,3,4- tetrahydroisoquinoline-1-carboxylate (11)}

To a stirred solution of compound $10 a(840 \mathrm{mg}, 1.72 \mathrm{mmol}$ 1.0 equiv) in acetone ( $34 \mathrm{~mL}, 0.05 \mathrm{M})$, under $\mathrm{Ar}$, were added $\mathrm{K}_{2} \mathrm{CO}_{3}$ $(1.20 \mathrm{~g}, 8.64 \mathrm{mmol}, 5.0$ equiv) and acetic anhydride $(162 \mu \mathrm{L}$ $1.72 \mathrm{mmol}, 1.0$ equiv). The suspension was stirred overnight, the solvent was evaporated, and the residue was partitioned between water $(25 \mathrm{~mL})$ and EtOAc $(25 \mathrm{~mL})$. The aqueous phase was extracted with EtOAc $(2 \times 25 \mathrm{~mL})$ and the combined organic layers were rinsed with brine $(50 \mathrm{~mL})$, dried $\left(\mathrm{Na}_{2} \mathrm{SO}_{4}\right)$, filtered, and concentrated under vacuum. The crude material was purified by flash chromatography (silica gel, hexanes/EtOAc 5:1) to give the title compound 11 ( $800 \mathrm{mg}, 88 \%$ ) as a colorless oil. ${ }^{1} \mathrm{H}$ NMR (400 MHz; $\left.\mathrm{CDCl}_{3}\right): \delta 4.66(\mathrm{~s}, 1 \mathrm{H}), 4.18$ (q, $\left.J=7.1 \mathrm{~Hz}, 2 \mathrm{H}\right), 3.81$ (1/2 ABX, $J=9.8$, $3.5 \mathrm{~Hz}, 1 \mathrm{H}), 3.70$ (s, 3H), $3.55(1 / 2 \mathrm{ABX}, J=9.8,7.6 \mathrm{~Hz}, 1 \mathrm{H}), 3.22-3.16$ (m, 1H), $2.74(1 / 2 \mathrm{ABX}, J=16.9,4.1 \mathrm{~Hz}, 2 \mathrm{H}), 2.38(\mathrm{~s}, 3 \mathrm{H}), 2.37-2.33$ $(\mathrm{m}, 1 \mathrm{H}), 2.29(\mathrm{~s}, 3 \mathrm{H}), 1.27(\mathrm{t}, J=7.1 \mathrm{~Hz}, 3 \mathrm{H}), 0.921(\mathrm{~s}, 9 \mathrm{H}), 0.10(\mathrm{~s}, 3 \mathrm{H})$, $0.07(\mathrm{~s}, 3 \mathrm{H}):{ }^{13} \mathrm{C}$ NMR $\left(101 \mathrm{MHz}, \mathrm{CDCl}_{3}\right): \delta 171.8,167.9,148.6,141.0$ 132.5, 131.5, 125.9, 125.8, 66.7, 61.5, 61.1, 55.8, 51.0, 32.6, 26.0, 20.6 18.4, 17.1, 14.4, -5.2, -5.3. $R_{f}\left(\mathrm{SiO}_{2}\right.$, hexanes/EtOAc 4:1) 0.45; $[\alpha]_{\mathrm{D}}^{25}-21.1\left(c 1.10, \mathrm{CHCl}_{3}\right)$; IR (film, $\left.\mathrm{CH}_{2} \mathrm{Cl}_{2}\right), \nu_{\max } 2956,2932,2856$, 1780, 1737, 1462, $1192 \mathrm{~cm}^{-1}$; HRMS $\left(\mathrm{MH}^{+}\right)$, found 532.1561 $\mathrm{C}_{23} \mathrm{H}_{37} \mathrm{BrNO}_{6} \mathrm{Si}$ requires 530.1574 .

4.6. (1S,3S)-Ethyl 8-acetoxy-3-(((tert-butyldimethylsilyl)oxy)methyl)-7-methoxy-6-methyl-1,2,3,4-tetrahydroisoquinoline1-carboxylate (12)

A solution of compound 11 (2.90 g, $5.46 \mathrm{mmol})$ in $\mathrm{MeOH}$ $(110 \mathrm{~mL}, 0.05 \mathrm{M})$, and Pearlman's catalyst $\left(20 \% \mathrm{Pd}(\mathrm{OH})_{2} / \mathrm{C}\right.$ $580 \mathrm{mg}$ ) were placed in a Fisher-Porter bottle, under Ar. The mixture was sparged with Ar for $5 \mathrm{~min}$ and the vessel was filled with hydrogen gas at 50 psi. The reaction was vigorously stirred overnight and then filtered through Celite ${ }^{\circledR}$ and the vessel was rinsed with $\mathrm{MeOH}(50 \mathrm{~mL})$ and EtOAc $(50 \mathrm{~mL})$. The solution was concentrated under vacuum to dryness and partitioned between satd aq $\mathrm{NaHCO}_{3}(75 \mathrm{~mL})$ and EtOAc $(75 \mathrm{~mL})$. The aqueous phase was extracted with EtOAc $(2 \times 75 \mathrm{~mL})$ and the combined organic layers were rinsed with brine $(50 \mathrm{~mL})$, dried $\left(\mathrm{Na}_{2} \mathrm{SO}_{4}\right)$, filtered, and concentrated under vacuum. The crude material was purified by flash chromatography (silica gel, hexanes/EtOAc 5:1, 4:1 and $3: 1)$ to give the title compound $\mathbf{1 2}(2.25 \mathrm{~g}, 91 \%)$ as a colorless oil. ${ }^{1} \mathrm{H}$ NMR (400 MHz; $\left.\mathrm{CDCl}_{3}\right): \delta 6.85(\mathrm{~s}, 1 \mathrm{H}), 4.65(\mathrm{~s}, 1 \mathrm{H}), 4.17(\mathrm{q}$ $J=7.1 \mathrm{~Hz}, 2 \mathrm{H}), 3.73(1 / 2 \mathrm{ABX}, J=9.8,3.7 \mathrm{~Hz}, 1 \mathrm{H}), 3.70$ (s, 3H), 3.52 (1/2 ABX, J=9.8, 7.2 Hz, 1H), 3.28-3.22 (m, 1H), 2.59 (1/2 ABX, $J=16.1,4.2 \mathrm{~Hz}, 1 \mathrm{H}), 2.50(1 / 2 \mathrm{ABX}, J=16.1,10.7 \mathrm{~Hz}, 1 \mathrm{H}), 2.28(\mathrm{~s}, 3 \mathrm{H})$ $2.27(\mathrm{~s}, 3 \mathrm{H}), 1.26(\mathrm{t}, J=7.1 \mathrm{~Hz}, 3 \mathrm{H}), 0.90(\mathrm{~s}, 9 \mathrm{H}), 0.07(\mathrm{~s}, 3 \mathrm{H}), 0.06(\mathrm{~s}$, $2 \mathrm{H}) .{ }^{13} \mathrm{C}$ NMR $\left(101 \mathrm{MHz}, \mathrm{CDCl}_{3}\right): \delta 172.2,168.3,148.2,141.6,131.5$, $131.1,129.2,124.0,66.7,61.3,60.6,55.6,50.7,30.2,26.0,20.6,18.4$ $16.0,14.4,-5.2,-5.3 . R_{f}\left(\mathrm{SiO}_{2}\right.$, hexanes/EtOAc $\left.4: 1\right) 0.42 ;[\alpha]_{\mathrm{D}}^{25}-17$ (c 0.42, $\mathrm{CHCl}_{3}$ ); IR (film, $\mathrm{CH}_{2} \mathrm{Cl}_{2}$ ), $\nu_{\max } 2954,2929,2857,1775$, $1737,1197 \mathrm{~cm}^{-1}$; HRMS $\left(\mathrm{MH}^{+}\right)$, found $452.244 . \mathrm{C}_{23} \mathrm{H}_{38} \mathrm{NO}_{6} \mathrm{Si}$ requires 452.2468 .

\section{7. (1S,3S)-Ethyl 8-acetoxy-2-(2-(benzyl(tert-butox-} ycarbonyl)-amino)acetyl)-3-(((tert-butyldimethylsilyl)oxy) methyl)-7-methoxy-6-methyl-1,2,3,4-tetrahydroisoquinoline1-carboxylate (13)

A solution of compound $12(2.20 \mathrm{~g}, 4.87 \mathrm{mmol}, 1.0$ equiv $), \mathrm{N}$ Bn- $N$-Boc-glycine (2.58 g, $9.74 \mathrm{mmol}, 2.0$ equiv), and EDCI ( $1.40 \mathrm{~g}$, $7.31 \mathrm{mmol}, 1.5$ equiv) in $\mathrm{CH}_{2} \mathrm{Cl}_{2}(2.5 \mathrm{~mL}, 2 \mathrm{M})$, under $\mathrm{Ar}$, was stirred for 2.5 days. The reaction was diluted with EtOAc $(200 \mathrm{~mL})$, and the solution was extracted with water $(100 \mathrm{~mL})$, satd aq $\mathrm{NaHCO}_{3}(2 \times 100 \mathrm{~mL})$ and brine $(100 \mathrm{~mL})$, dried $\left(\mathrm{Na}_{2} \mathrm{SO}_{4}\right)$, filtered, and concentrated under vacuum. The crude material was purified by flash chromatography (silica gel, hexanes/EtOAc $4: 1$, $3: 1$ and $2: 1$ ) to give the title compound $\mathbf{1 3}$ (3.15 g, 93\%) as a colorless oil. ${ }^{1} \mathrm{H}$ NMR (300 MHz; DMSO- $d_{6}, 393 \mathrm{~K}$, mixture of rotamers): $\delta 7.36-7.24(\mathrm{~m}, 5 \mathrm{H}), 6.94(\mathrm{~s}, 1 \mathrm{H}), 6.88(\mathrm{~s}, 1 \mathrm{H}$, minor rotamer), $5.48(\mathrm{~s}, 1 \mathrm{H}), 4.49(1 / 2 \mathrm{AB}, J=15.6 \mathrm{~Hz}, 1 \mathrm{H}), 4.39(1 / 2 \mathrm{AB}$ $J=15.6 .0 \mathrm{~Hz}, 1 \mathrm{H}), 4.33-4.27(\mathrm{~m}, 2 \mathrm{H}), 4.13-3.87(\mathrm{~m}, 3 \mathrm{H}), 3.69(\mathrm{~s}$ $3 \mathrm{H}), 3.66(\mathrm{~s}, 1 \mathrm{H}$, minor rotamer), 3.34-3.10 (br m, 2H), 3.07-2.91 (br m, 2H), $2.33(\mathrm{~s}, 3 \mathrm{H}), 2.24(\mathrm{~s}, 3 \mathrm{H}), 2.23(\mathrm{~s}, 3 \mathrm{H}$, minor rotamer) $2.23(\mathrm{~s}, 1 \mathrm{H}$, minor rotamer), $1.41(\mathrm{~s}, 9 \mathrm{H}), 1.21(\mathrm{t}, J=7.0 \mathrm{~Hz}, 3 \mathrm{H}$ minor rotamer), $1.12(\mathrm{t}, J=7.1 \mathrm{~Hz}, 3 \mathrm{H}), 0.92(\mathrm{~d}, J=0.6 \mathrm{~Hz}, 2 \mathrm{H}), 0.79$ $(\mathrm{s}, 9 \mathrm{H}), 0.08(\mathrm{~s}, 3 \mathrm{H}$, minor rotamer $), 0.04(\mathrm{~s}, 3 \mathrm{H}$, minor rotamer $)$ $0.03(\mathrm{~m}, 3 \mathrm{H}$, minor rotamer $),-0.11(\mathrm{~s}, 3 \mathrm{H}),-0.14(\mathrm{~s}, 3 \mathrm{H}) .{ }^{13} \mathrm{C}$ NMR $\left(101 \mathrm{MHz}, \mathrm{CDCl}_{3}\right.$, mixture of rotamers): $\delta 170.1,169.7,168.1,168.0$, $156.1,149.6,129.2,129.1,128.7,128.4,127.8,127.5,127.5,127.4$ $121.6,80.5,80.4,71.6,61.9,61.3,60.7,53.6,53.6,53.5,53.0,53.0$ 52.9, 52.9, 50.9, 47.7, 29.5, 28.5, 28.4, 26.0, 26.0, 25.9, 20.9, 18.3, $16.1,16.0,14.0,13.9,-5.3,-5.4,-5.4,-5.7 . R_{f}\left(\mathrm{SiO}_{2}\right.$, hexanes EtOAc 3:1) 0.30; $[\alpha]_{\mathrm{D}}^{25}+26.8\left(\right.$ c $0.995, \mathrm{CHCl}_{3}$ ); IR (film, $\mathrm{CH}_{2} \mathrm{Cl}_{2}$ ), $\nu_{\max }$ 2956, 2931, 2857, 1781, 1743, 1703, 1668, $1199 \mathrm{~cm}^{-1}$; HRMS $\left(\mathrm{MH}^{+}\right)$, found 699.3666. $\mathrm{C}_{37} \mathrm{H}_{55} \mathrm{~N}_{2} \mathrm{O}_{9} \mathrm{Si}$ requires 699.3677.

\section{8. (1S,3S)-Ethyl 2-(2-(benzyl(tert-butoxycarbonyl)amino) acetyl)-8-hydroxy-3-(hydroxymethyl)-7-methoxy-6-methyl- 1,2,3,4-tetrahydroisoquinoline-1-carboxylate (14)}

To a solution of compound 13 ( $765 \mathrm{mg}, 1.09 \mathrm{mmol}, 1.0$ equiv) in THF (10 mL, $0.11 \mathrm{M})$, under $\mathrm{Ar}$, were added $\mathrm{MeOH}(625 \mu \mathrm{L})$ and TBAF (1.0 M solution in THF, $2.18 \mathrm{~mL}, 2.0$ equiv). The reaction was stirred overnight and quenched with satd aq $\mathrm{NH}_{4} \mathrm{Cl}(50 \mathrm{~mL})$ and then diluted with EtOAc $(100 \mathrm{~mL})$. The phases were separated, the aqueous phase was extracted with EtOAc $(2 \times 25 \mathrm{~mL})$ and the combined organic layers were rinsed with brine $(50 \mathrm{~mL})$, dried $\left(\mathrm{Na}_{2} \mathrm{SO}_{4}\right)$, filtered, and concentrated under vacuum. The crude material was dissolved in the minimal amount of $\mathrm{CH}_{2} \mathrm{Cl}_{2}$ and purified by flash chromatography (silica gel, hexanes/EtOAc 2:1, then 1:1) to give the title compound $14(525 \mathrm{mg}, 82 \%)$ as a white amorphous solid. ${ }^{1} \mathrm{H}$ NMR (300 MHz; DMSO- $\left.d_{6}, 393 \mathrm{~K}\right): \delta 7.36-7.26(\mathrm{~m}, 5 \mathrm{H}), 6.96(\mathrm{~s}, 1 \mathrm{H})$ 5.50 (s, 1H), 4.49-4.40 (br m, 2H), 4.27-4.17 (br m, 2H), 4.07-3.89 $(\mathrm{m}, 3 \mathrm{H}), 3.70(\mathrm{~s}, 3 \mathrm{H}), 3.19-3.03(\mathrm{br} \mathrm{m}, 2 \mathrm{H}), 2.94-2.81(\mathrm{~m}, 2 \mathrm{H}$ overlapped with $\mathrm{H}_{2} \mathrm{O}$ signal), 2.34 (s, 3H), 2.25 (s, 3H), 1.41 (s, 9H), 
1.13 (t, $J=7.1 \mathrm{~Hz}, 3 \mathrm{H}) ;{ }^{13} \mathrm{C}$ NMR $\left(101 \mathrm{MHz}, \mathrm{CDCl}_{3}\right.$, mixture of rotamers): $\delta$ 170.2, 170.1, 168.0, 168.0, 156.4, 154.8, 152.8, 149.7, 145.0,141.7, 141.5, 138.1, 138.1, 138.0, 132.9, 132.8, 130.2, 130.0, 128.7, $128.5,128.4,128.3,128.1,127.8,127.8,127.7,127.5,127.5,127.1,124.2$, $121.2,80.9,80.4,65.1,63.8,62.0,60.6,53.7,53.5,52.7,52.0,51.0$, $47.9,30.6,30.0,29.5,28.5,28.4,20.9,16.2,13.8 ; \mathrm{mp} 80{ }^{\circ} \mathrm{C} ; R_{f}\left(\mathrm{SiO}_{2}\right.$, hexanes/EtOAc 1:1) 0.35; [ $\alpha]_{\mathrm{D}}^{25}+78\left(c 0.44, \mathrm{CHCl}_{3}\right)$; IR (film, $\left.\mathrm{CH}_{2} \mathrm{Cl}_{2}\right)$, $\nu_{\max } 3455$ (br), 2977, 2935, 1780, 1742, 1698, 1663, $1200 \mathrm{~cm}^{-1}$; HRMS $\left(\mathrm{MH}^{+}\right)$, found 585.2816. $\mathrm{C}_{31} \mathrm{H}_{41} \mathrm{~N}_{2} \mathrm{O}_{9}$ requires 585.2812.

4.9. (1S,3S)-Ethyl 2-(2-(benzyl(tert-butoxycarbonyl)amino)acetyl)-3-formyl-8-hydroxy-7-methoxy-6-methyl-1,2,3,4tetrahydroisoquinoline-1-carboxylate (15)

A solution of oxalyl chloride ( $825 \mu \mathrm{L}, 9.75 \mathrm{mmol}, 3.0$ equiv) in $\mathrm{CH}_{2} \mathrm{Cl}_{2}(22.5 \mathrm{~mL})$, under $\mathrm{Ar}$, was cooled to $-78{ }^{\circ} \mathrm{C}$, and DMSO (921 $\mu \mathrm{L}, 13.0 \mathrm{mmol}, 4.0$ equiv) was added dropwise. The resulting mixture was stirred an additional $30 \mathrm{~min}$ at $-78^{\circ} \mathrm{C}$. A solution of compound 14 (1.90 mg, $3.25 \mathrm{mmol}, 1.0$ equiv) in $\mathrm{CH}_{2} \mathrm{Cl}_{2}(10 \mathrm{~mL})$ at rt was then added slowly by cannula, and the mixture continued to stir at $-78{ }^{\circ} \mathrm{C}$ for $30 \mathrm{~min}$. Triethylamine $(4.50 \mathrm{~mL}, 32.5 \mathrm{mmol}$, 10 equiv) was then added dropwise, and the solution was stirred for $15 \mathrm{~min}$ at $-78{ }^{\circ} \mathrm{C}$ and an additional $30 \mathrm{~min}$ at $0{ }^{\circ} \mathrm{C}$. The reaction was quenched with satd aq $\mathrm{NH}_{4} \mathrm{Cl}(50 \mathrm{~mL})$ and allowed to warm to rt. The layers were separated, the aqueous phase was extracted with $\mathrm{CH}_{2} \mathrm{Cl}_{2}(3 \times 50 \mathrm{~mL})$ and the combined organic layers were rinsed with brine $(50 \mathrm{~mL})$, dried $\left(\mathrm{Na}_{2} \mathrm{SO}_{4}\right)$, filtered, and concentrated under vacuum. The crude material was purified by flash chromatography (silica gel, hexanes/EtOAc 2:1, then 1:1) to give the title compound $\mathbf{1 5}(1.65 \mathrm{~g}, 87 \%)$ as a colorless oil, which solidifies upon standing to afford a colorless amorphous solid. ${ }^{1} \mathrm{H}$ NMR ( $300 \mathrm{MHz}$; DMSO- $d_{6}, 373 \mathrm{~K}$, mixture of rotamers): $\delta 9.54(\mathrm{~s}, 1 \mathrm{H}$, minor rotamer), $9.28(\mathrm{~s}, 1 \mathrm{H}), 7.35-7.23(\mathrm{~m}, 5 \mathrm{H}), 7.08$ $(\mathrm{s}, 1 \mathrm{H}$, minor rotamer), $7.01(\mathrm{~s}, 1 \mathrm{H}), 6.94(\mathrm{~s}, 1 \mathrm{H}$, minor rotamer $)$, $6.91(\mathrm{~s}, 1 \mathrm{H}$, minor rotamer), $5.70(\mathrm{~s}, 1 \mathrm{H}), 5.10-4.88(\mathrm{~m}, 1 \mathrm{H})$, $4.52-4.28(\mathrm{~m}, 3 \mathrm{H}), 4.26-4.14(\mathrm{~m}, 1 \mathrm{H}), 4.13-3.98(\mathrm{~m}, 2 \mathrm{H})$, $3.97-3.86(\mathrm{~m}, 1 \mathrm{H}), 3.69(\mathrm{~s}, 3 \mathrm{H}$, minor rotamer), $3.68(\mathrm{~s}, 3 \mathrm{H}$, minor rotamer), $3.67(\mathrm{~s}, 3 \mathrm{H}), 3.38-3.27(\mathrm{~m}, 1 \mathrm{H}), 2.34(\mathrm{~s}, 3 \mathrm{H}), 2.32(\mathrm{~s}, 3 \mathrm{H}$, minor rotamer), 2.25 (s, 3H, minor rotamer), 2.24 (s, 3H, minor rotamer), $2.22(\mathrm{~s}, 3 \mathrm{H}), 1.41(\mathrm{~s}, 9 \mathrm{H}, \mathrm{minor}$ rotamer $), 1.40(\mathrm{~s}, 9 \mathrm{H})$, $1.36(\mathrm{~s}, 9 \mathrm{H}$, minor rotamer), 1.34 (s, 9H, minor rotamer), 1.12 (t, $J=7.2 \mathrm{~Hz}, 3 \mathrm{H}) .{ }^{13} \mathrm{C}$ NMR $\left(101 \mathrm{MHz}, \mathrm{CDCl}_{3}\right.$, mixture of rotamers): $\delta$ 201.2, 199.6, 199.2, 169.9, 167.8, 155.9, 155.8, 150.2, 149.7, 141.5, 141.0, 137.6, 137.5, 137.5, 133.6, 133.3, 128.6, 128.6, 128.5, 128.5, 128.4, 128.1, 128.0, 127.9, 122.6, 122.1, 81.0, 80.8, 62.7, 62.2, 60.9, 60.6, 60.6, 60.2, 53.7, 53.5, 53.3, 50.9, 47.8, 47.6, 47.1, 29.6, 28.5, 28.5, 28.4, 28.2, 20.9, 16.2, 13.8; $\mathrm{mp} 78^{\circ} \mathrm{C} ; R_{f}\left(\mathrm{SiO}_{2}\right.$, hexanes/EtOAc 1:1) $0.40 ;[\alpha]_{\mathrm{D}}^{25}+35\left(\right.$ c $\left.0.23, \mathrm{CHCl}_{3}\right)$; IR (film, $\left.\mathrm{CH}_{2} \mathrm{Cl}_{2}\right), \nu_{\max } 2978$, 2937, 1780, 1742, 1699, 1673, $1200 \mathrm{~cm}^{-1}$; HRMS $\left(\mathrm{MH}^{+}\right)$, found 583.2654. $\mathrm{C}_{31} \mathrm{H}_{39} \mathrm{~N}_{2} \mathrm{O}_{9}$ requires 583.2656 .

4.10. $(5 S, 8 S, 10 R, 11 S)$-10-tert-Butyl 5-ethyl 4-acetoxy-13benzyl-3-methoxy-2-methyl-7-oxo-5,7,8,9,10,11-hexahydro8,11-epiminoazepino[1,2-b]isoquinoline-5,10-dicarboxylate (20a) and $(5 R, 8 S, 10 R, 11 S)$-10-tert-butyl 5-ethyl 4-acetoxy-13benzyl-3-methoxy-2-methyl-7-oxo-5,7,8,9,10,11-hexahydro8,11-epiminoazepino[1,2-b]isoquinoline-5,10-dicarboxylate (20b)

To solution of compound 15 (1.65 g, $2.83 \mathrm{mmol}, 1.0$ equiv) in $\mathrm{CHCl}_{3}(28 \mathrm{~mL}, 0.1 \mathrm{M})$, under air, were added TEMPO (44 mg, $0.28 \mathrm{mmol}, 0.10$ equiv), and trifluoroacetic acid $(10.8 \mathrm{~mL}, 142 \mathrm{mmol}$, 50 equiv) and the flask was loosely capped with a Teflon ${ }^{\circledR}$ stopper. The solution was stirred for $4 \mathrm{~h}$, the solvent was evaporated to dryness under vacuum and the residue was taken up in $\mathrm{CHCl}_{3}$. The solution was cooled to $0{ }^{\circ} \mathrm{C}$ and then tert-butyl acrylate $(8.20 \mathrm{~mL}$,
$56.6 \mathrm{mmol}, 20$ equiv) and triethylamine $(3.95 \mathrm{~mL}, 28.3 \mathrm{mmol}$ 10 equiv) were added. The reaction was allowed to warm to rt and stirred overnight. The solution was diluted with EtOAc $(200 \mathrm{~mL})$, rinsed with satd aq $\mathrm{NH}_{4} \mathrm{Cl}(50 \mathrm{~mL})$ and brine $(50 \mathrm{~mL})$, dried $\left(\mathrm{Na}_{2} \mathrm{SO}_{4}\right)$, filtered, and concentrated under vacuum. The crude material was purified by flash chromatography (silica gel, hexanes/ EtOAc 4:1,3:1) to afford a $2.4: 1$ mixture of the title compounds 20a and $20 \mathrm{~b}(985 \mathrm{mg}, 59 \%)$ as a yellow oil, which was used in the next step without further purification. ${ }^{1} \mathrm{H}$ NMR $\left(400 \mathrm{MHz} ; \mathrm{CDCl}_{3}\right)$ : $\delta 7.41-7.22(\mathrm{~m}, 5 \mathrm{H}), 6.74(\mathrm{~s}, 1 \mathrm{H}$, minor diastereomer), $6.73(\mathrm{~s}, 1 \mathrm{H})$, $6.36(\mathrm{~s}, 1 \mathrm{H}$, minor diastereomer), $6.27(\mathrm{~s}, 1 \mathrm{H}), 5.51(\mathrm{~s}, 1 \mathrm{H}$, minor diastereomer), $5.50(\mathrm{~s}, 1 \mathrm{H}), 4.28-3.96(\mathrm{~m}, 6 \mathrm{H}), 3.89-3.71(\mathrm{~m}, 2 \mathrm{H})$, $3.75(\mathrm{~s}, 3 \mathrm{H}$, minor diastereomer), $3.72(\mathrm{~s}, 3 \mathrm{H}), 2.80-2.67(\mathrm{~m}, 2 \mathrm{H})$, 2.45 (dd, $J=13.0,9.8 \mathrm{~Hz}, 1 \mathrm{H}$, minor diastereomer), 2.40 (s, 3H), 2.39 (s, 3H, minor diastereomer), 2.28 (s, 3H, minor diastereomer), 2.26 $(\mathrm{s}, 3 \mathrm{H}), 2.13$ (dd, $J=13.3,9.5 \mathrm{~Hz}, 1 \mathrm{H}), 1.46(\mathrm{~s}, 9 \mathrm{H}$, minor diastereomer), $1.42(\mathrm{~s}, 9 \mathrm{H}), 1.24(\mathrm{t}, J=7.1 \mathrm{~Hz}, 3 \mathrm{H}), 1.20(\mathrm{t}, J=7.2 \mathrm{~Hz}, 3 \mathrm{H}$, minor diastereomer); ${ }^{13} \mathrm{C}$ NMR (101 MHz, $\left.\mathrm{CDCl}_{3}\right): \delta$ 172.4, 171.7, 168.7,167.9, 149.9, 141.6, 133.1,129.0,128.6, 128.4, 128.4, 127.4,127.3, 126.6, 125.0, 124.8, 117.3, 116.7, 104.6, 103.1, 81.4, 81.3, 65.1, 64.1, $63.1,62.6,62.4,62.3,60.7,60.6,52.7,51.8,51.3,50.7,50.0,48.0,34.3$, 31.9, 31.7, 28.2, 22.8, 21.0, 16.1, 14.2, 14.0; $R_{f}\left(\mathrm{SiO}_{2}\right.$, hexanes/EtOAc 3:1) 0.5 ; $[\alpha]_{D}^{25}-65.0\left(c 0.320, \mathrm{CH}_{2} \mathrm{Cl}_{2}\right.$ ); IR (film, $\left.\mathrm{CH}_{2} \mathrm{Cl}_{2}\right), \nu_{\max } 2980$, 2936, 1781, 1741, 1693, $1651 \mathrm{~cm}^{-1}$; HRMS $\left(\mathrm{MH}^{+}\right)$, found 591.2712. $\mathrm{C}_{33} \mathrm{H}_{39} \mathrm{~N}_{2} \mathrm{O}_{8}$ requires 591.2706

4.11. (5S,8S,10R,11S)-10-tert-Butyl 5-ethyl 13-benzyl-4hydroxy-3-methoxy-2-methyl-7-oxo-5,7,8,9,10,11-hexahydro8,11-epiminoazepino[1,2-b]isoquinoline-5,10-dicarboxylate (21a) and $(5 R, 8 S, 10 R, 11 S)$-10-tert-butyl 5-ethyl 13-benzyl-4hydroxy-3-methoxy-2-methyl-7-oxo-5,7,8,9,10,11-hexahydro8,11-epiminoazepino[1,2-b]isoquinoline-5,10-dicarboxylate (21b)

To a stirred solution of a 2.6:1 mixture of compounds 20a and 20b (410 mg, $0.695 \mathrm{mmol}, 1.0$ equiv) in THF/MeOH $1: 1(14 \mathrm{~mL}$, $0.05 \mathrm{M})$, under $\mathrm{Ar}$, was added $\mathrm{K}_{2} \mathrm{CO}_{3}(192 \mathrm{mg}, 1.39 \mathrm{mmol}$, 2.0 equiv). The suspension was stirred for $2.5 \mathrm{~h}$, the solvent was evaporated and the residue was partitioned between phosphate buffer $(0.1 \mathrm{M}, \mathrm{pH}=7.5,50 \mathrm{~mL})$ and EtOAc $(33 \mathrm{~mL})$. The aqueous phase was extracted with EtOAc $(2 \times 33 \mathrm{~mL})$ and the combined organic layers were rinsed with brine $(50 \mathrm{~mL})$, dried $\left(\mathrm{Na}_{2} \mathrm{SO}_{4}\right)$, filtered, and concentrated under vacuum. The crude material was purified by flash chromatography (silica gel, hexanes/EtOAc 4:1) to afford a 5:1 mixture of the title compounds 21a and 21b (255 mg, 67\%) as a pale yellow oil, which was used in the next step without further purification. ${ }^{1} \mathrm{H}$ NMR $\left(400 \mathrm{MHz} ; \mathrm{CDCl}_{3}\right)$ : $\delta 7.38-7.24(\mathrm{~m}, 5 \mathrm{H}), 6.76(\mathrm{~s}, 1 \mathrm{H}), 6.63(\mathrm{~s}, 1 \mathrm{H}$, minor diastereomer), $6.49(\mathrm{~s}, 1 \mathrm{H}, \mathrm{minor}$ diastereomer), $6.43(\mathrm{~s}, 1 \mathrm{H}, \mathrm{minor}$ diastereomer), $6.42(\mathrm{~s}, 1 \mathrm{H}), 6.39(\mathrm{~s}, 5 \mathrm{H}), 5.46(\mathrm{~s}, 1 \mathrm{H}$, minor diastereomer), 5.45 (s, 1H. minor diastereomer), $4.24(\mathrm{q}, J=7.1 \mathrm{~Hz}$, 2H), 4.19-3.9 (m, 5H), 4.07 (s, 1H), 3.86 (d, J=7.5 Hz, 1H), 3.84 (s, $1 \mathrm{H}$, minor diastereomer), $3.82(\mathrm{~s}, 3 \mathrm{H}), 3.31(\mathrm{dd}, J=9.8,6.0 \mathrm{~Hz}, 1 \mathrm{H}$, minor diastereomer), $2.79(\mathrm{dd}, J=9.5,4.6 \mathrm{~Hz}, 1 \mathrm{H}), 2.74-2.66(\mathrm{~m}$, $1 \mathrm{H}), 2.46$ (dd, $J=13.0,9.9 \mathrm{~Hz}, 1 \mathrm{H}$, minor diastereomer), $2.26(\mathrm{~s}, 3 \mathrm{H}$, minor diastereomer), $2.24(\mathrm{~s}, 3 \mathrm{H}), 2.13(\mathrm{dd}, J=13.4,9.6 \mathrm{~Hz}, 6 \mathrm{H})$, 1.46 (s, 9H, minor diastereomer), $1.42(\mathrm{~s}, 9 \mathrm{H}), 1.27(\mathrm{t}, J=7.1 \mathrm{~Hz}$, $3 \mathrm{H}), 1.24\left(\mathrm{t}, J=7.2 \mathrm{~Hz}, 3 \mathrm{H}\right.$, minor diastereomer); ${ }^{13} \mathrm{C} \mathrm{NMR}$ $\left(101 \mathrm{MHz}, \mathrm{CDCl}_{3}\right): \delta$ 172.4, 171.9, 170.7, 170.6, 170.4, 168.9, 146.9, $146.8,146.2,138.5,138.0,136.1,134.2,131.9,131.7,128.5,127.4$, 127.3, 126.6, 126.0, 119.1, 119.1, 110.8, 103.4, 81.3, 64.3, 62.7, 62.6, $60.8,60.8,52.2,52.2,52.1,51.5,50.8,48.2,32.1,28.2,28.1,22.8$,

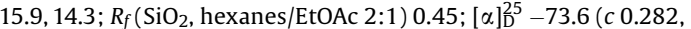
$\mathrm{CH}_{2} \mathrm{Cl}_{2}$ ); IR (film, $\mathrm{CH}_{2} \mathrm{Cl}_{2}$ ), $\nu_{\max } 3374$ (br), 2980, 2938, 1736, 1689, $1647,1154 \mathrm{~cm}^{-1}$; HRMS $\left(\mathrm{MH}^{+}\right)$, found 549.2606. $\mathrm{C}_{31} \mathrm{H}_{37} \mathrm{~N}_{2} \mathrm{O}_{7}$ requires 549.2601 . 
4.12. (5S,8S,10R,11S)-tert-Butyl 13-benzyl-5-formyl-4hydroxy-3-methoxy-2-methyl-7-oxo-5,7,8,9,10,11-hexahydro8,11-epiminoazepino[1,2-b]isoquinoline-10-carboxylate (22a) and $(5 R, 8 S, 10 R, 11 S)$-tert-butyl 13-benzyl-5-formyl-4-hydroxy3-methoxy-2-methyl-7-oxo-5,7,8,9,10,11-hexahydro-8,11epiminoazepino[1,2-b]isoquinoline-10-carboxylate $(22 \mathrm{~b})$

A solution of $\mathrm{LiAlH}_{4}$ in THF ( $1.0 \mathrm{M}, 447 \mu \mathrm{L}, 0.447 \mathrm{mmol}, 1.0$ equiv) was added dropwise to a solution of a 5:1 mixture of compounds 21a and 21b (245 mg, $0.447 \mathrm{mmol}, 1.0$ equiv) in THF ( $9 \mathrm{~mL}, 0.05 \mathrm{M})$, under $\mathrm{Ar}$, at $-10{ }^{\circ} \mathrm{C}$. The solution was stirred for $10 \mathrm{~min}$ at this temperature, quenched with EtOAc (12 mL) and satd aq Rochelle's salt $(12 \mathrm{~mL})$ and allowed to warm to rt. The flask was covered with aluminum foil and stirred overnight under a stream of Ar. The solution was diluted with phosphate buffer $(0.1 \mathrm{M}, \mathrm{pH}=7.5,50 \mathrm{~mL})$, the phases were separated and aqueous phase was extracted with EtOAc $(3 \times 33 \mathrm{~mL})$ and the combined organic layers were rinsed with brine $(25 \mathrm{~mL})$, dried $\left(\mathrm{Na}_{2} \mathrm{SO}_{4}\right)$, filtered, and concentrated under vacuum. The crude material was purified by flash chromatography (silica gel, hexanes/EtOAc 4:1) to afford a 3:1 mixture of the title compounds 22a and 22b (124 mg, 55\%) as a pale yellow oil, which was used in the next step without further purification. ${ }^{1} \mathrm{H}$ NMR $(400 \mathrm{MHz}$; $\left.\mathrm{CDCl}_{3}\right): \delta 9.48(\mathrm{~s}, 1 \mathrm{H}), 9.38(\mathrm{~s}, 1 \mathrm{H}$, minor diastereomer), 7.41-7.23 (m, $5 \mathrm{H}), 6.58(\mathrm{~s}, 1 \mathrm{H}), 6.57(\mathrm{~s}, 1 \mathrm{H}$, minor diastereomer), $6.43(\mathrm{~s}, 1 \mathrm{H}$, minor diastereomer), $6.41(\mathrm{~s}, 1 \mathrm{H}), 6.18(\mathrm{~s}, 1 \mathrm{H}$, minor diastereomer), $6.17(\mathrm{~s}$, $1 \mathrm{H}$, minor diastereomer), $4.25(1 / 2 \mathrm{AB}, J=13.5 \mathrm{~Hz}, 1 \mathrm{H}), 4.18(1 / 2 \mathrm{AB}$ $J=13.5 \mathrm{~Hz}, 1 \mathrm{H}), 4.07(\mathrm{~s}, 1 \mathrm{H}), 4.00(\mathrm{~s}, 1 \mathrm{H}$, minor diastereomer), $3.83(\mathrm{~s}$ $3 \mathrm{H}$, minor diastereomer), 3.81 (s, $3 \mathrm{H}$, minor diastereomer), 3.40 (dd, $J=9.7,6.0 \mathrm{~Hz}, 1 \mathrm{H}$, minor diastereomer), $2.81(\mathrm{dd}, J=9.5,4.7 \mathrm{~Hz}, 1 \mathrm{H}$ ) $2.73-2.67(\mathrm{~m}, 1 \mathrm{H}), 2.59$ (dd, $J=13.0,9.8 \mathrm{~Hz}, 1 \mathrm{H}$, minor diastereomer), 2.28 (s, 3H, minor diastereomer), 2.26 (s, 3H), 2.15 (dd, $J=13.4$ $9.6 \mathrm{~Hz}, 1 \mathrm{H}), 1.48$ (s, 9H, minor diastereomer), 1.46 (s, 9H); ${ }^{13} \mathrm{C} \mathrm{NMR}$ (101 MHz, $\mathrm{CDCl}_{3}$ ): $\delta$ 192.1, 191.3, 172.5, 171.9, 170.1, 145.7, 144.6, 138.6, $138.0,136.6,135.3,131.5,128.8,128.4,127.5,127.2,119.4,119.2,107.3$ 104.0, 102.7, 102.6, 81.4, 64.1, 64.0, 62.9, 62.8, 61.2, 61.1, 58.6, 58.5 51.6, 50.8, 48.8, 34.7, 32.4, 31.7, 29.8, 28.1, 22.8, 16.0, 14.3; $R_{f}\left(\mathrm{SiO}_{2}\right.$ hexanes/EtOAc 2:1) 0.42; $[\alpha]_{\mathrm{D}}^{25}-64.8$ (c $0.250, \mathrm{CH}_{2} \mathrm{Cl}_{2}$ ); IR (film, $\mathrm{CH}_{2} \mathrm{Cl}_{2}$ ), $\nu_{\max } 3331$ (br), 2977, 2935, 1733, 1679, 1642, $1154 \mathrm{~cm}^{-1}$. HRMS $\left(\mathrm{MH}^{+}\right.$), found 505.2345. $\mathrm{C}_{29} \mathrm{H}_{33} \mathrm{~N}_{2} \mathrm{O}_{6}$ requires 505.2339 .

4.13. (5S,8S,10R,11S)-tert-Butyl 13-benzyl-4-(benzyloxy)-5formyl-3-methoxy-2-methyl-7-oxo-5,7,8,9,10,11-hexahydro8,11-epiminoazepino[1,2-b]isoquinoline-10-carboxylate (23a) and $(5 R, 8 S, 10 R, 11 S)$-tert-butyl 13-benzyl-4-(benzyloxy)-5formyl-3-methoxy-2-methyl-7-oxo-5,7,8,9,10,11-hexahydro8,11-epiminoazepino[1,2-b]isoquinoline-10-carboxylate (5R,8S,10R,11S)-tert-butyl 13-benzyl-4-(benzyloxy)-5-formyl3-methoxy-2-methyl-7-oxo-5,7,8,9,10,11-hexahydro-8,11epiminoazepino[1,2-b]isoquinoline-10-carboxylate (23b)

To a stirred solution of a 3:1 mixture of compounds 22a and 22b (115 mg, $0.228 \mathrm{mmol}, 1.0$ equiv) and benzyl bromide (108 $\mu \mathrm{L}$, $0.912 \mathrm{mmol}, 4.0$ equiv) in DMF (7.6 mL, $0.03 \mathrm{M})$, under $\mathrm{Ar}$, were added tetrabutylammonium iodide $(9.0 \mathrm{mg}, 0.023 \mathrm{mmol}$, 0.10 equiv) and finely ground anhydrous $\mathrm{Na}_{2} \mathrm{CO}_{3}$ (241 mg, $2.28 \mathrm{mmol}, 10$ equiv). The mixture was vigorously stirred for $2 \mathrm{~h}$ and diluted with water $(25 \mathrm{~mL})$ and phosphate buffer $(0.1 \mathrm{M}$, $\mathrm{pH}=7.5,25 \mathrm{~mL})$. The aqueous phase was extracted with EtOAc $(3 \times 33 \mathrm{~mL})$ and the combined organic layers were rinsed with brine $(25 \mathrm{~mL})$, dried $\left(\mathrm{Na}_{2} \mathrm{SO}_{4}\right)$, filtered, and concentrated under vacuum. The crude material was purified by flash chromatography (silica gel, hexanes/EtOAc 6:1, 4:1) to afford a 2.2:1 mixture of compounds 23a and 23b (88 $\mathrm{mg}, 65 \%)$ as a pale yellow oil, which was used in the next step without further purification. ${ }^{1} \mathrm{H}$ NMR $\left(400 \mathrm{MHz} ; \mathrm{CDCl}_{3}\right)$ : $\delta 9.32(\mathrm{~s}, 1 \mathrm{H}), 9.19$ (s, 1H minor diastereomer), 7.48-7.22 (m, 10H), $6.63(\mathrm{~s}, 1 \mathrm{H}$, minor diastereomer), $6.62(\mathrm{~s}, 1 \mathrm{H}), 6.38(\mathrm{~s}, 1 \mathrm{H}$, minor diastereomer), $6.36(\mathrm{~s}, 1 \mathrm{H}), 5.37(\mathrm{~s}, 1 \mathrm{H}), 5.36(\mathrm{~s}$, minor diastereomer), $5.28(1 / 2 \mathrm{AB}, J=11.1 \mathrm{~Hz}, 1 \mathrm{H}$, minor diastereomer), 5.26 $(1 / 2 \mathrm{AB}, J=11.1 \mathrm{~Hz}, 2 \mathrm{H}), 5.20(1 / 2 \mathrm{AB}, J=11.1 \mathrm{~Hz}, 1 \mathrm{H}$, minor diastereomer), $5.14(1 / 2 \mathrm{AB}, J=11.1 \mathrm{~Hz}, 1 \mathrm{H}), 4.20(1 / 2 \mathrm{AB}, J=13.5 \mathrm{~Hz}$, $1 \mathrm{H}), 4.14(1 / 2 \mathrm{AB}, J=13.5 \mathrm{~Hz}, 1 \mathrm{H}), 4.05(\mathrm{~s}, 1 \mathrm{H}), 3.97$ (s, 1H, minor diastereomer), $3.86(\mathrm{~s}, 3 \mathrm{H}$, minor diastereomer), $3.84(\mathrm{~s}, 3 \mathrm{H}), 3.80$ $(1 / 2 \mathrm{AB}, J=13.5 \mathrm{~Hz}, 1 \mathrm{H}) 3.79(\mathrm{~d}, J=7.4 \mathrm{~Hz}, 1 \mathrm{H}), 3.75(\mathrm{~d}, J=6.9 \mathrm{~Hz}$, minor diastereomer), $3.68(1 / 2 \mathrm{AB}, J=13.5 \mathrm{~Hz}, 1 \mathrm{H}$, minor diastereomer), 3.37 (dd, $J=9.7,6.1 \mathrm{~Hz}, 1 \mathrm{H}$, minor diastereomer), 2.78 (dd, $J=9.6,4.7 \mathrm{~Hz}, 1 \mathrm{H}), 2.71-2.64(\mathrm{~m}, 2 \mathrm{H}), 2.53(1 / 2 \mathrm{ABX}, J=13.1$ $9.9 \mathrm{~Hz}, 1 \mathrm{H}$, minor diastereomer), 2.28 (s, 3H, minor diastereomer), $2.26(\mathrm{~s}, 3 \mathrm{H}), 2.10(\mathrm{dd}, J=13.3,9.7 \mathrm{~Hz}, 1 \mathrm{H}), 1.45$ (s, 9H minor diastereomer), $1.44(\mathrm{~s}, 9 \mathrm{H}) ;{ }^{13} \mathrm{C}$ NMR $\left(101 \mathrm{MHz}, \mathrm{CDCl}_{3}\right): \delta 192.5,191.7$, $171.9,169.8,168.8,150.4,150.3,148.3,148.1,138.6,138.1,136.9$ $136.9,136.6,135.3,133.7,128.9,128.8,128.8,128.6,128.6,128.5$ $128.5,128.4,128.3,127.4,127.2,126.9,123.1,122.8,115.0,114.6$ 103.9, 102.5, 81.4, 81.2, 75.0, 75.0, 65.0, 63.9, 63.1, 62.8, 60.5, 58.8 57.3, 52.8, 51.6, 48.8, 34.7, 32.2, 28.2, 16.0, 16.0; $R_{f}\left(\mathrm{SiO}_{2}\right.$, hexanes/ EtOAc 4:1) 0.45; $[\alpha]_{\mathrm{D}}^{25}-64\left(c 0.32, \mathrm{CH}_{2} \mathrm{Cl}_{2}\right.$ ); IR (film, $\mathrm{CH}_{2} \mathrm{Cl}_{2}$ ), $\nu_{\max }$ 3030, 2976, 2934, 1733, 1688, 1646, $1154 \mathrm{~cm}^{-1}$; HRMS $\left(\mathrm{MH}^{+}\right)$, found 595.2801. $\mathrm{C}_{36} \mathrm{H}_{39} \mathrm{~N}_{2} \mathrm{O}_{6}$ requires 595.2808.

To a stirred solution of a 2.2:1 mixture of compounds 23a and 23b ( $88 \mathrm{mg}, 0.15 \mathrm{mmol}, 1.0$ equiv) in THF ( $2 \mathrm{~mL}, 0.08 \mathrm{M})$, under $\mathrm{Ar}$, was added DBN ( $19 \mu \mathrm{L}, 0.15 \mathrm{mmol}, 1.0$ equiv). The mixture was stirred for $30 \mathrm{~min}$ and then diluted with phosphate buffer $(0.1 \mathrm{M}$ $\mathrm{pH}=7.5,50 \mathrm{~mL})$ and water $(50 \mathrm{~mL})$. The aqueous phase was extracted with EtOAc $(3 \times 33 \mathrm{~mL})$ and the combined organic layers were rinsed with brine $(25 \mathrm{~mL})$, dried $\left(\mathrm{Na}_{2} \mathrm{SO}_{4}\right)$, filtered, and concentrated under vacuum. The crude material was dissolved in the minimal amount of EtOAc purified by flash chromatography (silica gel, hexanes/EtOAc 4:1) to afford a 1:2.2 mixture of compounds 23a and 23b (64 $\mathrm{mg}, 72 \%$ ) as a pale yellow oil, which was used in the next step without further purification. ${ }^{1} \mathrm{H}$ NMR (400 $\left.\mathrm{MHz} ; \mathrm{CDCl}_{3}\right)$ : $\delta 9.32(\mathrm{~s}, 1 \mathrm{H}$, minor diastereomer), $9.19(\mathrm{~s}, 1 \mathrm{H}), 7.48-7.24(\mathrm{~m}, 10 \mathrm{H})$ $6.63(\mathrm{~s}, 1 \mathrm{H}), 6.62(\mathrm{~s}, 1 \mathrm{H}$, minor diastereomer), $6.38(\mathrm{~s}, 1 \mathrm{H}), 6.36(\mathrm{~s}$ $1 \mathrm{H}$, minor diastereomer), 5.37 (s, $1 \mathrm{H}$, minor diastereomer), 5.36 (s, $1 \mathrm{H}), 5.28(1 / 2 \mathrm{AB}, J=11.1 \mathrm{~Hz}, 1 \mathrm{H}), 5.26(1 / 2 \mathrm{AB}, J=11.1 \mathrm{~Hz}, 1 \mathrm{H}$, minor diastereomer), $5.19(1 / 2 \mathrm{AB}, J=11.1 \mathrm{~Hz}, 1 \mathrm{H}), 5.13(1 / 2 \mathrm{AB}, J=11.2 \mathrm{~Hz}$, $2 \mathrm{H}$, minor diastereomer), $4.20(1 / 2 \mathrm{AB}, J=13.4 \mathrm{~Hz}, 1 \mathrm{H}$, minor diastereomer), $4.14(1 / 2 \mathrm{AB}, J=13.5 \mathrm{~Hz}, 1 \mathrm{H}$ minor diastereomer $), 4.05$ $\left(\mathrm{s}, 1 \mathrm{H}\right.$, minor diastereomer), $3.97(\mathrm{~s}, 1 \mathrm{H}), 3.86\left(\mathrm{~s}, 3 \mathrm{H}, \mathrm{minor} \mathrm{di}^{-}\right.$ astereomer), $3.84(\mathrm{~s}, 3 \mathrm{H}$, minor diastereomer), $3.81(1 / 2 \mathrm{AB}$ $J=13.6 \mathrm{~Hz}, 1 \mathrm{H}$ ), 3.79 (d, $J=6.2 \mathrm{~Hz}, 4 \mathrm{H}), 3.75$ (d, $J=6.6 \mathrm{~Hz}, 3 \mathrm{H}$ ), 3.68 (1/ $2 \mathrm{AB}, J=13.4 \mathrm{~Hz}, 3 \mathrm{H}$ ), 3.37 (dd, $J=9.8,6.0 \mathrm{~Hz}, 1 \mathrm{H}$ ), 2.78 (dd, $J=9.5$, $4.7 \mathrm{~Hz}, 1 \mathrm{H}$, minor diastereomer), 2.71-2.65 ( $\mathrm{m}, 2 \mathrm{H}), 2.53$ (1/2 ABX $J=13.0,9.9 \mathrm{~Hz}, 3 \mathrm{H}), 2.28$ (s, 3H), 2.26 (s, 3H, minor diastereomer) 2.10 (dd, $J=13.4,9.5 \mathrm{~Hz}, 1 \mathrm{H}$, minor diastereomer), 1.45 (s, 9H), 1.44 (s, 9H, minor diastereomer); ${ }^{13} \mathrm{C}$ NMR $\left(101 \mathrm{MHz}, \mathrm{CDCl}_{3}\right): \delta 192.5$, 191.7, 172.5, 171.9, 168.8, 150.4, 148.1, 138.0,136.9, 135.3, 133.7, 128.9, $128.8,128.8,128.6,128.5,128.4,128.3,127.4,127.2,126.9,123.1$ $122.8,115.0,114.6,103.9,102.5,81.4,81.2,75.0,75.0,65.0,63.9,63.1$ 62.7, 60.4, 58.8, 57.3, 52.7, 51.6, 50.9, 48.8, 34.7, 32.2, 28.2, 28.1, 16.0 16.0; $R_{f}\left(\mathrm{SiO}_{2}\right.$, hexanes/EtOAc); $[\alpha]_{\mathrm{D}}^{25}+27\left(\right.$ c $\left.0.22, \mathrm{CHCl}_{3}\right) ; \mathrm{IR}($ film $\left.\mathrm{CH}_{2} \mathrm{Cl}_{2}\right), \nu_{\max } 3029,2969,2935,1732,1688,1647,1154 \mathrm{~cm}^{-1}$; HRMS $\left(\mathrm{MH}^{+}\right)$, 595.2789. $\mathrm{C}_{36} \mathrm{H}_{39} \mathrm{~N}_{2} \mathrm{O}_{6}$ requires 595.2808.

4.14. (5S,8S,10R,11S)-tert-Butyl 13-benzyl-4-(benzyloxy)-5(hydroxymethyl)-3-methoxy-2-methyl-7-oxo-5,7,8,9,10,11hexahydro-8,11-epiminoazepino[1,2-b]isoquinoline-10carboxylate (24a) and $(5 R, 8 S, 10 R, 11 S)$-tert-butyl 13-benzyl-4(benzyloxy)-5-(hydroxymethyl)-3-methoxy-2-methyl-7-oxo$5,7,8,9,10,11$-hexahydro-8,11-epiminoazepino[1,2-b]isoquinoline-10-carboxylate (24b)

To a stirred solution of a mixture of compounds $\mathbf{2 3} \mathbf{a}$ and $\mathbf{2 3} \mathbf{b}$ $(60 \mathrm{mg}, 0.10 \mathrm{mmol})$ in $\mathrm{EtOH}(5 \mathrm{~mL}, 0.20 \mathrm{M})$, at $0{ }^{\circ} \mathrm{C}$, under $\mathrm{Ar}$, was 
added $\mathrm{NaBH}_{4}$ ( $30 \mathrm{mg}, 0.80 \mathrm{mmol} 8.0$ equiv). The reaction was stirred at rt for $2 \mathrm{~h}$, quenched with $1 \mathrm{~N} \mathrm{HCl}(2.4 \mathrm{~mL}, 2.40 \mathrm{mmol}$, 24 equiv) and diluted with phosphate buffer $(0.1 \mathrm{M}, \mathrm{pH}=7.5$, $50 \mathrm{~mL})$. The aqueous phase was extracted with EtOAc $(3 \times 25 \mathrm{~mL})$ and the combined organic layers were rinsed with brine $(25 \mathrm{~mL})$, dried $\left(\mathrm{Na}_{2} \mathrm{SO}_{4}\right)$, filtered, and concentrated under vacuum. The crude material was purified by flash chromatography (silica gel, hexanes/EtOAc $4: 1$ ) to afford compounds 23a (18 $\mathrm{mg}, 30 \%$ ) as a colorless oil and compound $\mathbf{2 3 b}(38 \mathrm{mg}, 65 \%)$ as a colorless oil. Compound 23a: ${ }^{1} \mathrm{H}$ NMR $\left(400 \mathrm{MHz} ; \mathrm{CDCl}_{3}\right): \delta 7.50-7.22(\mathrm{~m}, 10 \mathrm{H})$, $6.62(\mathrm{~s}, 1 \mathrm{H}), 6.14(\mathrm{t}, J=6.1 \mathrm{~Hz}, 1 \mathrm{H}), 5.48(\mathrm{~s}, 1 \mathrm{H}), 5.18(1 / 2 \mathrm{AB}$, $J=11.1 \mathrm{~Hz}, 1 \mathrm{H}), 5.09(1 / 2 \mathrm{AB}, J=11.1 \mathrm{~Hz}, 1 \mathrm{H}), 4.10(\mathrm{~s}, 1 \mathrm{H}), 3.97(1 / 2$ $\mathrm{AB}, J=13.3 \mathrm{~Hz}, 1 \mathrm{H}), 3.87(1 / 2 \mathrm{AB}, J=13.3 \mathrm{~Hz}, 1 \mathrm{H}), 3.79(\mathrm{~d}, J=7.7 \mathrm{~Hz}$, $1 \mathrm{H}), 3.73$ (s, 1H), 2.69 (ddt, $J=27.0,9.0,4.6 \mathrm{~Hz}, 2 \mathrm{H}), 2.25$ (s, 3H), 2.06 (dd, $J=13.3,9.5 \mathrm{~Hz}, 1 \mathrm{H}), 1.90$ (br t, $6.0 \mathrm{~Hz}, 1 \mathrm{H}), 1.44(\mathrm{~s}, 9 \mathrm{H}) ;{ }^{13} \mathrm{C}$ NMR $\left(101 \mathrm{MHz}, \mathrm{CDCl}_{3}\right): \delta 171.9,171.7,150.5,148.2,138.3,137.2$, 135.6, 132.6, 128.7, 128.5, 128.4, 128.4, 127.6, 127.3, 122.1, 120.1, 103.7, 81.3, 75.1, 65.4, 64.2, 62.7, 60.4, 51.7, 51.3, 50.7, 31.6, 28.1, $28.1,15.9,14.3 ; R_{f}\left(\mathrm{SiO}_{2}\right.$, hexanes/EtOAc 4:1) 0.12; $[\alpha]_{\mathrm{D}}^{25}-60.0(c$ 0.895, $\mathrm{CHCl}_{3}$ ); IR (film, $\mathrm{CH}_{2} \mathrm{Cl}_{2}$ ), $\nu_{\max } 3447$ (br), 3063, 3030, 2934, $2870,1730,1676,1636,1154 \mathrm{~cm}^{-1}$; HRMS $\left(\mathrm{MH}^{+}\right)$, found 597.2971 . $\mathrm{C}_{36} \mathrm{H}_{41} \mathrm{~N}_{2} \mathrm{O}_{6}$ requires 597.2965. Compound 24b: ${ }^{1} \mathrm{H}$ NMR ( $400 \mathrm{MHz} ; \mathrm{CDCl}_{3}$ ): $\delta 6.62$ (s, 1H), 6.09 (dd, J=8.4, $4.4 \mathrm{~Hz}, 1 \mathrm{H}$ ), 5.45 (s, 1H), $5.17(1 / 2 \mathrm{AB}, J=11.1 \mathrm{~Hz}, 1 \mathrm{H}), 5.14(1 / 2 \mathrm{AB}, J=11.1 \mathrm{~Hz}, 1 \mathrm{H})$, 3.95 (s, $1 \mathrm{H}), 3.83$ (s, 3H), 3.78 (d, $J=13.5 \mathrm{~Hz}, 1 \mathrm{H}), 3.73$ (d, $J=6.6 \mathrm{~Hz}$, $1 \mathrm{H}), 3.63$ (d, $J=13.4 \mathrm{~Hz}, 1 \mathrm{H}), 3.63-3.50(\mathrm{~m}, 1 \mathrm{H}), 3.15$ (dd, $J=9.8$, $6.1 \mathrm{~Hz}, 1 \mathrm{H}), 2.63$ (dt, $J=12.8,6.5 \mathrm{~Hz}, 1 \mathrm{H}), 2.45$ (dd, $J=13.0,9.8 \mathrm{~Hz}$, $1 \mathrm{H}), 1.77-1.74($ br m, $1 \mathrm{H}), 1.45(\mathrm{~s}, 9 \mathrm{H}) ;{ }^{13} \mathrm{C} \mathrm{NMR}\left(101 \mathrm{MHz}, \mathrm{CDCl}_{3}\right)$ : $\delta$ 172.3, 170.4, 150.6, 147.9, 138.1, 137.2, 134.0, 132.5, 128.7, 128.7, $128.6,128.6,128.5,128.5,128.4,128.4,127.3,126.5,122.8,122.7$, $120.6,105.3,105.3,81.3,75.0,65.5,65.5,63.1,63.0,60.4,52.7$, 49.4, 49.4, 48.4, 34.8, 28.2, 16.0, 16.0; $R_{f}\left(\mathrm{SiO}_{2}\right.$, hexanes/EtOAc 4:1) $0.10 ;[\alpha]_{\mathrm{D}}^{25}+64\left(c \mathrm{0} 31, \mathrm{CHCl}_{3}\right.$ ); IR (film, $\mathrm{CH}_{2} \mathrm{Cl}_{2}$ ), $\nu_{\max } 3444$ (br), 3062, 3029, 2970, 2927, 1729, 1682, 1639, $1154 \mathrm{~cm}^{-1}$; HRMS $\left(\mathrm{MH}^{+}\right)$, found 597.2974. $\mathrm{C}_{36} \mathrm{H}_{41} \mathrm{~N}_{2} \mathrm{O}_{6}$ requires 597.2965.

\subsection{5. $(5 R, 8 S, 10 R, 11 S)$-tert-Butyl 4-hydroxy-5-(hydrox- ymethyl)-3-methoxy-2-methyl-7-oxo-5,7,8,9,10,11- hexahydro-8,11-epiminoazepino[1,2-b]isoquinoline-10- carboxylate (25)}

A solution of compound $\mathbf{2 4 b}(7.0 \mathrm{mg}, 0.012 \mathrm{mmol})$ in glacial acetic acid $(1 \mathrm{~mL})$ and $10 \% \mathrm{Pd} / \mathrm{C}(7 \mathrm{mg})$ were placed in round bottom flask and sparged with Ar for $5 \mathrm{~min}$. The vessel was evacuated and filled with hydrogen three times. The reaction was vigorously stirred overnight under hydrogen $(1 \mathrm{~atm})$. The suspension was diluted with $\mathrm{CH}_{2} \mathrm{Cl}_{2}(25 \mathrm{~mL})$ and then filtered through Celite ${ }^{\circledR}$ and the flask was rinsed with $\mathrm{CH}_{2} \mathrm{Cl}_{2}(3 \times 5 \mathrm{~mL})$. The solution was extracted with satd aq $\mathrm{NaHCO}_{3}(3 \times 15 \mathrm{~mL})$. The combined aqueous layers were diluted with phosphate buffer $(0.1 \mathrm{M}, \mathrm{pH}=7.5,25 \mathrm{~mL})$ and extracted with $\mathrm{CH}_{2} \mathrm{Cl}_{2}(3 \times 15 \mathrm{~mL})$. The combined organic layers were rinsed with brine $(50 \mathrm{~mL})$, dried $\left(\mathrm{Na}_{2} \mathrm{SO}_{4}\right)$, filtered, and concentrated under vacuum. The crude material was purified by flash chromatography (silica gel, $\mathrm{CHCl}_{3}$ / $\mathrm{MeOH}$ 97:3) to afford compound $25(4.6 \mathrm{mg}, 92 \%)$ as a colorless oil. ${ }^{1} \mathrm{H}$ NMR (400 MHz; $\left.\mathrm{CDCl}_{3}\right): \delta 6.40(\mathrm{~s}, 1 \mathrm{H}), 6.05$ (dd, $J=7.9$, $4.1 \mathrm{~Hz}, 1 \mathrm{H}), 5.53(\mathrm{~s}, 1 \mathrm{H}), 4.30(\mathrm{~s}, 1 \mathrm{H}), 4.09(\mathrm{~d}, J=6.7 \mathrm{~Hz}, 1 \mathrm{H})$, $3.78-3.74(\mathrm{~m}, 2 \mathrm{H}), 3.76(\mathrm{~s}, 3 \mathrm{H}), 3.65-3.60(\mathrm{~m}, 1 \mathrm{H}), 3.17$ (dd, $J=9.3$, $6.2 \mathrm{~Hz}, 1 \mathrm{H}), 2.61$ (dd, $J=13.1,9.4 \mathrm{~Hz}, 1 \mathrm{H}), 2.32(\mathrm{dt}, J=13.2,6.6 \mathrm{~Hz}$, $1 \mathrm{H}) 2.24(\mathrm{~s}, 3 \mathrm{H}), 1.47(\mathrm{~s}, 9 \mathrm{H}) ;{ }^{13} \mathrm{C}$ NMR $\left(101 \mathrm{MHz}, \mathrm{CDCl}_{3}\right): \delta 173.4$, 171.1, 145.2, 144.7, 144.7, 136.9, 136.8, 130.3, 127.1, 119.1, 112.9, $112.9,102.7,81.6,65.1,62.4,61.8,61.0,49.5,48.1,37.0,29.8,29.8$, 28.2, 15.9; $R_{f}\left(\mathrm{SiO}_{2}, \mathrm{CHCl}_{3} / \mathrm{MeOH} 95: 5\right)$ 0.17; $[\alpha]_{\mathrm{D}}^{25}+4.3$ (c 0.23, $\mathrm{CHCl}_{3}$ ); IR (film, $\mathrm{CH}_{2} \mathrm{Cl}_{2}$ ), $\nu_{\max } 3262$ (br), 2969, 2925, 2854, $1719,1683,1646,1154 \mathrm{~cm}^{-1}$; HRMS $\left(\mathrm{MH}^{+}\right)$, found 417.2033 . $\mathrm{C}_{22} \mathrm{H}_{29} \mathrm{~N}_{2} \mathrm{O}_{6}$ requires 417.2026 .
4.16. (5R,8S,10R,11S,11aS)-tert-Butyl 4-hydroxy-5-(hydroxymethyl)-3-methoxy-2-methyl-7-oxo-5,7,8,9,10,11,11a, 12octahydro-8,11-epiminoazepino[1,2-b]isoquinoline-10carboxylate (26)

To a solution of compound 25 (4.6 $\mathrm{mg}, 0.011 \mathrm{mmol})$ in EtOH $(1 \mathrm{~mL})$ in a $5 \mathrm{~mL}$ vial, was added a slurry of Raney ${ }^{\circledR}$ nickel 2800 (500 $\mu \mathrm{L}$ of commercially available water slurry, washed with EtOH $(3 \times 1 \mathrm{~mL})$ and suspended in EtOH $(1 \mathrm{~mL}))$. The vial was placed in a Fisher-Porter bottle, under Ar, the suspension was sparged with Ar for $5 \mathrm{~min}$ and the vessel was filled with hydrogen gas at $100 \mathrm{psi}$. The reaction was vigorously stirred overnight, diluted with EtOAc $(10 \mathrm{~mL})$ and satd aq Rochelle's salt $(10 \mathrm{~mL})$, and stirred vigorously for $2 \mathrm{~h}$. The biphasic suspension was filtered through Celite ${ }^{\circledR}$, the phases separated and the aqueous phase extracted with EtOAc $(3 \times 10 \mathrm{~mL})$. The combined organic phases were rinsed with brine $(25 \mathrm{~mL})$, dried $\left(\mathrm{Na}_{2} \mathrm{SO}_{4}\right)$, filtered, and concentrated under vacuum. The crude material was purified by flash chromatography (silica gel, $\mathrm{CHCl}_{3} / \mathrm{MeOH}$ 97:3) to afford compound $26(3.4 \mathrm{mg}, 74 \%)$ as a colorless oil. ${ }^{1} \mathrm{H}$ NMR $\left(400 \mathrm{MHz} ; \mathrm{CDCl}_{3}\right): \delta 6.51(\mathrm{~s}, 1 \mathrm{H}), 5.59(\mathrm{dd}, J=5.6$, $3.4 \mathrm{~Hz}, 1 \mathrm{H}), 3.96$ (d, $J=6.1 \mathrm{~Hz}, 1 \mathrm{H}), 3.88$ (dd, $J=10.9,3.2 \mathrm{~Hz}, 1 \mathrm{H}), 3.78$ (s, 3H), 3.77-3.76 (m, 1H), 3.67 (dt, $J=12.4,2.6 \mathrm{~Hz}, 1 \mathrm{H}), 3.61$ (dd, $J=11.1,5.8 \mathrm{~Hz}, 1 \mathrm{H}), 3.16$ (dd, $J=9.0,6.4 \mathrm{~Hz}, 1 \mathrm{H}), 2.84(\mathrm{t}, J=13.5 \mathrm{~Hz}$, 1H), 2.54 (dd, $J=14.7,2.2 \mathrm{~Hz}, 1 \mathrm{H}$ ), 2.50 (dd, $J=13.2,9.0 \mathrm{~Hz}, 1 \mathrm{H}), 2.27$ (s, 3H), $2.18(\mathrm{dt}, J=13.2,6.6 \mathrm{~Hz}, 1 \mathrm{H}), 1.53-1.45(\mathrm{~m}, 9 \mathrm{H}) ;{ }^{13} \mathrm{C}$ NMR $\left(101 \mathrm{MHz}, \mathrm{CDCl}_{3}\right): \delta 174.4,172.4,145.7,132.0,129.7,121.2,120.2$, 118.0, 81.5, 67.8, 63.0, 62.2, 61.0, 60.8, 52.6, 42.8, 38.8, 32.1, 29.9, 28.2, 15.9; $R_{f}\left(\mathrm{SiO}_{2}, \mathrm{CHCl}_{3} / \mathrm{MeOH} 95: 5\right) 0.20 ;[\alpha]_{\mathrm{D}}^{25}-36$ (c 0.080, $\mathrm{CHCl}_{3}$ ); IR (film, $\mathrm{CH}_{2} \mathrm{Cl}_{2}$ ), $\nu_{\max } 3286$ (br), 2958, 2925, 2855, 1729, $1652,1456 \mathrm{~cm}^{-1}$; HRMS $\left(\mathrm{MH}^{+}\right)$, found 419.2174. $\mathrm{C}_{22} \mathrm{H}_{31} \mathrm{~N}_{2} \mathrm{O}_{6}$ requires 419.2182 .

\section{Acknowledgements}

We gratefully acknowledge financial support from the National Institutes of Health (Grant RO1CA085419) and Bristol Myers Squibb Co (doctoral fellowship to A.J.).

\section{Supplementary data}

${ }^{1} \mathrm{H}$ and ${ }^{13} \mathrm{C}$ NMR spectra of all compounds. Supplementary data related to this article can be found at http://dx.doi.org/10.1016/ j.tet.2013.05.009.

\section{References and notes}

1. Scott, J. D.; Williams, R. M. Chem. Rev. 2002, 102, 1669-1730.

2. Whaley, H. A.; Patterson, E. L.; Dann, M.; Shay, A. J.; Porter, J. N. In Antimicrobial Agents and Chemotherapy, 1964: Proceedings of the Fourth Interscience Conference on Antimicrobial Agents and Chemotherapy, New York, NY, October 26-28, 1964; pp 83-86. http://books.google.com/books?ei=nm2aUd-aMaT9ygGOilDYCw\&id=1KETAQAAMAAJ\&dq=Antimicrobial + agents + and + chemotherapy-1964\&q=lemonomycin\#search_anchor-

3. Whaley, H. A.; Patterson, E. L.; Dann, M.; Shay, A. J.; Porter, J. N. Antimicrob. Agents Chemother. 1964, 8, 83-86.

He, H. Y.; Shen, B.; Carter, G. T. Tetrahedron Lett. 2000, 41, 2067-2071.

5. Takahashi, K.; Tomita, F. J. Antibiot. 1983, 36, 468-470.

6. Suzuki, K.; Sato, T.; Morioka, M.; Nagai, K.; Abe, K.; Yamaguchi, H.; Saito, T.; Ohmi, Y.; Susaki, K. J. Antibiot. 1991, 44, 479-485.

7. Hegde, V. R.; Patel, M. G.; Das, P. R.; Pramanik, B.; Puar, M. S. J. Antibiot. 1997, 50, 126-134

8. Li, W. Y.; Leet, J. E.; Ax, H. A.; Gustavson, D. R.; Brown, D. M.; Turner, L.; Brown, K.; Clark, J.; Yang, H.; Fung-Tomc, J.; Lam, K. S. J. Antibiot. 2003, 56, 226-231. Northcote, P. T.; Siegel, M.; Borders, D. B.; Lee, M. D. J. Antibiot. 1994, 47, 901-908

0. Sasaki, T.; Otani, T.; Matsumoto, H.; Unemi, N.; Hamada, M.; Takeuchi, T.; Hori, M. J. Antibiot. 1998, 51, 715-721.

11. Zhang, C. W.; Herath, K.; Jayasuriya, H.; Ondeyka, J. G.; Zink, D. L.: Occi, J.: Birdsall, G.; Venugopal, J.; Ushio, M.; Burgess, B.; Masurekar, P.; Barrett, J. F. Singh, S. B. J. Nat. Prod. 2009, 72, 841-847.

12. Ashley, E. R.; Cruz, E. G.; Stoltz, B. M. J. Am. Chem. Soc. 2003, 125, 15000-15001. 
13. Yoshida, A.; Akaiwa, M.; Asakawa, T.; Hamashima, Y.; Yokoshima, S.; Fukuyama, T.; Kan, T. Chem.-Eur. J. 2012, 18, 11192-11195.

14. Magnus, P.; Matthews, K. S. J. Am. Chem. Soc. 2005, 127, 12476-12477.

15. Magnus, P.; Matthews, K. S. Tetrahedron 2012, 68, 6343-6360.

16. Couturier, C.; Schlama, T.; Zhu, J. P. Synlett 2006, 1691-1694.

17. Wu, Y. C.; Bernadat, G.; Masson, G.; Couturier, C.; Schlama, T.; Zhu, J. P. J. Org Chem. 2009, 74, 2046-2052.

18. Bernadat, G.; George, N.; Couturier, C.; Masson, G.; Schlama, T.; Zhu, J. P. Synlett 2011, 576-578.

19. Siengalewicz, P.; Brecker, L.; Mulzer, J. Synlett 2008, 2443-2446.

20. Vincent, G.; Chen, Y. Y.; Lane, J. W.; Williams, R. M. Heterocycles 2007, 72, 385-398.

21. Scott, J. D.; Williams, R. M. Angew. Chem., Int. Ed. 2001, 40, 1463-1465.

22. Flanagan, M. E.; Williams, R. M. J. Org. Chem. 1995, 60, 6791-6797.

23. Liao, X. W.; Liu, W.; Dong, W. F.; Guan, B. H.; Chen, S. Z.; Liu, Z. Z. Tetrahedron 2009, 65, 5709-5715.

24. The lack of reactivity of the primary hydroxyl of $\mathbf{7}$ is consistent with the regioselectivity observed in the reaction between TBS-Cl and diols bearing the authors, which stated that the nucleophilicity of the primary hydroxyl is reduced by internal hydrogen bonding to the neighboring amino group.

25. Sales, M.; Charette, A. B. Org. Lett. 2005, 7, 5773-5776

26. Frie, J. L.; Jeffrey, C. S.; Sorensen, E. J. Org. Lett. 2009, 11, 5394-5397.
27. Lane, J. W.; Chen, Y. Y.; Williams, R. M. J. Am. Chem. Soc. 2005, 127, 12684-12690. 28. Chen, J. C.; Chen, X. C.; Bois-Choussy, M.; Zhu, J. P. J. Am. Chem. Soc. 2006, 128 87-89.

29. Zhu's conditions were also used by Liao (Ref. 22) to convert compound $\mathbf{6}$ into a trans-THIQ system, using 2-benzyloxyacetaldehyde.

30. Fukuyama, T.; Nunes, J. J. J. Am. Chem. Soc. 1988, 110, 5196-5198.

31. Mancuso, A. J.; Huang, S. L.; Swern, D. J. Org. Chem. 1978, 43, 2480-2482.

32. Vishnetskaya, M. V.; Yakimova, I. Y.; Sidorenkova, I. A. Russ. J. Phys. Chem. 2006 $80,176-180$

33. Vishnetskaya, M. V.; Yakimova, I. Y.; Sidorenkova, I. A. Russ. J. Phys. Chem. 2006 80, 173-175.

34. Vishnetskaya, M. V.; Ivanova, M. S.; Solkan, V. N.; Zhidomirov, G. M.; Mel'nikov, M. Y. Russ. J. Phys. Chem. A 2012, 86, 889-891.

35. As illustrated in Scheme 4 , we propose that the dipolarophile adds from the $\mathrm{Re}$ face of the iminium ion carbon to form 20a, which epimerizes under the reaction conditions to form 20b.

We propose that the observed chemoselectivity can be explained by the initial formation of a phenoxyaluminum hydride species, which upon delivery of one hydride to the ester, forms a stable seven-membered ring alkoxy(phenoxy) Compounds 23 a

nds 23a and 23b are unstable to silica gel. Consequently, we did not attempt their separation for the purpose of recycling of $\mathbf{2 3 a}$

Please cite this article in press as: Jiménez-Somarribas, A.; Williams, R. M., Tetrahedron (2013), http://dx.doi.org/10.1016/j.tet.2013.05.009 
APPENDIX 3

Research proposal 


\title{
Synthesis of Lagunamide C Research Proposal
}

\author{
Alberto Jiménez \\ Department of Chemistry
}

\begin{abstract}
A stereodivergent strategy for the structural revision of lagunamide $C$ has been proposed. This cyclodepsipeptide is a member of the aurilide class of natural products and was isolated from the marine cyanobacterium Lyngbya majuscula. It showed potent cytotoxic activities against a panel of cancer cell lines, including P388, A549, PC3, HCT8, and SK-OV3. Its polyketide fragment is synthetically challenging due to the presence of a 1,4-dihydroxy-2,5dimethyl structural motif. To set the configuration of the key stereocenters, I proposed a tunable route involving an acetate aldol reaction, a Charrette cyclopropanation, and a Corey-BakshiShibata (CBS) reduction.
\end{abstract}

\section{Introduction}

The lagunamides are a family of cytotoxic cyclodepsipeptides isolated by Tan and coworkers. ${ }^{1,2}$ These compounds belong to the aurilide class of natural products, ${ }^{3,4,5,6}$ which are the product of mixed NRPS-PKS systems. A sample of the marine cyanobacterium Lyngbya majuscula was collected at Pulau Hantu Besar, Singapore, in 2007. The chromatographic separation of the organic extracts afforded lagunamides $A, B$ and $C$, which showed potent cytotoxic activities against a panel of cancer cell lines, including P388, A549, PC3, HCT8, and SK-OV3 cells, with $\mathrm{IC}_{50}$ values ranging from $1.6 \mathrm{nM}$ to $24 \mathrm{nM}^{2,7}$

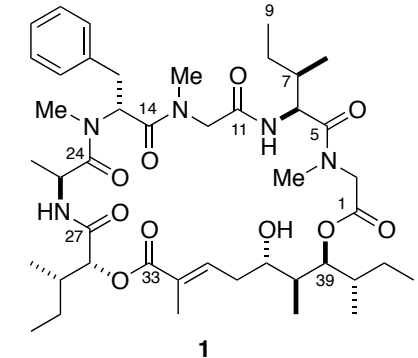

Lagunamide A (published structure)

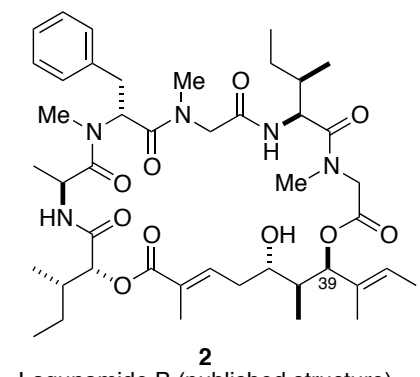

Lagunamide B (published structure)

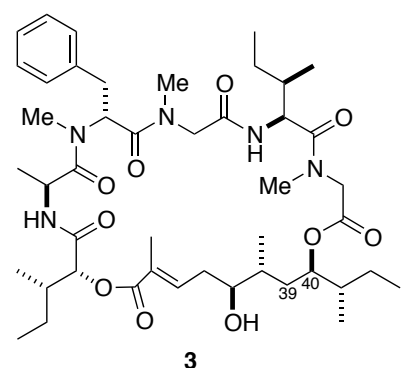

Lagunamide $\mathrm{C}$ (published structure)

Figure 1. Structures reported in the isolation articles

According to Tan and co-workers, the lagunamides comprise a polypeptide portion featuring a D-allo-2-hydroxyisoleucic acid fragment connected to L-Ala, N-Me-D-Phe, Gly, L-allo- 
isoleucine and $\mathrm{N}$-Me-L-Ala residues. The reported polyketide fragment for lagunamide $\mathrm{B}$ is structurally related to the one found in kulokekahilide-2, ${ }^{2,5}$ which has identical C-33 - C-38 and C-40 - C42 segments (lagunamide A numbering) and opposite stereochemistry at C-39 (see Figure 2). Both the reduction of the exocyclic double bond seen in lagunimides $A$ and $C$, and the presence of an extra methylene group in the polyketide fragment of lagunamide $C(C-39)$ are unprecedented features in the aurilide class of natural products.
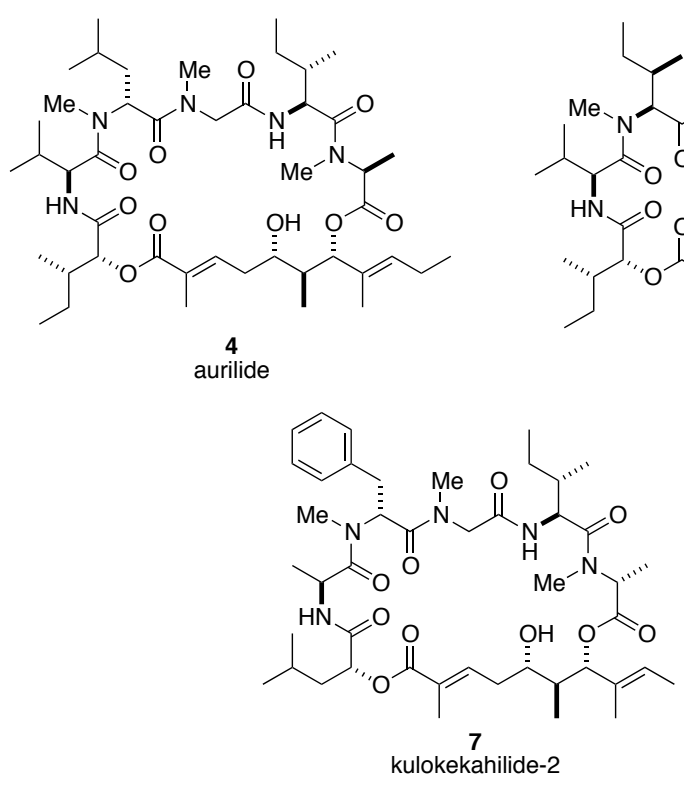

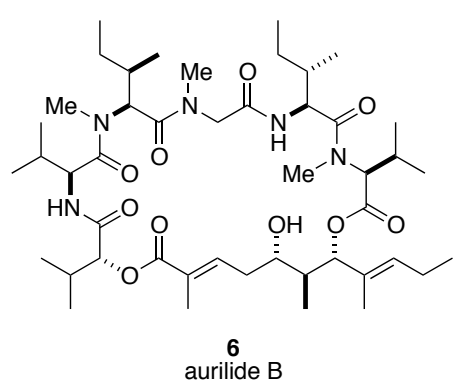

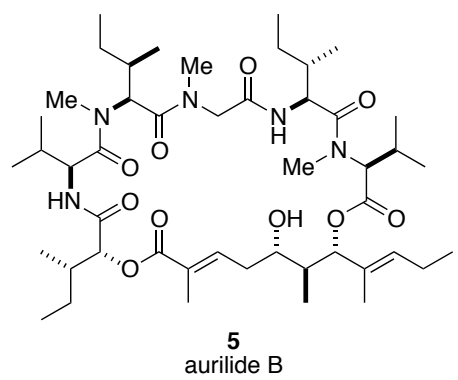

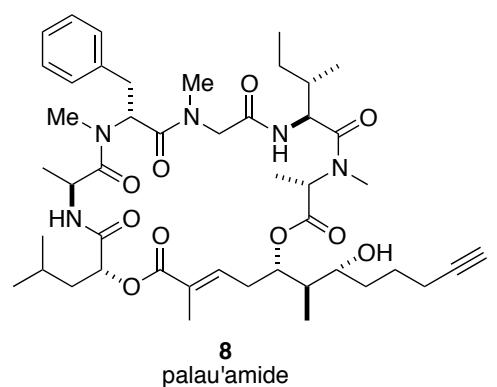

Figure 2. Aurilide Class of Natural products

In a recent communication, $Y e$ and coworkers published the total synthesis and structural revision of lagunamide $A .^{8}$ In the revised structure (9), the L-allo-isoleucine residue was replaced with a L-isoleucine residue and the absolute configuration at C-39 was inverted. Both structural features are consistent with all of the previously isolated members of the aurilide class. Consequently, I expect that the structures of lagunamide B (10) and C (11) must include a L-isoleucine residue in the northern part of the structure. In addition, I expect the polyketide found in lagunamide $B$ to be the same fragment found in kulokekahilide-2. Given the unprecedented nature of lagunamide C's polyketide fragment, I can only assume that the configurations at C-37, C-38 and C-41 must be identical to the ones found in the corresponding carbons in all of the other members of the aurilide class. This structural assignment is based on the assumption that similar enzymes are involved in the reduction events that form these stereocenters. Since the biosynthetic process that leads to the insertion of the extra methylene C-39 unit is unknown, the only information available to predict the stereochemistry at C-40 is the 
incorrect NMR analysis discussed in the original isolation paper, which was similar to the one employed to assign the stereochemistry of C-39 in lagunamides A and B. ${ }^{1,2}$ Consequently, I also expect the configuration at C-40 in the natural product to be consistent with all of the members of the aurilide class.
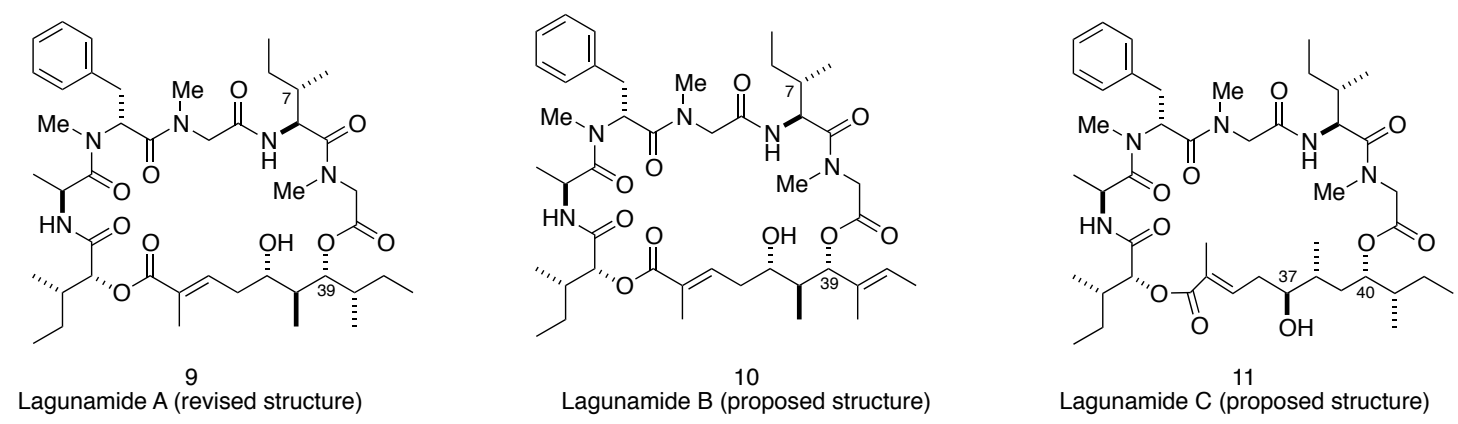

Figure 3. Revised and proposed structures for lagunamides A-C

\section{Proposed Area of Research}

To date, no synthesis of lagunamide $C$ has been reported and its structure has not been confirmed. Given its potent cytotoxic activities, effort should be directed towards establishing or confirming the correct structure of the compound, and using the synthetic routes to prepare analogs that could be used for structure-activity relationship (SAR) studies. This proposal will delineate efforts towards a) developing a stereodivergent synthetic route to access multiple possible diastereomers of the polyketide fragment, b) gaining access to lagunamide $\mathrm{C}$, and $\mathrm{c}$ ) gaining access to lagunamide $\mathrm{C}$ analogs.

\section{Retrosynthetic Analysis}

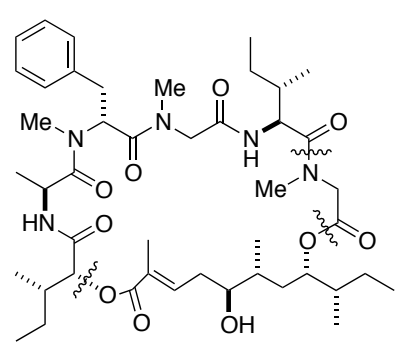

11

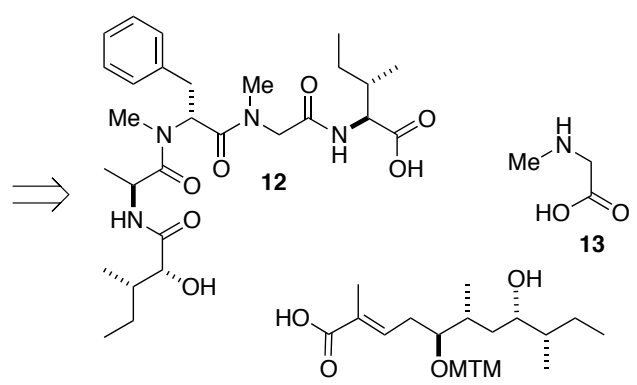

14

Scheme 1. Retrosynthetic Analysis for Lagunamide C (11) access 
Retrosynthetically, I envision the disconnection of the macrocycle to the three key units illustrated in Scheme 1. Given the ready availability of sarcosine (13) and the building blocks required to prepare compound 12, I expect that the main synthetic challenge will be the preparation of acid 14. As shown in Scheme 2, this key intermediate could be accessed via a Mukaiyama vinylogous aldol reaction ${ }^{9}$ of silyl ketene acetal 15 and aldehyde 16, which in turn could be obtained from alkene 17 through the reductive opening of iodomethylcyclopropane 18. The latter could be prepared from ester 19, through reduction to the allylic alcohol, followed by an asymmetric cyclopropanation and substitution with iodide. Compound 19 could be obtained through a Wittig reaction with aldehyde 20 , which in turn could be prepared using an acetate aldol reaction of thiazolidinethione 21 and (S)-2-methylbutanal (22).

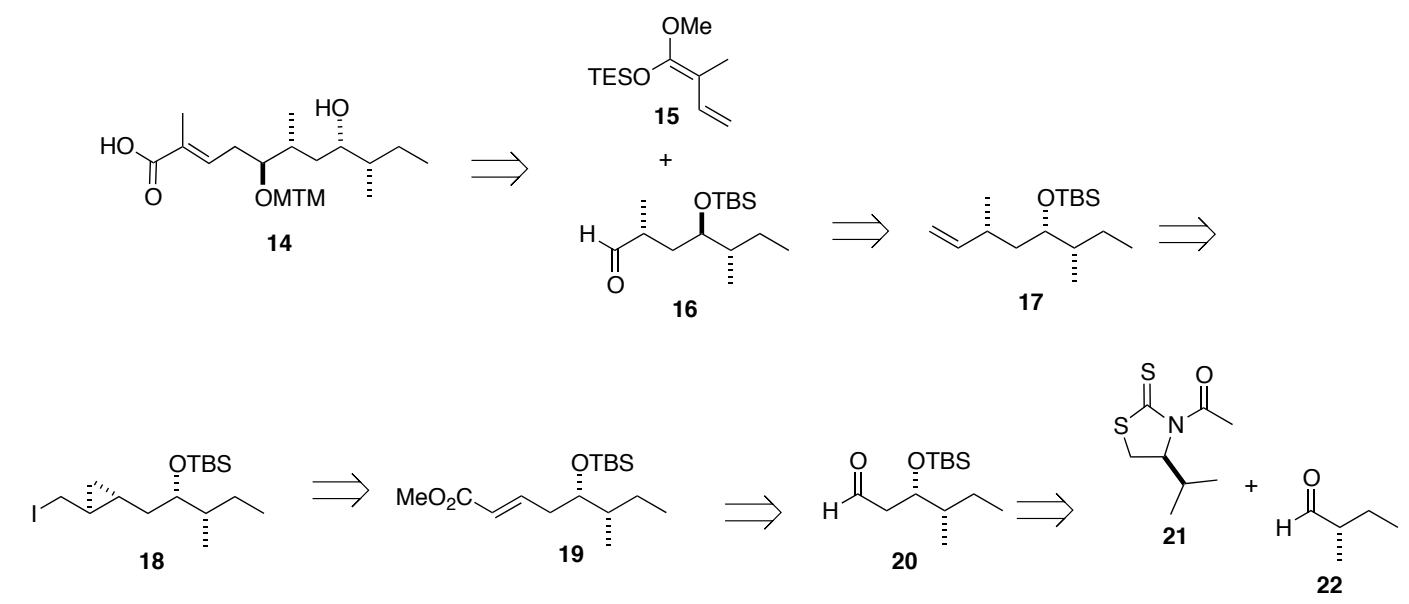

Scheme 2. Retrosynthetic Analysis for polyketide (14) access

\section{Proposed Synthesis of Lagunamide C}

Herein is the proposed convergent synthesis of Lagunamide C.

\section{a) Synthesis of polypeptide 33}

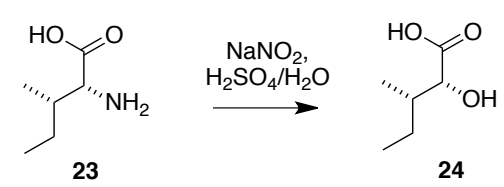

\section{Scheme 3. Synthesis of D-allo-2-hydroxyisoleucic acid}

Commercially available D-allo-isoleucine (23) will be diazotized and hydrolyzed with configuration retention, to provide D-allo-2-hydroxyisoleucic acid (24) (Scheme 3). ${ }^{10}$ 

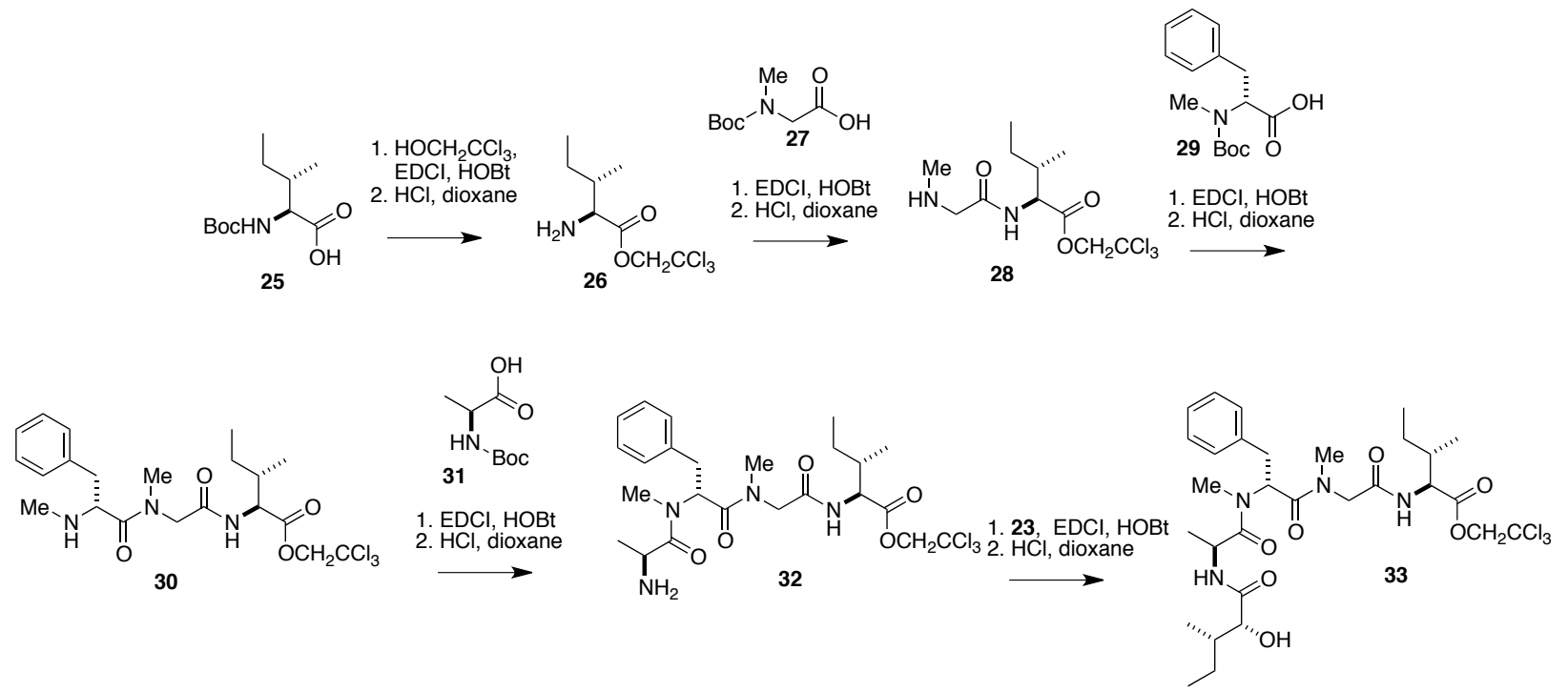

\section{Scheme 4. Proposed Synthesis of polypeptide 33}

For all of the peptide-coupling and esterification reactions, the choices of the acid activating reagent and the conditions will be based on factors such as price, convenience, product optical purity and yield, and will depend on the outcome of each particular reaction. The peptide couplings of Scheme 6 are shown using the EDCl/HOBt combination. If problems arise, any other standard carboxylic acid activating agents, such as DCC, HATU, PyBOP, BOP-Cl, DMAP, or the like, may be used. ${ }^{11,12}$

Commercially available $\mathrm{N}$-Boc-L-isoleucine will be converted into the corresponding trichloroethyl ester, followed by $\mathrm{N}$-Boc removal, ${ }^{13}$ to provide compound $\mathbf{2 6}$, which in turn will be coupled with $N$-Boc sarcosine (27) to give dipeptide 28 (Scheme 4). Tetrapeptide 32 will be prepared with two similar coupling/deprotection cycles involving $N$-Me-D-phenylalanine 29 and $\mathrm{N}$-Me-L-Ala 31. The esterification of D-allo-2-hydroxyisoleucic acid (24) with 32 will afford compound 33.

\section{b) Synthesis of aldehyde 45}

Commercially available (S)-2-methylbutanol will be oxidized with TEMPO/NaOCl to give aldehyde (S)-methylbutanal (22). ${ }^{14} \mathrm{I}$ intend to use an acetate aldol reaction between $\mathrm{N}$-acetyl thiazolidine-2-thione 21 and compound 22 to gain access to compound 35 (Scheme 5). According to Hodge and Olivo, ${ }^{15}$ the use of 2 equivalents of base generates an open transition state where the chiral auxiliary is not coordinated to the titanium atom, and leads to the desired anti product (Scheme 6). Presumably, the bidentate amine coordinates to the titanium atom and 
disfavors the coordination of the thiocarbonyl sulfur to the metal center. ${ }^{16}$ If problems arise, and the stereochemical outcome of the acetate aldol reactions are not optimal, I will explore the use of alternate thiazolidine-2-thiones, ${ }^{16,17,18,19}$ oxazolidine-2-thiones $^{19}$ or oxazolidinones ${ }^{20,21}$ to obtain the desired anti products with acceptable diastereomeric excesses. With compound 35 in hand, I will convert its secondary hydroxyl into the corresponding tert-butyldimethylsilyl ether, followed by direct reduction of the $\mathrm{N}$-acetyl thiazolidine-2-thione with DIBAL- $\mathrm{H}^{18}$ to provide aldehyde 20.

(S)-2-methylbutanol
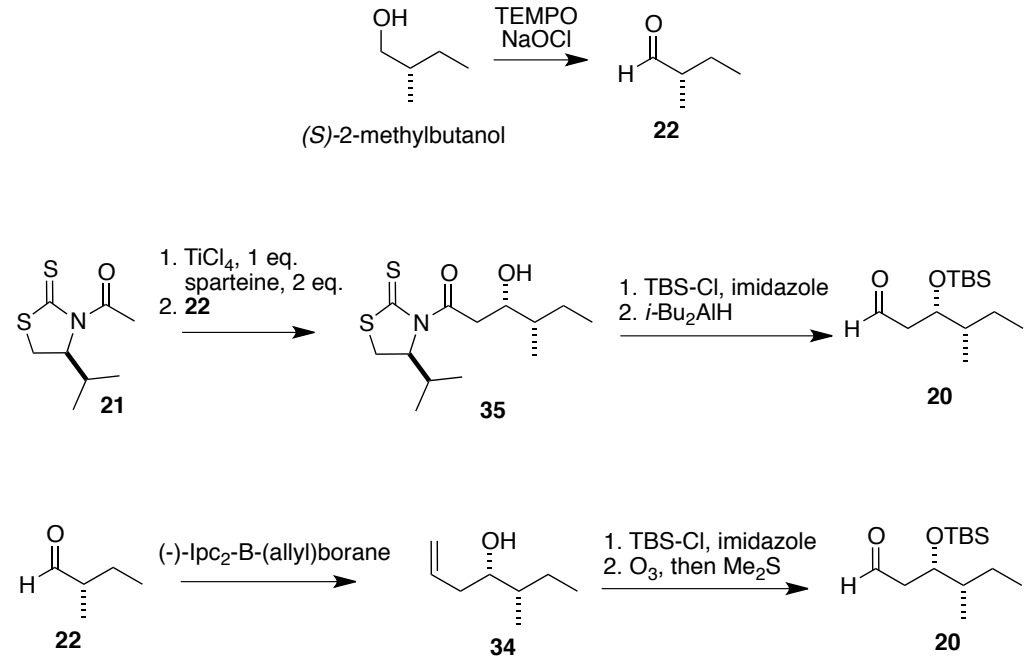

Scheme 5. Proposed syntheses of aldehyde 20

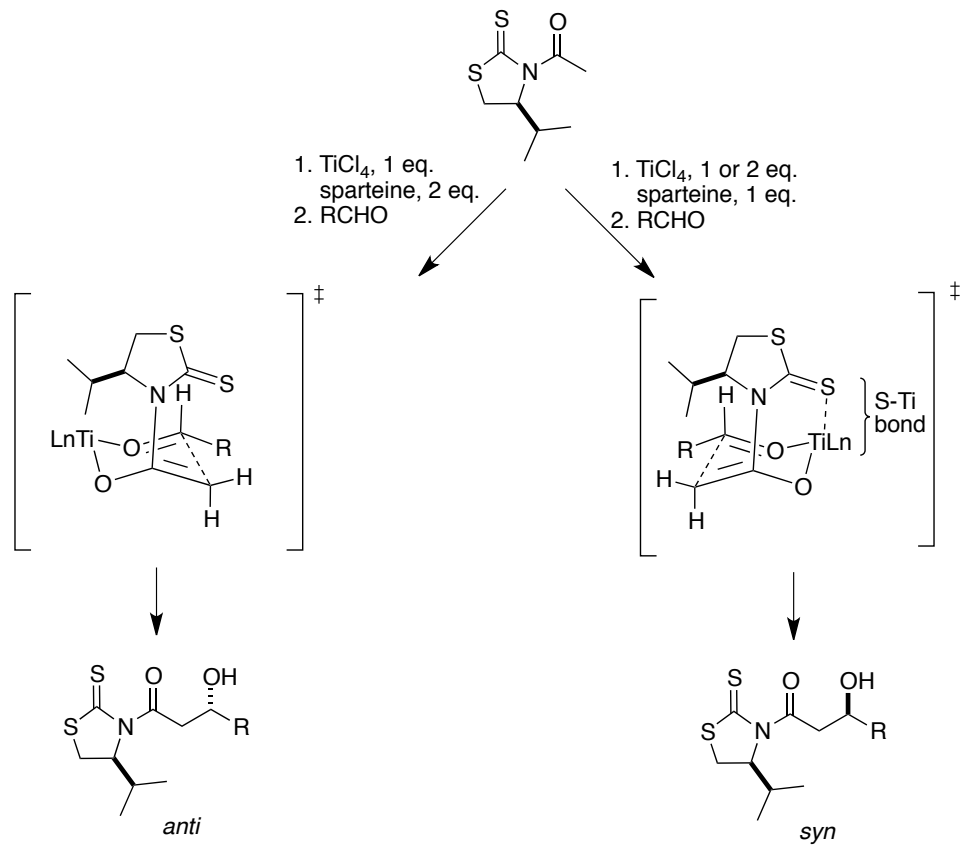

Scheme 6. Proposed transition states for the Ti-mediated acetate aldol reactions 


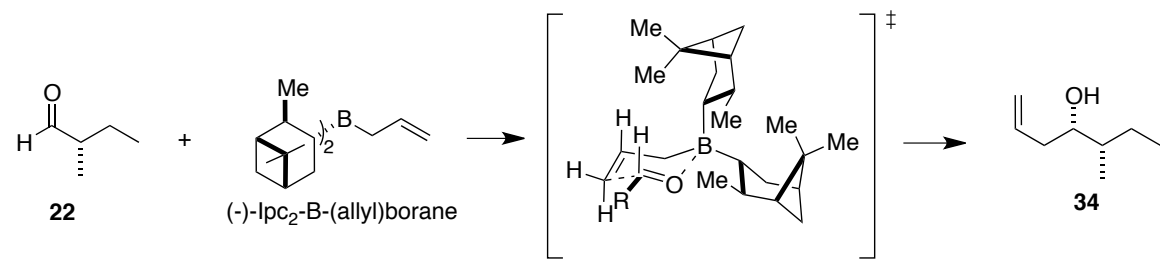

Scheme 7. Proposed transition state for the allylboration reaction

Alternatively, following the procedure reported by Brown, ${ }^{22}$ the allylboration of aldehyde 22 with (-)- $-\mathrm{pc}_{2}-\mathrm{B}-(\mathrm{allyl})$ borane will provide alcohol 34 (Scheme 5). The selectivity of this reaction can be explained by the chair-like transition state shown in Scheme 7, where the aldehyde carbon chain occupies an equatorial position and the facial selectivity is governed by the minimization of steric interactions between the axial Ipc ligand and the allyl side chain. ${ }^{23}$ TBS protection of 34, followed by reductive ozonolysis conditions would afford aldehyde 20 .

As shown in Scheme 8, aldehyde $\mathbf{2 0}$ will be reacted with stabilized Wittig reagent $\mathbf{3 6}$ to give ester 19. Reduction with two equivalents of DIBAL-H will provide allylic alcohol 37 , which in turn will be submitted to Charette's cyclopropanation conditions ${ }^{24}$ with diiodomethane, diethylzinc and $(R, R)$-dioxaborolane 38 to give compound 39. It has been proposed that the stereochemical outcome of the cyclopropanation reaction is governed by the formation of a zinc complex that includes the allylic alcohol-derived alkoxide and the dioxaborolane chiral catalyst (Scheme 9). ${ }^{25}$ Mesylation of primary alcohol 39, followed by substitution with iodide will afford substituted iodomethylcyclopropane 18. Following Charette's protocol, formation of a cyclopropylmethyllithium species via lithium-halogen exchange will trigger the formation of a homoallylic lithium species, which upon quenching with $\mathrm{H}_{2} \mathrm{O}$, will afford alkene 17 (Scheme 10). ${ }^{26}$ The low stability of the (cyclopropylmethyl)lithium species, which rearrange to homoallyl lithium species in the presence of lithium coordinating agents or solvents, was originally described by Lansbury. ${ }^{27}$ The process is thought to be driven by the gain in stability produced by the energy that is released when the strained cyclopropyl ring opens and forms the more stable homoallylic species. Compound 17 will be subjected to reductive ozonolysis conditions to provide aldehyde 16. Alternatively, the aldehyde could be prepared by treating alkene 17 with $\mathrm{OsO}_{4}$ and $\mathrm{NalO}_{4}$. Precedent for the approach for the proposed conversion of aldehyde 20 into aldehyde 16 can be found in a similar sequence described by Maier. ${ }^{28}$ 


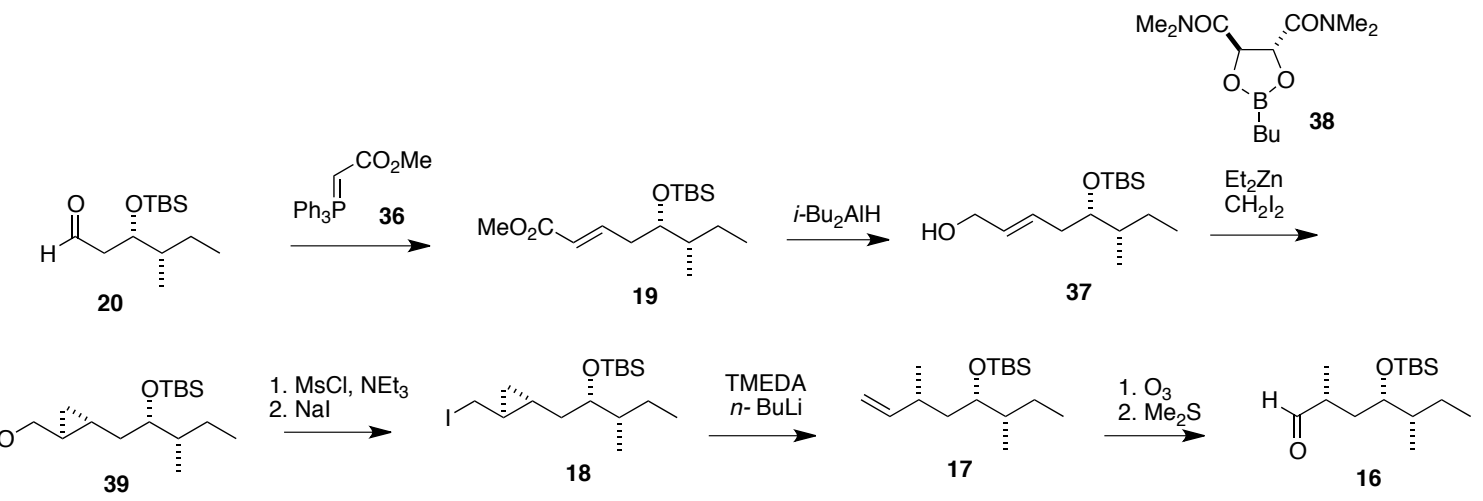

Scheme 8. Proposed synthesis of aldehyde 16

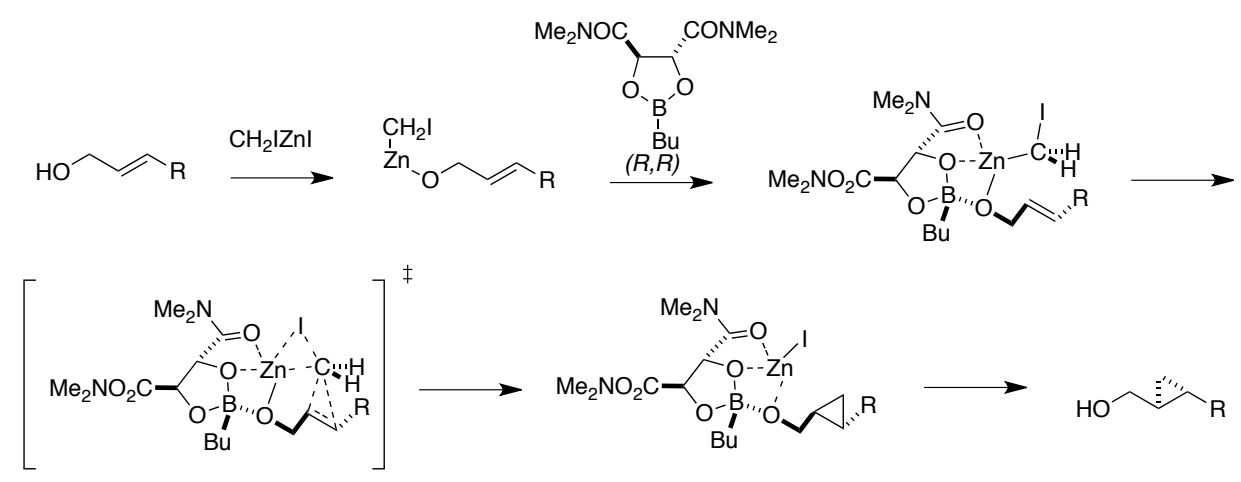

Scheme 9. Proposed rationale for the asymmetric cyclopropanation reaction

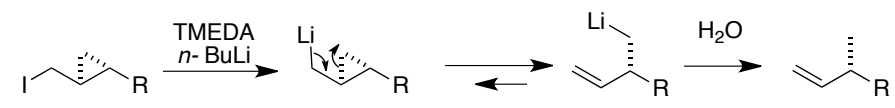

\section{Scheme 10. Lithium-mediated cyclopropyl ring opening}

\section{c) Synthesis of acid $\mathbf{5 0}$}

For the elongation of the polyketide chain, I intend to use a Mukaiyama vinylogous aldol reaction (MVAR) ${ }^{9}$ between aldehyde 16 and silyl ketene acetal 15. Analog transformations were used for the synthesis of the polyketide fragments found in several members of the aurilide class, including aurilide (4), ${ }^{3}$ kulokekahilide- $2^{29}$ (7) and palau'amide (8). ${ }^{30}$ According to the authors, all of these reactions produced single diastereomers, which had the undesired configuration at C-5 (Scheme 11). According to Evans, the high selectivity can be explained by a transition state that combines the mutually reinforcing effects of the $\alpha$-methyl and $\beta$-OTBS groups. ${ }^{31}$ The stereochemistry at C-5 was inverted by oxidizing the secondary alcohol and 
performing a sodium borohydride reduction, which provided the desired diastereomer stereoselectively. Several authors have reported similar stereoselectivity in other reactions involving $\alpha$-methyl- $\beta$-OTBS ketones. ${ }^{32,33,34}$ Based on both the above discussed influence of the $\alpha$ and $\beta$ groups in the outcome of the MVARs, and Evans' work on 1,3-asymmetric induction in hydride reductions of $\beta$-substituted ketones, ${ }^{35}$ I propose that the OTBS group also plays a significant role in the asymmetric induction of these reductions.

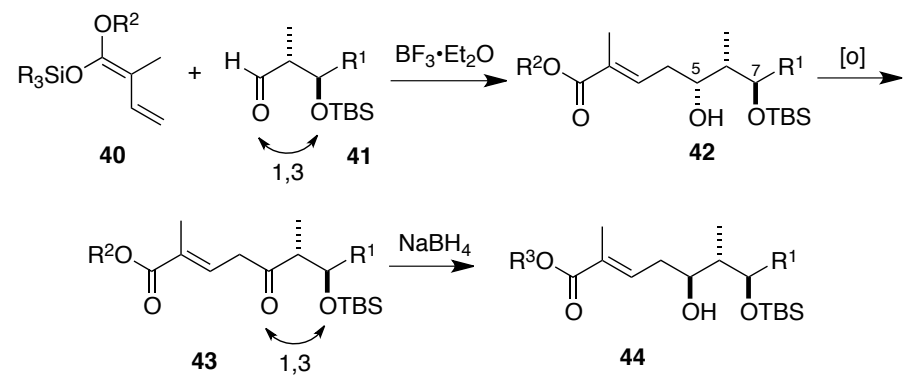

\section{Scheme 11. Asymmetric vinyloguos Mukaiyama aldol reaction/C-4 inversion sequence}

As shown in Scheme 12, the proposed aldehyde intermediate 16 is unsubstituted in the $\beta$ position and the OTBS group is in the $\gamma$ position. Based on the rationale provided for the asymmetric induction seen in Scheme 11, I do not foresee a high degree of selectivity with the proposed MVAR. In addition, I only found two loosely related examples, which used a $\mathrm{ZnCl}_{2}$ as the Lewis acid and gave a 3:1 mixture of diastereomers, ${ }^{36}$ or used a chiral catalyst for the asymmetric induction. ${ }^{37}$ In both cases, the aldehydes were structurally simpler than the proposed substrate. Consequently, attempting an asymmetric implementation of this particular MVAR could be a difficult endeavor and therefore I decided to propose a conservative approach for the elongation of the polyketide intermediate. This route involves the isolation of 45 as a diastereomeric mixture, the oxidation of the secondary hydroxyl using Dess-Martin periodane to give compound 46 and a Corey-Bakshi-Shibata (CBS) reduction ${ }^{38}$ of the ketone to afford hydroxyester 48. I chose a reaction involving an asymmetric catalyst because the keto substrate 46 does not have a protected hydroxyl in the $\beta$ position, and I do not expect that it will be stereoselectively reduced by an achiral reducing agent such as $\mathrm{NaBH}_{4}$. Based on a preliminary conformational analysis, I expect that the use of the (S)-(-)-2-methyl-CBS-oxazaborolidine 47 will lead to the preferential formation of transition state shown in Scheme 13, where the interactions between the bulkier ketone substituent and the methyl group attached to the boron atom are minimized. ${ }^{39}$ Accordingly, I expect that the hydride would add to the carbonyl's si face 
to afford compound 48. Protection of the free hydroxyl as the methylthiomethyl ether, ${ }^{40}$ followed by alkaline hydrolysis of the methyl ester with $\mathrm{LiOH}$ will afford carboxylic acid $\mathbf{5 0}$.
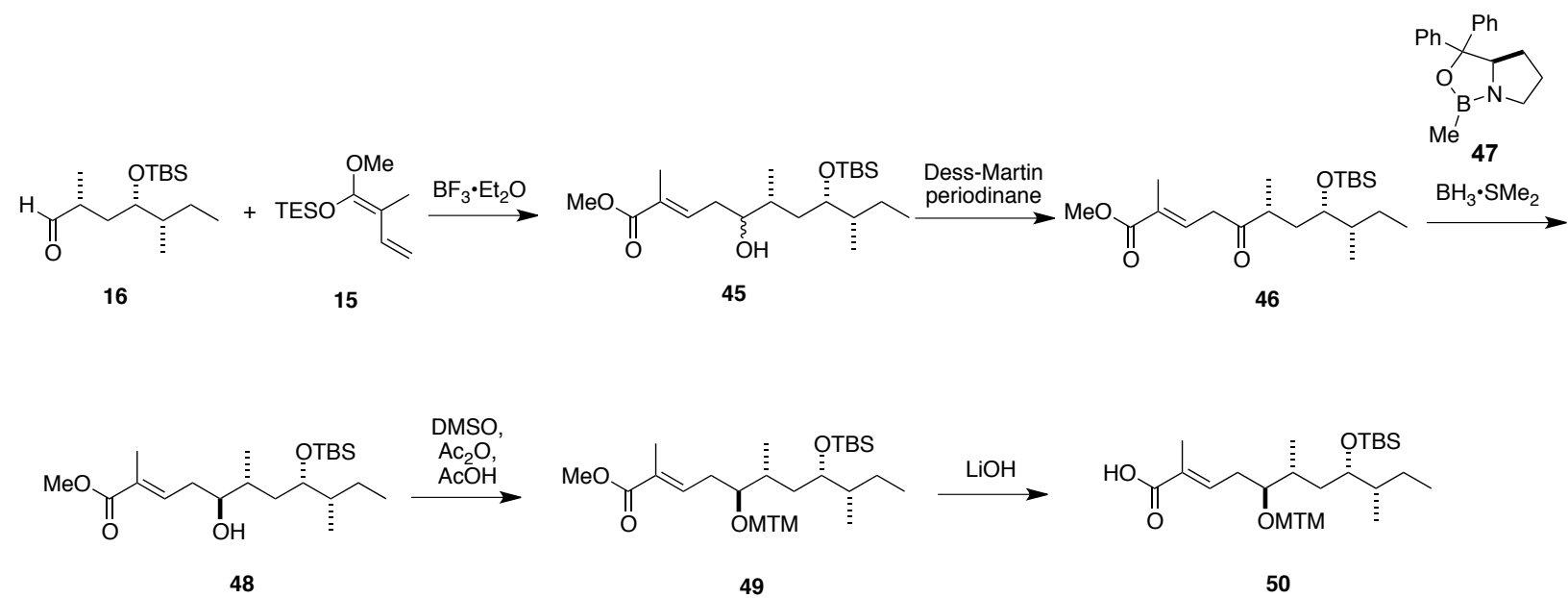

Scheme 12. Proposed synthesis of the protected polyketide fragment

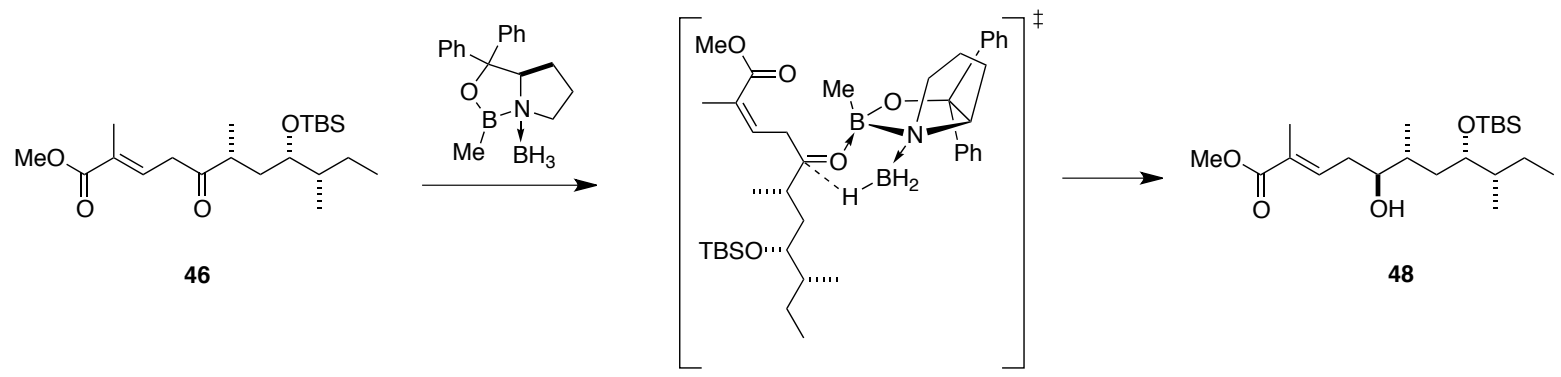

Scheme 13. Proposed transition state for the CBS reduction

\section{d) Synthesis of lagunamide C (11)}

As shown in Scheme 14, formation of the ester of protected acid $\mathbf{5 0}$ and polypeptide $\mathbf{3 3}$ using EDCl and DMAP will provide compound 51. Removal of the TBS group with HF/pyridine, followed by esterification with $\mathrm{N}$-Fmoc-sarcosine will afford compound $\mathbf{5 2}$. After removing the TCE ester and the Fmoc group, the resulting compound will be reacted with EDCI/HOAt to form the macrocycle. The removal of the MTM protecting group with $\mathrm{AgNO}_{3}$ will afford lagunamide $\mathrm{C}$ (11). Precedent for the conversion of polypeptide 33 into the unprotected macrocycle can be found in a similar sequence described by Yamada for the synthesis of aurilide. ${ }^{3}$ 


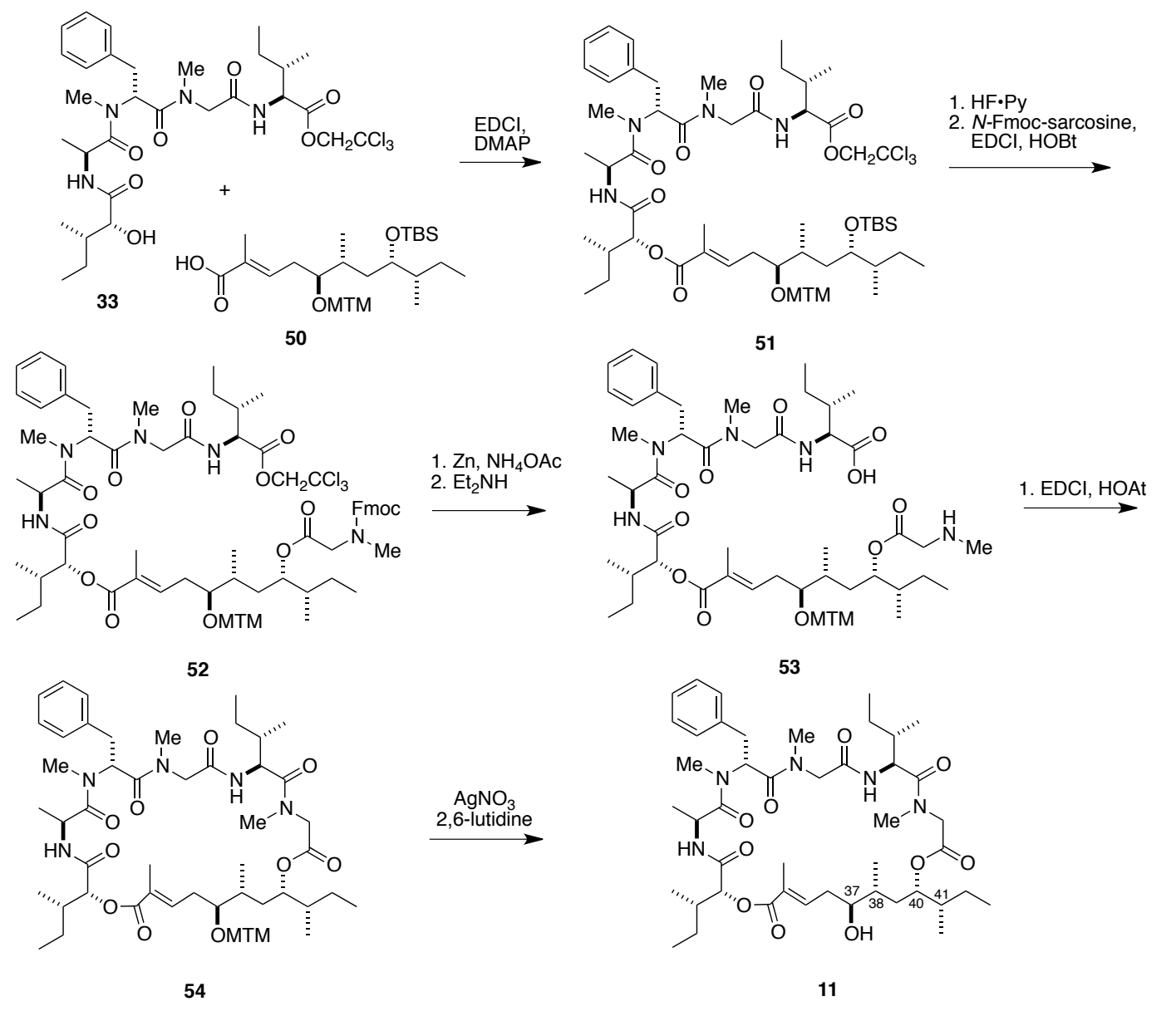

Scheme 14. Proposed completion of the synthesis of lagunamide $C$ (11)

\section{e) Synthesis of alternate diastereomers of the polyketide fragment}

The NMR spectrum of the synthetic macrocylcle will be compared with the reported NMR data for lagunamide C. If the NMR spectra do not match, I will adapt the sequence to synthesize diastereomers of acid $\mathbf{5 0}$, which will be used to build diastereomeric macrocycles in an attempt to synthesize the natural product. The choice of the chiral center(s) to be inverted will be based on the discrepancies of the corresponding ${ }^{13} \mathrm{C}$ and/or ${ }^{1} \mathrm{H}$ NMR signals. ${ }^{8}$ The synthesis of C-41 epimers of 11 could be performed by starting the sequence with (R)-2-butanol. This compound is not commercially available and can be obtained in 5 steps from (S)-3hydroxy-2-methylproprionate. ${ }^{41}$ The proposed reactions for setting the three remaining chiral centers involve the use of chiral catalysts that were chosen in order to minimize the effect of the previously installed stereocenters on the stereochemical outcome of each reaction. Thus, I expect that by using the enantiomers of thiazolidine-2-thione $\mathbf{2 1}$, dioxaborolane 38 and oxazaborolidine 47, under the conditions described above, I will be able to selectively access 
the diastereomers with opposite stereochemistry at C-40, C-38 and C-37, respectively. Alternatively, the stereochemistry of C-40 could be inverted by using thiazolidine-2-thione 21 with equimolar amounts of $\mathrm{TiCl}_{4}$ and sparteine. As shown in Scheme 6, these conditions would promote the formation of a closed transition state, which lead to the syn product. ${ }^{15}$ As mentioned above, if stereoselectivy problems arise, alternate thiazolidine-2-thiones, ${ }^{17,18,19,19}$ oxazolidine-2-thiones ${ }^{19}$ or oxazolidinones ${ }^{21,21}$ could be used to obtain the desired syn products. Furthermore, the use of $(+)-\mid \mathrm{Ip}_{2} \mathrm{~B}$ (allyl)borane instead of $(-)-\mid \mathrm{lp}_{2} \mathrm{~B}$ (allyl)borane in the allyboration reaction could also provide compounds with inverted stereochemistry at C-40.

\section{Biological evaluation}

The total synthesis of lagunamide $\mathrm{C}$ would allow the production of quantities appropriate for the confirmation of the reported biological activities and for conducting further studies that could provide information about its mode of action. In addition, the above described stereodivergent routes would allow the syntheses of lagunamide $C$ analogs that could be used for SAR studies. The information obtained from these preliminary biological studies could lay the groundwork for a broader program aimed at the generation of rationally designed lagunamide $\mathrm{C}$ analogs.

\section{Conclusion}

A stereodivergent synthetic route has been proposed for the structural revision of lagunamide $\mathrm{C}$ and the preparation of analogs thereof. The key reactions are a) an asymmetric acetate aldol reaction, b) a Charette asymmetric cyclopropanation, and c) Corey-Bakshi-Shibata (CBS) reduction. Upon confirmation of lagunamide C's structure, the biological activity of the synthetic material will be confirmed and its analogs will be evaluated. 


\section{References}

1. Lagunamides $A$ and $B$ : cytotoxic and antimalarial cyclodepsipeptides from the marine marine cyanobacterium Lyngbya majuscula. Tripathi, A., Puddick, J., Prinsep, M.R., Rottmann, M., Tan, L.T., J. Nat. Prod., 2010, 73, 1810.

2. Lagunamide $C$, a cytotoxic cyclodepsipeptide from the marine cyanobacterium Lyngbya majuscula Tripathi, A.; Puddick, J.; Prinsep, M.R.; Rottmann, M.; Chan, K.P.; Chen, D.Y.K.; Tan, L.T. Phytocemistry, 2011, 72, 2369.

3. Aurilide, a cytotoxic depsipeptide from the sea hare Dolabella auricularia: isolation, structure determination, synthesis, and biological activity, Suenaga, K.; Mutou, T.; Shibata, T.; Itoh, T.; Fujita, T.; Takada, N.; Hayamizu, K.; Takagi, M.; Irifune, T.; Kigoshi, H.; Yamada, K., Tetrahedron, 2004, 60, 8509.

4. Aurilides $B$ and $C$, cancer cell toxins from a Papua New Guinea collection of the marine cyanobacterium Lyngbya majuscule, Han, B.; Gross H.; Goeger D.E.; Mooberry S.L. Gerwick W.H. J Nat Prod., 2006, 69, 572.

5. Revised absolute stereochemistry of natural kulokekahilide-2, Takada, Y.; Umehara, M.; Nakao, Y.; Junji Kimura, J. Tet. Lett., 2008, 49, 1163.

6. The Structure of Palau'amide a Potent Cytotoxin from a Species of the Marine Cyanobacterium Lyngbya, Williams, P.G.; Yoshida, W.Y.; Quon, M.K.; Moore, R.E, Paul, V.J., Journal of Natural Products, 2003, 66, 1545.

7. Biochemical Studies of the Lagunamides, Potent Cytotoxic Cyclic Depsipeptides from the Marine Cyanobacterium Lyngbya majuscule, Tripathi, A.; Fang, W.; Leong, D.T.; Tan, L.T. . Mar. Drugs 2012, 10, 1126-1137.

8. Total Synthesis and Stereochemical Revision of Lagunamide A, Dai L.; Chen B.; Wang, Z.; Liu Y.; Xu, Z.; Ye, T. Chem. Commun., 2012, 48, 8697.

9. The vinylogous aldol reaction: a valuable, yet understated carbon-carbon bond-forming maneuver, Casiraghi, G.; Zanardi, F.; Appendino, G.; Rassu, G. Chem Rev. 2000, 100, 1929.

10. Antineoplastic Agents. 571. Total Synthesis of Bacillistatin 2, Pettit G.R.; Hu S.; Knight J.C.; Chapuis J.C. Journal of Natural Products, 2009, 72, 372.

11 Evolution of amide bond formation, Joullié, M.M.; Lassen ARKIVOC, 2010, 189.

12. Peptide Bond Formation-Carbodiimides, Podlech, J. in Houben-Weyl, Methods of Organic Chemistry, Synthesis of Peptides and Peptidomimetics, Georg Thieme Verlag: Stuttgart, 2001, Vol. E22a, 4th Ed, 517.

13. The total synthesis and structure-activity relationships of a highly cytotoxic depsipeptide kulokekahilide-2 and its analogs, Takada, Y.; Umehara, M.; Katsumata, R.; Nakao, Y.; Kimura, J. Tetrahedron, 2012, 68, 659.

14. A general synthetic method for the oxidation of primary alcohols to aldehydes: (S)-(+)-2methylbutanal, Anelli, P.L.; Montanari, F.; Quici, S. Organic Syntheses, 1990, 69, 212.

15. Stereoselective aldol additions of titanium enolates of $\mathrm{N}$-acetyl-4-isopropylthiazolidinethione, Hodge, M. B.; Olivo, H. F. Tetrahedron 2004, 60, 9397. 
16. Asymmetric Aldol Additions: Use of Titanium Tetrachloride and (-)-Sparteine for the Soft Enolization of $\mathrm{N}$-Acyl Oxazolidinones, Oxazolidinethiones, and Thiazolidinethiones, Crimmins, M. T.; King, B. W.; Tabet, E. A.; Chaudhary, K., J. Org. Chem.2001, 66, 894

17. Enantioselective Total Synthesis of (-)-Pironetin: Iterative Aldol Reactions of Thiazolidinethiones, Crimmins, M. T.; Dechert, A.-M. R., Org. Lett. 2009, 11, 1635.

18. Titanium Enolates of Thiazolidinethione Chiral Auxiliaries: Versatile Tools for Asymmetric Aldol Additions, Crimmins, M. T.; Chaudhary, K. Org. Lett. 2000, 2, 775.

19. The application of chiral oxazolidinethiones and thiazolidinethiones in asymmetric synthesis Velazquez, F.; Olivo, H.F., Curr. Org. Chem. 2002, 6, 303.

20. Diastereoselective Magnesium Halide-Catalyzed anti-Aldol Reactions of Chiral NAcyloxazolidinones, Evans, D.A.; Tedrow, J.S.; Shaw, J.T.; Downey C.W., J. Am. Chem. Soc. 2002, 124, 392.

21. Enantioselective Aldol Condensations II. Erythro-Selective Chiral Aldol Condensations via Boron Enolates, Evans, D. A.; Bartroli, J.; Shih, T. L. J. Am. Chem. Soc., 1981, 103, 2127.

$22 \beta$-Allyldiisopinocampheylborane: a remarkable reagent for the diastereoselective allylboration of .alpha.-substituted chiral aldehydes, Brown, H.C., Bhat, K.S., Randad, R.S., J. Org. Chem. 1987, 52, 319 .

$23 \beta$-Allyldiisocaranylborane: a new, remarkable enantioselective allylborating agent for prochiral aldehydes. Synthesis of homoallylic alcohols approaching $100 \%$ enantiomeric purities J. Org. Chem., 1984, 49, 4089.

24. Enantioselective Cyclopropanation of Allylic Alcohols with Dioxaborolane Ligands: Scope and Synthetic Applications, A. B. Charette, H. Juteau, H. Lebel, C. Molinaro, C., J. Am. Chem. Soc. 1998, 120, 11943.

25. Density Functional Theory Study of the Mechanism and Origins of Stereoselectivity in the Asymmetric Simmons-Smith Cyclopropanation with Charette Chiral Dioxaborolane Ligand, Wang, T.; Liang, Y.; Yu, Z.X., J. Am. Chem. Soc. 2011, 133, 9343

26. Regioselective opening of substituted (cyclopropylmethyl)lithiums derived from cyclopropylmethyl iodides, Charette, A.B.; Naud, J. Tetrahedron Lett., 1998, 39, 7259.

27. Preparation and Properties of Cyclopropylcarbinyllithium, Lansbury, P.T.; Pattison, V.A.; Clement, W.A.; Sidler, J.D., J. Am. Chem. Soc., 1964, 86, 2247.

28. Synthesis of the 8-Hydroxy Acid of Jasplakinolide, Wattanasereekul, S.; Martin E. Maier, M.E. Adv. Synth. Catal. 2004, 346, 855.

29. Kulokekahilide-2, a Cytotoxic Depsipeptide from a Cephalaspidean Mollusk Philinopsis speciosa, Nakao, Y.; Yoshida, W.Y.; Takada, Y.; Kimura, J.; Yang, L.; Mooberry, S.L.; Scheuer, P.J.; Journal of Natural Products, 2004, 67, 1332.

30. Synthesis of palau'amide and its diastereomers: confirmation of its stereostructure Sugiyama, H.; Watanabe, A.; Teruya, T.; Suenaga, K., Tetrahedron Lett., 2009, 50, 7343.

31. A Stereochemical Model for Merged 1,2- and 1,3-Asymmetric Induction in Diastereoselective Mukaiyama Aldol Addition Reactions and Related Processes, Evans, D. A.; Dart, M. J.; Duffy, J. L.; Yang, M. G. J. Am. Chem. Soc. 1996, 118, 4322.

32. A retro-Claisen approach to dolabriferol, Lister, T.; Perkins, M. Org. Lett., 2006, 8, 1827. 
33. Total synthesis of the polyene macrolide dermostatin A, Sinz, C.J.; Rychnovsky, S.D.; Tetrahedron, 2002, 58, 6561.

34. Stereoselective synthesis of the C33-C44 fragment of palauamide, Mohapatra, D.K.; Nayak, S., Tetrahedron Lett., 2008, 49, 786.

35. 1,3-Asymmetric Induction in Hydride Addition Reactions to $\beta$-Substituted Ketones. A Model for Chirality Transfer, Evans, D. A.; Dart, M. J.; Duffy, J. L. Tetrahedron Lett., 1994, 35, 8541.

36. Synthetic studies towards oxylipins: total synthesis of Constanolactones $A$ and $B$, Barloy-Da Silva, C.; Benkouider, A.; Pale, P., Tetrahedron Lett., 2000, 41, 3077.

37. Synthesis of the C1-C12 Fragment of Iriomoteolide 1a by Sequential Catalytic Asymmetric Vinylogous Aldol Reactions, Fang, L.; Xue, H.; Yang, J. Org. Lett., 2008, 10, 4645.

38. Highly enantioselective borane reduction of ketones catalyzed by chiral oxazaborolidines. Mechanism and synthetic implications Corey, E.J.; Bakshi, R.K.; Shibata S. J., Am. Chem. Soc., 1987, 109, 5551.

39. Reduction of Carbonyl Compounds with Chiral Oxazaborolidine Catalysts: A New Paradigm for Enantioselective Catalysis and a Powerful New Synthetic Method, Corey, E. J.; Helal, C. J. Angew. Chem. Int. Ed., 1998, 37, 1986.

40. Methylthiomethyl ethers: their use in the protection and methylation of hydroxyl groups, Pojer, P.M.; Angyal, S.J. Aust J. Chem., 1978, 31, 1031.

41. Approach toward the Total Synthesis of Orevactaene. 2. Convergent and Stereoselective Synthesis of the C18-C31 Domain of Orevactaene. Evidence for the Relative Configuration of the Side Chain Organ, M.G.; Bilokin, Y.V. Bratovanov, S., J. Org. Chem. 2002, 67, 5176. 


\section{LIST OF ABBREVIATIONS}

\begin{tabular}{|c|c|}
\hline A & Adenylation domain \\
\hline $\mathrm{ACP}$ & Acyl carrier protein \\
\hline $\mathrm{AcCl}$ & Acetyl chloride \\
\hline $\mathrm{AL}$ & Acyl-CoA ligase domain \\
\hline $\mathrm{Ac}_{2} \mathrm{O}$ & Acetic anhydride \\
\hline $\mathrm{AcOH}$ & Acetic acid \\
\hline $\mathrm{Bn}$ & Benzyl \\
\hline Boc & tert-Butoxycarbonyl \\
\hline $\mathrm{Boc}_{2} \mathrm{O}$ & Di-tert-butyldicarbonate \\
\hline $\mathrm{C}$ & Condensation domain \\
\hline CAN & Ceric ammonium nitrate \\
\hline $\mathrm{Cbz}$ & Benzyl chloroformate \\
\hline CSA & Camphorsulfonic acid \\
\hline DAST & Diethylaminosulfur trifluoride \\
\hline DBN & 1,5-Diazabicyclo[4.3.0]non-5-ene \\
\hline DBU & 1,8-Diazabicyclo[5.4.0]undec-7-ene \\
\hline DIBAL & Diisobutyl aluminum hydride \\
\hline DIPEA & Diisopropylethylamine \\
\hline DMAP & 4-(Dimethylamino)-pyridine \\
\hline DMF & Dimethylformamide \\
\hline DMP & Dess-Martin Periodinane \\
\hline
\end{tabular}




\begin{tabular}{|c|c|}
\hline DMDO & Dimethyldioxirane \\
\hline DMSO & Dimethylsulfoxide \\
\hline EDCI & 1-Ethyl-3-(3-dimethylaminopropyl)carbodiimide \\
\hline $\mathrm{Et}_{3} \mathrm{~N}$ & Triethylamine \\
\hline EtOAc & Ethyl Acetate \\
\hline Fmoc & (9H-fluoren-9-ylmethoxy)carbonyl \\
\hline HFIP & Hexafluoroisopropanol \\
\hline HATU & $O$-(7-Azabenzotriazol-1-yl)- $N, N, N^{\prime}, N^{\prime}$-tetramethyluronium hexafluorophosphate \\
\hline HOBt & 1-hydroybenzotriazole \\
\hline IBCF & Isobutyl chlorformate \\
\hline IBX & $o$-Iodoxybenzoic acid \\
\hline KHDMS & Potassium bis(trimethylsilyl)amide \\
\hline KOTMS & Potassium trimethylsilanolate \\
\hline LDA & Lithium $N, N$-diisopropylamide \\
\hline MIC & Minimal inhibitory concentration \\
\hline MS & Molecular sieves \\
\hline Ms & Methanesulfonyl \\
\hline$m$-CPBA & $m$-Chloroperbenzoic acid \\
\hline MeI & Methyl iodide \\
\hline MOM & Methoxymethyl \\
\hline NaHMDS & Sodium bis(trimethylsilyl)amide \\
\hline NBS & $N$-Bromosuccinimide \\
\hline NMM & $N$-Methylmorpholine \\
\hline
\end{tabular}




\begin{tabular}{ll} 
NMO & N-Methylmorpholine- $N$-Oxide \\
NMP & N-Methyl pyrrolidine \\
NRPS & Nonribosomal peptide synthetase \\
Ns & 2-Nitrobenzenesulfonyl \\
P & Peptidase domain \\
PCC & Pyridinium chlorochromate \\
PCP & Peptidyl carrier protein \\
Pd/C & Palladium on carbon \\
PS & Pictet-Spenglerase domain \\
Py & Pyridine \\
PyBOP & Benzotriazol-1-yl-oxytripyrrolidinophosphonium hexafluorophosphate \\
R & Reductase domain \\
REDAL & Sodium bis(2-methoxyethoxy)aluminum hydride \\
T & Thiolation domain \\
TBAF & Tetrabutylammonium fluoride \\
TBDPS & tert-Butyldiphenlsilyl \\
TBS & tert-Butyldimethylsilyl \\
TBSOTf & tert-Butyldimethylsilyl trifluoromethanesulfonate \\
THF & Tetrahydrofuran \\
TEMPO & $2,2,6,6-$ Tetramethyl-1-piperidinyloxy, free radical \\
TES & Triethylsilyl \\
TFA & Trifluoroacetic acid \\
TFE & Trifluoroethanol \\
\hline
\end{tabular}




$\begin{array}{ll}\text { TIPS } & \text { Triisopropylsilyl } \\ \text { TIPSOTf } & \text { Triisopropylsilyl trifluoromethylsulfonate } \\ \text { TMS } & \text { Trimethylsilyl } \\ \text { TMSOTf } & \text { Trimethylsilyl trifluoromethylsulfonate } \\ \text { TPAP } & \text { Tetrapropylammonium perruthenate } \\ \text { Ts } & p \text {-Toluenesulfonyl } \\ p \text {-TsOH } & p \text {-Toluenesulfonic acid }\end{array}$

